UNIVERSIDADE DE SÃO PAULO

FACULDADE DE FILOSOFIA, LETRAS E CIÊNCIAS HUMANAS DEPARTAMENTO DE HISTÓRIA

PROGRAMA DE PÓS-GRADUAÇÃO EM HISTÓRIA ECONÔMICA

OTÁVIO ERBERELI JÚNIOR

\title{
A TRAJETÓRIA INTELECTUAL DE ALICE PIFFER \\ CANABRAVA: UM OFÍCIO COMO SACERDÓCIO (1935-1997)
}

Versão corrigida

SÃO PAULO

2019 


\section{OTÁVIO ERBERELI JÚNIOR}

A TRAJETÓRIA INTELECTUAL DE ALICE PIFFER CANABRAVA: UM OFÍCIO COMO SACERDÓCIO (1935-1997)

Versão corrigida

Tese apresentada para a obtenção do título de Doutor em Ciências junto ao Programa de Pós-Graduação em História Econômica da Faculdade de Filosofia, Letras e Ciências Humanas da Universidade de São Paulo.

Orientadora: Profa. Dra. Raquel Glezer

\section{SÃO PAULO}


Autorizo a reprodução e divulgação total ou parcial deste trabalho, por qualquer meio convencional ou eletrônico, para fins de estudo e pesquisa, desde que citada a fonte.

Catalogação na Publicação

Serviço de Biblioteca e Documentação

Faculdade de Filosofia, Letras e Ciências Humanas da Universidade de São Paulo

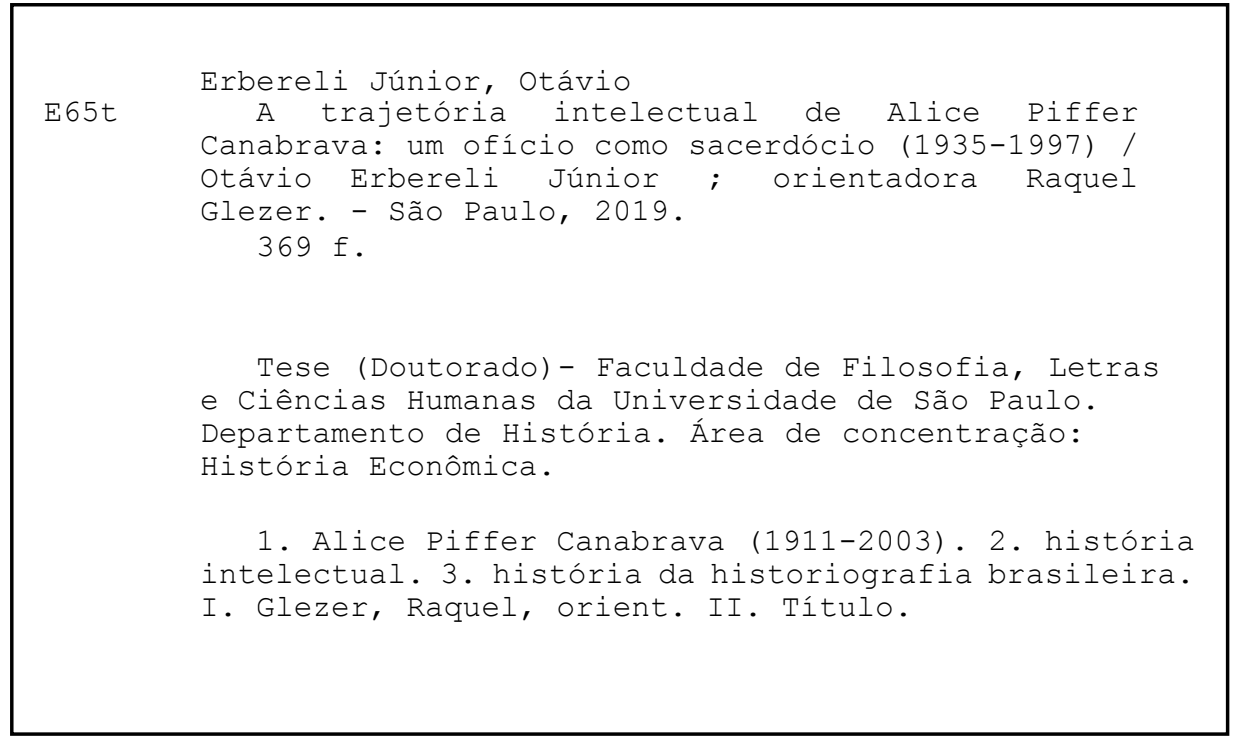


(1) $f$ C Universidade de SÃo paulo

FACULDADE DE FILOSOFIA, LETRAS E CIÊNCIAS HUMANAS

\section{ENTREGA DO EXEMPLAR CORRIGIDO DA DISSERTACÃO/TESE \\ Termo de Ciência e Concordância do (a) orientador (a)}

Nome do aluno: Otávio Erbereli Júnior

Data da defesa: 30/08/2019

Nome do Profa. orientadora: Raquel Glezer

Nos termos da legislação vigente, declaro ESTAR CIENTE do conteúdo deste EXEMPLAR

CORRIGIDO elaborado em atenção às sugestões dos membros da comissão Julgadora na sessão de defesa do trabalho, manifestando-me plenamente favorável ao seu encaminhamento e publicação no Portal Digital de Teses da USP.

São Paulo, 07/10/2019

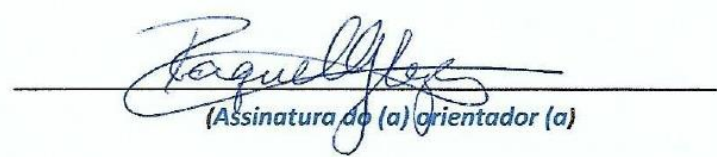


ERBERELI JÚNIOR, Otávio. A trajetória intelectual de Alice Piffer Canabrava: um ofício como sacerdócio (1935-1997). Tese apresentada a Faculdade de Filosofia, Letras e Ciências Humanas da Universidade de São Paulo para obtenção do título de doutor em História Econômica.

Aprovado em:

\section{Banca examinadora}

Orientadora: Profa. Dra. Raquel Glezer

Instituição: FFLCH/USP

Assinatura:

Profa. Dra. Maria da Glória de Oliveira

Instituição: UFRRJ/RJ

Julgamento:

Assinatura:

Profa. Dra. Karina Anhezini de Araújo

Instituição: FCHS/UNESP

Julgamento:

Assinatura:

Prof. Dr. Miguel Soares Palmeira

Instituição: FFLCH/USP

Julgamento:

Assinatura: 
Às mulheres que sofreram e sofrem com o machismo.

Às duas mulheres da minha vida: minha mãe, Cleude e minha irmã, Bruna. 


\section{Agradecimentos}

Agradeço à CAPES pela concessão de bolsa que resultou nessa tese. As opiniões, hipóteses e conclusões ou recomendações expressas neste material são de responsabilidade do autor não necessariamente refletem a visão da CAPES.

Várias pessoas me acompanharam nessa jornada até aqui. Sou extremamente grato à professora Raquel Glezer. Não poderia ter encontrado melhor orientadora. Raquel me ofereceu exatamente o que eu buscava e precisava: uma leitora diligente e atenta, que me proporcionou autonomia intelectual. Esse texto não seria o mesmo sem suas intervenções,

principalmente no sentido de deixá-lo mais enxuto, uma vez que logo ela constatou meus excessos de escrita... Muito obrigado professora Raquel!

Deixo aqui um agradecimento especial à Lúcia Carvalho. Essa tese seria bem diferente sem sua generosa doação da documentação de sua tia Alice Canabrava ao Arquivo IEB/USP no ano de 2015. Lúcia sempre me recebeu em sua casa com grande carinho e atenção, compartilhando suas memórias sobre sua tia. Nos tornamos amigos e sempre que posso vou visitá-la. Durante esse processo de doação, conheci a então diretora do Arquivo, Elizabete Marin Ribas, a Bete. Tive o prazer de conviver com essa mulher apaixonada pelo universo dos Arquivos durante o período em que trabalhei na descrição do Fundo Alice Piffer Canabrava. Pretendo finalizar o trabalho durante meu pósdoutorado.

Agradeço aos professores Paulo Teixeira Iumatti e Miguel Soares Palmeira pelo profícuo diálogo durante meu exame de qualificação. Tive o prazer de realizar meu estágio docência sob a supervisão de Miguel. Para mim, um momento de muito aprendizado com esse profissional extremamente humano e competente. Agradeço ainda às professoras Maria da Glória de Oliveira e Karina Anhezini de Araújo que, juntamente com Miguel, aceitaram participar da banca examinadora dessa tese. Glória contribuiu com sua perspicaz leitura quanto às questões de gênero imbricadas na tese e com uma leitura bastante generosa que promoveu estimulante diálogo. Deixo aqui um triplo agradecimento à Karina: por ter sido minha orientadora durante o mestrado, por sua leitura estimulante da tese e por ter aceitado fazer parte da banca em um momento em que teve pouco tempo para ler meu trabalho. 
Agradeço ao professor Flávio Saes por nossas conversas sobre Alice Canabrava. Flávio sempre foi muito atencioso ao compartilhar suas impressões sobre meu trabalho. Sou grato também à Thiago Lima Nicodemo que me pôs em contato com o professor Herbert S. Klein da Universidade de Stanford. Klein me abriu as portas para uma futura pesquisa na Califórnia.

A vida e essa jornada não teriam o mesmo sabor sem os amigos. Logo no primeiro Congresso do Programa de Pós-Graduação em História Econômica em dezembro de 2014, tive a felicidade de conhecer Carlos Alberto Vieira Borba, que se tornou um amigoirmão. Obrigado meu amigo pelos momentos de diversão, troca de angústias e de ideias compartilhadas. Agradeço também ao amigo-irmão Raphael Guilherme de Carvalho que tive o privilégio de conhecer em um evento no ano de 2016. Desde então, essa relação se fortalece com sua escuta generosa e troca de ideias sobre nosso trabalho, nossas angústias, ansiedades etc. Obrigado Rapha pelos momentos de diversão e conversas revigorantes. Outra presença constante em minha vida é de outro amigo-irmão: Mário Afonso Pontieri. Uma relação que resiste ao tempo. Caminhamos juntos há 26 anos. Muito obrigado pela amizade. Amiga de longa data, Mírian Senna de Araújo esteve comigo em vários momentos dessa jornada, proporcionando companheirismo e uma escuta atenta nos momentos mais difíceis. Obrigado pelo carinho Mí! O amigo Emerson Oliveira me proporcionou oportunidades de desabafo e diversão em minhas passagens por São Carlos/SP quando visitava minha família. Muito obrigado!

Agradeço ainda àqueles que estiveram presentes em minha defesa: Carlos Alberto Vieira Borba, Diego Além de Lima, Fernando Dizzio, João Grava, Mário Afonso Pontieri e Mirian Senna de Araújo.

Produzir uma tese é tarefa prazerosa, porém, que apresenta sentimentos variados ao longo do percurso: angústia, ansiedade, incerteza... Sem uma vida encantada, tal empreitada não seria possível. O samba encanta minha existência. Sem beber do samba, sem frequentar as rodas de samba de terreiro de São Paulo, minha vida não teria o mesmo sabor. Agradeço aos parceiros e parceiras do Núcleo de Resistência e Pesquisa Tudo Azul Paulistano, do qual foi me dada a honra de ser integrante desde 2017. Muito obrigado Tudo Azul!

A existência de um aparato de permanência estudantil na USP me proporcionou morar em São Paulo. Sem a possibilidade de morar no Conjunto Residêncial da USP 
(CRUSP), não poderia ter gozado da vida acadêmica na cidade universitária. A importância da universidade pública e gratuita é fundamental para o acesso daqueles que não atingiriam o doutoramento sem políticas sociais fundamentais, conquistadas à duras penas e negociações durante os governos Lula e Dilma. Nesse momento de ataque à universidade, é necessário dar luz às várias trajetórias que, sem um aparato de proteção social e financiamento público à pesquisa, não teriam, como se diz, chegado lá.

Por fim, minha família. Com minha mãe, dona de casa, aprendi o significado do afeto e da sensibilidade, do cuidado e do carinho. Muito obrigado minha mãe amada! Sem o afeto e o apoio de minha irmã, Bruna Thaís Erbereli, uma amorosa e dedicada fisioterapeuta, nada disso seria possível. Muito obrigado! Meu avô, Lourenço Paschoal, com quem convivi mais intensamente em seus últimos anos, me preencheu com sua musicalidade. Fica a saudade... O carinho de nossa cadelinha, Menina, torna minha vida mais leve.

Essa é uma tese sobre uma mulher, historiadora, que venceu as barreiras de gênero e se estabeleceu na vida acadêmica. É uma tese sobre mulher e para as mulheres que sofreram e sofrem com o machismo. 


\section{RESUMO}

\section{ERBERELI JÚNIOR, Otávio. A trajetória intelectual de Alice Piffer Canabrava: um}

ofício como sacerdócio (1935-1997). Tese (Doutorado). Faculdade de Filosofia, Letras e Ciências Humanas, Universidade de São Paulo, 2019.

Esta tese é o resultado de uma longa pesquisa que tem como objeto uma historiadora, Alice Piffer Canabrava (1911-2003) que atuou na Universidade de São Paulo. Está estruturada em quatro temas que permitiram identificar e reconstruir as culturas acadêmicas das unidades universitárias em que atuou como docente e nas quais tentou e desenvolveu sua carreira acadêmica, as redes de sociabilidade que estabeleceu através dos anos, sua relação com o Instituto de Estudos Brasileiros, especialmente no Encontro Internacional de Estudos Brasileiros. I Seminário de Estudos Brasileiros e as representações sobre sua pessoa.

Utilizamos como autores referenciais nos aspectos que consideramos adequados Fritz Ringer, Michel de Certeau, Paul Ricoeur e Bonnie Smith, além de outros que fazem parte da construção dos temas. O Fundo Alice Piffer Canabrava no Arquivo do Instituto de Estudos Brasileiros foi fonte fundamental para o desenvolvimento da pesquisa. Pelos temas apresentados, o trabalho pode ser classificado como história intelectual, história da historiografia brasileira e sociologia dos intelectuais.

Palavras-chave: Alice Piffer Canabrava (1911-2003). história intelectual. história da historiografia brasileira. 


\begin{abstract}
ERBERELI JÚNIOR, Otávio. The intellectual trajectory of Alice Piffer Canabrava: a craft as priesthood (1935-1997). Tese (Doutorado). Faculdade de Filosofia, Letras e Ciências Humanas, Universidade de São Paulo, 2019.

This thesis is the result of a long research whose object is a historian, Alice Piffer Canabrava (1911-2003), who worked at the University of São Paulo. It is structured in four themes that allowed to identify and reconstruct the academic cultures of the university units in which she acted as teacher and in which she tried and developed her academic career, the networks of sociability that she established over the years, her relation with the Institute of Brazilian Studies, especially at the International Meeting of Brazilian Studies. First Seminar of Brazilian Studies and the representations on her person.

We use as referential authors in the aspects that we consider appropriate Fritz Ringer, Michel de Certeau, Paul Ricoeur and Bonnie Smith, as well as others that are part of the construction of the themes. The Alice Piffer Canabrava Fund in the Archive of the Institute of Brazilian Studies was a fundamental source for the development of the research. Due to the themes presented, the work can be classified as intellectual history, history of Brazilian historiography and sociology of intellectuals.
\end{abstract}

Keywords: Alice Piffer Canabrava (1911-2003); intellectual history; history of Brazilian historiography. 


\section{LISTA DE QUADROS E TABELAS}

Quadro 1: notas de Alice Piffer Canabrava na Escola Normal em 1927.

Quadro 2: notas de Alice Piffer Canabrava em História e disciplinas de mesmo peso na Escola Normal em 1928, 1929 e 1930.

Quadro 3: notas de Alice Piffer Canabrava, Adélia Dranger, Maria A. V. Carvalho e Felicio Marchatti em História e Geografia na Escola Normal.

Quadro 4: número de participantes do EIEB. I SEB segundo país de origem 211

Quadro 5: número de participantes do EIEB. I SEB segundo Estado de origem....212

Quadro 6: número de participantes do EIEB. I SEB por área e segundo gênero....214

Tabela 1: grade curricular do curso de Ciências Econômicas da Faculdade de Ciências Econômicas e Administrativas (FCEA) da USP proposta por Comissão presidida por Alice Piffer Canabrava (1957).... .70

Tabela 2: grade curricular do curso de História da FFCL/USP de 1956 .114

Tabela 3: grade curricular do curso de História da FNFi/UB 


\section{LISTA DE FIGURAS E IMAGENS}

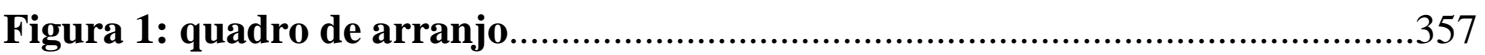

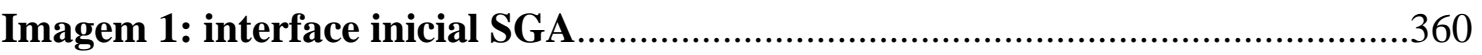

Imagem 2: formulário de descrição documental SGA ...........................................361

Imagem 3: carta de Zélia M. C. de Mello para Alice Piffer Canabrava.................362

Imagem 4: formulário de descrição documental SGA ….......................................363

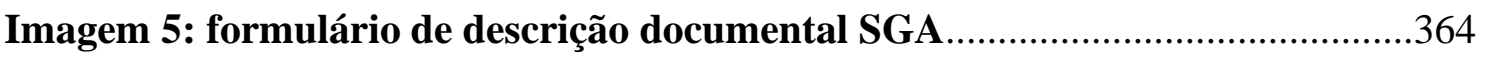

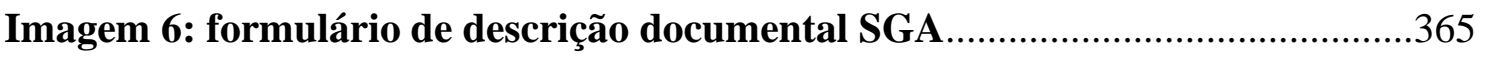

Imagem 7: formulário de descrição documental SGA............................................366

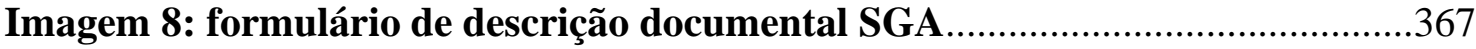

Imagem 9: formulário de descrição documental SGA ...........................................367 


\section{LISTA DE ABREVIATURAS}

AHECC: Arquivo Histórico Escola Normal Caetano de Campos/SP.

APUH: Associação dos Professores Universitários de História.

ANPUH: Associação Nacional dos Professores Universitários de História, atual Associação Nacional de História.

CRE: Centro de Referência em Educação Mario Covas/SP.

CRUSP: Conjunto Residencial da USP.

ECA: Escola de Comunicação e Artes/USP.

EIEB. I SEB: Encontro Internacional de Estudos Brasileiros. I Seminário de Estudos Brasileiros.

EFAP: Escola de Formação e Aperfeiçoamento dos Professores/SP.

FCEA: Faculdade de Ciências Econômicas e Administrativas, atual FEA Faculdade de Economia, Administração e Contabilidade/USP.

FFCL: Faculdade de Filosofia, Ciências e Letras, extinta em 1968.

FFLCH: Faculdade de Filosofia, Letras e Ciências Humanas/USP.

FNFi: Faculdade Nacional de Filosofia, atual Instituto de História/UFRJ.

HGCB: História Geral da Civilização Brasileira.

HCB: Cadeira de História da Civilização Brasileira.

IA: Instituto de Administração/FCEA/USP.

IEB: Instituto de Estudos Brasileiros/USP.

IMS: Instituto Moreira Salles/RJ.

MIS: Museu da Imagem e do Som/SP.

$\boldsymbol{R B H}$ : Revista Brasileira de História.

$\boldsymbol{R I E B}:$ Revista do Instituto de Estudos Brasileiros.

RIHGB: Revista do Instituto Histórico e Geográfico Brrasileiro.

SBPH: Sociedade Brasileira de Pesquisa Histórica/PR.

SEE: Secretaria de Educação do Estado de São Paulo.

UB: Universidade do Brasil, atual Universidade Federal do Rio de Janeiro/UFRJ.

UDF: Universidade do Distrito Federal, extinta em 1939.

USP: Universidade de São Paulo. 
UNESP: Universidade Estadual Paulista "Júlio de Mesquita Filho".

UMG: Universidade de Minas Gerais, atual UFMG.

URS: Universidade do Rio Grande do Sul, atual UFRS.

UPR: Universidade do Paraná, atual UFPR.

UEL: Universidade Estadual de Londrina/PR.

UEM: Universidade Estadual de Maringa/PR.

UEPG: Universidade Estadual de Ponta Grossa/PR.

UBA: Universidade da Bahia, atual UFBA.

UPE: Universidade de Pernambuco, atual UFPE. 


\section{SUMÁRIO}

Introdução. .17

Antes do ingresso na FFCL/USP. .27

Capítulo 1: Alice Piffer Canabrava entre duas culturas acadêmicas: a Faculdade de Filosofia, Ciências e Letras e a Faculdade de Ciências Econômicas e Administrativas da Universidade de São Paulo. .35

1.1 A cultura acadêmica da FFCL .......................................................36

1.2 A cultura acadêmica da FCEA.....................................................53

1.3 Na crise, uma noção de Ciência Econômica......................................61

1.4 A defesa da cadeira de História Econômica e sua dinâmica de funcionamento. .72

1.5 Alice no país da quantificação: quando os dados contradizem os modelos, há uma nova interpretação. .88

Capítulo 2: Tramas em Associação e Revista: redes de sociabilidade e identidade historiadora .101

2.1 "Na eventualidade de um congresso..." .105

2.2 Batalhando pela consolidação do campo..... .129

2.3 “A reflexão histórica alargada e aprofundada com o concurso de outras ciências".

Capítulo 3: Alice Piffer Canabrava, o Instituto de Estudos Brasileiros da USP e o "Encontro Internacional de Estudos Brasileiros. I Seminário de Estudos Brasileiros"... 179

3.1 A atuação de Alice no Conselho Administrativo do IEB/USP. 181

3.2 O "Encontro Internacional de Estudos Brasileiros. I Seminário de Estudos Brasileiros" e a tentativa de delimitação de uma história da historiografia brasileira. 


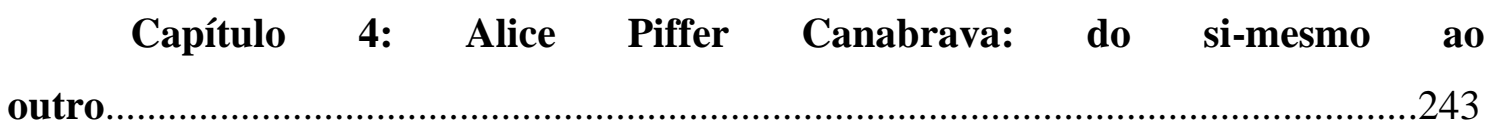

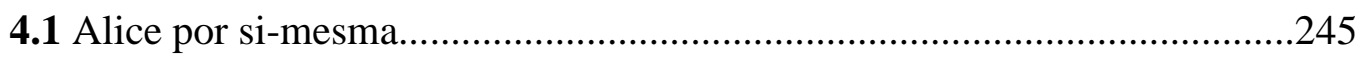

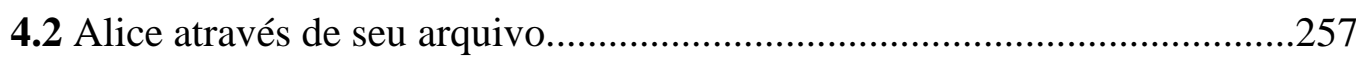

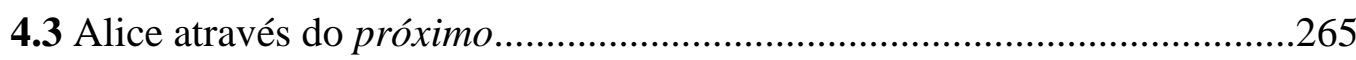

4.4 As representações de Alice..................................................................28

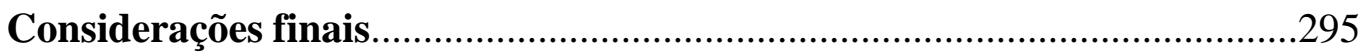

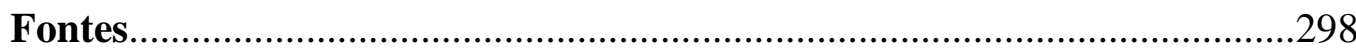

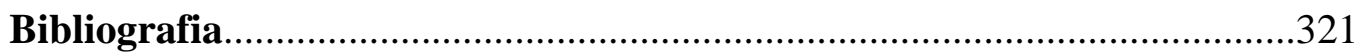

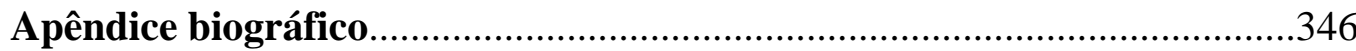

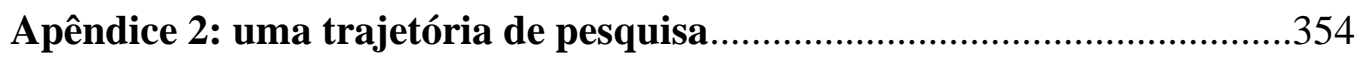




\section{Introdução}

“O senhor aí já leu a Alice Canabrava?” Assim indagava, jocosamente, o professor de Formação Econômica do Brasil quando cursava Ciências Econômicas na UNESP/Araraquara em $2004^{1}$. Dentre as leituras do programa que incluíam Celso Furtado, Caio Prado Júnior, Fernando Novais, Antonio Delfim Neto e outros, nos questionava, sugerindo leituras de autores como Raymundo Faoro, Sérgio Buarque de Holanda etc. Esta foi a primeira vez que ouvi o nome dessa mulher que me acompanharia por anos a fio.

Anos depois, enquanto estratégia para o ingresso no mestrado em História, escolhi tratar de alguma questão relacionada à história econômica, dado que na ocasião não possuía formação acadêmica em História e estava cursando uma especialização na área de História pela UEM/PR ${ }^{2}$. Sendo assim, ingressei no mestrado na UNESP/Assis em 2011 com a proposta de realizar "Uma história da história econômica no Brasil (1951-1972)". Escolhi três teses acadêmicas para analisar, em seus aspectos teóricos, metodológicos e principais referências, com o objetivo de demostrar mudanças e permanências na concepção de história econômica do período. A primeira tese escolhida, e que estabelecia o recorte temporal inicial, foi a tese com a qual Alice Piffer Canabrava tornou-se a primeira catedrática ${ }^{3}$ por concurso da Universidade de São Paulo (USP), $O$ Desenvolvimento da Cultura do Algodão na Província de São Paulo (1861-1875)4,

\footnotetext{
${ }^{1}$ Durante a graduação me dediquei ao estudo da história do pensamento econômico, particularmente da "Teoria Geral do Emprego, do Juro e da Moeda" do economista britânico John Maynard Keynes. A pesquisa foi financiada pela FAPESP (2004-2005) e resultou no artigo: ERBERELI JÚNIOR, Otávio. Rigidez de preços e salários na teoria keynesiana. Iniciativa Econômica. Araraquara, ano 4, n. 4, p. 53-63, 2004.

${ }^{2}$ Especialização concluída em 2012, com o artigo: ERBERELI JÚNIOR, Otávio. Abordagem acerca do aporte listiano para a formação do pensamento de Raúl Prebisch. Revista de Economia Política e História Econômica. Maceió, ano 9, n. 31, p. 146-182, 2014.

${ }^{3}$ A cadeira era a menor unidade de uma Faculdade ou Instituto que vigorou até a reforma universitária de 1968. A cadeira/cátedra era liderada pela figura do catedrático e em torno dele gravitavam os auxiliares de ensino e assistentes de pesquisa, dependentes funcionalmente do mesmo. Cada cadeira possuía sua própria biblioteca e cada catedrático exercia o controle sobre sua área de atuação específica. Na cadeira de História da Civilização Americana, por exemplo, não se poderia realizar pesquisas em História do Brasil.

${ }^{4}$ CANABRAVA, Alice Piffer. O Desenvolvimento da Cultura do Algodão na Província de São Paulo (1861-1875). $3^{\circ}$ edição. São Paulo: EDUSP/ANPUH, 2011. A primeira edição da tese foi publicada pela Indústria Gráfica Siqueira em 1951 e a segunda pela editora T. A. Queiroz em 1984. Ver: ERBERELI JÚNIOR, Otávio. Alice Piffer Canabrava e O Desenvolvimento da Cultura do Algodão na Província de São Paulo (1861-1875). Revista de Teoria da História. Goiânia, ano 4, n. 8, p. 35-64, 2012. ERBERELI JÚNIOR, Otávio. A Faculdade de Ciências Econômicas e Administrativas da Universidade de São Paulo e a escrita da história econômica de Alice Piffer Canabrava. História econômica \& história de empresas. São Paulo, v. 19, n.1, p. 9-40, 2016.
} 
defendida na cadeira de História Econômica da antiga Faculdade de Ciências Econômicas e Administrativas (FCEA) $)^{5}$ da USP. A segunda, a tese de doutoramento de José Roberto do Amaral Lapa, O Brasil e a Carreira da Índia, orientada por Sérgio Buarque de Holanda e defendida em $1966^{6}$. Por fim, a tese que dava a baliza temporal final da proposta, O Brasil no Comércio Colonial, de José Jobson de Andrade Arruda, orientada por Eduardo D’Oliveira França e defendida na Faculdade de Filosofia, Letras e Ciências Humanas (FFLCH) da USP em $1972^{7}$.

Ao longo da pesquisa, me dei conta da envergadura e ambição da proposta. Somado a isso, à medida em que "conhecia" mais e melhor essa mulher, notando que não havia nenhum trabalho de fôlego sobre ela, mas que havia um interesse da comunidade acadêmica por um estudo particular de sua trajetória e percebendo que várias questões poderiam ser pensadas a partir de Alice Canabrava, a escolhi como objeto de pesquisa. De minhas preocupações com a institucionalização da história no Brasil e com os fundamentos de sua escrita, foi produzida uma análise de sua produção historiográfica que resultou em minha dissertação de mestrado defendida em julho de 2014, A escrita da história entre dois mundos: uma análise da produção de Alice Piffer Canabrava (1935$1961)^{8}$.

Esta escolha de conversão total à História me reservaria ainda enormes alegrias. Certa feita, ao digitar Alice Piffer Canabrava no Google me deparei com um texto intitulado "a máquina da Canabrava". Na verdade, uma crônica de Mário Prata publicada em $O$ Estado de S. Paulo. Prata, que havia sido aluno de Alice Canabrava na FCEA/USP, relata a experiência de Lúcia Carvalho na casa de sua tia quando do falecimento desta. Um dos filhos de Lúcia chamou-a, empolgado, diante da máquina de escrever: "Mamãe, mamãe! Veja! Um computador que imprime no momento em que a gente digita!". Embasbacamento da criança diante da tecnologia obsoleta que lhe era tão estranha. Fazendo uso da tecnologia contemporânea, digitei no facebook "Lúcia Carvalho". Diante

\footnotetext{
${ }^{5}$ A Faculdade de Ciências Econômicas e Administrativas (FCEA) da USP, fundada em 1946, teve seu nome alterado em 1969 por conta da Reforma Universitária, passando a denominar-se Faculdade de Economia, Administração e Contabilidade (FEA).

${ }^{6}$ LAPA, José Roberto do Amaral. A Bahia e a Carreira da Índia. São Paulo: HUCITEC, 2000.

${ }^{7}$ ARRUDA, José Jobson de Andrade. O Brasil no Comércio Colonial. São Paulo: Ática, 1994.

${ }^{8}$ ERBERELI JÚNIOR, Otávio. A escrita da história entre dois mundos: uma análise da produção de Alice Piffer Canabrava (1935-1961). 2014. 243f. Dissertação (Mestrado em História) - Faculdade de Ciências e Letras, Universidade Estadual Paulista "Júlio de Mesquita Filho", Assis, 2014. Disponível em: $<$ http://hdl.handle.net/11449/113809>.
} 
de um perfil que trazia a informação de que havia cursado arquitetura na Faculdade de Arquitetura e Urbanismo (FAU) da USP, enviei uma daquelas mensagens que caem no "buraco negro" do facebook quando não se é "amigo" do destinatário. Me apresentei e expliquei sobre a pesquisa. Lúcia, imensamente gentil, disse-me que era sobrinha-neta de Alice Canabrava e mais: que ainda possuía algumas poucas "coisas" de sua tia e me convidou para vir à sua casa.

A oportunidade se concretizou quando, ao voltar do Rio de Janeiro em uma pesquisa no Acervo Francisco Iglésias no Instituto Moreira Salles - amigo e mais frequente correspondente de Alice - pude ir até à casa dela. Cheia de simpatia e hospitalidade - sabemos que isso é algo raro quando algum pesquisador busca informações diretamente com a família do autor ou autora pesquisados - ela rememorou histórias de e com sua tia e ficou contente que alguém estivesse "estudando" essa mulher. Depois de um saboroso bate-papo me disse que iria "descer" com o que tinha de sua tia. Tal foi meu misto de emoções quando ela veio com várias caixas e pastas me dizendo que ainda tinha mais... Cartas, cartões postais, fotografias, recibos, testamentos, periódicos, anotações, livros... Por três dias compartilhei de sua companhia e de suas histórias sobre sua tia enquanto fotografava todo o material. Estava guardado com carinho, porém requeria higienização e condições de armazenamento adequadas. Foi quando propus-lhe encaminhar o material para o Instituto de Estudos Brasileiros (IEB) da USP, uma vez que no mesmo existia o acervo Alice Piffer Canabrava, doado por Hebe Marsiglio Carvalho, sua mãe, em 2005 - uma questão que me acompanhava naquele momento era: "Por que todo o material não foi doado ao IEB e somente uma parte?" - e ela me relatou do apreço que sua tia tinha pelo IEB e pela figura de Sérgio Buarque de Holanda, o que depois pude constatar em sua correspondência.

Quando de minhas pesquisas no acervo Alice Piffer Canabrava do Arquivo IEB/USP, tive a satisfação de conhecer a chefe do arquivo, Elizabete Marin Ribas - a Bete -, uma apaixonada pelo mundo dos arquivos. Sua alegria foi imensa ao saber da intenção de Lúcia em doar o restante do espólio de Alice Canabrava. Entretanto, o momento não era favorável, uma vez que o arquivo estava em processo de mudança. Por razão semelhante, uma possível mudança de endereço, em fevereiro de 2015, Lúcia me contatou. Então, expliquei a situação à Bete que se dispôs a receber todo o material em 
meio à mudança de prédio. Lúcia e eu levamos todo o material ao IEB e Bete agradeceulhe com flores e um cartão. Momento emocionante para todos.

Efetuada a mudança e tendo em vista que havia dito à Bete que me dispunha a ajudá-la em que fosse necessário - o que não era figura de retórica - recebi o convite para descrever esta parte do espólio incorporada ao já existente Acervo Alice Piffer Canabrava. Aqui se inicia uma experiência ímpar, que muito contribuiu para meu trato com essas novas fontes e que descrevo no apêndice 2 .

Em sua fortuna crítica, analisada extensamente na introdução de nossa dissertação ${ }^{9}$, as três teses de Alice Canabrava são estudadas por três de seus exorientandos, Flávio Azevedo Marques de Saes, Nelson Hideiki Nozoe e Zélia Maria Cardoso de Mello e vinculadas, genericamente, a Escola dos Annales com a justificativa do uso sistemático da geografia e de fontes variadas ${ }^{10}$. Em artigo de Maria Alice Rosa Ribeiro sobre as primeiras pesquisadoras em história econômica no Brasil, o mesmo argumento é mobilizado: a produção historiográfica da historiadora tem a influência da escola dos Annales ${ }^{11}$. Canabrava é citada por José Honório Rodrigues como uma das poucas historiadoras preocupadas com a incipiente história econômica ao lado de outros autores como Amaro Cavalcanti, Leopoldo Bulhões, João Pandiá Calógeras, Antonio Carlos Ribeiro de Andrada, F. T. de Sousa Reis, Afonso Taunay, Roberto Simonsen, Alfredo Ellis Júnior, Caio Prado Júnior, Afonso Arinos de Melo Franco, Josias Leão, Marcos Carneiro de Mendonça, José Jobim, Pires do Rio, José J. F. Normano, Wanderley Pinho e Francisco Iglésias ${ }^{12}$. A autora também é mencionada pontualmente por José Roberto do Amaral Lapa como uma das poucas historiadoras que se preocuparam com a historiografia, ao lado de Nelson Werneck Sodré, José Honório Rodrigues, Sérgio Buarque de Holanda, Caio Prado Júnior e Octávio Tarquínio de Sousa citando sua colaboração no Manual Bibliográfico de Estudos Brasileiros ${ }^{13}$. Seu amigo e colega de

\footnotetext{
${ }^{9}$ Cf. ERBERELI JÚNIOR, op. cit., 2014, p. 15-21.

${ }^{10}$ Cf. MELlO, Zélia Maria Cardoso de; NOZOE, Nelson Hideiki; SAES, Flávio Azevedo Marques de. Três Pesquisas Pioneiras em História Econômica (as teses universitárias de Alice Piffer Canabrava). Estudos Econômicos. São Paulo. v. 15, n. especial, 1985.

${ }^{11}$ RIBEIRO, Maria Alice Rosa. As primeiras pesquisadoras brasileiras em história econômica e a construção da disciplina no Brasil. história econômica \& história de empresas. São Paulo. v. II, n. 2, 1999.

${ }^{12}$ RODRIGUES, José Honório. Teoria da História do Brasil. Introdução metodológica. $3^{\circ}$ edição. São Paulo: Companhia Editora Nacional, 1969, p. 167.

${ }^{13}$ LAPA, José Roberto do Amaral Lapa. História e Historiografia brasileira pós 64. Rio de Janeiro: Paz e Terra, 1985, p. 51.
} 
ofício, Francisco Iglésias aponta-a como pioneira nos estudos historiográficos, nos de história econômica e na mobilização do aparato metodológico da história quantitativa ${ }^{14}$.

A essa fortuna crítica veio somar-se nossa dissertação que, sinteticamente, objetiva analisar a produção historiográfica de Alice Canabrava a partir de sua formação e atuação nas FFCL $^{15}$ e FCEA da USP e como essa produção se alicerçou em sua formação geográfica com inspiração nos estudos da área de história da historiografia.

A presente tese parte de outras preocupações, mesmo que ainda dialogue com questões afeitas a área de história da historiografia, vinculadas a história intelectual, a sociologia dos intelectuais e aos estudos em torno da escrita de si e da (auto)biografia. Ao construir e analisar a trajetória intelectual da historiadora problematizamos questões afeitas ao ofício de historiador tendo como lócus privilegiado a universidade. Nesse sentido, acompanhar a participação dela na estruturação da primeira comunidade profissional de historiadores no Brasil, a antiga Associação de Professores Universitários de História (APUH), atual ANPUH, nos ajuda a compreender os debates e embates em torno da conformação do ofício de historiador em novos moldes, em torno de uma disputa sobre as regras do ofício. Nesse mesmo sentido, em torno da construção de instituições ligadas a universidade, analisar sua atuação junto ao IEB/USP e, especialmente, durante os trabalhos da área de história do Encontro Internacional de Estudos Brasileiros. I Seminário de Estudos Brasileiros, significa compreender as disputas em torno de uma tentativa de delimitação da área de história da historiografia brasileira, bem como seus pressupostos epistêmicos. Por fim, uma trajetória intelectual também comporta uma vida que por sua vez também se liga à memória desse sujeito. Assim, analisamos como suas relações de amizade e de afeto serviram para forjar sua memória e como essa é também objeto de disputas após seu desaparecimento. Ademais, nossa contribuição soma-se aos

\footnotetext{
${ }^{14}$ IGLÉSIAS, Francisco. Comentário. In: CANABRAVA, Alice Piffer; HOLANDA, Sérgio Buarque de; LUZ, Nicia Vilela. Anais Encontro Internacional de Estudos Brasileiros. I Seminário de Estudos Brasileiros. São Paulo: Universidade de São Paulo/Instituto de Estudos Brasileiros, 1972, p. 22. IGLÉSIAS, Francisco. A História no Brasil. In: FERRI, Mário Guimarães; MOTOYAMA, Shozo. História das Ciências no Brasil. São Paulo: EPU; Editora da Universidade de São Paulo, 1979, p. 271. IGLÉSIAS, Francisco. A Historiografia da América Latina. Revista de Historia de América. Havana, n. 75/76, 1973, p. 69. IGLÉSIAS, Francisco. Os historiadores do Brasil: capítulos de historiografia brasileira. Rio de Janeiro: Nova Fronteira; Belo Horizonte: UFMG, IPEA, 2000, p. 20, 168, 175, 231-232.

${ }^{15}$ Esta denominação, Faculdade de Filosofia, Ciências e Letras (FFCL) perdurou de sua fundação em 1934 até a reforma universitária de 1968, quando deu origem à outras Faculdades e Institutos, sendo um deles a atual Faculdade de Filosofia, Letras e Ciências Humanas (FFLCH).
} 
escassos trabalhos sobre trajetórias acadêmicas femininas que incorporam uma perspectiva de gênero, preocupação que perpassa toda a tese ${ }^{16}$.

A tese está dividida em quatro capítulos. No primeiro capítulo, denominado "Alice Piffer Canabrava entre duas culturas acadêmicas: a Faculdade de Filosofia, Ciências e Letras (FFCL) e a Faculdade de Ciências Econômicas e Administrativas (FCEA) da Universidade de São Paulo (USP)", analisamos a cultura acadêmica de cada um desses lugares sociais nos quais ela esteve inserida profissionalmente. Apesar das especificidades de cada um, naquele momento de baixa inserção da mulher na vida acadêmica brasileira, ainda se tratavam de lugares misóginos vis a vis o preterimento de Alice no concurso para a cadeira de História da Civilização Americana de 1946 e os constrangimentos enfrentados durante o período em que foi diretora da FCEA (19541957). A partir desse momento de crise, vislumbramos, através da proposta de reforma curricular dos cursos da FCEA em comissão presidida por ela, uma noção de Ciência Econômica e do perfil do profissional economista.

A cultura acadêmica peculiar da FCEA/USP permitiu à Alice forjar sua própria cultura acadêmica, ou seja, uma concepção de pesquisa e ensino em história, compreendida como dedicação integral ao ofício - daí o subtítulo de nossa tese. A manutenção da cadeira de História Econômica junto à FEA/USP após a reforma universitária, permitiu a continuidade de seu trabalho com a equipe de História dirigida por ela. A marca desse trabalho se consubstancia na gama de dissertações e teses orientadas ao longo dos anos 1970, bem como seus próprios trabalhos. Esses trabalhos possuem como unidade metodológica a história quantitativa e como unidade temática, $\mathrm{o}$ espaço paulista em vários momentos. Todas essas condições somadas ao seu processo de autonomia intelectual permitiram-lhe alçar uma nova interpretação de Brasil a partir de São Paulo. A principal inspiração teórica desse capítulo e que também acompanha a tese

\footnotetext{
${ }^{16}$ Há somente duas teses na área de história que se debruçam sobre trajetórias femininas: MACHADO, Daiane Vaiz. Por uma "ciência histórica": o percurso intelectual de Cecília Westphalen, 1950-1998. 2016. 338 f. Faculdade de Ciências e Letras de Assis - UNESP. Tese (Programa de Pós-Graduação em História e Sociedade). $2016 . \quad$ Disponível em: <https://repositorio.unesp.br/bitstream/handle/11449/143940/machado_dv_dr_assis_int.pdf?sequence=7 \&isAllowed $=\mathrm{y}>$. Acessado em 21 de abr. 2019. LIBLIK, Carmen Silvia da Fonseca Kummer. Uma história toda sua: trajetórias de historiadoras brasileiras (1934-1990). 2017. 343 f. Tese (Programa de PósGraduação em História) - SCH/UFPR, Curitiba, 2017. Disponível em: $<$ https://acervodigital.ufpr.br/bitstream/handle/1884/48871/R\%20-\%20T\%20\%20CARMEM\%20SILVIA\%20DA\%20FONSECA\%20KUMMER\%20LIBLIK.pdf?sequence=1\&isAllo wed=y $>$. Acessado em 21 de abr. 2019.
} 
é a noção de "cultura acadêmica" forjada por Fritz Ringer e a partir da qual pensamos as várias formas de ensinar e pesquisar e suas relações com a vida acadêmica e social em cada um desses lugares sociais e dela em particular. No que tange às fontes mobilizadas na escrita desse capítulo temos um conjunto de fontes atravessadas pela memória: duas entrevistas e um depoimento de Alice; entrevistas de coetâneos e cartas trocadas com seus próximos. Outro conjunto de fontes são as atas do Conselho Universitário e da Congregação da FCEA/USP e de matérias sobre a faculdade veiculadas no jornal $O$ Estado de S. Paulo.

No segundo capítulo, "Tramas em Associação e Revista: redes de sociabilidade e identidade historiadora”, acompanhamos, através principalmente dos Anais dos vários Simpósios, Alice durante a fundação da Associação dos Professores Universitários de História (APUH) na FFCL de Marília/SP em 1961 quando foi eleita primeira secretária da entidade até o momento em que encerra sua participação por meio da saída do conselho consultivo da Revista Brasileira de História $(R B H)$ em 1985. Através de sua atuação por 18 anos como secretária da APUH (1961-1978) - depois de 1971, ANPUH - e como presidente no biênio 1979-1981, podemos acompanhar a formação e maturação da primeira associação a congregar historiadores vinculados à vida acadêmico-universitária no Brasil, bem como seus esforços para que a mesma, através da fundação de núcleos regionais em cada estado da federação, atingisse grande capilaridade. Toda essa vasta rede de sociabilidade tecida por ela se materializa através das cartas circulares enviadas por ela aos associados e aos presidentes de cada núcleo regional.

Através de sua atuação nos vários Simpósios, na condição de expositora ou de debatedora, pudemos localizar para Alice uma identidade historiadora. Para tanto, valemo-nos da noção de "identidade historiadora" proposta por Francisco Falcon compreendida como a intenção do sujeito em produzir um texto histórico e o reconhecimento pelos pares desse mesmo texto. Ela, em relatório da equipe de história do Brasil e história da América apresentado no I Simpósio, identifica duas identidades historiadoras: uma corporificada em Afonso Taunay e tributária de uma "história historisante" a la século XIX e outra, corporificada em Lucien Febvre, que amplia a noção de fontes e promove o diálogo com as ciências sociais. Identificamos duas práticas na identidade historiadora de Canabrava: história se faz em diálogo com as ciências sociais, em seu caso, especialmente com a economia e com a mobilização de "fontes primárias". 
A fundação da $R B H$ em 1981, marca sua despedida da associação. Analisamos como se deu a fundação do primeiro periódico brasileiro vinculado à associação profissional de historiadores, seus percalços de publicação, até a saída definitiva de Alice Canabrava do conselho consultivo.

No terceiro capítulo, "Alice Piffer Canabrava, o Instituto de Estudos Brasileiros da USP e o 'Encontro Internacional de Estudos Brasileiros. I Seminário de Estudos Brasileiros", tendo por fontes as Atas do Conselho de Administração (CA) do IEB e os relatórios gerais de atividades publicados na Revista do IEB, analisamos a participação dela no setor de documentação e pesquisa e nos cursos de férias dessa instituição. O IEB foi criado a partir da concepção de Sérgio Buarque de Holanda de que uma realidade tão complexa como a brasileira não poderia ser tratada por uma única área, o que fica claro em seu projeto da coleção denominada de História Geral da Civilização Brasileira (HGCB). Tendo isso em perspectiva, e as insuficiências da cadeira de História da Civilização Brasileira em formar um pesquisador com experiência no manejo de fontes, Sérgio propôs em 1962 a criação do IEB. Nele foram congregadas as várias cadeiras das Faculdades da USP que tivessem como objeto de análise a realidade brasileira, dentre elas a História Econômica do Brasil da FCEA/USP.

No ano de 1966 estabeleceu-se um projeto de pesquisa comum, "O Brasil às vésperas da independência", reunindo-se todas as cadeiras e todos os historiógrafos do IEB. Alice ficou responsável pelos tópicos que trataram da vida econômica e social e que já haviam sido tratados por ela em seus cursos na FCEA e em suas pesquisas, não se constituindo em nova agenda de pesquisa. A participação de Canabrava no CA foi tímida até 1971 quando assumiu a chefia do setor de pesquisa e documentação. E passou a emitir pareceres sobre acesso à manuscritos do acervo do IEB, publicação de obras etc.

O IEB oferecia duas modalidades de curso: os cursos de extensão e os cursos de férias. Verificamos que a historiadora não participou de nenhum dos cursos de extensão, uma vez que se tivermos em vista os assuntos tratados, em muitos casos afeitos à história econômica, ela poderia ter proferido conferência, aula ou palestra. No caso dos cursos de férias, as temáticas, como os séculos do Barroco, mais afeitas à área de Literatura Brasileira vinculada à Aderaldo Castello, diretor da instituição desde 1966 até 1981, não propiciavam abordagem a partir de sua especialidade. Mesmo assim proferiu conferência sobre “A grande crise do século XVI" durante o curso de férias de 1976. Questionamo- 
nos se a área de História Econômica no IEB não foi marginalizada vis a vis a hegemonia da área de Literatura Brasileira comandada pelo diretor e que também acumulava as funções de chefe do setor cultural, responsável pelos cursos de extensão e férias.

A partir dos Anais do Encontro Internacional de Estudos Brasileiros. I Seminário de Estudos Brasileiros, I SEB, ocorrido no IEB em 1971, analisamos a monografia da área de História apresentada por Alice, com o fito de extrair uma noção de história da historiografia brasileira e a delimitação do campo a partir dos debates suscitados. Sua monografia, apesar de não apresentar sistematização e teoria, justificada pelo fato de que contara com pouco tempo para sua elaboração, foi dividida em várias partes para facilitar a análise. Destacamos, por ora, algumas características da monografia: o privilégio à área de história econômica; em alguns momentos a indistinção entre fonte e historiografia; a noção caiopradiana de sentido da colonização como espelho da historiografia, ou seja, conforme a historiadora acompanhava os liames da colonização apresentava novas fontes dela provenientes, bem como sua historiografia; análise de obras de autores de outras ciências sociais, o que denota sua concepção multidisciplinar.

Durante os debates, pudemos notar que a história da historiografia brasileira estava em disputa, principalmente a partir das análises de Cecília Westphalen e de Emília Viotti da Costa que discordaram em vários pontos da sua exposição, sendo que essa última propôs outra modalidade de análise, a partir do desenvolvimento sócioeconômico brasileiro. Francisco Iglésias propôs que Alice dividisse o relatório em fontes e historiografia, esclarecendo o conceito de história e o conceito de historiografia. Frédéric Mauro, por seu turno, propôs uma análise em três tempos da historiografia brasileira, baseado no esquema temporal tripartite de Braudel.

No quarto e último capítulo, “Alice Piffer Canabrava: do si-mesmo ao outro”, por meio dos estudos sobre escritas de si, (auto)biografia e correspondências privadas, inspirados na noção de identidade narrativa de Paul Ricoeur, analisamos como a historiadora forja uma memória de si que passa pelo outro, pelo próximo, por seu arquivo pessoal, bem como se dão as disputas em torno dessa memória após seu desaparecimento.

Por meio de um depoimento e duas entrevistas, em uma chave de incitação da memória que passa pelo outro, apresentamos três biografemas, as menores unidades que possibilitam o discurso (auto)biográfico, infância, vocação e ser comum, como pontos de um fio narrativo para uma invenção de si por Alice a partir dos estudos de Leonor Arfuch. 
A infância é mobilizada como instância explicativa na formação de seu caráter para o enfrentamento das condições adversas do concurso de 1946 junto a cadeira de História da Civilização Americana na FFCL/USP. A vocação, pensada a partir da proposta de Jeremy Popkin, é atribuída por Alice ao encantamento com Fernand Braudel e o ser comum, que passa pelo signo mitológico dos começos difíceis, está presente em suas dificuldades enfrentadas na FFCL, na direção da FCEA/USP e nas dificuldades quando de sua chegada nessa casa para obtenção de financiamento para suas pesquisas.

O Fundo Alice Piffer Canabrava do Arquivo IEB/USP nos dá a ver várias Alice: irmã, filha, professora, orientadora, amiga... A partir da inspiração em Michel de Certeau, a ausência como condição de possibilidade do discurso do historiador que tem acesso apenas aos rastros, lançamos algumas questões sobre esse acervo pessoal e, portanto, à ela. O que significam as presenças de cópias carbonadas de muitas cartas remetidas? Estaria ela arquivando a própria vida? Por que a documentação foi doada ao IEB? E por que em dois momentos diferentes?

Encontramos também várias Alice na correspondência com seus próximos. Com Francisco Iglésias, o principal afeto presente é a amizade estabelecida pela confiança e sinceridade. Essa amizade também é mobilizada enquanto método de trabalho historiográfico, uma vez que ele sempre pede a gentileza da amiga na apreciação de textos. Ademais, a admiração intelectual mútua é outra característica desta amizade e ele espera nela uma produção historiográfica que revolucionaria a historiografia econômica. O amigo insiste para que ela publique logo o livro com seus estudos sobre São Paulo, os contidos na História Geral da Civilização Brasileira e os que tem trabalhado. Contudo, é um livro sempre em espera.

Na correspondência com seu ex-orientando e professor da FEA/USP, Antonio Emílio Muniz Barreto, encontramos uma Alice maternal, para além da orientadora. O corpo, assim como na correspondência com Iglésias, também se faz presente, como nas notícias sobre saúde e na preocupação de Alice com a depressão de Antonio Emílio. A correspondência com sua colega de graduação Maria Celestina Teixeira Mendes Torres é marcada pela nostalgia. As amigas rememoram os professores franceses, a dedicação aos estudos, uma memória comum compartilhada. É a pessoa nostálgica dos tempos de FFCL/USP, apesar do trauma do concurso de 1946. Por fim, a correspondência com dois ex-orientandos, Zélia Maria Cardoso de Mello e Ronaldo Marcos dos Santos se dá pelo 
fato de que ambos estavam realizando estágio de pesquisa no exterior. A primeira em Londres e o segundo em Paris. Temos aqui a Alice orientadora, como no caso de Ronaldo, em que pede para que faça contatos e assista cursos, mas também há pedido de favores para Zélia, como compra de louças, o que somente é possível pelo fato de ambas serem mulheres.

Alguns autores tentaram forjar uma memória sobre ela. Por isso analisamos dois textos de Flávio Saes; de José Jobson de Andrade Arruda, Raquel Glezer e Maria Alice Rosa Ribeiro. São memórias em disputa, situação da qual esse trabalho também não está alheio.

\section{Antes do ingresso na FFCL/USP}

Alice Piffer Canabrava. Como se diz: nome forte. Nome que identifica um sujeito ${ }^{17}$. Porém um sujeito fragmentado, que se expressa em várias funções sociais: filha, irmã, estudante, professora, historiadora, acadêmica, mulher... Na busca por este outro, que se desdobra em tantos outros, (des)encontramos Alice, filha de um fazendeiro - que era casado e que não reconheceu a paternidade - e de uma costureira ${ }^{18}$ na minúscula Araras/SP da década de $1910^{19}$ em idas e vindas: sai, juntamente com sua irmã Clementina, para cursar o famoso colégio anglo-americano Stafford ${ }^{20}$. Colégio de classe média nos Campos Elíseos em São Paulo, por onde também passaram mulheres que iria

\footnotetext{
17 Talvez o nome seja a unidade identificadora que, ilusoriamente, mais tende a imprimir uma constância ao si, em um intento de totalização e unificação do eu. Cf. BOURDIEU, Pierre. A ilusão biográfica. In: Razões práticas: sobre a teoria da ação. $11^{a}$ edição. Campinas: Papirus, 2011, p. 77-80. Bourdieu, nesse texto publicado originalmente em 1986, promove uma homologia entre esta análise do nome e a análise do que denomina história de vida, que podemos compreender por biografia tradicional. Sua proposta é de inserir o indivíduo na estrutura do campo e analisar suas posições sucessivas em um devir que não pode ser vislumbrado a priori. "Os acontecimentos biográficos definem-se antes como alocações e como deslocamentos no espaço social, isto é, mais precisamente, nos diferentes estados da estrutura da distribuição dos diferentes tipos de capital que estão em jogo no campo considerado". Cf. Idem, p. 81-82. Também editado em: BOURDIEU, Pierre. A ilusão biográfica. In: AMADO, Janaína; FERREIRA, Marieta de Moraes (orgas.). Usos \& abusos da história oral. $8^{a}$ edição. Rio de Janeiro: FGV, 2006, p. 183-191.

${ }^{18}$ Cf. Certidão de Nascimento expedida em Araras/SP em 30 de jul. de 1987, Alice, formalmente, é filha de Vicente Leonardi e de Ottilia Piffer. Sua mãe Ottilia pediu ao amigo Vicente para que registrasse Alice como sua filha (informação fornecida por Lúcia Carvalho, meia sobrinha-neta de Alice, em 30 de junho de 2016). Ver: Certidão de Nascimento. Arquivo IEB/USP: APC-IC-001. Todas as referências com a sigla APC encontram-se no Arquivo IEB/USP.

${ }^{19}$ A estimativa populacional para Araras/SP em 1910 é de 21.574 habitantes. Cf. Annuario estatístico do Brazil - Vol. 1 (1908/1912) editado pela Directoria Geral de Estatística do Ministério da Agricultura, Indústria e Commércio.

${ }^{20}$ Dois boletins de Alice se encontram no Arquivo IEB/USP: um boletim de 1924 (APC-GIN-001), quando cursava o quinto ano do antigo ginásio e um de 1925 (APC-GIN-002).
} 
conhecer na antiga FFCL/USP, como Gilda de Mello e Souza ${ }^{21}$. Alice e sua irmã estudaram no internato deste colégio entre 1923 e 1925, curso complementar realizado após a conclusão do ensino médio em preparação para a Escola Normal ${ }^{22}$ - uma vez que à época apenas três cidades ofereciam o curso secundário oficial: São Paulo, Campinas e Ribeirão Preto ${ }^{23}$.

Minha irmã e eu fomos as únicas meninas da cidade a prosseguir os estudos após o término do primário. Viemos para o internato de excelente estabelecimento de ensino da capital, o Colégio Stafford, já desaparecido. $\mathrm{O}$ corpo docente constituía-se de professores leiga, dedicada e eficiente [sic]. Lá passei três anos antes de ingressar na Escola Normal. [...]. As classes eram mistas, admitindo-se, como externos, alunos do sexo masculino ${ }^{24}$.

Já aí demarca uma singularidade: sua irmã e ela foram as únicas da cidade a continuar os estudos, após a conclusão do ensino primário no grupo escolar de Araras/SP. Permanece em São Paulo para cursar a Escola Normal Caetano de Campos na Praça da República, entre 1926 e 1930. Em duas ocasiões rememorou ${ }^{25}$ este período formativo. Em entrevista concedida em 30 de setembro de 1981 na sala de gravações do Museu da

\footnotetext{
${ }^{21}$ Alice e sua irmã Clementina eram estranhas ao mundo em transformação da São Paulo da década de 1920 e não pertenciam à classe social que frequentava o Colégio, ligada aos tradicionais proprietários de terra e à burguesia industrial ascendente. Teriam Alice e sua irmã introjetado um novo habitus ou aí se iniciaria na trajetória de ambas a formação de um habitus clivado? Para Pierre Bourdieu e Jean-Claude Passeron, a escola contribui para reproduzir as diferenças sociais e os habitus de classe. Cf. BOURDIEU, Pierre; PASSERON, Jean-Claude. A Reprodução. Elementos para uma teoria do sistema de ensino. $6^{a}$ edição. Petrópolis: Vozes, 2013.

${ }^{22} \mathrm{O}$ sistema educacional paulista passou por profundas transformações durante a década de $1920 \mathrm{em}$ decorrência da reforma implantada por Sampaio Dória, diretor da Instrução Pública estadual. No que tange ao ensino primário, a idade escolar de ingresso passou dos sete, para os nove anos de idade, ministrado em dois anos. A segunda etapa desse ensino primário básico de dois anos é o ensino médio, ministrado em escolas reunidas e grupos escolares. Ao ensino médio segue-se o ensino complementar com duração de três anos, ministrado em escolas complementares que são anexas às escolas normais. $\mathrm{O}$ ensino complementar visa à preparação para as escolas normais ou para os ginásios. Portanto, o ensino primário em São Paulo passa para sete anos, sendo que apenas os dois primeiros anos são gratuitos e obrigatórios. Cf. NAGLE, Jorge. Ensino primário. In: Educação e Sociedade na Primeira República. $3^{\mathrm{a}}$ edição. São Paulo: EDUSP, 2009, p. 226-239.

${ }^{23}$ Inspirado em Erving Goffman, Pierre Bourdieu pensa o internato como uma instituição total. Neste aspecto, apesar de Alice e sua irmã serem provenientes de outra classe social, a estada nesse colégio de classe média de São Paulo, certamente inferiu ou interferiu na formação de um habitus, talvez clivado. Ver: GOFFMAN, Erving. Manicômios, prisões e conventos. $7^{\mathrm{a}}$ edição. São Paulo: Perspectiva 2010.

${ }^{24}$ CANABRAVA, Alice Piffer. Alice Piffer Canabrava: historiadora. In: BLAY, Eva Alterman; LANG, Alice Beatriz da Silva Gordo (orgas.). Mulheres na USP: horizontes que se abrem. São Paulo: Associação Editorial Humanitas, 2004, p. 101.

${ }^{25} \mathrm{~A}$ análise das memórias de Alice tem a inspiração teórica no livro de Paul Ricoeur. Cf. RICOEUR, Paul. Da memória e da reminiscência. In: RICOEUR, Paul. A memória, a história, o esquecimento. Campinas: Editora da Unicamp, 2007, p. 23-142.
} 
Imagem e do Som de São Paulo (MIS/SP), no projeto "Estudos Brasileiros"26 coordenado por Ernani da Silva Bruno, e tendo como entrevistadores Flávio Azevedo Marques de Saes $^{27}$, José Ribeiro de Araújo Filho ${ }^{28}$ e Oracy Nogueira ${ }^{29}$. Alice, ao abrir a entrevista perpassando sua trajetória a pedido de Bruno, afirma que o curso Normal foi "um excelente curso para a época" e que "recebi até prêmios na escola Normal, pelo professor de História" ${ }^{30}$. A importância deste prêmio para ela é grande, uma vez que em seu memorial para o concurso da cadeira de História da Civilização Americana da FFCL/USP de 1946, menciona que recebeu em 1930 o diploma de habilitação para o magistério público em São Paulo e o prêmio Barão do Rio Branco para o aluno com as maiores notas em História e Geografia durante o curso ${ }^{31}$.

Três anos depois, Alice Canabrava, em depoimento em sessão especial organizada pelo Centro de Estudos Rurais e Urbanos da USP (CERU), sob os auspícios de Eva Alterman Blay e Alice Beatriz da Silva Gordo Lang, durante a reunião anual da Sociedade Brasileira para o Progresso da Ciência (SBPC) em julho de 1984, também rememora os tempos da Escola Normal. O depoimento foi revisado por ela e exposto já sob o império da escrita, que exclui e silencia tantos aspectos ${ }^{32}$, e publicado em 2004 no livro "Mulheres na USP: horizontes que se abrem". A historiadora rememora sua formação na Escola

\footnotetext{
${ }^{26}$ O Projeto Estudos Brasileiros, “[...] tem por objetivo a gravação de depoimentos de intelectuais que se destacaram, por suas pesquisas e reflexões, nas áreas de História, Sociologia, Antropologia, Folclore e Economia voltadas para o estudo da realidade nacional". Cf. ESB (46) 1-12. Fundo Ernani da Silva Bruno. Arquivo IEB/USP.

${ }^{27}$ Flávio Azevedo Marques de Saes foi seu orientando de mestrado na atual FEA/USP e na ocasião da entrevista Alice se refere a ele como "o membro mais brilhante da equipe e no qual eu deposito as minhas maiores esperanças".

${ }^{28}$ Alice menciona no início da entrevista que a presença de Araújo Filho lhe lembra o geógrafo Pierre Monbeig.

${ }^{29}$ Oracy Nogueira foi figura atuante na institucionalização das ciências sociais no Brasil, professor da Escola Livre de Sociologia e Política de São Paulo (ELSP/SP), onde realizou sua graduação (1942) e mestrado (1945). Iniciou sua carreira no Instituto de Administração da FCEA em 1952; foi instrutor da cadeira XI de sociologia geral e aplicada até 1969; realizou concurso para professor adjunto em 1978 e em 1981 figurava como professor titular da disciplina "sociologia aplicada à economia". Cf. CANABRAVA, Alice Piffer (org. coord.). História da Faculdade de Economia e Administração da Universidade de São Paulo, 1946-1981. V. 2: Personália. São Paulo: FEA/USP, 1984, p. 67.

30 Cf. CANABRAVA, Alice Piffer. Entrevista. Projeto Estudos Brasileiros. MIS/SP, 1981. 00035EBR00026AD (Estudos brasileiros rolo 116.27 A-0150).

${ }^{31}$ Processo 46.1.126.8.7 (Arquivo da FFLCH da USP: inscrição no concurso para a Cadeira de História da Civilização Americana, 1946). Memorial, p. 1.

${ }^{32}$ Da operação científica e/ou historiográfica resulta uma escrita que "[...] julga-se por aquilo que cala. Ora, é preciso reconhecer, os estudos científicos - e, sem dúvida, também as obras que eles privilegiam comportam estranhas e vastas regiões de silêncio. Esses brancos desenham uma geografia do esquecido [itálico no original]". CERTEAU, Michel; JULIA, Dominique; REVEL, Jacques. A beleza do morto. In: CERTEAU, Michel de. A cultura no plural. $7^{a}$ edição. Campinas: Papirus, 2012, p. 73.
} 
Normal em contraponto com o ensino no curso de Geografia e História durante sua graduação (1935-1937) e mais uma vez demarca o alto desempenho em história. "A História sempre fora uma das matérias preferidas na Escola Normal, premiada como a melhor aluna do curso com base em leituras que ultrapassavam, em muito, as aulas do professor" 33 .

No livro de matrícula e notas da Escola Normal, encontramos as notas de Alice por disciplina durante os cinco anos do curso. Abaixo, o quadro das disciplinas com as respectivas notas para seu segundo ano, ou seja, 1927 (quadro 1) ${ }^{34}$ :

\begin{tabular}{|c|c|c|c|c|c|c|c|c|}
\hline Matérias & $\begin{array}{c}\text { Aplicação } \\
\text { (I } \\
\text { semestre) }\end{array}$ & Exame & $\begin{array}{c}\text { Aplicação } \\
\text { (II } \\
\text { semestre) }\end{array}$ & Exame & Soma & Média & Coeficiente & Pontos \\
\hline $\begin{array}{c}\text { Português } \\
\text { e } \\
\text { Caligrafia }\end{array}$ & 8 & 9,5 & 12 & 12 & 41,5 & 10,37 & 8 & 82,96 \\
\hline Latim & 12 & 12 & 12 & 12 & 48 & 12 & 5 & 60 \\
\hline Francês & 11 & 12 & 12 & 12 & 47 & 11,75 & 5 & 58,75 \\
\hline Inglês & 10 & 10 & 12 & 12 & 44 & 11 & 4 & 44,00 \\
\hline $\begin{array}{c}\text { Geografia } \\
\text { da }\end{array}$ & $\mathbf{1 1}$ & $\mathbf{1 1}$ & $\mathbf{1 2}$ & $\mathbf{9}$ & $\mathbf{4 3}$ & $\mathbf{1 0 , 7 5}$ & $\mathbf{6}$ & $\mathbf{6 4 , 5}$ \\
$\begin{array}{c}\text { América e } \\
\text { do Brasil }\end{array}$ & 12 & 11 & 12 & 12 & 47 & 11,75 & 6 & 70,5 \\
\hline Álgebra & 11 & 12 & 12 & 12 & 47 & 11,75 & 6 & 70,5 \\
\hline $\begin{array}{c}\text { Geometria } \\
\text { Plana }\end{array}$ & 6 & 6 & 6 & 6 & 24 & 6 & 4 & 24 \\
\hline Desenho & 10 & 10 & 12 & 8 & 40 & 10 & 3 & 30 \\
\hline Música & 12 & 12 & 12 & 10 & 46 & 11,5 & 3 & 34,5 \\
\hline Ginástica & & & & & & & & 539,71 \\
\hline Total & & & & & & & \\
\hline
\end{tabular}

(Fonte: Caderno de matrícula e notas (1926-1930), n. 60. Arquivo Histórico Escola Normal Caetano de Campos (AHECC). Centro de Referência em Educação Mário Covas (CRE). Escola de Formação e Aperfeiçoamento dos Professores (EFAP). Secretária de Educação do Estado de São Paulo (SEE/SP)).

Conforme podemos observar no quadro, a média de cada disciplina é calculada pelo somatório das notas de aplicação e exame dos dois semestres e dividido por quatro. Ao passo que os pontos derivam da multiplicação da média pelo coeficiente de cada

\footnotetext{
${ }^{33}$ CANABRAVA, op. cit., 2004, p. 90-91.

${ }^{34}$ Quanto às notas de seu primeiro ano de curso, 1926, não tivemos acesso ao livro onde constam as mesmas. Apenas encontramos as disciplinas e seus respectivos coeficientes multiplicativos: Português e Caligrafia (10); Francês (7); Inglês (6); Geografia Geral (8); Aritmética (8); Desenho (4); Música (4) e Ginástica (3). Ao contrário das tendências atuais em política pedagógica que valorizam mais o ensino de Língua Portuguesa e Matemática, podemos observar que a Geografia, por exemplo, possuía o mesmo nível de importância que a Matemática. A nota total de Alice para esse ano foi de 498,60.
} 
disciplina. A nota total, por sua vez, é calculada pelo somatório dos pontos de todas as disciplinas. Sendo assim, a maior nota obtida por Alice deu-se em Português e Caligrafia $(82,96)$ que possui a maior importância relativa, dado seu maior coeficiente (8) frente às outras disciplinas. A segunda maior nota foi obtida nas disciplinas de Álgebra e Geometria Plana (70,50), sendo que Geografia da América e do Brasil, conforme destacamos em negrito, foi a terceira maior nota obtida por ela e sua importância no quadro geral das disciplinas é igual às primeiras. Podemos notar também que a historiadora não possuía aptidão para as artes vis a vis suas baixas notas em Desenho e Música.

Para os anos seguintes, exporemos apenas as disciplinas de História e sua pontuação total com o fito de empreender comparação com outras disciplinas e colegas de curso (quadro 2).

\begin{tabular}{|c|c|c|}
\hline 1928 & 1929 & 1930 \\
\hline $\begin{array}{c}\text { História da Civilização } \\
\mathbf{( 6 ) : ~ 7 2 , 0 0}\end{array}$ & $\begin{array}{c}\text { História da América (6): } \\
\mathbf{7 2 , 0 0}\end{array}$ & $\begin{array}{c}\text { História do Brasil e } \\
\text { noções de direito usual } \\
\mathbf{( 7 ) : ~ 8 4 , 0 0}\end{array}$ \\
\hline $\begin{array}{c}\text { Geometria e } \\
\text { Trigonometria: } 72,00\end{array}$ & Química: 66,72 & $\begin{array}{c}\text { Higiene e noções de } \\
\text { puericultura: } 84,00\end{array}$ \\
\hline Biologia Animal e & Anatomia e fisiologia & \\
Vegetal: 69,00 & humanas: 70,50 & \\
\hline Total: 572,75 & Total: 539,47 & Total: 559,25 \\
\hline
\end{tabular}

(Fonte: Caderno de matrícula e notas (1926-1930), n. 60. AHECC. CRE Mário Covas. EFAP. SEE/SP).

O quadro acima traz as notas, por ano, das disciplinas de História em seus vários recortes e também as disciplinas que no currículo possuem o mesmo peso. Para efeito comparativo podemos considerar somente as disciplinas de mesmo coeficiente. Para o ano de 1928, entre as disciplinas com coeficiente seis, Alice obteve maior nota em História da Civilização e Geometria e Trigonometria. Para 1929, a maior nota obtida foi em História da América e em 1930 a maior nota foi obtida em História do Brasil e noções de direito usual, juntamente com Higiene e noções de puericultura. Ela realmente obtinha maiores notas nas disciplinas de História, porém, para as disciplinas com mesmo coeficiente, a diferença não era significativa. E sua média geral foi de 541,95 ao longo dos cinco anos de curso. 
Comparando seu desempenho com três colegas que se diplomaram no mesmo dia (2 de dezembro de 1930): Adélia Dranger, da primeira turma do curso de Filosofia da FFCL/USP ${ }^{35}$; Maria Augusta Vicente Carvalho, cuja trajetória desconhecemos, mas que sabemos que não foi à FFCL/USP, tendo, provavelmente, seguido o caminho da maioria das normalistas: dedicando-se ao ensino no jardim de infância ou no curso primário e Felicio Marchatti, cuja trajetória não apresenta indícios de que tenha frequentado a FFCL/USP e, provavelmente, como a maioria dos homens normalistas, tenha ido lecionar no ensino primário (quadro 3):

\begin{tabular}{|c|c|c|c|c|}
\hline Matéria & $\begin{array}{c}\text { Alice Piffer } \\
\text { Canabrava }\end{array}$ & Adélia Dranger & $\begin{array}{c}\text { Maria A. V. } \\
\text { Carvalho }\end{array}$ & $\begin{array}{c}\text { Felicio } \\
\text { Marchatti }\end{array}$ \\
\hline $\begin{array}{c}\text { Geografia da } \\
\text { América e do } \\
\text { Brasil }\end{array}$ & $\mathbf{6 4 , 5 0}$ & Não consta & $\mathbf{5 7 , 0 0}$ & $\mathbf{5 1 , 0 0}$ \\
\hline $\begin{array}{c}\text { História da } \\
\text { Civilização }\end{array}$ & $\mathbf{7 2 , 0 0}$ & $\mathbf{6 9 , 0 0}$ & $\mathbf{6 6 , 0 0}$ & $\mathbf{4 5 , 0 0}$ \\
\hline $\begin{array}{c}\text { História da } \\
\text { América }\end{array}$ & $\mathbf{7 2 , 0 0}$ & $\mathbf{7 2 , 0 0}$ & $\mathbf{6 4 , 5 0}$ & $\mathbf{4 6 , 5 0}$ \\
\hline $\begin{array}{c}\text { História do } \\
\text { Brasil e noções } \\
\text { de direito usual }\end{array}$ & $\mathbf{8 4 , 0 0}$ & $\mathbf{8 4 , 0 0}$ & $\mathbf{7 7 , 0 0}$ & $\mathbf{7 7 , 0 0}$ \\
\hline Média geral & $\mathbf{5 4 1 , 9 5}$ & $\mathbf{5 3 4 , 3 5}$ & $\mathbf{4 6 9 , 1 5}$ & $\mathbf{4 2 3 , 2 9}$ \\
\hline
\end{tabular}

(Fonte: Caderno de matrícula e notas (1926-1930), n. 60. Caderno de matrícula e notas (19261930), n. 61. AHECC. CRE Mário Covas. EFAP. SEE/SP).

Quando comparamos suas notas com as notas de Adélia Dranger, percebemos uma grande proximidade das médias gerais e também as mesmas notas em duas disciplinas, História da América e História do Brasil e noções de direito usual. Apesar do fato de a média geral dela ser maior que a de Adélia e em História da Civilização ter obtido três pontos a mais, o desempenho de ambas é bastante próximo. Diferentemente, quando a comparamos com Maria Carvalho, ou mesmo Adélia com esta última, a diferença passa a ser mais significativa. Em nenhuma disciplina do quadro acima, Maria Carvalho se aproxima das notas de Alice. O desempenho mais próximo de Maria se dá em relação à Adélia e mesmo assim em uma única disciplina: História da Civilização. O desempenho de Felicio Marchetti está muito aquém do dela e somente pode ser comparado à algumas

\footnotetext{
35 Cf. BLAY; LANG, op. cit., 2004, p. 50. Adélia Dranger nasceu no Rio de Janeiro em 30 de maio de 1910
} 
notas de Maria Carvalho como Geografia da América e do Brasil e História do Brasil e noções de direito usual.

Sendo assim, a singularidade de Alice Canabrava se expressa para além do fato de após passagem pela Escola Normal ter ido à FFCL/USP: seu desempenho nesta fase foi ímpar, especialmente no conjunto das disciplinas de Geografia e História, valendo-lhe o prêmio Barão do Rio Branco.

Como contraponto ao esquema de aulas de Fernand Braudel, que ela rememora para além de uma história dita tradicional, caracteriza o ensino de história na Escola da Praça da República: “Acostumados a conhecer as grandes figuras da História apenas pelos seus nomes, datas e alguns eventos, sobretudo guerras e batalhas [...]"36.

A clientela da Escola Normal era formada predominantemente por moças de classe média ${ }^{37}$. Muitas das quais, posteriormente, constituiriam também a clientela da FFCL/USP. Porém, a clivagem de gênero era nítida: as alas do prédio eram separadas por gênero e seus professores eram todos homens. As mulheres predominavam somente no jardim de infância. Esta clivagem também se manifestava no currículo. As mulheres não cursavam certas disciplinas, exclusivas dos homens, como Economia Política, por exemplo, e tinham disciplinas pensadas para elas, como Economia Doméstica. Claro sinal de que a formação seria complementar à vida familiar e não a única a que poderiam se dedicar. À mulher caberia atuar em âmbito privado na educação dos filhos e não se inteirar das questões políticas, sociais e econômicos que era terreno exclusivo destinado aos homens ${ }^{38}$. No período em que frequentou a Escola Normal (1926-1930), ainda encontramos a existência de classes masculinas e femininas, mas também de classes mistas. Já era um período de transição.

Alice, formada pela Escola Normal em $1930^{39}$, através de concurso, ingressou no ensino primário em Manduri em 1931, distrito de Piraju/SP e depois conseguiu transferência para sua cidade natal. "Passei a estudar francês com um suíço e percorri boa

\footnotetext{
${ }^{36}$ CANABRAVA, op. cit., 2004, p. 92.

${ }^{37}$ As mulheres puderam ingressar na Escola Normal somente a partir de 1875. Cf. BLAY, Eva Alterman; LANG, Alice Beatriz da Silva Gordo. O cenário paulista. In: _(orgas.). Mulheres na USP: horizontes que se abrem. São Paulo: Associação Editorial Humanitas, 2004, p. 22.

${ }^{38}$ Cf. REIS, Maria Candida Delgado. Masculino/feminino: fragmentos de uma construção assimétrica. In: (orga.). Caetano de Campos: fragmentos da história da instrução pública no Estado de São Paulo. São Paulo: Associação dos ex-alunos do Instituto de Educação Caetano de Campos, p. 93-104.

${ }^{39}$ Neste ano, o ensino primário era um ambiente predominantemente feminino. Dos 2.137 diplomados no ensino normal em São Paulo, 180 eram homens e 1.957 mulheres. Porém, os homens predominavam nos cargos burocrático-administrativos. Cf. BLAY; LANG, op. cit., 2004, p. 12-24.
} 
parte da literatura disponível sobre a 'escola nova', que fui adquirindo. Procurava enfronhar-me nos modernos métodos de ensino, sobretudo quanto à alfabetização"40.

Com a Revolução de 1930, Lourenço Filho assumiu a direção da Instrução Pública e pôde implementar seu projeto em todo o Estado de São Paulo, e com Fernando de Azevedo instituíra o Instituto Caetano de Campos, nos moldes de uma Escola Normal Superior, que seria incorporado pela FFCL, quando da fundação da USP em 1934. Para tanto, não somente o ensino da Escola Normal foi reformado, mas também seu prédio, para a construção de um terceiro andar, que abrigaria a então recém-fundada FFCL/USP, entre 1939 e $1949^{41}$. Anteriormente, a FFCL/USP ocupara vários prédios e suas seções ficaram espalhadas pela cidade, na Faculdade de Medicina, na Politécnica, na mansão Conselheiro Macedo Soares, espaço em que atualmente está localizada a biblioteca Mário de Andrade. Fernando de Azevedo foi o responsável pela ida da FFCL/USP para o terceiro andar do prédio do Instituto de Educação ${ }^{42}$. Porém, foi no ano de 1935 que ele elaborou um processo de recrutamento de alunos para a FFCL/USP que mudou a trajetória de Alice: o ingresso através de comissionamento de professores primários, com vencimentos, dependendo de alto desempenho escolar ${ }^{43}$.

Como tantas outras, fui uma das professoras do magistério primário beneficiadas pelo ato do Governo Estadual que facultou o comissionamento das interessadas junto à recém-criada Faculdade de Filosofia, Ciências e Letras da Universidade de São Paulo, desde que aprovadas em concurso de provas. A medida visava preencher o grande número de vagas ${ }^{44}$.

Diante da possibilidade de frequentar o curso de Geografia e História, com seus vencimentos de professora primária, o que de outra maneira não possibilitaria sua vinda para São Paulo, Alice se inscreve, e é aprovada, para os exames da subseção.

\footnotetext{
${ }^{40}$ CANABRAVA, op. cit., 2004, p. 90.

${ }^{41}$ Cf. MONARCHA, Carlos. Escola Normal da Praça: O Lado Noturno das Luzes. Campinas: EdUnicamp, 1999.

${ }^{42}$ MOREIRA LEITE, Mirian Lifchitz. O terceiro andar da Escola da Praça. In: REIS, Maria Candida Delgado (orga.). Caetano de Campos: fragmentos da história da instrução pública no Estado de São Paulo. São Paulo: Associação dos ex-alunos do Instituto de Educação Caetano de Campos, p. 105-114.

43 “[...] por meio do qual professores primários em exercício do magistério poderiam cursar a faculdade, sem prejuízo dos vencimentos, subsidiados pela Secretaria da Educação, aproveitando, assim, a capacidade instalada da Faculdade". BLAY, Eva Alterman; LANG, Alice Beatriz da Silva Gordo. A Faculdade de Filosofia Ciências e Letras. In: (orgas.), op. cit., 2004, p. 51.

${ }^{44}$ CANABRAVA, op. cit., 2004, p. 87.
} 


\section{Capítulo 1}

Alice Piffer Canabrava entre duas culturas acadêmicas: a Faculdade de Filosofia, Ciências e Letras e a Faculdade de Ciências Econômicas e Administrativas da Universidade de São Paulo

A noção de cultura acadêmica, formulada pelo historiador alemão radicado nos EUA Fritz K. Ringer, nos auxilia a pensar as concepções de determinada comunidade acadêmica quanto ao ensino, à pesquisa, o conhecimento produzido na universidade e sua relação com o poder estatal e a sociedade. Podemos definir a noção de cultura acadêmica como: "The network of interrelated and explicit beliefs about the academic practices of teaching, learning, and research, and about the social significances of these practices" ${ }^{\prime 4}$. Assim, iremos analisar como se deram as relações sociais, práticas de ensino e pesquisa e o significado social atribuído a elas nestes dois lugares sociais $^{46}$, a FFCL/USP e a FCEA/USP, e como Alice Canabrava (res)significou estas práticas e crenças.

Ao mobilizarmos a noção de cultura acadêmica, não pretendemos tomar o estudo de Ringer como a aplicação de um modelo fechado, mas sim enquanto inspiração teórica, pois sabemos que isso implicaria em analisar os textos e as trajetórias femininas não somente do corpo docente da subseção de Geografia e História, mas também de outras seções e subseções da FFCL ${ }^{47}$. Nosso procedimento foi o de comparar algumas trajetórias femininas, não somente pertencentes à subseção de Geografia e História, como Olga Pantaleão, mas também de outras seções, como de Filosofia, caso de Gilda de Mello e Souza e Ciências Sociais e Políticas, caso de Paula Beiguelman. Adotar por inteiro o modelo ringeriano implicaria em outra pesquisa. Ademais, não deixamos de comparar a cultura acadêmica forjada pela própria Alice a alguns de seus colegas de FCEA, como Paul Hugon, por exemplo.

\footnotetext{
${ }^{45}$ RINGER, Fritz K. Fields of knowledge: French academic culture in comparative perspective, 18901920. Cambridge: Cambridge University Press, 1992, p. 13.

${ }^{46}$ Lugar social no sentido formulado por Michel de Certeau em sua "operação historiográfica". Ver: CERTEAU, Michel De. A operação historiográfica. In: A Escrita da História. $3^{\circ}$ edição. Rio de Janeiro: Forense, 2011, p. 45-111.

47 Ringer toma por fonte toda a produção do corpo docente das faculdades de artes e ciências das universidades de Berlim, Munique, Freiburg e Heidelberg. Cf. RINGER, Fritz K. O declínio dos mandarins alemães: a comunidade acadêmica alemã, 1890-1933. Tradução de Dinah de Abreu Azevedo. São Paulo: EDUSP, 2000, p. 9-10.
} 


\subsection{A cultura acadêmica da FFCL}

Uma constante nas entrevistas, missivas e em um depoimento de Alice Canabrava é a rememoração do ambiente acadêmico da FFCL/USP, principalmente em relação aos constrangimentos de gênero, a inserção da mulher na sociedade dos anos 1930 e, especificamente, o fato de ter sido preterida em concurso em 1946, aos professores da subseção de Geografia e História e ao acolhimento e possibilidades de trabalho junto à FCEA/USP.

Em mencionada entrevista ao projeto "Estudos Brasileiros”, e já consagrada, com exatos trinta anos de catedrática junto à FCEA/USP, a professora, a pedido de Bruno, repassa sua autobiografia. Um dos pontos destacados por ela diz respeito aos professores que tiveram maior influência em sua formação.

[...] o professor Pierre Monbeig a quem eu já me referi e o professor Paul Fernand Braudel professor de História Geral. Depois eu segui os cursos, depois de formada em 37, eu segui os cursos do Jean Gagé. Mas já como... não era mais aluna regular. Tive também como professor, o professor Afonso de Taunay e Plinio Ayrosa. Que devo dizer que como professores eram antiquados ${ }^{48}$.

As presenças de Fernand Braudel, de Jean Gagé ${ }^{49}$ e de Pierre Monbeig remontam, além das afinidades culturais entre Brasil e França, à "missão francesa" nos primórdios de fundação da FFCL/USP e se ligam à análise e concepção de cultura acadêmica de Paulo Duarte e do grupo de intelectuais que orbitavam em torno do jornal $O$ Estado de $S$. Paulo $^{50}$. Para Paulo Duarte, um dos aliados dos Mesquita, o Brasil não possuía a tradição acadêmica e docente de dedicação integral ao ensino e à pesquisa. Sendo assim, em um primeiro momento, dever-se-ia recrutar professores estrangeiros, que seriam gradativamente substituídos por nacionais.

À FFCL foi destinado papel central na concepção da nova universidade. Para compreender este papel faz-se mister que nos remontemos à cultura acadêmica da elite

\footnotetext{
${ }^{48}$ CANABRAVA, op. cit., 1981.

49 Para uma breve biografia dos nomes citados, ver "Apêndice biográfico".

${ }^{50}$ No projeto de fundação da Universidade de São Paulo levado à cabo pelos intelectuais do grupo de $O$ Estado de S. Paulo e capitaneados por Júlio de Mesquita Filho, objetivava-se remir a derrota paulista nos intentos constitucionalistas de 1932 por meio da formação de elites que iriam dar novos rumos ao Estado e ao país. Cf. CARDOSO, Irene. A universidade da comunhão paulista. O projeto de criação da Universidade de São Paulo. São Paulo: Cortez, 1982. Parte das questões abordadas neste livro serviram de reflexão em trabalhos posteriores da autora sobre a universidade e sua inserção nos acontecimentos de maio de 1968. Cf. CARDOSO, Irene. Para uma crítica do presente. São Paulo: USP, curso de pós-graduação em Sociologia/ Ed. 34, 2001.
} 
paulista daquele momento. Em uma perspectiva comparada, o modelo de universidade concebido por este grupo se aproximava mais do modelo alemão que do modelo francês. Durante o Império Napoleônico as universidades foram extintas na França, uma vez que a visão dos revolucionários de 1789 se manifestava no sentido de que esta instituição representava o Antigo Regime e reproduziria o esquema das corporações de ofício. No século XIX o sistema universitário francês não apresentava unidade e havia a priorização das faculdades profissionais e a dissociação entre ensino e pesquisa. Na segunda metade do século XIX as universidades voltaram a existir, porém vinculadas a um ensino para as classes populares. As elites eram formadas em instituições de excelência em ensino e pesquisa. Marca do sistema universitário francês foi o forte vínculo dos intelectuais com o Estado e a ingerência e controle sobre a universidade ${ }^{51}$. A concepção de universidade durante o primeiro governo Vargas esteve bastante próxima deste modelo, uma vez que a criação da Universidade do Distrito Federal (UDF) em 1935 se deu através da incorporação de antigas escolas profissionais, como a Escola Politécnica, a Escola de Medicina e a Faculdade de Direito ${ }^{52}$.

No Estado Novo, a participação de intelectuais foi marcante. Na criação da Faculdade Nacional de Filosofia observa-se que ela não visava à pesquisa e formação em ciência básica, mas sim se tornar núcleo para a expansão docente de primeiro e segundo graus, dentro da perspectiva de Gustavo Capanema para a expansão do ensino básico. Ademais, a contratação de professores passava pela mais alta esfera governamental e os intelectuais eram recrutados de acordo com critérios ideológicos, como ser católico e não ser de esquerda, principalmente a partir da ingerência de Alceu Amoroso Lima ${ }^{53}$.

A cultura acadêmica do grupo de $O$ Estado de $S$. Paulo, com Fernando de Azevedo, Júlio de Mesquita Filho e Armando de Oliveira Salles concebia a universidade de um modo mais próximo ao modelo que encontramos na Alemanha do século XIX. A ideia de formar uma elite dirigente para a Nação e o Estado esteve fortemente presente na

\footnotetext{
${ }^{51}$ Sobre o modelo universitário francês ver: CHARLE, Christophe. La République des universitaires (18701940). Paris: Éditions Du Seuil, 1994.

52 Para um mapeamento das condições sociais e concepções através das quais as principais universidades brasileiras foram gestadas ver: MOROSINI, Marilia (orga.). A universidade no Brasil: concepções e modelos. Brasília: Instituto Nacional de Estudos e Pesquisas Educacionais Anísio Teixeira, 2006.

${ }^{53}$ Cf. PAULA, Maria de Fátima. USP e UFRJ: a influência das concepções alemã e francesa em suas fundações. Tempo Social. São Paulo, v. 14, n. 2, p. 147-161, 2002. Ver também: ___ A formação universitária no Brasil: concepções e influências. Avaliação. Campinas/Sorocaba, v. 14, n. 1, p. 71-84, 2009.
} 
cultura acadêmica alemã até a ascensão do Nacional-Socialismo em 1933. No final do século XVIII, com as tentativas de ingerência do Estado prussiano nas universidades, algo inadmissível para a cultura acadêmica de seus professores, começou a surgir o projeto de fundação de uma nova universidade em Berlim.

Numa série de memorandos programáticos, Kant, Schelling, Fichte, F. E. D. Schleiermacher e Humboldt desenvolveram seu ideal de liberdade acadêmica. Em seus escritos misturavam-se temas idealistas, neohumanistas e mesmo pietistas. As universidades, afirmavam, não eram escolas de treinamento de funcionários públicos, como havia sido Halle. A faculdade de artes (philosophische Fakultät) devia ser o coração da nova universidade, e não a faculdade de direito, a de medicina ou a de teologia ${ }^{54}$.

A concepção do grupo de $O$ Estado de $S$. Paulo também apontava que a nova universidade deveria se coadunar em torno de uma Faculdade de Filosofia, Ciências e Letras, para a qual todas as cadeiras de ciências básicas das faculdades profissionais, que se vinculariam à USP, deveriam ser transferidas.

Uma das soluções encontradas na década de 1930 para a constituição da universidade, marcadamente em São Paulo, foi a criação de uma unidade central, de caráter não profissional, a FFCL, na qual seriam reunidas todas as cátedras de ensino de tópicos gerais, até então dispersas pelas diversas faculdades profissionais ${ }^{55}$.

A célula mater da USP seria a FFCL, com seu fundamental papel em pesquisa, e pela qual todos os alunos da universidade deveriam passar. Este grupo de intelectuais não advogava a formação clássica de todos os alunos da USP, mas como uma de suas preocupações básicas era formar a elite, pela FFCL deveriam passar os futuros dirigentes do país e do Estado, bem como a futura elite científica.

Após a fundação da Universidade em 25 de janeiro de 1934, Júlio de Mesquita Filho encarregou Teodoro Ramos, primeiro diretor da FFCL e professor da Escola Politécnica, de ir à Europa para contratar professores. E George Dumas, um antigo professor que desde os anos 1920 realizava intercâmbios culturais com o Brasil foi fundamental no recrutamento dos professores franceses, bem como o embaixador da França no Brasil vis a vis a pressão exercida pelos italianos e alemães para ocuparem

\footnotetext{
${ }^{54}$ RINGER, op. cit., 2000, p. 37.

${ }^{55}$ CELESTE FILHO, Macioniro. A constituição da Universidade de São Paulo e a reforma universitária da década de 1960. São Paulo: EDUNESP, 2013, p. 17.
} 
cátedras na $\mathrm{FFCL}^{56}$. Esta leva de professores franceses ficou conhecida por "missão francesa", sendo fundamental para a compreensão do ambiente acadêmico no qual Alice Canabrava transitou durante o período entre 1935-1946 ${ }^{57}$. Nomes que mais tarde iriam impactar seus respectivos campos de conhecimento, como Fernand Braudel ${ }^{58}$, Claude Lévi-Strauss $^{59}$, Pierre Monbeig ${ }^{60}$, Roger Bastide ${ }^{61}$ etc, naquele momento eram jovens em início de carreira e vieram ao Brasil motivados por várias circunstâncias, sendo a principal delas a de que "na França, não havia verba para pesquisa em ciências sociais, [...], e as perspectivas de ingresso no ensino superior tampouco eram animadoras" ${ }^{\prime 2}$.

Fernand Braudel ${ }^{63}$ chegou à FFCL/USP em 1935, mesmo ano de ingresso de Canabrava no curso de Geografia e História, para substituir Émile Coornaert na cadeira de História da Civilização. As relações entre ambos se iniciaram ainda em sua graduação. Quando de seu retorno à França em 1937, Braudel recomendou a historiadora ao diretor da FFCL, com o intuito de que realizasse o doutoramento ${ }^{64}$. O orientador de sua tese,

\footnotetext{
${ }^{56}$ Cf. LIMA, Luís Corrêa. Fernand Braudel e o Brasil: vivência e brasilianismo (1935-1945). São Paulo: Editora da Universidade de São Paulo, 2009, p. 53-85.

${ }^{57}$ Ver: MASSI, Fernanda. Estrangeiros no Brasil: a missão francesa na Universidade de São Paulo. 1991. 283 f. Dissertação (Programa de Pós-Graduação em Antropologia Social) - IFCH, UNICAMP, Campinas, 1991. PETITJEAN, Patrick. As missões universitárias francesas na criação da Universidade de São Paulo (1934-1940). In: HAMBURGER, Amélia Império et alli. (orgs.). A ciência nas relações Brasil-França (1850-1950). São Paulo: Edusp/FAPESP, 1996, p. 259-330. CAPELATO, Maria Helena Rolim; FERLINI, Vera Lucia Amaral; GLEZER, Raquel. Escola uspiana de História. Estudos Avançados, São Paulo, v. 8, n. 22, p. 349-358, 1994. MARTINEZ, Paulo Henrique. Fernand Braudel e a primeira geração de historiadores universitários da USP (1935-1956): notas para estudo. Revista de História. São Paulo, v. 146, p. 11-27, 2002.

${ }^{58}$ Para uma biografia de Braudel, ver: DAIX, Pierre. Braudel. Paris: Flammarion, 1995.

59 Sobre sua experiência no Brasil, ver: PEIXOTO, Fernanda. Lévi-Strauss no Brasil: a formação do etnólogo. Mana. Rio de Janeiro, v. 4, n. 1, p. 79-107, 1998. Sobre o lugar da história no pensamento de Lévi-Strauss e a recepção de sua antropologia estrutural pelos historiadores ver: IEGELSKI, Francine. Astronomia das constelações humanas. Reflexões sobre Claude Lévi-Strauss e a história. São Paulo: Humanitas, 2016.

${ }^{60}$ Sobre os tempos de Monbeig no Brasil, ver: AB’SÁBER, Aziz Nacib. Pierre Monbeig: a herança intelectual de um geógrafo. Estudos Avançados. São Paulo, p. 221-232, 1994. Sobre a contribuição epistemológica de Monbeig para a geografia brasileira ver: SALGUEIRO, Heliana Angotti (org.). Pierre Monbeig e a geografia humana brasileira: a dinâmica da transformação. Bauru: Edusc, 2006. VITTE, Antonio Carlos. Breves considerações sobre o papel de Pierre Monbeig na formação do pensamento geomorfológico uspiano. Revista de Climatologia e Estudos da Paisagem. Rio Claro, v. 4, p. 50-69, 2009. ${ }^{61}$ Para uma síntese de sua estada no Brasil, ver: QUEIRÓZ, Maria Isaura Pereira de. Roger Bastide, professor da Universidade de São Paulo. Estudos Avançados. São Paulo, v. 8, n. 22, p. 215-220, 1994.

62 MASSI, Fernanda. Franceses e norte-americanos nas ciências sociais brasileiras (1930-1960). In: MICELI, Sérgio (org.) História das Ciências Sociais no Brasil. São Paulo: Vértice; Editora Revista dos Tribunais: IDESP, 1989, v. 1, p. 433.

${ }^{63}$ Sobre Braudel no Brasil ver: LIMA, op. cit., 2009.

64 "Tenho a honra de comunicar-lhe que os estudantes Sr. Eduardo de Oliveira França [sic], Senhoritas Alice Piffer Canabrava e Risoleta Violante Pereira, escolheram respectivamente para tese de doutorado, os seguintes assuntos que em princípio aceito, deixando a meus sucessores o cuidado de modificá-los, caso seja necessário:-1"As explicações econômicas do fim do Império Romano;"2"O papel de Lisboa na
} 
inclusive resenhada na revista Annales por Braudel ${ }^{65}$, foi justamente Jean Gagé, que chegou à FFCL em 1938 para substituir Braudel. Pierre Monbeig foi o segundo catedrático de Geografia Física e Humana. Chegou à FFCL em 1935 para substituir Pierre Deffontaines $^{66}$, que aceitara convite para fundar a cadeira de Geografia da recém-criada UDF no Rio de Janeiro.

Monbeig e Braudel são associados por Alice à uma nova concepção de ensino. A história ensinada por Braudel estava para além de uma história preocupada com datas, batalhas, eventos; e a geografia de Monbeig superava a geografia por ela denominada de "lista telefônica", característica do ensino de geografia na Escola Normal, resumida a decorar listas de topônimos ${ }^{67}$. O depoimento de Gilda de Mello e Souza, apesar de demarcar os aspectos relacionados aos constrangimentos de gênero e a angústia entre a escolha de um novo modelo feminino e a manutenção de um modelo tradicional, também aponta a importância de um novo modelo de ensino na FFCL, principalmente com os professores franceses. Gilda destaca as aulas referenciadas em bibliografia exposta aos alunos, ao contrário da tradição que imperava na Faculdade de Direito, em que predominava a improvisação e o brilho fácil ${ }^{68}$.

Ambos, Monbeig e Braudel, também são rememorados pelo trato ameno e pela proximidade com os alunos. "O refinamento no trato conjugava-se com a atitude espontânea e afável de nos deixar à vontade, sempre um tanto inibidas, a tropeçar em nosso francês mal falado"69. A presença dos professores franceses impunha aos alunos a necessidade de conhecer a língua francesa com o fito de compreender as aulas e se comunicar com eles. Mas que setor da sociedade paulistana nos anos 1930 dispunha de

\footnotetext{
História de Portugal e particularmente nas grandes descobertas marítimas";3"O movimento intelectual russo pré-revolucionário". Sou partidário do comissionamento eventual desses estudantes, pois seus trabalhos anteriores são uma garantia de sucesso". Carta de Fernand Braudel para o então diretor da FFCL/USP. APC-CT-P3, 1(2). Fundo Alice Piffer Canabrava. Arquivo IEB/USP. Essa é a forma de notação adotada para a descrição do espólio doado em 2005. APC refere-se às iniciais do nome de Alice Piffer Canabrava. CT significa correspondência de terceiros e $\mathrm{P}$, a pasta onde está o documento. O número antes do seguinte entre parênteses indica a sequência das cartas e o número entre parênteses o número de páginas. ${ }^{65}$ BRAUDEL, Fernand. Du potosi à Buenos Aires: Une route clandestine de l'argent. Fin du XVe, début du XVIIe siècle. Annales. Économie, Sociétés, Civilisations. Paris, n. 4, p. 546-550, 1948.

${ }^{66}$ Sobre o autor, ver: FERREIRA, Marieta de Moraes. Diário pessoal, autobiografia e fontes orais: a trajetória de Pierre Deffontaines. In: INTERNATIONAL ORAL HISTORY CONFERENCE (10.: 1998: Rio de Janeiro, RJ). Oral history challenges for the 21st century: proceedings [of the] X International Oral History Conference /Eds. Ilana Strozemberg... [et al]. Rio de Janeiro: CPDOC/FGV/Casa Oswaldo Cruz, v.1, p. 379-386, 1998.

${ }^{67}$ CANABRAVA, op. cit., 2004, p. 92-93; CANABRAVA, op. cit., 1981.

${ }^{68}$ MELLO E SOUZA, Gilda de. Gilda de Mello e Souza: Filósofa. In: BLAY; LANG, op. cit., 2004, p. 63.

${ }^{69}$ CANABRAVA, op. cit. 2004, p. 92.
} 
conhecimentos nessa língua? Afinal, qual era a clientela que frequentava as várias seções e subseções da FFCL/USP?

Os estudos de Fernando Limongi demonstram o perfil dos ingressantes nos cursos da FFCL em seus primeiros quatro anos, ou seja, entre 1934 e 1937 e dos ingressantes nas ditas faculdades profissionais, engenharia, medicina e direito. Pela falta de dados em relação aos ingressantes do curso de medicina, o autor trabalha com o perfil dos ingressantes nos cursos de engenharia da Escola Politécnica da USP, entre 1938 e 1941, e os ingressantes na Faculdade de Direito do largo São Francisco entre 1939 e 1942. A partir dos dados compulsados através dos históricos escolares dos alunos ou de seus prontuários junto à seção de alunos de cada instituição, o pesquisador constrói diversas tabelas quanto às origens destes alunos, principalmente no que diz respeito à proveniência do ensino médio ou do curso normal. Para os períodos recortados, não houve nenhum matriculado nas faculdades profissionais que fosse proveniente do ensino normal. Em sua grande maioria eram provenientes de colégios privados tradicionais da capital, como o Liceu Nacional Rio Branco e o Ginásio Paulistano, ou mantidos por instituições religiosas, como o Colégio São Luiz dos jesuítas ou o Colégio São Bento dos beneditinos. O hiato entre o término do ensino secundário e o início do curso superior era de um ano para os ingressantes em direito pela necessidade de preparação jurídica, e para os ingressantes da Escola Politécnica não se constata hiato, uma vez que a instituição oferecia curso básico quando do ingresso do aluno ${ }^{70}$.

Por sua vez, o perfil dos ingressantes nos cursos da FFCL era bastante diverso. Para sua primeira turma acorrera uma gama de profissionais já formados em outras instituições, principalmente na Faculdade de Direito, poucos ingressantes por exame vestibular e curiosos que assistiam às aulas descompromissadamente. Fernand Braudel relata o perfil dos alunos assistentes em suas aulas. "Minhas primeiras aulas foram em francês, e na sala havia representantes do governador, amigos de Júlio de Mesquita Filho, o dono do jornal $O$ Estado de São Paulo, e diversos grã-finos que deixavam carrões estacionados na porta. [...] Muitos vinham só para se distrair" ${ }^{\circ 1}$. Dos 182 ingressantes na FFCL em 1934, apenas 37 fizeram matrícula para o segundo ano. Diante de tal quadro,

\footnotetext{
${ }^{70}$ LIMONGI, Fernando. Mentores e clientela da Universidade de São Paulo. In: MICELI, Sérgio (org.) História das Ciências Sociais no Brasil. São Paulo: Vértice; Editora Revista dos Tribunais: IDESP, 1989, v. 1, p. 157-187.

${ }^{71}$ BRAUDEL, Fernand. Primeiras histórias. USP, 50 anos: Lembranças de um pioneiro francês. Isto É. São Paulo, n. 371, 01/02/1984.
} 
os dirigentes e fundadores da instituição lançaram mão do recrutamento por meio de comissionamento de professores do ensino primário para o ano de 1935. Neste grupo de alunos é que encontramos um novo perfil para a FFCL, principalmente em relação aos cursos de humanidades. "Criava-se, nesta emergência, a figura do comissionamento destes professores, isto é, a sua dispensa das funções didáticas sem prejuízo de seus vencimentos para fazer os cursos na FFCL"72. Com este empreendimento, em 1935, 100 professores do ensino primário se submeteram ao vestibular, sendo 85 os ingressantes. Pierre Monbeig relata esta mudança de perfil.

[...] é indispensável assinalar as condições absolutamente diversas do recrutamento dos estudantes para o primeiro e segundo anos. Quando de sua instalação a Faculdade atraíra alguns moços já nutridos de boa cultura [...]. O contingente do segundo ano, composto, na sua maior parte, de professores comissionados, de moças sobretudo, mais jovens do que os primeiros, ofereceu ao professor um material completamente diferente. De um lado, uma minoria desejosa sobretudo de completar sua cultura geral, tendo o gosto das ideias e das discussões; de outro lado, um grupo de jovens, animado de grande ardor para o trabalho, conhecendo perfeitamente as suas possibilidades, mas sabendo também que, antes de mais nada são professores e que é por esta razão que foram enviados à Faculdade. Os desejos e as aspirações de uns e de outros são diferentes, e esta situação formula o problema da Faculdade ${ }^{73}$.

O trabalho de Diogo da Silva Roiz acerca da institucionalização do curso de Geografia e História da FFCL/USP dos anos 1930 aos anos 1960 corrobora os resultados de Fernando Limongi e a constatação de Pierre Monbeig de que na primeira turma não havia nenhuma mulher matriculada no curso, mas que do segundo ano em diante sua presença aumenta progressivamente ${ }^{74}$. Na década de 1940, por exemplo, formaram-se 139 mulheres (correspondendo a $66,8 \%$ do total) e 69 homens $(33,2 \%)$ no curso de Geografia e História. Alice Piffer Canabrava ingressou no curso de Geografia e História no segundo ano da FFCL, ou seja, 1935, em um momento de mudança no perfil do ingressante e com o incentivo do comissionamento. Seu perfil se encaixa na descrição de Fernando Limongi, que o grupo dos ingressantes dos cursos da FFCL em 1935 foi

\footnotetext{
${ }^{72}$ LIMONGI, op. cit., 1989, p. 160.

${ }^{73}$ MONBEIG, Pierre. Orientação didática. In: Anuário da Faculdade de Filosofia, Ciências e Letras, 1934 1935, 1937, p. 106.

${ }^{74}$ ROIZ, Diogo da Silva. Entre a graduação e a cátedra: a movimentação dos alunos do curso de Geografia e História na Faculdade de Filosofia, Ciências e Letras da Universidade de São Paulo. In: caminhos (da escrita) da História e os descaminhos de seu ensino: a institucionalização do ensino universitário de História na Faculdade de Filosofia, Ciências e Letras da Universidade de São Paulo (19341968). $1^{\circ}$ edição. Curitiba: Editora Appris, 2012, p. 188-216.
} 
composto em sua grande maioria por ex-normalistas que trabalharam nas escolas de ensino primário, entre 2 e 4 anos e que não faziam parte dos grupos da elite dirigente, que rumavam para as faculdades profissionais, e nem dos "curiosos" com formação já em outro curso superior ${ }^{75}$.

Braudel e Monbeig também são assunto das cartas trocadas entre Alice e sua colega de turma, Maria Celestina Teixeira Mendes Torres ${ }^{76}$. As duas amigas rememoram a experiência comum, com nostalgia. Canabrava remete aos tempos da FFCL/USP.

Lembro-me muito bem quando fomos agraciadas com os cumprimentos de 'as duas melhores', palavras estas, ditas em francês, pelo terrível Professor, tinha para nós um significado especial, embora não se traduzisse em recompensa com a nota máxima, porque, ao que eu saiba, esta ninguém a mereceu do Prof. Monbeig. Dizia, com respeito a nossos trabalhos e a nossas provas, que não alcançavam o 'status' de 'estudante'; estudávamos, mas sem alcançar nível mais alto que o de um bom 'aluno'. Permanecíamos apenas muito boas alunas. Faltavanos os voos daqueles estudantes que, chegados à Universidade com uma base sólida e ampla, a proporcionada pelos liceus franceses, por exemplo, podem alcançar outro desempenho em cursos superiores. Mas como estudávamos! Eu devorava De Martonne, Brunhes, Vidal de La Blache, lia artigos de revistas especializadas. Estudei mais Geografia do que tudo o mais, sai da Faculdade com muito boa base em Geografia. Se tivesse conseguido trabalhar na equipe de Geografia teria me tornado Geógrafa. O Monbeig queria que eu fosse trabalhar com ele, mas não conseguiu verba ${ }^{77}$.

Além da rememoração do rigor com o qual Monbeig avaliava os alunos e, por conta disso, da necessidade de longas horas de estudo da literatura especializada, a historiadora menciona um fato importante para uma reflexão acerca do sistema de recrutamento por parte dos catedráticos ${ }^{78}$. Afirma que foi convidada por Monbeig para trabalhar com ele. Porém, a cadeira não possuía verba para a contratação de auxiliar de ensino. Este era um problema pelo qual passou a FFCL em seus primeiros anos de funcionamento e que foi tema de diversos textos publicados pelos primeiros catedráticos nos vários volumes do Anuário da FFCL/USP ${ }^{79}$. Sabemos que Alice, após concluir a

\footnotetext{
${ }^{75}$ LIMONGI, op. cit., 1989.

${ }^{76}$ Braudel é mencionado em três cartas por Alice Canabrava: APC-TORR-018. APC-TORR-006. APCTORR-008. Fundo Alice Piffer Canabrava. Arquivo IEB/USP.

77 São Paulo, 20 de janeiro de 1985. APC-TORR-005, p. 1. Fundo Alice Piffer Canabrava. Arquivo IEB/USP.

${ }^{78}$ Pierre Monbeig é assunto ainda de duas outras cartas remetidas por Alice à Mariinha: APC-TORR-006. APC-TORR-008. Fundo Alice Piffer Canabrava. Arquivo IEB/USP.

${ }^{79}$ No relatório do diretor da FFCL, Ernesto de Souza Campos, para o ano de 1937, há, por exemplo, tópico dedicado ao "problema dos assistentes", no qual aponta a falta de recursos financeiros para a contratação de assistentes. Cf. Relatório da direção da Faculdade de Filosofia, Ciências e Letras da Universidade de
} 
graduação, foi contratada em 1938 para ser auxiliar de ensino de Paul Vanorden Shaw, regente da cadeira de História da Civilização Americana. No caso da historiadora, com poucas condições financeiras de se sustentar em São Paulo sem emprego fixo após o fim do comissionamento, a possibilidade de permanecer na FFCL ficara condicionada à existência de verba em alguma cadeira e não se tratou de uma escolha temática ou por afinidade. Os relatos sobre os primórdios da FFCL comentando que os auxiliares de ensino e assistentes eram voluntários, não recebendo vencimentos, são numerosos ${ }^{80}$.

No já referido depoimento de 1984, publicado em 2004, Alice afirma:

Licenciada, o convite para trabalhar junto à Cadeira de História da América significou a oportunidade de permanecer na Faculdade, prosseguir nos estudos e me aproximar da especialização em História do Brasil, meu objetivo determinado desde que as fronteiras acadêmicas entre as disciplinas são fluidas como a própria ciência ${ }^{81}$.

Realmente Canabrava foi convidada por Shaw para ser auxiliar de ensino. Porém, há ainda uma importante nuance a ser considerada, talvez pelo fato de que o depoimento, originalmente oral, foi, depois, enquadrado pelo império da escrita ${ }^{82}$. Também na referida entrevista ao MIS/SP em 1981, ela traz mais um dado para refletirmos acerca do sistema de recrutamento dos primeiros auxiliares e assistentes. "Fui convidada pelo professor Plinio Ayrosa, pelo professor Pierre Monbeig e pelo professor Paul Vanorden Shaw. E eu escolhi o professor Paul Vanorden Shaw. Na realidade eu fui escolhida, porque foi o primeiro que pode dispor de recursos para me contratar" $" 83$. A historiadora poderia ter sido auxiliar e depois assistente de Plinio Ayrosa ${ }^{84}$ ou de Pierre Monbeig. Porém, a cadeira que dispunha de recursos na ocasião era a regida por Paul Vanorden Shaw. Em longa carta de 20 de janeiro de 1985, Alice comenta com sua amiga de graduação Mariinha que fora trabalhar com Shaw; rememora suas qualidades pessoais e intelectuais e as circunstâncias de sua morte:

São Paulo, referente ao ano de 1937. In: Anuário da Faculdade de Filosofia, Ciências e Letras, 1937-1938, 1938, p. 151-154.

${ }^{80}$ Além dessa questão, Antonio Candido aponta também para a falta de estabilidade dos assistentes, até mesmo após a obtenção do doutorado. Cf. MELLO E SOUZA, Antonio Candido de. Entrevista. In: FREITAS, Sonia Maria de. Reminiscências. São Paulo: Maltese, 1993, p. 35-57. Nos anos 1960 e 1970 a situação ainda era a mesma.

${ }^{81}$ CANABRAVA, op. cit., 2004, p. 97.

${ }^{82}$ Cf. CERTEAU, op. cit., 2011.

${ }^{83}$ CANABRAVA, op. cit., 1981.

${ }^{84}$ Plínio Ayrosa é assunto de parte de uma carta de Alice para Mariinha: APC-TORR-006, p. 2. Fundo Alice Piffer Canabrava. Arquivo IEB/USP. 
Fui trabalhar com o Prof. Paul Vanorden Shaw, excelente pessoa, professor medíocre; muito mais interessado no jornalismo, suas aulas eram um blá-blá-blá, como se diz hoje, generalidades sobre a América Latina, pela qual havia viajado muito. Contava casos, episódios de sua permanência neste ou naquele país, alguns até interessantes. Matéria, propriamente, nada. Sob a pressão dos alunos pediu demissão e foi para o Rio de Janeiro. Tornou-se importante, como adido cultural dos Estados Unidos [...]. Em uma das vezes que fui ao Rio vi-o por acaso na confeitaria Americana na Cinelândia, acompanhado por uma jovem mulata, nada feia. Soube depois, que tais companhias já datavam do tempo em que era professor da USP... Faleceu nos Estados Unidos, onde se encontrava em breve viagem, como fazia com frequência. Morte repentina, penso que do coração, porque sempre foi muito gordo. A esposa retornou aos E.U., onde já morava a filha, única, René, já casada. Até onde sou informada, nunca escreveu um livro. Foi convidado para vir trabalhar na USP porque mantinha relações com o país, o pai havia morado em S. Paulo onde possuiu uma livraria - a Livraria Vanorden - e falava português ${ }^{85}$.

Nota-se aqui um pequeno "desvio" em relação aos intentos da elite contratante quando da fundação da FFCL: Shaw não era professor em nenhuma instituição dos EUA quando chegou ao Brasil e seu recrutamento se deu por caminhos bem diferentes da "missão francesa". Mas, afinal, qual o destino dos que se formavam na FFCL, como se dava a sucessão nas cátedras?

Do total de 29 alunos matriculados no primeiro ano do curso de Geografia e História da FFCL em 1935, 12 eram do sexo masculino e 17 do sexo feminino ${ }^{86}$. Desta turma, somente dois alunos seguiram carreira como pesquisador e alcançaram a cátedra: Alice Piffer Canabrava e Eduardo D'Oliveira França ${ }^{87}$. Apesar das mudanças sociais ocorridas ao longo dos anos 1930, ainda havia resistência em relação ao lugar ocupado pela mulher. $\mathrm{O}$ domínio masculino estava presente nas cátedras e na pesquisa, sendo que à mulher que se formava na FFCL cabia a posição de professora no ensino secundário, caso de, por exemplo, três colegas de turma de Canabrava: Maria Celestina Teixeira Mendes Torres, Branca da Cunha Caldeira e Risoleta Violante Pereira ${ }^{88}$. Dos

\footnotetext{
${ }^{85}$ São Paulo, 20 de janeiro de 1985. APC-TORR-005, p. 1-2. Fundo Alice Piffer Canabrava. Arquivo IEB/USP.

${ }^{86}$ ROIZ, op. cit., 2012, p. 209.

${ }^{87}$ Eduardo D’Oliveira França foi assistente de Émile Léonard na cadeira de História da Civilização Moderna e Contemporânea e defendeu seu doutoramento em 1942 sob a orientação de Eurípedes Simões de Paula. Em 1951 tornou-se catedrático, substituindo Émile Léonard. Cf. ROIZ, op. cit., 2012, p. 164-183. ${ }^{88}$ Branca da Cunha Caldeira e Risoleta Violante Pereira foram bastante próximas a Braudel. Esta última, quando do retorno de Braudel à França, foi indicada por ele em carta ao diretor da FFCL com seu tema de doutorado, uma vez que seus trabalhos anteriores seriam garantia de sucesso na empreitada do doutoramento. Cf. Trecho de carta de 16 de outubro de 1937 de Fernand Braudel para o então diretor da FFCL/USP, APC-CT-P3, 1(2). Fundo Alice Piffer Canabrava. Arquivo IEB/USP.
} 
matriculados no segundo ano em 1935 na subseção de Geografia e História, dos alunos do sexo masculino, chama-nos a atenção: João Dias da Silveira, Astrogildo Rodrigues de Mello $^{89}$, Eurípedes Simões de Paula ${ }^{90}$ e Caio Prado Júnior ${ }^{91}$. Os três últimos formados em Direito pela Faculdade do Largo São Francisco. Sabemos que Caio Prado não terminou o curso. Porém, os dois outros atingiram a condição de catedráticos, substituindo os "mestres franceses" 92 .

As trajetórias de Alfredo Ellis Jr., Eurípedes Simões de Paula e Eduardo D’Oliveira França foram analisadas por Lidiane Rodrigues, com ênfase neste último. Sua hipótese é de que o fato desses três historiadores terem estudado na Faculdade de Direito os teria habilitado e legitimado a assumir cátedras na FFCL, principalmente com a anuência, quando não, interferência, de Fernand Braudel.

No que se refira a dimensões factuais e sociais, ficaram ocultadas as trajetórias femininas. Ao que tudo indica, o interdito a elas não era oriundo de Fernand Braudel. Possivelmente ele estivesse atrelado aos compromissos assumidos com a elite contratante. Vocalizando os valores dela, um expressivo depoimento de João Cruz Costa - que auxiliou o missionário em sua aclimatação no Brasil: "Isso de cátedras com catedráticos femininos não me parece coisa séria". Ademais, a pesquisa sugere que outros atributos, além da oposição homem/mulher,

\footnotetext{
${ }^{89}$ Após a saída em 1941 de Paul Vanorden Shaw da cadeira de História da Civilização Americana, assumiu a regência da cadeira interinamente, tendo por assistente Alice Canabrava. Em 1946 foi realizado concurso para o provimento da cátedra, em que concorreram Astrogildo, Odilon de Araujo Grellet e Alice Piffer Canabrava. Astrogildo, apesar de ter obtido menores notas que Canabrava, foi o escolhido, pois o regimento do concurso permitia que o presidente da banca decretasse o vencedor. Ver: ERBERELI JÚNIOR, op. cit., 2014, p. 75-94.

${ }^{90}$ Desde 2005, há material em 4 volumes que foi organizado pela historiógrafa Elisabeth Conceta Mirra do Centro de Apoio à Pesquisa em História "Sérgio Buarque de Holanda" do departamento de História da Faculdade de Filosofia, Letras e Ciências Humanas da Universidade de São Paulo. Ver: MIRRA, Elisabeth Conceta. O Prof. Dr. Eurípedes Simões de Paula, o Centro de Apoio à Pesquisa em História - CAPH e a Memória da FFCL-FFLCH/USP: trajetória e possibilidades. Revista de História. São Paulo, n. 160, p. 5169, 2009. Há um volume in memoriam. Ver: PAULA, Maria Regina Simões de; MELLO E SOUZA, Antonio Candido de. In Memoriam de Eurípedes Simões de Paula. São Paulo: Gráfica FFLCH/USP, 1983. ${ }^{91}$ A produção sobre Caio Prado Júnior é vasta. Citamos alguns trabalhos que tratam de sua historiografia e trajetória intelectual: ZOREK, Bruno de Macedo. Concepções de sujeito e objeto do conhecimento na obra de Caio Prado JR. 2007. 136 f. Dissertação (Programa de Pós-Graduação em História) - IFCH/UFRGS, 2007. IUMATTI, Paulo Teixeira; SEABRA, Manoel Fernandes; HEIDEMANN, Heinz-Dieter (orgs.). Caio Prado Jr. e a Associação dos Geógrafos Brasileiros. São Paulo: EDUSP/FAPESP, 2008. IUMATTI, Paulo Teixeira. Caio Prado Jr.: Uma trajetória intelectual. São Paulo: Brasiliense, 2007. IUMATTI, Paulo Teixeira. História, dialética e diálogo com as ciências: a gênese de Formação do Brasil contemporâneo, de Caio Prado Jr. (1933-1942). São Paulo: Intermeios/USP-Programa de Pós-Graduação em História Social, 2018.

${ }^{92}$ Sobre os anos de Caio Prado Júnior na FFCL/USP ver: MARTINEZ, Paulo Henrique. Admirável mundo novo (1934-1935). In: . A dinâmica de um pensamento crítico: Caio Prado Jr (1928-1935). São Paulo: EDUSP, 2008, p. $163-\overline{218}$.
} 
estivessem em jogo nas disputas, por exemplo, a origem "comissionada" ou já capitalizada culturalmente. A investigar ${ }^{93}$.

Eduardo D’Oliveira França substituiu a Émile Léonard na cadeira de História da Civilização Moderna e Contemporânea; Eurípedes Simões de Paula substituiu a Jean Gagé na cadeira de História da Civilização Antiga e Medieval e Astrogildo Rodrigues de Mello substituiu a Paul Vanorden Shaw, por ocasião do concurso de 1946, na cadeira de História da Civilização Americana. No caso da cadeira de História da Civilização Brasileira, Alfredo Ellis Júnior ${ }^{94}$ também havia cursado a Faculdade de Direito quando sucedeu a Afonso Taunay ${ }^{95}$.

Em se tratando da oposição homem/mulher, sugerida no excerto acima, têm-se alguns relatos das hostilidades em relação à mulher na FFCL, que ainda permaneciam na década de 1950. Em entrevista concedida em 2001 no projeto de autoria de Hélgio Trindade acerca da institucionalização das Ciências Sociais no Brasil, América Latina e França, a socióloga Heleieth Saffioti, quando questionada acerca de quem ministrava o curso de Sociologia na FFCL durante sua graduação (1956-1960), afirma que

Era o Fernando Henrique e o Octavio Ianni. Havia a Maria Sylvia que sofreu discriminações pelo fato de ser mulher. Inteligente ela é. Aquele livro dela Homens livres na sociedade escravocrata [sic] só recentemente que foi editado por uma editora comercial. Antes tinha sido editado por uma editora ligada à Maria Isaura, que era amiga da Maria Sylvia e conseguiu publicar, porque o Fernando Henrique e o Ianni dominavam todas as editoras ${ }^{96}$.

Para além da oposição homem/mulher, Lidiane Rodrigues também chama a atenção para a origem social dos catedráticos que sucederam os estrangeiros. Contudo, o fato de ser mulher possuía grande importância naquela cultura acadêmica, uma vez que

\footnotetext{
${ }^{93}$ RODRIGUES, Lidiane Soares. Armadilha à francesa: homens sem profissão. História da Historiografia. Ouro Preto, n. 11, 2013, p. 99.

${ }^{94}$ Para uma breve trajetória de Ellis Jr., desde seus tempos de infância até a cátedra de História da Civilização Brasileira da FFCL/USP, ver: ROIZ, op. cit., 2012, p. 114-119. Sobre o projeto de escrita da história de Ellis Jr., ver: ROIZ, Diogo da Silva. A dialética entre o "intelectual-letrado" e o "letradointelectual": projetos, tensões e debates na escrita da História de Alfredo Ellis Jr. e Sérgio Buarque de Holanda (1929-1959). 2013. 383 f. Tese (Programa de Pós-Graduação em História) - FCHS, UFPR, Curitiba, 2013. Disponível em: <https://www.acervodigital.ufpr.br/bitstream/handle/1884/29822/R\%20\%20T\%20-\%20DIOGO\%20DA\%20SILVA\%20ROIZ.pdf?sequence=1 >. Acessado em 21 de abr. 2019.

${ }^{95}$ Para uma análise detalhada da trajetória de Taunay e de seu projeto de escrita da história, ver: ANHEZINI, Karina. Um metódico à brasileira: a história da historiografia de Afonso Taunay (1911-1939). São Paulo: UNESP, 2011.

96 SAFFIOTI, Heleieth. Entrevista. In: TRINDADE, Hélgio. Ciências Sociais no Brasil: diálogos com mestres e discípulos. Brasília: Anpocs/Liber Livro Editora, 2012, p. 140.
} 
mesmo mulheres capitalizadas social e culturalmente, como Gilda de Mello e Souza, também enfrentaram as hostilidades do grupo masculino.

Heloísa Pontes ao citar as mulheres que participaram do grupo "Clima", destaca Maria de Lourdes dos Santos, Ruth Alcântara e Gilda de Moraes Rocha - sobrenomes de Gilda antes de se casar com Antonio Cândido de Mello e Souza. Todas as mulheres tiveram um papel subsidiário no grupo, principalmente como secretárias de seus respectivos maridos, com exceção de Gilda de Mello e Souza que tentou trilhar o caminho da escrita ficcional. Contudo, não foi adiante e decidiu se especializar na carreira acadêmica.

De todas as mulheres do grupo, Gilda foi a única que conseguiu conciliar o trabalho e as atribuições domésticas com a carreira universitária. Diferentemente de Maria Lourdes, que como ela também se profissionalizou na Universidade de São Paulo, Gilda não abriu mão de seus projetos intelectuais e da vontade de escrever ${ }^{97}$.

Porém, o fato de ser mulher e ter escolhido uma temática "de mulher" para sua tese de doutoramento, "O espírito das roupas", apresentada em 1950, fizeram com que fosse preterida na sucessão da cadeira de Sociologia I, regida por Roger Bastide, seu orientador de tese, em favor de Florestan Fernandes.

Concebido como um ensaio de sociologia estética, à boca pequena $\mathrm{o}$ tema da tese de Gilda foi considerado como fútil. Coisa de mulher. Na hierarquia acadêmica e científica da época, que presidia tanto a escolha dos objetos de estudo como a forma de exposição e explicação dos mesmos, a tese de Gilda constituiu "uma espécie de desvio em relação às normas predominantes" [Gilda em "O espírito das roupas"]. "Profana" e "plebéia", a moda, na escala de valor e legitimidade atribuídos por esse sistema classificatório, encontrava-se em uma posição diametralmente oposta ao tema da guerra, por exemplo, que Florestan Fernandes escolhera para a tese de doutorado, atividade masculina por excelência, "sagrada" e "nobre"

Referindo-se a seu ambiente familiar tradicional, tanto em Araraquara/SP quanto em São Paulo, onde se mudou para a casa em que morava Mário de Andrade, primoirmão de seu pai, com 12 anos de idade para dar prosseguimento aos estudos - no mesmo Colégio Stafford onde também Alice cursara o secundário - Gilda relata que, parte

\footnotetext{
${ }^{97}$ PONTES, Heloisa. Destinos mistos: os críticos do Grupo Clima em São Paulo (1940-68). São Paulo: Companhia das Letras, 1998, p. 127.

${ }^{98}$ PONTES, Heloisa. A paixão pelas formas. Gilda de Mello e Souza. Novos Estudos, São Paulo, n. 74, 2006, p. 90.
} 
daquilo de que fugia, oriundo exatamente daquelas tradições, acabava por encontrar na FFCL em seus colegas de curso.

\begin{abstract}
$\mathrm{Na}$ verdade, o antigo preconceito masculino de que eu havia fugido se infiltrara renitente, se bem que mais brando, entre os próprios colegas de curso. Um ou outro talvez acreditasse sinceramente nas vocações intelectuais femininas, mas a maioria achava que qualquer prognóstico sobre nós era prematuro, pois ainda não tínhamos feito a escolha "essencial" - igual para todos -, aquela que, a seu tempo, iria revogar as demais: a escolha do marido. Não raro víamos aflorar formas mais agressivas de resistência, a suspeita, por exemplo, de que a nossa inquietação fosse estacional, derivasse apenas de uma privação afetiva. Passaria com o tempo sem deixar sequelas, como o sarampo e a coqueluche. Muitos talvez nem se lembrem desse juízo simplista - para não dizer simplório - de nossas perplexidades ${ }^{99}$.
\end{abstract}

Sendo assim, mesmo com uma origem social distinta de Alice Canabrava e já capitalizada culturalmente quando do ingresso na FFCL em 1937, Gilda de Mello e Souza foi preterida por seus pares masculinos. Preterimento intensificado pelo tema de sua tese de doutoramento.

Na entrevista de 1981, quando questionada acerca das dificuldades que a mulher enfrentava naquele momento, Alice Canabrava afirma que as moças da Faculdade de Filosofia eram muito mal vistas, principalmente porque as excursões com o geógrafo Pierre Monbeig eram feitas também com a presença dos rapazes. Então, quem quisesse se posicionar contrariamente a este quadro de convívio misto cursava a Faculdade Católica, incorporada à atual Pontifícia Universidade Católica de São Paulo ${ }^{100}$. O depoimento de Mirian Moreira Leite, formada em Ciências Sociais em 1947 e doutora em História em 1983, concedido à Sônia Freitas em 1990 corrobora a permanência das barreiras em relação à mulher ainda nos anos 1940.

Não sei se você está se referindo à questão de ser mulher e universitária. Aí, no caso, se transformava realmente num caráter pioneiro e você tinha que enfrentar, não dentro da Faculdade, porque na Faculdade eu não senti, não tive oportunidade de sentir isso, mas dentro de sua família e na sua roda de amigos era considerado uma forma de exotismo $[\ldots]^{101}$.

Além das hostilidades em lócus institucional vivenciadas nas décadas iniciais da FFCL/USP, como relatado por Gilda de Mello e Souza, havia também problemas de sociabilidade no âmbito familiar. Nas entrevistas realizadas por Maria Helena Bueno

\footnotetext{
${ }^{99}$ SOUZA, op. cit., 2004, p. 69-70.

${ }^{100}$ CANABRAVA, op. cit., 1981.

${ }^{101}$ MOREIRA LEITE, Mírian. Entrevista. FREITAS, op. cit., 1993, p. 257-258.
} 
Trigo com o fito de perscrutar as trajetórias das mulheres na FFCL/USP, este tipo de relato era comum. Assim, afirma uma aluna de Letras das primeiras turmas:

[...] no tempo em que entrei para a Faculdade era impossível tomar-se uma decisão sem que pelo menos alguém na família estivesse de acordo e ajudasse a enfrentar os que discordavam. No meu caso foi minha mãe a minha grande aliada nas conversações familiares para que eu pudesse cursar a universidade ${ }^{102}$.

Em relação à ambientação daquele concurso para a cátedra de História da Civilização Americana de 1946, Alice rememora que, naquele momento, depois que defendeu sua tese de doutoramento e emergiu como possível candidata à cátedra, todos os catedráticos se voltaram contra ela.

[...] involuntariamente emergi, aos olhos dos meus colegas masculinos, como possível candidata ao provimento efetivo da cadeira de História da América, a ser posta em concurso. Até então, o relacionamento com esses colegas havia sido muito afável, direi até, não isento de estima pessoal $^{103}$.

Segundo Canabrava, vis a vis as notas de Jorge Americano que empataram o concurso, o regulamento estipulava que todos os membros da banca deveriam votar em um candidato para que ficasse em primeiro lugar. Então, dois deles votaram em Astrogildo Rodrigues de Mello e dois em Alice Canabrava, tendo cabido o desempate à Jorge Americano, que desempatou em favor de Astrogildo. Anos mais tarde, ela rememora que

[Jorge Americano] me mandou dizer que ele achava que o único erro na vida universitária profissional dele tinha sido decidir o concurso em favor da outra pessoa e não pra mim, mas que eu quisesse compreender que deram informações completamente erradas. Disseram que o outro candidato sofria de uma doença incurável e que por isso ficaria logo na pequena cátedra. E eu mandei dizer pela mesma pessoa, que ele não tivesse nenhum remorso, que estava tão feliz onde estava. Que por mãos tortas, linhas transversas, eu tinha encontrado um excelente caminho ${ }^{104}$.

Havia um acordo para que Astrogildo assumisse a cátedra, uma vez que contavam com seu afastamento pouco tempo depois. Contudo, tal estratégia não passou de engodo para ludibriar o então reitor Jorge Americano e evitar que uma mulher assumisse a cátedra. Assim, não fossem as disputas de poder em torno do concurso, ambos, Jayme

102 TRIGO, Maria Helena Bueno. Espaços e tempos vividos: estudo sobre os códigos de sociabilidade e relações de gênero na Faculdade de Filosofia da USP (1934-1970). 250 f. 1997. Programa de PósGraduação em Sociologia (Tese), FFLCH/USP, 1997, p. 61-62.

${ }^{103}$ CANABRAVA, op. cit., 2004, p. 98.

${ }^{104}$ CANABRAVA, op. cit., 1981. 
Coelho e Eremildo Vianna, membros externos da banca examinadora, provenientes da Faculdade Nacional de Filosofia da Universidade do Brasil, poderiam ter concedido à tese de Alice Canabrava notas tão altas quanto às de Sérgio Buarque de Holanda ${ }^{105}$. O depoimento de Olga Pantaleão, que também sofreu com as articulações do grupo masculino, é bastante esclarecedor dessa situação:

Finalmente, a Cátedra, posto final na carreira universitária na época, estava bem fora do alcance das mulheres: erguia-se uma muralha masculina contra a simples possibilidade. Nos anos 40, a única mulher catedrática na Congregação da Faculdade de Filosofia foi Noemy Silveira Rudolfer, que viera transferida do Instituto de Educação quando este foi extinto e, portanto, não tivera de pleitear a Cátedra. Durante quase um ano, de julho de 1946 a junho de 1947, mais uma mulher, eu mesma, pôde aparecer nesse quadro, regendo interinamente a Cadeira de História da Civilização Moderna e Contemporânea. Durou pouco tempo: por pressão e ação do grupo masculino dominante no curso de Geografia e História tive de deixar a Faculdade, tendo feito o restante de minha carreira fora da USP. E, finalmente, uma mulher fez o concurso para a Cátedra de História da Civilização Americana: Alice Piffer Canabrava. Foi um acontecimento! Mas, apesar de ter obtido as melhores notas, não ganhou o concurso: a banca examinadora escolheu o segundo colocado em notas, homem, naturalmente, dando-lhe a Cátedra; esse absurdo era possível, então, por força do regulamento do concurso, o qual permitia à banca votar no candidato que ficaria em primeiro lugar. Isso foi tudo o que aconteceu, na década de 40 , referente à ocupação da Cátedra pelas mulheres ${ }^{106}$.

Tudo bem ingressar na graduação por comissionamento; ser assistente; realizar doutoramento, mas "tudo menos a Cátedra!"107. Olga, desmotivada em se inscrever para o concurso da cadeira de História da Civilização Moderna e Contemporânea, na qual concorreria com Eduardo D’Oliveira França foi para a FFCL de Marília/SP, onde, juntamente com José Roberto do Amaral Lapa, fundou o curso de História daquela instituição $^{108}$.

Outro caso ocorrido já nos anos 1960, e que demonstra a persistência das barreiras masculinas contra as mulheres que quisessem ascender ao topo da carreira acadêmica, foi

\footnotetext{
${ }^{105}$ Os meandros do concurso estão por extenso em: ERBERELI JÚNIOR, Otávio. De preterida à preferida: considerações em torno da trajetória intelectual de Alice Piffer Canabrava (1935-1951). História da historiografia. Ouro Preto, n. 22, p. 97-115, 2016. Ver também: ARRUDA, José Jobson de Andrade. Alice Canabrava: História e Mito. In: CANABRAVA, Alice Piffer. O Desenvolvimento da Cultura do Algodão na Província de São Paulo (1861-1875). $3^{\circ}$ edição. São Paulo: EDUSP/ANPUH, 2011, p. 9-70.

106 PANTALEÃO, Olga. Olga Pantaleão. Historiadora. In: BLAY; LANG, op. cit., 2004, p. 113-114.

${ }^{107}$ Idem, p. 114.

${ }^{108}$ A FFCL de Marília/SP era um dos vários Institutos Isolados de Ensino Superior do Estado de São Paulo. Quando da fundação da UNESP em 1976, o curso de História foi extinto do campus de Marília.
} 
o de Paula Beiguelman ${ }^{109}$ no concurso para a cadeira de Política. Lourival Gomes Machado ${ }^{110}$ assumiu a cadeira logo após o retorno para a França de Charles Morazé. Nesta ocasião, Beiguelman ficara com as funções de primeira assistente, permanecendo no cargo até o falecimento de Gomes Machado. Para o concurso de 1968, Beiguelman seria a sucessora natural de Lourival Gomes Machado, uma vez que, além de sua assistente, também fora sua orientanda de doutoramento, com tese defendida em $1961^{111}$. Entretanto, foi preterida no concurso, e Fernando Henrique Cardoso tornou-se catedrático. "Deixando de lado a questão da competência dos candidatos envolvidos nesse concurso, é preciso ressaltar que Paula Beiguelman foi a segunda mulher (depois de Alice Canabrava) a disputar uma posição mais sólida na Faculdade de Filosofia" ${ }^{112}$. De fato, a assertiva de Pontes não é descabida ao mencionar que Paula Beiguelman foi a segunda mulher na história da FFCL/USP a disputar uma posição mais sólida, desconsiderando-se, para tanto, as competências dos candidatos, uma vez que tal certame não foi resolvido através dos atributos meritocráticos.

Questionada em entrevista em 2001 sobre a hipótese da existência de algum conflito no curso de Ciências Sociais, a socióloga Heleieth Saffioti afirma, mencionando o concurso para a cadeira de Política ocorrido em junho de 1968, que

Sim. Principalmente o do concurso. Foi armado pelo Florestan e pelo Fernando Henrique. O Florestan dizia sempre uma coisa: "Eu não crio gatos; eu crio tigres". Os bons alunos ouviam sempre. O Florestan tinha um ímpeto muito forte no sentido de ocupar os espaços da Maria Antônia. Então ajudou o Fernando Henrique a dar o bote na Política e evitava a cadeira de Sociologia II, que era do Ruy Coelho ${ }^{113}$.

A comparação com o caso de Alice Canabrava é inevitável. Ainda mais quando se toma ciência de que a historiadora fez questão de participar da banca examinadora do concurso de livre-docência de Paula Beiguelman. Em carta endereçada a seu amigo Francisco Iglésias e datada de 17 de junho de 1967, ela relata que, mesmo evitando participar de bancas examinadoras para concurso, uma vez que o sofrimento em duas

\footnotetext{
${ }^{109}$ Para uma trajetória intelectual de Paula Beiguelman, ver: SILVA, Dimitri Pinheiro da. Da política à ciência política, da ciência política à política: a trajetória acadêmica de Paula Beiguelman (1949-1969). 120 f. 2008. FFLCH/USP (dissertação), Programa de Pós-Graduação em Sociologia, 2008.

110 Para uma síntese de sua trajetória, ver: FERREIRA, Oliveiros. Lourival Gomes Machado. Estudos Avançados. São Paulo, v. 8, n. 22, p. 279-284, 1994.

${ }^{111}$ BEIGUELMAN, Paula. Formação política do Brasil: teoria e ação no pensamento abolicionista. V. 1. São Paulo: Livraria Pioneira Editora, 1967.

${ }_{112}$ PONTES, op. cit., 1998, p. 199.

${ }^{113}$ SAFIOTTI, op. cit., 2012, p. 141.
} 
bancas ainda estava muito presentificado, não poderia deixar de atender ao pedido de sua amiga Paula, especialmente naquelas circunstâncias em que Florestan Fernandes impunha seu imperialismo progressivamente, valendo-se das mais variadas articulações.

No caso particular do concurso da Paula, eu aceitei pela grande amizade e admiração que tenho pela Paula. Como tive oportunidade de dizer a ela, quando insistiu comigo pela aceitação (o meu primeiro gesto é recusar logo), eu me via impelida a aceitar a indicação, como uma imposição de amor, a que eu não podia fugir. Parecia-me também (o que eu não disse a ela), que seria omissão imperdoável de minha parte se eu não participasse do concurso para defender a Paula, sabendo que o Florestan Fernandes forçou sua própria participação na banca com o propósito de dificultar o mais possível o caminho de nossa amiga, para colocar na cadeira de Política um dos dois de seus assistentes: Fernando Henrique ou Octavio Ianni ${ }^{114}$.

\subsection{A cultura acadêmica da FCEA}

Por essas e outras, Alice Canabrava em sua última entrevista, após mencionar o quanto sofreu por ter sido preterida em concurso, qualifica a FFCL como um antro de "intelectualóides" extremamente preconceituosos em relação a mulher. Ao contrário da FCEA, onde postula que nunca teve o menor problema por sua condição de gênero.

$\mathrm{Na}$ Faculdade de Economia eu não sofri qualquer tipo de restrição ou de discriminação. O professor Teotônio [sic] Monteiro de Barros recebeu-me de braços abertos. O ambiente da Faculdade de Economia era bem diferente do da Faculdade de Filosofia. O pessoal da Faculdade de Economia ligava-se mais à vida ordinária, dos fatos, do cotidiano. $\mathrm{Na}$ Faculdade de Filosofia havia muitos "intelectualóides" que se diziam avançados, liberais, mas que no fundo, eram extremamente preconceituosos para com a mulher ${ }^{115}$.

Aqui, a historiadora está no entardecer da vida, com 86 anos e diante de seu orientando, Flávio Azevedo Marques de Saes. Trata-se de uma entrevista. Porém, desconhecemos o método utilizado por Saes e também as perguntas feitas, uma vez que não há esclarecimento em nota. Como no caso do depoimento proferido por ela em 1984

\footnotetext{
${ }^{114}$ Carta constante no acervo Francisco Iglésias do Instituto Moreira Salles (RJ): FI-C-CP (078), p. 4. Nesta carta relata que Florestan estava na banca e fez o que pôde para desqualificar a candidata, mas que esta foi aprovada. Contudo, não participou do concurso para a cadeira de Política de 1968. A banca examinadora foi formada por Ruy Coelho e Sérgio Buarque de Holanda - indicados pela Congregação - e Orlando de Carvalho, José Honório Rodrigues e Victor Nunes Leal, indicados pelo Conselho Técnico-Administrativo. Cf. SILVA, Dimitri Pinheiro da. Jogo de damas: trajetórias de mulheres nas ciências sociais paulistas (19341969). Cadernos Pagu. Campinas, n. 46, 2016, p. 188.

${ }^{115}$ CANABRAVA, Alice Piffer. Minhas Reminiscências. Economia aplicada. São Paulo, v. 1, n. 1, 1997, p. 163.
} 
com as pioneiras da USP, esta entrevista também foi enquadrada pelo império da escrita. A ocasião foi o lançamento do primeiro número de Economia Aplicada ${ }^{116}$.

No excerto destacado acima, Alice opõe a FFCL à FCEA, afirma que nesta última não sofreu nenhuma discriminação pelo fato de ser mulher e demarca também o caráter pragmático da Faculdade de Ciências Econômicas. Na entrevista concedida ao MIS/SP mais de dez anos antes, ao rememorar sua chegada à FCEA, destaca a acolhida do então diretor da recém-fundada faculdade, Theotônio Monteiro de Barros Filho.

De modo que quando cheguei na faculdade de economia, eu quero dizer que foi um ambiente pacífico, tranquilo. Nunca senti nenhum preconceito contra mim. Encontrei o diretor, o professor Theotônio Monteiro de Barros na época do meu concurso, e eu tive ocasião de dizer à ele, que sendo um homem que pertenceu ao patriciado, ele era filho ou neto do visconde de Congonhas, o aeroporto está situado no sítio do avô dele e que era um homem que pertencia ao patriciado, catedrático da faculdade de direito, que é uma faculdade tradicional, esse homem não teve nenhum preconceito em abrir o primeiro concurso da faculdade de economia para a história econômica da qual eu me candidatei. De modo que eu sou gratíssimo [sic] a ele até hoje e a memória dele. Não teve o menor, eu nunca senti na faculdade, podia ter atritos pessoais, como há em todos os lugares do mundo, como há entre os seres humanos, mas nunca por razão da minha condição de mulher ${ }^{117}$.

Devemos apontar que nos mencionados depoimento, tanto no constante às pioneiras da USP em 1984, publicada em 2004, como na entrevista a Flávio Saes publicada em 1997, as menções à FEA/USP se manifestam no sentido de condições extremamente favoráveis à pesquisa, bem como a demarcação de um ambiente institucional sem restrições à mulher. O mesmo podemos observar em relação ao trecho de entrevista transcrita acima. Porém, nesta última, livre dos enquadramentos da escrita e sem revisão da autora, apresenta uma contradição quanto à última característica apontada. O trecho de sua fala foi provocado pela pergunta de Flávio Saes acerca das dificuldades de sua carreira e como era ser mulher na universidade nos anos 1930. Após mencionar o preconceito por conta das excursões geográficas com Pierre Monbeig, nas

\footnotetext{
116 Trata-se de um periódico internacionalizado, publicado pelo departamento de Economia da FEA/USP e pela Fundação Instituto de Pesquisas Econômicas (FIPE). Na "carta dos editores" (Carlos Roberto Azzoni, Armênio de Souza Rangel e Dante Mendes Aldrighi) lê-se: "A revista ECONOMIA APLICADA [...] opta por uma linha editorial voltada exclusivamente para artigos científicos em economia aplicada". Com o fito de se diferenciar de revistas especializadas em teoria econômica, metodologia, história do pensamento econômico, história econômica etc. A entrevista de Alice insere-se na seção "como eu pesquiso", cujo objetivo é que professores prestem depoimento sobre suas atividades de ensino e pesquisa. Link do periódico disponível em: 〈http://www.revistas.usp.br/ecoa〉. Acessado em 21 de abr. 2019.

${ }^{117}$ CANABRAVA, op. cit., 1981.
} 
quais viajavam homens e mulheres; das dificuldades e oposições quando se candidatou ao concurso para a cadeira de História da Civilização Americana de 1946 e sobre sua ótima recepção na Faculdade de Economia, Canabrava rememora o que para ela foram anos de sofrimento, por conta do período em que exerceu a direção da FCEA entre 19541957.

Como catedrática... como 1954 eu estava substituindo, 54-57 que eu fui diretora, então eu fui a primeira mulher a entrar no conselho universitário, na qualidade de membro do conselho, e diretora de uma faculdade. E então aí foi um, outra forma de, vamos dizer, de oposição. Eu digo que nunca se opuseram a mim dentro da faculdade na qualidade de catedrático, no exercício profissional, mas entrando eu no período em que eu entrei e tive as minhas funções de diretora, foi um dos períodos mais difíceis... por outras razões, porque a faculdade naquela época, quer dizer, havia um grupo, a maioria dos professores pertenciam ao partido do Ademar de Barros, eram ademaristas e o governador que era o Jânio Quadros, considerava a faculdade um ninho de ademaristas e de ademaristas vagabundos, ademaristas que não trabalhavam. Então desenvolveu-se um processo de crise, houve uma intervenção na faculdade, comissão de inquérito. Todos os professores ouvidos para colocar... cujo objetivo final era colocar todos os professores na rua. E eu me investi contra essa injustiça. Qual havia dois ou três professores capitaneando, na crista da onda desse movimento. E eu me investi contra isso porque eu achava que... falei diretamente ao Jânio Quadros que eu nada tinha que ver com as convicções políticas dos professores. O meu dever como professor e como diretor era exclusivamente o problema funcional deles e mais nada dentro da faculdade. E me opus a essa demissão. Me opus a essa demissão, mas há um material interessantíssimo de todos os depoimentos dos professores e os argumentos mesmo, mas as razões eram no fundo todas políticas, de razão exclusivamente política capitaneada por professores que achavam que eles deveriam ser diretores e não eu. De modo que não foi fácil também esse período. Esse período foi extremamente difícil. Ainda que quando aceitei me dissessem, 'não você vai pra uma faculdade extremamente pequena, não vai ter trabalho, vai continuar suas pesquisas' ${ }^{\prime 18}$.

Aqui, exatamente quando está rememorando as dificuldades enfrentadas pela mulher na universidade aparece uma contradição, típica da rememoração: foi muito bem recebida na FCEA e não sofreu oposição alguma, até mesmo quando da abertura do concurso para a cadeira de História Econômica de 1951 através do qual se tornou a primeira catedrática da FCEA e da USP. Porém, na condição de diretora, o cenário mudou. Enquanto na FFCL para a mulher o interdito dizia respeito à cátedra, "tudo menos

${ }^{118}$ CANABRAVA, op. cit., 1981. 
a cátedra!", na FCEA, tudo menos a direção! Estes dois interditos e suas diferenças se relacionam com a cultura acadêmica de cada um destes lugares sociais.

Quando Alice assumiu a direção da FCEA, esta não possuía ainda um número suficiente de catedráticos - deveria haver $1 / 3$ de catedráticos no corpo docente para formação da Congregação, de acordo com o regulamento da faculdade - para escolher o diretor, de modo que, com o afastamento de Theotônio Monteiro de Barros Filho da direção, eleito deputado federal, o Conselho Universitário $(\mathrm{CO})$, funcionando como Congregação e Conselho Técnico-Administrativo (CTA) da FCEA, deveria indicar dois nomes ao governador do estado para que procedesse à escolha do novo diretor ${ }^{119}$. Na sessão $384^{\text {a }}$ do CO de 04 de novembro de 1954, após a resposta ao pedido de demissão de Theotônio Monteiro de Barros Filho proferida pelo reitor José de Mello Moraes, o mesmo propõe a escolha de dois nomes de professores da FCEA, preferencialmente catedráticos - lembrando que naquele momento haviam três professores catedráticos: Alice P. Canabrava, Dorival Teixeira Vieira e Mário Wagner Vieira da Cunha - para indicar ao governador do Estado para nomeação do novo diretor. O resultado da votação foi o seguinte: Alice Piffer Canabrava, 13 votos; Mário Wagner Vieira da Cunha, 10 votos; Antônio Cesarino Júnior, 4 votos e Edgard Radesca, um voto ${ }^{120}$. Indicados os nomes de Alice Piffer Canabrava e de Mário Wagner Vieira da Cunha, o então governador do estado Ademar Pereira de Barros nomeou Alice para diretora da FCEA. Ao contrário do rememorado por Alice no excerto destacado acima, esta não estava substituindo o exdiretor Monteiro Filho, mas sim foi votada pelo CO para ser indicada ao governador. Quando assumiu a direção, a FCEA ainda não possuía dez anos de existência e estava se consolidando no cenário paulistano.

A fundação de Faculdades de Economia no Brasil é comumente associada às transformações estruturais da economia brasileira após 1930, em um contexto de intensificação do processo de industrialização promovido pelo Estado por meio de uma política deliberada de substituição de importações, cujo efeito foi a intensa urbanização

\footnotetext{
${ }^{119} \mathrm{Na} 384^{a}$ sessão do CO de 04/11/1954, o reitor José de Mello Moraes responde ao ofício de Theotônio Monteiro de Barros Filho desejando-lhe que desempenhe o cargo com o mesmo empenho e brilho com os quais dirigiu a FCEA e contribuiu para a USP. Cf. Atas do CO v. 17, f. 41 e verso. Arquivo da Secretaria Geral. Reitoria da USP. Em nota, $O$ Estado de S. Paulo informou a demissão de Theotônio Monteiro de Barros Filho da direção da FCEA em função de sua eleição para deputado federal. Cf. "A Faculdade de Ciências Econômicas e Administrativas". O Estado de S. Paulo. 05/11/1954, p. 11.

${ }^{120}$ Sessão $384^{\text {a }}$ do CO. Atas do CO, v. 17, f. 42. Arquivo da Secretaria Geral. Reitoria da USP.
} 
durante as décadas seguintes. Em texto que abre o primeiro volume, denominado "A instituição", da História da Faculdade de Economia e Administração da Universidade de São Paulo, Alice sintetiza as condições para a fundação da FCEA/USP ${ }^{121}$. Não é por acaso que a historiadora "abre" o livro comemorativo dos 35 anos da FEA/USP. É a organizadora e coordenadora da obra, em dois volumes. Líder da equipe de História da FEA, suas histórias, profissional e pessoal, se confundem com a história desse lugar social. Em 1980 ela foi designada, pela diretoria da FEA, para participar da Comissão Especial responsável pela organização da obra e em 1982 foi alçada à condição de coordenadora dos trabalhos. Seu empenho na organização da obra pode ser acompanhado através de inúmeras cartas nas quais Alice solicita ao destinatário dados profissionais para compor o segundo volume, "Personália", onde consta pequena trajetória de todos, desde professores em todos os níveis, passando por funcionários do antigo Instituto de Administração (IA), até funcionários do quadro técnico-administrativo, que trabalharam na FEA desde sua fundação ${ }^{122}$.

A primeira Faculdade de Economia vinculada à uma universidade no Brasil foi a antiga Faculdade Nacional de Ciências Econômicas (FNCE) da Universidade do Brasil, fundada no mesmo ano da FCEA/USP ${ }^{123}$. Um Instituto de Ciências Econômicas e Comerciais estava presente como instituto oficial no decreto n. 6.283 de 25 de janeiro de 1934 que cria a Universidade de São Paulo. O capítulo IV deste decreto dispõe sobre a criação do Instituto, estabelecendo como seu objetivo "[...] promover a alta cultura econômica e comercial, e fornecer preparação científica para as profissões e ofícios de direção, atinentes à atividade econômica e comercial" ${ }^{124}$. Porém, como vimos, as condições sociais para tanto se consolidaram somente na década de $1940^{125}$.

\footnotetext{
${ }^{121}$ CANABRAVA, Alice Piffer. As condições sociais, econômicas e políticas da fundação. In: História da Faculdade de Economia e Administração da Universidade de São Paulo, 1946/1981. Vol. 1. A instituição. São Paulo: FEA/Associação dos ex-alunos FEA, 1984, p. 13.

122 Ver, por exemplo: APC-VIAC-001; APC-XAVI-001; APC-RODR-001; APC-PACE-001; APC-NASC001; APC-NASC-002; APC-NASC-003; APC-NEGR-001; APC-MENDR-001; APC-LEIT-001; APCLEME-001; APC-IKED-001; APC-IKED-002; APC-JEKA-001; APC-JEKA-002. Fundo Alice Piffer Canabrava. Arquivo IEB/USP.

${ }^{123}$ Sobre a formação da FNCE, ver: CASTRO, Nivalde José de. As origens da Faculdade Nacional de Ciências Econômicas da Universidade do Brasil. In: CASTRO, Nivalde José de. O Economista: a história da profissão no Brasil. Rio de Janeiro: COFECON; CORECON/RJ; CORECON/SP, 2001, p. 47-67.

${ }^{124}$ Capítulo IV. Decreto n. 6283 de 25/01/1934. Documentos. In: CANABRAVA, op. cit., 1984, p. 375.

${ }^{125}$ Os debates em torno da fundação da FCEA e seus desdobramentos também podem ser acompanhados em várias edições de $O$ Estado de S. Paulo, como o artigo "A Faculdade de Ciências Econômicas e Administrativas de São Paulo" de autoria do Sindicato dos Economistas no Estado de São Paulo e do Sindicato dos Contabilistas de São Paulo, publicado na seção "Colaboração dos leitores" em 14/02/1946,
} 
Em 1947 a FCEA contava com cinco departamentos aos quais eram vinculadas suas várias cadeiras. O departamento de Economia, o que mais nos interessa aqui, era formado pelas seguintes cadeiras: Geografia Econômica (cadeira IX); História Econômica (X); Sociologia Econômica (XI); Ciência das Finanças (XVIII); Economia Política e História das Doutrinas Econômicas (XIX); Valor e Formação de preços; moeda e crédito; comércio internacional e câmbios (XX); Repartição da renda social; evolução da conjuntura econômica e estudo comparativo dos sistemas econômicos (XXI) e Técnica Comercial e dos Negócios (XXII) ${ }^{126}$. Além de seus cinco departamentos, anexo à cadeira de Ciência da Administração, funcionava também o Instituto de Administração (IA).

O IA foi criado a partir do Departamento do Serviço Público do Estado de São Paulo (DSP). Sua criação se deu no bojo dos intentos de racionalização da Administração Pública no país, objetivando dirimir os comportamentos paternalista-patrimonialistas. $\mathrm{O}$ objetivo do IA era prestar serviços de pesquisa ao DSP e a vários órgãos da Administração Pública em suas várias esferas e também à administração privada. Para tanto, vários de seus setores foram transferidos para o IA: biblioteca e seus bibliotecários; serviço de documentação; setores de fisiologia do trabalho, psicologia aplicada, organização, pesquisas sociais, orçamento, direito, administração de pessoal, administração pública e história. Sendo assim, eram 19 cargos de técnico de administração, um de técnico de documentação e um de auxiliar de documentação ${ }^{127}$.

Ao deixar o posto de primeira assistente da cadeira de História da Civilização Americana da FFCL, após ter sido preterida no concurso de 1946, Alice foi para o IA através de nomeação por indicação do então diretor da FCEA, ao qual o instituto estava administrativamente subordinado, José Reis, ao reitor da USP. Após todo o tramite burocrático junto ao interventor federal no Estado de São Paulo, Alice Canabrava foi nomeada para o setor de História do IA. Sua função: realizar pesquisas em história da

p. 6. O artigo gira em torno da discussão da contribuição do ensino nas Faculdades de Ciências Comerciais anterior à criação das Faculdades de Ciências Econômicas e Administrativas vinculadas à universidade. O argumento central é de que não há um fosso tão grande entre a formação anterior e a atualmente realizada nas Faculdades de Ciências Econômicas e Administrativas de várias universidades.

126 Cf. Anuário da Faculdade de Ciências Econômicas e Administrativas (1946-1947). São Paulo, Faculdade de Ciências Econômicas e Administrativas da Universidade de São Paulo, 1948, p. 9-10. Além do departamento de Economia, a FCEA também possuía outros quatro departamentos: Matemática; Estatística; Organização e Contabilidade; e Direito.

${ }^{127}$ NOGUEIRA, Oracy. O Instituto de Administração - IA ( $1^{\text {a }}$ Fase). In: CANABRAVA, op. cit., 1984, p. 214. 
administração ${ }^{128}$. Alice foi chefe do setor técnico de História do IA, no qual ofereceu $\operatorname{cursos}^{129}$ e publicou pesquisas na Revista de Administração ${ }^{130}$. Este periódico, transferido do DSP para o IA, dirigido por Mário Wagner Vieira da Cunha, apresenta uma gama de estudos sobre comunidades, constituindo-se em lócus privilegiado para acompanhar a inserção no Brasil dos estudos da Escola de Chicago ${ }^{131}$.

Ela permaneceu no IA por apenas um ano, uma vez que em 1947 foi contratada para reger a cadeira de História Econômica da FCEA, após o desmembramento da cadeira de Sociologia Econômica, História Econômica e Geografia Econômica em outras três cadeiras, aprovado pelo CO em 07 de janeiro de $1947^{132}$. Seu ofício de nomeação para o IA da FCEA pelo interventor federal data de 27 de agosto de 1946. Um dia antes de completar um ano no cargo, a historiadora se transferia para a FCEA, assumindo a cadeira de História Econômica. E iniciou suas atividades docentes na FCEA à frente da Cadeira X de História Econômica no ano de 1948.

Como podemos notar, a FCEA nasce com uma especificidade que muito diferencia sua cultura acadêmica em relação à FFCL: possui um órgão anexo, o IA, dotado de grande estrutura para realizar pesquisas em administração com o fito de racionalizar toda a administração estatal. Outra marca distintiva da recém-fundada faculdade diz respeito ao recrutamento de seus professores. Este não se deu através de uma "missão" estrangeira como no caso da FFCL, mas sim por meio da incorporação de professores provenientes da Faculdade de Direito, das Faculdades de Comércio e da FFCL/USP. Theotônio Monteiro de Barros Filho, regente da cadeira de Ciências das

\footnotetext{
${ }^{128}$ Processo 46.1.7832.1.7 (Arquivo da Reitoria da USP: nomeação de Alice Piffer Canabrava à FCEA, 1946). Ofício n. 58.

${ }^{129}$ Alice Canabrava ministrou no "Seminário de estudos das fontes primárias para a História de S. Paulo no século XVI", o curso "Fontes primárias para o estudo da moeda e crédito no Estado de São Paulo no século XVI". O Seminário foi promovido pelo IA e ocorreu nas dependências do IHGSP nos meses de abril, maio e junho de 1948. Nícia Villela Luz, do IA, e Sérgio Buarque de Holanda também ministraram curso. Cf. Conferências e Cursos. O Estado de S. Paulo. 16/04/1948, p. 10.

${ }^{130}$ CANABRAVA, Alice Piffer. Tendência da bibliografia sobre a História Administrativa do Município. Revista de Administração. São Paulo, n. 1, p. 80-87, 1947. CANABRAVA, Alice Piffer. A Evolução das posturas municipais de Sant`Ana de Parnaíba, 1829-1867. Revista de Administração. São Paulo, n. 9, p. 34-62, 1949. CANABRAVA, Alice Piffer; CUNHA, Mário Wagner Vieira da. A Administração Municipal de Sant'Ana de Parnaíba nos anos de 1829-1867. Revista de Administração. São Paulo: Instituto de Administração, ns. 11-12, p. 3-83, 1949.

${ }^{131}$ Cf. LOPES, Juarez Brandão. Entrevista. In: BASTOS, Elide Rugai; ABRUCIO, Fernando; LOUREIRO, Maria Rita; REGO, José Márcio. Conversas com sociólogos brasileiros. São Paulo: Ed. 34, 2006, p. 95113.

132 Histórico da Faculdade de Ciências Econômicas e Administrativas (incluindo o Instituto de Administração). In: Anuário da Faculdade de Ciências Econômicas e Administrativas (1946-1947), op. cit., 1948, p. 133.
} 
finanças (XVIII) era catedrático da Faculdade de Direito, onde também obteve sua livredocência; o regente da cadeira de sociologia econômica (XI), José Ignácio Benevides de Rezende, também havia cursado a Faculdade de Direito, porém não possuía pósgraduação e atuava na Faculdade de Ciências Econômicas de São Paulo da Fundação Alvares Penteado ${ }^{133}$; Luiz de Freitas Bueno, chefe do departamento de estatística, havia se formado em engenharia elétrica pela Escola de Engenharia do Mackenzie; Dorival Teixeira Vieira, regente da cadeira de Valor e formação de preços; moeda e crédito; comércio internacional e câmbios (XX), era proveniente da FFCL, onde realizou doutoramento sob a orientação de Paul Hugon; Dirceu Lino de Mattos, regente da cadeira de Geografia Econômica (IX), havia cursado Geografia e História na FFCL e era professor da Escola Técnica de Comércio de São Paulo. Dos 16 regentes de cadeira de todos os departamentos da FCEA em seus dois primeiros anos de funcionamento, sete haviam cursado a Faculdade de Direito; cinco cursaram Faculdades de Comércio; quatro a FFCL/USP e um cursou Engenharia. Voltemo-nos para os assistentes e auxiliares de ensino. Dos 32 assistentes e auxiliares de ensino para o período 1946-1947, não obtivemos informações sobre sete. Dos 25 restantes, 11 cursaram faculdade de Direito; dois cursaram faculdade de Comércio; oito cursaram a FFCL; um cursou Filosofia na atual PUC/SP ${ }^{134}$; um cursou Odontologia ${ }^{135}$; o último da contagem cursou Escola Politécnica/USP. Portanto, nestes dois primeiros anos de funcionamento o predomínio em termos de formação tanto dos regentes quanto dos assistentes e auxiliares de ensino foi na área de Direito, seguida pelos oriundos da FFCL/USP.

Este fato em grande medida explica o perfil do curso de Ciências Econômicas durante sua primeira década de funcionamento. Ao traçar o percurso da cadeira de Economia Política e História das doutrinas econômicas da subseção de Ciências Sociais da FFCL para a FCEA/USP, para a qual se transferira com a reforma universitária de 1968, Diva Benevides Pinho demarca o que seria um diferencial fundamental e fundacional na cultura acadêmica das duas faculdades: “[...] diferentemente da FFCL, que

\footnotetext{
${ }^{133}$ Antes da instalação das Faculdades de Ciências Econômicas e Administrativas nos anos 1940, o ensino de Ciência Econômica possuía caráter mais técnico e estava vinculado ao ensino comercial.

134 Trata-se de Heraldo Barbuy.

135 Trata-se de Licurgo do Amaral Campos.
} 
recorreu a missões estrangeiras, a FCEA recrutou a maioria de seu corpo docente na própria USP, principalmente na FFCL, Direito e Poli"136.

\subsection{Na crise, uma noção de Ciência Econômica}

Os primeiros dez anos de funcionamento da FCEA foram bastante conturbados, sendo que durante a diretoria de Alice Canabrava (1954-1957) a faculdade enfrentou uma greve de três dias, 17, 18 e 19 de setembro de 1956, por parte dos alunos capitaneados pelo Centro Acadêmico Visconde de Cairu (CAVC), fundado em 22 de julho de 1946. Dentre as motivações para a greve estão as irregularidades na constituição e funcionamento do corpo docente e a campanha pela reforma curricular ${ }^{137}$. Conforme rememorado acima, houve uma intervenção do governo estadual, do governador Jânio Quadros, para instaurar uma sindicância na faculdade. A documentação que encontramos sobre esta crise da FCEA não trata de dois importantes aspectos rememorados pela historiadora: a perseguição política promovida por Jânio Quadros aos professores ademaristas e a oposição interna à sua diretoria.

As demandas dos estudantes da FCEA em relação à reforma curricular e ao corpo docente inserem-se em um quadro mais amplo, qual seja, a da progressiva organização dos movimentos sociais face, principalmente, ao aumento das taxas de inflação, o que conduzia ao crescente custo de vida, acentuado durante o governo de Juscelino

${ }^{136}$ PINHO, Diva Benevides. Economia Política e a história das doutrinas econômicas. Economia Aplicada, São Paulo, 1994, p. 326. As sociedades de classe, como o Sindicato dos Contabilistas de São Paulo e o Sindicato dos Economistas no Estado de São Paulo, desempenharam importante papel nas discussões sobre o ensino universitário em Administração, Contabilidade e Economia. Exemplo disso, encontramos em nota publicada pelas entidades em $O$ Estado de $S$. Paulo. Dentre outros pontos, sugerem que as cadeiras de Economia Política, Valor e Formação de Preços e a cadeira de Ciência da Administração sejam regidas por professores provenientes de centros mais avançados no estudo das ciências econômicas e administrativas em âmbito universitário, com o fim de formar seus sucessores brasileiros. Cf. Ao público e aos contabilistas e economistas do Estado de S. Paulo. A propósito da instalação da Faculdade de Ciências Econômicas e Administrativas na Universidade de São Paulo. O Estado de S. Paulo. 26/02/1946, p. 13.

${ }^{137}$ Cf. MARCOVITCH, Jacques. O Centro Acadêmico Visconde de Cairu (CAVC). In: CANABRAVA, op. cit., 1984, p. 337-346. Em 01 de junho de 1954 o CAVC organizou a conferência "Causas da corrupção no ensino e meios de combatê-la" ministrada por Heraldo Barbuy. Cf. Conferências e cursos. $O$ Estado de S. Paulo. 01/06/1954, p. 15. A greve de estudantes do CAVC parece estar ligada à um movimento maior, qual seja, a greve geral dos estudantes das instituições de ensino superior do Estado de São Paulo capitaneados pela União Estadual dos Estudantes em apoio ao grêmio da Escola Politécnica da USP e do grêmio da Escola Superior de Agricultura "Luiz de Queiroz" de Piracicaba. A Escola Politécnica não reconheceu a nova diretoria do grêmio e a Escola de Piracicaba estava sem diretor, uma vez que a Congregação não enviou nomes ao governo do Estado. Estes eventos conduziram à um questionamento maior: pode uma Congregação não reconhecer o grêmio ou centro acadêmico de sua Faculdade ou Escola? Pode uma faculdade da USP não enviar nomes para que o governo estadual escolha seu diretor e vice? Cf. O Conselho de presidentes da União Estadual de Estudantes declara greve geral. O Estado de S. Paulo. 16/09/1954, p. 12. 
Kubistchek (1956-1960), o qual utilizava como principal instrumento de financiamento dos gastos públicos a emissão primária de moeda ${ }^{138}$. Nesse contexto, ao lado do posicionamento estudantil junto às demandas das classes trabalhadoras, o fortalecimento da União Nacional dos Estudantes (UNE) tornou-se mais um elemento envolvido nas relações entre governos e universidade na busca pela autonomia universitária ${ }^{139}$. A relação dos governos, federal e estaduais, com as universidades em seu processo de institucionalização sempre foi conturbada.

No caso da USP e dos governos federal e estadual, José Sebastião Witter indica períodos-chave: desde o Estado Novo com um sistema universitário autoritário e unitário, com normas uniformizantes dos currículos, por exemplo; passando pelas conturbadas relações com o governo estadual de Jânio Quadros (1955-1959); pela tentativa de reforma de João Goulart; até a reforma universitária de 1968. O que mais nos interessa aqui é o caso das relações entre Jânio Quadros e o sistema universitário paulista, uma vez que a diretoria de Alice Canabrava foi exercida nesse período. O ponto inicial da crise se deu em relação à revogação do decreto 15.610 de 26 de janeiro de 1946, conhecido por “decreto Macedo Soares" que instituiu a lista dúplice para indicação do nome de diretor e vice-diretor das unidades da USP por suas respectivas Congregações ${ }^{140}$. Ademais, durante o governo de Jânio Quadros o orçamento destinado à USP também foi motivo de embates, uma vez que para o período 1953/1957 os 3,5\% da receita estadual destinados à USP foram reduzidos para $1,5 \%{ }^{141}$.

Uma das hipóteses aventadas por Diva B. Pinho quanto à mobilização dos alunos em torno do CAVC com o fito de requerer melhorias de ensino na faculdade é de que o

\footnotetext{
${ }^{138}$ Além da instabilidade econômica, o país também enfrentava séria instabilidade política, principalmente por conta do suicídio de Getúlio Vargas em 1954 e da necessidade de um golpe "preventivo" para garantir a posse de JK em 1956. Para um panorama político do período, ver: SKIDMORE, Thomas. Governo Transitório (1954-1956). In:__ Brasil: de Getúlio Vargas a Castelo Branco, 1930-1964. $7^{\text {a }}$ edição. Rio de Janeiro: Paz e Terra, 1982, p. 181-202. Para questões mais específicas do período como movimentos sociais, artísticos, estudantis e culturais no geral, ver os vários capítulos de: GOMES. Angela Maria de Castro Gomes et ali. O Brasil Republicano: sociedade e política (1930-1964). In: FAUSTO, Boris (dir.). História Geral da Civilização Brasileira. T. 3, v. 10. $9^{a}$ edição. Rio de Janeiro: Bertrand Brasil, 2007. E: PIERUCCI, Antônio Flávio de Oliveira et ali. O Brasil Republicano: economia e cultura (1930-1964). In: FAUSTO, Boris (dir.). História Geral da Civilização Brasileira. T. 3, v. 11. $9^{a}$ edição. Rio de Janeiro: Bertrand Brasil, 2007.

${ }^{139}$ Cf. CUNHA, Luiz Antônio. A Universidade crítica: o ensino superior na República Populista. Rio de Janeiro: Francisco Alves, 1983, p. 11-71.

${ }^{140}$ Cf. WITTER, José Sebastião. Uma universidade autônoma. In: um debate. $2^{\mathrm{a}}$ edição. São Paulo: EDUSP, 2006, p. 53-99.

${ }^{141}$ Cf. RODRIGUES, Lidiane Soares. Os catedráticos da USP e o governo Jânio Quadros. Revista Pensata. São Paulo, v. 2, n. 1, p. 90-107, 2012.
} 
espaço compartilhado entre a FFCL e a FCEA promoveu uma sinergia entre a Maria Antonia e a Faculdade de Economia, uma vez que a instalação desta se dera na esquina da rua Dr. Vila Nova com a rua Maria Antonia. Além disso, se podia entrar pela FFCL e sair pela FCEA e vice-versa e também possuíam espaços de sociabilidade comuns, como a cafeteria, por exemplo ${ }^{142}$. Em suas "reminiscências" de seus tempos de Maria Antonia, Diva Pinho rememora a crise que também atingiu a FFCL durante o governo Jânio Quadros e a postura do então diretor Eurípedes Simões de Paula. "Lembro-me de seu caminhar solitário e pensativo pelo pátio entre a FFCL e FCEA [...]. Precisava eliminar determinado percentual de docentes e funcionários, para atender imposições do então governador Jânio Quadros, mas seu coração relutava..."143.

Paul Singer, que ingressou na FCEA em 1956, assim como Diva Pinho, fez carreira na FCEA e atingiu a condição de professor titular, matiza a hipótese desta por meio da caracterização da FCEA como um ambiente político conservador em oposição à FFCL, intelectualmente brilhante, engajada e com vida política fervilhante. Para ele, “[...] a FCEA estava preocupada em delimitar um campo de competência técnica, no qual o economista - então um profissional relativamente novo e desconhecido - pudesse se autoafirmar [sic]" ${ }^{\prime 144}$. A partir de um debate sobre o plano de metas de JK realizado na faculdade em 1956, no qual os professores advogavam pela teoria clássica das vantagens comparativas e, por isso, o Brasil não deveria produzir automóveis e caminhões, Singer caracteriza seu corpo docente como neoclássico e pré-keynesiano. Corrobora a análise de Singer, uma nota emitida pelo CAVC em 02 de setembro de1954 e publicada no jornal $O$ Estado de S. Paulo. O CAVC

[...] declara que não tomou parte no movimento de solidariedade à greve de hoje, por julgar que, no momento atual, mais do que nunca, é com trabalho e não com a paralisação de atividades que só pode contribuir para aumentar a produção e, em consequência, baratear o custo de vida $^{145}$.

Podemos inferir das memórias de Diva Pinho e de Paul Singer que os alunos da FCEA estavam mais preocupados em se profissionalizar; em requerer um currículo que

\footnotetext{
142 PINHO, Diva Benevides. A FEA-USP no tempo: contribuição à memória de seus 60 anos. São Paulo: FEA/USP, 2006.

${ }^{143}$ PINHO, Diva Benevides. Reminiscências da faculdade da Maria Antonia. In: SANTOS, Maria Cecília Loschiavo dos (orga.). Maria Antônia: uma rua na contramão. São Paulo: Nobel, 1988, p. 147. Sobre os detalhes dessa crise na FFCL, ver: RODRIGUES, op. cit., 2012.

${ }^{144}$ SINGER, Paul. Nos arredores da Maria Antônia. In: SANTOS, op. cit., 1988, p. 83.

145 Comunicado do centro "Visconde de Cairu". O Estado de S. Paulo. 02/09/1954, p. 28.
} 
se adequasse aos seus anseios. Ao passo que os alunos da FFCL estavam envolvidos com questões de política nacional e seus desdobramentos. O número de alunos nos dez primeiros anos de funcionamento da FCEA era reduzido. Os formados pela FCEA entre 1949 e 1957 totalizavam 105 bacharéis em seus dois cursos: Ciências Econômicas e Ciências Contábeis e Atuariais ${ }^{146}$. Dos 75 bacharéis em Ciências Econômicas formados no período, temos 67 homens e 8 mulheres. Composição por gênero bastante diferente do curso de Geografia e História da FFCL, no qual, como apontado acima, já nos anos 1940 o número de mulheres superava o de homens. No caso do curso de Ciências Contábeis e Atuariais, dos 30 bacharéis formados no período, não há nenhuma mulher ${ }^{147}$. Segundo dados coletados por Diva Benevides Pinho, o período com menor número de mulheres formadas em Economia foi entre 1954-1958, apenas 6\% ${ }^{148}$.

Alice se apresentava diante de uma audiência predominantemente masculina e era a única mulher do corpo docente, até que no período entre 1959 e 1963, Lenita Côrrea Camargo atingiu a cátedra por concurso. Neste sentido, a inserção da mulher enquanto catedrática na FCEA se deu antes do que na FFCL, sendo que esta última não contou com nenhuma catedrática até a reforma de 1968, quando a cátedra foi extinta e a carreira docente organizada de outra maneira. Após a reforma, na atual FEA, Diva Benevides Pinho e Maria José Villaça atingiram o cargo de professor-adjunto por concurso em 1973. E Diva Pinho tornou-se a terceira mulher da história da FCEA a atingir o posto mais alto da carreira docente: o de professor titular, ao lado das catedráticas Alice Canabrava e Lenita Côrrea Camargo, em 1977.

É neste ambiente acadêmico que Alice Canabrava enfrenta a "primeira" crise da FCEA. Os estudantes, como apontado acima, tinham uma dupla demanda: reforma curricular e concurso para os professores, uma vez que muitos não tinham o ensino como prioridade da carreira profissional. Quanto ao ensino, os alunos demandavam uma

\footnotetext{
${ }^{146}$ Dados extraídos da lista de bacharéis: Cf. O corpo discente: 1946/81. In: CANABRAVA, op. cit., 1984a, p. 355-385.

${ }^{147}$ Na quarta sessão da Congregação da FCEA realizada em 10 de maio de 1950, a primeira sessão em que Alice participou, o então diretor Theotônio Monteiro de Barros Filho, também em sua primeira sessão, demonstrou preocupação com a baixa inserção dos contabilistas e atuários formados pela faculdade e propôs a formação de uma comissão para manter contato com várias entidades como a federação das indústrias e sindicatos para que se pudesse informar sobre o perfil do egresso da faculdade o que também alavancaria o número de matriculados. Cf. Ata da quarta sessão da Congregação. Atas. Congregação. São Paulo: FCEA/FEA, v. 1 (1946-1964), p. 8-10. Arquivo da assessoria acadêmica da FEA/USP.

${ }^{148}$ PINHO, op. cit., 2006, p. 41-57. Em seus primeiros 25 anos de existência (1946-1971) a participação da mulher entre os graduados em Economia foi de $10 \%$ e até o ano de 2004, o departamento de Economia da atual FEA/USP formou 930 mulheres de um total de 4.736 alunos, perfazendo $20 \%$ do total.
} 
formação mais específica, com mais disciplinas profissionalizantes. Até a reforma de 1968, predominava o ensino de economia política ligado à concepção francesa, de caráter institucionalista, como organizado por Paul Hugon, e seus cursos eram "[...] marcados por uma concepção predominantemente especulativa, pura, desinteressada, em busca da interpretação do mundo econômico a partir de debates fundamentalmente doutrinários, humanistas e históricos [itálico no original]" ${ }^{149}$. Com a crise institucional de 1954-1957, a concepção de ciência econômica na FCEA tornou-se predominantemente quantitativa e pragmática - intensificando-se com a reforma universitária de 1968 - principalmente com o financiamento de estudos de professores da FEA nos EUA. O desenvolvimento dos estudos quantitativos se liga aos esforços dos EUA durante a II Guerra Mundial, recrutando cientistas em todas as partes do mundo para o desenvolvimento de tecnologia militar. Foi assim que o currículo incorporou com força a econometria como subsidiária à formulação em teoria econômica. Ao lado dos econometristas, formou-se um grupo de professores que orientaram suas pesquisas inspirados na Nova Economia Institucional $(\mathrm{NEI})^{150}$.

A estrutura curricular no curso de ciências econômicas evoluiu, ao longo dos anos, de uma concepção de economia predominantemente especulativa e institucional para a aplicação de um instrumental analítico econométrico e a formulação da teoria econômica em linguagem matemática, possibilitando testes com dados empíricos e recursos da estatística e da econometria ${ }^{151}$.

Alguns indícios nos conduzem a matizar o período de direção de Alice Canabrava como único momento de crise da FCEA, uma vez que o problema da contratação do corpo docente, surgira logo no primeiro ano de funcionamento da faculdade. André Dreyfus, então diretor da FFCL, na sessão do CO de 29 de março de 1946, manifesta-se contrário à nomeação de catedráticos sem concurso.

Como diretor de uma Faculdade na qual a cátedra é conquistada após concurso de títulos e provas, venho manifestar a este Colendo Conselho o meu protesto contra a nomeação de catedráticos, independentemente

\footnotetext{
${ }^{149}$ PINHO, Diva Benevides. O tempo revisitado: releitura proustiana de 70 anos como estudante e docente da USP. São Paulo: FUNDACI, 2015, p. 99.

${ }^{150}$ A principal teoria da NEI é de que as instituições em uma sociedade, são formadas pelo processo de negociação entre indivíduos e grupos de indivíduos com o fito de reduzir os custos de transação, ou seja, custos potenciais de rompimento de acordos. Cf. BUENO, Newton Paulo. Possíveis contribuições da Nova Economia Institucional para à pesquisa em história econômica brasileira: uma releitura das três obras clássicas sobre o período colonial. Estudos Econômicos. São Paulo, v. 34, n. 4, p. 777-804, 2004.

${ }^{151}$ FISCHMANN, Alberto Américo; GUERREIRO, Reinaldo. As contribuições da FEA para o avanço da ciência e para a implementação de políticas públicas. In: GOLDEMBERG, José. USP 80 anos. São Paulo: EDUSP, 2015, p. 80.
} 
daquelas formalidades. Assim procedi no caso da Faculdade de Higiene e assim venho proceder no caso da Faculdade de Ciências Econômicas ${ }^{152}$.

Podemos notar que a questão da autonomia universitária não dizia respeito apenas à ingerência dos governos federal e estadual na Universidade. Havia também uma tentativa de controle das faculdades já estabelecidas, como a FFCL, sobre as mais novas. As faculdades tradicionais, como a Faculdade de Direito, a Escola Politécnica e a Faculdade de Medicina também tentavam exercer seu poder sobre as demais. O corpo docente da Escola Politécnica protestou junto ao CO contra a contratação sem concurso de três professores da FCEA ${ }^{153}$.

Pelo que pudemos inferir das duas fontes aqui privilegiadas, quais sejam, as atas do CO e matérias, notas e informações veiculadas em $O$ Estado de $S$. Paulo, o principal catalisador da crise enfrentada por Alice durante o período em que foi diretora da FCEA foram os protestos dos estudantes representados pelo CAVC. A greve de protesto por eles organizada durou três dias e foi anunciada pela imprensa em 16 de setembro de 1956. Através de uma nota publicada sob o título de "Greve de protesto dos alunos da Fac. de Ciências Econômicas", os alunos esclarecem que nos dias 17, 18 e 19 estarão em greve, alegando os seguintes motivos: a não renovação de contratos de professores que são assíduos em suas obrigações, ao passo que professores que não comparecem às aulas possuem situação estável; problemas de horários para a frequência das aulas, que mesmo tendo sido acordado com a direção não foram cumpridos; irregularidades de funcionamento do IA; a biblioteca não funciona por falta de regulamentação; não foi instalado o curso de doutoramento depois de 10 anos de funcionamento da faculdade; não funcionamento da Congregação. A nota esclarece ainda que irão enviar relatório à reitoria

\footnotetext{
${ }^{152}$ Ata da $218^{a}$ sessão do Conselho Universitário ocorrida em 29/03/1946. Atas do Conselho Universitário da Universidade de São Paulo. Vol. 8 (1946-1947). Arquivo da Secretaria Geral, f. 4-5. Reitoria da USP.

${ }^{153}$ Em "A nomeação de professores para a Faculdade de Ciências Econômicas” o jornal traz a notícia de que o $\mathrm{CO}$ aprovou, por unanimidade, protesto apresentado pela Congregação da Escola Politécnica. Ademais, a seção traz ainda dois protestos em nota: um do sindicato dos contabilistas ao diretor José Reis e outro ao interventor federal proveniente do sindicato dos economistas do estado de São Paulo. O primeiro protesta contra a nomeação de professor para reger a cadeira de Contabilidade Industrial e Agrícola, por não possuir título na área. $\mathrm{O}$ segundo, assevera que os profissionais vinculados ao sindicato não puderam concorrer às cadeiras, uma vez que o provimento destas se fez por meio de nomeação. Cf. $O$ Estado de $S$. Paulo. 24/07/1946, p. 5.
} 
e ao governo do Estado sobre a situação precária da faculdade e que "[...] o nosso movimento visa à moralização do ensino" 154 .

As demandas dos estudantes foram comentadas por Alice, ponto a ponto, em sessão do CO. No que tange aos horários de aulas, a historiadora afirma que a faculdade, por determinação do CO, enquadrou-se na lei federal de 1951 que instituiu a grade curricular mínima para os cursos de Ciências Econômicas e Ciências Contábeis e Atuariais. Portanto, os professores, auxiliares e assistentes se adaptaram à lei, reestruturando os horários da faculdade. Quanto ao caso de auxiliares e assistentes afirma que estão sendo fiscalizados por ela e que há um sistema de fichas de frequência, inclusive onde constam as faltas da própria diretora. Sobre a instauração do doutoramento, Canabrava relata que elaborou um anteprojeto que foi amplamente discutido com os professores da FCEA e que será remetido ao CO para aprovação. Pelo fato de que há duas bibliotecas na FCEA, uma da própria faculdade e outra do IA, a questão necessita de estudos para sua resolução ${ }^{155}$.

A mobilização dos estudantes, apoiados por outras entidades estudantis e noticiada pela imprensa, teve o resultado esperado ao atingir o governo e a reitoria. No dia seguinte ao término da greve $O$ Estado de $S$. Paulo informa que serão instituídas duas comissões para averiguar as demandas dos mesmos: uma instaurada pela reitoria e outra pelo governo do estado. Relata ainda que a reitoria encaminhou as demandas dos estudantes à comissão de correição, presidida por Eurípedes Simões de Paula e composta por Gama e Silva, da Faculdade de Direito; Antonio Guimarães Ferri, da Faculdade de Medicina Veterinária; João Alves Meira, da Faculdade de Medicina e Paulo Ribeiro Arruda, da Escola Politécnica. O governo instaurou sindicância sob a presidência de Alvaro Guimarães Filho, da Faculdade de Higiene e Saúde Pública ${ }^{156}$. Para $O$ Estado de S. Paulo esta foi a maior crise já enfrentada pela USP.

\footnotetext{
${ }^{154}$ Greve de protesto dos alunos da Fac. de Ciências Econômicas. O Estado de S. Paulo. 16/09/1956, p. 17. Em matéria de 19 de setembro de 1956 o jornal expõe que o centro acadêmico da FFCL apoia o movimento dos estudantes do CAVC e que a determinação do governo de não abonar as faltas dos dias de greve não tem efeito, uma vez que a frequência à faculdade é livre. Cf. Termina hoje a greve dos alunos de economia da USP. O Estado de S. Paulo. 19/09/1956, p. 31.

${ }^{155}$ Cf. $423^{a}$ sessão do CO: 24/09/1956. Atas do CO. v. 19, verso f. 94-verso f. 97. Arquivo da Secretaria Geral. Reitoria da USP.

${ }^{156}$ Cf. Retornam as aulas os estudantes de Ciências Econômicas. O Estado de S. Paulo. 20/09/1956, p. 12. No dia seguinte, o jornal noticiou que os estudantes iriam apresentar um memorial ao reitor em reunião no sábado e agradecem o apoio da UEE e do governo estadual. Cf. O reitor receberá sábado os grevistas. $O$ Estado de S. Paulo. 21/09/1956, p. 27.
} 
Abre-se agora, com a greve de protestos dos alunos da Faculdade de Ciências Econômicas e Administrativas da Universidade de São Paulo, novo foco de inquietações que, em última análise, patenteia o desacerto da orientação que vem presidindo aos destinos da escola desde a sua fundação $0^{157}$.

As três comissões à que se refere $O$ Estado de S. Paulo são: a primeira comissão presidida por Alvaro Guimarães Filho, da Faculdade de Higiene e Saúde Pública e composta por Gabriel Sylvestre Teixeira de Carvalho, da Faculdade de Medicina Veterinária e José Vicente de Freitas Marcondes, do departamento jurídico do Estado, instituída por Jânio Quadros em 19 de setembro de 1956, último dia da greve dos estudantes da FCEA; a segunda comissão, instituída pela reitoria à partir do apresentado pela primeira comissão, composta por Alvaro Guimarães Filho, Gabriel Sylvestre Teixeira de Carvalho e Theodureto de Arruda Souto ${ }^{158}$; e a comissão de correição presidida por Eurípedes Simões de Paula que elaborou anteprojeto de decreto à partir do relatório da comissão de sindicância instaurada pelo governo.

A partir do que foi aprovado na sessão do CO de 14 de dezembro de 1956, Jânio Quadros assinou o decreto n. 27.056 de 19 de dezembro de 1956 que instituiu uma comissão de ensino na FCEA e determinou outras providências. Dentre elas, as mais polêmicas e, por isso, discutidas, foram as que estabeleceram a extinção dos cursos diurnos ou noturnos da faculdade e a demissão de todos os auxiliares e assistentes nãoestáveis a partir de janeiro. Na referida sessão do CO, Alice se absteve de votar, afirmando que como diretora da FCEA

[...] tem procurado silenciar, não intervindo propriamente na discussão. Depois de historiar os fatos desde o início da crise, diz que solicitou demissão mas que o governo não a concedeu, sendo assim mantida no cargo. Todavia, dado seu grande amor à Escola e no desejo de facilitar a solução do caso, para que não haja por nenhum modo, qualquer

\footnotetext{
${ }^{157}$ Caso velho que se renova. O Estado de S. Paulo. 23/09/1956, p. 3.

158 O Estado de $S$. Paulo expôs alguns pontos do relatório dessa comissão como a extinção do curso diurno, a demissão de todos os assistentes e auxiliares de ensino a partir de primeiro de janeiro e a extinção do regulamento da faculdade. Diante disso, os professores e assistentes da FCEA se reuniram e através do professor Antonio Cesarino Júnior levaram algumas propostas ao reitor e ao CO: rever o regulamento da faculdade em 30 dias ao invés de extingui-lo até a elaboração de um novo; que o CO continue como Congregação e CTA da faculdade; que o caso dos assistentes seja discutido com os professores e que as gratificações de aulas reunidas (quando o professor atua em uma disciplina oferecida a dois cursos diferentes) sejam examinadas caso a caso ao invés de sua extinção total. Estão de acordo com a instituição da frequência obrigatória às aulas, da revisão da situação do corpo docente e também quanto à determinação de um amplo período de trabalho para o curso diurno (8-18h). Não concordam com a extinção do curso diurno e com a demissão de todos os assistentes. Cf. Contra a supressão dos cursos diurnos os professores da Fac. de Ciências Econômicas. O Estado de S. Paulo. 13/12/1956, p. 16.
} 
constrangimento dos senhores conselheiros, encaminhará amanhã mesmo, por ofício, novo pedido de demissão ${ }^{159}$.

Perante o decreto de Jânio Quadros, o reitor concedeu autonomia à FCEA no sentido de que seus professores deliberassem acerca da composição da comissão de ensino para propor medidas visando à reestruturação da faculdade. A comissão foi composta pela diretora da FCEA, Alice Canabrava e pelos chefes dos respectivos departamentos: Dorival Teixeira Vieira (departamento de Economia), Milton Improta (Organização e Contabilidade), Luiz Arthaud Berthet (Matemática), Flávio Fausto Manzoli em substituição a Luiz de Freitas Bueno (Estatística), Geraldo Campos Moreira (Direito) e pelo diretor do IA, Mário Wagner Vieira da Cunha ${ }^{160}$.

Na proposta da comissão, a FCEA manteria três tipos de cursos: curso básico; cursos profissionalizantes e cursos de especialização. O curso básico foi justificado por buscar igualar o nível cultural dos ingressantes vis a vis o fato de que são egressos de várias instituições de ensino secundário que possuem suas especificidades. Ademais, também se justifica por visar diminuir a evasão dos cursos, principalmente de Ciências Contábeis e Atuariais, uma vez que os ingressantes, na maioria dos casos, procedem à escolha do curso sem conhecer a área. Quanto aos cursos profissionalizantes, a proposta prevê o desmembramento do curso de Ciências Contábeis e Atuariais em dois: Ciências Contábeis e Ciências Atuariais, uma vez que cada área possui suas especificidades e a lei federal havia desdobrado tal curso. Ademais, seria criado o curso de Administração com o fito de suprir a demanda da indústria e do setor público por administradores com formação superior. Por fim, os cursos de especialização já previstos no regulamento da Faculdade (tabela 1) ${ }^{161}$.

\footnotetext{
${ }^{159} 429^{\mathrm{a}}$ sessão do CO. Atas do CO. v. 19, f. 199 e verso.

${ }^{160}$ Cf. Projeto da Comissão de Ensino da Faculdade, instituída em decorrência do decreto n. 27.056 de 19/12/1956: para estudar e propor medidas relativas à reestruturação da mesma (1957). In: CANABRAVA, op. cit., 1984, p. 403-412.

${ }^{161}$ Cf. Projeto da Comissão de Ensino da Faculdade, instituída em decorrência do decreto n. 27.056 de 19/12/1956: para estudar e propor medidas relativas à reestruturação da mesma (1957). In: CANABRAVA, op. cit., 1984, p. 403-412.
} 


\begin{tabular}{|c|c|c|c|}
\hline $\begin{array}{c}\text { Curso básico } 1^{\text {a }} \\
\text { série }\end{array}$ & $\begin{array}{c}\text { Curso básico } 2^{\mathbf{a}} \\
\text { série }\end{array}$ & $\begin{array}{c}\text { Ciências } \\
\text { Econômicas } \\
\text { série } \\
\end{array}$ & $\begin{array}{c}\text { Ciências } \\
\text { Econômicas } 4^{\text {a }} \\
\text { série } \\
\end{array}$ \\
\hline $\begin{array}{l}\text { Complementos de } \\
\text { Matemática }\end{array}$ & $\begin{array}{c}\text { História } \\
\text { Econômica Geral e } \\
\text { do Brasil }\end{array}$ & Teoria do Valor & $\begin{array}{l}\text { Formação dos } \\
\text { preços }\end{array}$ \\
\hline $\begin{array}{c}\text { Contabilidade } \\
\text { Geral e Mercantil }\end{array}$ & Estatística Geral & $\begin{array}{c}\text { Estatística } \\
\text { Econômica I }\end{array}$ & $\begin{array}{c}\text { Estatística } \\
\text { Econômica II }\end{array}$ \\
\hline $\begin{array}{l}\text { Instituições de } \\
\text { Direito Público }\end{array}$ & $\begin{array}{c}\text { Economia Política } \\
\text { (Introdução à } \\
\text { Ciência } \\
\text { Econômica) }\end{array}$ & Moeda e crédito & $\begin{array}{l}\text { História das } \\
\text { doutrinas } \\
\text { econômicas }\end{array}$ \\
\hline $\begin{array}{l}\text { Técnica Comercial } \\
\text { e dos Negócios }\end{array}$ & $\begin{array}{l}\text { Problemas de } \\
\text { Matemática } \\
\text { financeira }\end{array}$ & $\begin{array}{c}\text { Legislação } \\
\text { tributária e fiscal }\end{array}$ & $\begin{array}{c}\text { Comércio } \\
\text { Internacional e } \\
\text { câmbios }\end{array}$ \\
\hline $\begin{array}{l}\text { Geografia } \\
\text { Econômica }\end{array}$ & $\begin{array}{c}\text { Estrutura e análise } \\
\text { de balanços }\end{array}$ & $\begin{array}{l}\text { Ciência das } \\
\text { finanças }\end{array}$ & Política financeira \\
\hline $\begin{array}{l}\text { Sociologia } \\
\text { Econômica }\end{array}$ & $\begin{array}{c}\text { Introdução à } \\
\text { Ciência da } \\
\text { Administração }\end{array}$ & $\begin{array}{c}\text { Estrutura das } \\
\text { organizações } \\
\text { econômicas }\end{array}$ & $\begin{array}{l}\text { Evolução da } \\
\text { conjuntura } \\
\text { econômica }\end{array}$ \\
\hline $\begin{array}{l}\text { Instituições de } \\
\text { Direito Privado }\end{array}$ & $\begin{array}{l}\text { Instituições de } \\
\text { Direito social }\end{array}$ & $\begin{array}{l}\text { Repartição da } \\
\text { renda social }\end{array}$ & $\begin{array}{c}\text { Estudo } \\
\text { comparativo dos } \\
\text { sistemas } \\
\text { econômicos }\end{array}$ \\
\hline
\end{tabular}

(Fonte: elaboração própria a partir dos dados contidos em: CANABRAVA, op. cit., 1984, p. 409412).

O curso básico proposto é organizado em 14 disciplinas. Temos três disciplinas da área de Direito: Instituições de Direito Público; Instituições de Direito Privado e Instituições de Direito Social. Na área quantitativa temos três disciplinas: Complementos de Matemática; Problemas de Matemática financeira e Estatística Geral. A área de Contabilidade é representada pela disciplina de Contabilidade Geral e Mercantil, enquanto a de Administração é representada pela disciplina de Introdução à Ciência da Administração. A disciplina de Técnica Comercial e dos Negócios é comum às áreas de Administração e Contabilidade, enquanto Estrutura e Análise de Balanços é comum às áreas de Administração, Contabilidade e Economia. Quanto a esta última, há apenas uma disciplina específica: Economia Política (Introdução à Ciência Econômica). Por fim, quanto ao curso básico, temos três disciplinas que denominaremos de "formação geral em humanidades": Geografia Econômica, Sociologia Econômica e História Econômica Geral e do Brasil. Notamos o predomínio das grandes áreas do Direito, métodos 
quantitativos e formação geral em humanidades no curso básico, com três disciplinas cada uma.

Quanto ao curso específico de Ciências Econômicas, a comissão presidida por Alice, propõe uma grade curricular formada por 14 disciplinas, em equilíbrio com o curso básico. Quanto à sua composição por área, temos o seguinte quadro: uma disciplina da área de Direito, qual seja, Legislação tributária e fiscal; duas disciplinas da área quantitativa, representadas por Estatística Econômica I e Estatística Econômica II; duas disciplinas comuns à Administração, Ciência das finanças e Política financeira. As disciplinas específicas ao campo das Ciências Econômicas são 9: Teoria do valor; moeda e crédito; estrutura das organizações econômicas; repartição da renda social; formação dos preços; história das doutrinas econômicas; comércio internacional e câmbios; evolução da conjuntura econômica e estudo comparativo dos sistemas econômicos.

A partir da análise da grade curricular proposta pela Comissão de professores da FCEA presidida pela historiadora, percebemos a importância conferida à área de formação geral em humanidades, uma vez que os estudantes tomarão contato com esta, independentemente do curso escolhido. Quanto ao curso profissionalizante de Ciências Econômicas, notamos a presença de apenas uma disciplina afeita a área do Direito e a predominância de disciplinas específicas à formação do economista, o que indica a preocupação da comissão com a formação do profissional economista, uma vez que o índice para a autonomia das Ciências Econômicas enquanto campo do saber se dá por seu crescente desmembramento em relação ao Direito ${ }^{162}$.

Portanto, acompanhar a crise da FCEA enfrentada por ela durante o período em que foi diretora é vislumbrar uma proposta específica para a formação do economista no Brasil. A proposta de reforma curricular dos cursos da FCEA da comissão presidida por Alice P. Canabrava, a nosso ver, apresenta uma maior preocupação com o nível de profissionalização do curso de Ciências Econômicas, conforme a maior presença de disciplinas profissionalizantes, o que atendia a demanda para uma mudança de perfil do curso por parte dos alunos congregados em torno do Centro Acadêmico Visconde de Cairu.

\footnotetext{
${ }^{162}$ A autonomia da Economia Política em relação ao Direito é um dos índices para a profissionalização do curso de Ciências Econômicas, ver: CASTRO, Nivalde José de. A regulamentação da profissão. In: CASTRO, op. cit., 2001, p. 13-45.
} 
No tópico seguinte, analisaremos as disputas em torno da manutenção de cadeiras junto à FCEA no contexto da reforma universitária de 1968, os fatores que convergiram para a permanência da cadeira de História Econômica junto à reformada FEA e sua dinâmica de funcionamento.

\subsection{A defesa da cadeira de História Econômica e sua dinâmica de funcionamento}

Durante a reforma universitária da USP de 1968, que extinguiu o regime de cátedras e instituiu o departamento como a menor fração da universidade, várias disciplinas da FEA/USP foram incorporadas à outras unidades da USP como, por exemplo, as disciplinas e docentes do departamento de Matemática que foram alocados no Instituto de Matemática e Estatística (IME), fundado à partir da extinção da FFCL/USP; do departamento de Direito que foi incorporado à Faculdade de Direito. O departamento de Estatística foi extinto, mas seus docentes foram transferidos para o departamento de Economia, com destaque para Luiz de Freitas Bueno e Wilfred Leslie Stevens, proveniente da Universidade de Londres onde fora assistente de Erving Fisher, pioneiros na introdução de métodos quantitativos em teoria econômica no Brasil. O departamento de Ciências Culturais, instituído após portaria de 17 de janeiro de 1964, dirigido por Alice, reunia as cadeiras de: História Econômica Geral e Formação Econômica e Social do Brasil, regida por ela; Geografia Econômica Geral e do Brasil, regida por Dirceu Lino de Mattos; e Sociologia Geral e Aplicada, regida por José Ignácio Benevides de Rezende e, posteriormente, por Heraldo Barbuy. Apenas a cadeira de Geografia passou a integrar a FFLCH/USP ${ }^{163}$.

Mas, e quanto à cadeira de História Econômica Geral e Formação Econômica e Social do Brasil? Por que não foi incorporada também à FFLCH/USP? O indício que nos motivou a refletir sobre essa questão encontramos em missiva da historiadora endereçada à Francisco Iglésias em 31 de março de 1968 em meio às discussões sobre a reforma universitária no país:

\footnotetext{
${ }^{163}$ Cf. PINHO, Diva Benevides. Outros departamentos. In: CANABRAVA, 1984, op. cit., p. 79-84. Na definição dos departamentos, tivemos dois extremos: um representado pela Faculdade de Medicina, na qual cada cátedra deu origem a um departamento; e o outro, representado pela FEA, na qual cada departamento aglutinou várias das extintas cadeiras em três departamentos e cada um deles ficou responsável por um curso de graduação.
} 
A reforma da Universidade, da qual você me propõe um problema, está mais ou menos parada, ao que parece, depois do afastamento do Vicereitor em exercício, o Prof. Mário Guimarães Ferri. Ele estava trabalhando exaustivamente nesse setor, quando teve um enfarte em plena sessão do Conselho universitário. Continua afastado e com isso, pelo menos até onde sou informada, os problemas da reforma deixaram de ser prioritários. Fiz parte de uma comissão que devia fazer sugestões quanto ao ensino da História, no curso básico da Universidade, da qual faziam parte o Prof. Simões de Paula, como presidente, e a Profa. Nicia Vilela. Deliberamos, então, que todas as faculdades enviariam os seus alunos para seguir os cursos de História Moderna e Contemporânea e História do Brasil, na Filosofia, entendendo-se estes como cursos de História Geral. Não foi tratado o problema da História Econômica, o que seria objeto de nova comissão, pois que o caso não estava previsto nos objetivos para os quais havia sido nomeada a comissão em apreço. Todavia minha opinião firmada é que a História Econômica (Geral ou do Brasil) deve permanecer apenas no currículo da Faculdade de Ciências Econômicas, pois se trata de uma especialização muito particular no campo da História, especialização vinculada cada vez mais estreitamente a outras matérias que fazem parte do currículo da mesma Faculdade. A opinião do Prof. Simões de Paula é de que a História Econômica deve integrar o Instituto de Geografia e História. Se vier a ser consultada oficialmente sobre o problema, esta é a minha opinião. É a mesma do Prof. Camargo, com o qual debati o assunto. Como diretor da Faculdade de Ciências Econômicas ele terá que dar uma palavra decisiva no Conselho Universitário quando se tratar deste assunto e o fará segundo a minha opinião ${ }^{164}$.

Segundo o excerto acima, tomamos conhecimento de que uma comissão especial foi instituída para tratar do ensino de história e seu lugar na universidade durante a reforma. E mais: uma disputa em torno do destino da cadeira de História Econômica. Para Eurípedes Simões de Paula, a mesma deveria ser integrada à um futuro Instituto de Geografia e História, que não foi implantado, enquanto Alice advogava por sua permanência junto à FEA/USP, com o apoio do então diretor, José Francisco de Camargo.

Ao afirmar que Francisco de Camargo "fará segundo a minha opinião" junto ao $\mathrm{CO}$, realmente havia angariado o apoio do colega, uma vez que em sessão de 09 de dezembro de 1968, por exemplo, ao ser posta em votação a estrutura departamental do Instituto de Geociências e Astronomia, com suas respectivas disciplinas, foi aprovado a estrutura do departamento de Geografia com a integração do então departamento de Geografia da FFCL e da cadeira de Geografia da FCEA. Nessa ocasião Camargo faz questão de demarcar seu voto.

${ }^{164}$ FI-C-CP (083). Fundo Francisco Iglésias. Arquivo Instituto Moreira Salles/RJ. 
Votei favoravelmente à inclusão da cadeira de Geografia Econômica Geral e do Brasil da FCEA no departamento de Geografia do Instituto de Geociências e Astronomia por julgar que a Geografia representa mais um subsídio à Economia do que um método. Em relação tanto à História Econômica como à Sociologia Econômica, o nosso entendimento é diverso, motivo pelo qual fazemos esta declaração de $\operatorname{voto}^{165}$.

Na mesma sessão, quando a estrutura departamental do Instituto de Filosofia e Ciências Humanas, futura FFLCH/USP, foi posta em votação, com as presenças da cadeira de História Econômica Geral e Formação Econômica e Social do Brasil da FCEA junto ao departamento de História e da cadeira de Sociologia Geral e Aplicada da FCEA junto ao departamento de Sociologia e Antropologia, José Francisco logo se manifesta pela exclusão de ambas e sua manutenção junto à FCEA. Na sessão seguinte, a proposta de emenda de José Francisco de Camargo no que tange à manutenção da cadeira de História Econômica junto à FCEA foi aprovada em votação ${ }^{166}$.

A manutenção das disciplinas ligadas à antiga cadeira de História Econômica geral e Formação Econômica e Social do Brasil junto ao departamento de Economia da FEA/USP, significou também a permanência de Alice Canabrava neste lugar social no qual desempenhava suas funções docentes e de pesquisa desde 1946. Ademais, pôde manter a coesão da "equipe de história", como era conhecido o grupo de auxiliares de ensino e assistentes de pesquisa que gravitavam em torno da cadeira. Para ela, a história econômica deveria permanecer na FEA/USP devido às suas características peculiares, concebida como ligada às Ciências Econômicas. Não à toa, a partir de determinado momento, os alunos que trabalhavam com ela na cadeira de História Econômica eram todos provenientes do curso de graduação em Ciências Econômicas e não mais da FFCL.

A primeira assistente da cadeira de História Econômica foi Maria Celestina Teixeira Mendes Torres (1947-1948), colega de turma de Alice, e que se transformaria em amiga de rememorações quanto ao espaço comum da FFCL/USP. Durante o período em que Maria Celestina foi assistente de Canabrava, esta publicou três trabalhos: "Tendência da bibliografia sobre a história administrativa do munícipio"167; "Fontes

\footnotetext{
${ }^{165}$ Ata da $628^{\text {a }}$ sessão extraordinária do CO. 09/12/1968. Atas do CO, livro 34, p. 14. Arquivo da Secretaria Geral. Reitoria da USP.

${ }^{166}$ Cf. Ata da 632 ${ }^{\text {a }}$ sessão do CO. 13/01/1969. Atas do CO, livro 36, p. 14-18. Arquivo da Secretaria Geral. Reitoria da USP.

${ }^{167}$ CANABRAVA, Alice Piffer. Tendência da bibliografia sobre a História Administrativa do Município. Revista de Administração. São Paulo, n. 1, p. 80-87, 1947.
} 
primárias para o estudo da moeda e do crédito em São Paulo no século XVI"168 e "A influência do Brasil na técnica do fabrico do açúcar nas Antilhas francesas e inglesas no meado do século XVII (um caso de expansão da técnica portuguesa)"169. O primeiro, deriva de seus trabalhos junto ao IA e o último, da tese que lhe conferiu o título de livredocente em 1946 na FFCL/USP ${ }^{170}$. É possível que, para a pesquisa nos arquivos de São Paulo sobre moeda e crédito no século XVI, Alice tenha contado com a ajuda de Maria Celestina, uma vez que neste período estava preparando sua tese de cátedra sobre o algodão na província de São Paulo ${ }^{171}$.

Na sequência tivemos outra mulher, Mirian Lifchitz Moreira Leite (1948-1952), também proveniente da FFCL, porém, do curso de Ciências Sociais (1947). O período no qual Mirian trabalhou como sua assistente foi o mais produtivo de Alice, com os seguintes trabalhos: “A Evolução das posturas municipais de Sant'Ana de Parnaíba, 1829-1867”172, proveniente de seus trabalhos junto ao IA; introdução do livro "Bandeirantes no Paraguai. Século XVII. Documentos inéditos"173; "A Administração Municipal de Sant'Ana de Parnaíba nos anos de 1829-1867"174, proveniente de seus trabalhos junto ao IA; "Documentos sobre os índios do rio Juquiá"175, apresentação de documento em periódico; "Um Capítulo da História das Técnicas no Brasil: O emprego do Bagaço de Cana como Combustível dos Engenhos"176, apresentado no IV Congresso de História Nacional de

${ }^{168}$ CANABRAVA, Alice Piffer. As fontes primárias para o estudo da moeda e do crédito em São Paulo no século XVI. In: CANABRAVA, Alice Piffer. História Econômica: Estudos e Pesquisas. São Paulo: Hucitec; UNESP; ABPHE, 2005, p. 285-300.

169 CANABRAVA, Alice Piffer. A influência do Brasil na Técnica do Fabrico do Açúcar nas Antilhas Francesas e Inglesas no meado do século XVII. Anuário da Faculdade de Ciências Econômicas e Administrativas (1946-1947). São Paulo, Faculdade de Ciências Econômicas e Administrativas da Universidade de São Paulo, 1948, p. 63-76.

${ }^{170}$ CANABRAVA, op. cit., 1981a.

${ }^{171}$ CANABRAVA, op. cit., 2011.

172 CANABRAVA, Alice Piffer. A Evolução das posturas municipais de Sant'Ana de Parnaíba, 1829-1867. Revista de Administração. São Paulo, n. 9, p. 34-62, 1949.

173 CANABRAVA, Alice Piffer. Introdução. In: SANT’ANNA, Nuto (org.). Bandeiras no Paraguai. Século XVII (documentos inéditos). São Paulo: Divisão do Arquivo Histórico do Departamento de Cultura da Prefeitura do Município de São Paulo, 1949, p. VIII-XVI.

174 CANABRAVA, Alice Piffer; CUNHA, Mário Wagner Vieira da. A Administração Municipal de Sant'Ana de Parnaíba nos anos de 1829-1867. Revista de Administração. São Paulo: Instituto de Administração, ns. 11-12, p. 3-83, 1949.

175 CANABRAVA, Alice Piffer. Documentos sobre os índios do rio Juquiá. Revista do Museu Paulista. São Paulo, vol. III, p. 391-404, 1949a.

${ }^{176}$ CANABRAVA, Alice Piffer. Um capítulo da História das técnicas no Brasil: o emprego do bagaço de cana como combustível dos engenhos. Anais IV Congresso de História Nacional. Rio de Janeiro: Imprensa Nacional, v. 11, p. 459-471, 1950. 
1949; "Um desembarque clandestino de escravos em Cananéia, SP"177; "Os contratos de trabalho e os índios da Província de S. Paulo, 1853" "178, apresentação de documento em periódico; "As Chácaras paulistanas (primeiros estudos)" "179, apresentado na IV Assembleia Geral da Associação de Geógrafos Brasileiros (AGB) em 1950; “A Força Motriz: um problema da Técnica da Indústria do Açúcar Colonial. A solução antilhana e a brasileira" 180 , apresentado no I Congresso de História da Bahia em 1949; "A Lavoura canavieira nas Antilhas e no Brasil, na Primeira metade do século XVIII" ${ }^{181}$, também apresentado nesse último Congresso. Vis a vis o volume de sua produção para o período, Alice certamente contou com a ajuda de sua assistente no levantamento de fontes, principalmente as relacionadas à sua tese de cátedra em História Econômica, apresentada em 1951.

Fernando Henrique Cardoso (1952-1953), por indicação de Florestan Fernandes, quando estava no terceiro ano do curso de Ciências Sociais, foi trabalhar com Mário Wagner Vieira da Cunha junto ao antigo IA anexo à FCEA/USP, sob a supervisão de Lucila Hermann. Em seu quarto ano de graduação foi indicado por Mário Wagner Vieira da Cunha para ser assistente de Alice. Para Cardoso, ela foi

Uma grande orientadora. Nessa época, próximo ao quarto centenário da cidade de São Paulo, em 1954, ela fazia um levantamento sobre a questão do abastecimento da cidade. Ela me deu fundamentalmente duas tarefas: uma era ler as atas da Câmara dos Vereadores de São Paulo, nos arquivos que ficavam no prédio em que funcionou o DOPS e hoje está a Pinacoteca. A outra, dar o curso de História Econômica da Europa, matéria que eu pouco sabia. O José Albertino Rodrigues foi assistente dela e, mais tarde, o Fernando Novais. Mas ela brigava muito e brigou comigo também. Ela queria que trabalhássemos, digamos, num regime militar, com horário de entrar, de sair. Eu trabalhava muito ${ }^{182}$.

\footnotetext{
177 CANABRAVA, Alice Piffer. Um desembarque clandestino de escravos em Cananea, SP. Revista de História. São Paulo, n. 4, p. 559-562, 1950a.

${ }^{178}$ CANABRAVA, Alice Piffer. Os contratos de trabalho e os índios da Província de S. Paulo, 1853. Revista do Museu Paulista. São Paulo, vol. IV, p. 433-438, 1950 b.

${ }^{179}$ CANABRAVA, Alice Piffer. As Chácaras paulistanas (primeiros estudos). In: CANABRAVA, op. cit., 2005, p. 236-237.

${ }^{180}$ CANABRAVA, Alice Piffer. A força motriz: um problema da técnica da indústria do açúcar colonial (A solução antilhana e a brasileira). Anais do primeiro congresso de História da Bahia. Salvador: tipografia beneditina Ltda, v. IV, p. 337-350, 1950c.

${ }^{181}$ CANABRAVA, Alice Piffer. A lavoura canavieira nas Antilhas e no Brasil (primeira metade do século XVIII). Anais do primeiro congresso de História da Bahia. Salvador: tipografia beneditina Ltda, v. IV, p. 351-387, 1950c.

182 CARDOSO, Fernando Henrique. Entrevista. In: BASTOS, Elide Rugai; ABRUCIO, Fernando; LOUREIRO, Maria Rita; REGO, José Márcio. Conversas com sociólogos brasileiros. São Paulo: Ed. 34, 2006, p. 71.
} 
Essa rememoração de Fernando Henrique Cardoso se dá em uma chave de alteridade, ou seja, em um contato com o outro, neste caso o entrevistador, que lhe faz suprimir o tempo e recuar anos a fio. No caso de Alice, sua rememoração em relação ao ocorrido foi incitada por um próximo, Francisco Iglésias, mas em um processo de elaboração e ressignificação do trauma. Em carta de 14 de junho de 1954, Canabrava fala sobre si, em um evento relacionado ao seu assistente:

Aqui vamos indo, num mar de desesperança, de desencantamento. Tive um abalo moral profundo com o meu último assistente (lembra-se que experimentei um aluno, pela primeira vez?) e nem sei, daqui por diante, serei a mesma criatura, se conservarei aquele entusiasmo genuíno pela formação científica dos meus assistentes, que você deve ter percebido quando das nossas conversas em Ouro Preto ${ }^{183}$.

Desde então, ela não contratou nenhum assistente que já não possuísse a graduação. José Albertino Rosário Rodrigues, citado acima por Fernando Henrique Cardoso, ingressou na cadeira como auxiliar de ensino em 1952, após graduar-se em Ciências Sociais pela Escola Livre de Sociologia e Política/SP. Com a saída de Cardoso em 1954, assumiu as funções de assistente de pesquisa ao mesmo tempo em que cursava Geografia e História na FFCL/USP. Em seu lugar, como auxiliar de ensino, foi admitido Fernando Antonio Novais, que estava cursando o último ano do curso de Geografia e História da FFCL ${ }^{184}$.

Com a saída de José Albertino em 1957, Novais assumiu as funções de assistente de pesquisa no ano seguinte, permanecendo até 1961. Sobre esse período, em uma entrevista de setembro de 2000, Novais afirma que "[...] A Alice era uma pessoa muito difícil; depois disso, passamos dez anos sem nos falar. Quando percebi que ela estava descontente comigo, já estava casado e minha mulher esperando o primeiro filho; achei que ela não iria renovar o meu contrato"185. Essa impressão de Novais o fez procurar Eduardo D’Oliveira França e se integrar como assistente na cadeira de História da Civilização Moderna e Contemporânea da FFCL/USP.

Hans Bruno Eduardo Schellenberg inaugura a leva de assistentes de pesquisa e auxiliares de ensino formados em Ciências Econômicas pela FCEA. Schellenberg permaneceu como assistente de Alice até a extinção do regime de cátedras na FEA/USP

\footnotetext{
${ }^{183}$ FI-C-CP (062). Fundo Francisco Iglésias. IMS/RJ.

${ }^{184}$ Cf. CANABRAVA, op. cit., 1984a.

${ }^{185}$ NOVAIS, Fernando. Entrevista. In: MORAES, José Geraldo Vinci de; REGO, José Márcio. Conversas com historiadores brasileiros. São Paulo: Ed. 34, 2002, p. 121.
} 
em 1970. Porém, o contato entre ambos se manteve por carta, principalmente durante o período em que Schellenberg realizou doutoramento em Aachen na Alemanha (19731980) ${ }^{186}$ e depois, quando se mudou definitivamente para lá ${ }^{187}$. Ao lado de Schellenberg, a partir de 1967, figura Antônio Emílio Muniz Barreto, como instrutor, também graduado em Ciências Econômicas pela FCEA. Em 1969, Alice contava com Schellenberg como assistente de pesquisa; Muniz Barreto como auxiliar de ensino e Ronaldo Marcos dos Santos, graduado em Ciências Econômicas pela FCEA e seu futuro orientando de mestrado, como instrutor. Número inédito em torno da cadeira.

Ronaldo Marcos dos Santos também manteve correspondência com Alice, durante o período em que estagiou em Paris em preparação para sua tese de doutoramento e é autor da primeira dissertação orientada pela historiadora, intitulada " $\mathrm{O}$ término do escravismo na província de São Paulo (1885-1888)", defendida em 1972. Através dessas cartas tomamos ciência de que as redes de sociabilidade nas quais a historiadora estava inserida atingiam o outro lado do Atlântico. Em carta de 24 de janeiro de 1975 afirma:

\begin{abstract}
Procurei imediatamente informações sobre Maurice Niveau e soube que atualmente ele é reitor da academia em Grenoble, cargo muito alto na carreira universitária e por isso mesmo as pessoas duvidam que ele tenha tempo de ir ao Brasil principalmente porque no mês de outubro ele deve estar aqui para o reinicio dos cursos de graduação. Antes de tentar qualquer pessoa da equipe do Labrousse, fui imediatamente procurar o professor Vilar que foi muito atencioso. Contou-me que foi ao Canadá e agora na volta está muito preocupado porque a visão lhe falta progressivamente a cada dia. Verdadeira tortura para um intelectual desse porte: não poder mais ler. Mas o prof. Vilar indicou o seu assistente predileto, M. Verlay, e ficou de consultá-lo. Sei que está trabalhando sobre o século XIX, e Vilar acha que poderá dar um ótimo curso de metodologia em história econômica. Lembrei-me da nossa conversa a respeito da escolha de um professor para dar cursos na Faculdade e fiquei contente com a indicação de um jovem, talvez menos afeito aos formalismos e arrogância comuns à hierarquia acadêmica francesa. Quando entrar em contato direto com Verlay, enviarei o currículo e aguardarei da Senhora um veredicto definitivo ${ }^{188}$.
\end{abstract}

\footnotetext{
${ }^{186}$ Em carta de 14 de janeiro de 1976, Schellenberg comenta com "D. Alice” sobre várias características da cidade de Aachen e sobre sua viagem desde São Paulo. Cf. APC-SCHE-002. Fundo Alice Piffer Canabrava. Arquivo IEB/USP.

${ }^{187}$ Em uma dessas cartas enviada por Alice - cópia carbonada - em 26 de janeiro de 1986, o tom é ameno e o assunto é amplo, desde a construção de um novo prédio na FEA, passando pelo governo de Jânio Quadros, até o assalto à José Mindlin. Cf. APC-SCHE-003. Fundo Alice Piffer Canabrava. Arquivo IEB/USP.

${ }^{188}$ Paris, 24 de janeiro de 1975. APC-SANT-003, p. 1. Fundo Alice Piffer Canabrava. Arquivo IEB/USP.
} 
Alice Canabrava promovia cursos de pós-graduação em História Econômica com professores convidados do exterior e possuía uma estreita relação com Frédéric Mauro. Em carta de 06 de junho de 1970, por exemplo, a historiadora após mencionar que foi informada por Eurípedes Simões de Paula de sua vinda à São Paulo, convida-o para ministrar curso junto ao IPE/USP:

Dentro desta ordem de ideias, de acordo com a minha proposta junto ao Departamento de Economia, ficou aprovado por unanimidade, que eu lhe escrevesse naquele sentido. Peço-lhe, pois, para considerar a possibilidade de ministrar um curso de dois meses, agosto e setembro, junto aos cursos de pós-graduação do Instituto de Pesquisas Econômicas, desta Faculdade. [...] Cremos que seria de muito interesse um curso sobre métodos e as novas tendências na História Econômica. [...] Contudo, a sua sugestão, quanto a este problema, será preciosa ${ }^{189}$.

Estes intercâmbios intelectuais promovidos por Alice também são assunto de suas cartas com Francisco Iglésias.

Gostaria também de lhe ter contado sobre o contato que tive com o Mauro, aqui. Ele fez duas conferências específicas em minha Faculdade, na cadeira de História Econômica, sobre a História quantitativa. Ele almoçou duas vezes aqui comigo e ficamos conversando até 5 cair da tarde sobre tanta coisa interessante que mau vimos o tempo fluir. Gostaria também de lhe falar sobre o encontro com o Toynbee. Ele pronunciou uma conferência em minha Faculdade, cujo tema escolhi com antecedência, entre vários propostos: "Por que estudar História?" Fiz a versão para o português, do original em inglês, de modo que o imenso público que lotou completamente as dependências da Faculdade (auditório de 600 lugares, corredores, áreas laterais, hall), podia acompanhar com facilidade o conferencista. Tomamos chá juntos, a Sra. dele também e, antes de partir, ele me enviou uma carta que me comoveu muito e a guardo como preciosidade $^{190}$.

Estes são apenas dois exemplos dos intercâmbios intelectuais promovidos por ela através da cadeira de História Econômica e que não se restringiam apenas à França, como no caso do contato com o historiador britânico Arnold Joseph Toynbee. Além dos intercâmbios intelectuais em torno da cadeira e da produção intelectual da historiadora que analisaremos no próximo item, há também toda uma produção vinculada à equipe de história.

A dissertação de Ronaldo M. dos Santos foi defendida em 29 de setembro de 1972 junto à banca examinadora composta por Douglas Hume Graham e Eduardo D’Oliveira

\footnotetext{
${ }^{189}$ São Paulo, 6 de junho de 1970. APC-MAUR-001. Fundo Alice Piffer Canabrava. Arquivo IEB/USP.

${ }^{190}$ São Paulo, 11 de dezembro de 1966. FI-C-CP (075). Fundo Francisco Iglésias. IMS/RJ
} 
França, tendo recebido nota 9,0 com distinção ${ }^{191}$. Em sua introdução, Santos afirma que a produção sobre a transição do trabalho escravo para o trabalho livre é abundante na historiografia, demarcando, contudo, que os trabalhos sobre a transição na Província de São Paulo são mais escassos. Identifica duas teses em torno da abolição: uma, cujo eixo explicativo reside no movimento abolicionista e outra, que atribuiu a abolição à perda de produtividade. Situa seu trabalho na esteira da sugestão pioneira de Caio Prado Júnior em "Evolução Política do Brasil e outros estudos", em relação à mobilização dos próprios escravos. Nesse sentido, para ele, o trabalho de Emília Viotti da Costa, "Da senzala à colônia", é o que mais avançou no aspecto de atentar às revoltas dos escravos e suas fugas em massa. O objetivo de Santos é responder às seguintes perguntas: “[...] teria o escravo sozinho, condições de formular esses objetivos e levar à frente o seu protesto? Em que condições seriam eficazes as formas de protesto do negro? Qual seria a reação dos senhores ante a eficácia do protesto? Resultaria na mudança das relações de trabalho?"192. Suas principais fontes são três jornais da Província que Alice bem conhecia, uma vez que também os mobilizou em sua tese de cátedra: Província de São Paulo, Correio Paulistano e Diário Popular. E os manuscritos do Departamento do Arquivo do Estado de São Paulo envolvendo polícia, autos-crime, escravos e ofícios diversos.

A tese demonstrada por Santos é de que o escravo, apartado de suas raízes e isolado pelo sistema de produção cafeeiro, não poderia aderir à resistência cultural e seus protestos, portanto, poderiam objetivar somente à libertação, sem integração social via trabalho assalariado. Para ele, o movimento abolicionista forneceu as condições para uma pressão eficaz. Podemos notar uma ampla sistematização de dados em 10 tabelas e 6 gráficos. As tabelas sistematizam os dados da população escrava dos principais municípios produtores de café provenientes do "Relatório da Comissão Central de Estatística” do maço “Tempo do Império, escravos” depositado no Arquivo do Estado. Os gráficos, por sua vez, sistematizam a relação do número de liberdades

\footnotetext{
191 Cf. "Relação de dissertações Economia FEA/USP". Disponível em: <http://www.fea.usp.br/media/fck/MestEcon.pdf> Acessado em 06 de dez. 2016.

192 SANTOS, Ronaldo Marcos dos. O término do escravismo na Província de São Paulo (1885-1889). $167 f$. Dissertação. Instituto de Pesquisas Econômicas/USP (Programa de Pós-graduação em Economia), 1972, p. 13-14.
} 
condicionais/liberdades plenas vis a vis os meses dos anos entre 1887-1888 para Campinas, Piracicaba, Taubaté, Rio Claro, Amparo e Belém do Descalvado ${ }^{193}$.

O referido "abalo moral" sofrido quando da saída de Fernando Henrique Cardoso da cátedra e a incerteza quanto à relação com seus assistentes parece ter sido superada. Principalmente se tomarmos a estreita relação que Canabrava manteve com Muniz Barreto. Entre seus assistentes e depois da reforma universitária, foi seu principal correspondente, além de orientando de doutoramento. De uma forma de tratamento que se iniciava com "Muito caro Antonio Emilio Muniz Barreto"194, Alice transita para uma forma mais amigável e informal em suas despedidas: "Grande abraço da velha amiga"195; "Um forte abraço, com muita afeição da sua velha amiga"196. O principal motivador desta troca epistolar foi o fato de, após a morte de seus pais, Muniz Barreto necessitar, em várias ocasiões, se licenciar da FEA e residir na fazenda da família na região de Buenos Aires para cuidar de negócios. Os assuntos das missivas são os mais variados, envolvendo questões familiares de ambos; política brasileira e argentina; a FEA e a cadeira de História Econômica. No quarto capítulo abordamos uma escrita de si a partir da correspondência ativa e passiva de Alice e também a formação de uma memória a partir de seus próximos. Aqui nos deteremos aos fatos presentes nas cartas envolvendo a cadeira de História Econômica e a tese de Muniz Barreto.

Sua tese, "Evolução histórica do comércio argentino-brasileiro (1800-1930)" foi a primeira tese orientada por Canabrava e defendida em 23 de novembro de 1973, tendo recebido nota 9,0 da banca examinadora, composta por: José Francisco de Camargo, Heraldo Barbuy, Eduardo D’Oliveira França e Myriam Ellis ${ }^{197}$.

Em carta de 25 de maio de 1970, comenta sobre um aspecto das pesquisas para a elaboração de sua tese.

Eu estou passando alguns dias aqui e estou lendo bastante em relação a minha tese, já achei algumas coisas bastante interessantes, mas também achei que tenho que ler muito mais do que pensava. Aparentemente um dos grandes comerciantes entre o Brasil e a Argentina a partir de 1810 foi Rosas, que era dono de um "saladeiro" e exportava carne seca,

\footnotetext{
193 A dissertação foi publicada em livro: SANTOS, Ronaldo Marcos dos. Resistência e superação do escravismo na Província de São Paulo (1885-1888). São Paulo: IPE/USP, 1980.

${ }^{194}$ São Paulo, 16 de agosto de 1981. APC-CA-P4, 10-(4). Fundo Alice Piffer Canabrava. Arquivo IEB/USP. 195 Ibidem.

${ }^{196}$ São Paulo, $1^{\circ}$ de novembro de 1982. APC-CA-P4, 13-(4), p. 4. Fundo Alice Piffer Canabrava. Arquivo IEB/USP.

${ }_{197}$ Cf. "Relação de teses-Economia FEA/USP". Disponível em: $\langle$ http://www.fea.usp.br/media/fck/DoutEcon.pdf $>$. Acessado em 17 de dez. 2016.
} 
portanto estou lendo muito sobre ele. Mas devido à discutida personalidade de Rosas existe uma bibliografia infinita e felizmente bastante interessante, que complica as coisas ${ }^{198}$.

A tese compreende o desenvolvimento econômico brasileiro a partir do "sentido da colonização" formulado por Caio Prado Júnior e de seu desdobramento a partir do trabalho de Fernando A. Novais. O objetivo da tese é quantificar o fluxo comercial entre os dois países, por produto, no período recortado, trabalhado por décadas. Para tanto, uma massa de dados foi extraída do Archivo General de la Nación, referente às entradas e saídas do porto de Buenos Aires e dos Anuários Estadísticos del Comércio Exterior. Esses dados compilados foram apresentados em volume separado na forma de apêndice com 290 páginas. Sua sistematização se deu através de incontáveis tabelas e gráficos, sempre com considerações metodológicas quanto à homogeneidade dos dados, ou seja, sua serialização e lacunas ${ }^{199}$.

Esta tese é exemplar das orientações conduzidas por Canabrava ao longo dos anos 1970, o período em que mais orientou dissertações e teses, bem como de seus trabalhos publicados ao longo da década - que analisaremos no tópico seguinte - cuja unidade metodológica se encontra no aparato mobilizado a partir da história quantitativa. Esta marca está presente na dissertação de Flávio Azevedo Marques de Saes, “As ferrovias de São Paulo: paulista, mogiana e sorocabana - (1870-1940)" ${ }^{\prime 200}$, defendida em 27 de setembro de 1974 perante a banca composta por: José Francisco de Camargo e Eduardo de Oliveira França ${ }^{201}$. Em prefácio à dissertação publicada em livro, ela afirma que

A massa de dados quantitativos foi enriquecida com elementos hauridos em outras fontes, e pacientemente sistematizada em tabelas e vários quadros, que constituem parte muito importante do embasamento de toda a argumentação. Esta intimidade estatística permitiu a observação de vários problemas, em sua variação no tempo, subjacentes no processo histórico $[\ldots]^{202}$.

198 "El Callejon", Buenos Aires, 25 de maio de 1970. APC-CP-P4, 1-(2), p. 1-2. Fundo Alice Piffer Canabrava. Arquivo IEB/USP.

199 MUNIZ BARRETO, Antonio Emilio. Evolução histórica do comércio argentino-brasileiro (18001930). 396 f/290 f. 1972. 2v. Programa de Pós-Graduação em Economia (IPE/USP), 1972.

${ }^{200}$ SAES, Flávio Azevedo Marques de. As ferrovias de São Paulo, 1870-1940: expansão e declínio do transporte ferroviário em São Paulo. São Paulo: Hucitec, 1981.

${ }_{201}$ Cf. "Relação de dissertações Economia FEA/USP". Disponível em: <http://www.fea.usp.br/media/fck/MestEcon.pdf> Acessado em 17 de dez. 2016.

${ }^{202}$ CANABRAVA, Alice Piffer. Prefácio. In: SAES, op. cit., 1981, p. 10. 
Para a historiadora, os trabalhos de Ronaldo M. dos Santos e Flávio A. M. de Saes são os dois melhores que orientou, conforme exposto em carta à Maria Celestina Torres em 26 de setembro de 1983.

Estou vendo se consigo para V. a tese de Ronaldo Marcos dos Santos, sobre a resistência ao escravismo, uma das melhores que orientei. Pertence à coleção Ensaios, mas, segundo parece, a edição está esgotada. Outra tese muito boa, sobre ferrovias paulistas, de Flavio de Azevedo Marques Saes, orientada por mim, e muito boa, não foi editada na Faculdade, talvez lhe mande a edição em mimeo. São as duas melhores. Os trabalhos sobre as populações em Minas tem grande valor como obras pioneiras, nada se sabia sobre escravos e senhores mineiros, foi muita sorte encontrar os códices no convento ${ }^{203}$.

Os trabalhos mencionados sobre populações em Minas Gerais são de autoria de Iraci Del Nero da Costa. Sua dissertação intitula-se "Vila Rica: população (1719-1826)" e foi defendida em 29 de julho de 1977, perante a banca examinadora composta por Antônio Emilio Muniz Barreto e Maria Luiza Marcílio. O trabalho conta com um apêndice metodológico que trata da obtenção dos dados e de seu tratamento, inspirado pela metodologia de Michel Fleury, Louis Henry e Pierre Goubert, que se tornaram clássicos da história demográfica na França ${ }^{204}$. Sua tese, "Sobre a estrutura populacional de alguns núcleos mineiros no alvorecer do século XIX”, dá continuidade à sua dissertação ${ }^{205}$. Na esteira desses trabalhos inaugurais da tradição que se estabelecerá em demografia histórica na FEA/USP, está o trabalho de outro orientando, Francisco Vidal Luna, com sua tese intitulada "Minas Gerais: escravos e senhores - análise da estrutura populacional e econômica de alguns centros mineratórios (1718-1804)", defendida em 18 de setembro de 1980, perante a banca examinadora composta por Antônio Emilio Muniz Barreto, Oracy Nogueira e José Sebastião Witter, aprovada com distinção e louvor ${ }^{206}$.

As duas últimas teses orientadas por Alice Canabrava foram as de Zélia Maria Cardoso de Mello e Nelson Hideiki Nozoe. A tese de Zélia, "São Paulo, 1845-1895:

\footnotetext{
203 APC-TORR-002. Fundo Alice Piffer Canabrava. Arquivo do IEB/USP.

${ }^{204}$ COSTA, Iraci Del Nero da. Vila Rica: população (1719-1826). São Paulo: IPE/USP, 1979.

${ }^{205}$ COSTA, Iraci Del Nero da Costa. A tese foi defendida em 27 de fevereiro de 1981 e obteve nota 10,0 com distinção e louvor pela banca examinadora: Eni de Mesquita Samara, Heloisa Liberali Belloto, Antonio Emilio Muniz Barreto e Antonio Carlos Coelho Campino. Cf. "Relação de teses-Economia FEA/USP". Disponível em: 〈http://www.fea.usp.br/media/fck/DoutEcon.pdf $>$. Acessado em $17 \mathrm{de}$ dez. 2016. A tese foi publicada: COSTA, Iraci Del Nero da. Populações Mineiras: Sobre a estrutura populacional de alguns núcleos mineiros no alvorecer do século XIX. São Paulo: IPE/USP, 1981.

206 Cf. "Relação de teses-Economia FEA/USP". Disponível em: 〈http://www.fea.usp.br/media/fck/DoutEcon.pdf >. Acessado em 17 de dez. 2016. A tese foi publicada: LUNA, Francisco Vidal. Minas Gerais: escravos e senhores - análise da estrutura populacional e econômica de alguns centros mineratórios (1718-1804). São Paulo: IPE/USP, 1981.
} 
metamorfoses da riqueza. Contribuição ao estudo da passagem da economia mercantil escravista à economia capitalista", foi defendida em 03 de setembro de 1981 perante banca examinadora composta por Adroaldo Moura da Silva, Flávio Azevedo Marques de Saes, Fernando Antonio Novais e José de Souza Martins, aprovada com distinção e louvor $^{207}$. Quanto ao método quantitativo, Alice afirma na apresentação da publicação em livro:

A segurança no trato do material empírico, explorado até o limite, norteou a lucidez e a profundidade da análise. Esta, quanto ao quantitativo, foi balizada pelo intuito de conhecer, precisamente, nessa dimensão, o que havia, suscetível de ser explicado pela formulação estatística, e de integrar os resultados no discurso sem sobrecarregar o texto. São tabelas e gráficos $[\ldots]^{208}$.

Em carta de 16 de agosto de 1981 enviada à Muniz Barreto, comenta sobre a tese de Zélia:

A verdade é que a tese, sobre as transformações da riqueza paulista, está muito boa. Boa mesmo. Ela consultou pouco mais de 1300 inventários, dos quais utilizou mais de 700. Da Faculdade, farão parte da banca o prof. Flavio e o Prof. Adroaldo, de fora o prof. Fernando Novais e o prof. Martins, ambos da Faculdade de Filosofia ${ }^{209}$.

A tese de Nozoe, "A estrutura tributária e as atividades econômicas na capital paulista", foi defendida em 07 de dezembro de 1983 quando ela se encontrava aposentada. O candidato foi aprovado com distinção pela banca examinadora composta por Heloisa Liberalli Belloto, Oracy Nogueira, Flávio A. M. de Saes, e Eni de Mesquita Samara ${ }^{210}$. Seu trabalho trata, grosso modo, das transformações da estrutura tributária da capital paulista para o período 1889-1933 e, na esteira dos trabalhos orientados e realizados ao longo dos anos 1970, se fundamenta em metodologia quantitativa de tratamento dos dados obtidos dos livros de inscrição e de lançamento de impostos confeccionados pela Recebedoria de Rendas da Capital, em um montante de 57 mil lançamentos. A sistematização dos dados foi realizada através da elaboração de folhas de codificação para perfuração dos cartões para que o computador pudesse transpô-los para fitas magnéticas.

207 Cf. "Relação de teses-Economia FEA/USP". Disponível em: <http://www.fea.usp.br/media/fck/DoutEcon.pdf >. Acessado em 17 de dez. 2016.

208 CANABRAVA, Alice Piffer. Apresentação. In: MELLO, Zélia Maria Cardoso de. Metamorfoses da riqueza. São Paulo, 1845-1895. Contribuição ao estudo da passagem da economia mercantil-escravista à economia exportadora capitalista. São Paulo: Hucitec, 1985, p. 15.

${ }^{209}$ APC-CA-P4, 10-(4), p. 3. Fundo Alice Piffer Canabrava. Arquivo IEB/USP.

210 Cf. "Relação de teses-Economia FEA/USP". Disponível em: <http://www.fea.usp.br/media/fck/DoutEcon.pdf>. Acessado em 17 dez. 2016. 
Assim, foi possível elaborar os quadros estatísticos constantes do apêndice estatístico da tese $^{211}$.

Em carta à Muniz Barreto de $1^{\circ}$ de novembro de 1982, Alice aborda uma constante na troca epistolar entre os dois: a FEA e seus orientandos.

Nelson, o japonesinho está com a tese bem adiantada, ainda não vi mas já há coisas escritas para eu ler. Ronaldo M. Santos viu e disse-me que é excelente. Eu não duvido; o assunto é novo, o material excelente, o pesquisador tem fôlego. Como esta vai ser a última tese que vou dirigir, ou melhor, orientar, parece-me que fecho a série com chave de ouro $^{212}$.

A historiadora, por meio da permanência da cadeira de História Econômica junto à reformada FEA/USP, conseguiu organizar e coordenar em torno de si uma "equipe de história" em uma Faculdade de Economia, cuja marca principal ao longo dos anos 1970 foi a mobilização de todo aparato concernente aos métodos quantitativos. Caso a cadeira tivesse sido incorporada à FFLCH, dificilmente a historiadora teria conseguido estruturar uma equipe para este fim, uma vez que o curso de História não possuía em sua grade curricular disciplinas relacionadas aos métodos quantitativos, e nem equipamento para o tratamento dos dados.

Exemplo do sucesso desse empreendimento pode ser atestado através dos textos publicados em "A moderna história econômica" de 1976. O texto de abertura é da "matriarca" e se intitula "Terras e Escravos"213. A equipe de história se faz presente através dos textos de Antônio Emílio Muniz Barreto ${ }^{214}$, Flávio Azevedo Marques de Saes $^{215}$ e Iraci Del Nero da Costa ${ }^{216}$. Na apresentação, os coordenadores, Carlos Manuel Pelaéz e Mircea Buescu, identificam os lugares sociais onde as pesquisas em moderna história econômica têm sido realizadas, mencionando as pesquisas em torno do departamento de História da UFPR com Cecília Westphalen ${ }^{217}$ e Altiva Balhana; em torno

\footnotetext{
${ }^{211}$ NOZOE, Nelson Hideiki. São Paulo: economia cafeeira e urbanização. Estudo da estrutura tributária e das atividades econômicas na capital paulista (1889-1933). São Paulo: IPE/USP, 1984.

212 APC-CP-P4, 13-(4). Fundo Alice Piffer Canabrava. Arquivo IEB/USP.

213 CANABRAVA, Alice Piffer. Terras e Escravos. In: BUESCU, Mircea; PELAÉZ, Carlos Manuel (coords.). A moderna história econômica. Rio de Janeiro: APEC, 1976, p. 13-26.

214 MUNIZ BARRETO, Antônio Emílio. O Comércio: Brasil-Argentina (1867-1930). In: BUESCU; PELAÉZ, op. cit., 1976, p. 49-58. Nesse artigo, Muniz Barreto expõe sua metodologia de análise quantitativa através da utilização de métodos econométricos como as regressões simples e múltiplas.

215 SAES, Flávio Azevedo Marques de. Expansão e declínio das ferrovias paulistas: (1870-1940). In: BUESCU; PELAÉZ, op. cit., 1976, p. 77-85.

${ }^{216}$ COSTA, Iraci Del Nero da. Vila Rica: Mortalidade e morbidade (1799-1801). In: BUESCU; PELAÉZ, op. cit., 1976, p. 115-127.

${ }^{217}$ Para uma análise detalhada da trajetória de Cecília Maria Westphalen ver: MACHADO, Daiane Vaiz. Por uma "ciência histórica": o percurso intelectual de Cecília Westphalen, 1950-1998. 2016. 338 f.
} 
de Kátia Mattoso na Universidade Católica da Bahia e de Francisco Iglésias na UFMG. À FEA/USP é atribuído papel de destaque.

Um dos centros mais ativos é representado pela Faculdade de Economia e Administração e pelo Instituto de Pesquisas Econômicas da Universidade de São Paulo, em que, dentro da escola de pensamento econômico liderada pelo professor Delfim Netto e com a contribuição fundamental das professoras Alice P. Canabrava e Nícia Villela Luz, foram realizadas pesquisas e estudos, visando ao maior entrosamento entre a história e a economia ${ }^{218}$.

A referida "moderna histórica econômica" é concebida como "[...] a renovação da história econômica em três sentidos fundamentais: novas pesquisas, emprego do instrumental da teoria econômica, aplicação dos métodos quantitativos"219. A coesão metodológica da equipe de história em torno de Alice Canabrava, bem como seus trabalhos dos anos 1970 se dá por esses três sentidos fundamentais. Porém, como toda equipe, esta também não esteve imune aos conflitos, principalmente em torno da "sucessão".

Em mencionada carta de 16 de agosto de 1981, a historiadora afirma:

Creia-me, estou sempre a pensar em V., a sentir que a sua ausência significa um imenso vazio no setor de História Econômica na Faculdade. Julgo que, não se pode prescindir de sua atuação, com sua carga de integridade moral, de diplomacia, de bom senso, a oxigenar meandros escusos e inconfessos. Não sou somente eu que pensa assim, são muitos ${ }^{220}$.

Esses mencionados "meandros escusos e inconfessos" se manifestaram, por exemplo, por conta da preparação da tese de Zélia M. C. de Mello, como exposto:

Deverei pedir minha aposentadoria no fim de Setembro, a compulsória, pois desejo antes presidir ao concurso de doutoramento de Zélia. Este, ainda em segredo, dados os ventos contrários que sopraram de um setor negativo da equipe de História, que V. já deve imaginar qual seja. (Como, uma auxiliar de ensino, com tão pouco tempo na Universidade, ousa submeter-se, de entrada, a um exame de doutoramento?) ${ }^{221}$.

Nessa mesma carta, Canabrava expressa sua desilusão quanto às disputas de poder em torno da liderança da área de história da FEA:

Faculdade de Ciências e Letras de Assis - UNESP. Tese (Programa de Pós-Graduação em História e Sociedade). 2016.

218 BUESCU, Mircea; PELAÉZ, Carlos Manuel (coords.). Apresentação. A moderna história econômica. In:

${ }^{219}$ Idem, p. 7. (coords.). A moderna história econômica. Rio de Janeiro: APEC, 1976, p. 7-9.

${ }^{220}$ APC-CA-P4, 10-(4). Fundo Alice Piffer Canabrava. Arquivo IEB/USP.

${ }^{221}$ Ibidem. 
Possivelmente todos estes anos de frustração, cansada de ver a primazia do mundo material sobre o humano, do supérfluo sobre o essencial, do sucesso à custa do sentido moral, sinto-me desiludida. Na minha Faculdade sofro a campanha sub-reptícia mas sórdida, já há dois anos desencadeada por [...], cujo motivo principal é eu prestigiar outro para minha sucessão. Mas, no campo profissional conservo muitas alegrias, tenho o apoio e o respeito da imensa maioria, se não quase totalidade dos meus colegas e alunos ${ }^{222}$.

Os indícios nos conduzem a intuir que Flávio Azevedo Marques de Saes seria o escolhido pela matriarca para sucedê-la na liderança da equipe de História. Na entrevista concedida ao MIS/SP em 1981, exatamente o ano de sua aposentadoria, afirma que a escolha dos entrevistadores não foi casual, uma vez que Flávio Saes é "[...] o membro mais brilhante da equipe e no qual eu deposito as minhas maiores esperanças" 223 . Para ela, Flávio realmente alcançou a liderança da equipe dois anos depois. Em carta de 26 de outubro de 1983 endereçada à Muniz Barreto, ao tecer comentários sobre a equipe de História e seus amigos, comenta que

Flávio defendeu a tese de Livre-Docência. Uma pesquisa excelente sobre moeda, crédito e bancos em S. Paulo no período 1850/1930. As provas se constituíram em afirmação e demonstração daquelas sólidas qualidades intelectuais e morais que todos reconhecem e admiram. A nota foi 9,6, distinção, embora eu defendesse $10 \mathrm{em}$ tudo, mas pesou a bibliografia publicada, pouco extensa, apesar do alto nível. Com isso, ele postou-se na dianteira de toda a equipe. Prepara-se para gozar uma bolsa de estudos em França, em Paris; pretende partir em Fevereiro próximo e permanecer cerca de nove meses na Europa. Não preciso lhe dizer que fiquei muitíssimo feliz com a "performance". Eu o admiro profundamente ${ }^{224}$.

Nesse mesmo ano de 1983 é publicada uma coletânea de textos em homenagem à Canabrava, por conta de sua aposentadoria.

Reúnem-se neste volume estudos efetuados por professores do departamento de Economia da Universidade de São Paulo que têm ministrado, na FEA-USP, as disciplinas afetas à área de história econômica. Com esta publicação, presta-se, por motivos de aposentadoria, homenagem à professora Alice Piffer Canabrava que tanto tem contribuído para o desenvolvimento da Ciência da História no Brasil ${ }^{225}$.

\footnotetext{
${ }^{222}$ Ibidem. Escolhemos suprimir o nome vis a vis toda legislação vigente sobre a mobilização de cartas em estudos acadêmicos. Ver: VASCONCELLOS, Eliane. Intimidade das confidências. TERESA. Revista de Literatura Brasileira. São Paulo, n. 8/9, p. 372-389, 2008.

${ }^{223}$ CANABRAVA, op. cit., 1981.

${ }^{224}$ APC-CA-P4, 14-(6). Fundo Alice Piffer Canabrava. Arquivo IEB/USP.

${ }^{225}$ Cf. MUNIZ BARRETO, Antônio Emílio et alli. História econômica: ensaios. São Paulo: IPE/USP, 1983.
} 
Figuram como organizadores e autores: Muniz Barreto, Vidal Luna, Iraci da Costa, Zélia M. Cardoso de Mello, Nelson H. Nozoe, Flávio Saes e Thomaz de Aquino Nogueira Neto. Todos ex-orientandos de Alice, exceto o último.

No próximo item, nosso intento é explicitar e analisar como a adoção de métodos quantitativos na análise histórica, permitiu à Alice Canabrava uma interpretação de Brasil a partir de São Paulo. Para tanto, partimos de sua mobilização dos três intérpretes clássicos do Brasil: Caio Prado Júnior, Sérgio Buarque de Holanda e Gilberto Freyre.

1.5 Alice no país da quantificação: quando os dados contradizem os modelos, há uma nova interpretação 226

Embora a denominação de "intérpretes do Brasil" a autores dos anos trinta e quarenta do século XX seja uma classificação do final dos anos sessenta ${ }^{227}$, devemos lembrar que tais obras, sem referências as fortunas críticas posteriores, eram as que circulavam com maior destaque. Os autores assim denominados eram referências obrigatórias, tanto no mundo letrado ainda com pouca especialização profissional como na geração de pesquisadores que se formavam nas Faculdades de Filosofia a partir dos anos trinta, visando uma atividade científica e docente profissional. E as citações e utilizações de seus modelos explicativos significa apenas a inserção na discussão intelectual geracional.

Em seu texto nos Anais do I Seminário de Estudos Brasileiros, Alice Canabrava destaca Gilberto Freyre como pioneiro da moderna historiografia brasileira ao lado de Oliveira Vianna e Capistrano de Abreu ${ }^{228}$. “As obras de ambos [Gilberto Freyre e Oliveira

\footnotetext{
${ }^{226}$ Este item baseia-se em capítulo de livro escrito por ERBERELI JÚNIOR, Otávio e GLEZER, Raquel a ser publicado em: SILVA, Marcos; SECCO, Lincoln; BRITES, Olga. Mulheres interpretam o Brasil.

${ }^{227}$ CANDIDO, Antonio. O Significado de "Raízes do Brasil". In: HOLANDA, Sérgio Buarque de. Raízes do Brasil. 26a edição. Rio de Janeiro: José Olympio, 1995, p. 9-21.

${ }^{228}$ Em três ocasiões Alice comentou a obra de Capistrano de Abreu: CANABRAVA, Alice Piffer. Apontamentos sobre Varnhagen e Capistrano de Abreu. Revista de História. São Paulo, n. 88, p. 417-424, 1971. CANABRAVA, Alice Piffer. Roteiro sucinto do desenvolvimento da historiografia brasileira. In: CANABRAVA, Alice Piffer; HOLANDA, Sérgio Buarque de; LUZ, Nicia Vilela. Anais Encontro Internacional de Estudos Brasileiros. I Seminário de Estudos Brasileiros. São Paulo: Universidade de São Paulo/Instituto de Estudos Brasileiros, 1972. CANABRAVA, Varnhagen, Martius e Capistrano de Abreu. In: CANABRAVA, op. cit., 2005. No tópico 2.2 de minha dissertação, tratei das apropriações e análises da obra de Capistrano de Abreu empreendidas por Canabrava. Ver: ERBERELI JÚNIOR, op. cit., 2014, p. 116-141.
} 
Vianna] esses autores são indagações pioneiras sobre o processo social brasileiro" 229 . A moderna historiografia brasileira é, para ela, a que surgira nas Faculdades de Filosofia.

Em suas "reminiscências"230, aposentada e professora emérita, Canabrava menciona dois livros que a influenciaram, e um deles é Casa-Grande \& Senzala.

O segundo deles é Gilberto Freyre com Casa Grande e Senzala. Na época em que o livro saiu, houve muitas críticas, pois dizia-se que muitas de suas conclusões não se aplicavam ao sul. Não estou de acordo. É uma esquematização muito simplista dizer que não foi assim também no sul. Acho que há sutilezas, formas intermediárias ${ }^{231}$.

Em seu primeiro trabalho acadêmico, coautoria com Maria Celestina Teixeira Mendes Torres, ao menos um aspecto da região Nordeste analisada por Freyre em seu clássico pôde ser pensado pelas autoras no "sul" - a caracterização dos rios nordestinos. "No período colonial, o Piracicaba é um desses rios de que nos fala Freyre, 'rio do senhor de engenho, do fazendeiro, do escravo, do comércio dos produtos da terra que torna possível a sedentariedade rural'",232.

Do rio Piracicaba para os rios das pequenas Antilhas, os rios do Nordeste de CasaGrande \& Senzala aparecem como comparação em sua tese sobre a produção do açúcar nas ilhas inglesas e francesas do mar das Antilhas.

Se passarmos às áreas elevadas das Pequenas Antilhas, a maior parte dos rios que se precipitam das montanhas, quase secos durante parte do ano, verdadeiras torrentes na estação chuvosa, estão longe de apresentar os aspectos dos pequenos rios nordestinos tranquilos de que nos fala Freyre, propícios aos homens e fecundos para as culturas ${ }^{233}$.

A obra citada é avaliada por ela como um dos trabalhos contemporâneos que " [...] preferiram ocupar-se das influências da produção sobre a sociedade das áreas açucareiras" 234 . No prefácio, cita o sociólogo para explicar porque, dentre os produtos tropicais, o açúcar era o que mais despertava a atenção dos historiadores.

Talvez porque, a certa altura, como assinala Freyre, a história das regiões produtoras de açúcar tornou-se um capítulo da história daquele

229 CANABRAVA, Alice Piffer. Roteiro sucinto do desenvolvimento da historiografia brasileira. In: CANABRAVA, Alice Piffer; HOLANDA, Sérgio Buarque de; LUZ, Nicia Vilela. Anais Encontro Internacional de Estudos Brasileiros. I Seminário de Estudos Brasileiros. São Paulo: Universidade de São Paulo/Instituto de Estudos Brasileiros, 1972, p. 7.

${ }^{230}$ CANABRAVA, op. cit., 1997.

${ }^{231}$ CANABRAVA, op. cit., 1997, p. 158.

232 CANABRAVA, Alice Piffer; MENDES, Maria Teixeira. A Região de Piracicaba. Revista do Arquivo Municipal. São Paulo, v. 45, 1938, p. 306.

${ }^{233}$ CANABRAVA, op. cit., 1981a, p. 64.

${ }^{234}$ Idem, p. 14. 
produto, de tal modo a monocultura latifundiária e escravocrata dos engenhos influiu sobre as condições gerais de vida naquelas áreas ${ }^{235}$.

Trata-se de trecho do livro $O$ mundo que o português criou... de $1940 . \mathrm{Na}$ conferência apresentada no King's College da Universidade de Londres em 1937, intitulada "o Nordeste do Brasil e seus pontos de contacto com outras áreas americanas especializadas na produção do açúcar”, Freyre destaca a importância do elemento judaico em toda esta rede que se estendia desde Amsterdam, passando pelo Nordeste brasileiro até as Índias Ocidentais, principalmente no que tange aos elementos culturais ${ }^{236}$. A historiadora trata dos judeus no papel enquanto financiadores/banqueiros. Antes da introdução e depois do prefácio, se utiliza de um trecho dessa obra como epígrafe. Esta sintetiza um dos elementos presentes em sua análise e que talvez a tenha inspirado no trato da importância do negro e do judeu para as sociedades produtoras de açúcar da região do mediterrâneo americano.

Continuamos, nos nossos estudos nacionais e regionais sobre a história do açúcar, em particular e da grande lavoura, em geral, no continente americano, a não dispensar a atenção devida às semelhanças e às íntimas relações entre as várias sociedades monocultoras e escravocratas. Semelhanças que se desenvolveram, já por efeito da mesma técnica de produção, já pela irradiação de traços e pela interpenetração de influências de cultura, através da extraordinária mobilidade de dois elementos humanos associados mais ao trabalho, à técnica e ao comércio do açúcar que ao domínio imperial europeu no continente ou às solicitações de pátrias políticas em começo: o negro e o judeu ${ }^{237}$.

Como destacado pelo autor do excerto acima, não se dava a devida atenção às semelhanças entre as diversas áreas açucareiras monocultoras e escravocratas. No primeiro parágrafo de seu prefácio, Canabrava já se mostrava preocupada com essa questão. Pelo fato de que a tese foi escrita para concorrer a uma cadeira de História da Civilização Americana, sempre compara a produção açucareira nas Antilhas com a produção do Nordeste brasileiro ${ }^{238}$. "É inegável a semelhança entre as áreas açucareiras

\footnotetext{
235 Idem, p. 13.

${ }^{236}$ FREYRE, Gilberto. O Nordeste e seus pontos de contacto com outras áreas americanas especializadas na producção do açúcar. In:__ . O Mundo que o português criou. Aspectos das relações sociais e de cultura do Brasil com Portugal e as colônias portuguesas. Rio de Janeiro: José Olympio, 1940, p. 112-124. ${ }^{237}$ FREYRE, op. cit., 1940, p. 116.

${ }^{238}$ CANABRAVA, op. cit., 1981 a, p. 14.
} 
na América, seja na vida econômica e social, como na paisagem geográfica, em virtude da produção única do açúcar, da predominância do latifúndio e da escravidão africana"239.

A primeira referência a Sérgio Buarque de Holanda que encontramos na produção de Alice Canabrava é feita em seu estudo preliminar à obra de Antonil ${ }^{240}$. Trata-se do texto "A mineração: antecedentes luso-brasileiros \& metais e pedras preciosas", publicado em 1960 na História Geral da Civilização Brasileira (HGCB) ${ }^{241}$, coleção coordenada pelo historiador entre 1960 e $1972^{242}$. Na mesma coleção, ela publicou os capítulos "A Grande Propriedade Rural" $" 243$ e a "A Grande Lavoura"244.

Ao tratar da mineração na obra de Antonil, ela menciona que "o problema da prioridade de descobrimento de ouro nas gerais foi recentemente examinado por Sérgio Buarque de Holanda"245. O segundo momento em que Holanda é mencionado refere-se à análise dos roteiros expostos por Antonil, especialmente os dos bandeirantes e indica a leitura do primeiro capítulo de Caminhos e Fronteiras ${ }^{246}$, publicado em 1957: “A experiência indígena se transmitia em vários elementos, como a fila indiana, o modo de aprovisionamento de víveres, a sinalização, e na própria diretriz das rotas de penetração, desde o início trilhadas pelos paulistas" 247.

\footnotetext{
${ }^{239}$ Idem, p. 13.

${ }^{240}$ CANABRAVA, Alice Piffer (ed.). Cultura e opulência do Brasil; texto da edição de 1711 de André João Antonil. São Paulo: Nacional, 1967.

${ }^{241}$ Sobre a HGCB ver: VENÂNCIO, Giselle Martins; FURTADO, André Carlos. Brasiliana \& História Geral da Civilização Brasileira: escrita da história, disputas editoriais e processos de especialização acadêmica (1956-1972). Tempo \& Argumento. Florianópolis, v. 5, n. 9, 2013, p. 14.

${ }^{242}$ HOLANDA, Sérgio Buarque de. A mineração: antecedentes luso-brasileiros \& metais e pedras preciosas. In:__(dir.). História Geral da Civilização Brasileira. A época colonial. t. I, v. 2: administração, economia, sociedade. São Paulo: difusão europeia do livro, 1960, p. 228-258.

${ }^{243}$ CANABRAVA, Alice Piffer. A grande propriedade rural. In: HOLANDA, op. cit., 1960, p. 192-217. Para as citações seguintes deste texto utilizamos a versão presente em: CANABRAVA, Alice Piffer. História Econômica: Estudos e Pesquisas. São Paulo: Hucitec/UNESP/ABPHE, 2005.

${ }^{244}$ CANABRAVA, Alice Piffer. A grande lavoura. In: HOLANDA, Sérgio Buarque de. (dir.). História Geral da Civilização Brasileira. O Brasil monárquico. t. II, v. 4: declínio e queda do império. São Paulo: difusão europeia do livro, 1971, p. 85-137. Para as citações seguintes deste texto utilizamos a versão presente em: CANABRAVA, op. cit., 2005.

${ }^{245}$ CANABRAVA, op. cit., 1967, p. 80.

${ }^{246}$ Grosso modo, Caminhos e Fronteiras pode ser interpretado como proveniente do interesse de Sérgio Buarque pelos estudos de fronteira desenvolvidos por Frederick Jackson Turner. Quando retornava dos EUA, Sérgio Buarque apresentou crescente interesse sobre o processo de ocupação do Oeste brasileiro pelos paulistas/bandeirantes. Ver: WEGNER, Robert. A conquista do oeste: a fronteira na obra de Sérgio Buarque de Holanda. Belo Horizonte: Editora UFMG, 2000.

${ }^{247}$ CANABRAVA, op. cit., 1967, p. 94.
} 
Nos textos dos anos 1970 sobre a economia paulista dos séculos XVIII e XIX, Canabrava adota a explicação do historiador na caracterização do paulista quanto aos sítios volantes.

Junto ao morro os homens constroem sua casa de barro, coberta de palha ou de folhas, e aí vivem com sua família. Como bens dispõem de um cachimbo, uma espingarda para caçar e duas redes, uma na qual dormem, outra com qual praticam a pesca. Há os que só possuem as $\operatorname{redes}^{248}$.

Permanecem nestas áreas em torno de um ano. O tempo de desflorestar, semear e colher, no que procuram outras terras devolutas. Para compreender este tipo de comportamento, ela indica Monções e Caminhos e Fronteiras. "Sob o ângulo antropológico, o fenômeno tem raízes na profunda mistura étnica e cultural do colono adventício com as populações indígenas, no processo de sua adaptação às condições do meio americano" 249 .

A historiadora insere as obras de Holanda nos estudos das décadas de 1920 e 1930 sobre o desbravamento do sertão. "Sérgio Buarque de Holanda estudou aspectos significativos da implantação e expansão da civilização adventícia em nosso país (Monções, Caminhos e Fronteiras). Sua obra fundamental, Visão do Paraíso, ocupa-se dos motivos edênicos do descobrimento e colonização" 250 .

As relações dela com Sérgio Buarque de Holanda estavam além de uma interpretação de Brasil e de seu processo de colonização. Davam-se também na participação em projetos acadêmicos, como na $\mathrm{HGCB}$, na fundação da APUH e na criação do Instituto de Estudos Brasileiros (IEB/USP) em 1962, indicando uma relação pessoal além da acadêmica. Ela fez parte do primeiro conselho de administração do instituto, empossado em 10 de outubro de $1962^{251}$.

Buarque de Holanda participara de duas bancas da historiadora: em 1946, no concurso para a cadeira de História da Civilização Americana na FFCL e em 1951, no

\footnotetext{
${ }^{248}$ CANABRAVA, Alice Piffer. Uma Economia de Decadência: Os níveis de Riqueza na Capitania de São Paulo, 1765-1767. In: CANABRAVA, op. cit., 2005, p. 177-178. Originalmente publicado: CANABRAVA, Alice Piffer. Uma Economia de Decadência: Os níveis de Riqueza na Capitania de São Paulo, 1765-1767. Revista Brasileira de Economia. Rio de Janeiro, v. 26, n. 4, p. 193-221, 1972.

${ }^{249}$ CANABRAVA, Alice Piffer. Decadência e Riqueza. Revista de História. São Paulo, n. 100, 1974, p. 346.

${ }^{250}$ CANABRAVA, op. cit,, 1972, p. 7. Sobre Visão do Paraíso ver: NICODEMO, Thiago Lima. Urdidura do vivido: Visão do Paraíso e a obra de Sérgio Buarque de Holanda nos anos 1950. São Paulo: EDUSP, 2008.

${ }^{251}$ Cf. CALDEIRA, op. cit., 2002, p. 64.
} 
concurso para a cadeira de História Econômica da FCEA. Na primeira ocasião, apesar de Canabrava ter sido preterida, a maior nota obtida nas teses analisadas por ele fora concedida à tese dela - dez. Em quatro ocasiões ele fez menção à sua obra, como no artigo "História Econômica", publicado no Correio da Manhã em 24 de agosto de 1952, no qual se dedica a análise das teses universitárias de Alice, estabelecendo-a como sinônimo de História Econômica. O trabalho mais comentado por ele é a tese para a cadeira de História da Civilização Americana ${ }^{252}$.

$\mathrm{Na}$ perspectiva de desenvolvimento linear da historiografia brasileira, a historiadora aponta que Caio Prado Júnior marcava uma nova perspectiva depois de Capistrano de $\mathrm{Abreu}^{253}$. "Logo a seguir, viria o Caio Prado [Jr.], representando nova etapa. Penso em dois grandes livros. O primeiro deles é o Formação do Brasil Contemporâneo, escrito por Caio Prado, um grande historiador. Seu livro abriu muitas perspectivas, influenciou toda uma geração" 254 .

No texto de abertura das discussões da área de história nos Anais do I Seminário de Estudos Brasileiros, a historiadora, ao tratar das obras de síntese no âmbito da história econômica, destaca a grande importância da "Formação do Brasil Contemporâneo"255.

A Formação do Brasil Contemporâneo: Colônia, (1942) de Caio Prado Jr., significou um marco valioso no sentido de renovar a interpretação do processo histórico da Colônia. Mostrou que, sob as formas variáveis da produção colonial, estava subjacente uma estrutura homogênea, única, apesar de algumas variantes que indicam apenas ajustamentos ao tipo de produção $0^{256}$.

\footnotetext{
${ }^{252}$ HOLANDA, Sérgio Buarque de. História Econômica. In: COSTA, Marcos (org.). Para uma nova História. São Paulo: Fundação Perseu Abramo, 2004, p. 138.

${ }^{253}$ Sobre a obra de Capistrano na historiografia brasileira ver: CHRISTINO, Beatriz Protti. A rede de Capistrano de Abreu (1853-1927): uma análise historiográfica do rã-txa hu-ni-ku- i em face da Sulamericanística dos anos 1890-1929. 2006. 242 f. Tese (Programa de Pós-Graduação em Semiótica e Linguística Geral) - DL/FFLCH/USP, São Paulo, 2006. MESQUITA, Daniel. Descobrimentos de Capistrano: a História do Brasil "a grandes traços e largas malhas". Rio de Janeiro: Apicuri/Ed. PUC-Rio, 2010. OLIVEIRA, Josiane Roza de. Um historiador em formação: os primeiros anos da vida intelectual de Capistrano de Abreu (1875-1882). 2011. 309 f. Tese (Pós-Graduação em História das Ciências e Saúde Pública) - Casa de Oswaldo Cruz, Fundação Oswaldo Cruz, Rio de Janeiro, 2011. SOUSA, Ricardo Alexandre Santos de. Capistrano de Abreu: História Pátria, Cientificismo e Cultura - A construção da História e do Historiador. 2012. 309 f. Tese (Programa de Pós-Graduação em História das Ciências e da Saúde) - Casa de Oswaldo Cruz, Fundação Oswaldo Cruz, Rio de Janeiro, 2012. OLIVEIRA, Maria da Glória de. Crítica, método e escrita da história em João Capistrano de Abreu. Rio de Janeiro: Editora FGV, 2013. GONTIJO, Rebeca. O Velho vaqueano. $1^{\circ}$ edição. Rio de Janeiro: 7Letras, 2013.

${ }^{254}$ CANABRAVA, op. cit., 1997, p. 158.

${ }^{255}$ PRADO JÚNIOR, Caio. Formação do Brasil Contemporâneo: colônia. $1^{\mathrm{a}}$ edição. 1942. $11^{\mathrm{a}}$ reimpressão. $23^{\mathrm{a}}$ edição. São Paulo: Brasiliense, 2008.

${ }^{256}$ CANABRAVA, op. cit., 1972, p. 8.
} 
Consideramos que a interpretação de Brasil a que Alice Canabrava mais se vincula e que está mais presente em sua produção é a de Caio Prado Junior e seu "sentido da colonização", no qual a grande lavoura fornecera os liames da colonização como uma agricultura monocultora, escravista, latifundiária e voltada para o mercado externo.

Em sua tese de cátedra de 1951, a interpretação caiopradiana perpassa o trabalho, uma vez que o mote principal da análise é dado pela produção algodoeira na província de São Paulo como consequência dos problemas de fornecimento dos EUA à Inglaterra por conta da guerra de secessão. Ou seja, toda a dinâmica econômica da província naquele momento se dava pela orientação ao mercado externo, no fornecimento de matéria-prima à Inglaterra.

As datas que servem de limites cronológicos a este trabalho não representam marcos importantes na evolução econômica e social brasileira. Sua significação prende-se, estreitamente, ao desenvolvimento da cultura algodoeira em território paulista. Foram elas ditadas pelas circunstâncias do mercado internacional do algodão, as quais toda a história de seu desenvolvimento se encontra profundamente ligada ${ }^{257}$.

Apesar de Prado Júnior não estar citado diretamente no texto, entendemos que na análise está implícita esta interpretação, conforme o trecho acima. O mesmo ocorrera em sua tese de História da Civilização Americana. Ao dissertar acerca do método de cultivo da cana-de-açúcar nas Antilhas, Alice afirma tratar-se da mesma lavoura extensiva das áreas tropicais, tal como descrita por Prado Júnior ${ }^{258}$.

A queimada, o processo primitivo de plantio em covas à moda indígena, a falta quase total de utensílios agrícolas adequados, a ausência de qualquer preocupação para a escolha de mudas destinadas ao plantio, o desenvolvimento apenas espacial da lavoura canavieira antilhana, fazem dela o tipo da lavoura extensiva característica das colônias tropicais. Nesses aspectos, encontra sua equivalente na lavoura canavieira do Brasil $1^{259}$.

As ilhas inglesas e francesas do mar das Antilhas se constituíram em torno da grande lavoura para o fornecimento de gêneros ao mercado europeu, similarmente ao Brasil.

Em seu capítulo sobre "A Grande Propriedade Rural” publicado em 1960 na HGCB, Alice segue a interpretação de Caio Prado ao afirmar que as áreas coloniais

\footnotetext{
${ }^{257}$ CANABRAVA, op. cit., 2011, p. 71-72.

258 PRADO JUNIOR, Caio. Grande Lavoura. In:

${ }^{259}$ CANABRAVA, op. cit., 1981a, p. 80. , op. cit., 2008, p. 128-154.
} 
americanas se constituíram em função dos interesses comerciais europeus. "Quando procurarmos conhecer os elementos predominantes da colonização das Américas, ressalta como característica básica o fato de ter sido um capítulo da expansão comercial dos povos europeus na época moderna" ${ }^{260}$. E materialmente, a colonização se deu através da grande lavoura. "[...] a grande lavoura representa os próprios fundamentos da economia colonial" 261 .

No capítulo "A Grande Lavoura", no volume sobre o Brasil Monárquico, permanece a mesma interpretação e método: a inserção da economia brasileira nos grandes quadros da economia mundial e sua orientação externalista. Temos aí a presença de outra tese caiopradiana: a de que as características coloniais da economia brasileira se estendem por um longo tempo, para além do período colonial. “[...] o Brasil monárquico preservou as feições que distinguiam sua economia desde a aurora do período colonial, [...] orientando sua produção exclusivamente segundo as solicitações do mercado exterior" 262 .

O mote de interpretação de Cultura e Opulência de Antonil também é dado pela grande lavoura. "A descrição do engenho de açúcar em Cultura e Opulência nos reporta à grande lavoura colonial, latifundiária, monocultora e escravocrata, caracterizada por Caio Prado Júnior"263.

Entretanto, a interpretação a partir da grande lavoura sofreu uma inflexão quando Canabrava pesquisou a economia da capitania de São Paulo no século XVIII, e a partir dos dados encontrados e analisados por métodos quantitativos, encontrou uma outra interpretação.

Como vimos no tópico anterior, o investimento de Alice no emprego dos métodos quantitativos se vincula à cultura acadêmica específica da FEA/USP e também ao fato da historiadora estar inserida em redes de sociabilidade internacionais que permitiram uma série de intercâmbios intelectuais. Estes intercâmbios tomavam corpo através do convite para que especialistas de várias universidades do mundo ministrassem cursos junto à FEA/USP. No caso da história quantitativa, a historiadora contou com a colaboração de

\footnotetext{
${ }^{260}$ CANABRAVA, Alice Piffer. A Grande Propriedade Rural. In: CANABRAVA, op. cit., 2005, p. 37. ${ }^{261}$ Ibidem.

${ }^{262}$ CANABRAVA, Alice Piffer. A Grande Lavoura. In: CANABRAVA, op. cit., 2005, p. 103.

${ }^{263}$ CANABRAVA, Alice Piffer. João Antonio Andreoni e sua obra. In: , op. cit., 1967 , p. 45.
} 
Frédéric Mauro e do economista estadunidense Albert Fishlow ${ }^{264}$. Em carta de 21 de junho de 1968, Canabrava comenta com seu amigo Francisco Iglésias sobre a colaboração de Fishlow.

Na minha Faculdade, também programei um curso de História Quantitativa, no segundo semestre; será um curso intensivo, a ser ministrado pelo Prof. Fishlow, autoridade nos Estados Unidos sobre o assunto. O curso fará parte do currículo de pós-graduação para os que optaram este ano para a História Econômica ${ }^{265}$.

São Paulo foi tema constante na produção de Alice Piffer Canabrava. Em 1940, no IX Congresso Brasileiro de Geografia realizado na cidade de Florianópolis/SC, propôs uma caracterização para o bairro, entre outras características, como modalidade de povoamento rural localizado entre duas grandes propriedades ${ }^{266}$.

Em alguns de seus trabalhos sobre São Paulo, Alice Canabrava insere a região nos quadros da formação colonial para exportação a partir da grande lavoura, na perspectiva caiopradiana.

Os primórdios do desenvolvimento econômico da área que veio a constituir o Estado de São Paulo se prendem ao plano geral de colonização adotado pela metrópole portuguesa desde a terceira década do século XVI, com mira na ocupação definitiva da América Portuguesa por meio da agricultura ou, mais propriamente, pela grande lavoura $^{267}$.

Se quanto à sua tese de cátedra de 1951 pode-se afirmar que "[...] as condições essenciais à produção excluem as relações de propriedade ou de uso da terra, bem como as relações de trabalho nas suas múltiplas formas presentes nas unidades produtoras de algodão"268, nos trabalhos publicados ao longo dos anos 1970 ela tem como objeto de análise a estrutura da propriedade da terra - uma vez que sua interpretação se dá a partir da grande lavoura - a escravidão e os níveis de riqueza da capitania e província de São

\footnotetext{
${ }^{264}$ Naquele momento haviam duas tendências em história quantitativa: a francesa e a estadunidense. A história quantitativa francesa estava embasada metodologicamente nos estudos inaugurados por Ernest Labrousse ainda nos anos 1930, preocupado com a reconstituição dos fatos históricos. A história quantitativa estadunidense, por seu turno, estava ancorada no aparato econométrico e no teste de hipóteses, o que significava lançar perguntas como, e se as ferrovias não tivessem existido, qual teria sido o impacto sobre o desenvolvimento econômico estadunidense. Trata-se, portanto, não de reconstruir, mas sim de uma história contrafactual. Ver: BARROS, José D’Assunção. A história serial e história quantitativa no movimento dos Annales. História revista. Goiânia, v. 17, n. 1, p. 203-222, 2012.

${ }^{265}$ FI-C-CP (085). Acervo Francisco Iglésias. IMS/RJ.

${ }^{266}$ CANABRAVA, Alice Piffer. Primeiras notas para um estudo acerca dos bairros no estado de São Paulo. Anais do IX Congresso Brasileiro de Geografia. Rio de Janeiro, 1944, vol. III, p. 652.

${ }^{267}$ CANABRAVA, Alice Piffer. Esboço da História Econômica de São Paulo. In: BRUNO, Ernani Silva (org.). São Paulo: Terra e Povo. Porto Alegre: Editora Globo, 1967, p. 19.

268 ARRUDA, op. cit, 2014, p. 107.
} 
Paulo. Conforme Flávio Saes: "A partir desta tese [de 1951], as pesquisas de Alice P. Canabrava voltaram-se principalmente para a História Econômica do Brasil em geral e, em especial, de São Paulo"269.

Alice Canabrava identifica três atividades econômicas na capitania de São Paulo no início do governo do Morgado de Mateus (1765-1767): “[...] a economia de autosubsistência familiar, a de subsistência propriamente dita e a exclusivamente mercantil" ${ }^{270}$. A economia de autossubsistência era praticada nos sítios volantes e compreendia em torno de $50 \%$ da população. "Nessa população inventariada é impressionante o número de pessoas que "nada possuem""271. Porém, esta metade da população da capitania não estava nestas condições devido à decadência, mas sim caracterizavam um modo de vida, conforme interpretação de Sérgio Buarque de Holanda. Da população predominantemente rural da capitania, parcela significativa da outra metade praticava a economia de subsistência, na qual os ínfimos excedentes eram comercializados nos pequenos núcleos de povoação da capitania. Mercadores e homens de negócios, pequeno número na capitania, em torno de São Paulo, Santos e Sorocaba, concentravam a maior parte da riqueza, aproveitando os canais de comércio interregionais, propiciados pela localização da capitania. Estes homens apoiavam-se no negócio do gado, proveniente da rota do extremo sul a partir dos campos de Viamão no Rio Grande de São Pedro; no comércio do sal que chegava ao porto de Santos e também no negócio das manufaturas e dos escravos. Estes últimos constituíam os bens mais valiosos e a terra não possuía valor, uma vez que sua oferta era ilimitada enquanto fator de produção.

A análise de Alice Canabrava da riqueza e da população da capitania de São Paulo, no período considerado tradicionalmente pelos historiadores anteriores de decadência, demonstra, através de gráficos e tabelas, uma alta concentração da riqueza na economia mercantil. A análise quantitativa é fundamental para a historiadora chegar à esta constatação como afirma em carta à Francisco Iglésias com data de postagem em 26 de julho de 1981: "Sabia-se da decadência, mas desconhecia-se a extensão e profundidade, o que só foi possível avaliar com a informação quantitativa",272.

\footnotetext{
${ }^{269}$ SAES, Flávio Azevedo Marques de. Introdução. In: CANABRAVA, op. cit., 2005, p. 10.

${ }^{270}$ CANABRAVA, Alice Piffer. Uma Economia de Decadência: Os níveis de Riqueza na Capitania de São Paulo, 1765-1767. In: _ _ op. cit., 2005, p. 196.

${ }^{271}$ CANABRAVA, op. cit, 1974, p. 342.

${ }^{272}$ APC-CP-P1, 24(6), p. 6. Fundo Alice Piffer Canabrava. Arquivo IEB/USP.
} 
Neste ponto, ela se desprende da análise caiopradiana, visto que naquele momento a grande lavoura em São Paulo inexistia e a acumulação se dava a partir de uma dinâmica interna e não externa. E demonstra que a acumulação de capital em São Paulo, consensualmente ligada à expansão cafeeira para o oeste paulista e ao desenvolvimento do porto de Santos na segunda metade do século XIX, teve início um século antes ${ }^{273}$.

Dentro da profunda decadência que afetava a capitania, o nível de riqueza de seus homens de negócio vem demonstrar que o pequeno aglomerado paulistano desfrutava de atividade comercial de certa importância no cenário da capitania. Esta verificação nos permite recuar cerca de um século, o momento histórico no qual já se podem perceber os germes do desenvolvimento da capital paulistana ${ }^{274}$.

Canabrava postula que esta acumulação de capital por meio do setor mercantil foi a responsável pela estruturação posterior da grande lavoura do açúcar e do café.

Os engenhos expandiram-se com continuidade, por toda a região, depois de 1789, estimulados pelas condições favoráveis do comércio internacional e pelas medidas governamentais que tenderam a valorizar o porto de Santos. Em cerca de um quarto de século, a grande lavoura açucareira veio a dominar completamente a economia da área, e se tornou o motor da economia paulista ${ }^{275}$.

Mas por que recuar ao século XVIII paulista? Se no século XVIII a economia paulista estava em decadência e apresentava níveis de acumulação de capital razoáveis, porém incomparáveis com os níveis de acumulação propiciados pela produção açucareira e cafeeira, o cenário era bem diferente nos anos 1970, quando os estudos foram realizados.

São Paulo, e em especial a sua capital, havia alcançado um nível de industrialização e urbanização não comparáveis a nenhuma outra região do país ${ }^{276}$.

Ao centrar-se na análise da estrutura da terra e da posse de escravos na capitania de São Paulo em 1818, para analisar a distribuição da riqueza, a historiadora afirma que: “As tendências indicadas representam, sem dúvida, uma contribuição original, altamente

${ }^{273}$ CANABRAVA, op. cit., 1974, p. 365.

${ }^{274}$ CANABRAVA, Alice Piffer. Uma Economia de Decadência. In: _, op. cit., 2005, p. 199.

${ }^{275}$ CANABRAVA, Alice Piffer. Terras e escravos. In: ___ op. cit., 2005, p. 207. Publicado originalmente em: BUESCU; PELAÉZ, op. cit, 1976, p. 13-26.

276 SAES, Flávio Azevedo Marques de. O estado de São Paulo no século XX: café, indústria e finanças na dinâmica da economia paulista. In: ODALIA, Nilo; CALDEIRA, João Ricardo de Castro. (orgs.). História do Estado de São Paulo: a formação da unidade paulista. São Paulo: EDUNESP/Imprensa Oficial/Arquivo Público do Estado, 2010, v. 2, p. 13-40. LUCA, Tania Regina de. São Paulo no século XX: segunda metade. São Paulo: Imprensa Oficial; Poiesis, 2011. 
instrutiva para o melhor conhecimento da formação e do desenvolvimento econômico e social do que é, hoje, o polo moderno de nossa economia"277.

Nossa hipótese é de que Alice Canabrava estava preocupada em compreender como São Paulo e especificamente a capital, havia alcançado tamanho desenvolvimento, constituindo-se no polo mais dinâmico da economia brasileira.

No momento presente, no qual os problemas de transporte suscitados pela questão da energia, colocam-se acaloradamente dentre as mais vivas preocupações nacionais, Flávio Azevedo Marques de Saes, com sua tese de mestrado, nos proporciona uma análise muito densa sobre o funcionamento das ferrovias, no contexto das condições da economia paulista e na dinâmica do tempo sob perspectiva histórica ${ }^{278}$.

Ao longo da produção historiográfica de Alice Piffer Canabrava notamos que a noção de "grande lavoura" percorre tempos e espaços: das ilhas do mar do Caribe para o Nordeste brasileiro e daí para São Paulo, alvo de suas preocupações no último quartel do século XX. Contudo, as pesquisas realizadas sobre os séculos XVIII e XIX no espaço paulista sofreram uma inflexão: no período estudado, a acumulação de capital não se deu a partir da dinâmica externa ligada aos canais de exportação, mas sim à uma dinâmica interna existente nos canais de comércio inter-regionais. Posteriormente, a "grande lavoura" toma a dianteira no processo de acumulação com a economia açucareira e se estende à economia cafeeira, propiciando as condições para a industrialização de São Paulo.

Assim, anos antes das controvérsias historiográficas sobre o papel do mercado interno na dinâmica colonial, em detrimento da tradicional interpretação que vincula toda a dinâmica econômica colonial ao mercado externo e a visão de constituição da colônia como indutora do processo de industrialização europeu, em torno das contribuições de João Fragoso e Manolo Florentino ${ }^{279}$, Alice Piffer Canabrava demonstrava já em 1972 que na capitania de São Paulo na segunda metade do século XVIII havia se formado um

277 CANABRAVA, Alice Piffer. A Repartição da Terra na Capitania de São Paulo, 1818. Estudos Econômicos. São Paulo, v. 2, n. 6, 1972a, p. 77.

${ }^{278}$ CANABRAVA, Alice Piffer. Prefácio. In: SAES, Flávio Azevedo Marques de. As Ferrovias de São Paulo, 1870-1940. São Paulo: HUCITEC, 1981, p. 7-8.

${ }^{279}$ Ver estudos de Maria Yedda Linhares sobre a história da agricultura e do abastecimento; Ciro Flamarion Santana Cardoso sobre a dinâmica interna do mercado colonial e a brecha camponesa na economia escravista; Kátia de Queiroz Mattoso sobre a Bahia. Recente: FRAGOSO, João Luis Ribeiro; FLORENTINO, Manolo. O arcaísmo como projeto: mercado atlântico, sociedade agrária e elite mercantil em uma economia colonial tardia: Rio de Janeiro, c.1790-c.1840. Rio de Janeiro: Record, 2001. 
canal de acumulação a partir de uma dinâmica interna ligada ao comércio inter-regional e que só depois o espaço paulista entrara nos fluxos do mercado externo.

O fato de o rompimento com o modelo da "grande lavoura" como característica única do processo de ocupação territorial da colônia e império ter passado desapercebido no momento da publicação indica, para nós, o processo de autonomia da pesquisadora perante os "intérpretes" do Brasil. Teve ela a capacidade de reconhecer dados da realidade histórica documentada e os analisar com o instrumental teórico-metodológico que dispunha na época, deixando de lado a corrente dominante do pensamento historiográfico nacional no último quartel do século XX.

O processo de autonomia intelectual assim tornou-se, em nosso entender, a marca da trajetória da historiadora acadêmica que iniciou sua produção no final da década de 1930, acompanhou as discussões e debates das décadas seguintes, atualizou o seu instrumental com a história quantitativa, e pelos resultados obtidos teve a capacidade de estruturar um outro modelo explicativo: a existência de processo de acumulação mercantil via comércio inter-regional em região periférica aos centros da economia e administração na colônia e no império. 


\section{Capítulo 2}

\section{Tramas em Associação e Revista: redes de sociabilidade e identidade historiadora}

A noção de redes de sociabilidade forjada pelo historiador francês Jean-François Sirinelli ${ }^{280}$ é derivada de outra noção, mobilizada em sua tese de doutoramento: estruturas de sociabilidade ${ }^{281}$. Para o autor, trabalhar no cruzamento entre a história política, social e intelectual demanda mobilizar alguns instrumentos de investigação para o estudo dos intelectuais ${ }^{282}$. Afirma que os trabalhos de alguns sociólogos e cientistas políticos, como Pierre Bourdieu tem sido úteis aos historiadores e cita a tese de Christophe Charle sobre as elites intelectuais de fins do século XIX, como exemplo ${ }^{283}$. No sentido de desenvolver ferramentas de investigação para o campo, três lhe parecem salutares: o estudo dos itinerários, a observação das estruturas de sociabilidade e o fenômeno das gerações. "Structures de sociabilité? Entendons por là, d'abord, ainsi que l'a proposé un récent colloque, un 'groupe(ment) permanent ou temporaire, quel que soit son degré d'institutionnalisation, auquel on choisit de participer""284. Trata-se de um grupo permanente ou temporário, independente de seu grau de institucionalização, que um indivíduo escolhe participar. Citando Maurice Agulhon em texto preparatório para um colóquio de 1983, as estruturas de sociabilidade se constituem em domínio intermediário entre a família e a comunidade cívica ou política de pertencimento. Domínio este que

\footnotetext{
${ }^{280}$ Sirinelli concedeu entrevista à Marieta de Moraes Ferreira, na qual aborda seu itinerário intelectual e sua tese. Ver: SIRINELLI, Jean-François. Entrevista. Revista Brasileira de História. São Paulo, n. 65, p. 407-412, 2013.

${ }^{281}$ SIRINELLI, Jean-François. Khâgneux et normaliens des anées vingt. Histoire politique d'une génération d'intellectuels (1919-1945). Paris: Fayard, 1988. Defendida em 06 de janeiro de 1986 na Universidade de Paris X, sob a orientação de René Rémond, a tese trata da classe preparatória para a Escola Normal Superior (khâgnex) enfatizando uma geração de intelectuais pouco estudada até então.

${ }^{282}$ Sirinelli concebe duas noções de intelectual. Uma mais ampla, sociológica e cultural, que inclui jornalistas, professores secundários, estudantes universitários, mediadores culturais em geral e uma mais estreita, política, vinculada ao engajamento político, citando o exemplo de Claude Lévi-Strauss. Cf. SIRINELLI, Jean-François. Le hasard ou la nécessité? Une histoire en chantier: l'histoire de intellectuals. Vingtième Siècle, revue d'histoire. Paris, n. 9, 1986, p. 98-99. Ver também: SIRINELLI, Jean-François. Os intelectuais. In: RÉMOND, René (org.). Por uma história política. $2^{\mathrm{a}}$ edição. Rio de Janeiro: FGV, 2003, p. 242. Esse capítulo de Sirinelli, originalmente publicado em 1988, é seu primeiro texto traduzido em português e refina alguns argumentos desenvolvidos no artigo de 1986.

283 "Intellectuels et elites en France (1880-1900)" é o título original de sua tese defendida em 1986 na Universidade de Paris-I e orientada por Maurice Agulhon. Foi publicada em duas partes com títulos diferentes: CHARLE, Christophe. Les elites de la République (1880-1900). Paris: Fayard, 1987. CHARLE, Christophe. Naissance des "intellectuels" (1880-1900). Paris: Les éditions de Minuit, 1990.

${ }^{284}$ SIRINELLI, op. cit., 1986, p. 103.
} 
varia de acordo com a época e objeto estudados do meio intelectual e que constitui, como denominado por Sartre, um "pequeno mundo estreito". "Le langage courant a entériné le terme de 'réseaux' pour définir de telles structures"285. Essas redes de sociabilidade

[...] secretam, na verdade, microclimas à sombra dos quais a atividade e o comportamento dos intelectuais envolvidos frequentemente apresentam traços específicos. E, assim entendida, a palavra sociabilidade reveste-se portanto de uma dupla acepção, ao mesmo tempo "redes" que estruturam e "microclima" que caracteriza um microcosmo intelectual particular ${ }^{286}$.

Assim, procuraremos construir a rede de sociabilidade de Alice Canabrava a partir desse microcosmo intelectual particular, qual seja, a Associação dos Professores Universitários de História (APUH), a partir de 1971, Associação Nacional dos Professores Universitários de História (ANPUH). Pensar essa rede somente é possível porque ela ocupou o cargo de primeira secretária e de secretária geral desde a fundação da entidade, o que significou estabelecer contato permanente com outros membros da diretoria, com membros das diretorias dos vários núcleos regionais e com sócios em geral. Sendo assim, analisaremos a atuação da historiadora como secretária da entidade e como seus esforços estabeleceram uma vasta rede de sociabilidade através do aumento da capilaridade da associação.

As sociedades e associações científicas constituem-se, como apontado por Michel de Certeau, instituições de saber a partir das quais se originam as "ciências" modernas. Assim, as “disciplinas” nascem vinculadas à criação de grupos ${ }^{287}$. Tais agrupamentos pulularam durante todo o século XIX vis a vis a fundação do Instituto Histórico e Geográfico Brasileiro (IHGB) em $1838^{288}$. Entretanto, a APUH se insere em outro contexto, qual seja, das associações científicas surgidas sob a égide do mundo universitário e, especificamente, da profissionalização do ofício de historiador no Brasil. Uma história que se inicia com a fundação das primeiras Faculdades de Filosofia nos anos 1930 e atinge a criação dos primeiros programas de pós-graduação nos anos 1970.

\footnotetext{
${ }^{285}$ Idem, p. 103-104.

286 SIRINELLI, op. cit., 2003, p. 252-253.

${ }^{287}$ CERTEAU, op. cit., 2011, p. 51.

${ }^{288}$ A produção sobre o IHGB é extensa. Ver, por exemplo: GUIMARÃES, Manoel Luiz Salgado. Nação e civilização nos trópicos: O Instituto Histórico e Geográfico Brasileiro e o projeto de uma História Nacional. Estudos Históricos. Rio de Janeiro, n. 1, p. 5-27, 1988. GUIMARÃES, Lúcia Maria Paschoal. Da Escola Palatina ao Silogeu: Instituto Histórico e Geográfico Brasileiro (1889-1938). Rio de Janeiro: Museu da República, 2007.
} 
Contudo, a produção historiográfica universitária ainda competia com a produção dos institutos históricos.

Lúcia Maria Paschoal Guimarães, em conferência inaugural do "I Seminário Nacional de História da Historiografia Brasileira", realizado em outubro de 2008 na UERJ, ao analisar a contribuição de José Honório Rodrigues ${ }^{289}$, Sérgio Buarque de Holanda ${ }^{290}$ e Francisco Iglésias para a história da historiografia brasileira se detém sobre a contribuição desse último ${ }^{291}$. Iglésias divide a produção historiográfica brasileira em três momentos, sendo o segundo deles estabelecido entre a criação do IHGB (1838) e a reforma Francisco Campos que instituiu a criação das Faculdades de Filosofia (1931). Guimarães propõe que se alongue esse último marco até a fundação da APUH, uma vez que até esse momento a produção historiográfica ainda possuía enquanto instância legitimadora o IHGB, sendo que vários trabalhos produzidos no âmbito universitário eram apresentados em seus congressos de história nacional ${ }^{292}$.

Francisco José Calazans Falcon ${ }^{293}$, em texto publicado originalmente em 2000, propõe superar 1971 como marco da institucionalização da pesquisa acadêmica no Brasil, uma vez que toda a história institucional anterior permaneceria silenciada. Assim, remontando-se aos anos 1950 identifica vários dualismos: um teórico, com a "sociedade dual" de Jacques Lambert; outro historiográfico, que opôs marxistas e weberianos (culturalistas); e um acadêmico, entre historiadores "tradicionais" e os adeptos de uma renovação. A partir daí, o historiador demarca as principais tendências historiográficas da década de 1960: uma abordagem quantitativista à francesa que se consubstancia no Colóquio do CNRS em 1971 - caso dos trabalhos analisados acima de Alice Canabrava

\footnotetext{
${ }^{289}$ Principalmente a partir de sua obra, em vários volumes, A história da história do Brasil, publicadas entre 1978 e 1988.

${ }^{290}$ A autora analisa o seguinte texto de Sérgio Buarque: HOLANDA, Sérgio Buarque de. O pensamento histórico nos últimos 50 anos. In: MONTEIRO, Pedro Meira; EUGÊNIO, João Kennedy (orgs.). Sérgio Buarque de Holanda: perspectivas. Campinas: Editora UniCamp; Rio de Janeiro: EdUERJ, 2008, p. 601615.

${ }^{291}$ Trata-se do livro publicado postumamente: IGLÉSIAS, Francisco. Os historiadores do Brasil: capítulos de historiografia brasileira. Rio de Janeiro: Nova Fronteira; Belo Horizonte: UFMG/IPEA, 2000.

${ }^{292}$ GUIMARÃES, Lucia Maria Paschoal. Sobre a história da historiografia brasileira como campo de estudos e reflexões. In: NEVES, Lucia Maria Bastos Pereira das; GUIMARÃES, Lucia Maria Paschoal; GONÇALVES, Márcia de Almeida et alli (orgs.). Estudos de Historiografia Brasileira. Rio de Janeiro: Editora FGV, 2011, p. 19-35.

${ }^{293}$ Para a trajetória intelectual do historiador e de sua contribuição à historiografia brasileira, ver: FALCON, Francisco José Calazans. Entrevista. In: GONÇALVES, Márcia de Almeida; GONTIJO, Rebeca. Sobre história, historiografia e historiadores: entrevista com Francisco José Calazans Falcon. História da historiografia. Ouro Preto, n. 7, p. 365-382, 2011.
} 
- e uma qualitativa com inspiração nos Annales ou no marxismo. Em se tratando da profissionalização do ofício de historiador, Falcon acentua a importância do movimento docente em torno dos Simpósios da APUH, afirmando que "[...] o exame das comunicações neles apresentados, revela-nos já a presença das novas perspectivas metodológicos e debates teóricos que começam a superar ou questionar a tradição historiográfica empirista ainda dominante"294.

A partir das comunicações apresentadas e das intervenções nas diversas seções de estudos dos vários Simpósios da APUH/ANPUH, pretendemos analisar, como Alice Canabrava constrói uma identidade historiadora. Para tanto, mobilizamos a noção de identidade historiadora forjada por Francisco Falcon em dois sentidos complementares:

[...] a identidade como autoconsciência do historiador, a começar pela intenção de produzir um texto de história; identidade também, como reconhecimento do trabalho produzido pelo historiador como de história ou, o que vem a ser a mesma coisa, o reconhecimento de seu autor como historiador ${ }^{295}$.

Segundo Falcon, temos duas tendências contemporâneas, que se complementam, para refletirmos sobre uma identidade historiadora: uma identidade ligada ao ofício de historiador, ou seja, àquele que produz textos historiográficos e a identidade que parte do texto, ou seja, reconhecem-se marcas textuais e/ou metodológicas que identificam o texto como de história. Ademais, procuraremos pensar a APUH/ANPUH como uma comunidade epistêmica, ou seja, quais epistemologias históricas permitem formular uma identidade historiadora. Também não podemos ignorar o fato de que essa identidade historiadora forjada desde o século XIX com a profissionalização do ofício de historiador se deu através de uma concepção generificada e eurocentrada, e que ignora as relações do historiador com sua vida doméstica e familiar ${ }^{296}$. Sendo assim, investigaremos quais são

294 FALCON, Francisco José Calazans. A historiografia brasileira contemporânea, 1958-1969. In: . Estudos de teoria da história e historiografia, volume II: historiografia. São Paulo: Hucitec, 2015, p. 160.

${ }^{295}$ FALCON, Francisco José Calazans. A identidade do historiador. Estudos Históricos. Rio de Janeiro, n. 17, 1996, p. 13. Também em: FALCON, Francisco José Calazans. A historiografia contemporânea e a identidade do historiador. In: ___ Estudos de teoria da história e historiografia, volume I: teoria da história. São Paulo: Hucitec, 2011a, p. 58-82. Para uma análise do livro a partir de cinco organicidades (duplo significado de história; crise da história; realismo histórico; pós-modernidade e identidade disciplinar e historiadora) ver: D’ALESSIO, Marcia Mansor. História vivida, história pensada. História da historiografia. Ouro Preto, n. 11, p. 300-304, 2013.

${ }^{296}$ Nossa inspiração são as reflexões de Bonnie Smith: SMITH, Bonnie. Gênero e História: homens, mulheres e a prática histórica. Bauru/SP: EDUSC, 2003. A tese de Carmen Liblik, ao analisar as trajetórias de duas gerações de historiadoras, entre elas a primeira geração com Alice Canabrava, Olga Pantaleão, Eulália Lobo e Maria Yedda Leite Linhares, empreende reflexões epistemológicas que incorporam a 
os critérios epistemológicos de reconhecimento de um trabalho de historiador, demarcados por Alice Canabrava, que permitem seu pertencimento à comunidade historiadora.

\title{
2.1 "Na eventualidade de um congresso..."
}

Em mencionada entrevista concedida ao projeto "Estudos Brasileiros" do MIS/SP, em certo momento, Flávio Saes, mencionando que Alice participou da fundação da ANPUH e de sua diretoria, tendo sido também presidente, pede para que a historiadora comente sobre a importância da entidade para a comunidade de historiadores brasileiros e para a própria história.

\begin{abstract}
A ANPUH foi fundada em 1961. Ela foi fundada em Marília e, a propósito, na eventualidade de um congresso, de um encontro, chamo mesmo de simpósio sobre o ensino superior. Os professores estavam, assim um pouco perplexos sobre quais os rumos a seguir no ensino superior. E uma de suas perplexidades era justamente essa: deveria ser o curso superior somente para ensino ou deveria ser também para pesquisa? Eu fiquei na ANPUH durante 18 anos como secretária e nos últimos dois anos que terminaram agora em Julho de 81 eu fui presidente [...]. Durante os 20 anos de contato com a ANPUH foi muito fecundo, uma experiência muito rica, porque eu fiquei conhecendo professores do Brasil inteiro praticamente e tanto me correspondia e conhecia gente do Rio Grande do Sul, lá do fim, de Erechim, daquele fim de linha, como também do Acre, do Rio Branco, ou de Goiás, de Goiânia, de Formosa, de Caruaru no norte, de todo o Brasil. De modo que ela então me deu a possibilidade de contato e de conhecer as reais condições da produção histórica de todas essas faculdades que existem aí, as centenas de faculdades que proliferaram enormemente, principalmente nos anos 50. Grande proliferação das Faculdades de Filosofia no Brasil ${ }^{297}$.
\end{abstract}

Ao rememorar o momento fundador da ANPUH, há vinte anos, o "Simpósio de Professores de História do ensino superior”, realizado em Marília/SP em 1961, Alice nos fornece um indício quanto aos intentos de tal Simpósio: os rumos do ensino superior no Brasil, principalmente no que tange ao ensino e pesquisa. Outro aspecto rememorado pela historiadora diz respeito à uma vasta rede de sociabilidade por ela tecida a partir da

proposta de Bonnie Smith, principalmente em relação à vários aspectos da prática historiadora que foram alijadas do ofício durante sua profissionalização no século XIX, por serem consideradas características femininas, como a subjetividade, por exemplo. E também sobre as relações entre a vida profissional e a vida doméstica e familiar. Ver: LIBLIK, op. cit., 2017.

${ }^{297}$ CANABRAVA, op. cit., 1981. Grifos nossos. Em seu depoimento realizado na reunião anual da SBPC em julho de 1984 que reuniu as mulheres pioneiras da USP e que deu origem ao livro organizado por Eva Blay e Alice Lang em 2004, Alice não aborda a ANPUH. Cf. CANABRAVA, op. cit., 2004, p. 85-104. Tampouco em entrevista concedida a Flávio Saes em 1997. Cf. CANABRAVA, op. cit., p. 157-163, 1997. 
correspondência, na condição de seus 18 anos como secretária da entidade, o que lhe permitiu elaborar uma radiografia das condições da pesquisa histórica nas várias regiões do país.

Quanto ao momento fundador, como destacamos no excerto acima, Alice rememora sua eventualidade, ou seja, o que posteriormente seria denominado I Simpósio não teria sido organizado com a finalidade precípua de se fundar uma associação de historiadores. Francisco Falcon é outro historiador que participou desse Simpósio e que compartilha de uma memória comum quanto ao espaço de sociabilidade. Em uma imbricação entre história e memória, esse historiador, em conferência pronunciada por conta dos 50 anos de existência da ANPUH em 2011 no XXVI Simpósio Nacional de História ocorrido em São Paulo/SP, após analisar as circunstâncias que conduziram à realização do I Simpósio, bem como uma análise do mesmo, finaliza constatando que “[...] o objetivo a que se propunham os organizadores - um novo currículo para o curso de História - não foi atingido. Em compensação, produziu-se um fato que não estava previsto: a fundação da APUH!"298. Falcon, assim como Alice, também assinala que a fundação da entidade se deu por conta de uma eventualidade e que o objetivo principal do evento era de propor um novo currículo para o curso de História e vai mais longe: seu objetivo não teria sido atingido.

Na seção "noticiário" da Revista de História, encontramos explicitados os intentos desse Simpósio. Redigida por Eurípedes Simões de Paula, a notícia traz sua convocação pelos professores da “jovem" Faculdade e expõe seu objetivo.

Os professores de História dessa jovem Faculdade considerando insuficientes para a formação do futuro pesquisador e professor de História as matérias oferecidas pelo "currículo mínimo" exigido pelo Governo Federal, sobretudo na sua atual e defeituosa distribuição, em que até cadeiras básicas são prejudicadas por matérias de interesse menor, proporão uma revisão completa da estrutura do atual currículo 299 .

\footnotetext{
${ }^{298}$ FALCON, Francisco José Calazans. Memória e História. A fundação da ANPUH. In: SIMPÓSIO NACIONAL DE HISTÓRIA - ANPUH, XXVI, 2011b, São Paulo. Anais... São Paulo, 2011, p. 18. Disponível em: 〈http://www.snh2011.anpuh.org/conteudo/view?ID_CONTEUDO=776 >. Acessado em 22 de abr. 2019.

${ }^{299}$ PAULA, Eurípedes Simões de. I Simpósio de Professores de História do Ensino Superior. In: Noticiário. Revista de História. São Paulo, n. 46, 1961, p. 572. Ele também fornece detalhes dos temas que seriam tratados durante o Simpósio. A Revista de História passou a veicular informações sobre a recém-fundada Associação, como seus estatutos, Simpósios e circulares. Sobre a Revista de História e seu poder simbólico na conformação do campo historiográfico brasileiro, ver: NASCIMENTO, Bruno César. Para além do texto: os periódicos de história como elemento de definição do campo. O caso da Revista de História da USP (1950-2016). 2016. 347 f. Dissertação (Programa de pós-graduação em História Social das Relações
} 
O ponto fulcral diz respeito à formação do professor e/ou pesquisador de História. Na introdução dos Anais desse Simpósio ${ }^{300}$, também encontramos explicitado os intentos do encontro. A reunião é justificada pelo espraiamento das faculdades e dos colegas e pelos problemas quanto ao ensino de história.

Se houve mérito em nossa iniciativa, não pretendemos outra, liminarmente, que a de termos criado condições que não existiam antes do Simpósio, tanto para a possibilidade de contatos pessoais - quanto para um primeiro desbastamento do espesso feixe de problemas relativos ao ensino de História ${ }^{301}$.

Mas por que em Marília/SP e por que em 1961?

Francisco Falcon rememora que a "Semana de Estudos Americanos" ocorrida entre 12 e 18 de julho de 1959 na reitoria da Universidade do Brasil (UB), congregando professores da Faculdade Nacional de Filosofia (FNFi), da Pontifícia Universidade Católica do Rio de Janeiro (PUC/RJ), do Colégio Pedro II, da FFCL/USP, das Universidades da Bahia e Pernambuco, além de quatorze professores estadunidenses, foi o primeiro evento reunindo professores universitários de história com o fito de discutir o ensino da disciplina. Nessa ocasião, conheceu Eduardo D’Oliveira França, catedrático de História da Civilização Moderna e Contemporânea da FFCL/USP com quem teceria longa amizade, principalmente através de trocas intelectuais permanentes entre sua cadeira e a cadeira de História Moderna e Contemporânea da FNFi/UB, regida por Maria Yedda Leite Linhares, da qual era assistente.

Nessa ocasião, conheceu também Alice Piffer Canabrava, Eurípedes Simões de Paula e Sérgio Buarque de Holanda que o impressionaram. A partir desse momento, Falcon afirma que os intercâmbios intelectuais com São Paulo se intensificaram, estreitando contatos com Eduardo D’Oliveira França, Fernando Novais, Manuel Nunes Dias, Carlos Guilherme Mota e José Ribeiro Júnior, por meio de viagens à capital paulista, como em 1960 para participar, juntamente com Fernando Sgarbi Lima, da então Universidade do Estado da Guanabara, da "Jornada Henriquina", ocorrida entre 04 e 10

Políticas) - CCHN/UFES, Vitória, 2016. Ver: Revista de História: trajetórias historiográficas na Universidade de São Paulo. Serra/ES: Editora Milfontes, 2018.

300 Os Anais dos vários Simpósios da APUH/ANPUH estão disponíveis em: <https://anpuh.org.br/index.php/documentos/anais>. Acessado em 22 de abr. 2019.

${ }^{301}$ Introdução. In: SIMPÓSIO DE PROFESSORES DE HISTÓRIA DO ENSINO SUPERIOR EM 1961, I, 1961, Marília. Anais do I Simpósio de professores de História do ensino superior. Marília: Faculdade de Filosofia, Ciências e Letras, 1962, p. 9. 
de novembro na Casa de Portugal ${ }^{302}$. Em 1960 receberam na FNFi/UB a visita de Maria Clara Rezende Teixeira Constantino, regente da cadeira de Introdução aos Estudos Históricos e de Maria Conceição Vicente de Carvalho, regente da cadeira de Geografia Geral e do Brasil, ambas da FFCL/Marília ${ }^{303}$, que, em nome do departamento de História, convidaram professores da FNFi/UB para se juntar à eles em São Paulo com o fito de discutir o currículo mínimo do curso de História ${ }^{304}$. Em um contexto de debates efervescentes quanto às reformas sociais de base, incluindo-se a reforma universitária, somado ao fato de que a FFCL/Marília iniciou suas atividades no ano de 1959, não é de causar estranhamento que seus professores de história quisessem discutir o currículo básico de seu curso ${ }^{305}$.

Como rememorado por Francisco Falcon, em entrevista concedida à Marieta de Moraes Ferreira entre 2008 e 2009, houve reuniões em São Paulo com o fito de estabelecer os temários do Simpósio, bem como sua relatoria ${ }^{306}$. Logo após a realização do Simpósio, ocorrido entre 15 e 20 de outubro de 1961 na FFCL/Marília, o historiador publicou um texto no qual expõe sua visão sobre o evento. Podemos tomá-lo enquanto testemunho ${ }^{307}$.

\footnotetext{
${ }^{302}$ Cf. FALCON, Francisco José Calazans. A cadeira de História moderna e contemporânea e o ensino e a pesquisa histórica da FNFi - UB. In: FALCON, op. cit., 2015, p. 190-192.

${ }^{303}$ Maria Conceição Vicente de Carvalho concedeu depoimento como uma das pioneiras da USP, no qual rememorou, dentre outros, o preterimento de Alice no concurso para a cadeira de História da Civilização Americana da FFCL/USP em 1946; o papel de destaque de Olga Pantaleão na organização desse I Simpósio; as dificuldades enfrentadas quando em 1925 graduou-se em Química industrial pelo Instituto Mackenzie, ao não conseguir atuar na área devido às barreiras de gênero; seu ingresso na primeira turma de Geografia e História, no qual foi a primeira mulher a obter o título de doutora em Geografia no Brasil. Cf. CARVALHO, Maria Conceição Vicente de. Geógrafa. In: BLAY; LANG, op. cit., 2004, p. 117-123. Apesar de mencionar os casos de Alice e Olga, Maria Conceição silencia sobre si mesma, uma vez que não atingiu a cátedra na FFCL/USP, tendo que realizar sua carreira fora da USP.

${ }^{304}$ FALCON, op. cit., 2011b, p. 1-2.

${ }^{305}$ Sobre a história da FFCL de Marília ver: CASTILHO, Myrian Lucia Ruiz. Memória e história da formação da Faculdade de Filosofia, Ciências e Letras de Marília (1956-1976). 2009. 252 f. Tese (Programa de Pós-Graduação em Educação) - FFC/UNESP, Marília, 2009. A FFCL de Marília, assim como as Faculdades de Filosofia, Ciências e Letras de Assis, Araraquara, Franca, Rio Claro e São José do Rio Preto, fundadas ao longo dos anos 1950 e início dos anos 1960, deram origem à Universidade Estadual Paulista "Júlio de Mesquita Filho", a UNESP, em 1976.

${ }^{306}$ FALCON, Francisco José Calazans. Francisco Falcon. In: FERREIRA, Marieta de Moraes. A história como ofício: a constituição de um campo disciplinar. Rio de Janeiro: FGV, 2013, p. 288.

${ }^{307}$ Para Paul Ricoeur, o testemunho nos conduz ao processo efetivo da operação historiográfica, no sentido certeauniano da noção, uma vez que o mesmo abre uma sucessão epistemológica a partir da memória declarada, passando pelo arquivo e pelos documentos até atingir a prova documental. Essa operação pressupõe colocar o testemunho em suspeição, o que pode ser operado através da comparação com outros testemunhos ou pela reiteração do agente. Cf. RICOEUR, Paul. O testemunho. In: RICOEUR, op. cit., 2007, p. 170-175.
} 
Falcon aponta que, de início, viu com bons olhos a formação de equipes para a discussão dos temas que seriam levados ao Simpósio por cada um de seus relatores para a formação das respectivas mesas-redondas, o que expressaria a posição do grupo. Porém, quando chegou a São Paulo, decepcionou-se, uma vez que os organizadores estabeleceram enquanto norma que o relator teria liberdade de expor aquilo que julgasse importante, podendo ignorar as discussões da equipe de trabalho, o que para ele, teria se consubstanciado em mesas redondas que, via de regra, tomaram a feição de "batalha" entre o expositor e o plenário, “[...] não se podendo sentir a presença de nenhum trabalho de equipe" ${ }^{308}$.

Colocado em suspeição, em termos de confiabilidade, é necessário que o agente reitere seu testemunho. Falcon, exatamente 50 anos depois do I Simpósio, mantém as linhas gerais do que afirmara em 1961 logo após a realização do mesmo ${ }^{309}$. Ademais, como não podemos operar com outro elemento de suspeição do testemunho, como a comparação, por ausência dos mesmos, correremos o risco de compará-lo às intervenções realizadas pelos participantes do Simpósio, constantes nos Anais do evento.

A equipe de História Moderna e Contemporânea foi composta por Cecília Maria Westphalen, da FFCL da Universidade do Paraná (UPR), Fernando Sgarbi Lima, Francisco José Calazans Falcon, Maria Conceição Martins Ribeiro, instrutora da cadeira de História da FFCL de Rio Claro/SP; Olga Pantaleão, da FFCL/Marília e membro da comissão executiva ${ }^{310}$; e Eduardo D’Oliveira França, relator ${ }^{311}$. Uma importante nota abre o relatório de Eduardo França, qual seja, o fato de que o mesmo não enviou à comissão

\footnotetext{
${ }^{308}$ FALCON, Francisco José Calazans. O I Simpósio de Professores de História do Ensino Superior. Boletim de História. Centro de Estudos de História da Faculdade de Filosofia da Universidade do Brasil. Rio de Janeiro, n. 7, 1963, p. 189.

${ }^{309}$ Cf. FALCON, op. cit., 2011 b.

${ }^{310}$ Sobre a trajetória intelectual de Olga Pantaleão, ver: RIBEIRO, Maria Alice Rosa. Lutas e conquistas das primeiras historiadoras em História Econômica, 1934-1972. In: SAES, Alexandre Macchione. RIBEIRO, Maria Alice Rosa. SAES, Flávio Azevedo Marques de (orgs.). Rumos da história econômica no Brasil: 25 anos da ABPHE. São Paulo: Alameda, 2017, p. 144-152. Além de avaliar a contribuição de Alice Piffer Canabrava, Olga Pantaleão, Mafalda Zemella, Myriam Ellis, Nícia Villela Luz, Emília Viotti da Costa, Maria Thereza Schorer Petrone e Suely Robles de Queiroz à história econômica em âmbito universitário, Ribeiro adota uma perspectiva de gênero ao analisar as trajetórias de Alice, Olga e Mafalda, demarcando as hostilidades impostas pelo grupo masculino da FFCL/USP para que as três historiadoras não alçassem à cátedra.

${ }^{311}$ Equipes. In: Anais..., op. cit., 1962, p. 283.
} 
executiva seu relatório e que o texto apresentado nos Anais é apenas um resumo redigido pela mesma comissão ${ }^{312}$.

Tal fato nos conduz a problematizar e refletir sobre a natureza de nossa principal fonte desse capítulo, os Anais dos vários Simpósios da APUH/ANPUH ${ }^{313}$. Normatizados por um regulamento, que estabelecia rigidamente o tempo de fala, de intervenções e de réplicas, bem como, no caso desse I Simpósio, o poder de interromper e interditar o debate conferido ao presidente de cada mesa redonda - "ritual da circunstância" - devemos nos atentar aos mecanismos de enquadramento do discurso impostos por tal regulamento, o que permite e o que interdita. Em seu artigo $2^{\circ}$, o regulamento estabelecia que após a exposição do relator, os participantes poderiam realizar intervenções, restringindo-se ao que foi exposto, e que o relator poderia se abster de respondê-las, podendo encaminhálas para a mesa redonda. Ao presidente convidado da mesa redonda, Rubens Borba de Moraes ou Sérgio Buarque de Holanda, de acordo com o artigo $3^{\circ}$, caberia conceder a palavra, bem como interditá-la. A necessidade de se inscrever junto à secretaria e de ter que apresentar, por escrito, sua intervenção, indica também um policiamento do discurso. O tempo para intervenção foi estipulado em, no máximo, dez minutos e as réplicas em três minutos. Outra forma de policiamento discursivo adotada diz respeito às moções. Em seu título III, "Das moções e propostas fora da pauta do temário", o regulamento estabelece que "[...] A secretaria não está obrigada a encaminhar à mesa-redonda as moções que considerar afastadas dos intuitos do Simpósio"314. Assim, o regulamento estabelece o que, como e em que ocasião pode ser dito. Ademais, os relatórios e intervenções, bem como veremos nos demais Simpósios em relação às comunicações, se deram através da oralidade. Coube à comissão organizadora enquadrar a fala sob o império da escrita, o que implica em silenciamentos e exclusões ${ }^{315}$.

Um indício de que o trabalho em equipe realmente não se efetivou e que os membros de cada uma delas não sabiam, de antemão, o que seu relator iria apresentar,

\footnotetext{
${ }^{312}$ FRANÇA, Eduardo D’Oliveira. Resumo do relatório do prof. Eduardo D’Oliveira França. In: Anais..., op. cit., 1962, p. 103-110.

${ }^{313}$ Nossa inspiração teórica parte da ordem do discurso em nossa sociedade e seu principal mecanismo: a exclusão. "Sabe-se bem que não se tem o direito de dizer tudo, que não se pode falar de tudo em qualquer circunstância, que qualquer um, enfim, não pode falar de qualquer coisa. Tabu do objeto, ritual da circunstância, direito privilegiado ou exclusivo do sujeito que fala: temos aí o jogo de três tipos de interdições que se cruzam, se reforçam ou se compensam, formando uma grade complexa que não cessa de se modificar". Cf. FOUCAULT, Michel. A ordem do discurso. $24^{a}$ edição. São Paulo: Loyola, 2014, p. 9.

${ }^{314}$ Regulamento. In: Anais..., op. cit., 1962, p. 29.

${ }^{315}$ Cf. CERTEAU, op. cit., 2011.
} 
encontramos nas intervenções de Francisco Falcon, Olga Pantaleão, Cecília Westphalen e Fernando Lima, componentes da equipe de História Moderna e Contemporânea à exposição de Eduardo França. Este se ateve a propor caminhos para o melhoramento do ensino de História Moderna e Contemporânea, bem como para o curso de História. Para ele, deveria haver uma articulação entre as cátedras, no sentido de que as mesmas não se restringissem a períodos e que a primazia caberia à história do Brasil, enquanto articuladora. Devendo-se, contudo, manter o sistema de cátedras, com o fito de garantir sua liberdade. Destaca a importância da transmissão de técnicas de pesquisa, para além dos conteúdos e entre um currículo rígido e um flexível, advoga por um equilíbrio entre disciplinas obrigatórias e optativas, sendo que história moderna teria lugar no segundo ano e história contemporânea no terceiro, bastando três anos de curso, uma vez que o aluno deveria sair da graduação com um sólido conteúdo básico.

Se o relator mobilizou referências teóricas e/ou bibliográficas não sabemos, uma vez que, como apontado acima, não encaminhou sua versão do relatório à comissão executiva $^{316}$. Em sua intervenção, Cecília Westphalen destaca que deve-se transmitir aos alunos as técnicas das ciências sociais, defende a liberdade de cátedra e apresenta proposta de revogação da permissão de licenciados em Pedagogia e Ciências Sociais lecionarem História ${ }^{317}$. Fernando Sgarbi Lima ateve-se a concordar com o relator no que tange a se pensar o ensino a partir de temas e propôs a formação de uma comissão de cinco membros com o objetivo de estabelecer se o currículo seria dividido em temas ou períodos $^{318}$. Para Falcon, o problema do ensino de história moderna e contemporânea deveria passar pela discussão da reforma universitária e lança um protesto em relação ao fato de licenciados em Pedagogia poderem lecionar história ${ }^{319}$. Sua intervenção deu-se logo após a de Maria Yedda Leite Linhares que demarcou na exposição de Eduardo França uma contradição entre liberdade de cátedra, cátedra vitalícia e liberdade do professor. Para ela, a extinção da cátedra vitalícia não suprime a liberdade do professor.

\footnotetext{
${ }^{316}$ FRANÇA, op. cit., 1962, p. 103-110.

${ }^{317}$ WESTPHALEN, Cecília Maria. Exposições de simposistas. In: Anais..., op. cit., 1962, p. 112-113. O problema da permissão concedida pelo governo federal, através de portaria ministerial n. 478 de 08 de junho de 1954, para que licenciados em Pedagogia, Filosofia e Ciências Sociais possam ministrar História no então curso secundário gerou moção ao ministro da educação e cultura para que fosse revogada. Cf. moção 10. In: Anais..., op. cit., 1962, p. 291-292. Essa moção foi assinada por 26 professores, excluindose Alice Canabrava. Ademais, a conclusão de número 32 estabelece que somente licenciados em História podem ministrar aulas da disciplina no curso secundário. Cf. Conclusões. In: Anais..., op. cit., 1962, p. 304. ${ }^{318}$ LIMA, Fernando Sgarbi. Exposições de simposistas. In: Anais..., op. cit., 1962, p. 114.

${ }^{319}$ FALCON, Francisco José Calazans. Exposições de simposistas. In: Anais..., op. cit., 1962, p. 110-111.
} 
Quanto ao currículo, advoga por sua flexibilidade à exemplo das universidades de Brasília e do Cearáa ${ }^{320}$.

Podemos notar que as intervenções de Francisco Falcon e de Maria Yedda Linhares estavam preocupadas com o problema do currículo de história e do ensino de história a partir de uma perspectiva que envolvia pensá-los inseridos nas discussões então correntes sobre a reforma universitária. A intervenção de Olga Pantaleão, enquanto membro da comissão executiva do evento ${ }^{321}$, demarca que o debate em torno do sistema de cátedras foge um pouco ao temário ${ }^{322}$ - “tabu do objeto”. Em suas respostas, Eduardo França não fez nenhuma menção à reforma universitária; defendeu o regime de cátedras, destacando que vê uma espécie de "sofisma" entre os que advogam pelo fim da cátedra e a manutenção do catedrático. Para ele, a cátedra protegeria o professor contra ingerências políticas e econômicas ${ }^{323}$.

Nas últimas intervenções, Francisco Falcon e Maria Clara Constantino retomaram o problema do sistema de cátedras. Para esta última, a cátedra não deve depender do sistema de ensino e aponta que cada cadeira deve ter entre três e quatro professores trabalhando em cursos especializados, o que permite uma relação profícua entre ensino e pesquisa $^{324}$. Para Falcon, a liberdade de cátedra também deve ser possibilitada aos assistentes e não somente ao professor e posiciona-se contrariamente aos privilégios dos catedráticos, uma vez que impedem o ingresso de outros na carreira ${ }^{325}$.

Cecília Westphalen protesta no sentido de que a história do Brasil deva estar no centro do curso. Para ela, a história do Brasil deve estar integrada à "história do mundo"326. Maria Yedda Linhares partilha da mesma concepção epistemológica, uma vez que acentua que se deve partir de uma história geral e ressalta que não afirmou que a história do Brasil deva estar no centro do ensino ${ }^{327}$. Em resposta à intervenção de Falcon, França protesta que o sistema de cátedras seja garantista e afirma que os privilégios

\footnotetext{
${ }^{320}$ LINHARES, Maria Yedda Leite. Exposições de Simposistas. In: Anais..., op. cit., 1962, p. 110.

${ }^{321}$ A comissão executiva do evento foi formada por José Roberto do Amaral Lapa, Olga Pantaleão, Oswaldo Elias Xidieh, regente da cadeira de Noções de Sociologia, Uacury Ribeiro de Assis Bastos, regente da cadeira de História da América e presidida por Carl Laga, regente da cadeira de História Antiga e Medieval. Cf. Anais..., op. cit., 1962, p. 16.

${ }^{322}$ PANTALEÃO, Olga. Exposições de Simposistas. In: Anais..., op. cit., 1962, p. 111-112.

${ }^{323}$ FRANÇA, Eduardo D’Oliveira. Respostas às exposições. In: Anais..., op. cit., 1962, p. 114-116.

${ }^{324}$ CONSTANTINO, Maria Clara Rezende Teixeira. Últimas intervenções. In: Anais..., op. cit., 1962, p. 117.

${ }^{325}$ FALCON, Francisco José Calazans. Últimas intervenções. In: Anais..., op. cit., 1962, p. 116.

${ }^{326}$ WESTPHALEN, Cecília Maria. Últimas intervenções. In: Anais..., op. cit., 1962, p. 117.

${ }^{327}$ LINHARES, Maria Yedda Leite. Últimas intervenções. In: Anais..., op. cit., 1962, p. 117.
} 
indevidos devem ser extintos. Afirma ser partidário da liberdade de cátedra, inclusive que se preserve o direito dos professores escolherem seus auxiliares de confiança ${ }^{328}$. Ao mesmo tempo, concorda com Maria Clara Constantino no que toca à questão de vários professores por cadeira, o que seria útil para corrigir o monopólio do catedrático ${ }^{329}$.

O currículo do curso de História discutido nesse I Simpósio é oriundo do desmembramento do curso de Geografia e História por meio da lei federal n. 2.594 de 08 de setembro de $1955^{330}$. A preocupação dos professores reunidos em Marília com a efetivação de tal lei, uma vez que se configura em uma primeira condição de possibilidade rumo à delimitação de uma história disciplinar em moldes acadêmicos, se expressou através da aprovação de moção, proposta por Cecília Westphalen e Antonio Camillo de Faria Alvim, regente da cadeira de História do Brasil da FFCL da Universidade de Minas Gerais (UMG), que recomenda às autoridades competentes a separação dos cursos naquelas faculdades que ainda não a empreenderam ${ }^{331}$. O currículo mínimo do curso de História foi formado à partir das disciplinas constantes do antigo curso de Geografia e História estabelecidas no decreto-lei n. 1.149 de 04 de abril de 1939 que trata da organização da FNFi/UB: $1^{\text {a }}$ série: geografia física, geografia humana, antropologia, história da antiguidade e da idade média; $2^{\mathrm{a}}$ série: geografia física, geografia humana, história moderna, história do brasil e etnografia; $3^{\mathrm{a}}$ série: geografia do brasil, história contemporânea, história do brasil, história da américa e etnografia do Brasi1 ${ }^{332}$. Além de um currículo mínimo, o decreto-lei n. 9.092 de 26 de março de 1946, estabeleceu a nova duração do curso, que passaria de três para quatro anos, sendo que durante os três primeiros o aluno receberia a formação básica, para a obtenção do título de bacharel, e no quarto ano a formação didática, teórica e prática, logrando o título de licenciado ${ }^{333}$.

No caso específico da FFCL/USP, o desdobramento se deu através do decreto estadual n. 25.701 de 04 de abril de 1956. Abaixo, temos a grade curricular do curso de

\footnotetext{
${ }^{328}$ FRANÇA, Eduardo D’Oliveira. Respostas finais. In: Anais..., op. cit., 1962, p. 118.

329 Ibidem.

330 Cf. Legislação informatizada. Lei n. 2.594, de 08 de setembro de 1955. Disponível em: < http://www2.camara.leg.br/legin/fed/lei/1950-1959/lei-2594-8-setembro-1955-361157publicacaooriginal-1-pl.html>. Acessado em 24 de jul. 2017.

331 Moção 9. In: Anais..., op. cit., 1962, p. 291.

332 Cf. Legislação informatizada. Decreto-lei n. 1.190, de 04 de abril de 1939. Disponível em: <http://www2.camara.leg.br/legin/fed/declei/1930-1939/decreto-lei-1190-4-abril-1939-349241publicacaooriginal-1-pe.html>. Acessado em 24 de jul. 2017.

333 Cf. Legislação informatizada. Decreto-lei n. 9.092, de 26 de março de 1946. Disponível em: <http://www2.camara.leg.br/legin/fed/declei/1940-1949/decreto-lei-9092-26-marco-1946-416948publicacaooriginal-1-pe.html>. Acessado em 24 de jul. 2017.
} 
História da FFCL/USP logo após o decreto, com as três séries básicas e as disciplinas optativas (tabela 2).

\begin{tabular}{|c|c|c|c|}
\hline 1 série & 2a série & 3a série & Optativas \\
\hline $\begin{array}{c}\text { Introdução aos } \\
\text { estudos históricos }\end{array}$ & $\begin{array}{c}\text { História da } \\
\text { civilização } \\
\text { moderna }\end{array}$ & $\begin{array}{c}\text { História da } \\
\text { civilização } \\
\text { contemporânea }\end{array}$ & $\begin{array}{c}\text { História das ideias } \\
\text { políticas }\end{array}$ \\
\hline História da & História da & História da & História da \\
civilização antiga & civilização & civilização & filosofia \\
& brasileira & brasileira & \\
\hline História da & História da & História da & História econômica \\
civilização & civilização & civilização & História da \\
medieval & americana & americana & educação \\
\hline Antropologia & Etnografia geral & Etnografia do & História da \\
& & Brasil e noção de & literatura \\
\hline Geografia & História da & Disciplina optativa & História da arte \\
\hline & civilização ibérica & & Numismática \\
\hline & Disciplina optativa & & \\
\hline
\end{tabular}

(Elaboração própria a partir de PAULA, Eurípedes Simões. Desdobramento do curso de Geografia e História na Faculdade de Filosofia, Ciências e Letras da Universidade de São Paulo. In: Noticiário. Revista de História. São Paulo, n. 25, 1955, p. 285-286).

Os alunos que quisessem obter o título de licenciado poderiam cursar, no quarto ano, as disciplinas de psicologia educacional, didática geral e didática especial. E também duas ou três disciplinas optativas ${ }^{334}$. No que diz respeito especificamente ao conteúdo curricular e sua distribuição, apenas Amélia Americano Domingues de Castro, assistente da cadeira de didática geral e especial da FFCL/USP ${ }^{335}$ se manifestou pela presença de

\footnotetext{
${ }^{334}$ Cf. ROIZ, Diogo da Silva. Os caminhos (da escrita) da história e os descaminhos de seu ensino: a institucionalização do ensino universitário de História na Faculdade de Filosofia, Ciências e Letras da Universidade de São Paulo (1934-1968). Curitiba: Editora Appris, 2012, p. 72. Ver resenha: MACHADO, Daiane. Institucionalização acadêmica da História: entre o autodidatismo e a profissionalização. História da historiografia. Ouro Preto, n. 12, p. 242-247, 2013.

${ }^{335}$ Cf. Catálogo dos sócios fundadores. APUH. São Paulo: Secretaria geral, 1962, p. 5. Arquivo da ANPUH.
} 
didática em mais de um ano do curso, primeiro com uma didática geral e depois com uma didática especial ${ }^{336}$. No que Eduardo França, em sua resposta, apontou apenas que Amélia de Castro manteve seu ponto de vista quanto à didática ${ }^{337}$. Pudemos perceber que os debates concernentes ao temário de história moderna e contemporânea extrapolaram o interdito da comissão organizadora e adentraram à questão do sistema de cátedras. Também esteve presente um debate epistemológico em torno do lugar da história do Brasil no curso de História, se esta deveria ser o centro do curso ou se deveria ser abordada a partir de uma perspectiva da história mundial ${ }^{338}$.

O relatório do tema I, História Antiga e Medieval, foi elaborado por Eurípedes Simões de Paula, na ocasião, diretor da FFCL/Marília, e parte da perspectiva de sua experiência na FFCL/USP. Tal fato corrobora o testemunho de Francisco Falcon ${ }^{339}$, uma vez que a equipe do tema era formada por Aloysio do Rio Barbosa; Armando Souto Maior, da FFCL da Universidade de Pernambuco (UPE); Carl Laga; Eremildo Luiz Vianna, catedrático da FNFi/UB e Luiz Cézar Bittencourt Silva, da FFCL de Niterói/RJ ${ }^{340}$. Sua principal proposta é de separação das cadeiras de História da Civilização Antiga e Medieval em duas, justificada pelo fato de que as duas áreas possuem suas especificidades, sendo que uma delas encontra-se no argumento de que a história medieval estaria mais ligada à história moderna, como sua antessala. Tomando o currículo acima como modelo, para Eurípedes, tupi-guarani deveria ser extinta e antropologia juntamente com etnografia deveriam passar à optativas. Dentre as optativas que não figuram no currículo, deveriam ser criadas pré-história, epigrafia, paleografia e arqueologia - por sinal, disciplinas e técnicas bastante afeitas à história antiga e medieval. Passa pelos métodos de seminários que deveriam preponderar sobre as aulas expositivas

\footnotetext{
${ }^{336}$ Cf. CASTRO, Amélia Americano Domingues de. Últimas intervenções. In: Anais..., op. cit., 1962, p. 116.

${ }^{337}$ Cf. FRANÇA, Eduardo D’Oliveira. Respostas finais. In: Anais..., op. cit., 1962, p. 117.

${ }^{338}$ Sobre os debates em torno da história do Brasil e da história geral ao longo dos Simpósios da APUH/ANPUH, ver: SILVA, Paulo Thiago Santos Gonçalves da. A Associação Nacional dos Professores Universitários de História: espaço de identificação profissional e legitimação do saber histórico (19611977). 334f. 2014. Tese (Programa de Pós-graduação em História) - UnB. Brasília, IFCH, 2014, p. 209233. O autor sustenta a tese de que nos dois primeiros simpósios da APUH houve uma disputa entre paulistas e cariocas. Estes defenderiam a inserção dos debates em um contexto mais amplo, qual seja, das reformas sociais de base, enquanto os paulistas adotaram a postura de se ater ao temário do evento. Para Paulo Silva, após a eleição de Eurípedes Simões de Paula para a presidência da APUH em 1965, esse conflito teria sido silenciado pela hegemonia paulista na associação, juntamente com o secretariado de Alice Canabrava.

${ }^{339}$ Cf. FALCON, op. cit., 1963.

${ }^{340}$ Equipes. In: Anais..., op. cit., 1962, p. 283.
} 
(“preleções"); pela especialização e finaliza admoestando pelo fim do "mandarinato" de muitos catedráticos que não produzem e que impedem que seus assistentes o façam ${ }^{341}$.

Apenas um membro da equipe de história antiga e medieval se manifestou: Carl Laga, afirmando que o estudo da história universal deve ser privilegiado. No geral, as intervenções discordaram da ligação empreendida pelo relator entre história medieval e história moderna, solicitando maiores explicações; advogaram pela necessidade do tempo integral $^{342}$ e Hamilton Leite, regente da cadeira de História Antiga e Medieval da FFCL/UMG ${ }^{343}$, demarcou que, como Eurípedes tratou de uma experiência pessoal, suas afirmações necessitam ser cuidadosamente consideradas. Somente Francisco Falcon expressou preocupação com a formação de professores secundários e, juntamente com Othelo Laurent, regente da cadeira de História Antiga e Medieval da FFCL da Universidade do Rio Grande do Sul (URGS) ${ }^{344}$, com os alunos ${ }^{345}$.

No geral, as intervenções se ativeram ao relatório apresentado, instaurando pontuais desvios e diferenças, o que permitiu a Eurípedes Simões de Paula ver aprovada a moção 21, proposta por seus colegas Eremildo Luiz Vianna e Emília Thereza Álvares Ribeiro, professora de história medieval da FFCL/Niterói ${ }^{346}$, que recomenda às universidades a separação de História Antiga e Medieval em duas disciplinas ${ }^{347}$ e nas conclusões aprovadas de números 08 e 09 as quais determinam que história antiga e história medieval devem ser duas disciplinas ou duas cadeiras separadas e que devem haver cursos de especialização em história antiga e medieval, bem como sua complementação com latim e grego ${ }^{348}$.

Percebemos que os debates em torno da mesa redonda concernente ao tema 1 apresentaram considerações em torno das disciplinas que deveriam compor o currículo do curso de história, enquanto obrigatórias, optativas e as que deveriam também ser

\footnotetext{
341 PAULA, Eurípedes Simões de. História Antiga e História Medieval: dois espíritos e duas especializações. Problemas que suscita a sua definição numa só cadeira. In: Anais..., op. cit., 1962, p. 8188.

${ }^{342} \mathrm{Na}$ moção 3, proposta por Eduardo D’Oliveira França, os professores se dirigem aos poderes responsáveis solicitando o regime de tempo integral, justificado pela possibilidade de maior dedicação à pesquisa. Cf. Moção 3. In: Anais..., op. cit., 1962, p. 288-289.

${ }^{343}$ Cf. Catálogo dos sócios fundadores. APUH. São Paulo: Secretaria geral, 1962, p. 9. Arquivo da ANPUH.

344 Ibidem.

345 Exposições dos simposistas. In: Anais..., op. cit., 1962, p. 88-92.

${ }^{346}$ Cf. Catálogo dos sócios fundadores. APUH. São Paulo: Secretaria geral, 1962, p. 13. Arquivo da ANPUH.

${ }^{347}$ Moção 21. In: Anais..., op. cit., 1962, p. 298.

${ }^{348}$ Conclusões. In: Anais..., op. cit., 1962, p. 301 e 302.
} 
excluídas o que não aconteceu em torno do tema 2. Ademais, ao contrário dos trabalhos em torno do tema 2, os concernentes ao tema 1 não se puseram de acordo ao testemunhado por Francisco Falcon um ano após ter participado do evento, de que as mesas redondas teriam se resumido a "batalhas" entre os relatores e os participantes ${ }^{349}$.

Passaremos ao tema IV, uma vez que no conjunto dos temas tratados, os relatórios apresentados por Alice Canabrava e por Maria Yedda Linhares instauram uma diferença a ser inventariada ${ }^{350}$. Se os relatórios dos demais temas analisam um determinado currículo e propõe alterações, o relatório apresentado por Maria Yedda Linhares insere o problema do currículo a partir da reforma universitária e Alice Canabrava utiliza seu espaço de relatora para expor o que podemos considerar uma epistemologia histórica.

O tema IV tratou das "matérias complementares e auxiliares: o alargamento do horizonte no estudo da história”, e contou em sua equipe com Flecha Ribeiro; Guy de Hollanda, assistente da cadeira de História da América da FNFi/UB; José Roberto do Amaral Lapa, regente da cadeira de História do Brasil da FFCL/Marília; Maria Clara Constantino; Maria Conceição Vicente de Carvalho; Oswaldo Elias Xidieh; Ubaldo Martini Pupi, regente da cadeira de História da Filosofia da FFCL/Marília; e Eremildo Luiz Vianna como relator ${ }^{351}$. Este propõe definir como técnicas auxiliares, os saberes que não possuem autonomia em relação à história, enquanto as matérias complementares gozariam de autonomia em relação ao campo historiográfico.

Dentre as técnicas auxiliares, destaca a numismática, a diplomática, a pré-história e a arqueologia que poderiam figurar como optativas, uma vez que são dispensáveis como estudo autônomo; o estudo de arquivos e a paleografia, sendo que essa última deveria figurar como obrigatória, uma vez que, se o objetivo é formar professores para além de uma cultura livresca, deve-se estimular seu contato com a documentação. Entre as

\footnotetext{
${ }^{349}$ Cf. FALCON, op. cit., 1963.

${ }^{350}$ Nossa inspiração teórica aqui provém da epistemologia de Paul Veyne em sua aula inaugural proferida no Collège de France em 1975, na qual o historiador especializado na história de Roma parte da sociologia enquanto modelo geral de explicação da sociedade e que mobiliza a história enquanto rol de exemplos e de uma história que analisa as individuações inventariadas a partir dos conceitos operatórios da sociologia. Porém, após esse exercício de aproximação, Veyne dota a história de uma epistemologia própria. "A História pode ser definida como o inventário explicativo não dos homens ou das sociedades, mas daquilo que há de social no homem, ou, mais precisamente, das diferenças manifestadas por este aspecto social". Cf. VEYNE, Paul. O inventário das diferenças. História e sociologia. São Paulo: Brasiliense, 1983, p. 46. Para uma análise da epistemologia de Paul Veyne, ver: ALBERTTI, Luiz Antonio. Apresentação da epistemologia de Paul Veyne: entre a história e a filosofia. 2007. 154 f. Dissertação (Programa de pósgraduação em história e sociedade) - FFCL/UNESP. Assis, 2007.

${ }^{351}$ Equipes. In: Anais..., op. cit., 1962, p. 283-284.
} 
matérias complementares afirma que a equipe responsável pelo tema destacou: estética, história do pensamento científico, história das religiões; história das ideias políticas e história das doutrinas econômicas que deveriam ser obrigatórias, objetivando uma melhor compreensão das teorias política e econômica; as introduções metodológicas à história, juntamente com as teorias da história deveriam figurar como obrigatórias, sendo que a primeira deveria ter lugar na primeira série e a segunda na terceira, por sua ligação com a filosofia. Geografia humana e econômica, assim como antropologia dispensariam defesas quanto à sua importância, devendo ser matérias obrigatórias. No que tange à etnografia brasileira e tupi-guarani propõe que sejam optativas e que história da filosofia seja ministrada em cursos de pós-graduação, para que o futuro professor não se perca nas correntes de ideias e despreze os fatos sociais e econômicos. Por fim, quanto à sociologia propõe que figure como obrigatória na forma de introdução às ciências sociais de acordo com as demandas específicas do ofício de historiador ${ }^{352}$.

Por mais que Eremildo Vianna fizesse referência à uma suposta colaboração da equipe, as intervenções de Maria Clara Constantino, José Roberto do Amaral Lapa e Guy de Hollanda, evidenciam um desconhecimento do que seria tratado no relatório. Eremildo Vianna, como docente do curso de História da FNFi/UB, empreendeu sua proposta a partir do currículo dessa faculdade (tabela 3).

352 VIANNA, Eremildo Luiz. Matérias complementares e auxiliares: o alargamento do horizonte no estudo da História. In: Anais..., op. cit., 1962, p. 141-147. 


\begin{tabular}{|c|c|c|c|}
\hline Primeiro ano & Segundo ano & Terceiro ano & Quarto ano \\
\hline $\begin{array}{c}\text { Introdução } \\
\text { metodológica a } \\
\text { história }\end{array}$ & $\begin{array}{l}\text { História da idade } \\
\text { média }\end{array}$ & $\begin{array}{c}\text { História } \\
\text { contemporânea }\end{array}$ & $\begin{array}{l}\text { História da } \\
\text { América }\end{array}$ \\
\hline $\begin{array}{l}\text { História da } \\
\text { antiguidade }\end{array}$ & História moderna & História da américa & $\begin{array}{c}\text { Psicologia } \\
\text { educacional }\end{array}$ \\
\hline Geografia humana & História do Brasil & História do Brasil & $\begin{array}{l}\text { Fundamentos } \\
\text { biológicos, } \\
\text { sociológicos e } \\
\text { filosóficos da } \\
\text { educação }\end{array}$ \\
\hline \multirow[t]{2}{*}{ Etnologia } & $\begin{array}{c}\text { Etnografia do } \\
\text { Brasil }\end{array}$ & $\begin{array}{c}\text { História das ideias } \\
\text { políticas }\end{array}$ & $\begin{array}{c}\text { Didática geral e } \\
\text { especial }\end{array}$ \\
\hline & & & $\begin{array}{c}\text { Administração } \\
\text { escolar }\end{array}$ \\
\hline
\end{tabular}

(Fonte: FERREIRA, Marieta de Moraes. A História como ofício: a constituição de um campo disciplinar. Rio de Janeiro: Editora FGV, 2013, p. 51).

Se tomarmos o currículo acima, do curso de história da FNFi/UB que vigorava à época do I Simpósio, e a proposta de Eremildo Vianna, podemos notar que ainda permanecia enquanto disciplina obrigatória etnografia do brasil, do qual o relatório de Simões de Paula também propunha a exclusão - o curso da FFCL/USP ainda apresentava tupi-guarani enquanto disciplina obrigatória. Dentre as matérias complementares que Vianna propunha que fossem obrigatórias, etnologia figurava no currículo, bem como introdução metodológica à história, geografia humana e história das ideias políticas. Porém, ainda havia todo um rol de matérias auxiliares obrigatórias que não figuravam no currículo: história das doutrinas econômicas, história da arte, geografia econômica, introdução às ciências sociais e teorias da história. Bem como a paleografia enquanto técnica auxiliar. Nenhuma das técnicas auxiliares propostas por Vianna como optativas estavam presentes no currículo do curso de História da FNFi/UB ${ }^{353}$.

\footnotetext{
${ }^{353}$ As seguintes disciplinas figuravam como optativas: civilização greco-romana, história ibérica, formação dos estados modernos, nacionalismo asiático, problemas do oriente médio, américa pré-colombiana, o panamericanismo, o mundo eslavo, evolução do parlamentarismo inglês, geografia histórica, história econômica, história social, história das doutrinas econômicas, história das artes, história da educação, história da igreja, evolução do império britânico. Cf. FERREIRA, op. cit., 2013, p. 50.
} 
Essa foi a primeira vez que Alice interveio em mesa redonda. Demonstrando uma preocupação com os métodos quantitativos e com a ciência econômica, o que expressa seu lugar social de fala, uma historiadora vinculada à uma Faculdade de Economia, Alice questiona o relator se economia política e estatística são consideradas por ele como matérias complementares, na qual obteve resposta positiva ${ }^{354}$. Como veremos abaixo, a importância dos métodos quantitativos e da estatística será evocada em seu relatório, bem como a compreensão da história enquanto ciência social informada, principalmente, pelo recurso à economia e aos métodos quantitativos.

Podemos perceber que o relatório de Vianna, ao contrário dos anteriormente analisados, centra sua preocupação na formação do professor, o que pode ser compreendido pela cultura acadêmica peculiar do curso de História da FNFi/UB, cujo cuidado primeiro era com a formação do professor de história, conforme rememorado por Maria Yedda Linhares em entrevista concedida à Marieta de Moraes Ferreira em $1991^{355}$. Para esta última, mesmo após a separação do curso de Geografia e História da FNFi/UB, “[...] persistiu igualmente um modelo de curso que privilegiava a formação de profissionais para o ensino secundário desvinculados da pesquisa histórica" ${ }^{356}$. Para Vianna, como apontado acima, paleografia deveria figurar como disciplina obrigatória, uma vez que se deveria estimular o contato do futuro professor com a documentação. Como vimos, no relatório de Simões de Paula, paleografia deveria ser disciplina optativa e Maria Yedda Linhares em sua primeira intervenção ao relatório de Vianna, afirma que a mesma seria dispensável à formação do professor ${ }^{357}$. Porém, em sua última intervenção, propõe que seja ministrada enquanto curso intensivo de um mês, objetivando a utilização pelo futuro professor de documentos da "história brasileira" do século XVI ou da história portuguesa do século $\mathrm{XV}^{358}$. Tal debate foi equacionado através das "conclusões", as quais foram elaboradas apenas pelos professores que compunham a comissão executiva do Simpósio, ou seja, os professores da FFCL/Marília, o que lhes conferia o poder de interditar discursos desviantes. Concluíram que o ensino de paleografia pode ser obrigatório, uma vez que é imprescindível para a formação do especialista, porém não do

\footnotetext{
${ }^{354}$ CANABRAVA, Alice Piffer. Exposições de simposistas. In: Anais..., op. cit., 1962, p. 151.

${ }^{355}$ FERREIRA, op. cit., 2013, p. 230.

356 FERREIRA, Marieta de Moraes. Um novo desenho: o curso de História, da FNFI à UFRJ. In: FERREIRA, op. cit., 2013, p. 50.

${ }^{357}$ Exposições de simposistas. In: Anais..., op. cit., 1962, p. 149.

${ }^{358}$ Últimas intervenções. In: Anais..., op. cit., 1962, p. 154.
} 
professor secundário, bastando a este os rudimentos da técnica ${ }^{359}$. Apesar das conclusões terem sido elaboradas pelos professores de Marília, essa conclusão específica expressa um equilíbrio entre as disputas engendradas em torno da matéria.

O tema VI tratou da especialização em História e contou com equipe formada por Guy de Hollanda, Maria Clara Constantino, Maria Yedda Linhares, Ricardo Román Blanco, professor da Universidade de Valladolid e professor contratado de paleografia e diplomática da FFCL/USP, Uacury de Assis Bastos e Carl Laga na condição de relator $^{360}$. O relator demarca a necessidade de se superar uma definição negativa de especialização como tudo aquilo que não for afeito ao curso de formação básica e fundamental, ou em relação à cursos monográficos. Compreende por especialização: “[...] uma aquisição gradativa de conhecimentos mais precisos, caracterizada por um contato direto com as fontes da História, em vista de chegar a um trabalho sintético e pessoal, como última finalidade" 361 . Por isso, para ele, especialização é sinônimo de pesquisa e pode ser efetuada durante os anos de formação básica. Os debates giraram em torno dessa questão.

A intervenção de Eremildo Vianna aponta o problema de se compreender a especialização apenas como um método de pesquisa durante a formação básica do aluno, admoestando que nos EUA tampouco na Europa existe especialização durante os anos de formação $^{362}$. A especialização, enquanto atitude de pesquisa, conforme exposto no relatório, deve ser reservada para o curso de pós-graduação, conforme apontado por Fernando Sgarbi Lima ${ }^{363}$ e corroborado por Guy de Hollanda ${ }^{364}$ e Francisco Falcon. Esse, ainda critica a base comparativa de Carl Laga, qual seja, as condições de pesquisa em países como EUA e Austrália, o que foge à realidade brasileira ${ }^{365}$. Tal fato pode ser compreendido pelo lugar de fala de Laga a partir de suas experiências como professor na Bélgica.

Em suas respostas, Laga propôs uma mudança de nomenclatura, ao invés de “especialização" utilizar "treinamento" para os anos de formação básica e manteve sua

\footnotetext{
${ }^{359}$ Conclusões. In: Anais..., op. cit., 1962, p. 302.

${ }^{360}$ LAGA, Carl. A especialização. As condições por ela pressupostas e as possibilidades inerentes ao curso de História do Brasil. In: Anais..., op. cit., 1962, p. 189-205.

${ }^{361}$ Idem, p. 200.

362 VIANNA, Eremildo Luiz. Exposições de simposistas. In: Anais..., op. cit., 1962, p. 206.

${ }^{363}$ LIMA, Fernando Sgarbi. Exposições de simposistas. In: Anais..., op. cit., 1962, p. 207.

${ }^{364}$ HOLLANDA, Guy de. Exposições de simposistas. In: Anais..., op. cit., 1962, p. 208-209.

${ }^{365}$ FALCON, Francisco José Calazans. Exposições de simposistas. In: Anais..., op. cit., 1962, p. 209.
} 
posição quanto a iniciar os alunos na pesquisa o quanto antes ${ }^{366}$. Durante as últimas intervenções, um adendo de Francisco Fálcon nos chama a atenção, mais uma vez, para os não-ditos e interditos presentes nos Anais desse Simpósio. “[...] nega ter feito qualquer crítica à escolha do relator. Tampouco quis alicerçar as críticas num ponto de vista racial ou nacional, acentua. Finalmente nega ter havido uma reação provocada por um complexo de subdesenvolvimento" ${ }^{367}$. Essa intervenção está registrada nos Anais, antes do comentário de Olga Pantaleão que o incitou. "Acha que há procedência em comparar o Brasil e a Austrália, desde que não aceitemos que as diferenças em nível de vida criem um complexo de subdesenvolvimento que paralisa os esforços, mas sim um incentivo, como foi o intuito do relator" ${ }^{368}$. Tal fato nos aponta mais um problema a ser considerado em relação ao trato com essa fonte específica: as intervenções e respostas não possuem a linearidade transmitida por seus registros nos Anais.

Podemos perceber quão vaga era a noção de especialização enquanto curso, muito distante daquilo que se iria instaurar sob a égide do sistema de pós-graduação em 1971. Tal constatação possibilita uma história da pós-graduação em história no Brasil, reconhecendo uma problemática anterior e para além da implantação de um sistema autoritário e centralizado, no qual docentes e discentes não foram ouvidos, instaurandose como discurso fundador. Porém, mítico. Como afirma Francisco Falcon em palestra proferida em 1997, por ocasião da I semana do curso de mestrado em História da UERJ, é necessário desnaturalizar essa história.

Em nome de uma fórmula abstrata, 'programas de pós-graduação em história', apaga(m)-se a(s) memória(s) de inúmeros debates, mutações, conflitos, além das informações acerca de docentes e discentes, trabalhos realizados, orientações teóricas etc. Ao fim e ao cabo, portanto, chega-se à história homogeneizada e asséptica, naturalizada e triunfalística que todos conhecemos bastante ${ }^{369}$.

O tema V, "o lugar das disciplinas pedagógicas no curso de História”, contou em sua equipe com Amélia Americano Domingues de Castro, Brasil Pinheiro Machado, catedrático de História do Brasil da FFCL/UPR, Guy de Hollanda, José Roberto do Amaral Lapa, Maria Clara Constantino e Maria Yedda Leite Linhares na condição de

\footnotetext{
${ }^{366}$ LAGA, Carl. Respostas às exposições. In: Anais..., op. cit., 1962, p. 209-213.

${ }^{367}$ FALCON, Francisco José Calazans. Últimas intervenções. In: Anais..., op. cit., 1962, p. 213-214.

${ }^{368}$ PANTALEÃO, Olga. Últimas intervenções. In: Anais..., op. cit., 1962, p. 214.

${ }^{369}$ FALCON, Francisco José Calazans. Palestra do prof. Francisco Calazans Falcon. Revista Maracan. Rio de Janeiro, v. 1, n. 1, 1999, p. 119.
} 
relatora $^{370}$. A autora, no primeiro parágrafo, dá o tom de análise e abrangência de seu relatório, uma vez que procura refletir sobre o problema das Faculdades de Filosofia na formação de professores. Porém, aponta que tal questão se relaciona à inserção dessas faculdades na universidade, o que, portanto, insere-as na reforma universitária que, por sua vez, se liga à sociedade, da qual provém e a qual atende ${ }^{371}$.

Maria Yedda Linhares em nenhum momento se refere às disciplinas e matérias que deveriam ou não constar no currículo do curso de História, como o fizeram outros relatores. Além de inserir a problemática do curso de História na realidade social brasileira e, portanto, da reforma universitária necessária, o relatório apresentou propostas de aplicação imediata elaboradas em conjunto com Amélia Americano de Castro, Guy de Hollanda e Altiva Pilatti Balhana, livre-docente de História da América da FFCL/UPR: encaminhar ao ministério da educação os resultados do Simpósio e um apelo para que a reforma universitária seja acelerada; enviar aplausos aos idealizadores da Universidade de Brasília, dentre eles Darcy Ribeiro, com o qual atuou ${ }^{372}$ e da Universidade do Ceará, Walnir Chagas, por sua contribuição ao ensino superior brasileiro; propor que os departamentos de História das Faculdades de Filosofia revejam seus currículos com o fito de que sejam mais eficientes na formação do professor de nível médio, por meio de cursos introdutórios nas diferentes ciências sociais, cursos gerais de história, disciplinas de caráter regional e um melhor entrosamento entre didática e as disciplinas básicas; revogar a lei que permite a outros licenciados lecionarem História no ensino secundário, excetuando-se regiões onde exista carência dos mesmos, com a condição de ser aplicada uma prova de suficiência; fundação de colégios de aplicação, devendo funcionar como centros de experiências e pesquisas pedagógicas, integrados às faculdades e capazes de influenciar o ensino secundário ${ }^{373}$; didática especial deve ser ministrada por licenciado em história ${ }^{374}$ e devem fazer parte de seu programa a análise de programas, compêndios

\footnotetext{
${ }^{370}$ Cf. Equipes. In: Anais..., op. cit., 1962, p. 284.

${ }^{371}$ LINHARES, Maria Yedda Leite. O lugar das disciplinas pedagógicas no curso de História. In: Anais..., op. cit., 1962, p. 159.

${ }^{372}$ Cf. LIBLIK, Carmen Silvia da Fonseca Kummer. Trajetória de Maria Yedda Linhares: notas sobre a construção de um devir. História da Historiografia. Ouro Preto, n. 22, 2016, p. 121.

373 A conclusão 19 dispõe sobre o colégio de aplicação exatamente nesses termos. Cf. Conclusões. In: Anais..., op. cit., 1962, p. 303.

${ }^{374}$ A conclusão 18 especifica o perfil do professor de didática especial: "[...] deve ser recrutado entre os licenciados de História, ouvido o departamento de História a respeito de sua habilitação na matéria; deve ter habilitação pedagógica e espirito de pesquisa para campo da metodologia de ensino; deve lecionar no Colégio de Aplicação, para desenvolver sua experiência no campo do ensino; deve reger Didática Especial de apenas uma disciplina”. Conclusões. In: Anais..., op. cit., 1962, p. 302-303.
} 
e meios audiovisuais ${ }^{375}$; expõe os requisitos mínimos para a formação do professor de ensino médio; as Faculdades de Filosofia devem organizar periodicamente cursos de aperfeiçoamento para os professores do ensino secundário ${ }^{376}$; que as Faculdades de Filosofia editem textos para o ensino secundário ${ }^{377}$.

Podemos perceber que a preocupação primeira das propostas é com a formação do professor de História para o então ensino secundário, mesmo tendo apontado em seu relatório que o projeto visionário da FFCL/USP como integrador entre ensino e pesquisa, infelizmente, tenha malogrado, silenciando quanto à formação do pesquisador. Tal postura expressa a cultura acadêmica de seu lugar de fala, qual seja, o curso de História da FNFi/UB. Em mencionada entrevista à Marieta Ferreira, Linhares demarca a tendência de seu curso à formação de professores em contraponto com seus colegas de São Paulo, dentre eles Alice Canabrava:

Era muito comum eu e meu marido pegarmos um avião na quinta-feira e irmos até lá. Encontrávamos com Novais, Alice Canabrava, Octávio Ianni, Fernando Henrique Cardoso, tomávamos um chope ou jantávamos, e no dia seguinte eu ia às livrarias. Era muito importante esse convívio, fazia parte da nossa prática. Vivíamos sonhando em pesquisar como eles. Agora, uma coisa que desenvolvemos muito mais do que eles foi o curso de formação de professores. Essa foi realmente a nossa grande contribuição ${ }^{378}$.

Ademais, boa parte do que ela e seus colegas propuseram para "aplicação imediata" obteve representatividade através das moções aprovadas e das conclusões finais do Simpósio, exceto à que propunha enviar aos órgãos governamentais as conclusões do Simpósio, o pedido para que se acelere a reforma universitária e o voto de congratulações aos idealizadores da Universidade de Brasília e da reforma da Universidade do Ceará. Sua postura pode ser compreendida a partir de sua trajetória intelectual engajada, no projeto de concepção da Universidade de Brasília e diretora da Rádio MEC. Yedda Linhares logrou a cátedra de História Moderna e Contemporânea em 1955, sucedendo à Carlos Delgado de Carvalho por convite do mesmo. Poderíamos, em um primeiro momento, acreditar que essa historiadora, ao contrário da trajetória de suas colegas

\footnotetext{
375 É exatamente o que dispõe a conclusão 20. Cf. Conclusões. In: Anais..., op. cit., 1962, p. 303.

${ }^{376}$ A conclusão 28 dispõe sobre os cursos de férias dos professores secundários ofertados pelas Faculdades de Filosofia, com o fito de que sejam mais longos e intensivos que os atuais. Cf. Conclusões. In: Anais..., op. cit., 1962, p. 304.

${ }^{377}$ LINHARES, op. cit., 1962, p. 177-178.

${ }^{378}$ LINHARES, op. cit., 2013, p. 230.
} 
analisadas em nosso primeiro capítulo, não enfrentou barreiras de gênero ao alçar o posto máximo na incipiente vida acadêmico-universitária brasileira. Tal crença é suspensa quando tomamos conhecimento de que o sucessor de Delgado de Carvalho seria Antero Manhães. Porém, esse faleceu subitamente 379 .

O tema VII, "reestruturação do currículo", cuja relatoria coube à Olga Pantaleão, foi o centro do Simpósio e o que causou os mais acerbos debates. Sua equipe era formada pelos relatores de todos os outros temas, ou seja, por Eurípedes Simões de Paula, Eduardo D’Oliveira França, Carl Laga, Eremildo Luiz Vianna, Maria Yedda Linhares e Alice Canabrava, somados aos membros da secretaria do evento, ou seja, Maria Clara Constantino e Maria Conceição Vicente de Carvalho. Olga Pantaleão inicia seu relatório esclarecendo que os membros da equipe se reuniram uma vez em São Paulo para tratar do tema, exceto Maria Yedda Linhares que não pôde comparecer. A ausência de Linhares também se fez notar no relatório, uma vez que, por consenso dos presentes, o tema da reforma universitária não seria tratado.

$\mathrm{Na}$ reunião discutiram-se problemas referentes ao aspecto legal a considerar-se numa reestruturação do currículo, e concordou-se em que não competia a nós, neste Simpósio, discutir uma reforma geral da Universidade ou das Faculdades de Filosofia, cabendo-nos procurar estabelecer um currículo para o curso de História, de modo a aproveitar pelo menos as bases dessa reforma em qualquer estrutura universitária que se venha a $\operatorname{adotar}^{380}$.

Pantaleão menciona que a equipe abordou o tema da pós-graduação e que a mesma ficou encarregada de tratar do problema. Em seguida esclarece que a equipe não se manifestou quanto ao conteúdo específico do currículo, sendo que apenas Eurípedes Simões de Paula demarcou sua preferência de que as matérias complementares se concentrassem no primeiro ano do curso $^{381}$. Esse é o primeiro relatório em que o autor explicita que não houve a participação de membros da equipe em seu conteúdo principal. Pantaleão esclarece que a reestruturação do currículo é um primeiro passo para o equacionamento de uma série de outros problemas que ela não ignora, como o sistema de cátedras, o da formação de docentes para o ensino superior, de bibliotecas especializadas, de acesso à documentação etc. Mas que esse constitui-se em um primeiro passo para se pensar o ensino de história.

\footnotetext{
${ }^{379}$ Cf. LIBLIK, op. cit., 2016, p. 124-125.

${ }^{380}$ PANTALEÃO, Olga. Reestruturação do currículo. In: Anais..., op. cit., 1962, p. 219.

${ }^{381}$ Idem, p. 219-220.
} 
Pantaleão expõe suas preocupações com o curso de História na estrutura institucional pensada para a UnB, discorre sobre a dicotomia entre formação de professores/formação de pesquisadores e adentra na estrutura curricular. Advoga a favor do curso em quatro anos, onde nos três primeiros o aluno teria a formação básica e no quarto ano cursaria disciplinas optativas e apresentaria um trabalho orientado por algum professor de cadeira específica, ao contrário do que ocorria, onde o último ano geralmente era dedicado somente à didática. Quanto ao número de matérias, sugere que cada série (com duração de um ano) tenha no máximo seis matérias, uma vez que é necessário tempo de estudo e de reflexão do aluno ${ }^{382}$. A não ser que se adote o sistema por semestres, podendo incluir assim mais matérias. Quanto às matérias que comporiam o currículo, Pantaleão divide o mesmo em: grupo de matérias fundamentais, de história propriamente dito; grupo de matérias sobre aspectos especiais da história e um grupo de matérias auxiliares e complementares. E assim como os relatores dos demais temas, sua preocupação é apontar quais disciplinas deveriam compor o currículo do curso de História $^{383}$.

Durante as intervenções, alguns discordaram de pontos específicos, como Cecília Westphalen ${ }^{384}$, outros propuseram seu próprio currículo, como Guy de Hollanda ${ }^{385}$, e outros ainda rejeitaram por completo o currículo apresentado pela relatora, caso de Eremildo Luiz Vianna que "[...] preferiu ficar com o seu currículo que tem somente quatro

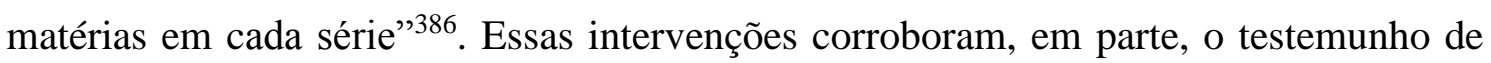
Falcon de que os debates durante as mesas redondas se consubstanciaram em verdadeiras batalhas entre os relatores e os participantes ${ }^{387}$. Alice, em sua intervenção, propõe que se adote o esquema da Faculdade de Medicina da USP de Ribeirão Preto/SP, coordenando cadeiras e disciplinas. Propugna que as cadeiras sejam divididas em disciplinas, onde em torno de cada professor haveriam assistentes que ministrariam as mesmas.

Nessa linha de orientação, poder-se-ia por na cadeira de História Moderna, como disciplinas, a Paleografia e a História Ibérica ou na

\footnotetext{
${ }^{382}$ Uma moção proposta por Francisco Falcon, Guy de Hollanda, Eremildo Vianna etc, excetuando-se Alice Canabrava e Olga Pantaleão, recomendou ao ministro de educação e cultura que tomasse providências para que o curso de História não apresentasse mais de 05 cadeiras ou disciplinas por série. Cf. Moção 17. In: Anais..., op. cit., 1962, p. 296-297.

383 PANTALEÃO, op. cit., 1962.

${ }^{384}$ WESTPHALEN, Cecília Maria. Exposições de simposistas. In: Anais..., op. cit., 1962, p. 249-250.

${ }^{385}$ HOLLANDA, Guy. Exposições de simposistas. In: Anais..., op. cit., 1962, p. 250-254.

${ }^{386}$ VIANNA, Eremildo Luiz. Exposições de simposistas. In: Anais..., op. cit., 1962, p. 266.

${ }^{387}$ FALCON, op. cit., 1963.
} 
cadeira de História Antiga, a Arqueologia, resolvendo assim problemas de currículo. Sobrariam, com essa organização, claros que poderiam ser preenchidos com uma cadeira de Economia, por exemplo. Dado o desenvolvimento em todos os ramos da História da parte correspondente à História Econômica, não se pode fazer a História Moderna e Contemporânea sem conhecimento da Economia. O professor de Economia poderia encarregar um assistente de dar Estatística, pois ao professor de História Moderna e Contemporânea são indispensáveis as técnicas de medir ${ }^{388}$.

Aqui podemos perceber uma concepção de história que se liga às ciências sociais, especificamente à economia e à mobilização dos métodos quantitativos, como em sua intervenção durante os debates em torno do tema IV, quando questionou se economia política e estatística eram consideradas matérias complementares pelo relator.

Para Alice Canabrava, história da arte deve ser ministrada em um ano ${ }^{389}$, ao passo que história moderna e contemporânea, história do Brasil e história da América em dois. Discorda de Eduardo D’Oliveira França, no sentido de que história da América deve ser ministrada em apenas um ano ${ }^{390}$, lembrando que o ano letivo no Brasil possui menos de doze meses, o que não seria suficiente para o ensino da matéria. Por fim, questiona por que a relatora propõe uma cadeira de Introdução aos Estudos Históricos no primeiro ano e uma de Teoria da História no terceiro, uma vez que tomando por base quatro autores não mencionados - que tratam de questões afeitas à método e introdução aos estudos históricos, essas não se alteraram ao longo dos últimos quarenta anos, podendo esses assuntos serem tratados em uma única cadeira. A posição de Alice, somada à de outros colegas, estabeleceu como recomendação às Faculdades de Filosofia o ensino obrigatório de introdução metodológica à história no primeiro ano e de teorias da história, incluindo história da historiografia, em uma única cadeira ${ }^{391}$. Essa preocupação com a formação/reflexão teórico-metodológica pode ser tomada como resultado da progressiva autonomização do campo historiográfico desde a separação dos cursos de Geografia e História em 1956 e como um esforço na busca pela profissionalização do ofício. Nesse mesmo ano, Jean Glénisson inaugurou a cadeira de Introdução aos Estudos Históricos da FFCL/USP, na qual permaneceu por dois anos e produziu o livro Iniciação aos Estudos

\footnotetext{
${ }^{388}$ CANABRAVA, Alice Piffer. Exposições de simposistas. In: Anais..., op. cit., 1962, p. 268.

${ }^{389}$ Uma das conclusões do Simpósio foi exatamente que se incluísse história da arte no currículo do curso. Cf. Conclusão 17. In: Anais..., op. cit., 1962, p. 302.

${ }^{390}$ FRANÇA, Eduardo D’Oliveira. Exposições de simposistas. In: Anais..., op. cit., 1962, p. 264-265.

${ }^{391}$ Cf. Moção 22. In: Anais..., op. cit., 1962, p. 298-299.
} 
Históricos baseado em suas aulas, publicado em 1961 e traduzido por Pedro Moacyr Campos $^{392}$.

Diante do exposto em relação aos debates afeitos ao principal tema desse Simpósio, a reestruturação curricular, não se chegou à um consenso quanto ao currículo ideal para o curso de História ${ }^{393}$. Apenas que os cursos de História das Faculdades de Filosofia não obedecessem à um currículo uniforme, mas sim que cada departamento pudesse pensar seu próprio currículo de acordo com suas condições institucionais, financeiras e regionais ${ }^{394}$.

Porém, como rememorado por Francisco Falcon e por Alice Canabrava, nessa eventualidade e diante do malogro do objetivo principal do evento fundou-se a APUH a partir da aprovação da moção de José Roberto do Amaral Lapa. Ao mesmo tempo em que propõe a criação de uma entidade que congregue todos os professores de História do ensino superior, também apresenta, de modo ainda incipiente, seus objetivos.

Considerando o isolamento em que trabalham os professores universitários de História, uns em relação aos outros. Considerando a importância que, em nossos dias, assume o diálogo para o cientista. Considerando o êxito que, no gênero, tem logrado outras iniciativas, submeto à apreciação dessa mesa redonda a proposta de criação de uma entidade que possa congregar os professores universitários de História ${ }^{395}$.

Os objetivos da entidade são, então, o de pôr em contato os professores universitários de história espalhados pelo país, favorecendo a importância que assumia, naquele momento, o diálogo com os pares. A moção traz ainda um importante dado para reflexão: outras iniciativas como essa já foram tomadas em outras áreas do conhecimento. Os historiadores universitários, portanto, estariam "atrasados" em relação ao mundo científico associativo.

\footnotetext{
${ }^{392}$ GLÉNISSON, Jean. Iniciação aos Estudos Históricos. 6a edição. Rio de Janeiro: Bertrand Brasil, 1991. O livro conta com um balanço da historiografia brasileira: CAMPOS, Pedro Moacyr. Esboço da historiografia brasileira nos séculos XIX e XX. In: GLÉNISSON, op. cit., 1991, p. 250-293.

${ }^{393}$ Além dos relatórios temáticos apresentados, esse Simpósio contou com uma conferência de abertura proferida por Pedro Calmon. CALMON, Pedro. História do Brasil, programa de cultura, consciência e patriotismo. In: Anais..., op. cit., 1962, p. 35-47. E duas outras conferências: MOLLAT, Michel. Pour étude équilibrée d'histoire, recherche et enseignement. In: Anais..., op. cit., 1962, p. 49-61. REIS, Arthur Cezar Ferreira. As regiões brasileiras: formação, peculiaridades e integração no nosso processo histórico. In: Anais..., op. cit., 1962, p. 63-75.

${ }^{394}$ Cf. Moção 24. In: Anais..., op. cit., 1962, p. 300. Cf. Conclusões 03 e 04. In: Anais..., op. cit., 1962, p. 301.

${ }^{395}$ LAPA, José Roberto do Amaral. Moção 1. In: Anais..., op. cit., 1962, p. 287-288.
} 


\subsection{Batalhando pela consolidação do campo}

Em âmbito nacional podemos destacar três entidades associativas cuja fundação remonta-se aos anos 1930-1940 ${ }^{396}$ : a Sociedade Brasileira para o progresso da Ciência (SBPC), a Sociedade de Estudos Históricos (SEH) e a Associação dos Geógrafos Brasileiros $(\mathrm{AGB})^{397}$. A SEH, refundada em 1950, uma vez que passou por efêmera existência em 1942, com o nome originário de "Sociedade Paulista de Estudos Históricos", em uma das salas da FFCL/USP em reunião ocorrida em 06 de outubro de 1950 com os objetivos de pesquisar, estudar e divulgar assuntos de interesse histórico, principalmente brasileiros, congregava professores, alunos e ex-alunos da FFCL/USP, inclusive Alice Canabrava ${ }^{398}$. A segunda, fundada na casa de Pierre Deffontaines em 1934, juntamente com Caio Prado Júnior, Rubens Borba de Moraes e Luís Flores de Moraes $\mathrm{Rego}^{399}$, congregava também profissionais provenientes da geologia, que atuavam em órgãos como o IBGE e o Conselho Nacional de Geografia (CNG), sendo que a participação de alunos da FFCL/USP também era estimulada. Alice participava da entidade desde 1936, quando estava em seu segundo ano de graduação ${ }^{400}$, apresentou trabalho em uma Assembleia Geral da entidade ${ }^{401}$ e proferiu conferência sobre "A lavoura algodoeira de S. Paulo no século XIX”, apresentada em reunião cultural da AGB, conforme nota da entidade na seção "Movimentos associativos" de O Estado de S. Paulo $^{402}$.

\footnotetext{
${ }^{396}$ Para um estudo detalhado de uma das primeiras associações a congregar historiadores profissionais, a American Historical Association (1884), e sua busca por delimitar a objetividade enquanto principal característica epistemológica, ver: NOVICK, Peter. That noble dream. The "objectivity question" and the American Historical Profession. New York: Cambridge University Press, 1988.

${ }^{397}$ Sobre a AGB, ver: ANTUNES, Charlles da França. A Associação dos Geógrafos Brasileiros (AGB) origens, ideias e transformações: notas de uma história. 2008. 311 f. Tese. (Programa de pós-graduação em Geografia) - IG/UFF, Niterói, 2008.

${ }^{398}$ MATOS, Odilon Nogueira de. Sociedade de Estudos Históricos. In: Noticiário. Revista de História. São Paulo, n. 6, 1951a, p. 467-468. Sua primeira diretoria foi formada por Eurípedes Simões de Paula (presidente), Odilon Nogueira de Matos (tesoureiro) e Aldo Janotti (secretário). Conselho Consultivo: Astrogildo Rodrigues de Mello, Eduardo D’Oliveira França e João Cruz Costa. Todos professores da FFCL/SP.

${ }^{399}$ CUSTÓDIO, Vanderli. Fundamentos teórico-metodológicos do ensino e da pesquisa em Geografia: textos selecionados das primeiras publicações da Associação dos Geógrafos Brasileiros (AGB) GEOGRAFIA (1935-1936) e BOLETIM DA AGB (1941-1944). São Paulo: AGB, 2012, p. 2.

${ }^{400}$ Cf. Processo 46.1.126.8.7 (Arquivo da FFLCH da USP: inscrição no concurso para a Cadeira de História da Civilização Americana, 1946). Memorial, p. 2.

${ }^{401}$ CANABRAVA, Alice Piffer. As Chácaras paulistanas (primeiros estudos). In: CANABRAVA, op. cit., 2005, p. 233-242.

${ }^{402}$ Associação dos Geógrafos Brasileiros. O Estado de S. Paulo, 09/12/1949, p. 5.
} 
A SEH pode ser compreendida como um empreendimento eminentemente paulista e praticamente restrito ao âmbito da FFCL/USP e não exclusiva para historiadores, conforme constatamos em seus estatutos ${ }^{403}$. Em 1961 contava com 84 sócios $^{404}$, enquanto o I Simpósio da APUH congregou 81 professores universitários, dos 141 inscritos, provenientes dos Estados de São Paulo (40 comparecimentos), Minas Gerais (10), Paraná (10), Guanabara (9), Rio Grande do Sul (5), Rio de Janeiro (3), Pernambuco (2), Bahia (2), Rio Grande do Norte (2), Santa Catarina (1) e Goiás (1) ${ }^{405}$, que se conformaram nos primeiros núcleos regionais da entidade, conforme estabelecido por seus primeiros estatutos registrados em São Paulo em 07 de junho de $1962^{406}$. Portanto, a APUH nasce representada pela participação de membros provenientes de 11 Estados brasileiros.

Esses 81 participantes e sócios-fundadores da APUH elegeram sua primeira diretoria: Eremildo Luiz Vianna (presidente); Cecília Maria Westphalen (vicepresidente); Sérgio Buarque de Holanda (secretário geral); Alice Piffer Canabrava (primeira secretária); Jorge Calmon (segundo secretário) Antonio Camilo de Faria Alvim (primeiro tesoureiro); Armando Souto Maior (segundo tesoureiro); e José Roberto do Amaral Lapa (diretor de publicações) ${ }^{407}$. Após a eleição, Cecília Westphalen encampou proposta para que o próximo Simpósio fosse realizado em sua Faculdade por ocasião das comemorações de seus 50 anos de fundação.

Apesar de Sérgio Buarque ter sido eleito secretário geral da recém-criada entidade, Alice foi a secretária geral do II Simpósio dos Professores Universitários de História, realizado na FF/UPR em Curitiba/PR entre 27 de outubro e 31 de outubro de 1962, com a temática geral, escolhida pela diretoria, "A propriedade e o uso da terra", propondo a abordagem das seguintes temáticas específicas: modalidades de posse; formas de exploração - indústria extrativa, lavoura e pecuária; técnicas de utilização e estruturas agrárias $^{408}$.

\footnotetext{
${ }^{403}$ Estatutos da Sociedade de Estudos Históricos. In: Noticiário. Revista de História. São Paulo, n. 5, 1951, p. 228-229.

${ }^{404}$ RODRIGUES, Maria Regina da Cunha. Atividades da Sociedade de Estudos Históricos em 1961. In: Noticiário. Revista de História. São Paulo, n. 49, 1962, p. 282.

${ }^{405}$ Cf. Anais..., op. cit., 1962, p. 23-26.

${ }^{406}$ Cf. Estatutos da Associação dos Professores Universitários de História. In: Noticiário. Revista de História. São Paulo, n. 50, 1962, p. 568-572.

${ }^{407}$ Idem, p. 9.

${ }^{408}$ Cf. SIMPÓSIO DE PROFESSÔRES UNIVERSITÁRIOS DE HISTÓRIA - APUH, II, 1962, Curitiba. Anais...Curitiba: UFPR, 1962a, p. 18.
} 
Esse Simpósio foi organizado por meio de sessões científicas para apresentação de trabalhos e de sessões plenárias para deliberação de decisões concernentes aos rumos da associação, como eleição de sua diretoria e escolha da sede e temática do Simpósio seguinte. Porém, a preocupação com o ensino de história, temática central do I Simpósio, é uma constante ao longo dos Simpósios seguintes, principalmente através de suas moções e conclusões. Exemplo dessa postura encontramos na moção 2, que tendo em perspectiva a autonomia concedida às Faculdades de Filosofia para decidirem quanto à seu currículo e que o ministério da educação e cultura preparava um currículo mínimo com excesso de disciplinas, o que feria a concedida autonomia, o II Simpósio sugeriu a adoção do seguinte currículo mínimo, ficando à cargo de cada Faculdade de Filosofia complementá-lo de acordo com suas necessidades e escolhas: Introdução aos Estudos Históricos; História Antiga; História Medieval; História Moderna e Contemporânea; História do Brasil e História da América ${ }^{409}$.

As comunicações apresentadas nas cinco sessões científicas, excetuando-se uma, tocaram direta e/ou indiretamente no problema contemporâneo da reforma agrária ${ }^{410}$. Assim, tomados em conjunto, esses dois primeiros Simpósios da APUH apresentam uma preocupação com o contemporâneo, com o que hoje denominaríamos tempo presente. Em seu discurso de abertura do II Simpósio, Cecília Westphalen aponta a preocupação das elites dirigentes com o desenvolvimento econômico brasileiro por meio das reformas de base e propõe uma função social para o historiador naquele momento. Para ela, essas elites

[...] não tem porém lembrado que nenhuma conjuntura pode ser tratada isolada do seu contexto estrutural, e a História que acompanha e analisa os processos de longa duração, pode fornecer elementos indispensáveis à compreensão dos acontecimentos presentes e até mesmo apontar soluções concretas ${ }^{411}$.

Aqui temos uma proposta de função social do historiador bastante arrojada para o contexto brasileiro. Em um momento em que a prática historiadora em moldes universitários ainda não está consolidada, o historiador poderia trabalhar em prol do

\footnotetext{
${ }^{409}$ Cf. Moção 2. In: Anais..., op. cit., 1962a, p. 25-26.

${ }^{410}$ A única comunicação que não aborda o tema da reforma agrária é: RIBEIRO, Emília Thereza Alves. Problemas jurídico-sociais do Estado muçulmano, para o cultivo do Iraq, nos primeiros séculos do Islã. In: Anais..., op. cit., 1962a, p. 111-124.

${ }^{411}$ WESTPHALEN, Cecília Maria. Discurso de instalação do II Simpósio. In: Anais..., op. cit., 1962a, p. 22.
} 
desenvolvimento econômico. Porém, para tanto, esse historiador deve estar informado por uma história estrutural que privilegie os processos de longa duração. Uma possibilidade de inteligibilidade para os discursos e pronunciamentos é interrogá-los a partir de suas condições de possibilidade e de seu lugar de enunciação ${ }^{412}$. Cecília Westphalen, catedrática de História Moderna e Contemporânea, retornou em 1959 da VI seção da Escola Prática de Altos Estudos (EPHE), onde tomou contato com a epistemologia histórica braudeliana, e em conjunto com Brasil Pinheiro Machado, catedrático de História do Brasil e Altiva Pilatti Balhana, organizaram um projeto de pesquisa articulado à compreensão da história no rol das ciências sociais, com a incorporação da história quantitativa a la Annales, com foco nos estudos sobre imigração, estruturas agrárias e relações comerciais, em uma história rigorosamente "científica" 413.

Essa noção do papel social do historiador não deve ser compreendida como um engajamento, mas sim como uma expertise de natureza técnica a partir de um conhecimento cientificamente orientado. Naquele momento, pensar o ofício de historiador para além da universidade constitui-se em pioneirismo - com exceção dos EUA, onde historiadores econômicos e sociais trabalharam no New Deal e nos think tanks - ou talvez em utopia, uma vez que no contexto europeu o historiador não havia surgido como expert, exceção do caso Dreyfus na França. Ou seja, mobilizado seu saber nos tribunais, como no caso francês para iluminar questões relacionadas à resistência ou no caso canadense para reiterar ou obliterar direitos indígenas obtidos em tratados com os colonizadores. Ou ainda, por meio da atuação em empresas de consultoria para o setor público ou privado, caso da public history estadunidense ou da engenharia histórica francesa, em menor escala. Essas novas práticas historiadoras contemporâneas, principalmente a partir dos anos 1970 nos EUA e 1980 na França, fornecem subsídios para se refletir acerca de uma identidade historiadora para além de uma comunidade

\footnotetext{
${ }^{412}$ Cf. ALBUQUERQUE JÚNIOR, Durval Muniz de. A dimensão retórica da historiografia. In: LUCA, Tania Regina de; PINSKY, Carla Bassanezi (orgas.). O historiador e suas fontes. São Paulo: Contexto, 2009, p. 223-249.

${ }^{413}$ Cf. MACHADO, op. cit., 2016, p. 58. Ver também: MACHADO, Daiane Vaiz. Modo de ser historiadora: Cecília Westphalen no campo historiográfico brasileiro da segunda metade do século XX. História da historiografia. Ouro Preto, n. 22, p. 134-151, 2016a.
} 
restrita aos muros da universidade, o que também, consequentemente, significa refletir sobre uma epistemologia própria ${ }^{414}$.

Os primeiros estatutos da APUH interditam qualquer possibilidade de manifestação da associação em assuntos políticos e/ou religiosos ${ }^{415}$. Para que o historiador pudesse colaborar na empreitada do desenvolvimento econômico, reservado à tecnocracia representada principalmente por economistas e engenheiros ${ }^{416}$, uma condição sine qua non seria a de superar uma postura histórica simplesmente erudita e diletante $^{417}$ e firmar as bases de uma história científica. Esse é um dos objetivos da nova associação que deve ser o farol a orientar o barco da história. "Reunindo profissionais da História, em grau universitário, por certo ela irá orientar os estudos históricos, em nosso meio, com a seriedade e o nível compatíveis com o verdadeiro espírito científico que deve animar as Universidades brasileiras" ${ }^{418}$. Objetivo ambicioso para uma associação com apenas um ano de existência. A juventude da entidade será escamoteada pelo recurso ao evento fundador, qual seja, o Simpósio de Marília e à invenção de uma tradição ${ }^{419}$.

A instalação do II Simpósio dos Professores Universitários de História significa estar consolidada a Associação dos Professores Universitários de História que surgiu, sem dúvida, graças à iniciativa pioneira dos professores da Faculdade de Filosofia, Ciências e Letras de Marília ${ }^{420}$.

Logo após a realização desse II Simpósio, Alice escreve para Francisco Iglésias ${ }^{421}$ informando sobre o envio de cópia dos estatutos com as emendas aprovadas em assembleia aos diretores de núcleos regionais. Em seguida, despede-se afirmando que "[...] Considero entre os mais suaves dos meus encargos, como secretária da A.P.U.H., escrever a você, conselheiro consultivo, consagrado por aclamação em plenário, durante o II Simpósio" ${ }^{222}$. Aqui, a despeito de Sérgio Buarque ter sido eleito secretário geral da

\footnotetext{
${ }^{414}$ Cf. DUMOULIN, Olivier. Hoje: a encomenda e a expertise, em nome do interesse geral, em nome dos interesses particulares. In: Autêntica, 2017, p. 25-138.

${ }^{415}$ Cf. Estatutos..., op. cit., 1962, p. 568.

${ }^{416}$ Ver: GOMES, Angela de Castro (coord.). Engenheiros e economistas: novas elites burocráticas. Rio de Janeiro: FGV, 1994.

${ }^{417}$ WESTPHALEN, op. cit., 1962a, p. 22.

${ }^{418}$ Ibidem.

${ }^{419}$ Nossa inspiração aqui provém de: HOBSBAWN, Eric; RANGER, Terence. A invenção das tradições. Rio de Janeiro: Paz e Terra, 1984.

${ }^{420}$ WESTPHALEN, op. cit., 1962a, p. 22.

${ }^{421}$ Para um texto de homenagem, ver: PAULA, João Antonio de. Francisco Iglésias, um historiador para o nosso tempo. In: SAES; RIBEIRO; SAES, op. cit., 2017, p. 263-284.

${ }^{422}$ São Paulo, 13 de novembro de 1962. Acervo Francisco Iglésias. Instituto Moreira Salles (IMS) do Rio de Janeiro. FI-C-CP (068).
} 
associação, Alice figura como tal. Como observado por Karla Bessa, se tomarmos os Anais dos vários Simpósios da APUH/ANPUH, no organograma da associação Canabrava figura como primeira secretária durante os primeiros dez anos de vida da entidade, passando à secretária geral, formalmente, somente a partir de $1973^{423}$. De 1961 até 1969 a secretaria geral da associação coube à Sérgio Buarque de Holanda. Porém, como estabeleciam os primeiros estatutos em seu título III que rege a administração da associação, todo o despacho do expediente ${ }^{424}$ cabia aos secretários. Nesse sentido, mesmo que todo o despacho tenha sido realizado pela historiadora durante esses 8 anos em que Sérgio foi secretário geral da entidade, não violava a norma estatutária.

A vida doméstica das historiadoras possui suas singularidades e deve também ser considerada como aspecto importante do exercício do ofício. No geral, são mulheres solteiras, como Alice e que desenvolvem enquanto tática ${ }^{425}$ pessoal e profissional, compartilhar moradia com outras colegas de ofício, com irmãs e/ou mães. Nessa relação afetiva, muitas mulheres contam com a ajuda de suas companheiras, mães e/ou irmãs na operação de seus trabalhos, como revisão, edição, levantamento de fontes etc ${ }^{426}$. A historiadora, a partir de certo momento de sua vida, morava com sua irmã Clementina Canabrava, professora na Cultura Inglesa de São Paulo e seu mordomo, Guilherme Alhberg. Esse último foi contratado pelas irmãs para que ambas pudessem se dedicar à sua profissão. Não há indícios de que a irmã de Alice a tenha auxiliado em trabalhos de pesquisa, uma vez que a historiadora, como vimos, contava, a partir de seu ingresso na FCEA/USP com assistentes de pesquisa. Porém, um indício aponta para o desejo de que Clementina pudesse auxiliá-la em seus trabalhos de cópia de fontes. Em carta de 01 de dezembro de 1977, Clementina afirma que seu chefe sugeriu que se aposente. Se assim o fizer, Alice teria nela uma voluntária para o "[...] copeia [sic] Tina, copeia [sic]"427.

Como veremos, Sérgio Buarque considerava Alice como um de seus pares, dedicando-a artigos e colocando-a como figura de proa na historiografia brasileira, uma

\footnotetext{
${ }^{423}$ Cf. BESSA, Karla Adriana Martins. Três nomes, três caminhos: José Honório Rodrigues, Eurípedes Simões de Paula, Alice P. Canabrava e a historiografia brasileira no século XX. História \& Perspectivas. Uberlândia, n. 27/28, 2002/2003, p. 94-95.

${ }^{424}$ Cf. Estatutos..., op. cit., 1962, p. 569.

${ }^{425}$ Cf. CERTEAU, op. cit., 2014.

${ }^{426}$ Cf. SMITH, Bonnie. Mulheres profissionais: um terceiro sexo? In: SMITH, op. cit.,, 2003, p. 387-441.

${ }^{427}$ APC-CANA-003. Fundo Alice Piffer Canabrava. Arquivo IEB/USP.
} 
vez que a mesma foi encarregada de abrir os debates do setor de História do Encontro Internacional de Estudos Brasileiros. I Seminário de Estudos Brasileiros ${ }^{428}$.

No IV Simpósio realizado em Porto Alegre em 1967, os diretores de cada núcleo regional presidiram as sessões de estudos ${ }^{429}$. Alice Canabrava, na condição de primeira secretária, estabelecia correspondência com esses diretores, o que nos permite dar corpo a esta rede de sociabilidade urdida durante seu secretariado. Os seguintes diretores de núcleos regionais presidiram sessões de estudo durante esse IV Simpósio: Dante de Laytano (FFCL/UFRS), Walter Piazza (FFCL/UFSC), Cecília Maria Westphalen (FFCL/UFPR), Eduardo D’Oliveira França (FFCL/USP), Amaro Xisto de Queiroz (FF/UFMG), Luiz Cesar Bittencourt Silva (FFCL/UFF), Alvamar Furtado de Mendonça (FFCL/UFRN) e Maria Yedda Leite Linhares (FFCL/UFRJ ${ }^{430}$. O número de trabalhos apresentados não permitiu que os diretores dos onze núcleos presidissem mesas. Infelizmente, não há correspondência entre Alice e esses diretores de núcleo no Fundo Alice Piffer Canabrava do Arquivo IEB/USP. Porém, ao tomarmos os correspondentes de Alice presentes no subgrupo "relações sociais" do quadro de arranjo do referido fundo e cotejarmos com os participantes dos núcleos regionais estabelecidos por ocasião do que se tornou o I Simpósio, podemos ampliar essa rede.

Em relação ao núcleo de MG, além da correspondência com Francisco Iglésias, Alice também estabeleceu relações com Norma de Góes Monteiro, auxiliar de ensino da cadeira de História do Brasil da FFCL/UMG ${ }^{431}$, presente no I Simpósio. Nenhuma das cartas que restaram dessa relação tratam de assuntos concernentes à APUH/ANPUH ${ }^{432}$. Porém, ao tratar de assuntos privados, como a queda de Canabrava em asfalto molhado, tal fato indica que, para além de um espaço de sociabilidade marcado pelo profissionalismo, o convívio em torno da APUH/ANPUH também forjou relações de afeto, característica, como apontado por Sirinelli, de toda microssociedade ${ }^{433}$. Outro

\footnotetext{
${ }^{428}$ Cf. CANABRAVA, op. cit., 1971.

${ }^{429}$ Cf. PAULA, Maria Regina da Cunha Rodrigues Simões de. O IV Simpósio Nacional dos Professores Universitários de História. In: SIMPÓSIO DE PROFESSORES UNIVERSITÁRIOS DE HISTÓRIA APUH, IV, 1967, Porto Alegre. V. II. Anais.... São Paulo: FFCL/USP, 1969, p. 15-16.

${ }^{430}$ Cf. Programa do IV Simpósio Nacional dos Professores Universitários de História. In: Anais..., op. cit., 1969, p. 29-34.

${ }^{431}$ Cf. Catálogo dos sócios fundadores. APUH. São Paulo: Secretaria geral, 1962, p. 11. Arquivo da ANPUH.

${ }_{432}$ Cf. APC-MONT-001; APC-MONT-002; APC-MONT-004; APC-MONT-005. Fundo Alice Piffer Canabrava. Arquivo IEB/USP.

${ }^{433}$ Cf. Sirinelli, op. cit., 2003, p. 250.
} 
correspondente do núcleo de MG foi Daniel Valle Ribeiro, catedrático de História Antiga e Medieval da FFCL/UMG ${ }^{434}$. Quanto à correspondência com membros do núcleo da Guanabara, há uma carta enviada à Célia Freire D’Aquino Fonseca, da FFCL/UFRJ e segunda-tesoureira da associação durante a gestão 1967-1969. Nela, Alice afirma que no segundo semestre estará mais tranquila, uma vez que até julho estará repleta de trabalho por conta da organização do XI Simpósio ${ }^{435}$. Outra correspondente do núcleo da Guanabara foi Aidyl Ferreira de Carvalho Preis, assistente da cadeira de História Antiga da FFCL/UFRJ. Em uma dessas cartas Alice tratou dos preparativos para o X Simpósio Nacional da ANPUH realizado em Niterói em 1979, o qual abordaremos mais adiante ${ }^{436}$.

Alice também manteve correspondência com três membros do núcleo da BA: Luís Henrique Dias Tavares, catedrático de História do Brasil da FFCL/UBA; Cid José Teixeira Cavalcanti, catedrático de História da Arte da FFCL/UBA e Kátia Mattoso ${ }^{437}$. Em uma das cartas, Dias Tavares afirma que recebeu das mãos de Jorge Calmon uma carta enviada por ela e que está tomando providências para a reorganização do núcleo da $\mathrm{BA}^{438}$, indício de que também os núcleos regionais apresentavam dificuldades de organização. As duas cartas enviadas a Cid José Teixeira Cavalcante tratam da organização do XII Simpósio na BA, organizado por ele na condição de vice-presidente da associação ${ }^{439}$ e de um artigo que escreveu sobre a ANPUH, a $R B H$ e Alice, que a sensibilizou ${ }^{440}$. As cartas de Kátia Mattoso tratam de sua colaboração junto à revista do IPE/USP sobre história dos preços de escravos ${ }^{441}$, um dos tópicos de interesse de Canabrava, como vimos no primeiro capítulo.

\footnotetext{
${ }^{434}$ Cf. Belo Horizonte, 26 de junho de 1973. APC-RIBE-001. Fundo Alice Piffer Canabrava. Arquivo IEB/USP.

${ }^{435}$ Cf. São Paulo, 22 de abril de 1981. APC-FONS-001. Fundo Alice Piffer Canabrava. Arquivo IEB/USP. ${ }^{436}$ Cf. APC-PREI-002; APC-PREI-003; APC-PREI-005. Fundo Alice Piffer Canabrava. Arquivo IEB/USP.

${ }^{437}$ Sobre a trajetória intelectual e a produção historiográfica de Kátia Mattoso, ver: REIS, João José; SOUZA, Evergton Sales. Katia Mytilineou de Queirós Mattoso. Afro-Ásia. Salvador, n. 48, p. 363-381, 2013. Katia Mattoso realizou doutorado em Ciência Política na Universidade de Lausanne nos anos 1950. Seu orientador advertiu que, pelo fato de ser mulher, não conseguiria ser professora universitária, o que motivou sua vinda para o Brasil.

${ }^{438}$ Cf. Salvador, 21 de junho de 1974. APC-TAVA-001. Fundo Alice Piffer Canabrava. Arquivo IEB/USP. 439 Cf. São Paulo, 27 de outubro de 1983. APC-CAVA-002. Fundo Alice Piffer Canabrava. Arquivo IEB/USP.

${ }^{440}$ Cf. São Paulo, 16 de abril de 1982. APC-CAVA-001. Fundo Alice Piffer Canabrava. Arquivo IEB/USP. ${ }^{441}$ Cf. APC-MATT-002. APC-MATT-004. APC-MATT-005. APC-MATT-007. Fundo Alice Piffer Canabrava. Arquivo IEB/USP.
} 
Além da correspondência com Dante de Laytano do núcleo do RS, Alice também estabeleceu trocas epistolares com Helga Iracema Landgraf Piccolo, especialista em história do RS da FFCL/URS. As cartas tratam da Revista Brasileira de História $(R B H)$, da participação de Alice no III Colóquio de Estudos Teuto-Brasileiros, ocorrido na UFRS entre 14 e 18 de outubro de 1974, no qual Canabrava apresentou uma conferência sobre a influência da historiografia alemã na historiografia brasileira ${ }^{442}$ e de sua saída da presidência da associação em $1981^{443}$.

Além de Alvamar Furtado de Mendonça, diretor do núcleo regional do RN, Alice também mantinha correspondência com Hélio Dantas, membro do conselho consultivo (1965-1967) e segundo secretário (1970-1971) ${ }^{444}$. Quanto aos demais núcleos existentes, GO e PE, certamente a historiadora manteve correspondência ao menos com os diretores de cada um deles. Porém, não há nenhuma carta em seu fundo com membros desses núcleos. Conforme analisaremos, o processo de arquivar a própria vida implica também em seleções. Canabrava, na condição de secretária da APUH/ANPUH por 18 anos, certamente teria um volume de correspondência concernente à essa entidade muito maior do que a que consta em seu fundo no Arquivo IEB/USP.

Entre seus principais correspondentes, Francisco Iglésias se destaca mais uma vez como aquele com o qual Alice teceu o maior número de considerações acerca da vida associativa dos historiadores acadêmicos brasileiros coadunados em torno da APUH/ANPUH. Em carta de 02 de janeiro de 1963 enviada para Francisco Iglésias na condição de secretária da APUH, a historiadora informa que

Em sessão do Núcleo Regional do Estado de São Paulo, realizada em 30 de Novembro p. p., propôs seu diretor, o Prof. Doutor Simões de Paula, a realização de um trabalho de levantamento das fontes primárias para a História, existentes neste Estado, assunto este que consta do III Simpósio, a ser realizado no mês de Julho em Fortaleza, no Ceará ${ }^{445}$.

Por meio do excerto de correspondência acima tomamos conhecimento de que o III Simpósio da APUH seria realizado no mês de julho na cidade de Fortaleza/CE. Por

\footnotetext{
${ }^{442}$ CANABRAVA, Varnhagen, Martius e Capistrano de Abreu. In: CANABRAVA, op. cit., 2005, p. $245-$ 270.

${ }^{443}$ Cf. APC-PICC-001, APC-PICC-002, APC-PICC-003, APC-PICC-005, APC-PICC-006, APC-PICC007. Fundo Alice Piffer Canabrava. Arquivo IEB/USP.

${ }^{444}$ Natal, 08 de abril de 1970. APC-DANT-001. Fundo Alice Piffer Canabrava. Arquivo IEB/USP. Tratase de convite para ministrar curso de história econômica do Brasil.

${ }^{445}$ São Paulo, 02 de janeiro de 1963. FI-C-CP (070). Acervo Francisco Iglésias. Instituto Moreira Salles (IMS) do Rio de Janeiro.
} 
meio de outra carta, Alice comunica Francisco Iglésias de que o III Simpósio, programado para ocorrer entre 28 de julho e 02 de agosto de 1963 foi adiado para a primeira quinzena de novembro do mesmo ano ${ }^{446}$. Ao tomarmos a série de Anais da APUH/ANPUH constatamos uma descontinuidade nos anos de realização dos Simpósios: dos Anais do II Simpósio realizado em 1962 há um salto para os Anais do III Simpósio realizado somente em 1965. O estranhamento em relação a tal descontinuidade se acentua ao tomarmos ciência de que os estatutos estabeleciam que os Simpósios seriam realizados anualmente $\mathrm{u}^{447}$.

Mas por que tal Simpósio não ocorreu na cidade de Fortaleza em 1963 ?

Os Anais do III Simpósio da APUH realizado em Franca/SP entre 03 e 07 de novembro de 1965 trazem relatório de autoria de Maria Regina da Cunha Rodrigues Simões de Paula, auxiliar de ensino da cadeira de História da Civilização Ibérica da FFCL/USP ${ }^{448}$. Nele, a autora afirma que "Este III Simpósio, por motivos que não valem a pena sejam lembrados, não se realizou na capital cearense como estava programado [...]"449. Não encontramos indícios que nos conduzissem a inferir acerca das motivações que levaram a não realização do III Simpósio conforme programado para Fortaleza em 1963. Vimos que sua data foi alterada do mês de julho para o mês de novembro. Uma hipótese é de que com o crescimento das tensões político-sociais e, finalmente, com o golpe civil-militar de 1964, não se tenham apresentado condições para a realização do Simpósio. Por outro lado, a explicação para a realização do III Simpósio somente no ano de 1965, pode ser encontrada na dificuldade em congregar os professores universitários em torno da incipiente associação.

Como vimos, se a fundação da APUH se deu na ocasião de uma eventualidade, esse III Simpósio nos parece padecer da mesma característica. Eurípedes Simões de Paula ao pronunciar conferência na FFCL de Franca/SP tomou conhecimento de que seria realizada, sob os auspícios de seu departamento de História, uma semana de estudos históricos. Assim, em contato com José F. Carrato, chefe daquele departamento,

\footnotetext{
${ }^{446}$ Cf. São Paulo, 24 de junho de 1963. FI-C-CP (071). Acervo Francisco Iglésias. Instituto Moreira Salles (IMS) do Rio de Janeiro.

${ }^{447}$ Cf. Estatutos..., op. cit., 1962, p. 570.

${ }^{448}$ Cf. PAULA, Maria Regina da Cunha Rodrigues Simões de. Relatório sobre o III Simpósio dos Professores Universitários de História. In: SIMPÓSIO DE PROFESSORES UNIVERSITÁRIOS DE HISTÓRIA - APUH, III, 1965, Franca. Anais.... São Paulo: FFCL/USP, 1967, p. 7-16. Publicado também na "Revista de História".

${ }^{449}$ Cf. PAULA, op. cit., 1967, p. 10.
} 
Eurípedes e Alice Canabrava desdobraram o que seria uma semana de história no III Simpósio da APUH.

[...] a Profa. Alice Piffer Canabrava começou a enviar circulares a todos os núcleos da APUH e aos professores do ensino superior de História e também aos universitários de História através de suas entidades de classe, a fim de que cada Centro estudantil enviasse um representante, na qualidade de observador ${ }^{450}$.

Apesar da eventualidade do Simpósio, compareceram cerca de 85 professores. Os Anais não trazem a relação nominal dos presentes, o que não nos permite mapear a origem de cada participante. Porém, como houve a apresentação de 18 trabalhos e destes, 14 são provenientes do núcleo regional de $\mathrm{SP}$, podemos deduzir que a maioria dos participantes fosse proveniente desse Estado ${ }^{451}$. Assim como no discurso de abertura do II Simpósio proferido por Cecília Westphalen e analisado acima, nesse relatório também há uma tentativa discursiva de se consolidar a associação, com o fito de escamotear seus problemas iniciais de organização. "Com essa conjuntura de fatores, o saldo do III Simpósio, rapidamente promovido, foi, inegavelmente, dos mais positivos. Ainda mais, consolidou a Associação dos Professores Universitários de História (APUH) que agora reencontrou o seu caminho" $" 452$.

Esses relatórios serão apresentados por Maria Regina Simões de Paula até o Simpósio Nacional de 1977 e podem ser tomados como o discurso oficial de cada evento, uma vez que, a partir desse III Simpósio, todos os Anais são organizados e editados por Eurípedes Simões de Paula. Maria Regina Simões de Paula, na condição de esposa de Eurípedes, atua também como sua secretária, condição comum à mulher casada com intelectual $^{453}$. Ao final do relatório, Maria Regina apresenta a eleição da nova diretoria para o biênio 1965-1967: Eurípedes Simões de Paula (presidente); Francisco Iglésias (vice-presidente); Sérgio Buarque de Holanda (reeleito secretário geral); Alice Piffer Canabrava (reeleita primeira secretária); José F. Carrato (segundo secretário); Cecília Maria Westphalen (primeira tesoureira); Walter Piazza (segundo tesoureiro) e José Roberto do Amaral Lapa (reeleito para Imprensa e Propaganda) ${ }^{454}$. Nessa mesma sessão plenária que elegeu a nova diretoria, foi deliberado que os Simpósios seriam realizados a

\footnotetext{
${ }^{450}$ Idem, p. 8.

${ }^{451}$ Idem, p. 11.

${ }^{452}$ Idem, p. 8.

${ }^{453}$ Cf. SMITH, op. cit., 2003.

${ }^{454}$ Cf. Idem, p. 16.
} 
cada dois anos e não anualmente, conforme estabeleciam os primeiros estatutos ${ }^{455}$. A temática escolhida para o IV Simpósio foi "Colonização e migração" e "O levantamento de fontes primárias" ${ }^{456}$ e seu local de realização seria escolhido pela nova diretoria em consulta aos núcleos regionais ${ }^{457}$. Ademais, foi deliberado que a diretoria, em conjunto com os núcleos regionais, encarregaria vários professores especializados para apresentação de comunicações "fundamentais", sem prejuízo das demais apresentações $^{458}$.

Em carta de 01 de dezembro de 1965, Francisco Iglésias responde à Alice sugerindo nomes para abordagem do tema principal do IV Simpósio a ser realizado em 1967. Iglésias desdobra o tema central por períodos e sugere nomes. Sobre "imigração e colonização no Brasil" afirma que "[...] entre os autores que já se dedicaram ao tema, os principais não são historiadores nem professores de História"459. A resposta de Canabrava, estabelecendo sua preferência por professores associados, é sintomática de um empreendimento que busca sua coesão através do pertencimento à comunidade de professores universitários de história. "Simões e eu discutimos juntos as suas sugestões mas acabamos por optar pela escolha de pessoas que pertencem exclusivamente à nossa entidade $[\ldots]^{\prime, 460}$.

A dificuldade em se organizar os primeiros Simpósios é uma marca da incipiente comunidade dos historiadores acadêmicos congregada em torno da APUH. O relatório de Maria Regina Simões de Paula sobre o IV Simpósio da entidade realizado entre 03 e 08 de setembro de 1967 na cidade de Porto Alegre/RS, naturaliza sua organização em torno

\footnotetext{
455 Os primeiros estatutos da APUH estão registrados no $3^{\circ}$ Oficial de Registro de Títulos e Documentos e Civil de Pessoa Jurídica da Comarca de São Paulo - Capital, sito à Praça Padre Manoel da Nóbrega, 20, centro. Solicitamos a esse cartório, "certidão em breve relato", que identifica todas as averbações realizadas até a data de emissão da mesma, ou seja, 25 de julho de 2017. Através da leitura dos relatórios de cada Simpósio, identificamos mudanças estatutárias nos anos de 1965, que estabeleceu a realização dos Simpósios bianualmente, 1973, 1975, 1977 e 1981. Com essa pesquisa em cartório, objetivávamos obter os estatutos que apresentaram mudanças com o fito de compará-los, bem como as Atas de cada Assembleia Geral da entidade ou sessões plenárias. Infelizmente, a "certidão em breve relato" identificou mudanças nos estatutos somente a partir de 29 de novembro de 1984.

${ }^{456}$ Esse subtema foi proposto por Eurípedes Simões de Paula durante o II Simpósio e tornou-se constante em todos os Simpósios seguintes. O núcleo regional de SP estabeleceu enquanto prática, o levantamento das fontes primárias em diversos arquivos do Estado com o fito de mapear e preservar essas fontes, conforme diversas moções que apelaram para autoridades públicas para preservação e proteção de acervos, bem como criação de arquivos locais e regionais.

${ }^{457}$ Cf. PAULA, op. cit., 1967, p. 15.

${ }^{458}$ Ibidem.

${ }^{459}$ Belo Horizonte, 01 de dezembro de 1965. FI-C-CA. Acervo Francisco Iglésias. IMS/RJ, p. 1.

${ }^{460}$ São Paulo, 01 de maio de 1966. FI-C-CP (088). Acervo Francisco Iglésias. IMS/RJ.
} 
dos esforços pessoais de Eurípedes Simões de Paula junto ao presidente do núcleo do RS em evento em São Paulo e silencia quanto aos desvios de sua organização ${ }^{461}$. Estratégia discursiva compreensível diante dos esforços para o estabelecimento de uma comunidade historiadora que necessita forjar uma coesão e identidade próprias ${ }^{462}$.

Em carta de 01 de maio de 1966, Alice pede à Iglésias para que, como vicepresidente da associação, inicie contatos com o fito de que o IV Simpósio se realize em MG.

[...] gostaria que V. entrasse em entendimentos com o prof. Amaro Xisto para examinar com muito interesse a possibilidade de se realizar o próximo Simpósio em Minas Gerais. Acho o seu estado ideal para o próximo certame: é um estado central, facilmente acessível, e com o grande atrativo da riqueza do patrimônio histórico arquitetônico. Conversei com o Simões sobre isso e ele é da mesma opinião que eu. Faço um apelo a V. para iniciar já os entendimentos de modo que possamos contar com o IV Simpósio em Minas Gerais, se possível no mês de Setembro de 67, na Semana da Pátria ${ }^{463}$.

Em sua resposta, Iglésias comenta que Amaro Xisto e Daniel Valle Ribeiro entraram em contato com o diretor da Faculdade de Filosofia de Juiz de Fora para a realização do IV Simpósio. O mesmo teria se surpreendido com a vultuosidade do evento e com os recursos necessários para o mesmo e responderia dentro de 30 dias. Quanto à possibilidade de realização do evento em Belo Horizonte, pontua que: "Francamente, não vejo facilidades em $\mathrm{BH}$, pela falta de recursos, e, sobretudo, pela falta de alguém que queira responsabilizar-se pelas tarefas. Um Congresso tem que ser carregado por alguém, um apóstolo, sabemos pela experiência dos anteriores" ${ }^{\text {464 }}$. Iglésias declina quanto à possibilidade de realização e aponta para uma importante característica da organização dos primeiros congressos da APUH: a necessidade do esforço individual para a realização do mesmo. Eurípedes Simões de Paula parece ser esse "apóstolo" que não economiza empenho para a realização dos primeiros Simpósios. Porém, Simões conta com o apoio de duas mulheres, que, juntamente com ele, formam o que Maria Regina Simões de Paula

\footnotetext{
${ }^{461}$ Cf. PAULA, Maria Regina da Cunha Rodrigues Simões de. O IV Simpósio Nacional dos Professores Universitários de História. In: SIMPÓSIO DE PROFESSORES UNIVERSITÁRIOS DE HISTÓRIA APUH, IV, 1967, Porto Alegre. V. II. Anais.... São Paulo: FFCL/USP, 1969, p. 7-20.

462 Apoiamos-nos aqui nas reflexões de: POLLAK, Michel. Memória e identidade social. Estudos Históricos. Rio de Janeiro, v. 5, n. 10, p. 200-212, 1992.

${ }^{463}$ São Paulo, 01 de maio de 1966. FI-C-CP (088). Acervo Francisco Iglésias. IMS/RJ.

${ }^{464}$ Belo Horizonte, 20 de Junho de 1966. APC-CP-P1,2-(1). Fundo Alice Piffer Canabrava. Arquivo IEB/USP.
} 
denomina "tripé operacional" da associação ${ }^{465}$. Ao contrário do relatado por essa última, a ideia de se realizar o IV Simpósio no RS vis a vis o insucesso junto ao núcleo de MG teria partido de Alice que sugeriu tal possibilidade à Eurípedes, dada a presença em São Paulo de Dante de Laytano no I Colóquio Brasil-Japão realizado pelo departamento de Estudos Orientais da FFCL/USP e pela UNESCO. "Dei a ideia ao Dr. Simões de Paula para falar com ele e não podíamos, no momento, encontrar maior boa vontade. Ficou assentado que o IV Simpósio se realizará no Rio Grande do Sul, em Porto Alegre, em 1967, na Semana da Pátria (Setembro) "466.

A partir daí caberia à Alice enviar as circulares a todos os sócios da APUH, bem como às entidades estudantis, informando acerca de sua realização em Porto Alegre. Porém, um ano após o envio da primeira circular informando sobre a realização do IV Simpósio naquela cidade ${ }^{467}$, permanecia a incerteza quanto à sua realização. Em carta de 17 de junho de 1967 à Francisco Iglésias, a historiadora afirma que tem enviado cartas à Dante de Laytano em caráter emergencial e que esse não as tem respondido e aventa a possibilidade de que o IV Simpósio possa ser realizado na cidade de Assis/SP, uma vez que seus professores realizaram oferta e haveria a hospitalidade das famílias locais ${ }^{468}$.

Eurípedes Simões de Paula em seu discurso de abertura desse Simpósio rememora os Simpósios anteriores e vincula os intentos dos historiadores ali reunidos a partir do recurso à duas identidades historiadoras: Marc Bloch e Lucien Febvre ${ }^{469}$. Como veremos no próximo item desse capítulo, para forjar sua própria identidade historiadora Alice vincula Febvre à renovação em história em oposição à "histoire historisante" corporificada por Afonso Taunay ${ }^{470}$. Apesar dessas tentativas discursivas de estabelecimento de uma maturidade da APUH, em sua primeira década de existência a

\footnotetext{
${ }^{465}$ PAULA, Maria Regina Rodrigues Simões de. A Associação Nacional dos Professores Universitários de História e o VI Simpósio. In: SIMPÓSIO DE PROFESSORES UNIVERSITÁRIOS DE HISTÓRIA APUH, VI, 1971, Goiânia. V. I. Anais.... São Paulo: FFLCH/USP, 1973, p. 7-25. Para Paulo Thiago Santos Gonçalves da Silva, a maior participação de paulistas ao longo dos Simpósios, bem como a direção a cargo de Eurípedes Simões de Paula e Alice Canabrava e a consequente centralização na FFCL/FFLCH/USP caracterizaria a APUH/ANPUH como um empreendimento paulista. Para o autor, haveria também uma disputa pela imposição de uma vertente historiográfica a partir da experiência uspiana. Cf. SILVA, op. cit., 2014.

${ }^{466}$ São Paulo, 06 de agosto de 1966. FI-C-CP (072). Acervo Francisco Iglésias. IMS/RJ.

${ }^{467}$ PRIMEIRA CIRCULAR: IV SIMPÓSIO - PORTO ALEGRE - 1967. FI-C-CP (073). Acervo Francisco Iglésias. IMS/RJ.

${ }^{468}$ São Paulo, 17 de junho de 1967. FI-C-CP (078). Acervo FI. IMS/RJ.

${ }^{469}$ Cf. PAULA, Eurípedes Simões de. Discurso do Prof. Eurípedes Simões de Paula. In: Anais..., op. cit., 1969, p. 49-53.

${ }^{470}$ Cf. CANABRAVA, op. cit., 1962, p. 124.
} 
entidade passou pela incerteza quanto ao local e data de realização de seu Simpósio seguinte.

Em carta de 31 de março de 1968 a Francisco Iglésias, que partilha da mesma experiência associativa, uma vez que esteve presente em praticamente todos os Simpósios e em vários cargos da APUH/ANPUH, Alice, em tom de desabafo, aponta vários problemas da associação, como a incerteza quanto à realização dos Simpósios, a qualidade dos trabalhos e a difícil relação com Eurípedes Simões de Paula. "A dificuldade está em que nunca podemos ter certeza de que o compromisso assumido pelo grupo de um Estado pode ser cumprido, e temos o exemplo do que aconteceu com o Ceará" ${ }^{\prime 71}$. O mesmo se deu em relação à organização do V Simpósio ocorrido em Campinas/SP de 01 a 07 de setembro de 1969. No Simpósio anterior, cinco cidades se candidataram para receber o V Simpósio: Recife, João Pessoa, Salvador, Niterói e Assis. A escolha seria efetuada a partir da análise da candidatura por Eurípedes Simões de Paula e Canabrava, consultado o conselho da associação ${ }^{472}$. Para auscultar as reais possibilidades de realização do Simpósio, Alice adotou a estratégia, sempre que possível, do contato têteà-tête, para além da correspondência, como relatado a Francisco Iglésias:

$\mathrm{Na}$ Bahia concertei com os professores de lá a realização do V Simpósio em Salvador. Foi este um dos objetivos de minha passagem por Salvador após a estada em Recife. Já o diretor do Arquivo da prefeitura, doutor Luís Enrique Tavares, que passou um dia em Porto Alegre por ocasião do Simpósio, havia me informado que o governador Luís Viana via com prazer a possibilidade de ser realizado o próximo Simpósio em seu estado. Estou esperando a palavra oficial, por meio de uma carta dos professores de lá, para distribuir a primeira circular ${ }^{473}$.

Pela primeira vez, o relatório de Maria Regina Rodrigues Simões de Paula não silencia quanto às dificuldades de organização do V Simpósio, uma vez que o mesmo estava programado para ocorrer na Universidade Católica de Salvador ${ }^{474}$. Porém, também não esclarece quanto às motivações para sua não realização nessa cidade. Uma hipótese

\footnotetext{
${ }^{471}$ São Paulo, 31 de março de 1968. FI-C-CP (083). Acervo FI. IMS/RJ.

${ }^{472}$ Cf. PAULA, op. cit., 1969, p. 8.

${ }^{473}$ São Paulo, 21 de junho de 1968. FI-C-CP (085). Acervo Francisco Iglésias. IMS/RJ.

${ }^{474}$ PAULA, Maria Regina Rodrigues Simões de. O V Simpósio Nacional dos Professores Universitários de História. In: In: SIMPÓSIO DE PROFESSORES UNIVERSITÁRIOS DE HISTÓRIA - APUH, V, 1969, Campinas. V. I. Anais..., São Paulo: FFLCH/USP, 1971, p. 7-23.
} 
aventada é de que com a radicalização da repressão consubstanciada pelo AI-5 em 31 de dezembro de 1968, vários professores do núcleo da BA tenham sido cassados ${ }^{475}$.

Quanto à difícil relação com Eurípedes Simões de Paula apontada acima, Alice não concorda com a presidência em mais de um mandato, acusa o mesmo de "patriarcalismo", uma vez que cede às pressões após tudo ter sido acordado com ela quanto aos trâmites dos Simpósios, não respeitando seu secretariado, tampouco a diretoria da associação.

\begin{abstract}
A ANPUH vive sob o patriarcalismo do Prof. Simões de Paula e temos que reconhecer que este aspecto de sua personalidade também é alimentado pelo muito de patriarcalismo que resta em grande parte dos professores universitários: a capacidade de agir e pensar de forma impessoal, atentos às relações de amizade, às reações emocionais. A diretoria da ANPUH só existe no papel, é o presidente que decide tudo, que publica tudo, não aceita (já insisti várias vezes) fazer uma seleção para os Anais. Ele trabalha exaustivamente durante os Simpósios, dá o melhor que pode, dispende dinheiro próprio antes de receber o que rende a taxa de participação do Simpósio etc. etc. É uma soma grande de serviços, dedicação, mas tudo vem viciado na forma de origem, o comportamento patriarcal. Tenho falado a ele muitas vezes, diz que não tem remédio, é assim, morre assim. Deste modo, os aspectos negativos dos certames se acentuam cada vez mais ${ }^{476}$.
\end{abstract}

O desrespeito ao acordado com Alice em relação à várias questões concernentes à administração da APUH/ANPUH, passaria por uma questão de gênero? Fosse Sérgio Buarque de Holanda o secretário de fato, a postura de Eurípedes permaneceria a mesma? O diagnóstico de Alice, contido no excerto acima, é que Eurípedes desrespeitava toda a diretoria, não sendo uma questão particular relacionada a seu secretariado. Fato é que do “tripé operacional” da associação, ou seja, Eurípedes Simões de Paula, Alice Canabrava e Cecília Westphalen, todos eram catedráticos e as duas últimas tinham sua produção associada às mais recentes renovações historiográficas ${ }^{477}$. Apesar do fato de que na FFCL/USP somente em 1968 uma mulher alcançou a condição de catedrática, não podemos apontar uma postura misógina de Eurípedes em relação à Alice na gestão da associação. De qualquer modo, as redes de sociabilidade, além de comportarem relações

\footnotetext{
${ }^{475}$ Ver: MOTTA, Rodrigo Patto Sá. As universidades e o regime militar: cultura política brasileira e modernização autoritária. Rio de Janeiro: Zahar, 2014.

476 São Paulo, 03 de agosto de 1973. FI-C-CP (103). Acervo Francisco Iglésias. IMS/RJ.

477 Cf. ERBERELI JÚNIOR, op. cit., 2014. MACHADO, op. cit., 2016. SAES, Flávio Azevedo Marques de. Alice Piffer Canabrava (1911-2003). In: SAES; RIBEIRO, SAES, op. cit., 2017, p. 237-261.Saes analisa a contribuição de Alice à historiografia econômica, demarcando a preocupação de suas três teses com o estatuto colonial, o que a aproximaria de Roberto Simonsen e Caio Prado Júnior.
} 
de amizade, como no caso de Francisco Iglésias e de outros correspondentes, assistentes e orientandos de Canabrava, como vimos, também comportam disputas e hostilidades ${ }^{478}$. Essas relações desgastaram a historiadora, que em diversos momentos cogitou deixar a associação.

Em carta de 31 de março de 1968 a Francisco Iglésias, Alice, em tom de confidência, afirma que "[está] pensando em deixar em definitivo a secretaria (a primeira e única pessoa a quem falo é a você) da APUH, pois não estou vendo possibilidade de melhora da situação, permanecendo indefinidamente o Simões na presidência" ${ }^{479}$. Na carta seguinte enviada à Iglésias a historiadora reitera seu descontentamento em relação à associação.

Como já lhe escrevi na carta anterior, ando cansada da secretaria da APUH, estou pensando em deixar a função e apenas me preocupa a vivencia da entidade. Consegui agora, nesta viagem ao Norte, o compromisso da fundação do Núcleo Regional em Alagoas e Sergipe, deste modo ficam faltando pouquíssimos estados para se atingir uma estrutura nacional da nossa Associação. O funcionamento efetivo dessa estrutura nacional será obra do tempo. Por enquanto acho que o papel maior da nossa organização será o de estabelecer contato entre os professores dos vários estados, conhecermo-nos mutuamente, trocar informações bibliográficas e também dar oportunidade a muitos professores de conhecer o Brasil, que é imenso, e ignorado por um bom numero de professores de História. A parte cientifica em nível elevado será a fase seguinte, mas alguma coisa já tem resultado como estimulo à pesquisa, ao melhoramento do currículo. Nossa entidade refletirá sempre o estado do conhecimento e da pesquisa histórica em nosso país ${ }^{480}$.

Alice se preocupava com a capilaridade da Associação e na referida viagem ao “norte”, estabeleceu relações para a fundação dos núcleos de Alagoas e Sergipe. Em 1971, quando a Associação comemorou seus 10 anos de existência e, por conta de sua capilaridade, teve sua denominação alterada para ANPUH, havia os seguintes núcleos regionais em funcionamento: RN, PE, BA, MG, GB, SP, PR, RS, GO, RJ, ES, PB, SC, SE, AM e Brasília ${ }^{481}$. Quanto à função da APUH, Canabrava destaca seu papel nos intercâmbios intelectuais e reitera sua preocupação com o nível científico da entidade.

\footnotetext{
${ }^{478}$ Cf. SIRINELLI, op. cit., 2003, p. 250.

${ }^{479}$ São Paulo, 31 de março de 1968. FI-C-CP (083), Acervo Francisco Iglésias. IMS/RJ.

${ }^{480}$ São Paulo, 21 de junho de 1968. FI-C-CP (085). Acervo Francisco Iglésias. IMS/RJ.

${ }^{481}$ Cf. PAULA, Maria Regina da Cunha Rodrigues Simões de. A Associação Nacional dos Professores Universitários de História e o VI Simpósio (Goiânia, 5 a 12 de setembro de 1971). In: SIMPÓSIO NACIONAL DE PROFESSORES UNIVERSITÁRIOS DE HISTÓRIA - ANPUH, VI, 1971, Goiânia. V. I. Anais..., São Paulo: FFLCH/USP, 1973, p. 7-25.
} 
Sua crítica à Eurípedes no excerto de carta transcrito acima endereçada à Francisco Iglésias quanto a se operar uma seleção de trabalhos publicados para os Anais remete à questão da qualidade científica do que é apresentado nos Simpósios da Associação. Na citada entrevista ao MIS/SP em 1981 ao mencionar suas atividades junto à ANPUH afirma que

[...] um dos problemas que nós tínhamos nos simpósios era justamente da seleção dos trabalhos, porque nós sempre permitimos que todos falassem, que todos apresentassem as suas comunicações. E publicavam-se todas elas seja do nível que for. E havia muita gente dizendo que ao invés de três volumes ou dois, deveria haver um volume só, com as publicações, comunicações selecionadas. Eu sempre fui contrária à essa ideia, porque eu achava que aqueles volumes eram o retrato do ensino superior de História no Brasil. Eu acho que não se deve dar uma imagem falsa a posteridade, se deve mostrar que esses professores vinham aqui com esses trabalhos, pensando que eram grandes trabalhos. E que eram trabalhos ao nível de um aluno, a nível de aluno, mas que nós publicávamos porque... achávamos também o seguinte: se não publicássemos esses trabalhos os professores não voltariam, o importante era eles virem, tomarem contato com os outros professores, ouvirem os cursos ${ }^{482}$.

No excerto acima, já afastada da secretaria da associação e de sua presidência durante o biênio 1979/1981, Alice não se preocupa com a qualidade dos trabalhos apresentados. Ao contrário, seu discurso aponta para o fato de que seriam uma verdadeira radiografia da produção historiográfica brasileira em âmbito universitário. O estatuto público de sua entrevista e a preocupação em forjar uma memória de si certamente não permitiriam as mesmas críticas engendradas em âmbito privado, quase confessional, a seu amigo Francisco Iglésias. Para ela, deveria haver em cada simpósio a apresentação de três ou quatro trabalhos fundamentais de historiadores renomados concernentes ao tema principal, ficando aberta a participação de todos os associados presentes nas discussões e também poderiam apresentar trabalhos nas sessões sobre os outros temas do Simpósio ${ }^{483}$.

O nível desses professores que acorriam aos Simpósios e apresentavam "trabalhos em nível de aluno", deveria ser corrigido por meio dos cursos. Assim, a ANPUH se tornaria uma verdadeira escola a balizar o nível das Faculdades de Filosofia, principalmente diante da substituição do ensino de história no curso secundário pelo

\footnotetext{
${ }^{482}$ CANABRAVA, op. cit., 1981.

${ }^{483}$ Cf. São Paulo, 31 de março de 1968. Carta de Alice Canabrava à Francisco Iglésias. FI-C-CP (083). Acervo Francisco Iglésias. IMS/RJ.
} 
ensino de estudos sociais ${ }^{484}$. Os cursos da ANPUH foram introduzidos no VIII Simpósio Nacional realizado em Aracaju/SE entre 01 e 07 de setembro de 1975, abertos também a participação de estudantes e professores secundários. Alice Canabrava ministrou curso de história econômica; Marilda Corrêa Ciribelli, do IFCS/UFRJ e membro do conselho consultivo da ANPUH, sobre Metodologia; Cecília Westphalen ministrou curso sobre História Contemporânea; e Niko Zuzek, da FFLCH/USP, sobre História Medieval ${ }^{485}$.

Os Anais apresentam os tópicos abordados em cada curso, bem como sua bibliografia. O curso ministrado por Alice e denominado "Uma perspectiva da formação econômica do Brasil" apresenta o livro fundamental de Celso Furtado, "Formação Econômica do Brasil", lançado em 1959486. Sua escolha por esse curso nos informa sobre seu lugar institucional de fala, ou seja, professora catedrática de História Econômica, bem como de sua predileção por uma história cuja principal disciplina a se dialogar é a ciência econômica. A principal característica do livro de Celso Furtado é empreender um exercício de macroeconomia retrospectiva, ou seja, o aparato teórico keynesiano é mobilizado para explicar a formação da economia brasileira desde o período colonial até a contemporaneidade ${ }^{487}$. O curso ministrado por Cecília Westphalen sobre "a crise da civilização ocidental" colocou a audiência em contato com importante reflexão contemporânea acerca do esgotamento explicativo de todo aparato epistemológico que pautou a modernidade. Para tanto, Westphalen mobilizou no rol bibliográfico do curso, leituras de M. Foucault, R. Aron. H. Marcuse, F. Braudel, L. Strauss etc ${ }^{488}$.

\footnotetext{
${ }^{484}$ Esta passou a ser uma preocupação recorrente em várias moções. Em uma delas, por ocasião do VII Simpósio Nacional realizado em 1973, foi aprovada moção, assinada também por Alice Canabrava, e elaborado documento que rechaça os estudos sociais enquanto disciplina. Cf. Moção 9. In: Anais..., op. cit., 1974, p. 68-71. Entre as moções aprovadas na sessão plenária do VIII Simpósio Nacional de 1975, uma delas foi encaminhada ao ministro de educação e cultura quanto ao problema dos estudos sociais em detrimento da história, "[...] a mais fundamental das Ciências Humanas". PAULA, Maria Regina Rodrigues Simões de. Na plataforma nordestina o VIII Simpósio de História (Aracaju/75). In: SIMPÓSIO NACIONAL DE PROFESSORES UNIVERSITÁRIOS DE HISTÓRIA - ANPUH, VIII, 1975, Aracaju. V. I. Anais..., São Paulo: FFLCH/USP, 1976, p. 14-15.

485 PAULA, op. cit., 1976, p. 18-19.

${ }^{486}$ Cf. CANABRAVA, Alice Piffer. Uma perspectiva da formação econômica do Brasil. In: Anais..., v. I, op. cit., 1976, p. 44-45.

${ }^{487}$ Cf. CARVALHO, Fernando Cardim de. Keynes e o Brasil. Economia e Sociedade. Campinas, v. 7, n. especial, p. 569-574, 2008.

${ }^{488}$ Cf. WESTPHALEN, Cecília Maria. A crise da civilização ocidental. In: Anais..., v. I, op. cit., 1976, p. 45-46.
} 
Os cursos intensivos continuaram ao longo dos Simpósios seguintes ${ }^{489}$. O que Alice objetivava com eles, como vimos, era elevar o nível da produção veiculada aos Anais. Isso significava aderir à uma epistemologia histórica específica, aquela vinculada por ela à renovação historiográfica, ou seja, àquelas identidades historiadoras corporificas na revista dos Annales, cuja principal característica é o diálogo com as ciências sociais, e superar um modelo de história qualificado por ela como factual ${ }^{490}$. Em sua avaliação da produção veiculada nos Anais publicados até o Simpósio de 1971, Canabrava afirma que, "[...] ainda que heterogênea em sua força interpretativa ou como expressão da História factual, esta contribuição revela o esforço paulatino, crescente à medida que decorre o tempo, para conferir à nossa Associação seu status científico" ${ }^{\text {491 }}$.

Nesse mesmo discurso em que avalia a produção veiculada nos Anais dos vários Simpósios, Alice também dá o estado de organização da entidade em vários Estados por meio de seus núcleos regionais e aponta para seu crescimento, o que acarreta a necessidade de mudanças estruturais ${ }^{492}$. A principal mudança proposta por uma leva de associados, em moção subscrita por cerca de cem sócios, dizia respeito à participação ${ }^{493}$. Desde os primeiros estatutos da entidade somente os associados, ou seja, professores universitários, com comprovada produção historiográfica, poderiam apresentar trabalhos e tecer comentários nas sessões científicas e nas assembleias gerais. Somente os professores associados podiam votar com o fito de decidir os rumos da associação. Estudantes universitários e professores secundários, que cada vez mais acorriam aos Simpósios, inclusive em alguns deles superando o número de professores universitários, estavam excluídos de tomar a palavra, tinham seu discurso interditado por força

\footnotetext{
${ }^{489}$ Ver: Cursos. In: In: SIMPÓSIO NACIONAL DE PROFESSORES UNIVERSITÁRIOS DE HISTÓRIA - ANPUH, IX, 1977, Florianópolis. V. I. Anais..., São Paulo: FFLCH/USP, 1979, p. 123-133. Cursos. In: SIMPÓSIO NACIONAL DE PROFESSORES UNIVERSITÁRIOS DE HISTÓRIA - ANPUH, X, 1979, Niterói. Elenco. São Paulo: ANPUH, 1979a, p. 10-17. Cursos. In: SIMPÓSIO NACIONAL DE PROFESSORES UNIVERSITÁRIOS DE HISTÓRIA - ANPUH, XI, 1981, João Pessoa. Elenco. São Paulo: ANPUH, 1981, p. 25-31.

${ }^{490}$ Cf. CANABRAVA, Alice Piffer. Discurso da Profa. Alice Piffer Canabrava, $1^{a}$ secretária da ANPUH. In: Anais..., v. I, op. cit., 1972, p. 85-91. Sabemos que esta estratégia discursiva em relação à desqualificar a produção historiográfica precedente com a pecha de factual, meramente política etc, foi uma postura recorrente de Lucien Febvre. Ver: FEBVRE, Lucien. Combates pela história. Lisboa: Editorial Presença, 1985.

${ }^{491}$ CANABRAVA, op. cit., 1972, p. 89.

${ }^{492}$ Cf. CANABRAVA, op. cit., 1972.

${ }^{493}$ Cf. PAULA, Maria Regina da Cunha Rodrigues Simões de. IX Simpósio de História. Mudanças Estruturais (Florianópolis, 1977). In: Anais..., op. cit., 1979, p. 13-32.
} 
estatutária $^{494}$. Um grupo de 29 professores, incluindo-se Alice Canabrava, encampou proposta de mudança estatutária no IX Simpósio Nacional realizado em Florianópolis em 1977, que permitisse aos professores secundários, professores de matérias afins, estudantes de graduação e pós-graduação a participação em todas as reuniões da entidade, inclusive apresentando comunicação, exceto direito de voto em assembleia ${ }^{495}$. Após os mais acerbos debates, a proposta foi aprovada por 73 votos contra $14^{496}$.

O endosso de Alice à proposta de mudança estatutária que permitiria a participação de estudantes nos causa estranhamento, uma vez que, como analisamos acima, a preocupação com o nível das comunicações era uma constante. Parece-nos que sua posição em relação à questão não se alterou. Porém, Alice escolheu se posicionar publicamente pela abertura da associação, uma vez que desde o VI Simpósio Nacional realizado em Goiânia em 1971 o número de estudantes e professores secundários superava o de professores universitários ${ }^{497}$. Esse Simpósio foi o último em que todos os trabalhos apresentados foram publicados nos Anais devido a trágica morte de Eurípedes Simões de Paula, atropelado em rua do centro de São Paulo ${ }^{498}$.

Eurípedes, como apontado por Alice em nota que abre os Anais do IX Simpósio, se empenhava para que todas as comunicações fossem publicadas, empregando, inclusive, recursos próprios para tanto ${ }^{499}$. No X Simpósio, realizado em Niterói em 1979, pela primeira vez desde a fundação, os Anais não foram publicados. Apenas o programa, o regulamento e os resumos dos trabalhos apresentados em forma de "elenco"500. Outra

${ }^{494}$ Cf. Estatutos..., op. cit., 1962.

495 Cf. Proposta 4. In: SIMPÓSIO NACIONAL DE PROFESSORES UNIVERSITÁRIOS DE HISTÓRIA - ANPUH, IX, 1977, Florianópolis. V. I. Anais..., São Paulo: FFLCH/USP, 1979, p. 105-106. Além de Alice, assinaram a proposta: Fernando Novais, Ibrahin João Elias, Maria Stella Bresciani, Dea Fenelon, Maria Clementina Pereira Cunha, Valmir Martins, Edgar de Decca, Antonio Montenegro, José Jobson Arruda, Ademar Martins, Elmar Jonas Manique da Silva, Maria Luiza Tucci Carneiro, José Bueno Conti, Maria José Elias, Monica Hirst, Ana Maria de Almeida Camargo, Iraci Galvão Salles, Lucia Helena Gaeta Aleixo, Raquel Glezer, José Ribeiro Júnior, Victor Valla, Maria Lucia Rangel Ricci, Carlos Humberto Correa, Holien Gonçalves Bezerra, Sara Regina Silveira de Souza, Dalísia Elizabeth Doles, Maria Arminda do Nascimento Arruda e Vera Hercília Borges.

496 Ibidem.

497 A primeira vez em que o relatório de Maria Regina Simões de Paula apresentou o número de participantes do Simpósio por categoria foi referente ao VI Simpósio Nacional realizado em Goiânia em 1971. Neste, o número de estudantes universitários somado ao de professores secundários atingiu 476 e os professores universitários se fizeram representar por 298 participantes. Cf. PAULA, op. cit., 1972. Ao longo dos Simpósios seguintes, a participação de estudantes universitários e professores secundários aumentaria progressivamente.

${ }^{498}$ Cf. PAULA, op. cit., 1979.

${ }^{499}$ Cf. CANABRAVA, Alice Piffer. Nota explicativa. In: Anais..., op. cit., 1979, p. 5-9.

500 SIMPÓSIO NACIONAL DE PROFESSORES UNIVERSITÁRIOS DE HISTÓRIA - ANPUH, X, 1979, Niterói. Elenco. São Paulo: ANPUH, 1979. 
ausência: os relatórios de Maria Regina da Cunha Rodrigues Simões de Paula. Como analisamos acima, Canabrava era contrária à publicação de todos os trabalhos apresentados. Essa pode ser uma das explicações para a extinção dos Anais, ao lado dos altos custos de sua publicação. Nesse Simpósio introduziu-se nova sessão temática aprovada em Simpósio anterior, denominada “pesquisas em andamento". A singularidade desse X Simpósio que mais nos interessa aqui é o fato de que Alice foi eleita presidente da ANPUH. Na diretoria central, como primeiro secretário, ao lado da secretária geral Maria Yedda Linhares, figura Flávio Azevedo Marques de Saes ${ }^{501}$. Esta não é a primeira vez que membros da equipe de História Econômica da FEA/USP estão ao lado da historiadora na direção da ANPUH. Durante o biênio 1977/1979 Antonio Emílio Muniz Barreto atuou como primeiro secretário da entidade e deve ter auxiliado Alice com os trâmites da secretaria da entidade ${ }^{502}$. Alice também convidava seus orientandos para ministrarem cursos, caso de Antonio Muniz Barreto ${ }^{503}$ e Flávio Saes ${ }^{504}$. Ademais, ela estimulou a participação de seus assistentes desde os princípios da associação, como podemos constatar pela participação de Hans Bruno Eduardo Schellenberg no II Simpósio $^{505}$.

Ao lado da progressiva participação dos estudantes nos Simpósios da ANPUH, também devemos nos lembrar que após longo período de sombras, o país novamente se articulava em torno dos movimentos sociais com vistas à abertura e posterior redemocratização. Assim, ao lado de uma maior abertura da associação, também havia um grupo que procurava trazer à ANPUH questões do tempo presente, uma marca, como vimos, dos primeiros dois Simpósios. Dessa forma, a determinação estatutária que interditava qualquer manifestação política por parte da associação tornava-se cada vez mais insustentável. Em carta a Francisco Iglésias de 26 de julho de 1981, logo após seu retorno do XI Simpósio Nacional realizado em João Pessoa, Alice afirma que

Na sessão de abertura houve dois discursos não esperados, da esquerda ostensiva, a proclamar as torturas e outras vicissitudes do passado, a incitar os presentes a uma ação politica efetiva. Então, entrei com o meu discurso, apolítico, histórico, e foi como água na fervura. Eu já havia

\footnotetext{
${ }^{501}$ SIMPÓSIO NACIONAL DE PROFESSORES UNIVERSITÁRIOS DE HISTÓRIA - ANPUH, XI, 1981, João Pessoa. Elenco. São Paulo: ANPUH, 1981, p. 12.

${ }^{502}$ Cf. Idem, p. 11.

${ }^{503}$ MUNIZ BARRETO, Antonio Emílio. A Primeira República. In: Anais..., op. cit., 1979, p. 131-132.

${ }^{504}$ SAES, Flávio Azevedo Marques de. Desenvolvimento Econômico Brasileiro - (1930-1960). In: Anais..., op. cit., 1979, p. 13-14.

${ }^{505}$ Cf. Participantes do II Simpósio. In: Anais..., op. cit., 1962a, p. 17.
} 
recomendado que não aceitaria manifestações políticas no Simpósio. Parece incrível que, justamente quando a SBPC tudo faz para se livrar da carga política em seus trabalhos, a ANPUH, por uma de suas alas, muito deseja uma atuação política efetiva, ostensiva. E, dentro desta posição, o prof. Sílvio Frank Alem, um garotão, imaturo apesar dos 35 anos, programou, ou melhor, solicitou a participação dos "simposiastas" numa marcha contra a carestia e depois pediu assinaturas em protesto contra o governador por um problema de honorários de professores, um adendo que não entendi bem. No meu argumento, a ANPUH deve estar aberta à análise de qualquer problema político, do passado recente, desde que seja sob base científica ${ }^{506}$.

Pelo excerto de carta acima, percebemos que Alice identifica, em tom pejorativo, um grupo de simposistas por "esquerda ostensiva". Sua postura é de que a associação, ao tratar de questões políticas do "passado recente" o faça segundo os crivos de uma história orientada cientificamente, o que para ela, significa sem envolvimento com movimentos políticos ou uma história engajada. O modelo de associação é a SBPC. A filiação da ANPUH à SBPC em $1969^{507}$ pode ser tomado como reconhecimento de que os historiadores congregados em torno da associação, ou seja, a comunidade profissional de historiadores acadêmicos opera em bases científicas.

A abertura da ANPUH à ampla participação, somado a uma ala que apregoava o engajamento político como parte de uma identidade historiadora, resultou em uma primeira cisão encampada por Cecília Westphalen que liderou a fundação da Sociedade Brasileira de Pesquisa Histórica (SBPH) ${ }^{508}$. Em carta de 21 de janeiro de 1981 endereçada à Francisco Iglésias, Alice critica os intentos de Westphalen quanto a fundação de uma sociedade de caráter elitista:

Cecília Westphaen está coordenando a fundação de uma outra sociedade de Historiadores, com 40 fundadores, grupo eletista [sic], da qual se excluem alunos e jovens em inicio de carreira. Sempre advoguei que a nossa Associação deve estar sempre aberta aos jovens, estudantes, como os que se iniciam na carreira. Viajei largamente por nossos Brasis, conheci de perto a carência da grande maioria de nossas Faculdades, em termos de bibliotecas, de professores, de recursos para pesquisa, de remuneração condizente. Ao meu ver, estes é que precisam da Associação, os maiorais podem dispensa-la [sic]. A maior tarefa da Associação tem sido levar os discentes e docentes carentes a ouvir algumas aulas de bons professores, ter contato com pesquisadores, tomar conhecimento das potencialidades dos arquivos, muitas vezes, ao alcance de seus olhos, mas, sobre os quais, nunca foram iniciados. Esta

\footnotetext{
${ }^{506}$ São Paulo, 26 de julho de 1981. APC-CP-P1,24-(6). Fundo Alice Piffer Canabrava. Arquivo IEB/USP. ${ }^{507}$ Cf. Proposta n. 3. In: Anais..., op. cit., 1974, p. 72.

${ }^{508}$ Sobre essa nova associação e o papel de Westphalen em seu desenvolvimento, ver: MACHADO, op. cit., 2016, p. 237-256.
} 
é uma realidade social que não se pode ignorar. Ao que me parece, a nova entidade que está em formação, pretende repetir o mesmo vício da repartição dos bens - mais farinha para o bolo dos privilegiados ${ }^{509}$.

Canabrava advogava pela participação de todas as categorias na associação, sua única restrição, como vimos, era quanto à publicação dos trabalhos nos Anais. Nem todos deveriam ser publicados. Porém, todos poderiam apresentar comunicações. A entidade proposta por Cecília Westphalen objetivava congregar somente professores universitários, em uma retomada do que fora a $\mathrm{APUH}^{510}$. Por outras razões, vinculadas ao cansaço e à um novo empreendimento intelectual, Alice também se afastaria da entidade fundada por ela e seus colegas há vinte anos.

Alice fez questão de demarcar para seus companheiros de ANPUH, especificamente à José Ribeiro Júnior, que almejava candidatar-se à vice-presidência, que não seria candidata à presidente da entidade para o biênio 1981/1983. Em carta de 4 de junho de 1981 endereçada a Francisco Iglésias afirma que

[...] Afinal, em 9 de Maio já comuniquei ao Prof. Ribeiro Junior que não sou candidata à presidência da ANPUH para o bieno [sic] 1981/83, nem aceitarei indicação para o posto. Escreveu-me duas cartas pedindo reconsideração (Que será da ANPUH sem a Senhora!) mas mantenhome irredutível. Deixo definitivamente a cúpula da Associação (por enquanto é segredo). Irei a João Pessoa presidir o $\mathrm{XX}^{\circ}$ [sic] Simpósio e transmitir a função, como tarefa a cumprir [...]. Muito aprendi e muito me desiludi nesta caminhada da presidência e sob muitos aspectos estes dois últimos anos me foram mais difíceis do que o conjunto dos 18 anos anteriores nos quais trabalhei junto à entidade como $1^{\circ}$ secretario [sic] e secretário Geral ${ }^{511}$.

No excerto de carta acima, Canabrava afirma que os dois anos em que foi presidente da associação foram mais difíceis do que os 18 anos em que atuou como secretária. Por que Alice deixou a diretoria da ANPUH? Os únicos indícios que temos dizem respeito ao cansaço expresso por ela em várias cartas a seu amigo Francisco Iglésias, como analisamos acima. Ademais, a historiadora estava à frente de um novo empreendimento intelectual fundado por ela: a Revista Brasileira de História $(R B H)$, órgão da ANPUH ${ }^{512}$.

\footnotetext{
${ }^{509}$ São Paulo, 21 de janeiro de 1981. FI-C-CP (124). Acervo Francisco Iglésias. IMS/RJ.

${ }^{510}$ Cf. MACHADO, op. cit., 2016.

511 São Paulo, 04 de junho de 1981. FI-C-CP (127). Acervo Francisco Iglésias. IMS/RJ.

512 Para um mapeamento da produção historiográfica veiculada à $R B H$, ver: MELLO, Ricardo Marques de. Tendências historiográficas na Revista Brasileira de História, 1981-2000. 125 f. Tese (Doutorado em História) - Universidade de Brasília, Brasília, 2012. Ver: MELLO, Ricardo Marques de. Tendências historiográficas na Revista Brasileira de História: 1981-2000. Curitiba: Editora Prismas, 2016. Ver
} 
O texto de abertura do primeiro número da $R B H$ denomina-se "Associação dos Professores Universitários de História". Nele, Alice demarca os intentos da nova Revista: substituir os Anais dos Simpósios da $\mathrm{ANPUH}^{513}$. Aí reside a singularidade da $R B H$ : o primeiro periódico brasileiro vinculado a uma associação profissional de historiadores ${ }^{514}$. No texto que abre a sessão "noticiário" da Revista, Raquel Glezer, secretária da $R B H$, historia as duas reuniões realizadas na casa de Alice Canabrava que resultaram na fundação do periódico ${ }^{515}$. Na primeira, realizada em 03 de julho de 1980, Alice apresentou aos presentes - Flávio Saes, segundo secretário da ANPUH; José Ênio Casalecchi, segundo tesoureiro; Fernando Novais, do conselho consultivo e Raquel Glezer, secretária do núcleo da ANPUH/SP representando seu diretor, José Ribeiro Júnior - os intentos da Revista, qual seja, substituir os Anais da ANPUH, uma vez que sua publicação se mostrava cada vez mais inviável devido aos altos custos de publicação de todos os trabalhos apresentados em Simpósio. Quanto à forma de financiamento da nova Revista, Canabrava buscou agências de fomento como o CNPq, a FINEP e a CAPES, tendo obtido recursos dessa última para a publicação dos dois primeiros números. "Sugeriu-se no decorrer da reunião vários nomes ao periódico; debateu-se o número de páginas; a divisão do conteúdo; preço e outros problemas correlatos" ${ }^{\text {"516. }}$.

Uma segunda reunião foi realizada na casa de Alice no dia 08 de agosto de 1980, com convocação da diretoria e do conselho consultivo da ANPUH com o fito de divulgar as decisões tomadas pela presidente e encaminhar as questões legais. Nela, com a presença de Rosa Maria Godoy Silveira, representando o vice-presidente, Silvio Frank Alem; Flávio Saes, Caio César Boschi, primeiro tesoureiro; Fernando Novais, Rui C. Wachowicz do conselho consultivo e Raquel Glezer, discutiram-se possibilidades de

também a I parte de: SANTOS, Geminiano Wagner dos. A invenção da historiografia brasileira profissional, acadêmica: geografia e memória disciplinar, disputas político-institucionais e debates epistemológicos acerca do saber histórico no Brasil (1980-2012). 435 f. Tese (Doutorado em História) Universidade Federal de Pernambuco, 2018.

513 CANABRAVA, Alice Piffer. A Associação dos Professores Universitários de História. Revista Brasileira de História. São Paulo, v. 1, n. 1, 1981b, p. 9.

${ }^{514} \mathrm{O}$ mesmo se deu em relação à American Historical Review. Cf. PERPÉTUO, César Haueisen Zimerer. Historiografia americana em revista: a American Historical Review (1895 a 1915). 100 f. 2017. Dissertação (Programa de Pós-Graduação em História), CCHN/UFES, Vitória, 2017, p. 20.

515 Para uma autobiografia intelectual da historiadora, acompanhada por uma análise das mudanças do campo historiográfico, ver: GLEZER, Raquel. Do todo ao fragmento: um breve olhar sobre a pesquisa histórica no Brasil. In: BENTIVOGLIO, Júlio; NASCIMENTO, Bruno César (orgs.). Escrever história: historiadores e historiografia brasileira nos séculos XIX e XX. Serra: Milfontes, 2017, p. 123-136.

${ }^{516}$ GLEZER, Raquel. A fundação da Revista. In: Noticiário. Revista Brasileira de História. São Paulo, v. 1, n. 1, 1981, p. 129. 
nome do periódico, suas sessões, apresentação gráfica e seu registro legal. Ficou estabelecido o nome do periódico e suas sessões: artigos, bibliografia e noticiário (principalmente com o fito de conferir publicidade aos eventos de cada núcleo regional da entidade).

Seus dois primeiros números seriam impressos na gráfica da Escola de Comunicações e Artes (ECA) da USP. Definiu-se também o organograma da Revista: um diretor, sempre o presidente da ANPUH; um secretário, Raquel Glezer e um conselho consultivo responsável pela avaliação do material a ser publicado: Carlos Roberto Antunes dos Santos (PR), Denis Bernardes (PE), Francisco Iglésias (MG), Helga Piccolo (RS), Janaina Amado (GO), José Ribeiro Júnior (SP), Katia Mattoso (BA), Rosa Maria Godoy Silveira $(\mathrm{PB})^{517}$. Por meio da fundação da $R B H$, Alice vencia a disputa em torno da publicação dos Anais, uma vez que agora, somente trabalhos de alto nível científico seriam publicados.

Logo após essa reunião, a historiadora tratou de escrever, em nome da ANPUH, à Francisco Iglésias.

É para nós motivo de grande prazer, comunicar-lhe que o seu nome foi indicado para integrar o Conselho de Redação, cuja essencial função é opinar sobre a matéria a ser divulgada pelo periódico. Ao transmitir-lhe a grata notícia, juntamente com os nossos cumprimentos, pedimos que nos informe se aceita a indicação e, ao mesmo tempo, em caso afirmativo, vimos convoca-lo para uma primeira reunião em São Paulo, no corrente mês de Agosto, para selecionar o material a ser impresso nos dois primeiros números. Sendo muito restrito o tempo de que dispomos para remeter ao prelo os originais, solicitamos sua resposta com a maior urgência, certos de que podemos contar com a colaboração. Dada a carência de recursos, a Associação não poderá se responsabilizar pelas despesas de transporte e de hospedagem ${ }^{518}$.

O excerto de carta acima nos informa sobre como se procedeu a escolha para a formação do conselho consultivo da $R B H$. Ao contrário do conselho consultivo da ANPUH, recrutado por meio de eleição, o conselho da $R B H$ foi formado a partir de indicação pelos membros da diretoria e conselho consultivo da ANPUH presentes na reunião de fundação da revista na casa de Alice. A presença de um conselho consultivo denota o caráter profissional do empreendimento, ao contrário do personalismo que marcou a Revista de História, conhecida como "revista do Eurípedes", em sua $1^{\circ}$ fase,

\footnotetext{
${ }^{517}$ Idem, p. 129-130.

${ }^{518}$ São Paulo, 18 de agosto de 1980. FI-C-CP (117). Acervo Francisco Iglésias. IMS/RJ.
} 
uma vez que o mesmo realizava todo o trabalho de seleção, edição e divulgação do material $^{519}$. Porém, se a presença de um conselho consultivo denota maior grau de profissionalismo, não significa que não haja margem para algum personalismo. Assim, em várias ocasiões Canabrava solicita a colaboração, em forma de artigo, de seu amigo Francisco Iglésias, mesmo como integrante do conselho consultivo da $R B H$.

Em carta de 21 de setembro de 1980 à Francisco Iglésias, Alice, em nome da ANPUH, agradece seu aceite em colaborar na nova revista como conselheiro consultivo e pede ao amigo que envie um artigo para publicação. "Gostaríamos muito de publicar um artigo seu, no $1^{\circ}$ ou no $2^{\circ}$ número; sei que tem uma série de comentários, divulgados em jornal, sobre as obras dos brasilianistas, assunto de grande importância e interesse" ${ }^{\text {20 }}$. Em resposta, Iglésias agradece por ter sido escolhido conselheiro da Revista e que "[...] infelizmente não poderá contribuir com nenhum artigo, uma vez que não está trabalhando em nada que resulte em artigo imediato" ${ }^{521}$. Em outras cartas, Canabrava insiste na colaboração do amigo em forma de $\operatorname{artigo}^{522}$.

Não me conformo com sua resposta, em não poder dar o artigo para o numero 2 da Revista, que é também sua, e muito lucraria em "status" com a sua colaboração. Veja se reforma sua resolução e me manda o artigo, pois ainda não mandei o numero 2 para o prelo, na esperança de que possa contar com o seu artigo. Um pouco de boa vontade Iglésias! ${ }^{523}$.

Ao convidar Francisco Iglésias para publicar artigo na $R B H$, Alice Canabrava lança mão de uma tática comum adotada por diretores e/ou fundadores de periódicos

\footnotetext{
519 Os depoimentos sobre a vida intelectual e administrativa de Eurípedes Simões de Paula caracterizam a "Revista de História" como "sua" revista, porém, em um tom apologético. É o que se pode ver em: NASCIMENTO, Bruno César. Um novo projeto para a História no Brasil. Eurípedes Simões de Paula e a Revista de História da USP. In: BENTIVOGLIO, Júlio; NASCIMENTO, Bruno César (orgs.). Escrever história: historiadores e historiografia brasileira nos séculos XIX e XX. Serra: Milfontes, 2017, p. 227-250. O autor amplia sua análise sobre o periódico para além de 1983, quando a Revista de História adentra em nova fase. Ver: NASCIMENTO, Bruno César. A Revista de História da Universidade de São Paulo em perspectiva. In: ARRAIS, Cristiano Alencar; BENTIVOGLIO, Júlio (orgs.). As revistas de história e as dinâmicas do campo historiográfico. Serra: Milfontes, 2017, p. 81-104. Para as disputas conceituais em torno de teoria e historiografia, o ensino de história e compreensões e diagnósticos sobre a historiografia brasileira, ver: NICODEMO, Thiago Lima; PEREIRA, Mateus Henrique de Faria; CRISTOVÃO DOS SANTOS, Pedro Afonso. Teoria, historiografia e ensino nas páginas da Revista de História da USP (19501960). In: ARRAIS; BENTIVOGLIO, op. cit., 2017, p. 105-130.

${ }^{520}$ FI-C-CP (119). Acervo Francisco Iglésias. IMS/RJ.

${ }^{521}$ Belo Horizonte, 23 de setembro de 1980. APC-CP-P1,20-(1). Fundo Alice Piffer Canabrava. Arquivo IEB/USP.

${ }^{522}$ Cf. São Paulo, 1981. APC-CP-P1,13(5). São Paulo, 31 de dezembro de 1981. APC-CP-P1, 28-(4). Fundo Alice Piffer Canabrava. Arquivo IEB/USP.

${ }^{523}$ São Paulo, 03 de janeiro de 1981. FI-C-CP (123). Acervo Francisco Iglésias. Arquivo IMS/RJ.
} 
recém-surgidos, qual seja, a arregimentação de nomes já estabelecidos no campo historiográfico, que darão notoriedade ao novo empreendimento intelectual frente aos periódicos existentes ${ }^{524}$. Apesar das recorrentes insistências da historiadora, Francisco Iglésias iria colaborar com artigo somente no número 5 da Revista ${ }^{525}$.

Outro assunto tratado por Canabrava nas cartas com Iglésias diz respeito às dificuldades de publicação da $R B H$. O primeiro número foi impresso na gráfica da ECA/USP e contou, para tanto, com a colaboração de seu então diretor Eduardo D’Oliveira França. Porém, com a morosidade por parte dos funcionários, Alice decidiu contratar uma gráfica privada para a impressão dos números 3 e 4 . "Resolvemos enviar os $n^{\circ}$ s 3 e 4 para uma empresa privada, pois a ECA (Escola de Comunicações e Artes da USP), onde foi editado o No 1 e onde "jaz" o $n^{\circ} 2$, não se interessa em cumprir prazos. Até hoje não entregou o vol. 2 que deveria ser distribuído em Setembro"526. Para que a impressão da $R B H$ ficasse à cargo de empresa privada, Canabrava realizou cotação de preços e pediu para Helga Piccolo pesquisar quanto ficaria a impressão em gráfica de Porto Alegre. Em carta de 17 de outubro de 1981 agradece pelo envio do orçamento, mais caro do que a impressão em São Paulo e comenta sobre o atraso do segundo número. "O número 2 da Revista deve sair do prelo este mês. Já com atraso, pois devia ser distribuido [sic] no mês de Setembro. Mas como proceder com o emperramento da Editora? No próximo mês irá ao prelo o no 3, para o qual andei fazendo as pesquisas de preço"527.

Alice, durante as eleições para o biênio 1981/1983 havia sido eleita membro do conselho consultivo, uma vez que como apontamos acima, se recusou a continuar como presidente e, por conta da fundação da $R B H$, constava como editora da mesma. Como confidenciou em carta de 07 de maio de 1982 à Francisco Iglésias, permaneceria à frente da Revista por ela fundada somente até a impressão do número 4, que coincidiria com o término de seu mandato como editora. "O número 4 deverá ir logo ao prelo, para que se

\footnotetext{
${ }^{524}$ Cf. BENTIVOGLIO, Júlio. Revistas de história: objeto privilegiado para se estudar a história da historiografia? In: ARRAIS; BENTIVOGLIO, op. cit., 2017, p. 23. O autor propõe uma agenda de pesquisa para os periódicos e vislumbra uma história das revistas de história como disciplina. Apesar da presença de capítulos sobre importantes periódicos nacionais, como a Revista de História e a Revista do Instituto Histórico e Geográfico Brasileiro, e internacionais, como as Historische Zeischrift, Révue de Synthèse, Hispanic Historical Review, American Historical Review e a English Historical Review, a RBH não foi contemplada.

${ }^{525}$ IGLÉSIAS, Francisco. A historiografia brasileira atual e a interdisciplinaridade. Revista Brasileira de História. São Paulo, v. 3, n. 5, p. 129-141, 1983.

526 São Paulo, 06 de janeiro de 1982. FI-C-CP (132). Acervo Francisco Iglésias. Arquivo IMS/RJ.

${ }^{527}$ APC-PICC-007. Fundo Alice Piffer Canabrava. Arquivo IEB/USP.
} 
possa regularizar a peridiocidade [sic] da Revista, programada a distribuição para Março e Setembro. Como já lhe disse, só fico na Associação até Julho do próximo ano - se não renunciar antes" ${ }^{528}$. Alice, no entanto, permaneceu na direção da $R B H$ até a publicação do número 5. No biênio seguinte (1983/1985) estiveram à frente da editoria da Revista: José Jobson de Andrade Arruda, Marcos Antonio da Silva e Edgard Salvadori de Decca, passando Alice a figurar como conselheira consultiva ${ }^{529}$. O noticiário do número 6 é aberto com uma nota aos leitores.

Implantada a revista, já publicados cinco números até o primeiro semestre de 1983, a Profa. Dra. Alice Piffer Canabrava, sua Diretora Fundadora, considerou cumprida sua tarefa inicial, manifestando o desejo de se manter ligada à publicação através da colaboração com artigos sobre temas que tem pesquisado ${ }^{530}$.

Alice Canabrava nunca publicou na $R B H$ e não temos indício de que tenha continuado no conselho consultivo da mesma depois de $1985^{531}$.

\section{3 "A reflexão histórica alargada e aprofundada com o concurso de outras} ciências"

Entre as temáticas abordadas no I Simpósio, afirmamos que o tratamento concedido por Alice Canabrava e por Maria Yedda Linhares a seus respectivos temas instauram uma diferença a ser inventariada e um desvio em relação aos demais. No entanto, também há uma diferença entre as abordagens de ambas. Se Linhares está preocupada com a formação de professores de história para o então ensino secundário e insere o problema a partir da reforma universitária, Alice aponta a necessidade de se pensar a formação do historiador e do professor de história a partir de uma análise epistemológica da história do Brasil e da história da América, tema do relatório III daquele Simpósio ${ }^{532}$, cuja equipe foi formada por Astrogildo Rodrigues de Mello, catedrático de História da Civilização Americana da FFCL/USP, Eurípedes Simões de Paula, José Roberto do Amaral Lapa, Manuel Maurício de Albuquerque, assistente da

\footnotetext{
${ }^{528}$ FI-C-CP (138). Acervo Francisco Iglésias. IMS/RJ.

529 Cf. SIMPÓSIO NACIONAL DE PROFESSORES UNIVERSITÁRIOS DE HISTÓRIA - ANPUH, XIII, 1985, Curitiba. Elenco. São Paulo: ANPUH, 1985, p. 6.

530 ARRUDA, José Jobson de Andrade. DECCA, Edgard Salvadori de. SILVA, Marcos Antonio. Aos leitores. In: Noticiário. Revista Brasileira de História. São Paulo, v. 3, n. 6, 1983, p. 153.

${ }^{531}$ Cf. <https://anpuh.org.br/index.php/2015-01-20-00-01-55/revistas-anpuh/rbh〉.

532 CANABRAVA, Alice Piffer. O estudo da História da América e da História do Brasil no curso universitário: ensino tradicional e renovação. In: Anais..., op. cit., 1962, p. 119-127.
} 
cadeira de História do Brasil da FNFi/UB, Leda Maria Pereira Rodriguez, catedrática de História do Brasil da FFCL "Sedes Sapientiae" da PUC/SP533, Olga Pantaleão e Uacury Ribeiro de Assis Bastos ${ }^{534}$.

Causa-nos estranhamento o fato de que história do Brasil e história da América tenham sido tratadas em um único relatório, uma vez que ambas eram ministradas em cadeiras diferentes, ao contrário de história antiga e de história medieval, ministradas por uma mesma cadeira, bem como história moderna e história contemporânea. Uma hipótese aventada é que história da América não gozava do mesmo prestígio que as demais disciplinas, uma vez que tanto na FFCL/USP quanto na UDF/RJ, tal cadeira, ao contrário das demais, excetuando-se história do Brasil, não contou com a presença de professores franceses. Em São Paulo, a cadeira foi regida por Paul Vanorden Shaw, que não formou sucessores, uma vez que seus dois assistentes, Alice e Astrogildo, realizaram doutoramento sob a orientação de Jean Gagé ${ }^{535}$. No Rio de Janeiro, a cadeira de História da Civilização na América foi regida por João Batista de Melo e Sousa ${ }^{536}$ e, a partir de 1939, com a extinção da UDF e a criação da FNFi/UB, a cadeira de História da América passaria a ser regida por Silvio Júlio de Albuquerque Lima ${ }^{537}$. Ademais, sua relatoria não coube à professor vinculado à cadeira de História da América, caso de Astrogildo Rodrigues de Mello e Uacury de Assis Bastos. Tampouco por catedrático e/ou regente de História do Brasil, mas sim à Alice Canabrava, que contava na ocasião com dez anos como catedrática de História Econômica Geral e do Brasil junto à FCEA/USP. Atuando na formação de futuros economistas, a formação de professores para o então ensino secundário não fazia parte de sua prática docente. Entretanto, como analisado no capítulo 1, Alice preocupava-se com a formação de seus auxiliares de ensino e assistentes de pesquisa. Em 1961, a cadeira estava em um momento de transição, com a saída de Fernando Novais e a chegada de Hans Eduardo Bruno Schellenberg, primeiro assistente de pesquisa recrutado na própria FCEA.

\footnotetext{
${ }^{533}$ Cf. Catálogo dos sócios fundadores. APUH. São Paulo: Secretaria geral, 1962, p. 13. Arquivo da ANPUH.

${ }^{534}$ Cf. Equipes. In: Anais..., op. cit., 1962, p. 283.

${ }^{535}$ Cf. PAULA, Maria Regina da Cunha Rodrigues Simões de. Teses defendidas no departamento de História da Universidade de São Paulo (1939-1974). In: Notícia informativa. Revista de História. São Paulo, n. 100, p. 821-856, 1974.

${ }^{536}$ FERREIRA, Marieta de Moraes. A UDF e o primeiro curso universitário de História do Rio de Janeiro. In: FERREIRA, op. cit., 2013, p. 23.

${ }^{537}$ FERREIRA, Marieta de Moraes. O curso de História e Geografia da FNFi: um projeto de história nacional. In: FERREIRA, op. cit., 2013, p. 37.
} 
Em 1961 Alice havia proferido palestra no curso de férias na FFCL/URGS em parceria com o "Luso-Brazilian Center" da Universidade de Wisconsin ${ }^{538}$ e no ano anterior contribuíra com capítulo denominado "A grande propriedade rural" na História Geral da Civilização Brasileira coordenada por Sérgio Buarque de Holanda ${ }^{539}$. Desde 1956, esse historiador ocupava a cátedra de História da Civilização Brasileira da FFCL/USP. Mas, por que Sérgio Buarque não foi o relator da temática concernente à história do Brasil e sim Canabrava? Alice, desde há muito gozava de prestígio junto à comunidade historiadora em âmbito internacional, como atestado pela resenha escrita por Fernand Braudel de sua tese de doutoramento sobre o comércio português no rio da prata, que vinculava-a à orientação dos Annales.

Sur ces pays déshérités, au début de leur rude vie « coloniale », une jeune historienne brésilienne, Alice Piffer Canabrava, formée, orientée, je peux bien le dire, par la lecture et la connaissance de nos Annales, vient d'écrire un livre, son premier livre, dont il m'est agréable de dire la très grande importance ${ }^{540}$.

A tese com a qual concorreu à cadeira de História da Civilização Americana em 1946, e no qual foi preterida, em torno da produção do açúcar nas ilhas inglesas e francesas do mar das Antilhas, caracterizado por ela como "o mediterrâneo americano" ${ }^{541}$, mereceu a atenção do historiador português Vitorino Magalhães Godinho e também figura em resenha na revista Annales.

Mais il n'est pas possible de résumer l'étude extrêmement riche, bien étayée et toujours vivante d'Alice Piffer Canabrava. C'est vraiment de l'histoire au sens où nous l'entendons aux Annales: totale, humaine. Ici nous avons affaire à des groupes humains dont le milieu géographique nous a été présenté - et nous prenons une connaissance claire et minutieuse des techniques agricole, industrielles et commerciales ${ }^{542}$.

A recepção de sua tese não se deu apenas em âmbito francês, mas também nos EUA. Lewis Hanke, em balanço analisando a produção historiográfica sobre a presença

\footnotetext{
${ }^{538}$ CANABRAVA, Alice Piffer. Manufaturas e indústrias no período de D. João VI no Brasil (1963). In: CANABRAVA, op. cit., 2005, p. 85-101.

${ }^{539}$ CANABRAVA, Alice Piffer. A Grande Propriedade Rural. In: HOLANDA, Sérgio Buarque de. (dir.). História Geral da Civilização Brasileira. Época Colonial: Administração, Economia, Sociedade. t. I, v. 2. São Paulo: Difusão européia do livro, 1960, p. 192-217.

${ }^{540}$ BRAUDEL, Fernand. Du potosi à Buenos Aires: Une route clandestine de l'argent. Fin du XVe, début du XVIIe siècle. Annales. Économie, Sociétés, Civilisations. Paris, n. 4, 1948, p. 547.

${ }^{541}$ CANABRAVA, Alice Piffer. O Açúcar nas Antilhas (1697-1755). $2^{\circ}$ edição. São Paulo: Instituto de Pesquisas Econômicas, 1981a. O título original da tese é: "A Indústria do Açúcar nas Ilhas Inglesas e Francesas do Mar das Antilhas (1697-1755)".

${ }^{542}$ GODINHO, Vitorino Magalhães. Industrie et commerce Antillais. Sur le sucre des Antilles. Annales. Économie, Sociétés, Civilisations. Paris, n. 4, 1948. p. 544.
} 
portuguesa na América espanhola, cita as pesquisas de Alice e de Charles Boxer. "The researches of Charles R. Boxer and Alice P. Canabrava, and others makes unnecessary further attention here to the large and illegal trade between Peru and Brazil"543.

Em âmbito nacional, sua tese de doutoramento figurou na Revista do IHGB em 1945, logo após ter sido publicada no Boletim da cadeira de História da Civilização Americana em $1944^{544}$. Feijó Bittencourt enquadra o trabalho na perspectiva da história social, necessária para a superação de uma história-filosófica, vinculando-a como produto da "Escola de Filosofia da USP" cuja prática de ensino se inspiraria na concepção de história de Capistrano de Abreu. Alice Canabrava teria lançado novo olhar para além da história política que destaca a disputa entre poderes coloniais e poderes locais. "Entretanto, ninguém imbuído dessa artificial concepção política da História, não via o grande desenrolar das questões econômicas dando feição e formação própria à história do Prata" $" 545$.

Como explicar as resenhas de sua tese de doutoramento em dois canais de divulgação historiográfica que hoje nos parecem tão distintos? Nas décadas de 1940 e 1950 o IHGB ainda figurava como a instituição legitimadora da produção historiográfica nacional. A produção historiográfica universitária ainda era reduzida e buscava também sua legitimação, o que pode ser atestado pela presença dos trabalhos de Alice Canabrava, Olga Pantaleão, Nícia Villela Luz e Maria da Conceição Martins Ribeiro no IV Congresso de História Nacional promovido por aquele silogeu em 1949. A seção de História Econômica e Social desse congresso estava organizada de acordo com a proposta de Capistrano de Abreu em seu "Capítulos de História Colonial”. Alice apresentou comunicação denominada "Um capítulo da história das técnicas no Brasil: o emprego da cana como combustível dos engenhos", certamente fruto de suas reflexões empreendidas em sua tese de livre-docência ${ }^{546}$. Assim, o IHGB, por sua longevidade, poderia ser tomado como uma instituição tradicional. Porém, o mesmo não pode ser afirmado quanto à sua produção historiográfica, distante de uma história mestra da vida e de uma história-

\footnotetext{
${ }^{543}$ HANKE, Lewis. The portuguese in Spanish America, with special reference to the Villa Imperial de Potosí. Revista de Historia de América. Pan American Institute of Geography and History, n. 51, 1961, p. 16.

${ }^{544}$ CANABRAVA, op. cit., 1944.

${ }^{545}$ BITTENCOURT, Feijó. O COMÉRCIO BRASILEIRO NO RIO DA PRATA - 1580-1640) - por Alice P. Canabrava. Revista do Instituto Histórico e Geográfico Brasileiro. Rio de Janeiro, v. 186, 1945, p. 209. ${ }^{546}$ CANABRAVA, op. cit., 1981a.
} 
filosófica outrora praticada, abria-se à recepção de obras oriundas das faculdades de filosofia. "[...] o conjunto dos trabalhos publicados nos Anais do IV Congresso de História Nacional revela que a produção da história do Brasil colonial alcançara um grau de maturidade que não mais admitia uma volta aos modelos tradicionais"547. Quanto aos Annales, uma hipótese aventada é de que buscavam firmar seu empreendimento historiográfico para além do território francês. Nada melhor do que mobilizar a participação de Braudel na "missão francesa" para estabelecer uma conexão annaliste na América Latina.

A obra de Alice Canabrava é tomada por José Honório Rodrigues como uma das pioneiras em história econômica, ao lado de Caio Prado Júnior, Roberto Simonsen, Alfredo Ellis Júnior dentre outros ${ }^{548}$. Francisco Iglésias, em balanço historiográfico da produção em história econômica no Brasil afirma, após as obras de síntese de Caio Prado Júnior e Celso Furtado, a necessidade de se empreender estudos monográficos com o fito de se fazer avançar o campo e cita como exemplo dois trabalhos da historiadora.

[...] o único modo de contribuir para o aprofundamento da história econômica do Brasil, está, pois, no estudo de um setor, com pesquisas extensas e intensas. Como exemplo dessa atitude, poderíamos lembrar ALICE P. CANABRAVA, com suas obras exaustivas e bem sucedidas (O comércio português no rio da Prata - 1580/1640; O desenvolvimento da cultura do algodão na Província de São Paulo $1861 / 1875)^{549}$.

O reconhecimento de Alice pelos pares passava também por Sérgio Buarque de Holanda. Em diversos balanços historiográficos, Sérgio Buarque analisa algum texto de sua autoria ${ }^{550}$. Em artigo publicado originalmente em 1952 e intitulado "História Econômica", Sérgio analisa as três teses acadêmicas de Canabrava e estabelece-a como sinônimo do campo ${ }^{551}$.

\footnotetext{
${ }^{547}$ GUIMARÃES, Lucia Maria Paschoal. IV Congresso de História Nacional: tendências e perspectivas da história do Brasil colonial (Rio de Janeiro, 1949). Revista Brasileira de História. São Paulo, v. 24, n. 48, 2004, p. 164.

${ }^{548}$ RODRIGUES, José Honório. Teoria da História do Brasil. Introdução metodológica. $3^{\circ}$ edição. São Paulo: Companhia Editora Nacional, 1969, p. 167.

${ }^{549}$ IGLÉSIAS, Francisco. Historiografia econômica brasileira. In: IGLÉSIAS, Francisco. Introdução à Historiografia Econômica. Belo Horizonte: Faculdade de Ciências Econômicas/UMG, 1959, p. 87.

${ }^{550}$ HOLANDA, op. cit., 2008. HOLANDA, Sérgio Buarque de. Sobre o Colloquium. In: COSTA, Marcos (org.). Escritos coligidos, 1950-1979. São Paulo: Editora Fundação Perseu Abramo; Editora UNESP, 2011. HOLANDA, Sérgio Buarque. Portugueses na América. In: COSTA, op. cit., 2011a.

${ }^{551}$ HOLANDA, op. cit., 2004.
} 
No início do relatório, Alice esclarece que a equipe responsável pelo tema, decidiu acolher a proposta de Cecília Westphalen para que o mesmo fosse tratado a partir do problema entre ensino tradicional e renovação, refletindo o dualismo acadêmico apontado por Falcon nos anos 1950 entre "renovação" e "tradição" "552.

A equipe sugeriu ao relator, como definição do problema, o apelo no sentido de que, no ensino da História do Brasil e da América, nas Faculdades de Filosofia, deve-se dar preferência à História da Cultura, e não propriamente à História Política, à História Administrativa, à História Biográfica etc., etc. A colocação do problema nestes termos não é ocasional, mas profundamente significativa da fase atual do desenvolvimento da Historiografia ${ }^{553}$.

Podemos inferir que, se o tratamento proposto para o tema se deu através da sugestão de uma abordagem renovadora do ensino de história do Brasil e da América, significa que, até aquele momento, predominava um ensino "tradicional" nas Faculdades de Filosofia. Caso de Hélio Vianna, catedrático de História do Brasil da FNFi/UB, “[...] muito focado na História política e com grande apreço por um excessivo detalhamento de fatos e datas, não acrescentava nada de muito inovador e estimulante em seus cursos"554. O mesmo se dava na cadeira de História da América, regida por Silvio Júlio.

Para sairmos do eixo Rio-São Paulo, uma vez que esse Simpósio contou com a participação de professores de outros estados, como 10 participantes de MG e outros 10 do PR, por exemplo, o caso da Faculdade de Filosofia (FAFI) da UMG ilustra uma tendência diversa em relação à FNFi/UB. Ambos os catedráticos, de História do Brasil e de História da América, respectivamente, Antonio Camillo de Faria Alvim e José Albamo de Morais, apesar de bacharéis em Direito, apresentavam uma prática de ensino distante daquela empreendida por Hélio Vianna e Silvio Júlio. O programa de ensino de Faria Alvim apresentava conteúdos elaborados a partir da leitura de Gilberto Freyre e de Sérgio Buarque de Holanda, e o de Albamo de Morais, trazia tópicos que poderíamos considerar de história da cultura, como hábitos e costumes dos povos pré-colombianos ${ }^{555}$.

Se formos mais para o sul, quanto ao ensino de história do Brasil e de história da América, na URGS temos conhecimento apenas de que o catedrático da primeira cadeira, Dante de Laytano, que também pertencia ao IHGRS, empreendia pesquisas e que não se

\footnotetext{
${ }^{552}$ FALCON, op. cit., 2015.

${ }^{553}$ CANABRAVA, op. cit., 1962, p. 121.

${ }^{554}$ FERREIRA, op. cit., 2013, p. 43.

${ }^{555}$ SANTOS, op. cit., 2013, p. 113-123.
} 
restringia apenas ao ensino como seus demais colegas, sendo o único que nas décadas iniciais do curso (1940/1950) escolheu se dedicar plenamente às atividades docentes e de pesquisa. Laytano marca uma diferença no perfil docente do curso de Geografia e História dessa instituição, uma vez que a preocupação central do curso e, nesse aspecto se aproxima do caso da FNFi/UB, era formar professores para o ensino secundário ${ }^{556}$. Foi responsável pela criação do Gabinete de Pesquisas Históricas do Rio Grande do Sul, primeira instituição no interior da UFRGS dedicada à pesquisa histórica, o qual congregava professores das disciplinas de história do Brasil e história do RS, já arejados em uma historiografia universitária como Silvia Petersen, Sandra Pesavento, Helga Piccolo. Em seus tempos de catedrático, na inexistência de uma disciplina de história do RS, dividia com essa última historiadora, sua assistente, o curso de história do Brasil de modo que pudesse tratar da história regional, cabendo à Piccolo os demais tópicos da cadeira $^{557}$. Ademais, como vimos, Laytano, juntamente com Helga Piccolo, foram responsáveis por organizar o núcleo regional da APUH no RS.

Se nos distanciarmos dos grandes centros, a situação quanto ao ensino de história do Brasil e de história da América é diferente, e o apelo de Cecília Westphalen juntamente com a equipe de Alice Canabrava se torna mais intelectivo. O curso de História da Universidade Federal de Alagoas, por exemplo, foi fundado por um padre católico em 1952 e seu corpo docente era formado por bacharéis em Direito, Engenharia e Medicina, marcados pelo autodidatismo e ligados ao Instituto Histórico e Geográfico de Alagoas. O perfil do curso somente se alteraria na década de $1970^{558}$.

Na região centro-oeste, o quadro não era diferente. O curso de Geografia e História da Faculdade de Filosofia da Universidade Católica de Goiás foi fundado em 1949 por religiosos com o fito de suprir a carência de professores e contou em seu corpo docente com padres, advogados, juízes, médicos e até farmacêuticos, cuja característica principal era o autodidatismo. Nos anos 1960 e 1970, os professores formados pela primeira geração passaram a fazer parte do corpo docente. Esses professores também passaram a

\footnotetext{
${ }^{556}$ Cf. RODRIGUES, Mara Cristina de Matos. O papel da universidade no "campo da história": o curso de Geografia e História da UPA/URGS na década de 1940. MÉTIS: história \& cultura. Caxias do Sul, v. 2, n. 2, p. 75-102, 2002.

${ }^{557}$ Cf. RODRIGUES, Mara Cristina de Matos. A formação superior em História na UPA/URGS/UFRGS de 1943-1971. História da historiografia. Ouro Preto, n. 11, p. 122-139, 2013.

${ }^{558}$ Cf. PORTO, Ana Luiz Araújo. O curso de História na Universidade Federal de Alagoas: dos primórdios à sua consolidação (1952-1979). Crítica histórica. Maceió, n. 1, p. 72-84, 2010.
} 
atuar junto ao curso de História quando da fundação da Universidade Federal de Goiás já nos anos 1960 e muitos deles realizaram seu doutoramento na USP nos anos $1970^{559}$.

Infelizmente ainda não contamos com trabalhos sobre o curso de História nos interiores do Brasil, o que nos impede de tecer uma radiografia completa do problema. No entanto, pelos intercâmbios intelectuais promovidos entre os professores das Faculdades de Filosofia preparatórios para esse Simpósio, o diagnóstico apontava para um ensino "tradicional" junto às cadeiras de História do Brasil e de História da América.

O relatório apresentado por Alice não traz marcas de oralidade e como o relatório de Maria Yedda Linhares, traz referências bibliográficas. Canabrava pôde, após a apresentação e debate de seu relatório durante a mesa-redonda do tema, enviar seu relatório revisado. Assim, o que temos é um texto que poderia ser publicado em qualquer outro espaço de divulgação historiográfico. Por mais que a historiadora se refira por duas vezes à equipe do tema, as intervenções de alguns de seus membros, como José Roberto do Amaral Lapa, Olga Pantaleão, Cecília Westphalen e Leda Maria Rodriguez fornecem indícios que corroboram o testemunho de Francisco Falcon ao afirmar que o relator estava dotado de autonomia em relação às discussões empreendidas durante o trabalho de equipe realizado em São Paulo antes do evento ${ }^{560}$.

Alice estrutura seu texto em torno das noções de "tradição" e de "renovação" da historiografia naquele momento. Essa dupla epistemológica se encarna em duas identidades historiadoras ao longo do texto: Afonso Taunay e Lucien Febvre, e no tratamento concedido à um objeto da história da historiografia brasileira, qual seja, o bandeirismo. A escolha dessa temática para apoiar seu argumento quanto à mudança de tratamento concedida a esse objeto não é fortuita. Quando Alice Canabrava ingressou na cadeira de História da Civilização Americana em 1938 como assistente de Paul Vanorden Shaw, seu primeiro trabalho de pesquisa foi um extenso levantamento bibliográfico sobre as bandeiras no arquivo público do Estado de São Paulo ${ }^{561}$. Além desse estudo, também foi responsável pela organização e comentário da bibliografia sobre bandeirismo no

\footnotetext{
${ }^{559}$ Cf. BORGES, Simone Aparecida. Os cursos de História da Universidade Católica de Goiás e da Universidade Federal de Goiás: um olhar histórico. 2006. 239 f. Dissertação (Programa de Pós-Graduação em Educação) - FE/UFG, Goiânia, 2006.

${ }^{560}$ Cf. FALCON, op. cit., 1963.

561 CANABRAVA, Alice Piffer. Ensaio Bibliográfico sobre as Bandeiras. Boletim Bibliográfico. São Paulo, Biblioteca Municipal de São Paulo, vol. V, p. 7-20, 1944a. CANABRAVA, Alice Piffer. Ensaio Bibliográfico sobre as Bandeiras. Boletim Bibliográfico. São Paulo, Biblioteca Municipal de São Paulo, v. VIII, p. 33-84, 1945.
} 
Manual Bibliográfico de Estudos Brasileiros, dirigido por Rubens Borba de Moraes e Willian Berrien ${ }^{562}$. Nesse mesmo ano de 1949 ela prefaciou livro que reúne documentos sobre as bandeiras no Paraguai ${ }^{563}$.

Alice divide a abordagem do bandeirismo paulista, "fenômeno social", em dois momentos. Um primeiro, que parte do estabelecimento de uma tradição oral do bandeirismo no último quartel do século XVIII instituída por Pedro Taques de Almeida Paes Leme em seu Nobiliarquia paulistana, passa por todo o século XIX e atinge seu ápice com a obra de Afonso Taunay, História Geral das Bandeiras Paulistas que reúne as mais importantes “fontes primárias" e "fontes secundárias" sobre esse objeto. De Pedro Taques à Taunay, uma plêiade de historiadores estabeleceu fatos, documentos, biografias, roteiros relacionados à exploração e ocupação do território pelos bandeirantes ${ }^{564}$. Em um segundo momento, Canabrava identifica uma mudança de abordagem após o primeiro quartel do século $\mathrm{XX}$, no qual o movimento bandeirante é compreendido enquanto unidade, enquanto "expressão da coletividade bandeirante": a sociedade paulista dos séculos XVII e XVIII. Esses historiadores, como Oliveira Vianna, Alfredo Ellis Júnior, Alcântara Machado de Oliveira, Benedito Bastos Barreto, Sérgio Buarque de Holanda e Jaime Cortesão, se debruçaram sobre a compreensão dessa unidade em termos de seu contato com o meio físico, com o meio social e cultural e de seu alcance na formação econômico-social brasileira.

A primeira concepção de bandeiras Alice vincula à Afonso Taunay, uma história em sua "fase empírica", preocupada com o relato e o arrolamento dos fatos registrados e a segunda a partir de uma epistemologia da história informada pelas ciências sociais. Causa-nos estranhamento o lugar ocupado por Capistrano de Abreu e seu Caminhos antigos e povoamento do Brasil de 1930, nessa breve análise de Canabrava sobre o bandeirismo. Capistrano figura entre os representantes da "fase empírica", preocupada

\footnotetext{
${ }^{562}$ CANABRAVA, Alice Piffer; MORAES, Rubens Borba de. História. Período Colonial. In: MORAES, Rubens Borba de; BERRIEN, Willian (dirs.). Manual Bibliográfico de Estudos Brasileiros. Rio de Janeiro: SOUZA, 1949, p. 401-407.

563 CANABRAVA, Alice Piffer. Prefácio. In: Bandeirantes no Paraguai. Século XVII. Documentos Inéditos. São Paulo: Divisão do Arquivo Histórico do Departamento de Cultura da Prefeitura do Município de São Paulo, 1949a, p. VIII-XVI.

${ }^{564}$ Dentre os citados por Alice Canabrava nesse intercurso estão: José de Souza Azevedo Pizarro e Araujo, Baltazar da Silva Lisboa, Inácio Acioli de Cerqueira e Silva, Braz da Costa Rubim, Joaquim Felício dos Santos, José Martins Pereira de Alencastre, Luís Antônio da Silva e Souza, Orville Derby, Diogo de Vasconcelos, João Pandiá Calógeras, Gentil de Assis Moura, Francisco Borges de Barros e Capistrano de Abreu.
} 
com o estabelecimento dos fatos. Em seu mencionado estudo bibliográfico sobre as bandeiras, a historiadora apresenta uma análise dúbia sobre o historiador cearense. Em um primeiro momento, Capistrano é caracterizado como pioneiro ao empregar a geografia em seus estudos.

Capistrano foi o primeiro historiador contemporâneo a tratar da influência do elemento geográfico como fator da conquista, frisando a importância histórica das grandes vias fluviais na formação territorial do país. Muitos problemas econômicos e sociais do drama da dilatação geográfica do território, foram referidos por ele ${ }^{565}$.

Sabemos que uma das marcas da produção historiográfica de Capistrano é a mobilização da antropogeografia de Friedrich Ratzel ${ }^{566}$. Vários autores apontam como diferencial da obra de Capistrano em relação aos estudos históricos de seu tempo a mobilização do aparato proveniente das ciências sociais, como a $\operatorname{sociologia}^{567}$ e a economia ${ }^{568}$. No mesmo parágrafo em que consta o excerto acima, Alice afirma que

[...] seu avanço em relação aos estudos precedentes, foi resultado da consulta de maior número de fontes originais referentes ao bandeirismo, negligenciadas pelos seus contemporâneos. Mas, em virtude do culto estrito da documentação, da minúcia erudita, da tendência para os problemas de detalhe, [...] tendeu para a transcrição dos dados documentais, com poucas observações rápidas ${ }^{569}$.

Os estudos sobre Capistrano de Abreu geralmente dividem sua prática historiadora em duas: uma mais "empírica" e outra já informada pelo recurso às ciências sociais ${ }^{570}$. Canabrava parece ter inaugurado esse viés de análise.

O apelo da equipe de história do Brasil e da América pela "renovação" do ensino de história é tomado por Alice enquanto ressonância daquele formulado por Marc Bloch e Lucien Febvre no primeiro número da Revista Annales de 1929, qual seja, o de inserir a história no rol das ciências sociais e compreendê-la enquanto uma disciplina enquadrada

\footnotetext{
${ }^{565}$ CANABRAVA, op. cit., 1944a, p. 13-14.

${ }^{566}$ Em 1927, apesar de não citar Ratzel, mas somente Wappaeus e Sellin, Pandiá Calógeras aponta para a mobilização da moderna Geografia alemã por Capistrano e o qualifica de "antropogeógrafo". Cf. CALÓGERAS, João Pandiá. ["Necrológio de Capistrano de Abreu"]. Atas da $6^{\text {a }}$ Sessão Ordinária, 13/09/1927. Revista do IHGB. Rio de Janeiro, t. 101, v. 155, 1927, p. 352.

${ }^{567}$ Para Capistrano, sem o auxílio da nova "ciência sociológica", não era possível perceber as relações constitutivas dos diferentes aspectos e fatores da vida de um povo. Cf. OLIVEIRA, op. cit., 2013, p. 53. PEREIRA, op. cit., 2002, p. 125.

${ }^{568}$ GONTIJO, op. cit., 2013, p. 240.

${ }^{569}$ CANABRAVA, op. cit., 1944a, p. 14.

570 Ver, por exemplo: FALCON, Francisco José Calazans. Capistrano de Abreu e a historiografia cienticifista: entre o positivismo e o historicismo. In: NEVES, Lucia Maria Bastos Pereira das et all. (org.). Estudos de Historiografia Brasileira. Rio de Janeiro: Editora FGV, 2011c.
} 
nas conquistas intelectuais de seu tempo. A historiadora define o objeto dessa história, e que foi exemplificado pela segunda fase de estudos do bandeirismo enquanto unidade social, a partir de Lucien Febvre e Georges Gurvitch. Ela mobiliza "Combates pela história" para afirmar que seu objeto é o conhecimento, explicação e interpretação das sociedades humanas no tempo e em sua totalidade. Apoiada em Gurvitch, define a "realidade histórica" como parte privilegiada da realidade social. Os "nós", os grupos, as classes, as sociedades globais que tomam consciência delas próprias ${ }^{571}$.

A referência a Gurvitch evoca a sociologia e a operação intelectual engendrada por Fernand Braudel nos anos 1940-1950 de oposição à uma gama de historiadores e sociólogos que destacavam a descontinuidade temporal como marca da realidade histórica $^{572}$. Braudel, em artigo de 1953, analisa a primeira parte do livro de Georges Gurvitch intitulado Vocation actuelle de la sociologie, publicado em 1950. Para Braudel, a crítica de Gurvitch à concepção de continuidade temporal dos historiadores, manifestada em suas análises sobre as filosofias da história, se traduz em um antihistoricismo que instaura enquanto única referencialidade temporal o presente, ou seja, há uma impossibilidade quanto a existência da própria disciplina histórica ${ }^{573}$.

Em artigo publicado na seção "Debates e Combates" da revista Annales, Gurvitch contrapõe os métodos da história e da sociologia, bem como seu tratamento concedido à temporalidade. Chama atenção a nota de Braudel que abre o artigo, demarcando que o que será tratado pelo autor está em discordância com sua própria compreensão e de Lucien Febvre quanto à relação entre história e sociologia. Para ambos, não há uma oposição entre "história ou sociologia", mas sim uma relação entre "história e sociologia". O artigo de Gurvitch não trata a história da maneira exposta por Braudel em sua análise do livro do sociólogo, qual seja, que a história deva lidar simplesmente com as descontinuidades. Para Gurvitch, o método sociológico é tipológico e acentua a descontinuidade dos tipos e das escalas, bem como das relações entre os fenômenos sociais totais e suas estruturas, enquanto o método da história é individualizante, juntando os pontos entre os tipos sociais que ela singulariza e individualiza ao limite, sem o recurso

\footnotetext{
571 CANABRAVA, op. cit., 1962.

572 VOIGT, André Fabiano. Um debate sobre a descontinuidade temporal: Fernand Braudel, Gaston Bachelard, Gaston Roupnel e Georges Gurvitch. História da historiografia. Ouro Preto, n. 13, p. 188-203, 2013.

573 BRAUDEL, Fernand. Georges Gurvitch ou la discontinuité du social. Annales: économies, sociétés, civilisations. Paris, ano 8, n. 3, p. 347-361, 1953.
} 
à uma solução de continuidade entre as estruturas globais e os fenômenos sociais globais, reconstruindo a continuidade do tempo. Assim, para o autor, a tendência da história, do ponto de vista do método, seria mais continuísta que a sociologia, mesmo que ambas se debrucem sobre o mesmo objeto: os fenômenos sociais globais. O ponto nodal da análise de Gurvitch e, portanto, sua crítica à história está na distinção entre realidade histórica e ciência história. A segunda, estabelece para a realidade histórica uma continuidade artificial a partir de uma filosofia da história teleológica. Sua crítica, portanto, aos historiadores, se manifesta no sentido de apontar a artificialidade de sua narrativa continuísta do tempo vis a vis a descontinuidade da realidade histórica ${ }^{574}$. A oposição de Braudel às teses do tempo descontínuo dos anos 1940-1950 foi um dos fatores que permitiu o estabelecimento de sua formulação tripartite do tempo histórico. A referência de Alice à Georges Gurvitch pode ser compreendida a partir do projeto annaliste de, ao mesmo tempo, integrar aquilo que lhe interessa epistemologicamente, neste caso a continuidade do tempo histórico, e de expurgar o desvio, neste caso de Braudel, a ruptura. Ao final, tem-se uma história social que é ciência social, mas que silencia o desvio.

Para exemplificar o recurso da história às ciências sociais e também, mais uma vez para contrapor os dois modelos de historiador, Alice se vale de artigo de Charles Morazé publicado em 1957 na Revue historique sobre Lucien Febvre e seus intercâmbios intelectuais para formular a pergunta e acentuar sua relação com as ciências sociais ${ }^{575}$ : “O que lia Lucien Febvre?” A Revue de Synthese Historique de Henri Berr; os Annales de Géographie, o Année Sociologique, os trabalhos de Vidal de la Blache, Durkheim, Camille Jullian, Rauh etc, alguns deles citados por Lucien Febvre no prefácio de "Combates pela história" de 1952, incluindo o próprio Charles Morazé576. Canabrava lança a mesma pergunta em relação à Afonso Taunay, para ela, um dos grandes historiadores brasileiros cuja formação intelectual se prende à tradição do século XIX. Em sua mesa de trabalho poderíamos encontrar coletâneas de documentos, vários números das revistas dos institutos históricos regionais, mas principalmente do IHGB. “Dois historiadores, duas épocas na História da Historiografia: a História puramente narrativa (histoire événementielle ou histoire historisante) e a reflexão histórica alargada

\footnotetext{
${ }^{574}$ GURVITCH, Georges. Continuité et discontinuité en histoire et en sociologie. Annales: économies, sociétés, civilisations. Paris, ano 12, n.1, p. 73-84, 1957.

${ }^{575}$ MORAZÉ, Charles. Lucien Febvre et l'histoire vivante. Revue historique. Paris, t. 217, f. 1, p. 1-19, 1957.

${ }^{576}$ FEBVRE, Lucien. Prefácio. In: . Combates pela história. Lisboa: Editorial Presença, 1985, p. 7-10.
} 
e aprofundada com o concurso de outras ciências"577. Dentre elas, cita a sociologia, a antropologia e a economia, com seu desenvolvimento da teoria econômica nos últimos 20 anos que teria promovido uma aproximação cada vez maior entre historiadores e economistas. Para exemplificar essa colaboração entre historiadores e economistas Alice remete-nos ao volume 17 de 1957 do The Journal of Economic History, formado por 4 números. A quantidade de artigos não nos permite avaliar, nesse momento, a procedência da afirmação de Canabrava, mas um rápido olhar sobre seu número 1, por exemplo, nos mostra resenhas de livros de Marc Bloch, Lucien Febvre, Pierre Chaunu etc, ou seja, um periódico anglo-saxão com intensa circulação internacional.

Para Alice, essa mudança epistemológica representada por Lucien Febvre na maneira de se abordar os objetos da história, conduziu à prática de uma história econômica e social. Para tanto, julga indispensável o recurso à análise quantitativa por meio da estatística. Apesar de Lucien Febvre e Marc Bloch não terem adotado em sua prática historiográfica os recursos estatísticos, como faria Ernest Labrousse e cujo modus operandi econômico e estatístico ganharia força somente nos anos 1950, reconheciam sua importância, principalmente a partir dos trabalhos de François Simiand. "Febvre vê o futuro da história no recurso aos métodos estatísticos, não podendo mais os historiadores contentar-se com a paleografia e a diplomática" ${ }^{978}$.

Ao mobilizar a estatística, o historiador muda sua relação com as fontes. Tal aspecto também é abordado por Alice a partir da proposta de Lucien Febvre pela ampliação do estatuto das fontes para além do documento escrito. Para a historiadora, o documento escrito permanece fundamental, e também faz coro aos que militam pela preservação dos arquivos, quanto a necessidade de preservação e divulgação dos arquivos públicos e eclesiásticos e da transferência dos arquivos particulares para domínio público $^{579}$. Porém, assinala que outros elementos também registram a presença do

\footnotetext{
577 CANABRAVA, op. cit., 1962, p. 124.

578 DELACROIX, Christian.; DOSSE, François.; GARCIA, Patrick. As correntes históricas na França: séculos XIX e XX. Rio de Janeiro: FGV, 2012, p. 181. Bloch é mais crítico em relação à mobilização da estatística no aparato analítico de Simiand, uma vez que para ele a quantificação, sem negar sua importância, não seria suficiente para explicar o comportamento econômico coletivo. Cf. Idem, p. 182. ${ }^{579}$ Duas moções foram aprovadas no I Simpósio expressando preocupação com a preservação de fontes. Uma que apela à conferência dos bispos do Brasil para que se preservem os documentos paroquiais e se facilite o acesso dos historiadores aos mesmos. Cf. Moção 19. In: Anais..., op. cit., 1962, p. 297. E outra que apela às autoridades competentes para que criem arquivos e museus locais e regionais com o fito de se preservar a documentação histórica. Cf. Moção 20. In: Anais..., op. cit., 1962, p. 298.
} 
homem, conforme citação de "Combates pela história", como a paisagem, a língua, os edifícios, as plantas, os animais, as áreas cultivadas etc ${ }^{580}$.

Outro ponto tratado por Alice e que foi sugerido pela equipe do tema, é a história comparada. Se a história é a mais difícil de todas as ciências, segundo a concepção de Fustel de Coulanges, para Canabrava, a área mais difícil da história é a história comparada, uma vez que ela necessita ter claro quais são os dados comparáveis quando se pretende aproximar a história de regiões diferentes no tempo e espaço. A historiadora cita a crítica de Henri-Irenée Marrou à obra de Arnold Toynbee A study of history em relação ao método comparativo ${ }^{581}$. Marrou questiona o método de Toynbee ao comparar elementos de vinte e uma civilizações sem considerar as essências de cada uma delas em sua realidade total, mas simplesmente sublinhando suas analogias parciais. Ademais, critica a concepção de civilização de Toynbee como um organismo que "cresce, declina e morre", calcada em uma assimilação de categorias provenientes da biologia ${ }^{582}$. A study of history é a monumental obra de Toynbee (1889-1975) publicada em 12 volumes entre 1934 e 1961 que empreende uma história comparada das civilizações. Mesmo que se possa detectar uma mudança na concepção de história do autor ao longo dos volumes, de um empirismo expresso em uma história factualista e descritiva que depois incorpora a teologia como seu leitmotiv, "[...] a aproximação com uma concepção calcada nas ciências da natureza é que sustenta sua metodologia comparativa" ${ }^{\Perp 583}$.

Se formos à referência da citação de Marrou em nota ao final do texto, constataremos que Alice referencia apenas o tomo 217 da Revue Historique, sem seu respectivo fascículo. A citação é extraída de artigo sobre metodologia histórica, sendo este o segundo de uma série de três. Nele, o autor justifica um segundo artigo sobre a questão à partir de uma tendência internacional de reflexão sobre o ofício de historiador, iniciando com a análise do manifesto de Herbert Butterfield, um historiador de Cambridge, por uma história da historiografia consubstanciado em seu livro de 1955 Man

\footnotetext{
${ }^{580}$ CANABRAVA, op. cit., 1962, p. 123-124.

581 Para uma breve análise da história comparada das civilizações de Toynbee, ver: BARROS, José D’Assunção. Arnold Toynbee e a história comparada das civilizações. Biblos. Rio Grande, n. 23, p. 219229, 2009. Para um histórico do método comparativo, ver: ___. Origens da história comparada. A experiência com o comparativismo histórico entre o século XVIII e a primeira metade do século XX. Anos 90. Porto Alegre, v. 14, n. 25, p. 141-173, 2007.

${ }^{582}$ CANABRAVA, op. cit., 1962, p. 125.

583 ARRAIS, Cristiano. Arnold Toynbee (1889-1975). In: BENTIVOGLIO, Julio; LOPES, Marcos Antônio. A Constituição da História como Ciência. De Ranke a Braudel. Petrópolis: Vozes, 2013, p. 267.
} 
on his past, the study of the history of historical scholarship. O exercício de Marrou, partindo de Butterfield e incorporando os estudos de Arnaldo Momigliano e de Pieter Gayl é o de empreender uma história da historiografia desde os "antigos", passando pelos "modernos" até os historiadores profissionais contemporâneos. Arnold Toynbee é incorporado a esse rol via Gayl, uma vez que esse ocupou a posição de antagonista do historiador britânico durante uma série de debates promovidos pela BBC de Londres em 1946, 1949, 1952 e 1954 denominada "Debates with historians". Os comentários de Marrou sobre a obra de Toynbee, incluindo seu A study of history, tomam menos de 04 páginas em um artigo de 19 páginas $^{584}$. Sendo assim, ao contrário do que poderíamos inferir, ou seja, que o artigo referenciado por Alice fosse todo dedicado a magnum opus do historiador britânico, e que, portanto, tratava-se de um artigo sobre história comparada, não é o caso.

Tal escolha, nos leva ao questionamento das motivações de Canabrava: Por que ao tratar da história comparada a historiadora mobiliza Marrou e não Marc Bloch e seu Por une histoire comparée des sociétés européennes de $1928^{585}$ ? Afinal, o método proposto por Marc Bloch neste texto está longe de qualquer modelo tributário às ciências naturais $^{586}$. Ao escolher um autor que critica o método comparativo em Toynbee, Alice, indiretamente adere à história comparada de Marc Bloch. Ademais, para nós, seu intento naquele momento era frisar o recurso da história às ciências sociais, demarcando que qualquer assimilação à partir das ciências naturais, como a biologia, por exemplo, estava fora "das conquistas intelectuais de seu tempo" e deveria ser rechaçada, como o faz Marrou em relação à Toynbee. Alice sugere enquanto inspiração para os historiadores que se propõe a realizar história comparada, os trabalhos de análise quantitativa dos economistas estadunidenses. Trata-se da "cliometria", cujo principal expoente é o economista Robert Fogel com sua obra "Time on the Cross" em parceria com Stanley Engerman, uma vertente da história quantitativa estadunidense, desenvolvida nos anos

\footnotetext{
${ }^{584}$ MARROU, Henri-Irénée. L'histoire et les historiens. Second chronique de méthodologie historique. Revue historique. Paris, t. 217, f. 2, p. 270-289, 1957.

585 BLOCH, Marc. Pour une histoire comparée des sociétés européenes. Revue de Synthèse Historique. Paris, n. XLVI, p. 15-50, 1928. Republicado em: BLOCH, Marc. História e historiadores. Lisboa: Teorema, 1998, p. 119-150.

586 Para uma breve apresentação do projeto de história comparada de Marc Bloch, ver: BARROS, José D'Assunção. História comparada - da contribuição de Marc Bloch à constituição de um moderno campo historiográfico. História Social. Campinas, n. 13, p. 7-21, 2007a. Ver também: AYMARD, Maurice. Histoire et comparaison. In: ATSMA, Hartmut; BURGUIÈRE, Andre (dirs.). Marc Bloch aujourd'hui. Histoire comparée \& sciences sociales. Paris: L'École des Hautes Études em Sciences Sociales, 1990.
} 
1950, cujo sucesso ficou restrito àquele país norte-americano devido ao prestígio internacional da história quantitativa francesa ${ }^{587}$.

Ao final do relatório, Alice, sempre utilizando-se do "nós" legitimador dos pares da equipe ${ }^{588}$, aborda o problema, que também veio à tona em outras mesas redondas, do lugar da cadeira de História do Brasil como centro do curso. Para ela, a história do Brasil, deve estar inserida em um contexto mundial que a remete à história moderna e contemporânea e essas, por sua vez, à história antiga e medieval. Assim, os recursos de pesquisa não devem estar centrados na cadeira de história do Brasil e nada impede que se empreendam esforços para o desenvolvimento de pesquisas em história moderna e contemporânea nas Faculdades de Filosofia ${ }^{589}$.

Para nós, o relatório de Alice, encampado por Cecília Westphalen, José Roberto do Amaral Lapa, Eurípedes Simões de Paula, Astrogildo Rodrigues de Mello, Olga Pantaleão etc, pode ser tomado enquanto manifesto pela renovação do ensino de história, mas, sobretudo, como manifesto pela renovação da história. Sua estratégia discursiva se dá pela oposição de duas identidades historiadoras: Afonso Taunay e Lucien Febvre. O que significa, naquele momento, vincular Taunay à uma epistemologia da história que remonta ao século XIX e Febvre à outra, informada pelas ciências sociais e sinônimo de renovação? Se tivermos em perspectiva que a tese de doutoramento de Alice foi prefaciada por Afonso Taunay quando de sua publicação no Boletim da cadeira de História da Civilização Americana em 1944 e ao mesmo tempo por Braudel na revista Annales trata-se muito mais de encampar a estratégia de Lucien Febvre em relação aos historiadores metódicos do século XIX, ou seja, desqualificar para ganhar terreno e fixar um modelo historiográfico. Em inícios dos anos 1960, em um contexto intelectual no qual os Annales estão na hegemonia do campo historiográfico francês, o que também se consubstancia através da ocupação de cargos-chave no ambiente institucional e de financiamentos, a "renovação" tem que se distanciar de qualquer resquício que possa ainda remontá-la ao século XIX. A história, agora, deve ser ciência social, deve ser, portanto, história social. A legitimação de tal discurso também se dá por meio de quem o

\footnotetext{
587 Ver: NOGUERÓL, Luiz Paulo Ferreira. Histórias econômicas de economistas - Cliometria e Nova Economia Institucional. Locus: revista de história. Juiz de Fora, v. 14, n. 1, p. 91-112, 2008.

${ }^{588}$ Para Michel de Certeau o "nós" do autor se insere em uma convenção. "No texto, ele é a encenação de um contrato social 'entre nós'. É um sujeito plural que 'sustenta' o discurso. Um 'nós' se apropria da linguagem pelo fato de ali ser posto como locutor". CERTEAU, op. cit., 2011, p. 55.

${ }^{589}$ CANABRAVA, op. cit., 1962, p. 125-126.
} 
emite. Em 1961, como afirmamos acima, a produção historiográfica de Alice era toda orientada pela ciência econômica e preparava a introdução da nova edição de Cultura e Opulência do Brasil por suas Drogas e Minas de Antonil. No testemunho de Francisco Falcon, o relatório de Alice,

[...] marcou o primeiro sopro "atual" do Simpósio, numa síntese brilhante e quase sempre de vanguarda. Ergueu-se, afinal, um relator para defender as conexões entre a História e as Ciências Sociais; tendência tão sensível na História dos nossos dias; a importância da História Comparada; a colocação da História do Brasil no plano geral da História do Mundo ${ }^{590}$.

Ao corporificar em Lucien Febvre a renovação historiográfica em contraposição à tradição identificada em Afonso Taunay, a historiadora, além de identificar a si com aquela epistemologia da história e suas práticas, ou seja, incorporar uma história social, opera discursivamente para que a associação esteja epistemologicamente orientada segundo aquela noção de história, mesmo que, como vimos, em sua avaliação, os trabalhos apresentados nos vários Simpósios apresentem traços de uma história factual.

Em discurso proferido por ocasião dos dez anos da entidade durante o VI Simpósio Nacional ocorrido na cidade de Goiânia em 1971, ela estabelece como condição social de possibilidade para a existência da associação a criação das Faculdades de Filosofia, pioneiramente as de São Paulo (FFCL/USP em 1934) e do Rio de Janeiro (UDF/RJ em 1935). Em nível intelectual, científico, ela realiza esforço discursivo no sentido de estabelecer a entidade como praticante de uma moderna historiografia orientada pelo empreendimento de 1929 em torno da criação da revista Annales.

Sob esta influência desenvolveu-se a moderna historiografia brasileira, da qual a ANPUH constitui uma expressão. Qualificando-a como "moderna", queremos acentuar que, lhes dá força e ao mesmo tempo a distingue de outras correntes do pensamento histórico, a compreensão metodológica que a situa no centro das ciências do Homem e no universo da História Geral ${ }^{591}$.

Como vimos acima, nos discursos de Eurípedes Simões de Paula, em uma tentativa de invenção de uma identidade dos profissionais de história em torno de Marc Bloch e Lucien Febvre, e de Cecília Westphalen, em torno de Fernand Braudel, ela

\footnotetext{
${ }^{590}$ FALCON, op. cit., 1963, p. 193.

${ }^{591}$ CANABRAVA, Alice Piffer. Discurso da Profa. Alice Piffer Canabrava, $1^{\mathrm{a}}$ secretária da ANPUH. In: Anais..., v. I, op. cit., 1973, p. 86.
} 
também recorre aos primeiros annalistes para estabelecer os contornos do que poderíamos considerar uma comunidade epistêmica profissional.

Os pressupostos epistemológicos de uma história cientificamente orientada, cujas práticas ela remete aos primeiros annalistes são reiterados por ocasião do lançamento da $R B H$, em texto que historiciza a associação. O exercício discursivo empreendido por Canabrava é de forjar uma memória associativa que vincula a ANPUH, desde suas origens, como expressão de uma moderna historiografia brasileira, sem lugar para o amadorismo anterior. Essa moderna historiografia seria fruto da influência dos primeiros professores franceses presentes nos empreendimentos da FFCL/USP e da UDF/RJ.

A História é compreendida no centro das Ciências do Homem e cada uma de suas qualificações, no universo da História Geral. Destarte, ao desenvolver-se a nossa entidade, tornaram-se claros os vínculos que a ligavam ao movimento intelectual que se expressa, desde 1929, nas páginas dos Annales ${ }^{592}$.

Como apontamos algumas vezes acima, a principal ciência social a orientar a história praticada por Alice, é a ciência econômica. Em duas ocasiões, ela mobiliza sua leitura de Formação Econômica do Brasil de Celso Furtado para apontar imprecisões de análise ${ }^{593}$. A primeira se deu por conta de comunicação apresentada por Eurípedes Simões de Paula, durante o II Simpósio, na qual o mesmo aponta para a característica autárquica dos latifúndios do período colonial ${ }^{594}$. Em sua intervenção, Canabrava contesta a autarquia dos engenhos de açúcar do período colonial afirmada pelo expositor. Para ela, a publicação de "As contas do engenho Sergipe Conde", pelo Instituto do Açúcar e do Álcool, demonstra a especialização dos grandes engenhos, onde se comprava o mais comezinho. Citando Celso Furtado, afirma que em Formação Econômica do Brasil, o autor demonstra que a alta rentabilidade conduziu à especialização. Todos os fatores de

\footnotetext{
${ }^{592}$ CANABRAVA, op. cit., 1981 b, p. 4.

${ }^{593}$ Este livro de Celso Furtado possui poucas referências historiográficas pelo fato de que em suas linhas podemos reconhecer interpretações de vários historiadores brasileiros. Em sua tese de doutoramento L'économie coloniale brésilienne (XVIe et XVIIe siècles), defendida na Universidade de Paris em 1948, há uma primeira parte em que o economista apresenta suas referências historiográficas, dentre elas Capistrano de Abreu, Caio Prado Júnior, Gilberto Freyre etc. Somente através do cotejo entre Formação Econômica do Brasil de 1959 e das obras anteriores de Celso Furtado é que podemos reconhecer marcas historiográficos. Cf. SZMRECSÁNYI, Tamás. Sobre a formação da Formação Econômica do Brasil de C. Furtado. Estudos Avançados. São Paulo, v. 3, n. 37, p. 207-214, 1999. Para uma ampla análise da obra ver: ARAÚJO, Tarcísio Patricio de; VIANNA, Salvador Teixeira Werneck; ACAMBIRA, Júnior (orgs.). 50 anos de Formação Econômica do Brasil: ensaios sobre a obra clássica de Celso Furtado. Rio de Janeiro: Ipea, 2009.

${ }^{594}$ PAULA, Eurípedes Simões de. As origens do latifúndio: da 'villa' romana aos engenhos e fazendas do Brasil Colonial. In: Anais..., op. cit., 1962a, p. 85-101.
} 
produção, portanto, estiveram concentrados na produção de açúcar ${ }^{595}$. A segunda se deu por ocasião da comunicação de Maria Stella Bresciani, inserida no projeto coordenado por Carlos Guilherme Motta ${ }^{596}$, durante o VII Simpósio Nacional ocorrido em 1973 em Belo Horizonte ${ }^{597}$. Em sua intervenção, Alice tece considerações quanto à figura do agregado e seu desaparecimento por conta da cultura cafeeira. Sua hipótese é de que a expansão do café significou uma valorização da terra. Sendo assim, o dono da terra não teria interesse em cedê-la ao trabalhador livre para o plantio de subsistência, mas sim auferir renda a partir da cultura cafeeira utilizando-se do braço escravo. Ademais, aponta que com uma oferta de terras abundante, não há estímulo para o desenvolvimento técnico, conforme explicado por Celso Furtado no capítulo X de Formação Econômica do Brasil $^{598}$.

Como analisamos acima, a compreensão do aparato econômico mobilizado por Celso Furtado em seu livro, pressupõe o domínio da macroeconomia keynesiana. Grosso modo, A teoria geral do emprego, do juro e da moeda publicado por John Maynard Keynes (1883-1946) ${ }^{599}$ em 1936, demonstra que as teorias neoclássicas com inspiração principalmente em David Ricardo e em Adam Smith não eram suficientes para explicar os momentos de crise do capitalismo. A proposta de Keynes para superar as crises do capitalismo, principalmente durante baixas do ciclo econômico, era de se implantar políticas monetárias e fiscais anticíclicas. Assim, em face à crise de emprego enfrentada nos EUA por conta da depressão de 1930, onde as teorias neoclássicas se mostraram insuficientes, uma vez que seu corolário de que "a oferta gera sua própria demanda" perdeu capacidade explicativa, a política de Keynes sugeria criar demanda pelo lado da oferta de empregos, ou seja, adotar uma política fiscal expansionista com o fito de gerar empregos públicos, resolvendo o problema do emprego e da superprodução por meio do aumento da demanda. Para Celso Furtado, a política adotada de queima dos estoques de café seria uma política anticíclica de matiz keynesiana.

No Brasil, um dos primeiros expoentes do pensamento keynesiano, apesar de suas poucas referências explícitas à Keynes, foi Celso

\footnotetext{
${ }^{595}$ CANABRAVA, Alice Piffer. Intervenções. In: Anais..., op. cit., 1962, p. 105.

${ }^{596}$ MOTTA, Carlos Guilherme. Mudanças sociais e estruturas mentais no Brasil (1789-1937). In: Anais..., op. cit., 1974, p. 56.

${ }^{597}$ BRESCIANI, Maria Stella. Escravos, libertos e imigrantes: estudo sobre a passagem do trabalho escravo para o livre em Campinas e Porto Feliz de 1870 a 1910. In: Anais..., op. cit., 1974, p. 947-949.

${ }^{598}$ CANABRAVA, Alice Piffer. Intervenções e respostas. In: Anais..., op. cit., 1974, p. 969-970.

${ }^{599}$ Para uma biografia em três volumes de Keynes, ver: SKIDELSKY, Robert. John Maynard Keynes 18831946: Economist, Philosopher, Statesman. London: Penguin books, 2005.
} 
Furtado. Nesta direção, talvez sua obra mais influente tenha sido a Formação Econômica do Brasil, trabalho brilhante e seminal, de leitura fluente e impactante até o presente, imediatamente reconhecida como uma aplicação da abordagem macroeconômica proposta por Keynes à historiografia econômica ${ }^{600}$.

Assim, as constantes referências de Alice à Formação Econômica do Brasil de Celso Furtado, são indício de que estava familiarizada com o aparato da teoria keynesiana. Ainda durante o VII Simpósio Nacional ocorrido em Belo Horizonte em 1973, ela intervém durante comunicação de Adalberto Marson, do departamento de História da FFLCH/USP, onde coloca em diálogo algumas teorias do desenvolvimento formuladas por sociólogos e a teoria de Alberto Torres sobre as relações cidade-campo ${ }^{601}$. Em sua intervenção, Canabrava qualifica Keynes como “o último dos grandes neoclássicos” e questiona se Alberto Torres seria um pioneiro do intervencionismo estatal no Brasil ${ }^{602}$. Ao propor a intervenção estatal na esfera econômica, Keynes não poderia ser tomado enquanto neoclássico, mesmo que tenha dialogado com esses teóricos e os conhecesse profundamente. Uma hipótese por nós aventada quanto à interpretação de Alice da obra de Keynes, está relacionada ao fato de que a obra de Keynes pode ser lida como um caso específico da teoria neoclássica, ou seja, uma teoria para a crise.

Durante o III Simpósio realizado em Franca em 1965 com a temática geral “artesanato, manufatura e indústria”, seu amigo Francisco Iglésias apresentou trabalho que versou sobre "artesanato, manufatura e indústria. Nota conceitual e tentativa de aplicação no Brasil"603. Em sua intervenção, Alice Canabrava ressalta a qualidade do trabalho, reconhecendo a grande dificuldade de periodização do desenvolvimento das transformações da matéria prima e da produção de bens de consumo e produção no Brasil. Porém, questiona-se sobre a validade da periodização proposta, apontando algumas contradições, como o estabelecimento do segundo momento com D. João VI, uma vez que o próprio autor afirma que não se concretizaram as políticas de desenvolvimento intentadas, tendo permanecido muito mais no campo das possibilidades do que da realidade; quanto ao terceiro momento, a partir de 1850, Iglésias afirma que a reforma

\footnotetext{
${ }^{600}$ CARVALHO, op. cit., 2008, p. 571.

${ }^{601}$ MARSON, Adalberto. Urbanização e relações cidade-campo na obra de Alberto Torres. In: Anais..., 1974, op. cit., p. 791-803.

${ }^{602}$ CANABRAVA, Alice Piffer. Intervenções. In: Anais..., op. cit., 1974, p. 805.

${ }^{603}$ IGLÉSIAS, Francisco. Artesanato, manufatura e indústria. Nota conceitual e tentativa de aplicação no Brasil. In: Anais..., op. cit., 1966, p. 105-124.
} 
tarifária não logrou seus objetivos e a economia cafeeira continuou a expandir-se e o texto refere-se às "chamadas fábricas" e não às fábricas propriamente ditas; no quarto impulso, no início do período republicano, Iglésias conclui que se caracteriza mais pela manufatura; no quinto momento, com a I Guerra, as alterações seriam de cunho mais quantitativo do que qualitativo. Tendo isso em vista, pergunta se o "take-off", a arrancada para a industrialização no Brasil não se daria somente a partir da II Guerra ${ }^{604}$. Para tecer comentários acerca da comunicação de Iglésias, Alice necessitaria conhecer a teoria do desenvolvimento do economista Rostow, para compreender o conceito de "take-off". Mais uma vez o lugar de fala de Alice, ou seja, catedrática de História Econômica Geral e Formação Econômica do Brasil pode explicar a mobilização de conhecimentos em teorias do desenvolvimento econômico.

Ainda durante esse Simpósio, na comunicação de Sônia Aparecida Siqueira ${ }^{605}$, Alice Canabrava, após cumprimentar a autora pelas pesquisas desenvolvidas, assinala uma imprecisão conceitual na mobilização do conceito de estamento formulada por Max Weber. Após explanar sobre em que consistiu o erro da comunicação, Alice reafirma um dos corolários da história por ela praticada e que sintetiza, para nós, sua epistemologia da história, bem como parte de sua identidade historiadora: "O desenvolvimento da História como ciência, requer do historiador sólida formação teórica no campo amplo das ciências sociais" $" 606$.

No mencionado VII Simpósio de 1973, sua intervenção à comunicação "Insurreições liberais: fenômeno urbano?"607 denota sua preocupação com o rigor conceitual em história:

[...] ao nível conceitual, não cabe a caracterização fundamental que distingue a cidade: o aglomerado de população que produz para exportar (bens e serviços) e importa para sobreviver. Esta é a cidade propriamente dita. Parece-lhe que nos textos em estudo, a distinção é feita quanto ao local de residência - a área rural ou o núcleo chamado "urbano", sem possibilidade, aos autores da comunicação, de uma vinculação conceitual ${ }^{608}$.

\footnotetext{
${ }^{604}$ CANABRAVA, Alice Piffer. Intervenções. In: Anais..., op. cit., 1966, p. 127-128.

${ }^{605}$ SIQUEIRA, Sônia Maria. Artesanato e privilégios. Os artesãos no Santo Ofício no Brasil do século XVIII. In: Anais..., op. cit., 1966, p. 503-522.

${ }^{606}$ CANABRAVA, Alice Piffer. Intervenções. In: Anais..., op. cit., 1966 p. 524.

${ }^{607}$ CAVALCANTI, Zélia. MARSON, Izabel. MOURA, Sérgio Lobo de. Insurreições liberais: fenômeno urbano? In: Anais..., op. cit., 1974 p. 333-343.

${ }^{608}$ CANABRAVA, Alice Piffer. Intervenções. In: Anais..., op. cit., 1974, p. 344.
} 
Detivemo-nos nas intervenções em que Alice mobiliza a ciência econômica para empreender suas análises e/ou comentários, bem como naquelas em que a mesma reitera a necessidade de rigor conceitual como uma das condições de possibilidade para o exercício de uma história informada pelo aparato teórico das ciências sociais. Porém, Alice Canabrava realizou um número maior de intervenções nos vários Simpósios da ANPUH em que participou e que mereceriam um texto separado. 


\section{Capítulo 3}

\section{Alice Piffer Canabrava, o Instituto de Estudos Brasileiros da USP e o “Encontro Internacional de Estudos Brasileiros. I Seminário de Estudos Brasileiros"}

A criação do IEB/USP remonta à uma cultura acadêmica peculiar de Sérgio Buarque de Holanda à frente da cadeira de História da Civilização Brasileira da FFCL/USP. Sérgio assumiu interinamente a cadeira por ocasião da aposentadoria de Alfredo Ellis Júnior, no segundo semestre de 1956 e tornou-se catedrático por concurso em 1958 quando apresentou a tese Visão do Paraíso ${ }^{609}$. Dois anos depois, Sérgio figurava como coordenador da História Geral da Civilização Brasileira (HGCB), na qual contribuíram vários de seus assistentes, bem como Alice Canabrava com dois capítulos, marcando o período de predomínio das contribuições de autores vinculados à USP, signo de um empreendimento intelectual especializado ${ }^{610}$.

Para Sérgio, os trabalhos desenvolvidos em torno da cadeira não atingiam os objetivos por ele desejados, quais sejam, formar professores e pesquisadores em história do Brasil que pudessem exercer seu ofício de forma autônoma, principalmente na lide com as fontes e estabelecer uma perspectiva multidisciplinar de pesquisa em história do Brasil. Para tanto, Sérgio propôs em 1962 ao então diretor da FFCL/USP, Candido Lima da Silva Dias e ao reitor da USP, Antônio Barros de Ulhôa Cintra, a criação de um Instituto dedicado aos estudos brasileiros que gozasse de autonomia financeira e administrativa. Esse é um aspecto importante, uma vez que essa autonomia também permitiria uma autonomia intelectual, posto que não estaria sujeito ao rígido regime de cátedras. Esse Instituto deveria congregar todas as cadeiras da USP que se dedicassem

\footnotetext{
${ }^{609}$ Cf. Cadeira de História da Civilização Brasileira. In: Noticiário. RIEB. São Paulo, n. 2, 1967, p. 189193. Os vários números da RIEB estão disponíveis em: 〈http://www.revistas.usp.br/rieb>. Acessado em 22 de abr. 2019.

${ }^{610}$ Cf. FURTADO, André Carlos. Coleção História Geral da Civilização Brasileira (HGCB): organização interna, especialização acadêmica, disputas letradas e editoriais. In: __. As edições do cânone. Da fase buarqueana na coleção História Geral da Civilização Brasileira (1960-1972). 2014. 248 f. Dissertação (Programa de Pós-Graduação em História) - IH/UFF, Niterói, 2014, p. 69-102. Durante o período em que Sérgio foi coordenador da HGCB (1960-1972), que correspondem à "Época colonial” e "O Brasil Monárquico", das 132 colaborações, 82 são da USP e 50 de outras instituições, sendo 33 colaborações do próprio Sérgio. Para Furtado, esse perfil indica para a urdidura das redes de sociabilidade de Sérgio, bem como a publicação da coleção sob os auspícios da USP. Em livro: FURTADO, André Carlos. As edições do cânone - Da fase buarqueana na coleção "História Geral da Civilização Brasileira" (1960-1972). Niterói: Eduff, 2016.
} 
aos estudos da realidade brasileira, uma vez que, como podemos depreender de seu projeto da $\mathrm{HGCB}$, Sérgio concebia que uma realidade tão complexa não poderia ser apreendida por uma única disciplina, mas sim que deveria haver um esforço multidisciplinar de tratamento, ou seja, cada disciplina daria seu olhar sobre o Brasil, porém, sem perder suas características teórico-metodológicas em prol de seu objeto ${ }^{611}$.

O Conselho de Administração (CA) do IEB foi empossado em 10 de outubro de 1962, composto pelas seguintes cadeiras e seus respectivos catedráticos: História da Civilização Brasileira, Sérgio Buarque de Holanda (FFCL); Geografia do Brasil, Aroldo de Azevedo (FFCL); Literatura Brasileira, Mário Pereira de Souza Lima (FFCL); Antropologia e Etnografia do Brasil, Egon Schaden (FFCL); História Econômica Geral e do Brasil, Alice Piffer Canabrava (FCEA); Geografia Econômica Geral e do Brasil, Dirceu Lino de Mattos (FCEA); Economia Brasileira, Antônio Delfim Netto (FCEA); História da Arquitetura no Brasil, Eduardo Kneese de Mello (FAU). Notamos o predomínio de catedráticos da FFCL, seguidos pelos da FCEA, dentre eles Alice Canabrava, única mulher. Esse conselho elegeu a primeira diretoria do IEB: Sérgio Buarque de Holanda e Aroldo de Azevedo ${ }^{612}$.

Ao longo de sua existência, o IEB adquiriu e/ou recebeu por doação conjuntos documentais, uma das principais preocupações de Sérgio Buarque com o treinamento no manejo de fontes ${ }^{613}$, livros e obras de arte que deram origem a seu arquivo, biblioteca e coleção de artes visuais. Além disso, ofereceu cursos de extensão desde 1966, criou uma revista no mesmo ano, a Revista do Instituto de Estudos Brasileiros (RIEB), realizou exposições, produziu documentários e promoveu variegados eventos sobre temas brasileiros, incluindo-se o de maior envergadura e participação: o "Encontro Internacional de Estudos Brasileiros. I Seminário de Estudos Brasileiros”, doravante I SEB, ocorrido em $1971^{614}$.

Através da atuação de Alice Canabrava no CA do IEB, objetivamos mapear sua participação nos cursos oferecidos, o que significa pensar sua contribuição à área de

\footnotetext{
${ }^{611}$ Cf. CALDEIRA, João Ricardo de Castro. IEB: origem e significados. Uma análise do Instituto de Estudos Brasileiros. São Paulo: Oficina do livro Rubens Borba de Moraes/Imprensa oficial do Estado, 2002. ${ }^{612}$ Ibidem.

${ }^{613}$ Cf. BATISTA, Marta Rossetti. Sérgio Buarque de Holanda e o Instituto de Estudos Brasileiros. In: CALDEIRA, João Ricardo de Castro. Perfis buarqueanos: ensaios sobre Sérgio Buarque de Holanda. São Paulo: Fundação Memorial da América Latina/IMESP, 2005, p. 49-55.

${ }^{614}$ Cf. CALDEIRA, op. cit., 2002.
} 
estudos brasileiros através de uma abordagem que privilegia a história econômica. Ademais, como uma das coordenadoras da área de história do I SEB, buscamos refletir sobre o significado de se pensar a história inserida na área de estudos brasileiros, bem como a contribuição desse seminário para a história da historiografia brasileira. Para tanto, mobilizamos enquanto fonte, as "Atas do Conselho de Administração do IEB/USP" produzidas durante o período no qual Alice esteve nesse Conselho (1962-1981); os "relatórios gerais de atividade" do IEB/USP publicados na RIEB; e os Anais do Encontro Internacional de Estudos Brasileiros. I Seminário de Estudos Brasileiros.

Os "relatórios gerais de atividade" passaram a ser publicados na RIEB a partir de 1968 e podem ser tomados como um discurso de construção pública do Instituto. Ademais, os "relatórios gerais" silenciam quanto à alguns aspectos da formação dos vários acervos do IEB, como o fato de que a proposta para aquisição do acervo pessoal de Mário de Andrade ter sido capitaneada por Antonio Cândido de Mello e Souza em carta ao então diretor do IEB José Aderaldo Castello ${ }^{615}$ e não por este último conforme relatório geral para o ano de $1967^{616}$.

As "Atas do Conselho de Administração" registram as reuniões desse conselho desde 1964, quando ainda eram realizadas na residência de Sérgio Buarque de Holanda e nos permitem analisar a instituição de um ponto de vista em que os problemas de sua construção se tornam mais evidentes. As atas, ainda, podem ser pensadas como uma série de ordenamentos discursivos, os quais são policiados pelo diretor e selecionados pelo secretário a partir de quem toma a palavra.

\subsection{A atuação de Alice Canabrava no Conselho Administrativo do IEB/USP}

A primeira reunião do CA do IEB ocorreu na residência de Sérgio Buarque de Holanda, em 30 de janeiro de 1964, com a presença de José Aderaldo Castello ${ }^{617}$, Egon

\footnotetext{
${ }^{615}$ Cf. Ata do Conselho de Administração do Instituto de Estudos Brasileiros.

${ }^{616}$ Cf. Relatório Geral das Atividades do Instituto de Estudos Brasileiros da Universidade de São Paulo em 1967.

${ }^{617}$ Substituiu Mário Pereira de Souza Lima, regente da cadeira desde 1939 por conta do desdobramento da antiga cadeira de Literatura Luso-brasileira em duas: cadeira de Literatura brasileira e cadeira de Literatura portuguesa. Lima tornou-se catedrático por concurso em 1945 e permaneceu na regência da cadeira até sua aposentadoria em 1963. Cf. Cadeira de Literatura brasileira. In: Noticiário. RIEB. São Paulo, n. 3, 1968, p. 193-198.
} 
Schaden, Dirceu Lino de Mattos e Eduardo Kneese de Mello ${ }^{618}$. A ausência de Alice Canabrava se fez notar até a décima segunda reunião, já em sua sede no prédio da reitoria da cidade universitária, ocorrida em 06 de maio de $1966^{619}$, sob a diretoria de Egon Schaden e Sérgio Buarque ${ }^{620}$. Porém, sem tomar a palavra. Anos se passariam até que Alice assumisse a chefia do setor de pesquisa e documentação do IEB, bem como a coordenação da área de história do I SEB em 1971. A partir daí, sua presença no CA seria uma constante, ao contrário de seus dois colegas da FCEA: Antonio Delfim Netto ${ }^{621}$ e Dirceu Lino de Mattos, com presenças esporádicas.

Chefiado primeiramente por Sérgio Buarque ainda sob a denominação de setor de pesquisas, o setor de pesquisa e documentação foi criado com o fito de descentralizar as decisões e iniciativas que cabiam ao diretor. A esse setor " [...] caberia a coordenação de um trabalho de equipe que contaria com a colaboração de todas as cadeiras que compõem o IEB"622. Essa é uma característica da cultura acadêmica do IEB, preconizada por Sérgio Buarque, que instaura uma diferença em relação à FFCL e à FCEA: uma pesquisa coletiva que envolva todas as cadeiras representadas no instituto. No regime de cátedras vigente na FFCL, sabemos que cada catedrático cuidava de sua respectiva área e que, em muitos casos, qualquer tentativa de se tratar de assuntos ou períodos de outras cátedras era logo tolhida.

O primeiro trabalho de equipe coordenado pelo setor de pesquisas foi implantado em 1966 e denominado “As vésperas da independência”. Seu programa foi sistematizado em doze tópicos: antecedentes; a Europa no alvorecer do século XIX; consequências da migração da família real; organização político-administrativa; as etnias e o problema da mão de obra; a vida urbana; a vida rural; a vida econômica; vias e meios de transporte; a vida financeira; a vida cultural; o Brasil reino. Nestes doze tópicos incluíram-se vários

${ }^{618}$ Cf. Ata da $1^{\text {a }}$ reunião do Conselho de Administração ocorrida em 30/01/1964. Atas do Conselho de Administração do Instituto de Estudos Brasileiros da Universidade de São Paulo. Livro I (1964-1977). Fundo IEB. IEB001-01-0002. Arquivo IEB/USP, f. 2.

${ }^{619}$ Cf. Ata da $12^{\mathrm{a}}$ reunião do CA ocorrida em 06/05/1966. Atas do CA do IEB/USP. Livro I. Fundo IEB. IEB001-01-0014. Arquivo IEB/USP, verso f. 23.

${ }^{620}$ Cf. Instituto de Estudos Brasileiros. Regulamento - Histórico - Organização. In: Noticiário. RIEB. São Paulo, n. 1, 1966, p. 188.

${ }^{621}$ A ausência de Delfim Netto no CA do IEB pode ser explicada pelo afastamento de suas funções acadêmicas por conta da participação como ministro da fazenda nos governos dos ditadores Costa e Silva (1967-1969) e Médici (1969-1973). Para sua trajetória intelectual e política ver: MACEDO, Roberto. Antonio Delfim Netto. Estudos Avançados. São Paulo, v. 15, n. 43, p. 375-388, 2001.

${ }^{622}$ Instituto de Estudos Brasileiros. Regulamento - Histórico - Organização. In: Noticiário. RIEB. São Paulo, n. 1, 1966, p. 189. 
itens divididos entre as várias cadeiras componentes do IEB. O tópico vida econômica, foi desdobrado em: atividades na lavoura; a economia açucareira; o café e outras culturas; a criação de gado e os produtos derivados; as feiras de gado; o extrativismo vegetal; a mineração e as primeiras fundições; o sal e o salitre; manufaturas e ofícios mecânicos; o comércio exterior; o comércio interno e seus problemas. O tópico vias e meios de transporte, por sua vez, desdobrou-se em: caminhos e estradas; tropas e tropeiros. Pousos de tropas; a navegação; os portos. Ambos ficaram à cargo da cadeira de História Econômica e, portanto, de Alice Canabrava ${ }^{623}$.

As discussões acerca dessa pesquisa em equipe tiveram lugar ainda no ano de 1965 durante reunião do CA da qual Alice esteve ausente. Aroldo de Azevedo propôs, e o CA acatou, que Sérgio Buarque propusesse a organização, execução e a temática da pesquisa conjunta ${ }^{624}$. Na reunião seguinte, Buarque de Holanda comenta que não elaborou um plano de trabalho para a pesquisa em grupo, uma vez que preferia ouvir todas as cadeiras e suas propostas. Apenas sugeriu o período que se estende da chegada da família real em 1808 até a abdicação de D. Pedro I em 1831, uma vez que, para ele, este é um período pouco estudado, mas que traz fatos importantes para o desenvolvimento histórico do país. Aroldo de Azevedo afirma que esboçou um projeto de pesquisa que se estende de 1822 a 1831, de acordo com o que julga mais significativo para o período em termos geográficos. Para ele, o recorte proposto por Sérgio, vice-reinado, reinado e Brasil independente não apresentaria uma unidade. Porém, poder-se-ia pensar o período anterior ao proposto por Azevedo como "antecedentes". O historiador argumenta que não vê problemas em se tomar o período por ele proposto como recorte para a pesquisa em grupo, uma vez que os fatos que seriam estudados possuem estreitas relações com a vinda da família real ${ }^{625}$.

Eduardo Kneese de Mello toma a palavra para afirmar que concorda com o ponto de vista de Sérgio Buarque, demarcando a importância da missão artística francesa no desenvolvimento das artes em geral. Aderaldo Castello corrobora a proposta de Sérgio argumentando sobre a importância para o movimento romântico no Brasil das reformas

\footnotetext{
${ }^{623}$ Cf. Instituto de Estudos Brasileiros. Regulamento - Histórico - Organização. In: Noticiário. RIEB. São Paulo, n. 1, 1966, p. 189-191.

${ }^{624}$ Cf. Ata da $5^{\text {a }}$ reunião do CA ocorrida em 20/08/1965. Atas do CA do IEB/USP. Livro I. Fundo IEB. IEB001-01-0006. Arquivo IEB/USP, verso f. 7.

${ }^{625}$ Cf. Ata da 6 a reunião do CA ocorrida em 03/09/1965. Atas do CA do IEB/USP. Livro I. Fundo IEB. Arquivo IEB/USP. IEB001-01-0007, f. 9-verso f. 9.
} 
implantadas por D. João VI como a criação da biblioteca nacional, da imprensa régia etc. Por fim, Buarque de Holanda afirma que, em termos práticos, pode-se dividir o recorte da pesquisa em dois: um período entre 1808 e 1822 e outro de 1822 a 1831, sem o prejuízo daqueles aspectos que podem ser tratados ao longo de todo o período estabelecido. A proposta foi unanimemente aprovada pelos conselheiros ${ }^{626}$. Quanto ao título da pesquisa, Egon Schaden, diretor, afirma que o primeiro será escolhido de acordo com o andamento da mesma, possibilitando uma ideia mais clara dos vários aspectos a serem analisados. Schaden, questiona sobre os aspectos sociológicos do trabalho, uma vez que não há representante dessa área no conselho. Ficou deliberado que essa parte da pesquisa seria orientada pelo próprio Schaden e que toda a parte pertinente às artes, ficaria a cargo de Eduardo K. de Mello. Por fim, solicita que cada catedrático elabore seu plano de pesquisa e o encaminhe à Sérgio Buarque ${ }^{627}$.

A partir dessas reuniões do CA tomamos ciência de que o representante de cada cadeira componente do IEB ficou responsável por enviar seu projeto à Sérgio Buarque. Quanto ao problema da periodização, o programa nos deixa antever que se abordou desde o período que antecede a vinda da família real, portanto, anterior à 1808 , e se estende até $1822^{628}$. Ao tomarmos o projeto enviado por Alice para integrar a pesquisa coletiva coordenada por Sérgio Buarque de Holanda e cotejarmos o mesmo com sua produção historiográfica, percebemos que a historiadora já havia tratado de vários de seus tópicos em pesquisas anteriores. Quanto à atividade açucareira, por exemplo, Canabrava dominava todos os meandros do assunto desde a elaboração de sua tese para concorrer à cadeira de História da Civilização Americana em 1946, A Indústria do Açúcar nas Ilhas Inglesas e Francesas do Mar das Antilhas (1697-1755) ${ }^{629}$, reiterada em estudos posteriores $^{630}$, inclusive em capítulo de livro encomendado por Sérgio Buarque de

\footnotetext{
${ }^{626}$ Ata da $6^{\text {a }}$ reunião do CA ocorrida em 03/09/1965. Atas do CA do IEB/USP. Livro I. Fundo IEB. Arquivo IEB/USP. IEB001-01-0007, verso f. 9.

${ }^{627} \mathrm{Cf}$. Idem, verso f. 9-f. 10.

${ }^{628}$ Cf. Instituto de Estudos Brasileiros. Regulamento - Histórico - Organização. In: Noticiário. RIEB. São Paulo, n. 1, 1966, p. 189-191.

${ }^{629}$ Por ocasião do concurso foram entregues cem cópias conforme exigência do edital. Foi publicada em livro somente em 1981, por conta dos 35 anos de fundação da FEA/USP: O Açúcar nas Antilhas (16971755). $2^{\circ}$ edição. São Paulo: Instituto de Pesquisas Econômicas, 1981a.

${ }^{630}$ CANABRAVA, Alice Piffer. A influência do Brasil na Técnica do Fabrico do Açúcar nas Antilhas Francesas e Inglesas no meado do século XVII. In: Anuário da Faculdade de Ciências Econômicas e Administrativas (1946-1947). São Paulo: USP; Faculdade de Ciências Econômicas e Administrativas, p. 63-76, 1948. CANABRAVA, Alice Piffer. Um capítulo da História das técnicas no Brasil: o emprego do bagaço de cana como combustível dos engenhos. Anais IV Congresso de História Nacional. Rio de Janeiro: Imprensa Nacional, v. 11, p. 459-471, 1950c. CANABRAVA, Alice Piffer. A força motriz: um problema
} 
Holanda e que seria publicado na HGCB: "A grande propriedade rural"631. Nesse capítulo, ainda, tratou de várias culturas e sua estrutura de propriedade como o fumo e o algodão. Canabrava também abordou aspectos concernentes à manufatura e ofícios mecânicos do recorte da pesquisa coletiva em uma palestra proferida no curso de férias (1961-1962) do "Luso-brazilian center" da Universidade de Wisconsin em parceria com a UFRGS, intitulada "Manufaturas e indústrias no período de D. João VI no Brasil"

Em relação a outros itens do projeto coletivo, a historiadora, provavelmente, estava trabalhando neles. Como outro capítulo que integraria a HGCB de Sérgio Buarque: "A grande lavoura" ${ }^{633}$. Nele, Alice aborda as grandes lavouras do café, da cana, do fumo e do cacau, bem como seu comércio externo, este último, também um dos itens do projeto de pesquisa coletiva. Todos esses itens já haviam sido abordados em seus cursos. Apesar de não termos em mãos os programas da cadeira de História Econômica ao longo das décadas, podemos inferir que alguns temas, por terem sido alçados ao cânone de clássicos na literatura, não deixaram de ser tratados ao longo das décadas. É o caso dos tópicos do curso de História Econômica do Brasil, 1500-1914, oferecido por Canabrava à turma de Ciências Econômicas da FCEA em 1948. Ela divide o curso em dois grandes períodos: 1500-1808 e 1808-1914, ou seja, assim como na pesquisa coletiva, o impacto da vinda da família real é mais do que um marco, traz profundas mudanças estruturais. Para o período 1500-1808, aborda em seu curso: as condições da colonização; o ciclo do pau-brasil; o ciclo da cana de açúcar; o ciclo da mineração; a pecuária; a mão de obra; o comércio; os transportes; a moeda ${ }^{634}$. Ademais, para o ano letivo de 1950 , ela ofereceu um seminário sobre "O desenvolvimento da indústria no Brasil", no qual abordou as atividades

da técnica da indústria do açúcar colonial (A solução antilhana e a brasileira). Anais do primeiro congresso de História da Bahia. Salvador: tipografia beneditina Ltda, v. IV, p. 337-350, 1950c. CANABRAVA, Alice Piffer. A lavoura canavieira nas Antilhas e no Brasil (primeira metade do século XVIII). Anais do primeiro congresso de História da Bahia. Salvador: tipografia beneditina Ltda, v. IV, p. 351-387, 1950c.

${ }^{631}$ CANABRAVA, Alice Piffer. A grande propriedade rural. In: HOLANDA, op. cit., 1960, p. 192-217.

${ }^{632}$ CANABRAVA, Alice Piffer. Manufaturas e indústrias no período de D. João VI no Brasil. In: CANABRAVA, Alice Piffer. História Econômica: estudos e pesquisas. São Paulo: Hucitec; Unesp; ABPHE, 2005, p. 85-101.

${ }^{633}$ CANABRAVA, Alice Piffer. A grande lavoura. In: HOLANDA, Sérgio Buarque de. (dir.). História Geral da Civilização Brasileira. O Brasil monárquico. t. II, v. 4: declínio e queda do império. São Paulo: difusão europeia do livro, 1971, p. 85-137.

${ }^{634}$ Cf. Cadeira X - História Econômica. In: Programas. Anuário da Faculdade de Ciências Econômicas e Administrativas (1946-1947). São Paulo: USP; Faculdade de Ciências Econômicas e Administrativas, 1948, p. 160. Para o ano letivo de 1950, Alice oferece o mesmo curso de história econômica do Brasil. Ver: Cadeira X - História Econômica. In: Programas. Anuário da Faculdade de Ciências Econômicas e Administrativas (1949-1950). São Paulo: USP; Faculdade de Ciências Econômicas e Administrativas, 1950, p. 75. 
industriais da colônia, item também presente no programa de pesquisa conjunta ${ }^{635}$. Assim, não podemos afirmar que por conta da pesquisa conjunta no IEB, Alice Canabrava tenha elaborado uma nova agenda de pesquisa.

Além dos catedráticos de cada área constitutiva do IEB, seu corpo de pesquisadores, contratados na função de historiógrafos, estava ligado ao setor de pesquisas e também participavam da pesquisa coletiva "As vésperas da independência", caso de Maria Odila Dias Curly, auxiliar de ensino da cadeira de História da Civilização Brasileira $^{636}$, através do "[...] levantamento de um índice de informações dos livros dos viajantes Cralke Abel, Sir James Edward Alexander e de Henry Maril Brackenridge"637. Foi somente nesse "relatório de atividades" que se especificou a colaboração de um historiógrafo no projeto "O Brasil às vésperas da independência", novo título do projeto. Nos demais, a contribuição de cada um deles é exposta de forma genérica: "Todos os historiógrafos acima referidos colaboram na pesquisa integrada sobre ' $O$ Brasil às vésperas da independência', em andamento, conforme plano geral já divulgado em relatórios anteriores - 1966, 1967"638. A última menção à pesquisa coletiva no "relatório geral de atividades" data de 1970. Quando Alice Canabrava assume em 1971 o setor de pesquisa e documentação, figura apenas a síntese dos relatórios de pesquisa de cada historiógrafo ${ }^{639}$.

Quanto aos resultados da pesquisa coletiva, não encontramos nenhuma menção à mesma em nenhum dos números consultados da RIEB, principal canal de publicação dos trabalhos produzidos pelos pesquisadores e pelos catedráticos e seus assistentes de pesquisa, para o período 1966-1970. Tampouco em livro publicado pelo instituto ${ }^{640}$.

\footnotetext{
${ }^{635}$ Ibidem.

${ }^{636}$ Cf. Cadeira de História da Civilização Brasileira. In: Notícias. RIEB. São Paulo, n. 2, 1967, p. 189-193.

${ }^{637}$ Cf. Relatório geral das atividades do Instituto de Estudos Brasileiros da Universidade de São Paulo em 1967. In: Noticiário. RIEB. São Paulo, n. 5, 1968, p. 185. Maria Odila tomou contato com esses viajantes durante a elaboração de sua dissertação: $O$ Brasil na historiografia romântica inglesa; $R$. Southey e W. Scott: um estudo de afinidades de visão histórica, defendida em 1965. Sua tese de doutoramento, orientada por Sérgio Buarque de Holanda, foi integralmente dedicada à Southey. Ver: DIAS, Maria Odila Leite da Silva. O fardo do homem branco: Robert Southey, historiador do Brasil. São Paulo: Nacional, 1974.

${ }^{638}$ Relatório geral das atividades do Instituto de Estudos Brasileiros da Universidade de São Paulo em 1968. In: Noticiário. RIEB. São Paulo, n. 6, 1969, p. 200. Ver também: Relatório geral das atividades do Instituto de Estudos Brasileiros da Universidade de São Paulo em 1969. In: Noticiário. RIEB. São Paulo, n. 8, 1970, p. 186. Relatório geral das atividades do Instituto de Estudos Brasileiros da Universidade de São Paulo em 1970. In: Noticiário. RIEB. São Paulo, n. 11, 1972, p. 182.

${ }^{639}$ Cf. Relatório geral das atividades do Instituto de Estudos Brasileiros da Universidade de São Paulo em 1971. In: Noticiário. RIEB. São Paulo, n. 12, 1972, p. 205.

${ }^{640}$ Cf. CALDEIRA, op. cit., 2002, p. 146-150.
} 
Tomamos conhecimento, através da ata de uma reunião do CA, da existência de um livro de atas do setor de pesquisas. Porém, durante nossa consulta ao Fundo IEB do Arquivo IEB/USP não localizamos o mesmo ${ }^{641}$.

Como afirmamos acima, Alice assumiu as funções de chefe do setor de pesquisa e documentação em 1971. Durante a reunião de número 54 do CA, a sexta reunião em que Alice Canabrava participou, em função de pedido de pós-graduando para efetuar cópia de manuscrito, o CA decidiu instituir um regulamento para consulta à cargo da historiadora e votou em seu nome para chefiar aquele setor ${ }^{642}$. Ela foi indicada para tal posto, uma vez que, desde que Sérgio Buarque solicitara sua demissão da cadeira de História da Civilização Brasileira em 1969, em ato de apoio àqueles colegas que haviam sido aposentados compulsoriamente pela ditadura ${ }^{643}$, Carlos Drummond, da cadeira de Línguas indígenas do Brasil da FFCL ${ }^{644}$ chefiava interinamente o setor ${ }^{645}$. No lugar de Sérgio Buarque no CA, passou a figurar a livre-docente Nícia Villela Luz ${ }^{646}$, regente interina da cadeira de História da Civilização Brasileira da FFCL ${ }^{647}$.

${ }^{641}$ O Fundo IEB do Arquivo IEB/USP ainda não está aberto à consulta pública. É composto por 8343 documentos divididos em dois agrupamentos: "diretorias" e "séries documentais". Porém, seu nível de descrição não atinge suas inúmeras unidades documentais, o que não nos permite localizar em cada caixa o documento procurado.

${ }^{642} \mathrm{Cf}$. Ata da $54^{\mathrm{a}}$ reunião do CA ocorrida em 22/10/1971. Atas do CA do IEB/USP. Livro I. Fundo IEB. Arquivo IEB/USP. IEB001-01-0056, verso f. 141.

${ }^{643}$ Cf. CARVALHO, Rapahel Guilherme de. Sérgio Buarque de Holanda, do mesmo ao outro: escrita de si e memória (1969-1986). 2017. 328 f. Setor de Ciências Humanas - UFPR. Tese (Programa de PósGraduação em História). 2017, p. 146-147. Disponível em: <https://acervodigital.ufpr.br/bitstream/handle/1884/46337/R\%20-\%20T\%20$\% 20$ RAPHAEL $\% 20$ GUILHERME $\% 20$ DE $\% 20$ CARVALHO.pdf? sequence $=1$ \&isAllowed $=\mathrm{y}>$. Acessado em 30 de set. 2019.

${ }^{644}$ Tal cadeira foi criada em 1962 após a extinção da cadeira de Etnografia e língua tupi-guarani por conta do falecimento de Plínio Ayrosa, vinculada à antiga seção de Geografia e História. Carlos Drummond atuava como livre-docente junto à cadeira de Ayrosa e assumiu, por contrato, a regência da cadeira de Línguas indígenas do Brasil, vinculada, dessa vez, à seção de Letras. Como seu assistente figura Jurn Jacob Philipson, que também trabalhava na cadeira de Ayrosa. Cf. Cadeira de Línguas indígenas do Brasil. In: Notícias. RIEB. São Paulo, n. 2, 1967, p. 195-198.

${ }^{645}$ A partir de 1965 a referida cadeira passou a contar com representação no IEB. Cf. Instituto de Estudos Brasileiros. Regulamento - Histórico - Organização. In: Noticiário. RIEB. São Paulo, n. 1, 1966, p. 187.

${ }^{646}$ Esta não é a primeira vez que os caminhos de Nícia Villela Luz, bacharel em Geografia e História pela FFCL/USP em 1942, e de Alice Canabrava se cruzaram na USP. Em 1947, ambas trabalhavam como técnico de administração no setor de História do Instituto de Administração anexo à FCEA/USP. Sua principal contribuição à historiografia econômica é seu estudo sobre a industrialização brasileira antes de 1930, A luta pela industrialização do Brasil, 1808 a 1930, em um momento no qual o debate sobre desenvolvimento econômico, de matiz nacionalista era candente. Cf. RIBEIRO, Maria Alice Rosa. Lutas e conquistas das primeiras historiadoras em história econômica 1934-1972. In: SASES; RIBEIRO; SAES, op. cit., 2017, p. 168-174.

${ }^{647}$ Nícia V. Luz substituía Sérgio Buarque quando este estava impossibilitado de comparecer às reuniões, como, por exemplo na $14^{\mathrm{a}}$ reunião. Cf. Ata da $14^{\mathrm{a}}$ reunião do CA ocorrida em 23/09/1966. Atas do CA do IEB/USP. Livro I. Fundo IEB/USP. Arquivo IEB/USP; IEB001-01-0016, verso f. 27. 
A sucessão de Sérgio Buarque de Holanda na cadeira de História da Civilização Brasileira da FFCL é um acontecimento que Alice acompanhou e que nos deixa entrever sua relação com esse historiador. Sérgio Buarque pretendia se aposentar desde 1966, uma vez que já possuía anos de trabalho para tanto. Porém, a grande questão que surgia no horizonte, e que preocupava o historiador, dizia respeito à sua sucessão. Em carta de Alice Canabrava a seu amigo Francisco Iglésias datada de 01 de maio de 1966, a historiadora afirma que teve com Sérgio Buarque e que este sugeriu o nome de Iglésias para sucedêlo.

Sérgio e eu tínhamos muita esperança de que V. viesse para a Cadeira de História do Brasil, na aposentadoria do Sérgio. Ninguém mais indicado do que V. Por que não se anima? Além dos seus predicados intelectuais, V. tem grandes amigos na Filosofia que o receberiam de braços abertos. E, para matar as saudades de Minas e da família, a distância não é muito grande nos fins de semana. Pense seriamente no assunto, Iglésias, e se resolva. Venha ${ }^{648}$.

Vimos que a cultura acadêmica da FFCL/USP se caracterizava por seu caráter misógino. Some-se a isso outro aspecto dessa cultura, qual seja, a interdição de recrutamento em relação aos outsiders ${ }^{649}$. Desde a vinda da "missão francesa", a dinâmica de sucessão das cátedras se dava através da escolha do pupilo pelo professor estrangeiro. Daí em diante, os professores brasileiros continuaram com essa dinâmica sucessória, onde não havia espaço para as mulheres, tampouco para outsiders. Como sabemos, a cadeira de História da Civilização Brasileira foi deixada à cargo de professores brasileiros desde sua fundação. Porém, todos provenientes de instituições paulistas. O fato de Francisco Iglésias, um mineiro, professor da Faculdade de Ciências Econômicas da UFMG, ter sido cotado para ocupar aquela cadeira, denota o prestígio intelectual de que gozava e a força de seu capital intelectual no campo universitário paulista. Por isso, talvez, não fosse considerado um outsider.

\footnotetext{
${ }^{648}$ São Paulo, 01 de maio de 1966. FI-C-CP (088). Acervo Francisco Iglésias. Instituto Moreira Salles/RJ (IMS/RJ).

${ }^{649}$ A partir de Norbert Elias, a figuração estabelecidos-outsiders pode ser compreendida a partir dos diferenciais de poder no campo acadêmico, ou seja, a legitimação dos estabelecidos na instituição mais tradicional, mais antiga, caso da FFLCH, garante também a posse dos critérios que normatizam uma produção historiográfica como profissional ou não. Cf. ELIAS, Norbert. Introdução. Ensaio teórico sobre as relações estabelecidos-outsiders. In: ELIAS, Norbert; SCOTSON, John. Os estabelecidos e os outsiders: sociologia das relações de poder a partir de uma pequena comunidade. Rio de Janeiro: Zahar, 2000, p. 1950 .
} 
Alice também sondava junto aos integrantes da cadeira, quais seriam as possibilidades em relação à Iglésias, mobilizando sua rede de sociabilidade em prol do amigo.

Ontem dei uma prosa com a Nícia a propósito da Cadeira de História do Brasil. Ela não tem pretensão alguma à Cadeira. Está desolada com a situação que poderá se criar com a aposentadoria do Dr. Sérgio. Receberia você como um Salvador. Como vê, você tem o acolhimento cordial e amigo de todos os elementos da Cadeira. Que deseja mais? $?^{650}$

Nícia antevia conflitos, tensões e disputas em torno da sucessão da cadeira, mesmo sendo, juntamente com Myriam Ellis, as únicas livre-docentes da cadeira, portanto, as mais capitalizadas intelectualmente. Dos oito auxiliares de ensino e assistentes de pesquisa junto à cadeira, cinco eram mulheres, o que denota uma postura aberta por parte de Sérgio Buarque de Holanda em relação às mulheres no ensino e na pesquisa ${ }^{651}$.

Através de outra carta de Alice à Iglésias, já em fins de 1966, podemos inferir que a amiga havia conseguido convencer Iglésias para que assumisse a cadeira em março de 1967. Porém, Iglésias declinou e a historiadora ficou magoada pelo fato de que tomou conhecimento de sua desistência por outrem.

[...] Fiquei esperando no decorrer de toda sua visita, que você me desse conta pessoalmente, de sua decisão. Afinal, tinha ficado assentado que você viria para a cadeira em Março. O Dr. Sérgio ficou radiante, pois havia me pedido para lhe escrever e eu acedi com muita alegria, pois achei a ideia magnífica. Em nossa conversa de sábado passamos perto do assunto, roçamos nele, por assim dizer, mas você preferiu calar-se: fiquei magoada e por isso lhe disse, quando nos despedimos, que iria escrever-lhe ${ }^{652}$.

Quais as razões pelas quais Francisco Iglésias não aceitou cargo de tamanho prestígio, uma vez que a FFCL/USP era o centro da produção historiográfica em nível universitário no Brasil e contava com o capital político de Sérgio Buarque? Alice Canabrava, ainda indignada com seu declinar, encontra na timidez do amigo uma explicação.

Eu ainda não me conformei e não me convenci da sua decisão de não vir para a Cadeira de $\mathrm{H}$. do Brasil. Não me parece válida toda a sua justificação no sentido de não lutar. Muita gente tinha a impressão de

\footnotetext{
${ }^{650}$ São Paulo, 06 de agosto de 1966. FI-C-CP (072). Acervo Francisco Iglésias. IMS/RJ.

${ }^{651}$ Além de Myriam Ellis, que regia o curso noturno, e Nícia, integravam a cadeira, até 1967, os seguintes membros: Maria Thereza Schorer Petrone, Maria Odila Dias Curly, Laima Mesgravis, Paulo Pereira de Castro, Odilon Nogueira de Mattos e José Sebastião Witter. Cf. Cadeira de História da Civilização Brasileira. RIEB. São Paulo, n. 2, 1967, p. 190.

${ }^{652}$ São Paulo, 11 de dezembro de 1966. FI-C-CP (075). Acervo Francisco Iglésias. IMS/RJ.
} 
que o Dr. Sérgio pediria a aposentadoria ao iniciar-se o ano acadêmico. Não o fez, porque não via alguém a altura para sucede-lo. Sabe qual foi a única pessoa, que, segundo consta, iria apresentar-se? O Carrato. E você pode bem imaginar o quanto teremos que lamentar se tal coisa ocorrer algum dia. Eu apenas compreendo que você é tímido e esta é a sua razão, a essência do problema. É pena porque o caminho está aberto, o porto ao alcance de suas forças. ${ }^{63}$

Outra hipótese aventada para que Francisco Iglésias não aceitasse a sucessão diz respeito à sua consciência de que o campo universitário uspiano tendia mais ao conflito do que o estabelecimento científico em que se encontrava ${ }^{654}$. A carta que Iglésias envia à Alice Canabrava em 24 de abril de 1982 se dá por conta da notícia da morte de Sérgio Buarque. Após exaltar os dotes intelectuais e humanos de Sérgio, Iglésias rememora a ocasião em que lhe foi facultado sucedê-lo junto à cadeira de História do Brasil e demarca umas das razões pelas quais declinou do convite.

Tenho como de meus orgulhos o ter sido distinguido por ele. Chegou a ponto de imaginar que eu deveria ser seu sucessor na Faculdade de Filosofia! Compreendi a magnanimidade e por um momento sequer me passou pela ideia aceitar o convite. Imagino de quanto me livrei não entrando naquele serpentário, onde ele pairava como um pássaro ou uma borboleta, sem tomar conhecimento das mesquinharias que se passavam à sua volta ${ }^{655}$.

Diante da não aceitação de Iglésias, houve contatos entre Sérgio Buarque e Caio Prado Júnior para que este último assumisse a cadeira. Porém, sua condição de exilado não o permitiria ${ }^{656}$. A possibilidade de José Ferreira Carrato, livre-docente em história do Brasil $^{657}$, assumir o posto de Sérgio Buarque era visto por Alice com lamentação. Porém, o destino da cadeira foi tomado por Iglésias com indignação como podemos inferir de sua carta à amiga.

Soube, com escândalo, da designação de Brasil Bandechi para a cadeira de História do Brasil. Pobre curso de História, pobre Faculdade de Filosofia, mísera História do Brasil! Não sei, mas acho que há certo clima de abastardamento na Universidade de São Paulo. Desculpe o tom violento, mas pelo que as vezes sei e vejo, acho que não pode ser de outro modo. A Escola em que deram aulas Braudel, Lucien Febvre,

\footnotetext{
${ }^{653}$ São Paulo, 02 de abril de 1967. FI-C-CP (076). Acervo Francisco Iglésias. IMS/RJ.

${ }^{654}$ SANTOS, op. cit., 2013, p. 135.

${ }^{655}$ Belo Horizonte, 24 de abril de 1982. APC-CP-P2, 10-(2). Fundo Alice Piffer Canabrava. Arquivo IEB/USP.

${ }^{656}$ Cf. CARVALHO, op. cit., 2017, p. 167-168.

${ }^{657}$ Cf. Faculdade de Filosofia, Letras e Ciências Humanas da Universidade de São Paulo. Relatório do departamento de História. 1970. In: Noticiário. Revista de História. São Paulo, n. 85, 1971, p. 269.
} 
Jaime Cortesão, Sérgio Buarque de Holanda merecia destino mais nobre. Havia algo de errado para chegar-se ao ponto que se chegou ${ }^{658}$.

Carrato não assumiu o posto de Sérgio Buarque, mas sim Brasil Bandecchi. Deduzimos que a indignação de Iglésias deve-se ao fato de que Bandecchi era um outsider da FFLCH, uma vez que havia cursado a Faculdade de Direito da USP e era ligado ao Instituto Histórico e Geográfico de São Paulo, lugares que naquele momento já haviam sido superados como espaços de legitimação da produção historiográfica brasileira. Havia outros professores e professoras com sólida carreira acadêmica e com capital intelectual inflado pela conquista de títulos que garantiriam sua posição hierárquica. Porém, Bandecchi saltou de bacharel em Direito à catedrático de História do Brasil.

Na ocasião em que Alice assumiu a chefia do setor de pesquisa e documentação o IEB contava com um contingente de dez historiógrafos que participavam da pesquisa coletiva "O Brasil às vésperas da independência" e realizavam suas pesquisas individuais: Yêdda Dias Lima, licenciada em Letras vernáculas pela FFCL em 1965, ingressou no IEB em 1967 na área de literatura brasileira, e em 1971 desenvolvia "Pesquisa sobre os éditos e inéditos das academias, atos acadêmicos e festejos públicos comemorativos no Brasil de 1641 a 1822"; Telê Porto Ancona Lopes, ingressou no IEB em 1969 na área de literatura brasileira, suas pesquisas se concentraram no acervo Mário de Andrade; Camila Mendes de Almeida, ingressou no IEB em 1969 na área de literatura brasileira, realizou suas atividades nesse ano de 1971 junto ao acervo Mário de Andrade e ao arquivo Fernando Mendes de Almeida e ingressou no curso de pós-graduação em literatura brasileira sob a orientação de José Aderaldo Castello, então diretor do IEB e chefe do setor cultural; Heloísa Liberalli Bellotto, ingressou no IEB em 1969 na área de história da civilização brasileira, trabalhando com a coleção Lamego e em trabalho de equipe para transcrição paleográfica de manuscritos do século XVIII (Pernambuco) e de bibliografia para redação de texto sobre o recôncavo baiano; Cecília de Lara, ingressou em 1970 na área de literatura brasileira desenvolvendo atividades junto ao acervo Mário de Andrade e dando continuidade a suas pesquisas sobre periódicos modernistas, publicou tese sobre "Klaxon" e "Terra roxa"; Marta Rossetti Batista, ingressou no IEB como arquiteta em 1967 na área de história da arquitetura no Brasil e nesse ano de 1971 desenvolveu trabalho

\footnotetext{
${ }^{658}$ Belo Horizonte, 06 de dezembro de 1971. APC-CP-P1,5-(2). Fundo Alice Piffer Canabrava. Arquivo IEB/USP.
} 
junto ao acervo Mário de Andrade para preparação de exposição; Yone Soares de Lima, ingressou no IEB em 1970 na área de história da arquitetura no Brasil, desenvolveu trabalhos junto ao acervo Mário de Andrade, realizou pesquisa sobre Clóvis Graciano e sua obra; Arlinda Rocha Nogueira, seu ingresso no corpo de pesquisadores do IEB data de 1969 na área de história da civilização brasileira, deu continuidade a pesquisa junto aos manuscritos da coleção Lamego e defendeu sua tese sobre imigração japonesa para a cafeicultura paulista (1908-1922); José Eduardo Marques Mauro, incorporou-se como historiógrafo no IEB em 1970 na área de história da civilização brasileira, e nesse ano de 1971 deu prosseguimento a seu trabalho junto à coleção Lamego e iniciou a redação de sua tese sobre A crise de 1929 em São Paulo; Lucy Maffei Hutter, seu ingresso no IEB data de 1969 na área de história da civilização brasileira e nesse ano de 1971 continuou com seus trabalhos junto à coleção Lamego e defendeu sua tese sobre a imigração italiana em São Paulo. Todos os historiógrafos também participaram do I SEB ${ }^{659}$.

Se nos atentarmos ao perfil de gênero deste corpo de historiógrafos, temos predominância do elemento feminino. Perfil muito diferente do corpo de conselheiros, onde havia apenas duas mulheres: Alice e Myriam Ellis, que sucedeu Nícia V. Luz por conta da aposentadoria dessa ${ }^{660}$. Tal conformação refletia ainda uma cultura acadêmica que não via com bons olhos a ascensão feminina ao mais alto grau da hierarquia acadêmica, qual seja, a cátedra ${ }^{661}$. Além de estarem em maior número no corpo de historiógrafos, também eram as mais qualificadas: dos dez pesquisadores, quatro possuíam doutoramento, quatro mulheres. Em termos de área de pesquisa temos quatro pesquisadores na área de história da civilização brasileira; quatro na área de literatura brasileira e dois na área de história da arquitetura no Brasil. As áreas de geografia do Brasil; geografia econômica geral e do Brasil; antropologia e etnografia do Brasil; línguas indígenas do Brasil; economia brasileira; e história econômica geral e do Brasil não possuíam pesquisador.

A que se deve essa ausência? Podemos apenas aventar algumas hipóteses. A primeira vincula-se ao poder institucional capitalizado por Sérgio Buarque de Holanda e

\footnotetext{
${ }^{659}$ Cf. Relatório de atividades do Instituto de Estudos Brasileiros da Universidade de São Paulo em 1971. RIEB. São Paulo, n. 12, 1972a, p. 205-209.

${ }^{660} \mathrm{Cf}$. Ata da $54^{\mathrm{a}}$ reunião do CA ocorrida em 22/10/1971. Atas do CA do IEB/USP. Livro I. Fundo IEB. Arquivo IEB/USP. IEB001-01-0056, verso f. 139.

${ }^{661}$ Essa situação foi bem diferente durante os anos em que Sérgio Buarque esteve à frente da cadeira de HCB.
} 
por José Aderaldo Castello, o que explicaria a predominância, respectivamente, das áreas de história e literatura. Como veremos, Castello ocupou a diretoria do IEB durante o período 1967-1981. Outra hipótese diz respeito ao próprio acervo do instituto. Durante os anos 1960, o IEB adquiriu ou recebeu por doação importantes acervos como a coleção do historiador Yan de Almeida Prado (adquirida pela USP em 1962 e doada ao IEB em 1966), o acervo Mário de Andrade (adquirido em 1966), a coleção do historiador Alberto Lamego (doada pela FFCL em 1968), a biblioteca Jorge Tibiriça Filho (adquirida em 1969) e o arquivo do sociólogo Fernando de Azevedo (1969) ${ }^{662}$. Pelo conteúdo e constituição desses acervos, depreende-se que as áreas privilegiadas para pesquisa seriam exatamente as três citadas. Ademais, no caso específico de economia brasileira, como afirmamos acima, seu catedrático estava afastado e a não houve preocupação em substituí-lo. Quanto ao catedrático de geografia econômica, Dirceu Lino de Mattos, seus interesses acadêmicos não parecem estar ligados ao IEB.

Ao que pudemos inferir do contato com as fontes, o chefe do setor de pesquisa e documentação coordenava apenas as pesquisas que envolviam projetos comuns à todas as cadeiras - conforme citação acima, referente aos objetivos do setor - e não às áreas. Cada área era coordenada pelo seu respectivo catedrático. Assim, quando Alice assumiu o setor, não há indícios de que a pesquisa conjunta "O Brasil às vésperas da independência" estivesse em funcionamento. Talvez essa seja a razão motivadora para que ela tenha aceitado o cargo, uma vez que suas pesquisas individuais, orientações e cursos junto à FEA, bem como o secretariado da ANPUH consumiam todo seu tempo. Uma função que parecia estar ligada à sua chefia foi a emissão de pareceres. Na mesma reunião em que Canabrava tornou-se chefe do setor de pesquisa e documentação, ao tratar das publicações a serem lançadas, o CA decidiu que o trabalho enviado por Maria de Lourdes Vieira Lira, Dízimos reais na capitania de São Paulo, seria encaminhado à historiadora para emissão de parecer ${ }^{663}$.

Também cabia ao chefe do setor de pesquisa e documentação emitir parecer sobre as funções dos pesquisadores, como por exemplo, o pedido de afastamento de Cecília de Lara por duas tardes com o fito de efetuar pesquisas para a confecção de sua tese. Nessa ocasião, o diretor em exercício, Eduardo Kneese de Mello, solicitou à Alice emissão de

\footnotetext{
${ }^{662}$ Cf. CALDEIRA, op. cit., 2002, p. 94-101.

${ }^{663}$ Cf. Ata da $54^{a}$ reunião do CA ocorrida em 22/10/1971. Atas do CA do IEB/USP. Livro I. Fundo IEB. Arquivo IEB/USP. IEB001-01-0056, f. 143.
} 
parecer $^{664}$. O mesmo ocorria em relação ao acesso aos acervos do instituto. Canabrava emitiu parecer favorável à solicitação encampada por Myriam Ellis para que os alunos matriculados no programa de pós-graduação do departamento de História pudessem realizar suas pesquisas no $\mathrm{IEB}^{665}$. Na reunião seguinte, a historiadora toma a palavra e emite seu parecer sobre publicação de manuscritos inéditos, sendo da alçada exclusiva do instituto sua publicação na íntegra. Afirma também que está elaborando o regulamento sobre a consulta de manuscritos, conforme havia sido solicitado pelo diretor Aderaldo Castello ${ }^{666}$.

Além do setor de pesquisa e documentação, integrava o instituto, o setor cultural. Esse setor foi criado, assim como seu correlato, pela necessidade, em 1965, de descentralizar as decisões que cabiam exclusivamente ao diretor. Assim, definiram-se seus objetivos e o novo setor "[...] ficaria encarregado dos cursos, palestras, conferências a serem realizadas por iniciativa do IEB, e de publicações" ${ }^{667}$. Quanto aos cursos, o IEB ofereceu duas modalidades: os cursos de extensão e os cursos de férias. O primeiro curso de extensão intitulado "Música colonial brasileira" foi ministrado em 1965 pelo musicólogo Francisco Curt Lange, tratando da escola de música mineira e seus principais vultos de fins do século XVIII ${ }^{668}$. Entre 1965 e 1981, foram oferecidos quatro cursos de extensão.

O curso "O Rio Grande do Sul” foi oferecido em 1967 e contou com oito tópicos a serem desenvolvidos em certo número de aulas por especialistas convidados. A terra gauchesca em seus aspectos fisiográficos foi tratado em nove aulas por Aziz Ab'Saber; a formação histórica do RS, por Sérgio Buarque; alguns aspectos do folclore gaúcho, por Alceu Maynard Araújo; arte e arquitetura no RS, por Eduardo K. de Mello e Walter Zanini; perspectivas do cinema no RS, por Paulo Emílio Salles Gomes; perspectivas literárias do RS, por José Aderaldo Castello. O tópico “O Rio Grande do Sul numa perspectiva de desenvolvimento sócio-econômico" foi ministrado por Maria Isaura

\footnotetext{
${ }^{664}$ Cf. Ata da $55^{\text {a }}$ reunião do CA ocorrida em 19/11/1971. Atas do CA do IEB/USP. Livro I. Fundo IEB. Arquivo IEB/USP. IEB001-01-0057, verso f. 146.

${ }^{665}$ Ata da $60^{\mathrm{a}}$ reunião do CA ocorrida em 23/06/1972. Atas do CA do IEB/USP. Livro I. Fundo IEB. Arquivo IEB/USP. IEB001-01-0062, verso f. 160.

${ }^{6} 66$ Ata da $61^{\mathrm{a}}$ reunião do CA ocorrida em 11/08/1972. Atas do CA do IEB/USP. Livro I. Fundo IEB. Arquivo IEB/USP. IEB001-01-0063, f. 162.

${ }^{667}$ Cf. Instituto de Estudos Brasileiros. Regulamento - Histórico - Organização. In: Noticiário. RIEB. São Paulo, n. 1, 1966, p. 189.

${ }^{668}$ Cf. CALDEIRA, op. cit., 2000, p. 105.
} 
Pereira de Queiroz em nove aulas ${ }^{669}$. A abordagem seria propícia ao tratamento por Alice Canabrava. Não sabemos se a historiadora foi convidada e se o foi se declinou, uma vez que em setembro de 1967 estava em Porto Alegre participando do IV Simpósio Nacional da APUH. Ademais, como demarcamos acima, Canabrava não participava das reuniões do CA com frequência naquele momento.

Nesse mesmo ano, no mês de agosto, foi oferecido curso de "cultura e civilização brasileira", a pedido da reitoria, para 50 alunos da universidade de Estocolmo que visitavam o país. Causa estranhamento a ausência de palestra sobre aspectos da história econômica brasileira, de sua antropologia e línguas indígenas ${ }^{670}$. Ainda em 1967 sob o título de "Uma visão do Brasil", o IEB organizou e coordenou uma série de 20 palestras, a pedido e com o patrocínio do jornal A Tribuna e do conselho cultural da prefeitura de Santos/SP. Dentre as temáticas tratadas, nenhuma abordou os aspectos econômicos da história brasileira e Odilon Nogueira de Matos proferiu duas palestras sobre "Uma visão da história do Brasil”"671. Essas palestras tiveram continuidade no mês de outubro de 1968 em Santos/SP. Porém, mais uma vez, sem a participação de Alice. A palestra de Nícia Vilella Luz que versou sobre "Visão histórica do processo de industrialização do Brasil" ${ }^{\text {"672 }}$ possui relação com as pesquisas de Canabrava. Porém, não sabemos da dinâmica de escolha dos participantes para cada curso: se o participante era convidado e escolhia a temática, ou se antes definia-se a temática e depois o participante era convidado.

O último curso de extensão do período, realizado em 1969, tratou do "Recôncavo baiano" em parceria com a UFBA e foi realizado na cidade de Salvador com proposta de “[...] integração de áreas de maior interesse - História, Geografia, Sociologia, Antropologia (Cultura Popular e Linguística), Literatura, Arte e Arquitetura"673, excluindo-se as áreas de história econômica e geografia econômica. Porém, se nos debruçarmos sobre o programa da área de história coordenado por Sérgio Buarque e por

\footnotetext{
${ }^{669}$ Cf. Relatório de atividades do Instituto de Estudos Brasileiros da Universidade de São Paulo em 1967. RIEB. São Paulo, n. 5, 1968, p. 187.

${ }^{670}$ Cf. Idem, p. 187-188.

${ }^{671}$ Cf. Idem, p. 188.

${ }^{672}$ Cf. Relatório de atividades do Instituto de Estudos Brasileiros da Universidade de São Paulo em 1968. RIEB. São Paulo, n. 6, 1969, p. 204. Também foi oferecido o curso de extensão denominado "O teatro jesuítico e barroco do século XVI ao XVIII”, ministrado por Claude-Henri Frèches da Universidade de Aiux-Provence. Cf. Idem, p. 205.

${ }^{673}$ Relatório de atividades do Instituto de Estudos Brasileiros da Universidade de São Paulo em 1969. RIEB. São Paulo, n. 8, 1970, p. 193.
} 
José Calazans (UFBA), tomamos conhecimento de que aspectos como a economia açucareira, organização da economia regional, livre-comércio e tentativas de industrialização foram abordados no curso ${ }^{674}$. As quatro conferências proferidas no IEB durante o ano de 1969 versaram sobre literatura, refletindo a hegemonia da área, reflexo da gestão de Aderaldo Castello, ao mesmo tempo, diretor e chefe do setor cultural ${ }^{675}$.

O ano de 1972 inaugurou os cursos de férias do IEB. Porém, esse projeto não partiu do CA, mas sim, refletindo a política universitária do período, foi instituído pela reitoria, sem consulta prévia ao conselho ${ }^{676}$. A fim de tratar do curso de férias, o CA se reuniu em 06 de janeiro de 1972, uma vez que o mesmo seria ministrado em fevereiro. A portaria baixada pelo então reitor Miguel Reale estabelecia que o curso abordasse as seguintes áreas em uma perspectiva interdisciplinar ou de integração: história da civilização brasileira, história econômica do Brasil, geografia econômica do Brasil, literatura brasileira, o pensamento filosófico no Brasil, aspectos da sociologia brasileira, antropologia brasileira, artes plásticas no Brasil, música brasileira (erudita e popular), cinema e folclore. O CA escolheu como coordenador do curso, João Baptista Borges Pereira, da cadeira de Antropologia e etnografia do Brasil, responsável também pela escolha do tema ${ }^{677}$. Percebemos que todas as áreas do IEB foram contempladas, exceto economia brasileira e que outras também foram incluídas como pensamento filosófico no Brasil e sociologia. Ademais, pela ausência de Aderaldo Castello, outro integrante do CA pôde coordenar o curso, uma vez que todos os cursos seguintes seriam por ele coordenados, até sua saída da diretoria do IEB.

O primeiro curso de férias abordou o "Brasil - década de 1920 - comemorativo do cinquentenário da semana de arte moderna". Vários aspectos dessa década foram abordados. Dentre os que não o foram, figura a história econômica do período ${ }^{678}$. Porém, caberia à Alice nesse ano, coordenar o "Ciclo de conferências sobre migrações europeias”. Em reunião do CA de 26 de maio de 1972, a reitoria solicitou que o IEB

\footnotetext{
${ }^{674}$ Cf. Curso integrado sobre o Recôncavo. In: Noticiário. RIEB. São Paulo, n. 8, 1970, p. 159-160.

${ }^{675}$ Cf. Relatório de atividades do Instituto de Estudos Brasileiros da Universidade de São Paulo em 1969. RIEB. São Paulo, n. 8, 1970, p. 196.

${ }^{676} \mathrm{Cf}$. Ata da $53^{\mathrm{a}}$ reunião do CA ocorrida em 31/05/1971. Atas do CA do IEB/USP. Livro I. Fundo IEB. Arquivo IEB/USP. IEB001-01-0055, f. 135-138.

${ }^{677} \mathrm{Cf}$. Ata da $57^{\mathrm{a}}$ reunião do CA ocorrida em 06/01/1972. Atas do CA do IEB/USP. Livro I. Fundo IEB. Arquivo IEB/USP. IEB001-01-0059, verso f. 150-f. 152.

${ }^{678}$ Cf. Relatório de atividades do Instituto de Estudos Brasileiros da Universidade de São Paulo em 1972. RIEB. São Paulo, n. 14, 1973, p. 171-172.
} 
promovesse um ciclo de conferências em comemoração ao vigésimo aniversário do Comitê Intergovernamental para as Migrações Europeias (CIME). Canabrava, escolhida para coordenar o ciclo, convidou José Francisco de Camargo, que possui produção sobre movimentos populacionais, e Maria Thereza Schorer Petrone para proferir conferências, sendo que houve um nome indicado pela reitoria para proferir a palestra de encerramento: E. K. Rahardt, chefe da missão no Brasil ${ }^{679}$.

Os cursos de férias subsequentes, até 1975, abordaram aspectos concernentes às décadas seguintes: 1930, 1940 e 1950. Assim, o curso de férias de 1973, coordenado por Aderaldo Castello, foi organizado em aulas e depoimentos de convidados sobre a situação de sua área de pesquisa durante os anos 1930. O depoimento da área de história, por exemplo, coube à Sérgio Buarque e a aula sobre o estado da área nos anos 1930 foi ministrada por Maria Thereza Schorer Petrone ${ }^{680}$. Alice nesse momento participava ativamente das reuniões do CA, o que propiciaria sua participação no curso, principalmente no que tange à aspectos econômicos da década de 1930, marcada por profunda crise econômica. Ao contrário do curso anterior, o curso de férias oferecido em 1974 trouxe conferência sobre "o desenvolvimento econômico e industrial" na década de 1940, proferida por Dênio Nogueira ${ }^{681}$.

Quanto ao IV curso de férias ofertado em 1975, deliberou-se que seguiria a lógica dos cursos anteriores e que, portanto, esse versaria sobre a década de 1950. Foi estabelecido em reunião pelos conselheiros, que cada um deles indicaria dois nomes para proferir conferência, no mesmo esquema do curso de 1973, qual seja, um nome que trataria do estado de sua área durante a década e outro que proferiria depoimento ${ }^{682}$. O quarto ponto da reunião do CA de oito de novembro de 1974 tratou desses aspectos concernentes a esse curso de férias. Em primeiro lugar, definiram-se as áreas: geografia, história social, história econômica, história política, sociologia, antropologia, educação, literatura, artes e arquitetura. Em relação à indicação de nomes para palestra e depoimento, apenas João Baptista Borges Pereira sugeriu os nomes de, respectivamente,

\footnotetext{
${ }^{679} \mathrm{Cf}$. Ata da $59^{\mathrm{a}}$ reunião do CA ocorrida em 06/01/1972. Atas do CA do IEB/USP. Livro I. Fundo IEB. Arquivo IEB/USP. IEB001-01-0061, verso f. 157-f. 158.

${ }^{680}$ Cf. Relatório sucinto das atividades do Instituto de Estudos Brasileiros da Universidade de São Paulo em 1973. RIEB. São Paulo, n. 15, 1974, p. 178-179.

${ }^{681}$ Cf. Relatório sucinto das atividades do Instituto de Estudos Brasileiros da Universidade de São Paulo em 1974. RIEB. São Paulo, n. 17, 1975, p. 158-159.

${ }^{682} \mathrm{Cf}$. Ata da $74^{\mathrm{a}}$ reunião do CA ocorrida em 04/10/1974. Atas do CA do IEB/USP. Livro I. Fundo IEB. Arquivo IEB/USP. IEB001-01-0076, verso f. 217-f. 218.
} 
Amadeu José Duarte Lanna e Egon Schaden. Maria Isaura Pereira de Queiroz, por sua vez, indicou Mário Wagner Vieira da Cunha para o depoimento e Lia Garcia Fukui para a palestra sobre o estado da arte em sociologia na década de 1950. Para a área de história política foi indicado Francisco de Assis Barbosa, sem constar o sujeito da indicação. Alice Canabrava tomou a palavra para afirmar que traria as indicações dos outros nomes até o dia onze ${ }^{683}$.

Os indicados acima, aceitaram proferir palestras e depoimentos. Quanto à área de história econômica, Dênio Chagas Nogueira proferiu depoimento sobre a economia brasileira durante a década de 1950 e forneceu um panorama geral sobre a história econômica do período ${ }^{684}$. Não haveria pessoa mais indicada do que Alice Canabrava para proferir o depoimento, bem como analisar a história econômica do Brasil, inclusive como área de conhecimento. Dificilmente a historiadora teria indicado Dênio Nogueira para se pronunciar sobre a área de história econômica, uma vez que este não fazia parte de sua rede de sociabilidade e, principalmente, não se tratava de um acadêmico ${ }^{685}$.

O curso de férias de 1976 não seguiu a lógica de organização anterior, por décadas. Durante reunião do CA ocorrida em 23 de julho de 1975, Aderaldo Castello propôs que os conselheiros, bem como o representante dos pesquisadores, José Eduardo Marques Mauro, apresentassem, para a próxima reunião, possíveis temas, bem como o programa do curso. Nessa mesma reunião, Alice propôs a realização para fevereiro de 1976 de um curso sobre os rumos da pesquisa em história econômica do Brasil, comprometendo-se a apresentar projeto na próxima reunião ${ }^{686}$. Na reunião seguinte, ocorrida em 10 de outubro de 1975, Aderaldo Castello propôs por tema do curso de férias "Séculos XVII e XVIII e o Barroco no Brasil", tendo sido unanimemente aprovado ${ }^{687}$. Na ata dessa reunião não

\footnotetext{
${ }^{683} \mathrm{Cf}$. Ata da $76^{\mathrm{a}}$ reunião do CA ocorrida em 08/11/1974. Atas do CA do IEB/USP. Livro I. Fundo IEB. Arquivo IEB/USP. IEB001-01-0078, verso f. 221-f. 222.

${ }^{684}$ Cf. Relatório das atividades do Instituto de Estudos Brasileiros da Universidade de São Paulo em 1975. RIEB. São Paulo, n. 18, 1976, p. 157.

${ }^{685}$ Dênio Nogueira integrou o Instituto de Pesquisas e Estudos Sociais (IPÊS) e o Instituto Brasileiro de Ação Democrático (IBAD), opondo-se ao governo João Goulart e apoiando o golpe civil-militar que depôs o presidente. Graduado em Ciências Econômicas em 1943 pela Faculdade de Ciências Econômicas da UFRJ, durante o regime militar, nos 1960, ocupou vários cargos em instâncias econômicas dos governos dos ditadores Castello Branco e Costa e Silva, como o Banco Central, do qual foi o primeiro presidente, e o ministério da fazenda. Cf. disponível em: <http://www.fgv.br/cpdoc/acervo/dicionarios/verbetebiografico/denio-chagas-nogueira $>$. Acessado em 22 jan 2018.

${ }^{686} \mathrm{Cf}$. Ata da $79^{\mathrm{a}}$ reunião do CA ocorrida em 23/07/1975. Atas do CA do IEB/USP. Livro I. Fundo IEB. Arquivo IEB/USP. IEB001-01-0081, f. 231-verso f. 231.

${ }^{687} \mathrm{Cf}$. Ata da $80^{\mathrm{a}}$ reunião do CA ocorrida em 10/10/1975. Atas do CA do IEB/USP. Livro I. Fundo IEB. Arquivo IEB/USP. IEB001-01-0082, f. 233-verso f. 233.
} 
consta se os demais conselheiros apresentaram suas propostas como acordado na reunião anterior, tampouco se Alice apresentou seu projeto para o curso sobre história econômica do Brasil. Entretanto, mais uma vez como coordenador do curso de férias, Castello encampou tema relacionado à sua área de atuação.

Nessa mesma reunião foram escolhidas as áreas que seriam estudadas e sugeriuse nomes de conferencistas. As áreas aprovadas foram: história social, política e econômica, geografia urbana, arquitetura, pintura, escultura e literatura. E para as conferências, os seguintes nomes: Manoel Correia de Andrade, Augusto Carlos da Silva Telles, Valentín Calderon de la Vara, Nestor Goulart Reis Filho, Milton Dias (geografia urbana), José Antonio Gonçalves de Mello Neto (história), José Honório Rodrigues (história), Castello, Antonio Soares Amora e Segismundo Spina (literatura). Myriam Ellis sugeriu Sérgio Buarque de Holanda para a área de história e Alice Canabrava se comprometeu a apresentar conferência sobre "A grande crise do século XVI" e indicou Antonio Emílio Muniz Barreto para apresentar palestra sobre "Ajustamento da economia à crise internacional". Porém, a historiadora não apresentou o programa de curso sobre os rumos da pesquisa em história econômica do Brasil. Por fim, os conselheiros se comprometeram a apresentar por escrito o nome dos conferencistas e seus substitutos eventuais $^{688}$.

Ao cotejarmos o que foi deliberado durante as reuniões que trataram da organização do curso e seu programa, notamos que alguns dos nomes sugeridos não estiveram presentes. Talvez por impossibilidade, ou porque decidiu-se por outros nomes. Ademais, o curso foi dividido em dois: o primeiro sobre o Barroco nos séculos XVI e XVII e o segundo, a ser realizado em 1977, abordando o Barroco no século XVIII. Dos indicados para proferir conferência, Nestor Goulart Reis Filho, Milton Dias, José Antonio Gonçalves de Mello Neto, José Honório Rodrigues, Segismundo Spina, Sérgio Buarque e Antonio Emílio Muniz Barreto não puderam aceitar o convite. Alice proferiu a conferência pela qual havia se encarregado e no lugar de Antonio Emílio Muniz Barreto, figura um de seus ex-alunos, Ibrahin João Elias. Canabrava também deve ter indicado seu amigo Francisco Iglésias que tratou dos aspectos políticos e sociais dos séculos XVI e $\mathrm{XVII}^{689}$.

\footnotetext{
${ }^{688} \mathrm{Cf}$. Idem.

${ }^{689}$ Cf. Relatório das atividades do Instituto de Estudos Brasileiros da Universidade de São Paulo em 1976. RIEB. São Paulo, n. 19, 1977, p. 142-143.
} 
O curso de férias de 1977, como afirmamos, realizou-se como uma extensão do curso anterior, tratando do "Século XVIII e o Barroco no Brasil". Em reunião do CA, com a presença de Alice, ocorrida em nove de novembro de 1976, Aderaldo Castello afirmou que, devido à escassez de recursos, os convidados para ministrar o curso teriam que ser exclusivamente de São Paulo e encarregou os conselheiros de apresentar nomes dentro de uma semana ${ }^{690}$. O relatório de atividades de 1977 traz somente o nome dos conferencistas, sem detalhar os temas abordados. Dentre eles figuram Iraci Del Nero da Costa e Francisco Vidal Luna, certamente indicados por Canabrava ${ }^{691}$. Supomos que o tema tratado por eles se relacione à população escrava de Minas Gerais, temas, como vimos no primeiro capítulo, de suas pesquisas de mestrado e doutorado.

Para o ano seguinte, Aderaldo Castello, em reunião do CA de 17 de fevereiro de 1978, da qual Alice esteve ausente, afirmou que solicitou à reitoria para que o curso fosse realizado no mês de julho vis a vis a restrição orçamentária do instituto e a possibilidade de angariar recursos para sua realização até julho. Tendo isso em perspectiva, apresentou duas propostas para o curso. A primeira no formato de seminário que seria realizado em quatro partes do Brasil: São Paulo, Rio de Janeiro, Porto Alegre e Belo Horizonte ou Brasília sobre o estado das pesquisas em ciências sociais e humanas, além da situação das instituições de ensino e pesquisa na área. Seria convidado um pesquisador de renome em cada área para que desenvolvesse as orientações teórico-metodológicas, a relação da teoria com a realidade brasileira e um depoimento pessoal. O curso seria ministrado intensivamente com a formação de uma mesa redonda com todos os pesquisadores. Sua realização em São Paulo demonstraria sua viabilidade de realização em outros estados.

A segunda proposta para o curso de férias estaria vinculada à comemoração dos 50 anos de várias obras importantes como "A bagaceira", "Macunaíma” etc. A designação do curso seria: "A década de 1920 e os acontecimentos literários e artísticos de 1928”. O CA escolheu a segunda proposta, uma vez que a primeira implicaria gastos que excediam as possibilidades orçamentárias do IEB $^{692}$. O fato de Castello apresentar duas propostas

\footnotetext{
${ }^{690}$ Cf. Ata da $82^{a}$ reunião do CA ocorrida em 09/11/1976. Atas do CA do IEB/USP. Livro I. Fundo IEB. Arquivo IEB/USP. IEB001-01-0084, verso f. 240.

${ }^{691}$ Cf. Relatório das atividades do Instituto de Estudos Brasileiros da Universidade de São Paulo em 1977. RIEB. São Paulo, n. 21, 1979, p. 145.

${ }^{692}$ Cf. Ata da $86^{\mathrm{a}}$ reunião do CA ocorrida em 17/02/1978. Atas do CA do IEB/USP. Livro II. Fundo IEB. Arquivo IEB/USP. IEB001-02-0003, f. 4-verso f. 4.
} 
parece estar ligado a uma estratégia ${ }^{693}$ na qual, ao apresentar uma proposta exequível e outra não, pressupunha que o CA escolheria a primeira, relacionada exatamente à sua área de pesquisa e interesse. O curso foi coordenado por Castello e Nilo Scalzo, presidente da comissão de literatura do Conselho Estadual de Cultura de São Paulo. Assim como o relatório anterior, no que tange ao curso de férias, as informações são exíguas e não há sequer a relação de palestrantes. Apenas um informe sobre a realização do curso e seu tema geral ${ }^{694}$.

Em reunião do CA realizada em 16 de junho de 1978, da qual Alice esteve ausente, Aderaldo Castello expôs a proposta de Canabrava para realização de um curso de férias sobre história quantitativa sob o título “A medida em história econômica". Os conselheiros decidem aguardar a presença da historiadora na próxima reunião para tratarem do assunto ${ }^{695}$. A reunião seguinte foi realizada em 22 de setembro de 1978, da qual Alice esteve ausente ${ }^{696}$. A reunião subsequente ocorreu somente em cinco de outubro de 1979, uma vez que o IEB passou por mudança de sede, do prédio de geografia e história, para o bloco D do Conjunto Residencial da USP (CRUSP). Canabrava, ao tomar a palavra e tecer considerações sobre sua proposta de ofertar curso de férias sobre história quantitativa ministrado por professores da FEA, afirma que não há condições para sua realização nesse momento e pede licença para retomar o assunto em outra ocasião ${ }^{697}$. Essa não é a primeira vez em que Alice propõe curso de férias e declina. Nesse caso específico, como sua proposta se deu mais de um ano antes, talvez seus planos tenham mudado.

O último curso de férias realizado no período em que Canabrava fez parte do CA do IEB ocorreu no ano de 1980. Nesse momento, Alice estava às vésperas de sua aposentadoria. Em reunião do CA ocorrida em 27 de junho de 1980, com a presença da historiadora, Aderaldo Castello apenas comunica que o curso de férias seria realizado no mês de julho com o patrocínio da Secretaria de Cultura da Prefeitura de São Paulo, sem

\footnotetext{
${ }^{693}$ No sentido formulado por Michel De Certeau, ou seja, a estratégia como esfera de atuação e dominação dos mais fortes. Cf. CERTEAU, op. cit., 2014.

${ }^{694}$ Cf. Relatório de atividades do Instituto de Estudos Brasileiros da Universidade de São Paulo em 1978. RIEB. São Paulo, n. 21, 1979, p. 152.

${ }^{695} \mathrm{Cf}$. Ata da $87^{\mathrm{a}}$ reunião do CA ocorrida em 16/06/1978. Atas do CA do IEB/USP. Livro II. Fundo IEB. Arquivo IEB/USP. IEB001-02-0004, verso f. 8.

${ }^{696} \mathrm{Cf}$. Ata da $88^{\mathrm{a}}$ reunião do CA ocorrida em 22/09/1978. Atas do CA do IEB/USP. Livro II. Fundo IEB. Arquivo IEB/USP. IEB001-02-0005.

${ }^{697}$ Cf. Ata da $89^{\mathrm{a}}$ reunião do CA ocorrida em 05/10/1979. Atas do CA do IEB/USP. Livro II. Fundo IEB. Arquivo IEB/USP. IEB001-02-0006, f. 20-verso f. 20.
} 
mencionar ou discutir qual seria sua temática ${ }^{698}$. Pela segunda vez o curso não foi coordenado por Aderaldo Castello, mas sim por Edith Pimentel da FFLCH sob o tema "Expansão da língua" ${ }^{699}$. Essa é a primeira vez, desde sua fundação em que o IEB não apresentou relatório de atividades para o ano de 1979. Seria elaborado um pequeno relatório, de apenas quatro páginas, abrangendo os anos 1979-1981, uma vez que durante esses anos seu CA esteve envolvido na elaboração e efetivação de seu novo regimento, posto que o instituto era regido ainda por sua portaria de criação de 1963, não tendo se enquadrado na reforma universitária da USP efetivada em 1970.

A elaboração e discussão do regimento do IEB foram marcadas por avanços, recuos e conflitos, principalmente em torno da figura de seu diretor José Aderaldo Castello, que podem ser acompanhados pelas Atas das reuniões do CA, uma vez que os relatórios de atividades silenciam sobre essa questão, posto que seu intento está ligado à construção de um discurso público sobre a instituição.

As discussões acerca do regimento do IEB, com a presença de Alice, se iniciaram na reunião de número 69 ocorrida em 17 de agosto de 1973. Nessa ocasião, Aderaldo Castello afirma que o novo regimento já havia sido aprovado em reunião anterior, mas que gostaria de rediscutir alguns pontos. Cada conselheiro recebeu cópia do regulamento. A partir dela, Canabrava notou que geografia econômica do Brasil não estava incluída como área do IEB e questionou Castello a esse respeito. O mesmo afirmou que a exclusão se deve ao fato de que, ao contrário de história econômica do Brasil, geografia econômica deixou de integrar a FEA e também argumenta que sua inclusão implicaria o desdobramento do instituto em muitas áreas ${ }^{700}$. Alice não foi a única a questionar o novo regimento. Eduardo K. de Mello criticou a inclusão da área de literatura comparada, argumentando que seria necessário um especialista com profundo conhecimento em literatura brasileira e em todas as demais literaturas ${ }^{701}$. Mesmo com essas críticas o regimento foi aprovado e encaminhado para as unidades que integram o IEB para emissão de parecer por parte de suas respectivas congregações.

\footnotetext{
${ }^{698}$ Cf. Ata da $90^{\text {a }}$ reunião do CA ocorrida em 27/06/1980. Atas do CA do IEB/USP. Livro II. Fundo IEB. Arquivo IEB/USP. IEB001-02-0007, verso f. 21-f. 22.

${ }^{699}$ Cf. O Instituto de Estudos Brasileiros - 1979/81. RIEB. São Paulo, n. 23, 1981, p. 148.

${ }^{700} \mathrm{Cf}$. Ata da $69^{\mathrm{a}}$ reunião do CA ocorrida em 17/08/1973. Atas do CA do IEB/USP. Livro I. Fundo IEB. Arquivo IEB/USP. IEB001-01-0071, verso f. 198-f. 199.

${ }^{701}$ Idem, f. 199.
} 
Com dez anos de existência o IEB não possuía em seu CA representante de seu numeroso corpo de pesquisadores. O quarto ponto da reunião do CA ocorrida em 12 de outubro de 1973 tratou da solicitação dos 11 pesquisadores para que possuíssem dois representantes junto ao conselho. Porém, o mesmo aprovou somente um representante, sem direito à voto, até aprovação do novo regimento ${ }^{702}$. A entrada de um representante do corpo de pesquisadores somente foi possível porque os conselheiros, na condição de grupo estabelecido, não mais gozava de coesão, o que fez diminuir seu diferencial de poder em relação aqueles e que lhes valia a condição de outsiders.

Na reunião seguinte, da qual Alice esteve ausente, Aderaldo Castello informou que José Eduardo Marques Mauro e Marta Rosseti Batista foram eleitos, respectivamente, titular e suplente do corpo de pesquisadores ${ }^{703}$. Através da menção aos pareceres e eleição de representante de cada congregação das unidades que comporiam o IEB segundo o novo regulamento, tomamos conhecimento de que suas áreas seriam ampliadas, incorporando novas unidades criadas a partir da reforma universitária de 1970. Além da FFLCH, FEA e FAU que já faziam parte do instituto, a Escola de Comunicação e Artes (ECA) e a Faculdade de Educação (FE) também integrariam o IEB. Aderaldo Castello afirma que apenas esta última se manifestou de modo correto; FEA e ECA se anteciparam e indicaram seus representantes e FFLCH e FAU não se manifestaram ${ }^{704}$. Ainda nessa reunião, Castello apresentou projeto de regulamento para o setor de arquivo e documentação. Como vimos acima, Alice Canabrava, como chefe do setor de pesquisa e documentação, havia se incumbido de apresentar tal regulamento. $O$ fato de Alice não estar presente nessa reunião na qual Castello apresenta seu regulamento, denota lance estratégico desse último ${ }^{705}$. Não consta em ata que o regulamento tenha sido discutido, apenas há transcrição do mesmo ${ }^{706}$.

Como explicar o fato de que Aderaldo Castello permaneceu na diretoria do IEB entre 1967 e 1981, ou seja, por 15 anos, quando a portaria que regimentava o instituto estabelecia um mandato de dois anos? Castello foi eleito diretor pelo CA em 1966, ao

\footnotetext{
${ }^{702}$ Cf. Ata da $70^{\text {a }}$ reunião do CA ocorrida em 12/10/1973. Atas do CA do IEB/USP. Livro I. Fundo IEB. Arquivo IEB/USP. IEB001-01-0072, verso f. 201- f. 202.

${ }^{703}$ Cf. Ata da $71^{\mathrm{a}}$ reunião do CA ocorrida em 05/04/1974. Atas do CA do IEB/USP. Livro I. Fundo IEB. Arquivo IEB/USP. IEB001-01-0073, verso f. 204.

${ }^{704}$ Idem, verso f. 206-f. 207.

${ }^{705}$ Cf. CERTEAU, op. cit., 2014.

706 Cf. Ata da $71^{\mathrm{a}}$ reunião do CA ocorrida em 05/04/1974. Atas do CA do IEB/USP. Livro I. Fundo IEB. Arquivo IEB/USP. IEB001-01-0073, verso f. 209-verso f. 211.
} 
término da diretoria de Egon Schaden ${ }^{707}$. Seu mandato terminaria em 1968. Porém, por proposta de Sérgio Buarque de Holanda, unanimemente aprovada pelo CA, foi solicitado ao conselho universitário, e aprovado, a prorrogação de seu mandato por mais um ano ${ }^{708}$. Portanto, deveria haver novas eleições em outubro/novembro de 1969. O que encontramos nas reuniões desse período foi o silêncio de Castello e dos conselheiros quanto às eleições. Os indícios, como os mandatos prorrogados de Aderaldo Castello constantes nos relatórios de atividades do IEB para o período 1969-1971, nos conduzem a inferir que Castello gozava de alto prestígio junto ao reitor da USP, uma vez que este era o responsável por prorrogar seu mandato. No ano de 1972, Castello estava afastado de suas atividades de diretor, por conta de viagens e cursos ministrados na França e Eduardo Kneese de Mello esteve à frente do IEB. Porém, entre 1973 e 1980, Castello manteve-se como diretor.

A situação de Castello esteve acomodada até que o corpo de pesquisadores decidiu reunir seu capital político. Até esse momento, os estatutos iam e vinham das congregações das unidades integrantes do IEB para reparos e considerações. Nessa reunião, na qual Alice esteve presente, Castello afirmou que o regimento seria encaminhado à reitoria para aprovação $^{709}$. Em reunião realizada em 09 de novembro de 1976, Castello afirma que propôs à reitoria a realização de eleições em lista tríplice até que fosse aprovado o regimento do instituto. A resposta da reitoria se deu no sentido de que o IEB deveria gerirse através da portaria de 1963, ou seja, da portaria que estabeleceu sua fundação, com a ressalva de que esta não colidisse com o estabelecido pelo Regimento Geral da USP. Assim, Castello, mais uma vez, prorrogava as eleições, uma vez que o IEB não poderia realizar eleições em lista tríplice, pois sua portaria estabelecia lista simples e o regimento geral da USP lista tríplice ${ }^{710}$.

Em reunião realizada em 08 de julho de 1977, José Eduardo Marques Mauro testava seu capital político junto ao CA. O mesmo apresentou projeto de regimento elaborado pelos pesquisadores e afirmou que o regimento proposto pelo CA não foi

\footnotetext{
${ }^{707}$ Cf. Relatório de atividades do Instituto de Estudos Brasileiros da Universidade de São Paulo em 1967. In: Noticiário. RIEB. São Paulo, n. 5, 1968, p. 180.

${ }^{708}$ Cf. Relatório de atividades do Instituto de Estudos Brasileiros da Universidade de São Paulo em 1968. In: Noticiário. RIEB. São Paulo, n. 6, 1969, p. 197.

${ }^{709}$ Cf. Ata da $79^{\mathrm{a}}$ reunião do CA ocorrida em 23/07/1975. Atas do CA do IEB/USP. Livro I. Fundo IEB. Arquivo IEB/USP. IEB001-01-0081, verso f. 231- f. 232.

${ }^{710} \mathrm{Cf}$. Ata da $82^{\mathrm{a}}$ reunião do CA ocorrida em 09/11/1976. Atas do CA do IEB/USP. Livro I. Fundo IEB. Arquivo IEB/USP. IEB001-01-0084, verso f. 241-verso f. 244.
} 
discutido com eles, ao que Castello afirma que o foi, porém que Mauro não estava presente. Posto em votação, o CA - infelizmente a ata não discrimina os votos para podermos analisar o equilíbrio de forças do conselho - aprovou o regimento que havia sido proposto por Castello ${ }^{711}$. O vai-e-vem do regimento continuaria junto à reitoria, bem como o centralismo de Castello. Através da ata da $86^{\mathrm{a}}$ reunião tomamos ciência de que o regimento retornou da reitoria com parecer de vários órgãos, foi reelaborado pelo próprio Castello e apresentado ao CA, que o aprovou por unanimidade. Alice não esteve presente nessa reunião ${ }^{712}$. Sua ausência pode estar ligada ao fato de que não mais chefiava o setor de documentação e pesquisa, uma vez que seu nome deixou de aparecer nos relatórios de atividade do IEB a partir de 1977.

A eleição da nova diretoria do IEB ficou condicionada à aprovação do novo regimento, o que ocorreria somente em 1981. No mesmo diapasão do clima autoritário pelo qual passava o país, mesmo quando Castello ia até o reitor Miguel Reale para colocar seu cargo à disposição, este não aceitava, declarando que dever-se-ia esperar a aprovação do novo regimento ${ }^{713}$. Em 1980, com uma década de implementação da reforma universitária na USP, Castello sabia que não mais poderia postergar as eleições através do vai-e-vem do projeto de regimento junto à reitoria, uma vez que o corpo de pesquisadores iniciou sua pressão também junto à esta e que o panorama político do país também passava por uma distensão.

Nas reuniões seguintes, constatamos que o capital político de Castello declinava, uma vez que não gozava do apoio de todos os membros do $\mathrm{CA}$, dentre eles Alice Canabrava e Myriam Ellis. Ademais, o CA aprovou a solicitação do corpo de pesquisadores para que tivesse sua representatividade aumentada com a incorporação de mais dois pesquisadores ${ }^{714}$.

\footnotetext{
${ }^{711}$ Cf. Ata da $85^{a}$ reunião do CA ocorrida em 08/07/1977. Atas do CA do IEB/USP. Livro II. Fundo IEB. Arquivo IEB/USP. IEB001-02-0002, f. 2.

${ }_{712}$ Cf. Ata da $86^{a}$ reunião do CA ocorrida em 17/02/1978. Atas do CA do IEB/USP. Livro II. Fundo IEB. Arquivo IEB/USP. IEB001-02-0003, f. 6-verso f. 6.

${ }^{713} \mathrm{Cf}$. Ata da $87^{\mathrm{a}}$ reunião do CA ocorrida em 16/06/1978. Atas do CA do IEB/USP. Livro II. Fundo IEB. Arquivo IEB/USP. IEB001-02-0004, f. 8.

${ }^{714}$ Cf. Ata da $90^{\mathrm{a}}$ reunião do CA ocorrida em 27/06/1980. Atas do CA do IEB/USP. Livro II. Fundo IEB. Arquivo IEB/USP. IEB001-02-0007, verso f. 23- f. 24. Ata da 91 a reunião do CA ocorrida em 15/08/1980. Atas do CA do IEB/USP. Livro II. Fundo IEB. Arquivo IEB/USP. IEB001-02-0008, f. 25-f. 28. Ata da 92 ${ }^{\mathrm{a}}$ reunião do CA ocorrida em 28/11/1980. Atas do CA do IEB/USP. Livro II. Fundo IEB. Arquivo IEB/USP. IEB001-02-0009, verso f. 28-f. 29. Ata da 92 ${ }^{\mathrm{a}}$ reunião do CA ocorrida em 28/11/1980. Atas do CA do IEB/USP. Livro II. Fundo IEB. Arquivo IEB/USP. IEB001-02-0010, verso f. 29-verso f. 32.
} 
Em reunião de 14 de dezembro de 1980, foi retomada a discussão sobre o regimento do IEB: prosseguir com a aprovação do regimento encaminhado em 1975; escolher o regimento simplificado proposto pelo reitor ou discutir o projeto de regimento proposto pelos pesquisadores. José Eduardo Marques Mauro afirma que a proposta dos pesquisadores se dá em uma perspectiva de que o IEB se constitua em um centro interunidades para que o mesmo não perca sua autonomia. Na sequência, Castello afirma que a reunião foi convocada exclusivamente para debater os rumos do regimento e que, por isso, inicia a votação para escolha entre reabrir as discussões ou dar prosseguimento à aprovação do regimento antigo, demarcando que a abertura de novas discussões implicaria o retorno do processo ao CA. Alice, Myriam, Carlos Drummond e João Baptista votaram pela abertura das discussões. Castello votou contra, afirmando que por sua experiência de 15 anos no IEB, se as discussões fossem reabertas o instituto estaria ameaçado e anuncia sua demissão. Drummond e João Baptista ponderaram, mas Castello afirma que "[...] já havia resolvido em pedir demissão quando os pesquisadores enviaram a carta para todos os conselheiros. Sentiu-se violentado e sua autoridade posta em dúvida". Dito isso, retirou-se $\mathrm{e}^{715}$.

Em carta à Francisco Iglésias, Alice comenta sobre o pedido de demissão de Aderaldo Castello.

O Aderaldo Castelo foi obrigado a renunciar à direção do Instituto de Estudos Brasileiros, depois de 12 anos [sic] no posto, encompridados graças às manobras no preparo dos estatutos da instituição, que ia à Reitoria e retornava para emendas, em circuitos que se alongavam anos a fio, pois a aprovação final dos estatutos levaria à eleição para o novo diretor, que não seria necessariamente o Castelo ${ }^{716}$.

Myriam Ellis foi designada pelo reitor como diretora "pro tempore" até a aprovação do novo regimento e realização de eleições. Para Alice, a demissão de Castello, além de significar mudança na diretoria do IEB, também importava em alterações nos projetos de pesquisa do instituto e em sua concentração por áreas. Na mesma carta citada acima, ela dá impressão do caráter de Castello à frente do IEB e que, deixando a diretoria, as pesquisas não mais se concentrariam na área de sua especialidade, ou seja, literatura brasileira e, especificamente, o modernismo.

\footnotetext{
${ }^{715}$ Cf. Ata da $93^{\text {a }}$ reunião do CA ocorrida em 14/12/1980. Atas do CA do IEB/USP. Livro II. Fundo IEB. Arquivo IEB/USP. IEB001-02-0011, verso f. 40-f. 41.

${ }^{716}$ São Paulo, 1981. APC-CP-P1,13(5). Fundo Alice Piffer Canabrava. Arquivo IEB/USP.
} 
O Castelo é muito autocrático, um ditador, de cinco em cinco anos queimava todo o acervo administrativo do Instituto de Estudos Brasileiros, manobrava o Conselho Diretor com a ocultação de fatos não favoráveis, perseguia funcionários e pesquisadores, não admitia que qualquer pessoa lá dentro fizesse sucesso, mal começava a aparecer as azinhas eram aparadas lá dentro. Todos o odeiam lá no Instituto. Pessoalmente não tenho queixa dele, nossas relações foram sempre amenas, mas sempre distantes. Agora o Instituto pode realizar uma pluralidade de iniciativas, desde que nos últimos anos pendeu mais para a Literatura Brasileira e, neste, para o Modernismo ${ }^{717}$.

No entanto, as tensões para discussão do regimento não se aplacaram, uma vez que membros do CA, como Carlos Drummond e João Baptista Borges Pereira possuíam posição de apoio à Aderaldo Castello. Em reunião ocorrida em 19 de maio de 1981, da qual Alice esteve ausente, uma vez que completou 70 anos e se aposentou compulsoriamente - o que implica no desligamento automático de qualquer cargo em exercício -, João Baptista Borges Pereira afirma que dever-se-ia recompor o conselho, dado o afastamento de Delfim Netto e de Aderaldo Castello de seus respectivos departamentos e de Dirceu Lino de Mattos e Antonio Rocha Penteado, por ocasião de suas aposentadorias, antes de se discutir o regimento. Myriam Ellis afirma ter preferido atender à solicitação do reitor, no que João Baptista insistiu na questão da representatividade, que gerou a indignação de José Eduardo Marques Mauro.

O prof. José Eduardo diz que parecem subterfúgios que aqui são colocados para não se discutir o regimento e parece até que todo o movimento dos pesquisadores foi feito apenas para derrubar o diretor. O prof. João Baptista observa que não quer levantar discussões já havidas entre o prof. José Eduardo e o prof. Castello e que está apenas levantando uma preliminar ${ }^{718}$.

O debate seguinte se deu em torno de discutir se o regimento poderia ser apreciado mesmo na ausência de Alice e de Benedito Lima. Para João Baptista Borges Pereira a questão da representatividade é fundamental. Os representantes dos pesquisadores, José Eduardo Marques Mauro, Marta Rosseti Batista e Cecília Lara, afirmam que o regimento foi discutido em outras ocasiões sem a presença de todos os conselheiros. Myriam Ellis afirma que se pode iniciar as discussões acerca do regimento, uma vez que as ausências mencionadas configuram uma questão e a representatividade outra. Ademais, assevera que mesmo na ausência permanente de Delfim Netto e Dirceu Lino de Mattos o regimento

\footnotetext{
${ }^{717}$ Idem, p. 5-6.

${ }^{718}$ Ata da $96^{\mathrm{a}}$ reunião do CA ocorrida em 19/05/1981. Atas do CA do IEB/USP. Livro II. Fundo IEB. Arquivo IEB/USP. IEB001-02-0014, verso f. 63.
} 
foi discutido, não havendo preocupação em se estabelecer suplência durante a diretoria anterior. João Baptista insiste que Delfim Netto estava afastado de suas funções em seu departamento e que o CA não aprovou proposta de substituição do conselheiro ${ }^{719}$.

Dada a dificuldade em se reunir os membros do CA, houve a formação de uma comissão para elaborar o projeto do novo regimento composta por dois conselheiros, Myriam Ellis como presidente e João Baptista Borges Pereira e dois pesquisadores, José Eduardo Marques Mauro e Cecília Lara. Aderaldo Castello, que exercia a vice-diretoria "pro tempore", e Marta Rosseti foram indicados como suplentes ${ }^{720}$. O novo regulamento estabelecia o IEB como centro especializado e não como centro interunidades, com o objetivo de manter sua autonomia financeira. Quanto à representatividade, o Conselho Deliberativo passou a ser formado por dois pesquisadores e oito professores, e seus respectivos suplentes, entre dois indicados pelos departamentos das unidades componentes do IEB com a titulação mínima de doutor, sendo que o representante seria escolhido ainda pelo reitor entre esses dois nomes.

Quanto ao conjunto de disciplinas integrantes do instituto, temos o seguinte quadro: geografia humana do Brasil (departamento de Geografia da FFLCH); antropologia do Brasil (departamento de Ciências Sociais da FFLCH); literatura brasileira (departamento de Línguas clássicas e vernáculas da FFLCH); línguas indígenas do Brasil (departamento de Linguística e línguas orientais); Arquitetura do Brasil (departamento de História, Arquitetura e Estética do Projeto da FAU); história econômica do Brasil (departamento de Economia da FEA); história da educação no Brasil (departamento de Filosofia da Educação e Ciência da Educação da FE). Quanto aos pesquisadores, estes se reúnem em torno das seguintes especialidades: história (política, econômica, social e cultural do Brasil); geografia regional do Brasil; literatura e teatro; português do Brasil, falares regionais; artes plásticas e arquitetura no Brasil; música erudita e popular no Brasil, que poderiam ser alteradas ou acrescentadas de acordo com as necessidades e interesses da instituição ${ }^{721}$.

\footnotetext{
${ }^{719}$ Cf. Ata da $96^{a}$ reunião do CA ocorrida em 19/05/1981. Atas do CA do IEB/USP. Livro II. Fundo IEB. Arquivo IEB/USP. IEB001-02-0014, f. 64-f. 69.

${ }^{720} \mathrm{Cf}$. Ata da $97^{\mathrm{a}}$ reunião do CA ocorrida em 26/05/1981. Atas do CA do IEB/USP. Livro II. Fundo IEB. Arquivo IEB/USP. IEB001-02-0015, verso f. 75.

${ }^{721}$ Cf. Ata da $98^{a}$ reunião do CA ocorrida em 22/07/1981. Atas do CA do IEB/USP. Livro II. Fundo IEB. Arquivo IEB/USP. IEB001-02-0016, verso f. 75-f. 86.
} 
A partir de sua aprovação junto ao Conselho Universitário, Myriam Ellis foi eleita diretora com mandato de quatro anos a partir de lista tríplice enviada ao reitor ${ }^{722}$. Em carta à Francisco Iglésias, Alice relata decisão fundamental de Myriam Ellis para a memória do IEB, qual seja, depois de quase três décadas de existência e diante dos rumores de que Castello se vinculava como fundador da instituição, monumentalizar Sérgio Buarque e sua obra.

Ainda no começo de Dezembro fui à cerimônia de inauguração do retrato do Dr. Sérgio Buarque de Holanda no Instituto de Estudos Brasileiros, do qual foi fundador. Junto ao retrato está a parte essencial do texto que instruiu o processo. A nova Diretora da instituição, Dra. Miriam Ellis, julgou necessário proceder o mais cedo possível à cerimônia porque Aderaldo Castelo, não conseguindo ser eleito, disseminava a ideia de que fora o fundador ${ }^{723}$.

\subsection{O "Encontro Internacional de Estudos Brasileiros. I Seminário de}

\section{Estudos Brasileiros" e a tentativa de delimitação de uma história da historiografia}

\section{brasileira}

Ocorrido entre os dias 13 e 25 de setembro de 1971, os dois eventos foram concebidos de maneira complementar a partir das áreas componentes do IEB, representadas por suas cadeiras, somadas às áreas de sociologia, pensamento brasileiro e história da educação: geografia, antropologia, história, literatura brasileira e arquitetura. Podemos notar a ausência das áreas de economia brasileira e línguas indígenas do Brasil. No regulamento geral do Seminário de Estudos Brasileiros, elaborado por seu coordenador e diretor do IEB José Aderaldo Castello, estava previsto pelo menos cinco áreas das sete listadas: história, economia, literatura, antropologia, sociologia, arte e arquitetura e geografia ${ }^{724}$. Tal regulamento foi publicado originalmente em 1970 e um dos indícios para a ausência das áreas mencionadas está relacionado à dificuldade de organização do evento, assumida por seu coordenador geral durante a sessão de abertura.

Infelizmente, motivos vários, de ordem material ou de determinados acertos, retardaram as providências preliminares, enquanto o período previsto para a realização dos programas permanecia o mesmo. Daí,

\footnotetext{
${ }^{722}$ Os três nomes mais votados foram: Carlos Drummond (oito votos), José Eduardo Marques Mauro (seis votos) e Myriam Ellis (seis votos). Cf. Ata da $1^{\mathrm{a}}$ reunião do Conselho Deliberativo ocorrida em 19/11/1981. Atas do CD do IEB/USP. Livro III (1981-1989). Fundo IEB. Arquivo IEB/USP. IEB001-03-0001, f. 4.

${ }^{723}$ São Paulo, 31 de dezembro de 1981. APC-CP-P1, 28-(4). Fundo Alice Piffer Canabrava. Arquivo IEB/USP.

${ }^{724}$ Cf. CASTELLO, José Aderaldo. Regulamento geral do Seminário de Estudos Brasileiros. In: Anais Encontro Internacional de Estudos Brasileiros. I Seminário de Estudos Brasileiros. V. I. São Paulo: Instituto de Estudos Brasileiros, 1972, p. 22-24.
} 
certa precipitação, determinados atrasos e violação de prazos e compromissos relativamente às normas gerais e regulamentares, enquanto por outro lado se impunham as limitações das proporções iniciais do projeto $^{725}$.

Outra hipótese aventada para a ausência da área de economia brasileira nesse I SEB diz respeito ao fato que Antônio Delfim Netto, membro do Conselho de Administração do IEB, estava afastado de suas funções acadêmicas ${ }^{726}$. Seu nome não aparece entre os membros do Conselho de Administração do IEB que também compuseram a Comissão Deliberativa do evento: Alice Piffer Canabrava; Antônio Rocha Penteado, da área de geografia do Brasil da FFLCH/USP; Carlos Drummond, de línguas indígenas do Brasil da FFLCH/USP; Dirceu Lino de Mattos, de geografia econômica do Brasil da FEA/USP; Eduardo Augusto Kneese de Mello, de história da arquitetura do Brasil da FAU/USP; Nícia Villela Luz, de história da civilização brasileira da FFLCH/USP; João Baptista Borges Pereira, de antropologia e etnografia do Brasil da FFLCH/USP e José Aderaldo Castello, de literatura brasileira da FFLCH/USP ${ }^{727}$. Ademais, também foram convidados para compor o conselho deliberativo, os seguintes professores: Alfredo Bosi, Antônio Cândido de Mello e Souza, Aroldo de Azevedo, Egon Schaden, Flávio Motta, João Alexandre Barbosa, João Cruz Costa, José Carlos Garbuglio, Laerte Ramos de Carvalho, Maria Isaura Pereira de Queiroz, Sérgio Buarque de Holanda e Walter Zanini. Se nos atentarmos para o perfil de gênero desse conselho, temos a presença de apenas três mulheres: Alice, Maria Isaura de Queiroz e Nícia Villela Luz.

Quanto aos participantes, a partir do que consta em cada regulamento geral, podemos dividi-los em dois grupos: especialistas estrangeiros em assuntos brasileiros convidados para o evento, brasileiros convidados que atuam em centros de pesquisa sobre estudos brasileiros no exterior e especialistas em geral $^{728}$; graduados e pós-graduandos ${ }^{729}$. Porém, no caso destes últimos, constatamos que sua participação se restringiu à condição

\footnotetext{
${ }^{725}$ CASTELLO, José Aderaldo. Saudação do coordenador geral. In: Anais... v. I, op. cit., 1972, p. 8.

${ }^{726}$ Cf. ROSA, Waldeir Moreno. A práxis de Antônio Delfim Netto no reordenamento político-econômico da ditadura bonapartista: ideólogo orgânico da autocracia burguesa. 182 f. 2015. Dissertação (Programa de Pós-Graduação em História) - FCS/PUC-SP, São Paulo, 2015.

${ }^{727}$ Cf. Organização e regulamentos gerais. In: Anais... v. I, op. cit., 1972, p. 15.

${ }^{728}$ Cf. Regulamento geral do Encontro Internacional de Estudos Brasileiros. In: Anais... v. I, op. cit., 1972, p. 20.

${ }^{729}$ Cf. CASTELLO, José Aderaldo. Regulamento geral do Seminário de Estudos Brasileiros. In: Anais... v. I, op. cit., 1972, p. 24.
} 
de ouvintes, à semelhança do que ocorria em vários Simpósios da APUH/ANPUH analisados no capítulo 2. Apenas os especialistas tinham a palavra autorizada.

Quando tomamos a lista de participantes por país, temos o seguinte quadro $\left(\right.$ Quadro 4) ${ }^{730}$ :

\begin{tabular}{|c|c|}
\hline Países & Número de presentes \\
\hline França & 13 \\
\hline EUA & 11 \\
\hline Alemanha & 2 \\
\hline Inglaterra & 2 \\
\hline Itália & 2 \\
\hline Argentina & 1 \\
\hline Equador & 1 \\
\hline
\end{tabular}

(elaboração própria a partir de: Anais Encontro Internacional de Estudos Brasileiros. I Seminário de Estudos Brasileiros. V. I. São Paulo: Instituto de Estudos Brasileiros, 1972).

A presença de pesquisadores franceses como Paul Arbousse-Bastide, Frédéric Mauro e Pierre Monbeig podem ser explicadas pelos laços que remontam à instalação da FFCL/USP. O comparecimento significativo de estadunidenses pode ser compreendido através da política dos EUA no pós-II Guerra Mundial de conhecer minuciosamente as várias regiões do globo visando atingir seus objetivos geopolíticos estratégicos. A partir desse esforço sabemos que os mesmos formaram uma grande rede de brasilianistas.

Quanto aos pesquisadores brasileiros, temos o seguinte quadro segundo Estado de origem (Quadro 5):

\footnotetext{
${ }^{730}$ Cf. Participantes estrangeiros e nacionais. In: Anais... v. I, op. cit., 1972, p. 27-56. Estamos considerando apenas os presentes e não os inscritos, dentre os quais figuram importantes autores com laços na FFCL/USP, como Roger Bastide, além da ausência de dois pesquisadores uruguaios, de um venezuelano e de um equatoriano. Através das atas de reunião do CA do IEB, tomamos conhecimento que foram convidados vinte professores, dentre os quais Fernand Braudel, que não pôde comparecer. Cf. Ata da $53^{\mathrm{a}}$ reunião do CA ocorrida em 31/05/1971. Atas do CA do IEB/USP. Livro I. Fundo IEB. Arquivo IEB/USP. IEB00101-0055, f. 139.
} 


\begin{tabular}{|c|c|}
\hline Estado de origem & Número de presentes \\
\hline São Paulo & 192 \\
\hline Guanabara & 9 \\
\hline Rio Grande do Sul & 7 \\
\hline Paraná & 5 \\
\hline Minas Gerais & 3 \\
\hline Pernambuco & 3 \\
\hline Bahia & 2 \\
\hline Ceará & 2 \\
\hline Brasília & 2 \\
\hline Pará & 2 \\
\hline Santa Catarina & 1 \\
\hline Mato Grosso & 7 \\
\hline
\end{tabular}

(elaboração própria a partir de: Anais Encontro Internacional de Estudos Brasileiros. I Seminário de Estudos Brasileiros. V. I. São Paulo: Instituto de Estudos Brasileiros, 1972).

A predominância de paulistas pode ser explicada pela proximidade geográfica, acrescida pelo fato de que, além de centros universitários estabelecidos na capital, o Estado de São Paulo contava com uma rede de Faculdades de Filosofia isoladas em seu interior. O mesmo podemos afirmar em relação à antiga Guanabara. Sua capital contava com um maduro sistema universitário ${ }^{731}$ comprovado com a presença de representantes de instituições como o Museu Nacional, o Centro Brasileiro de Pesquisas Educacionais e o Instituto Universitário de Pesquisas, por exemplo. O RS contava até 1971 com duas instituições de ensino e pesquisa consolidadas: UFRGS e PUC/RS ${ }^{732}$ que também se fizeram representar no evento. O Estado do Paraná, além de sua Universidade Federal e Universidade Católica na capital, contava, assim como São Paulo, com a capilaridade de

\footnotetext{
${ }^{731}$ Ver: FÁVERO, Maria de Lourdes Albuquerque; LIMA, Helena Ibiapina. A Universidade Federal do Rio de Janeiro (UFRJ): origens, construção e desenvolvimento. In: MOROSINI, op. cit., 2006, p. 65-80. SEGENREICH, Stela Cecília. Pontifícia Universidade Católica do Rio de Janeiro (PUC-RJ): pioneirismo e mudança. In: MOROSINI, op. cit., 2006, p. 173-186. MANCEBO, Deise. Universidade Estadual do Rio de Janeiro (UERJ): da gênese utilitária aos compromissos "pró-ciência". In: MOROSINI, op. cit., 2006, p. 245-253.

${ }^{732}$ FRANCO, Maria Estela Dal Pai; MOROSINI, Marília Costa. Universidade Federal do Rio Grande do Sul (UFRGS): da universidade técnica à universidade inovadora. In: MOROSINI, op. cit., 2006, p. 81-95. ABRAHÃO, Maria Helena Menna Barreto; MOROSIN, Marília Costa. Pontifícia Universidade Católica do Rio Grande do Sul (PUC-RS): uma universidade inovadora no contexto da confessionalidade. In: MOROSIN, op. cit., 2006, p. 187-199.
} 
suas Faculdades de Filosofia pelo interior, como as UEL e UEPG, que também enviaram pesquisadores $^{733}$. Os dois centros universitários mais antigos da região nordeste, as Universidade da Bahia e Universidade de Pernambuco, também estiveram presentes somando um total de 6 especialistas inscritos. Porém, se somarmos o número de participantes dos outros Estados, 45, e compararmos com São Paulo, o predomínio paulista ainda permanece.

Se nos atentarmos para o perfil de gênero dos inscritos, 180 homens e 129 mulheres, e tomarmos o evento enquanto uma radiografia do campo de estudos brasileiros, inclusive em sua inserção internacional, há maior presença masculina, com um número significativo de mulheres. Nesse sentido, podemos afirmar que as mulheres possuíam grande inserção nos estudos brasileiros e que sua participação docente nas Faculdades e Universidades aumentou como resultado da reforma universitária, uma vez que praticamente todos os elementos femininos do evento eram professoras. Entretanto, quando nos atentamos para a composição de gênero das coordenações de área, o quadro é outro, e o número de homens (12) é mais que o dobro do número de mulheres (5) ${ }^{734}$. Nesse aspecto, se considerarmos que a coordenação de sessões e/ou mesas em eventos pode ser tomada como signo de reconhecimento no campo ${ }^{735}$, as mulheres ainda não gozavam do mesmo prestígio que os homens e, em um quadro mais amplo, não por falta de especialistas, como pudemos constatar por sua massiva presença, mas sim devido às permanentes barreiras de gênero. Nesse sentido, as mulheres ainda ocupavam posições subalternas na hierarquia acadêmica daquele momento frente a composição por gênero do secretariado desse I SEB: 18 mulheres e 7 homens ${ }^{736}$.

Ao nos atentarmos para os presentes em cada área, temos o seguinte quadro (Quadro 6):

\footnotetext{
${ }^{733}$ MICHELOTTO, Regina Maria. Universidade Federal do Paraná (UFPR): uma universidade para a classe média. In: MOROSINI, op. cit., 2006, p. 53-63.

${ }^{734}$ Cf. Anais..., op. cit., 1972.

${ }^{735}$ Cf. OFFENSTADT, Nicolas. Colloques. In: DELACROIX, Christian; DOSSE, François; GARCIA, Patrick; OFFENSTADT, Nicolas (Orgs.). Historiographies: concepts et débats I. Paris: Gallimard (Folio histoire), 2010, p. 89.

${ }^{736}$ Cf. Anais..., op. cit., 1972.
} 


\begin{tabular}{|c|c|c|c|}
\hline Área & $\begin{array}{c}\text { Número de } \\
\text { Participantes }\end{array}$ & Homens & Mulheres \\
\hline Geografia & 35 & 13 & 22 \\
\hline Antropologia & 72 & 40 & 15 \\
\hline Sociologia & 31 & 20 & 4 \\
\hline História & 33 & 8 & 0 \\
\hline História da & 12 & 8 & 14 \\
\hline Educação & 8 & & 1 \\
\hline Pensamento & & 26 & \\
\hline Brasileiro & 40 & 9 & \\
\hline $\begin{array}{c}\text { Literatura } \\
\text { Brasileira }\end{array}$ & 10 & & \\
\hline Arquitetura & & & \\
\hline
\end{tabular}

(fonte: elaboração própria a partir de: Anais Encontro Internacional de Estudos Brasileiros. I Seminário de Estudos Brasileiros. V. I. São Paulo: Instituto de Estudos Brasileiros, 1972) ${ }^{737}$.

A área de antropologia é a que apresenta o maior número de participantes, 72, uma vez que também reuniu a "VIII reunião brasileira de Antropologia"738, seguida pelas áreas de literatura brasileira (40), geografia (35), história (33) e sociologia (31). Esses números denotam a importância dessas disciplinas na abordagem dos estudos brasileiros. No entanto, quando nos atentamos para o perfil de gênero dessas áreas, a que apresenta maior inserção da mulher é a Antropologia (32), seguida pela Geografia (22), Sociologia (15), Literatura brasileira (14) e História (13). As áreas com menor inserção feminina são as de Pensamento brasileiro (0), Arquitetura (1) e História da Educação (4). A única área em que o número de mulheres superou a de homens é a de Geografia.

Quanto ao modus operandi do evento, esse foi organizado em sessões plenárias e grupos de trabalho que hierarquizaram academicamente o I SEB, uma vez que as sessões plenárias foram reservadas para os seminários e comunicações de convidados especiais e apresentação de propostas. Ao contrário dos vários Simpósios da APUH/ANPUH que analisamos no capítulo anterior, nesse evento todos os inscritos poderiam encaminhar sugestões e comentários após a apresentação da "introdução monográfica" por seu

\footnotetext{
${ }^{737}$ Do "Número de participantes" excluímos os secretários e secretárias, pois muitos não eram da área.

738 Sobre as reuniões ver: CORREA, Mariza. As Reuniões Brasileiras de Antropologia - 50 anos. Campinas: Editora da Unicamp, 2003.
} 
coordenador e comentários dos convidados ${ }^{739}$. O mesmo procedimento metodológico que adotamos na lide com os vários Anais de Simpósios da APUH/ANPUH cabe também aqui, ou seja, a consideração de que os Anais do EIEB. I SEB foram produzidos através do enquadramento dos discursos ${ }^{740}$ pelo império da escrita ${ }^{741}$. Cada área deveria apresentar uma introdução monográfica para discussão.

Os trabalhos da área de História deste I SEB foram coordenados por Sérgio Buarque de Holanda, Alice Canabrava e Nícia Vilella Luz e secretariados por Arlinda Rocha Nogueira, José Eduardo Marques Mauro e Lucy Maffei Hutter. A introdução monográfica da área, denominada "Introdução ao estudo da História do Brasil", foi elaborada por Alice Canabrava, Nícia Villela Luz e José Eduardo Marques Mauro. Essa "Introdução" está dividida em três partes: "Roteiro sucinto do desenvolvimento da historiografia brasileira" "742, "A pesquisa histórica no Brasil"743 e "Bibliografia"744. Essa "Introdução" foi publicada de modo resumido nos Anais do evento, excluída a "bibliografia" elaborada por Nícia V. Luz. Pelo fato de que os comentadores receberam a versão completa do texto para análise, como preconizado pelo regulamento, adotamos aqui essa versão. A mesma será cotejada com a versão resumida, uma vez que essa última traz o que Alice julga essencial na historiografia brasileira ${ }^{745}$.

A sessão plenária que discutiu a monografia apresentada tomou três dias de trabalho e foi composta por Richard Morse na condição de presidente; Sérgio Buarque de Holanda e Alice Canabrava como coordenadores; Frédéric Mauro, Francisco Iglésias, Richard Graham e Cecília Westphalen na condição de comentadores convidados. O convite para Morse presidir a mesa provavelmente partiu de Sérgio Buarque de Holanda e Alice Canabrava, uma vez que Morse, desde 1947, quando chegou dos EUA para

\footnotetext{
${ }^{739}$ Cf. Regulamento interno. In: Anais... v. I, op. cit., 1972, p. 25-26.

${ }^{740}$ Cf. FOUCAULT, op. cit., 2014.

${ }^{741}$ Cf. CERTEAU, op. cit., 2011.

${ }^{742}$ CANABRAVA, Alice Piffer. Roteiro sucinto do desenvolvimento da historiografia brasileira. In: HOLANDA, Sérgio Buarque; CANABRAVA, Alice Piffer; LUZ, Nícia Villela. Introdução ao estudo da história do Brasil. Encontro Internacional de Estudos Brasileiros. I Seminário de Estudos Brasileiros. São Paulo: Instituto de Estudos Brasileiros, 1971, p. 2-39.

${ }^{743}$ MAURO, José Eduardo Marques. A pesquisa histórica no Brasil. In: HOLANDA; CANABRAVA; LUZ, op. cit., 1971, p. 41-61.

${ }^{744}$ LUZ, Nícia Villela. Bibliografia. In: HOLANDA; CANABRAVA; LUZ, op. cit., 1971, p. 62-173.

745 Ao buscar os Anais do SIEB. I SEB na biblioteca Florestan Fernandes da FFLCH/USP, por acaso encontrei a versão completa do texto de Alice Piffer Canabrava. Ao se realizar a busca no banco de dados das bibliotecas da USP, o texto de Alice aparece apenas nas bibliotecas do IEB e Brasiliana Mindlin. Cf. <www.dedalus.usp.br>. Acessado em 07 jan. 2019.
} 
realizar pesquisa sobre a cidade de São Paulo, travou contato com os dois historiadores ${ }^{746}$. Por se tratar de um brasilianista, e considerando que um congresso fixa as hierarquias acadêmicas, os reconhecimentos sociais e intelectuais ${ }^{747}$, Richard Morse foi elevado à condição de grande especialista presente da área.

A presença de Frédéric Mauro pode ser atribuída às relações históricas entre os professores franceses e a FFCL. Ademais, como vimos, Alice mantinha trocas intelectuais com o historiador francês e ambos foram sócios-honorários da Associação Brasileira de Pesquisadores em História Econômica ${ }^{748}$. Richard Graham, brasilianista e professor da Universidade do Texas, era amigo de longa data de Sérgio Buarque de Holanda ${ }^{749}$ e possuía relações com historiadores brasileiros, dentre eles Alice Canabrava ${ }^{750}$. Em carta de 10 de dezembro de 1970, Graham, na condição de editor associado da Hispanic American Historical Review, convida Alice para resenhar o livro "Comercio y Contrabando en el Río de la Plata y Chile, 1700-1811" de Sérgio Villalobos ${ }^{751}$. Francisco Iglésias e Cecília Westphalen, além das relações de sociabilidade com Sérgio e Canabrava, também gozavam de alto prestígio intelectual no campo historiográfico brasileiro.

Além destes, também participaram do seminário na área de história: Amaro Quintas, Anita Novinsky, Antonio Rubbo Muller, Elcio Dolabela, Elisabeth Anne Kuznesof, Francisco José Calazans Falcon, Heloísa Froes Leme, Hermann Kellenbenz, Ibrahim João Elias ${ }^{752}$, Jamil Abid, Jeanne Berrance de Castro, José Sebastião Witter, Julia Maria Leonor Scarano, Maria Beatriz Nizza da Silva, Maria da Conceição Martins

\footnotetext{
${ }^{746}$ Cf. MORSE, Richard. Entrevista. In: BOMENY, Helena Maria Bousquet. Uma entrevista com Richard Morse. Estudos históricos. Rio de Janeiro, v. 2, n. 3, p. 77-93, 1989. Entrevista realizada em Washington em abril de 1988. Quando menciona seus intercâmbios intelectuais com brasileiros, Morse afirma: "Havia ainda Alice Canabrava, que estava fazendo uma história econômica que foi muito útil em termos de fontes documentais".

${ }^{747}$ Cf. OFFENSTADT, op. cit., 2010, p. 89.

748 Cf. RIBEIRO, Maria Alice Rosa. Notas sobre os sócios-honorários da Associação Brasileira de Pesquisadores em História Econômica - ABPHE. In: SAES; RIBEIRO; SAES, op. cit., 2017, p. 331-333. ${ }^{749}$ Cf. CARVALHO, 2017, p. 86.

${ }^{750}$ Ademais, foi professor visitante do Programa de Pós-Graduação em História Social da FFLCH/USP em 1976. Cf. MESGRAVIS, Laima. O curso de pós-graduação do departamento de História da Faculdade de Filosofia, Letras e Ciências Humanas da Universidade de São Paulo. Revista Brasileira de História. São Paulo, n. 5, v. 3, 1983, p. 93.

${ }^{751}$ Cf. Austin, 10 de dezembro de 1970. APC-GRAH-001. Fundo Alice Piffer Canabrava. Arquivo IEB/USP.

${ }^{752}$ A lista de participantes da área de história traz o nome de Ibrahin João Elias como "Ibrahin José Elias". Lembramos que o mesmo foi auxiliar de ensino de Alice na FCEA/USP.
} 
Ribeiro, Maria José Elias, Mário Bruno, Paulo Sérgio de Moraes Sarmiento Pinheiro, Sebastião Romano Machado, Thomas Skidmore e Walmir Batista Correia ${ }^{753}$.

Além dos convidados, Manuel Correia de Oliveira Andrade, Sérgio da Costa Franco, Antonietta de Aguiar Nunes e Emília Viotti da Costa apresentaram considerações e/ou comentários sobre a monografia da área. Ademais, Carlos Manuel Pelaez apresentou nota sobre o estado e o futuro das pesquisas em história econômica do Brasil ${ }^{754}$. Além da sessão que comentou a monografia também houveram apresentações de comunicações com respectivo relator à critério de professor designado a priori. Assim, tivemos a apresentação de cinco trabalhos, seus respectivos comentários e respostas finais. A comunicação de Júlia Maria Leonor Scarano, "Comentários sobre imigrantes que demandaram uma zona cafeeira" 755 foi comentada por Francisco Falcon; Jeanne Berrance de Castro apresentou comunicação intitulada "Considerações a respeito da população preta escrava e livre num período de mudança: 1875-1930"756, comentada por Thomas Skidmore; A comunicação de Frédéric Mauro, "Remarques sur quelques sources

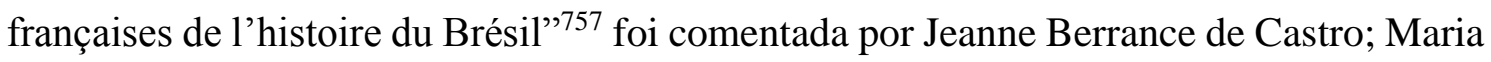
da Conceição Martins Ribeiro apresentou o trabalho "A problemática da arquivística nacional" ${ }^{\text {758 }}$ comentado por Antonietta de Aguiar Nunes. Por fim, Hermann Kellenbez apresentou comunicação intitulada "Um mercador neerlandês em Lisboa tratando com o Brasil" ${ }^{\prime 759}$, comentado por Alice Canabrava.

Em seu texto, Alice não se preocupa em sistematizar por itens. Podemos dividi-lo em várias partes: uma parte em que ela, mesmo mencionando poucos trabalhos que considera historiográficos, debruça-se em analisar as fontes produzidas pela história do Brasil e sua tipologia; uma segunda parte em que trata da produção historiográfica, principalmente do século XIX; uma terceira, na qual vê surgir uma moderna historiografia

\footnotetext{
${ }^{753}$ Cf. Participantes: In: Anais..., v. II, op. cit., 1972, p. 3-4.

${ }^{754}$ PELAEZ, Carlos Manuel. A note on the state and the future of research on Brazilian Economic History. In: Anais..., op. cit., 1972, v. II, p. 69-71.

${ }^{755}$ SCARANO, Júlia Maria Leonor. Comentários sobre imigrantes que demandaram uma zona cafeeira. In: Anais..., v. II, op. cit., 1972, p. 71-83.

${ }^{756}$ CASTRO, Jeanne Berrance de. Considerações a respeito da população preta escrava e livre num período de mudança: 1875-1930. In: Anais..., v. II, op. cit., 1972, p. 88-98.

${ }^{757}$ MAURO, Frédéric. Remarques sur quelques sources françaises de l'histoire du Brésil. In: Anais..., v. II, op. cit., 1972, p. 101-112.

${ }^{758}$ RIBEIRO, Maria da Conceição Martins. A problemática da arquivística nacional. In: Anais..., v. II, op. cit., 1972, p. 114-124.

${ }^{759}$ KELLENBEZ, Hermann. Um mercador neerlandês em Lisboa tratando com o Brasil. In: Anais..., v. II, op. cit., 1972, p. 127-157.
} 
a partir das primeiras Faculdades de Filosofia, mencionando também nomes que toma por pioneiros ao adotarem os procedimentos metodológicos provenientes das ciências sociais e uma produção que divide por áreas e temas: história econômica, história social, escravidão etc.

Na primeira parte de seu texto, a historiadora cita e comenta uma grande variedade de fontes que se estendem das três primeiras décadas do século XVI, passam pelos séculos XVII e XVIII até a "História do Brasil" de frei Vicente do Salvador, publicada em 1627, considerada a primeira história do Brasil. Em relação àquelas três primeiras décadas, afirma que as fontes são exíguas pelo fato de que os responsáveis pela descoberta e primeiros contatos com o território estavam mais preocupados com sua ação do que em narrar fatos. Para essas décadas estabelece como margens "A Carta de Pero Vaz de Caminha", à qual trata por relato de viagem enquanto gênero literário, comentada por Jaime Cortesão - Alice faz questão de sempre citar um comentador da fonte por ela descrita - e o "Diário de Navegação" de Pero Lopes de Souza com comentários de Eugênio de Castro em edição de 1947. Entre essas margens elenca "documentos importantes": carta de D. Manoel aos reis católicos participando o descobrimento do Brasil, a carta de Américo Vespúcio a Soderini, a relação do piloto anônimo, o livro da nau Bretoa, a nova gazeta da terra do Brasil, todos reproduzidos na "História da Colonização Portuguesa no Brasil”, dirigida por Carlos Malheiros Dias entre 1921$1926^{760}$.

O movimento de análise empreendido pela historiadora a partir daqui será o de demonstrar que a cada momento da colonização uma nova gama de fontes é produzida. Assim, com os fundamentos da colonização "[...] multiplicam-se agora as fontes; sua natureza se torna variada, alarga-se o quadro da referência geográfica"761. Perpassa as fontes "oficiais", como as cartas de doação e os forais das capitanias e para o conhecimento da ocupação do litoral cita as "obras" de Pero de Magalhães Gândavo ("Tratado da terra do Brasil", "História da Província de Santa Cruz") e de Gabriel Soares

\footnotetext{
${ }^{760} \mathrm{Na}$ versão resumida de seu "roteiro", que denominamos "resumo", Alice também enquadra a documentação produzida nas três primeiras décadas do século XVI entre a "Carta" de Caminha e o "Diário" de Pero Lopes. A documentação produzida entre àqueles, ela afirma que foi analisada na obra coordenada por Carlos Malheiros Dias. Cf. CANABRAVA, 1972, op. cit., p. 4-5.

${ }^{761}$ CANABRAVA, Alice Piffer. Roteiro sucinto do desenvolvimento da historiografia brasileira. In: CANABRAVA, Alice Piffer; LUZ, Nícia Villela; MAURO, José Eduardo Marques. Introdução ao estudo da história do Brasil. São Paulo: IEB/USP, 1971a, p. 3.
} 
de Souza ("Tratado descritivo do Brasil"), qualificando-as como “[...] as mais importantes fontes descritivas de procedência particular"762.

Alice perpassa as fontes de origem jesuítica, qualificando-as também como descritivas ao lado de crônicas, cartas e sermões ${ }^{763}$. Chegando aos séculos XVII e XVIII, ela aponta uma inflexão no processo de exploração e colonização, qual seja, sua interiorização e as invasões estrangeiras gerando uma nova conjuntura. "O processo de exploração e colonização assumiu novas feições características, dentro dos mesmos móveis subjacentes que dão o caráter fundamental à colonização, do ponto de vista econômico-social, ou seja, os objetivos mercantis" ${ }^{\text {"764 }}$. A historiadora compreende o processo de colonização a partir do modelo interpretativo de Caio Prado Júnior, mesmo que em alguns textos tenha se descolado dele, conforme já apresentado acima. Assim, nessa primeira parte do texto sua tipologia e análise de fontes podem ser compreendidos como espelho do sentido da colonização caio pradiano ${ }^{765}$. Para os séculos supracitados são produzidas fontes relacionadas à ocupação do interior do território, ou seja, ligadas ao bandeirismo e aqui aparece a primeira referência à obra propriamente historiográfica, "História geral das bandeiras paulistas" de Afonso Taunay, seguida pela obra de Pedro Taques de Almeida Paes Leme ${ }^{766}$.

O mesmo crivo de análise é mobilizado na exposição das fontes do século XVIII, relacionadas à mineração. Preocupada com as condições econômico-sociais da colonização e demarcando sua escassez, Alice dá grande importância ao que ela qualifica como "informe” de André João Antonil, "Cultura e Opulência do Brasil por suas drogas e minas"767. Para o conhecimento das fontes relativas à defesa do território na região norte

\footnotetext{
${ }^{762}$ Idem, p. 4. No "resumo", Canabrava menciona apenas Gabriel Soares de Souza, sem citar documentação. Cf. CANABRAVA, op. cit., 1972, p. 5.

${ }^{763}$ No "resumo". Alice menciona apenas a obra de Serafim Leite, "A história da Companhia de Jesus" (1928-1950). Cf. CANABRAVA, op. cit., 1972, p. 5.

${ }^{764}$ CANABRAVA, op. cit., 1971a, p. 6.

${ }^{765}$ Rebeca Gontijo ao analisar o texto de Alice em sua versão resumida, publicada nos Anais do evento, sugere que o mesmo se dá em uma chave na qual a historiografia é espelho da história. Cf. GONTIJO, Rebeca. Revisão e prospecção da historiografia no Brasil nos anos 1970. In: BENTIVOGLIO; NASCIMENTO, op. cit., 2017, p. 94.

${ }^{766}$ Pelo fato de que em seu "resumo" Alice menciona apenas Taunay, podemos depreender que esse autor seja considerado por ela o mais importante quando o assunto diz respeito à ocupação do território. Cf. CANABRAVA, op. cit., 1972, p. 5.

${ }^{767}$ Alice produziu extenso prefácio para a publicação desse texto em 1967, ver: CANABRAVA, op. cit., 1967. Menciona também "Triunfo Eucarístico" de Simão Ferreira Machado (1734) e "Cartas Chilenas" de Manoel Antônio Gonzaga. Em seu "resumo" o destaque é dado à "Cultura e Opulência do Brasil por suas drogas e minas" e "Diálogos das grandezas do Brasil". Cf. CANABRAVA, op. cit., 1972, p. 5.
} 
e nordeste, ela recorre à obra de José Honório Rodrigues, "Historiografía del Brasil. Siglo XVII"768. Outra obra historiográfica analisada brevemente nessa primeira parte de seu "roteiro" é "Os jesuítas no Grão-Pará, suas missões e a colonização" na qual João Lúcio de Azevedo apresenta, do ponto de vista dos missionários, a atividade jesuítica na Amazônia a partir, principalmente, das cartas de Antônio Vieira. Em seguida, sua preocupação, a partir de seu lugar social, qual seja, especialista em história econômica, se volta para listar as fontes propícias a uma escrita da história que privilegie "[...] as condições da vida econômica e social da Colônia"769. Para ela, a primeira fonte para uma história econômica da colônia é "Diálogos das grandezas do Brasil" cuja autoria foi atribuída a Ambrósio Fernandes Brandão por José Gonçalves de Melo. Destaca também a importância de "Economia cristã dos senhores do governo dos escravos" de Jorge Benci, como fonte para uma história social da escravidão.

Voltando a Antonil, ela recoloca o que havia classificado enquanto "informe", referindo-se à "Cultura e opulência do Brasil por suas drogas e minas", como historiografia. Nesse aspecto, lembramos que na tese com a qual concorreu à cátedra de História da Civilização Americana em 1946, Alice mobilizou essa fonte produzida pelo jesuíta italiano no que tange à técnica de produção do açúcar ${ }^{770}$. Ela trata também de fontes e de obras que demonstram um rompimento com o sistema colonial no século XVIII. Como exemplo da penetração do iluminismo menciona "Autos da inconfidência" (1789). Nesse mesmo diapasão, a "Recopilação de notícias soteropolitanas e brasílicas" (1802) de Luís dos Santos Vilhena é tomada como de grande importância para a descrição da economia colonial, denotando preocupação quantitativa com a população, o comércio e a produção, bem como uma crítica ao sistema colonial. A crítica ao sistema colonial também está presente em "Memória sobre o preço do Açúcar" (1791) e no "Ensaio Econômico sobre o comércio de Portugal e suas colônias" (1794) de José Joaquim da Cunha Coutinho, bem como nas "Cartas econômico-políticas sobre a agricultura e o comércio da Bahia" (1807) de Rodrigues de Brito ${ }^{771}$.

\footnotetext{
${ }^{768}$ Em seu "resumo" não há citação de nenhuma fonte e/ou obra sobre o assunto. Cf. CANABRAVA, op. cit., 1972, p. 5.

${ }^{769}$ CANABRAVA, op. cit., 1971a, p. 10.

${ }^{770}$ Cf. CANABRAVA, op. cit., 1981 a.

${ }^{771}$ Cf. CANABRAVA, op. cit., 1971a, p. 12-13. Todos esses escritos são mencionados em seu "resumo". Cf. CANABRAVA, op. cit., 1972, p. 6.
} 
Pudemos perceber nessa primeira parte do texto de Alice que, por mais que a mesma tenha se concentrado em elencar fontes para a história colonial, geradas pelo processo de colonização, também listou algumas obras que ela mesma qualifica como historiografia. Essa pode ser uma das razões pelas quais, como veremos, Francisco Iglésias, em seu comentário ao "roteiro", tenha explicitado a necessidade de se definir fonte, história e historiografia.

Outra parte de seu "roteiro" que podemos analisar em conjunto enquadra-se entre a "História do Brasil" (1627) de frei Vicente do Salvador, passa pela criação do IHGB e análise de autores vinculados a esse sodalício, Varnhagen e Capistrano de Abreu até a fundação das primeiras Faculdades de Filosofia. Alice adota enquanto prática, o mesmo método anterior quanto às fontes, ou seja, nesse caso, sempre que analisa uma obra traz à baila também um comentador. Assim procede com frei Vicente do Salvador, com comentário de Capistrano. Porém, por vezes traz seu comentário, sua análise. "O pitoresco, o sobrenatural e os fatos históricos se entremeiam em agradável narrativa. Apesar desse característico, a obra é indispensável quanto aos anos que abrange (15001624), pois muitas das fontes aventadas como de sua consulta se perderam"772. Em seguida trata do livro "História da América Portuguesa" (1730) de Rocha Pitta, com comentário de Charles Boxer, passando por Robert Southey e o comentário de Oliveira Lima até atingir a fundação do IHGB em 1838, “[...] um marco, pela influência profunda que exerceu na historiografia brasileira, o mais importante centro de estudos históricos

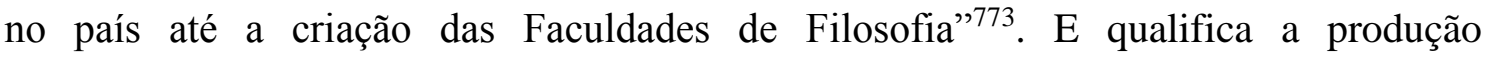
historiográfica do silogeu como nativista, expressa em seus trabalhos que enaltecem a figura do índio, a exaltação nacional por meio do culto biográfico e o "culto" documental expresso pela divulgação de importantes fontes em sua revista e também nas revistas de seus congêneres estaduais.

Em sua análise da obra "História geral do Brasil" (1853) de Francisco Adolfo de Varnhagen, a historiadora demarca aproximações e distanciamentos em relação ao que caracteriza como procedimento metodológico da produção do IHGB. Para ela, a obra de Varnhagen se distancia do indianismo e da exaltação nacional imbuídos nas obras dos homens do instituto. Por outro lado, “[...] ligou-se aos seus grandes objetivos e constituiu

\footnotetext{
772 CANABRAVA, op. cit., 1971a, p. 13.

${ }^{773}$ Idem, p. 14. Em seu "resumo" analisa as obras de frei Vicente do Salvador, "[...] primeiro esboço de elaboração sobre o nosso passado", Rocha Pita e Southey. Cf. CANABRAVA, op. cit., 1972, p. 6.
} 
o monumento da historiografia brasileira do século XIX"774. Quanto à formação intelectual do Visconde de Porto Seguro, ela o qualifica como um autodidata por seu trânsito e prática em diversos arquivos do mundo propiciada por sua atividade diplomática. Por sua preocupação com a exegese documental, ela o aproxima da "escola" de Ranke $^{775}$. Essa característica permite à Alice diferenciar a história produzida por Southey, uma história romântica, apaixonada e amadora e a de Varnhagen, com rigor técnico e a devida "imparcialidade". Assim, "História geral do Brasil" se filia a uma história filosófica, sob a égide da razão. Porém, mesmo pretendendo-se uma história geral, é marcada por uma abordagem político-administrativa, com uma sólida arquitetura de fatos e uma "massa ciclópica de materiais", nos dizeres de Capistrano de Abreu. É em suma, uma história factual que, como apontado por D’Avezac, é também uma história das elites, um "espelho do autor".

Essa não é a primeira vez em que Alice Canabrava analisa a obra de Varnhagen. Sua longa prática historiadora permitiu-lhe também realizar incursões teóricometodológicas em um momento em que a história da historiografia não gozava da robustez contemporânea em termos de área de pesquisa, onde o mais comum era que historiadores com longa prática de pesquisa tecessem reflexões dessa natureza ${ }^{776}$.

Na mesa redonda organizada pela ANPUH/PR por ocasião da XXIII reunião anual da SBPC realizada em Curitiba no mês de julho de 1971, Canabrava apresentou comunicação intitulada "Apontamentos sobre Varnhagen e Capistrano de Abreu"777. Ela inicia sua comunicação caracterizando o IHGB à mesma forma do empreendido em seu "roteiro", por vezes, com os mesmos dizeres. Ao iniciar o comentário sobre a obra "História geral do Brasil", indica como data de publicação o ano de 1854, ao contrário do que iria expor em seu "roteiro": $1853^{778}$. Alice trata o ofício de historiador de Varnhagen enquanto vocação, conforme o mesmo se expressara em certa ocasião. Também comenta sobre sua facilidade de acesso a documentos inéditos por conta de sua atividade

\footnotetext{
${ }^{774}$ CANABRAVA, op. cit., 1971a, p. 15.

775 A erudição histórica e a crítica textual de Varnhagen podem ser tributadas ao iluminismo português. Cf. SILVA, Taíse Tatiana Quadros da. A erudição ilustrada de Francisco Adolfo de Varnhagen (1816-77) e a passagem da historiografia das belas letras à historiografia nacional: breve análise histórica. In: GUIMARÃES, Manoel Luiz Salgado (org.). Estudos sobre a escrita da história. Rio de Janeiro: 7 Letras, 2006, p. 114-138.

${ }^{776}$ Excetuando-se, principalmente, José Honório Rodrigues.

777 CANABRAVA, Alice Piffer. Apontamentos sobre Varnhagen e Capistrano de Abreu. Revista de História. São Paulo, n. 88, p. 417-424, 1971.

${ }^{778}$ A primeira edição da obra data de 1854.
} 
diplomática. Em seguida, passa à caracterização da formação intelectual do autor, afirmando que pouco se sabe sobre a mesma e que raros são os autores estrangeiros citados em suas cartas. Como faria em seu "roteiro", a preocupação com a exegese documental, ou seja, com a crítica documental, o aproxima da "escola" alemã de Ranke, assinalando também as aproximações e distanciamentos em relação aos preceitos gerais do IHGB. "Em suma, uma História factual, um paradigma da História empírica, individualista e psicológica"779.

Em relação a Capistrano de Abreu, a parte que ocupa no "roteiro" é toda derivada desse texto anterior. Alice Canabrava aproxima Varnhagen e Capistrano no que tange ao cuidado com a crítica documental e o estabelecimento das fontes, aproximando-o da escola histórica alemã, leia-se Ranke ${ }^{780}$. Aponta como diferencial de Capistrano, a incorporação das nascentes ciências sociais em sua história, principalmente da tradição geográfica ratzeliana, da ocupação territorial em "Caminhos Antigos e Povoamento do Brasill”. Além de Ratzel, aponta para o conhecimento de vários autores citados nas cartas publicadas por José Honório Rodrigues, como Taine, Buckle, Comte, Spencer, Schmoller, Peschel, Sombart etc. Para ela, "Capítulos de história colonial” é a primeira obra de geografia humana brasileira e Capistrano constitui-se como elo entre Varnhagen e uma história informada pelas nascentes ciências sociais que teria lugar nas Faculdades de Filosofia. Contudo, “[...] Faltou-lhe, [...], muitas vezes, uma problemática consistente, de modo a conferir a seu pensamento uma diretriz fundamental de interpretação para dar aos elementos de análise a argamassa da unidade teórica"781.

A primeira crítica formulada por ela quanto a esse aspecto diz respeito ao capítulo sobre a época do couro no qual Capistrano analisou o condicionamento do homem ao meio. Porém, não mobilizou em sua análise a noção de gênero de vida forjada por Paul Vidal de la Blache. Nesse mesmo diapasão, em sua crítica quanto aos preconceitos presentes na obra de Varnhagen, Capistrano não se atentou para o fato de que os mesmos estavam vinculados à classe social do Visconde de Porto Seguro, conceito objeto de autores por ele cultivados como Schmoller e Bücher. A última crítica quanto à mobilização teórica de autores das ciências sociais por Capistrano trata de sua análise do

\footnotetext{
${ }^{779}$ CANABRAVA, op. cit., 1971, p. 419.

${ }^{780}$ Para o historiador estadunidense Robert Conrad, Capistrano foi o Ranke brasileiro. CONRAD, Robert. João Capistrano de Abreu, brazilian historian. Revista de hístoria de América, n. 59, p. 149-164, 1965.

${ }^{781}$ CANABRAVA, op. cit., 1971, p. 422.
} 
processo de colonização, não tendo estabelecido um vínculo entre esse último e o mercantilismo, presente em Schmoller desde 1884.

Capistrano não foi o único a dialogar com as nascentes ciências sociais. Alice eleva ao mesmo nível do historiador cearense, Tobias Barreto, Sílvio Romero, Euclides da Cunha e "outros ensaístas". Menciona historiadores que se inspiraram em Capistrano, como Afonso Taunay, Pandiá Calógeras, Alfredo Ellis Júnior, Castro Carreira, Pereira da Costa, Felisberto Freire etc, porém que do "mestre" apreenderam apenas a crítica documental, sendo "representantes da história factual"782. Alguns se alçaram para além de uma história narrativa, preocupados com o processo social, tais como João Ribeiro, Joaquim Nabuco e Paulo Prado. "Podem ser considerados outros tantos elos da fase de transição, na qual a obra de J. Capistrano de Abreu constitui o marco que lhe dá o cunho essencial" ${ }^{, 783}$.

A fundação das Faculdades de Filosofia, primeiro a FFCL/USP em 1934, depois a UDF em 1935, e também a Escola Livre de Sociologia e Política de São Paulo em 1933, estabelecem, para Alice, um novo marco na produção historiográfica brasileira. Sabemos que, inicialmente, a fundação das Faculdades de Filosofia foi motivada pela necessidade de formar professores para o ensino secundário e que a pesquisa histórica se estabeleceu para formar seus próprios quadros. Levaria alguns anos para que as mesmas dessem frutos em termos de produção historiográfica. Por isso, podemos pensar em uma invenção da tradição ao se estabelecer como marco para uma nova história a fundação das mesmas.

Alice Canabrava destaca a importância da "missão francesa" no estabelecimento da moderna historiografia brasileira, cuja principal característica está no diálogo com as ciências sociais, principalmente a geografia. Ela perpassa uma vasta produção, cuja inspiração teórica provém das ciências sociais, não somente no âmbito universitário, mas também fora dele, como as contribuições de Almeida Prado, Otávio Tarquínio de Souza, Roberto Simonsen, Caio Prado Júnior etc. Por várias vezes em seu "roteiro", simplesmente recorre à um elenco de obras e autores, lembrando um dos procedimentos da história da historiografia de José Honório Rodrigues dos anos 1950/1960 ${ }^{784}$. Oliveira

\footnotetext{
${ }^{782}$ CANABRAVA, op. cit., 1971a, p. 21.

${ }^{783}$ CANABRAVA, op. cit., 1971a, p. 22.

${ }^{784}$ GUIMARÃES, Manoel Luiz Salgado. Historiografia e cultura histórica: notas para um debate. Ágora. Santa Cruz do Sul, v. 11, n. 1, p. 31-47, 2005.
} 
Vianna e Gilberto Freyre são tomados enquanto pioneiros nos estudos sobre o processo social brasileiro.

[...] sugeriram pesquisas mais profundas, numa época em que ainda predominava o interesse pela cronologia, pela acumulação dos fatos, pela simples compilação de documentos. Ambos situam-se, deste modo, na madrugada dos dias de sol que vieram depois, com o alargamento considerável do horizonte científico no campo das Ciências Sociais, e o consequente amadurecimento dos estudos sobre o processo social brasileiro ${ }^{785}$.

Assim, passa em revista toda uma produção cuja principal característica é a incorporação das preocupações e da inspiração provenientes das ciências sociais até tratar de áreas específicas como a história econômica, a história social, a história política e a história administrativa.

Dentre os temas tratados por essa nova produção e que aparecem simultaneamente em seu "roteiro" e em seu "resumo", temos o tema do desbravamento do sertão. "Um trabalho paciente de investigação documental cadastrou a ocupação do interior do território, identificou suas principais figuras, fixou datas essenciais, apontou seus roteiros" ${ }^{\text {786 }}$. Para Alice, o que Capistrano de Abreu produziu de melhor tratou exatamente dessa temática. Destaca ainda as contribuições de Afonso Taunay, de Alcântara Machado, com sua preocupação pelo cotidiano do bandeirante e sua vida material, Cassiano Ricardo, Sérgio Buarque de Holanda, que produziu os trabalhos mais importantes sobre o tema e Jaime Cortesão, que concedeu atenção aos fatores geográficos, inspirado pelo conceito de gênero de vida de Vidal de la Blache ${ }^{787}$.

A área que ocupa mais páginas do "roteiro" é a história econômica. Canabrava dá grande importância às obras de síntese de Roberto Simonsen, Caio Prado Júnior e Celso Furtado. Quanto ao primeiro, e o que qualifica como primeira "história econômica do Brasil” de 1937, afirma que sua inspiração no tratamento do período colonial provém de João Lúcio de Azevedo em seu livro "Épocas de Portugal econômico" e sua teoria dos ciclos econômicos: pau-brasil, cana de açúcar, ouro etc. Mesmo que esta teoria seja

\footnotetext{
785 CANABRAVA, op. cit., 1971a, p. 24. No "resumo" ela também considera os dois autores como pioneiros da moderna historiografia brasileira, qual seja, aquela informada pelas ciências sociais. Cf. CANABRAVA, op. cit., 1972, p. 7.

${ }^{786}$ CANABRAVA, op. cit., 1971a, p. 25.

${ }^{787}$ Esses mesmos autores foram rapidamente citados em seu "resumo". Cf. CANABRAVA, op. cit., 1972, p. 7.
} 
passível de críticas, ela destaca a importância da quantificação sistematizada em gráficos e tabelas e a extensa base documental mobilizada pelo autor.

Para a historiadora, "Formação do Brasil contemporâneo" de 1942 de Caio Prado Júnior, empreende um salto interpretativo quanto ao período colonial, visto que a preocupação do autor está em estabelecer uma análise estrutural da colônia. Ao contrário da análise de Simonsen, que estabelece uma relação entre os ciclos econômicos e o comércio exterior, afirma que Caio Prado insere a colonização brasileira no quadro mercantil da Europa moderna. Seu modelo interpretativo demonstra que sobre uma base homogênea, qual seja, o latifúndio, a monocultura e a mão de obra escrava, estrutural, variam as formas de exploração, como a mineração, o açúcar, o tabaco etc. Quanto à base documental, o ineditismo fica por conta do tratamento conferido às mesmas.

E "Formação Econômica do Brasil”, publicado em 1959, de Celso Furtado, apresenta estreita base documental. Porém, sua contribuição está na análise do desenvolvimento econômico brasileiro em perspectiva histórica com o apoio na teoria econômica. É o aparato teórico mobilizado por Celso Furtado que permite alçar uma nova interpretação do processo de desenvolvimento econômico brasileiro baseado na análise dos diferenciais de renda, na formação do mercado interno, nos desequilíbrios regionais, na industrialização etc.

Antes de analisar as obras de síntese, Alice menciona o que para ela constituí um grande número de monografias, com grande quantidade de dados acumulados, como os relatórios do Ministério da Agricultura, Comércio e Obras Públicas, do Ministério da Fazenda e dos Presidentes de Província ${ }^{788}$. Menciona também os trabalhos sobre a grande lavoura, citando apenas o de Afonso Taunay sobre o café, "História do café no Brasil". Em seguida, passa ao que qualifica por "análises descritivas", como as de Say, "Histoire des relations commerciales entre la France et le Brésil” (1839), de Van de StratenPonthoz, "Le budget du Brésil" (1854), de F. de Paula Cândido, "Os clamores da agricultura no Brasil" (1859), de S. Ferreira Soares, "Notas estatísticas sobre a produção agrícola e carestia dos gêneros alimentícios" (1860), de A. Ferreira Viana, "A crise comercial do Rio de Janeiro em 1864” (1864) e o depoimento do Visconde de Mauá.

\footnotetext{
788 Estes relatórios foram mobilizados em sua tese de cátedra em história econômica na FCEA. Cf. CANABRAVA, op. cit., 2011.
} 
Na sequência, muda essa tipologia de "análises descritivas" para "obras" e coloca as mesmas ao lado da produção de autores como Castro Carreira, Pandiá Calógeras e Wileman. E Vitor Viana e Lemos Brito empreenderam a primeira tentativa na escrita de uma história econômica do Brasil, porém, desprovida de base teórica e sistematização. Mais uma vez notamos a oscilação conceitual: qualifica enquanto "monografias", o que são fontes e estas enquanto "análises descritivas". Estas últimas, modula enquanto historiografia.

Uma outra produção em história econômica tratada por Alice diz respeito àquela produzida sob os auspícios das Faculdades de Filosofia e das Faculdades de Economia. Quanto à primeira, qualifica as mesmas como monográficas e de ampla e sólida base documental, como os trabalhos de Myriam Ellis, Francisco Iglésias, Stanley Stein, Nícia Villela Luz, Maria Thereza Schorer Petrone, Manuel Nunes Dias e os seus próprios. Menciona ainda os estudos de Fernando Henrique Cardoso, Otávio Ianni e Warren Dean, sobre o desenvolvimento industrial brasileiro, o trabalho de Richard Grahan, "Britain \& the onset of modernization in Brazil, 1850-1915" e a tese de Frédéric Mauro. Passando às contribuições dos economistas, ressalta a mobilização da teoria econômica e dos métodos quantitativos, mencionando como exemplo as obras de Delfim Netto, Werner Baer, Olivier Onody, M. Pelaez, Mário Henrique Simonsen e o trabalho de levantamento estatístico promovido pela Fundação Getúlio Vargas do Rio de Janeiro. Destaca ainda os trabalhos em história quantitativa empreendidos por historiadores, como os de Cecília Westphalen, F. Mauro, J. Johnson, Gadiel Perucci, Kátia Mattoso, Eulália Lobo, Mircea Buescu e Anibal Vilela ${ }^{789}$. Podemos aproximar essas análises da produção de áreas empreendidas por ela, na qual lista autores e obras, mas também analisa algumas delas, dos balanços historiográficos que se tornaram comuns entre as décadas de 1940 e $19600^{790}$. Ademais, passar em revista uma determinada produção, destacando-se alguns nomes pode ser tomado como um empreendimento intelectual que instaura determinado cânone,

\footnotetext{
${ }^{789}$ Cf. CANABRAVA, op. cit., 1971a, p. 27-33. Em seu "resumo", Alice menciona as primeiras tentativas de síntese de Vitor Viana, Lemos Brito, Contreiras Rodrigues e a obra de João Lúcio de Azevedo que inspirou estudos posteriores como o de R. Simonsen. Analisa as contribuições de Caio Prado e Celso Furtado até chegar nos economistas: Delfim Netto, Werner Baer, Olivier Onody, Manoel Pelaez, Mário H. Simonsen, Albert Fishlow etc. Cf. CANABRAVA, op. cit., 1972, p. 8.

${ }^{790}$ Cf. GONTIJO, Rebeca; FRANZINI, Fábio. Panorama da historiografia brasileira contemporânea (19301980). In: ABRÃO, Janete Silveira (orga.). Brasil: interpretações \& perspectivas. São Paulo: Marcial Pons/Universidade de Alcalá, 2016, p. 15-38. Os autores adotam a noção de balanço historiográfico a partir de BLAKE, Horst Walter. Para uma nova história da historiografia. In: MALERBA, Jurandir (org.). A história escrita: teoria e história da historiografia. São Paulo: Contexto, 2006, p. 27-64.
} 
no caso para a história econômica, Roberto Simonsen, Caio Prado Júnior e Celso Furtado $^{791}$. A partir desse balanço, podemos depreender uma noção de história econômica a partir de sua inserção nos estudos brasileiros.

Marcado por uma descontinuidade, Alice aborda uma produção sobre o escravismo antes de realizar balanço da área de história social. Ela inicia seu balanço sobre os estudos do escravismo caracterizando as obras produzidas no século XIX e a importância de Joaquim Nabuco. Para uma síntese do pensamento abolicionista até a abolição da escravidão cita Emília Viotti da Costa. Do ponto de vista legal, a sistematização foi realizada por Perdigão Malheiros e menciona que livros mais recentes retomaram a história do desenvolvimento de tal instituição, como os de Evaristo de Moraes e M. Goulart. Destaca a obra de Nina Rodrigues como pioneira, uma vez que tomou o negro por objeto, para compreensão de sua cultura, mesmo que naquele momento, 1971, julgasse que seu embasamento teórico estivesse ultrapassado, “[...] conservam valor permanente como documentário" ${ }^{\text {792 }}$. Podemos inferir aqui que a historiadora toma a obra de Nina Rodrigues enquanto fonte, ao lado de outros autores que caracteriza da mesma forma como Artur Ramos, Manoel Querino e Edison Carneiro. Em seguida, ela aborda os trabalhos sociológicos e em ciência política que se debruçaram sobre a análise do desenvolvimento da escravidão em âmbito regional. Alguns são apenas citados, como os de Donald Pierson, Roger Bastide, Florestan Fernandes, Otávio Ianni e Fernando Henrique Cardoso. Outros, como os trabalhos de Paula Beiguelman, "Pequenos estudos de ciência política”, “A formação política do Brasil”, "A formação do povo no complexo cafeeiro", são analisados. Em seguida, a historiadora cita novamente o trabalho de Emília Viotti da Costa.

Depreendemos que seu "roteiro" carece de revisão pela autora, uma vez que em sua resposta aos comentários de Frédéric Mauro, afirma que nenhuma corrente teórica do pensamento histórico brasileiro foi tratada "[...] dado o curto prazo para a elaboração"793. O pouco tempo para a elaboração do "roteiro" também pode ser tomado enquanto um elemento explicativo para sua não sistematização. Finaliza esse balanço temático citando

\footnotetext{
${ }^{791}$ Cf. GONTIJO, Rebeca. A história da historiografia no Brasil, 1940-1970: apontamentos sobre sua escrita. In: Anais do XXVI Simpósio Nacional de História. São Paulo: ANPUH, 2011, p. 1-11.

${ }^{792}$ CANABARAVA, op. cit., 1971a, p. 34.

${ }^{793}$ Cf. CANABRAVA, Alice Piffer. Resposta da profa. Dra. Alice Piffer Canabrava. In: Anais..., v. II, op. cit., 1971, p. 48.
} 
livro de Leslie Bethell que retoma as considerações de A. K. Manchester sobre a extinção do tráfico no contexto das relações anglo-luso-brasileiras ${ }^{794}$.

No que tange à história social, afirma que "[...] até recentemente estiveram implícitos naqueles que trataram da escravidão, da imigração, das guerras, dos costumes, da religião, dos problemas demográficos e educacionais, das minorias étnicas etc" ${ }^{\text {"795. Para }}$ ela, as primeiras tentativas de interpretação dos fatos sociais no contexto brasileiro se deram através de ensaios e críticas, destacando Joaquim Nabuco, Tobias Barreto, Silvio Romero, Gilberto Amado, Contreiras Rodrigues e Vicente Licínio Cardoso. Menciona também os trabalhos que se realizaram à partir de incursões de campo no quadro regional, como "a obra magistral" de Euclides da Cunha, "Os sertões", e "O juazeiro de Padre Cícero" de autoria de M. B. Lourenço Filho, “[...] pesquisa realizada nos anos vinte, valiosa pelos dados empíricos recolhidos e pelo esforço de explicação das características sociais e psicológicas"796. Em seguida, elenca obras e autores em torno de alguns temas da história social, como o trabalho de Maria Isaura Pereira de Queiroz sobre o messianismo; o trabalho de Costa Pinto sobre as rivalidades entre famílias; os trabalhos sobre urbanização, de autores como M. Diegues, Paul Singer, P. Geiger, Pierre Deffontaines, G. L. Barros etc; os livros de Nelson Werneck Sodré, sobre a gênese e o desenvolvimento da burguesia brasileira e "a grande obra de síntese" de Fernando de Azevedo, "A cultura brasileira"797.

Uma área que está presente em seu "roteiro", mas não em seu "resumo" é a história das ideias. Essa ausência pode ser explicada pelo fato de que Alice em seu "roteiro" apenas lista algumas obras e autores em um parágrafo, sem tecer comentário sobre nenhuma delas. Para ela, a história política é a área que mais produziu bibliografia e que, portanto, recebeu maior atenção dos historiadores. Identifica seu surgimento com os “escritos” de José da Silva Lisboa, "Memória dos benefícios políticos” (1816) e de Luiz

\footnotetext{
${ }^{794}$ Em seu "resumo" Alice toma por pioneiras as análises de Donald Pierson, Roger Bastide e Florestan Fernandes. Afirma ainda que na mesma linha interpretativa estão os trabalhos de Fernando H. Cardoso e Otávio Ianni. Quanto à Paula Beiguelman, assinala que formulou hipóteses vigorosas em seus trabalhos. A obra de Leslie Bethell também é citada, tendo por inspiração o livro de A. K. Manchester. Cf. CANABRAVA, op. cit., 1972, p. 8.

${ }^{795}$ CANABRAVA, op. cit., 1971a, p. 34.

${ }^{796}$ Idem, p. 35.

${ }^{797}$ Em seu "resumo" Alice menciona as obras de Euclides da Cunha e M. B. Lourenço Filho e as pesquisas sobre o messianismo, a urbanização e a família, sem citar autores. Apenas Nelson Werneck Sodré é mencionado e seus estudos sobre o desenvolvimento da burguesia brasileira. Cf. CANABARAVA, op. cit., 1972, p. 8-9.
} 
Gonçalves dos Santos, "Memórias para servir à história do reino do Brasil” (1825). Em seguida, classifica a produção em história política de acordo com a periodização tradicional: independência, primeiro reinado, segundo reinado e república. Quanto à independência e o primeiro reinado, Alice destaca Varnhagen, Oliveira Lima e Tobias Monteiro e cita suas principais obras.

Varnhagen contribuiu com sua 'História da independência' (livro
póstumo), baseado em farta documentação que incluiu os primeiros
jornais da época, as informações orais recolhidas de muitos coevos, a
correspondência oficial dos representantes diplomáticos ${ }^{798}$.

No que tange ao segundo reinado, afirma que foram raros os autores que se aventuraram a realizar síntese, como Joaquim Nabuco, J. M. Pereira da Silva, Oliveira Lima e Stanley Stein. Paula Beiguelman inseriu o problema da escravidão nos debates dos partidos políticos e J. Camillo de Oliveira Torres, com seu "A democracia coroada" (1957), interpretou as instituições imperiais como resultado das ideologias constitucionais do século XIX. Quanto ao período republicano, o balanço qualifica sua produção da mesma forma: são raros os trabalhos de síntese. Dentre eles menciona "História da República, 1889-1945” de José Maria Belo; "Política Geral do Brasil”, de José Maria dos Santos; "A república que a revolução destruiu" de Sertório de Castro e a "História da República" de Hélio Vianna. Afirma que a bibliografia mais rica sobre o período versa sobre assuntos restritos. Porém, não menciona trabalhos nessa seara. Sobre o período pósproclamação, lista obras e autores que qualifica como ensaios sobre os problemas iniciais da vida republicana, como os de Assis Brasil, Joaquim Nabuco, A. Guyer de Azevedo, Santa Rosa, Souza Bandeira, Rui Barbosa e Dantas Barreto. Lista também o que qualifica como ensaios sobre a década de 1930, como os trabalhos de Melo Franco, Maurício de Medeiros, Barbosa Lima Sobrinho, A. J. do Amaral. Arrais Monte e Almir Andrade. As obras de Plínio Salgado e Gustavo Barroso sobre o integralismo, as que tratam de Luis Carlos Prestes, as obras de Francisco de Campos, João Neves da Fontoura e João Alberto Barros Lins.

Sobre os problemas da política local e votações, cita Orlando de Carvalho e Vitor Nunes Leal. E dedica um pequeno parágrafo à contribuição de Otávio Tarquínio de Souza no que diz respeito à renovação do gênero biográfico. Para ela, seus trabalhos sobre as grandes figuras do Império, permite vislumbrar os quadros políticos e sociais do período.

${ }^{798}$ CANABRAVA, op. cit., 1971a, p. 36. 
Retomando sua periodização, elenca e tece breves comentários sobre os estudos que privilegiaram o período pós-1889, como o livro de F. Lowenstein, "Brazil under Vargas"; os trabalhos de Edgard Carone; o livro "Les trois âges du Brésil", de Charles Morazé; "Ordem e Progresso" de Gilberto Freyre e a "História sincera da República” de Leôncio Basbaum. Por fim, menciona os trabalhos de Thomas Skidmore e de Hélio Silva como importantes por seu valor de sistematização dos fatos e acumulação de dados empíricos $^{799}$. Nesse aspecto, o modus operandi de Alice nesse trecho de seu "roteiro", assim como em outras partes do mesmo, remonta à procedimento adotado pela história da historiografia dos anos 1940, como o "Manual Bibliográfico de Estudos Brasileiros", organizado por Rubens Borba de Moraes e William Berrien e "O que se deve ler para conhecer o Brasil" de Nelson Werneck Sodré ${ }^{800}$, qual seja, uma lista de obras com breves comentários.

O último balanço de área empreendido por Alice em seu "roteiro" explora a história administrativa. E afirma que as contribuições nessa área foram realizadas predominantemente por especialistas nos vários ramos do direito e menciona como exemplo a síntese de Waldemar Ferreira "História do direito brasileiro" (1951-1956), pertencente à história factual. Entre os historiadores, o cenário não é melhor, destacandose as sínteses cronológicas, de Rodolfo Garcia e Max Fleiuss. Por isso, duas obras lhe parecem renovadoras da área: "Portuguese society in the tropics" (1965) de Charles Boxer e "Royal government" (1968) de Dauril Aldrin"

Em seguida, Alice Canabrava avalia rapidamente a contribuição de "História Geral da Civilização Brasileira" à historiografia brasileira, afirmando que suas páginas

\footnotetext{
${ }^{799}$ Cf. CANABRAVA, op. cit., 1971a, p. 36-38. Em seu "resumo" Canabrava sistematiza a produção em história política adotando o mesmo critério, qual seja, pela periodização tradicional. Para o período monárquico, cita os nomes de Varnhagen, Oliveira Lima e Tobias Monteiro, sem mencionar suas obras. Para a independência e o primeiro reinado figura Joaquim Nabuco com "Um estadista do Império". No que tange ao segundo reinado até 1879 , menciona o nome de Pereira da Silva e afirma que suas obras sistematizaram as fontes primárias do período. Passando à fase republicana, cita como obras significativas as de Thomas Skidmore, "Politics in Brazil" e as de Hélio Silva. Por fim, destaca o que denomina "literatura de ensaios", sem mencionar autores e obras. Afirma que "[..] ventilou numerosos problemas da realidade nacional, e deu a conhecer como os contemporâneos sentiram tais problemas e como incidiram sobre eles suas reflexões". CANABRAVA, op. cit., 1972, p. 9.

${ }^{800}$ Cf. FRANZINI, Fábio; GONTIJO, Rebeca. Memória e história da historiografia no Brasil: a invenção de uma moderna tradição, anos 1940-1960. In: SOIHET, Rachel et al (orgas.). Mitos, projetos e práticas políticas: memória e historiografia. Rio de Janeiro: Civilização Brasileira, 2009, p. 143-149.

${ }^{801}$ Cf. CANABRAVA, op. cit., 1971a, p. 39. Em seu "resumo" afirma que na área predominam os trabalhos de juristas, sem, no entanto, citar nomes e obras, tampouco qualificar sua produção. Assevera que a área tem-se renovado com os estudos comparativos de Charles Boxer, "Portuguese society in the tropics" (1965) e de Dauril Aldrin, "Royal government" (1968). Cf. CANABRAVA, op. cit., 1972, p. 9.
} 
demonstram os avanços e o estado da arte do ofício de historiador no Brasil. Outra contribuição que reflete o desenvolvimento dos estudos históricos no Brasil, segundo ela, são os periódicos como a "Revista do Serviço do Patrimônio Histórico e Artístico Nacional", a "Revista de História" da USP, a "Revista de Estudos Políticos" da UFMG e a "Estudos históricos", sediada na FFCL de Marília/SP" 802 . Por fim, Alice faz “[...] uma referência especial à extensa obra de José Honório Rodrigues, o autor que mais se tem ocupado com o desenvolvimento da historiografia brasileira. Cujos livros constituem excelentes roteiros sobre o assunto" 803 . À mesma maneira de seu "roteiro" encerra seu "resumo" qualificando José Honório Rodrigues como aquele que "[...] mais tem meditado e escrito sobre os problemas de que é objeto esta síntese" ${ }^{\text {"84 }}$. Nesse aspecto, causa-nos estranhamento o fato de Alice não ter mobilizado nenhum texto de José Honório em seu "roteiro", tampouco ter estabelecido os critérios metodológicos e epistemológicos que nortearam sua análise. Esse estranhamento também foi sentido por Francisco Iglésias, como veremos em seu longo comentário.

Pudemos perceber em seus balanços temáticos e de área a presença de outras disciplinas que não a história. Tal fato denota a noção de Alice de que para a compreensão da história do Brasil outros saberes também devem ser mobilizados, em uma perspectiva multidisciplinar, característica exatamente da concepção de estudos brasileiros do IEB, consubstanciada na cultura acadêmica proposta por Sérgio Buarque de Holanda.

Podemos afirmar que Frédéric Mauro não comenta o "roteiro" de Alice, mas propõe um método de análise para a história da historiografia. Afirma que fará suas observações a partir da tese que irá defender seu orientando, Guy Martinière, na Universidade de Paris, sobre a historiografia econômica brasileira, na qual analisa as ideologias presentes nessa produção. Assim, propõe que se analise a historiografia brasileira a partir do que denomina correntes de pensamento, como o marxismo, cujo exemplo citado é de Nelson Werneck Sodré e a corrente weberiana, com José Honório Rodrigues. Sua proposta para Alice é de fazer a história da historiografia brasileira em

\footnotetext{
802 Em seu "resumo" Alice toma a HGCB coordenada por Sérgio Buarque como "[...] padrão do desenvolvimento atingido pelos estudos históricos, com respeito ao Brasil, em nosso país". Cf. CANABRAVA, op. cit., 1972, p. 9. Alice não menciona a importância dos periódicos no desenvolvimento da historiografia brasileira.

${ }^{803}$ CANABRAVA, op. cit., 1971a, p. 39.

${ }^{804}$ CANABRAVA, op. cit., 1972, p. 9.
} 
três níveis, os quais, podemos ligar aos três tempos braudelianos ${ }^{805}$ : um nível superior, vinculado às "obras mestras", ou seja, os principais acontecimentos da ciência histórica (o tempo curto braudeliano); o nível intermediário, da produção corrente vinculada à produção de teses, monografias, periódicos etc (o tempo da conjuntura); e o nível inferior, das "estruturas mentais" (o tempo longo), "[...] quer dizer, a ideia que cada geração se faz da História e da ciência histórica, conscientemente, subconscientemente ou inconscientemente. Deste modo podemos melhorar nossa visão sobre a evolução da ciência histórica brasileira" ${ }^{\prime 206}$.

Podemos perceber que a proposta de Mauro não está vinculada à um empreendimento que compreende a historiografia enquanto espelho da história ou enquanto espelho do sentido da colonização, um aspecto que identificamos no "roteiro" de Alice, mas sim uma historiografia que se atenta às vinculações ideológicas dos autores ao lado de uma história da historiografia em três níveis. Em sua resposta à Mauro, a historiadora explica que, dado o exíguo período para elaboração da monografia, não adotou a estratégia de análise a partir das "correntes teóricas" presentes no "pensamento histórico brasileiro", o que, parece ser, para ela, sinônimo de historiografia. Como afirmamos acima, ela não explicitou seu método de análise da história da historiografia brasileira.

Sua resposta à Mauro, permite-nos inferir algo sobre esse método. Canabrava pondera que o estudo do desenvolvimento da historiografia brasileira pode ser empreendido de várias formas, inclusive através dos níveis propostos por Mauro. "Na técnica utilizada, algumas obras consideradas representativas de seu desenvolvimento no tempo, e relativas aos setores mais importantes do pensamento histórico, são utilizadas; pelo método ou pelos conceitos, significaram um horizonte novo no conhecimento do passado"807. Em função dessa afirmação cita as "obras mestras" de Varnhagen, Capistrano, Caio Prado, Sérgio Buarque etc. Pondera que reconhece a dificuldade em distinguir essas obras mestras da vasta produção monográfica, de ensaios e "obras empíricas" e que se limitou a apontar tendências. Pela exposição de sua monografia notamos que Alice não adotou enquanto critério exclusivo de sua análise mudanças

\footnotetext{
${ }^{805}$ Cf. GONTIJO, op. cit., 2017, p. 97.

${ }^{806}$ MAURO, Frédéric. Comentários. In: Anais..., v. II, op. cit., 1972, p. 20.

${ }^{807}$ CANABRABA, Alice Piffer. Resposta da profa. Dra. Alice Piffer Canabrava. In: Anais... v. II, op. cit., 1972, p. 48.
} 
significativas de métodos e conceitos o que teria resultado em uma monografia mais sintética, mas sim elencou um sem número de fontes, monografias, teses, obras e periódicos.

Francisco Iglésias, diferentemente de Mauro, assenta seu comentário sobre o "roteiro" de Alice. Após elogiar o empreendimento dos três autores da monografia da área de história, faz apologia à sua colega de ofício e amiga: consagrada historiadora da área de história econômica e executora de importantes roteiros como o que escreveu sobre as fontes primárias para o estudo da moeda e do crédito em São Paulo, sua bibliografia sobre bandeiras etc. Iglésias compreende que a amiga, assim como o fizeram José Honório Rodrigues e Sérgio Buarque de Holanda no que tange ao período colonial, trate como historiografia o que na verdade se constitui enquanto fontes como os relatos de viagem, crônicas e depoimentos, uma vez que procedendo de outra forma o "roteiro" se iniciaria somente no século XIX. Sugere que, por isso, ela divida seu "roteiro" em duas partes: uma que trate das fontes e de sua tipologia e outra propriamente historiográfica.

Uma das preocupações de Iglésias em seu comentário, dado a identificação em outros balanços e no roteiro de Alice em relação à indistinção entre fontes e historiografia, é definir o que compreende por história e historiografia. Para Iglésias, história diz respeito ao acontecimento e historiografia é o relato, descrição e análise do mesmo. A partir daí, define uma história da historiografia. "Se a Historiografia é a arte de escrever a História ou estudo sobre as obras históricas, se é o conjunto das obras de História, uma história da historiografia brasileira deve ser o estudo dos livros que já se escreveram sobre História do Brasil" ${ }^{\prime 808}$. Nesse aspecto, podemos perceber que Francisco Iglésias, ao contrário de Alice, estava preocupado com a delimitação do campo da história da historiografia como aquele que analisa obras produzidas por historiadores.

Em seguida, o tom do comentário é de concordância com Alice, ao lado de algumas considerações críticas, como em relação ao IHGB. Para Iglésias, a historiadora poderia ter apontado que o Instituto se transformou em espaço de comemorações, tendendo ao academicismo. Quanto à Varnhagen e Capistrano, afirma que estão bem avaliados e situados, asseverando, entretanto, que os continuadores da tradição do Visconde de Porto Seguro mereciam maior espaço de análise como Rio Branco, Pandiá Calógeras e Taunay. Para Iglésias, as contribuições de Joaquim Nabuco e de Paulo Prado

${ }^{808}$ IGLÉSIAS, Francisco. Comentários. In: Anais... v. II, op. cit., 1972, p. 23. 
deveriam ser mais bem analisadas e não apenas citadas. Quanto ao momento das Faculdades de Filosofia e de Ciências Econômicas, Iglésias sugere que Alice poderia ter analisado a grade curricular do curso de História, uma vez que pode servir de subsídio para se analisar o problema da formação de historiadores frente a formação de professores para o ensino secundário. Concorda com a avaliação da amiga quanto à Oliveira Vianna e Gilberto Freyre, assim como em relação aos historiadores "contemporâneos" como Sérgio Buarque, Caio Prado e Celso Furtado. No entanto, José Honório Rodrigues, como apontamos acima, mereceria mais espaço em seu "roteiro", principalmente por sua reflexão sobre historiografia, objeto da monografia de Alice. Por fim, Iglésias termina seu comentário de forma elogiosa e apologética.

O que está registrado enquanto resposta de Alice Canabrava ao comentário à Iglésias nos faz indagar acerca das limitações de registro dos Anais, uma vez que diante de extenso arrazoado do historiador mineiro, a historiadora teria se limitado à responder que "[...] as deficiências apontadas quanto ao tratamento de alguns autores pelo prof. Iglésias em seu generoso comentário, serão consideradas devidamente na edição impressa" ${ }^{809}$. Infelizmente, não temos conhecimento do modus operandi de registros das falas daqueles que tomaram a palavra. Se os secretários realizaram uma síntese dessas falas, ou se todas foram gravadas e posteriormente enquadradas pelo signo da escrita.

Para Richard Graham, o "roteiro" de Alice pode ser tomado como uma primeira atualização do "Manuel bibliográfico de estudos brasileiros" organizado por Rubens Borba de Morais e William Berrien. "I am moved to ask wheter the present Introdução [sic] could not serve as first version of a new updated and revised history section of another Manual [sic]"810. Nesse aspecto, como afirmamos acima, seu "roteiro" pode ser tomado como um exemplo da história da historiografia típica dos anos 1940-1950, com listas de obras comentadas.

A contribuição de Cecília Westphalen pode ser tomada como uma análise crítica das condições do ofício de historiador no Brasil e de sua produção, para além de um comentário ao texto de Alice. Para Westphalen, a produção vinculada ao IHGB esteve ligada ao pensamento histórico renovador dos principais centros europeus, especificamente com a escola histórica alemã. Exemplo disso foi a monografia

${ }^{809}$ CANABRABA, Alice Piffer. Resposta da profa. Dra. Alice Piffer Canabrava. In: Anais... v. II, op. cit., 1972, p. 48.

${ }^{810}$ GRAHAM, Richard. Comentários. In: Anais..., v. II, op. cit., 1972, p. 35. 
apresentada por Martius e Westphalen erige Varnhagen e Capistrano como seus continuadores. Contudo, em inícios do século XX, enquanto o "pensamento histórico" se renovava sob os impulsos da Revue de Synthèse Historique, o IHGB e a produção historiográfica brasileira entrou, em seus dizeres, em um processo de "esclerosamento", aprofundado pelo alheamento dos historiadores brasileiros frente aos "debates e combates" dos historiadores dos Annales com a história historizante. Para Westphalen,

O resultado óbvio desse alheiamento e do distanciamento das fontes primárias foi a produção de uma História do Brasil, erudita e diletante, operando quase sempre no campo da história política, fática por excelência, e tendo apenas a biografia ou os manuais com generalizações de segunda mão, como forma de apresentação dos trabalhos. De tal maneira que acabou por praticar-se no Brasil, sob a égide dos Institutos Históricos, sobretudo daqueles Estaduais, uma historiografia sem qualquer significação científica ${ }^{811}$.

Westphalen identifica na fundação das Faculdades de Filosofia uma tentativa de superar tal esclerosamento através da formação de professores para o ensino secundário e de pesquisadores. Cita o exemplo da FFCL/USP com a vinda de professores estrangeiros. Entretanto, aponta como caso que foge à regra, uma vez que a grande maioria das faculdades contou em seu quadro docente com historiadores vindos da tradição dos institutos, principalmente nas cadeiras de história do Brasil. Outro problema diagnosticado diz respeito ao rígido regime de cátedras, que instaura o catedrático como proprietário daquela área do saber.

Uma parcela de professores, preocupados com esse quadro, se reuniu no I Simpósio de Professores Universitários de História também com o fito de se colocar a história do Brasil no centro das pesquisas. Para Westphalen, “[...] a reação contra esta tentativa, motivada por preconceitos vários e pela intransigência de catedráticos, ficou também documentada nos Anais, ainda que nem sempre com a veemência dos termos que, na ocasião, foram ouvidos"812. Porém, acentua que atitudes renovadoras ainda são incipientes conforme o estudo promovido por Katia Abud e Raquel Glezer do então Centro de Documentação Histórica da FFCL/USP, que mostra que a maioria dos pesquisadores de história do Brasil são estrangeiros.

Quando tomamos essa análise de Westphalen e a comparamos com o "roteiro" percebemos mais diferenças que semelhanças. A única semelhança diz respeito ao fato

\footnotetext{
811 WESTPHALEN, Cecília Maria. Comentários. In: Anais..., v. II, op. cit., 1972, p. 38.

${ }^{812}$ Idem, p. 39.
} 
de que Westphalen também aponta para a insuficiência de Capistrano em relação à incorporação das nascentes ciências sociais. Westphalen não estabelece Capistrano como sinônimo de uma moderna historiografia brasileira como o fez Alice, mas sim toma-o enquanto continuador de Martius ao lado de Varnhagen. Outra diferença entre ambas se trata da avaliação quanto à efetiva contribuição das Faculdades de Filosofia para a renovação dos estudos históricos no Brasil. Podemos afirmar que Canabrava, em uma invenção de uma tradição, eleva a importância daquelas à um patamar que não condiz com aquele seu momento real de renovação da produção historiográfica. Para Westphalen, uma moderna historiografia brasileira ainda está por se fazer.

Não à toa, em sua resposta à Westphalen Alice Canabrava discorda de sua avaliação quanto à história historizante, assinalando que várias obras produzidas sob essa metodologia e concepção são fundamentais como "instrumentos de trabalho para o pesquisador". Ademais, a história escrita pelos eruditos, tão criticados por Westphalen, trouxe menos prejuízo ao ofício que a de amadores. Quanto ao "esclerosamento" diagnosticado por Westphalen, Alice assevera que a implantação tardia dos cursos de ciências sociais no Brasil resultaram em um atraso quanto às renovações trazidas pela Revue de Synthèse Historique e os Annales ${ }^{813}$.

Podemos tomar o comentário de Manuel Correia de Andrade como um apêndice à monografia da área de história, uma vez que sua preocupação é mapear os estudos históricos no nordeste e propor temas de pesquisa que tem a região como lócus privilegiado. Não por acaso, pois Correia de Andrade foi um dos maiores geógrafos brasileiros do século XX e o que mais contribuiu para o estudo da região norte e nordeste, marcadamente através de uma abordagem interdisciplinar apoiando-se também na história, sociologia, economia e antropologia ${ }^{814}$. Correia de Andrade diagnostica que, da mesma forma que o desenvolvimento é desigual entre as regiões do país, assim também acontece com a produção historiográfica. Os poucos historiadores nordestinos, como Oliveira Lima e Capistrano de Abreu, desenvolveram seus trabalhos na região sudeste. Ademais, aponta para a necessidade de reedição de importantes obras nordestinas dos

${ }^{813}$ CANABARAVA, Alice Piffer. Resposta da profa. Dra. Alice Piffer Canabrava. In: Anais..., v. II, op. cit., 1972, p. 48.

${ }^{814}$ A biblioteca, juntamente com seu arquivo pessoal, foi doada ao IEB/USP em 2014. Para uma análise da trajetória do geógrafo a partir da formação de sua biblioteca, ver: AMOROSO, Marta; IUMATTI, Paulo Teixeira. A construção de uma biblioteca na trajetória de Manuel Correia de Andrade. RIEB. São Paulo, n. 60, p. 199-210, 2015. 
séculos XIX e XX; realiza mapeamento sobre o potencial de pesquisa nos arquivos e bibliotecas, bem como a importância das fontes publicadas nas revistas dos institutos históricos, marcadamente os de $\mathrm{PE}$ e $\mathrm{CE}^{815}$. Alice, em sua resposta, tece elogios à contribuição de Andrade sobre "a bibliografia com respeito ao desenvolvimento da história do Nordeste" e se justifica, afirmando que “[...] dada a escassez do tempo para seu preparo, tomou-se como diretriz a consideração das obras sobre o Brasil em geral. Por esta razão não foram considerados os estudos regionais" ${ }^{\prime 16}$.

Nas "sessões do grupo de trabalho", dedicadas ao debate do "roteiro" de Alice, as “anotações à margem do relatório de história" de Emília Viotti da Costa instauram uma diferença quando comparadas aos outros comentários, pontuais e curtos ${ }^{817}$. Costa objetiva analisar as contribuições de trabalhos provenientes de outras áreas, como economia e sociologia, de autores como Maria Silvia de Carvalho Franco, Fernando Henrique Cardoso, Otávio Ianni, Luiz Pereira, Paul Singer e Luciano Martins para a historiografia brasileira, que também foram relembrados por Alice. Para avaliar esse revisionismo, que, segundo ela, está ligado à caracterização do modelo de desenvolvimento brasileiro, com autores como Boris Fausto, Warren Dean e Ralph de la Cava, Costa afirma a necessidade de retroceder às tendências da historiografia brasileira dos séculos XIX e XX.

Costa, ao contrário de outros comentadores desse I SEB, não trata a historiografia vinculada ao IHGB de modo homogêneo, identificando duas tendências: uma erudita, tributária de correntes europeias, marcada pela exegese documental e representada por Varnhagen e outra, retórica ou discursiva, identificada com Pereira da Silva. Porém, destaca também o que há de comum entre ambas: uma história que enfatiza o papel dos personagens e que possui uma noção vaga de povo, abstrata, semelhante à Michelet. Essa historiografia apresentaria uma concepção de história evolucionista e providencialista.

A segunda fase da historiografia brasileira recortada por Costa diz respeito às três últimas décadas do século XIX. Uma historiografia identificada com os anos 1870 e que

\footnotetext{
${ }^{815}$ Cf. ANDRADE, Manuel Correia de Oliveira. Comentários. In: Anais..., v. II, op. cit., 1972, p. $43-47$. ${ }^{816}$ CANABRAVA, Alice Piffer. Comentários da profa. Dra. Alice Piffer Canabrava. In: Anais..., v. II, op. cit., 1972, p. 48.

817 Sérgio da Costa Franco e Antonietta de Aguiar Nunes apresentaram comentários pontuais ao "roteiro" de Alice. Elzio Dolabela apresentou adendo às considerações de Emília Viotti e Sérgio Buarque de Holanda realizou apontamento crítico à qualificação do latifúndio durante o império por Emília Viotti da Costa. Para Sérgio, o latifúndio durante o império não teve a importância política concedida pela autora, uma vez que aqueles que viviam de rendas de suas terras não possuíam representação nos ministérios e nas câmaras legislativas. Cf. Anais..., v. II, op. cit., 1972, p. 49-50 e p. 62-63.
} 
se apresentou sob as tendências da sociologia, antropologia e antropogeografia, incorporando o determinismo geográfico e racial na análise da sociedade brasileira. Nesse ponto de sua história da historiografia brasileira, Costa estabelece um vínculo entre a produção dos anos 1870-1900 e as mudanças econômicas, políticas, sociais etc., pelas quais passava o país, principalmente com os diagnósticos de ensaístas de que o fim da escravidão e a proclamação da república não foram suficientes para superar problemas que julgavam provenientes da primeira e da monarquia.

Esse panorama, para Costa, fez surgir um Sílvio Romero e as críticas de José Veríssimo à Varnhagen ampliando a "consciência histórica" vis a vis o período anterior com a incorporação de novos temas e conceitos: o meio, a raça e as instituições constituem um novo esquema interpretativo que aparecerá em Euclides da Cunha, Capistrano de Abreu etc. Nesse mesmo período a escravidão se estabelece como categoria explicativa, com destaque para a obra de Joaquim Nabuco. Da mesma forma, a proclamação da república traz o problema das oligarquias e suas bases: o latifúndio e o clientelismo. Outro problema presente na primeira república diz respeito ao domínio do capital estrangeiro, sobre os quais se debruçaram Silvio Romero, Manoel Bonfim e Coelho Rodrigues. Para Costa, nesse momento, “[...] a consciência histórica amplia-se: o estudo do meio, das raças, da mestiçagem, das oligarquias, das instituições, do latifúndio escravista passam ao primeiro plano substituindo as crônicas exaustivas dos feitos dos administradores coloniais" "818. Para ela, Oliveira Vianna e Gilberto Freyre são os herdeiros dessa tradição no século XX.

Para Emília Viotti, os anos 1930 apresentam um arcabouço teórico novo. Ao lado da historiografia tradicional "èvénementielle" ou retórica e apologética, tem-se uma historiografia sociológica, psicológica, cultural, antropológica e geográfica. Seu destaque é para o livro de Caio Prado Júnior "Evolução política do Brasil”, publicado em 1933, marca do surgimento de uma nova corrente historiográfica. Ao lado de "Formação do Brasil Contemporâneo" (1942), Costa aponta "Raízes do Brasil" (1936) de Sérgio Buarque e "Panorama do segundo império" (1938) de Nelson Werneck Sodré, como obras que dão novo rumo à historiografia brasileira e refletem sua maturidade. Ainda nos anos

${ }^{818}$ COSTA, Emília Viotti da. Anotações à margem do relatório de história. In: Anais..., v. II, op. cit., 1972, p. 55. Para a concepção teórico-metodológica da autora ver: COSTA, Emília Viotti da. A dialética invertida: 1960-1990. In: _. A dialética invertida e outros ensaios. São Paulo: Editora Unesp, 2014, p. 9-28. COSTA, Emília Viotti da. O historiador e a sociedade. In: COSTA, op. cit., 2014, p. 209-219. 
1930, seu diagnóstico quanto às Faculdades de Filosofia possui, assim como o de Westphalen, tom crítico, uma vez que para ela não resultou em enriquecimento imediato. Ao contrário, produziu um "descaminho" resultante do que denomina "academicismo", ou seja, a produção intelectual vinculada à obtenção de títulos, ao "carreirismo", a falta de lastro da atividade acadêmica com os problemas da sociedade resultaram na "[...] multiplicação de estudos sobre temas irrelevantes" $"$.

Da década de 1930, Costa salta para os anos 1950. Às transformações decorrentes do intenso processo de urbanização e industrialização do centro sul acentuando os desequilíbrios regionais, Emília Viotti vincula o surgimento da teoria da sociedade dual de Jacques Lambert. A partir desse esquema conceitual, surgem interpretações que comparam o desenvolvimento brasileiro ao desenvolvimento europeu, estabelecendo que o Brasil "rural" estaria em um estágio feudal, ao lado de um Brasil moderno, industrializado e capitalista. Assim, multiplicaram-se os estudos socioeconômicos e históricos baseados no modelo da sociedade dual. Costa lista uma grande variedade temática, sem citar autores. Os únicos citados são Inácio Rangel e Wanderley Guilherme dos Santos, ao passo que o ISEB é mencionado como instituição representativa de estudos inspirados no esquema da sociedade dual, principalmente a oposição entre os interesses da burguesia nacional em relação ao capital estrangeiro.

Para Emília, esse esquema perde força explicativa como resultado da crise econômica e do projeto desenvolvimentista de JK ao lado da radicalização do processo político que tem seu fim com o golpe militar de 1964. É nesse ponto que ela retorna ao ponto de partida de sua intervenção. Para ela, nos anos sessenta, trabalhos de sociólogos e economistas procuraram demonstrar o caráter capitalista da economia brasileira, o que já havia sido feito por Caio Prado Júnior. A partir dessa revisão crítica, com obras de Antonio Barros de Castro, Warren Dean, Fernando Henrique Cardoso, Boris Fausto e Lourdes Sola, procurou-se rever as posições de vários grupos sociais outrora tomadas como antagônicas, demarcando-se agora suas origens comuns e compatibilidade de interesses. Outro ponto alvo de revisão é a relação entre os interesses da burguesia nacional e do capital estrangeiro, outrora tomados como antagônicos, exemplificado pelo trabalho de Luciano Martins, "Burguesia nacional e desenvolvimento econômico brasileiro". Entretanto, para ela esses estudos carecem de base empírica como lastro

${ }^{819}$ Idem, p. 57. 
comprobatório de suas teorias, excetuando-se os trabalhos de Warren Dean. Assim, “[...] fica evidente a necessidade e colaboração interdisciplinar: os historiadores brasileiros se ressentem, em geral, da falta de domínio conceitual enquanto sociólogos e economistas; quando interpretam o passado pairam frequentemente nas abstrações" ${ }^{820}$. Emília Viotti da Costa finaliza sua intervenção com um elenco de propostas temáticas para a história do Brasil. Pelo fato de que objetivamos analisar sua contribuição à história da historiografia brasileira, não nos debruçaremos sobre essa parte prospectiva.

Alice sistematiza sua resposta à Emília em três partes. Na primeira trata da historiografia da primeira metade do século XIX. Para Canabrava, a noção de povo de Michelet não é vaga. Ao contrário, como um elemento do povo se identificava com ele, como personificação de seus ideais. Quanto à caracterização da obra de Pereira da Silva como retórica, essa não seria a questão para ela, mas sim, como apontado por Otávio Tarquínio de Souza, sua debilidade no que tange às fontes, podendo ser qualificado enquanto memorialista ${ }^{821}$. Na segunda parte de sua resposta, ela discorda no que tange à qualificação da historiografia brasileira das últimas três décadas do século XIX de evolucionista e positivista. Para Alice, alguns historiadores foram influenciados por Comte, Taine, Buckle, Spencer etc. Porém, não se reconhece nos autores mais significativos do período a tentativa de estabelecimento de uma lei geral que conduza a história do Brasil, como apontado por João Cruz Costa. Dentre eles, menciona Euclides da Cunha e Capistrano de Abreu, que se atentaram ao meio natural e deram sua maior contribuição junto à geografia humana. Porém, discorda de Costa, quando essa afirma que o esquema interpretativo vigente no período fosse vinculado à tríade raça, meio, instituições. Canabrava aponta que Capistrano de Abreu em seu "Capítulos de história colonial" não trata do índio tampouco do negro e que esses elementos somente aparecem em João Ribeiro e João Francisco Lisboa. "É somente com Oliveira Viana que a trilogia traz mais um cunho fundamental e originalidade ao pensamento histórico brasileiro" ${ }^{\$ 22}$.

Outra crítica encetada nessa parte de sua resposta diz respeito à definiçãa de Emília Viotti da década de 1870.

Algumas observações da profa. Emília Viotti Costa sobre a década dos 1870 precisam ser reformuladas. As referências quanto à modernização

\footnotetext{
${ }^{820}$ Idem, p. 60.

${ }^{821}$ Cf. CANABRAVA, Alice Piffer. Resposta da profa. Alice Piffer Canabrava. In: Anais..., v. II, op. cit., 1972, p. 63-64.

${ }^{822}$ Idem, p. 66.
} 
do processo de produção, onde foi possível, à substituição do fazendeiro de tipo tradicional escravocrata e senhorial pelo fazendeiro mais progressista, de mentalidade empresarial, mais favorável ao trabalho livre, fatores estes que se correlacionam com a intensificação dos investimentos estrangeiros, experiências com trabalho livre, imigração, desenvolvimento das vias férreas, parecem-nos prematuras. A História Econômica não se nutre dos fatos individuais, mas sim dos fenômenos de massa ${ }^{823}$.

A partir daí o que se segue é uma verdadeira aula de história econômica. Todas as especificações apontadas por Emília são relativizadas a partir do estabelecimento de um panorama geral da história econômica brasileira da década de 1870 e sua inserção na economia mundial. Assim, para Alice, a importância da década mencionada não está em suas transformações, mas sim na tomada de consciência quanto ao auge do processo de deterioração do sistema econômico e político, cujo diagnóstico exemplar pode ser encontrado em "O abolicionismo" de Joaquim Nabuco.

Na terceira e última parte de sua resposta, a menos extensa, Alice afirma que Viotti caracterizou com propriedade a produção ensaística. Contudo, para ela tal produção carece de uma ancoragem nas ciências sociais, refletindo a ausência de tradição científica em nosso país ${ }^{824}$.

${ }^{823}$ Idem, p. 66.

${ }^{824}$ Idem, p. 68. 


\section{Capítulo 4}

\section{Alice Piffer Canabrava: Do si-mesmo ao outro}

Biografias, autobiografias, depoimentos, entrevistas, testemunhos, diários, cartas... Modalidades de escrita de si e do outro. Na era vitoriana as autobiografias e biografias sobre homens de grande envergadura moral conheceram intensa inflação ${ }^{825}$. Porém, o historiador estava alijado desse processo, uma vez que a disciplina histórica em sua busca por cientificidade, o que implicava também um afastamento em relação à literatura, estava encarregada de contar a história de outra personagem: o Estado $^{826}$. Os únicos indivíduos que poderiam ter suas histórias de vida narradas seriam aqueles que contribuíram para erigir esse grande Estado. Assim, durante todo o século XIX até a primeira metade do século $\mathrm{XX}$, a biografia foi tomada enquanto gênero menor pelos historiadores e também por membros das nascentes ciências sociais, exemplificado pelo ataque de François Simiand ao "ídolo do individual"827.

Na segunda metade do século XX temos o retorno do sujeito à historiografia. Porém, quem retorna, já retorna outro. Com o auxílio da etnografia, da psicanálise, da literatura, e da filosofia não se concebe mais um sujeito com uma identidade que não varie no tempo ${ }^{828}$.

No Brasil, a principal preocupação do IHGB era com a construção da nacionalidade. Para auxiliar nesse intento, a partir da gestão de Januário da Cunha Barbosa, logo em 1839, foi lançada na $R I H G B^{829}$ uma seção que deveria biografar as personagens mais ilustres da nação em uma chave de exemplaridade para o presente $a$ la Plutarco ${ }^{830}$. Contudo, do final do século XIX até início do século XX temos uma inflexão

\footnotetext{
${ }^{825}$ Cf. GAY, Peter. O coração desvelado: a experiência burguesa da rainha Vitória a Freud. São Paulo: Companhia das letras, 1999.

${ }^{826}$ Sabina Loriga perpassa esse processo de alijamento do indivíduo da disciplina histórica do século XIX. Porém, mostra a relação entre indivíduo e história em alguns historiadores como Herder, Humboldt, Droysen, Dilthey, Lamprecht, Buckhardt, Carlyle e Tolstoi. Cf. LORIGA, Sabina. O pequeno x: da biografia à história. Belo Horizonte: Autêntica, 2011.

${ }^{827}$ Cf. SIMIAND, François. Método histórico e ciência social. Bauru: EDUSC, 2003 [1903].

828 Cf. ALBUQUERQUE JÚNIOR, Durval Muniz de. O significado das pequenas coisas. História, prosopografia e biografemas. In: AVELAR, Alexandre; BISSO, Benito Schmidt (orgs.). Grafia da vida: reflexões e experiências com a escrita biográfica. São Paulo: Letra e Voz, 2012, p. 16-38.

${ }^{829}$ Sobre a RIHGB, ver: GUIMARÃES, Lúcia Maria Paschoal. Produção e disseminação do saber histórico no oitocentos: a Revista do Instituto Histórico e Geográfico Brasileiro. In: ARRAIS; BENTIVOGLIO, op. cit., 2017, p. 31-53.

${ }^{830}$ A tese de doutoramento de Maria da Glória de Oliveira debruça-se sobre essa seção da RIHGB entre 1839-1899 com o fito de perscrutar os mecanismos pelos quais essas biografias alçaram um estatuto
} 
desse procedimento. Esse período é caracterizado pelo abandono da perspectiva biográfica marcada apenas com necrológios, mas que serviam para discutir questões metodológicas e filológicas. Na primeira metade do século XX, merece destaque o historiador Octávio Tarquínio de Sousa que não se liga à ideia de uma biografia exemplar, mas sim para dar vida e cor à nacionalidade ${ }^{831}$. Porém, somente nos anos 1970 e 1980 , tendo o espaço universitário como lugar privilegiado de legitimação e produção, encontramos uma retomada da biografia com inspiração nas renovações historiográficas estrangeiras a partir da micro-história italiana, da "história vista de baixo" britânica e dos estudos de Michel Foucault ${ }^{832}$.

Uma das formas de se pensar esse novo sujeito e uma identidade que não é fixa, podemos encontrar na noção de identidade narrativa ${ }^{833}$. A noção de identidade narrativa forjada por Paul Ricoeur a partir de uma hermenêutica do sujeito nos permite escapar de uma concepção de sujeito que não muda ao longo do tempo, o cogito cartesiano, e de um sujeito enquanto ilusão, o anti-cogito nietzschiano. A identidade narrativa se define a partir da dialética entre mesmidade e ipseidade. A mesmidade, ou a identidade-idem, se define pela permanência do caráter do sujeito no tempo, ou seja, pode ser expressada por suas impressões digitais, seu DNA e seu registro civil, por exemplo. A ipseidade, ou a identidade-ipse, pode ser definida como o empenho da palavra do sujeito que se atestará no futuro. Essa dimensão da identidade se relaciona com o próximo e com o outro, uma vez que necessita de um paciente de atestação. Assim, a identidade narrativa nos permite pensar um sujeito em seus aspectos que permanecem no tempo, bem como naquilo que $\operatorname{muda}^{834}$.

científico, através de uma cronologia, da formação de um arquivo e do uso metódico dos documentos, ou seja, transformar a biografia em historiografia. Cf. OLIVEIRA, Maria da Glória de. Escrever vidas, narrar a história: a biografia como problema historiográfico no Brasil oitocentista. Rio de Janeiro: Editora FGV, 2012.

${ }^{831}$ Ver: GONÇALVES, Márcia de Almeida. Em terreno movediço. Biografia e história na obra de Octávio Tarquínio de Sousa. Rio de Janeiro: EDUERJ, 2009.

${ }^{832}$ Cf. SCHMIDT, Benito Bisso. Escrever biografias no Brasil hoje: entre inovações e modelos tradicionais. In: DUTRA, Eliana de Freitas (orga.). O Brasil em dois tempos: história, pensamento social e tempo presente. Belo Horizonte: Autêntica, 2013, p. 205-217.

${ }_{833}$ Maria da Glória de Oliveira demonstra como essa noção pode ser um antídoto à crítica de Pierre Bourdieu no que tange à ilusão biográfica. Ver: OLIVEIRA, Maria da Glória de. Quem tem medo da ilusão biográfica? Indivíduo, tempo e histórias de vida. Topói. Rio de Janeiro, v. 18, n. 35, p. 429-446, 2017. Através das noções de biografia de Buckhardt, Carlyle e Taine, não-lineares, Loriga contrapõe à crítica de Pierre Bourdieu. Cf. LORIGA, Sabina. A biografia como problema. In: REVEL, Jacques (org.). Jogos de escala: a experiência da microanálise. Rio de Janeiro: Editora FGV, 1998, p. 225-249.

${ }^{834}$ Ver: RICOEUR, Paul. Prefácio. In:

O si-mesmo como outro. São Paulo: WMF Martins Fontes, 2014, p. XI-XLII. RICOEUR, Paul. Quinto estudo. Identidade pessoal e identidade narrativa. In: 


\subsection{Alice por si-mesma}

Na entrevista concedida por Alice à Flávio Saes, José Ribeiro de Araújo Filho e Oracy Nogueira no dia 30 de janeiro de 1981 na sala de gravações do Museu da Imagem e do Som de São Paulo (MIS/SP) por ocasião do projeto "Estudos Brasileiros" coordenado por Ernani da Silva Bruno, esse último sugere que a historiadora empreenda uma introdução autobiográfica ${ }^{835}$. O projeto “[...] tem por objetivo a gravação de depoimentos de intelectuais que se destacaram, por suas pesquisas e reflexões, nas áreas de História, Sociologia, Antropologia, Folclore e Economia voltadas para o estudo da realidade nacional"836. Canabrava figura ao lado de Abgar Bastos, Antonio Candido, Florestan Fernandes, Gilberto Freyre, Heitor Ferreira Lima, Paulo de Almeida Prado, Pasquale Petrone, Rossini Tavares de Lima, Rubens Borba de Morais, Sergio Buarque de Holanda, Tito Livio Ferreira e o brasilianista Robert Levin.

A rememoração da historiadora nesse caso particular é incitada pelo outro. Pensamos a entrevista "como género de la presencia, [que] marcará, de modo netamente

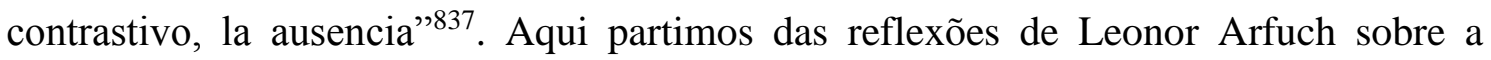
entrevista no espaço biográfico, neste caso, autobiográfico. Das possibilidades de expressão de si, a entrevista é a que possui maior efeito de presença - mesmo que a marca da autobiografia seja a de um ausente, seja o passado, seja o si-mesmo como outro ${ }^{838}$. Esse efeito de presença deriva das múltiplas vozes envolvidas na narrativa: a do entrevistado, seu corpo se faz presente, a do entrevistador e a do público. O entrevistador também é coautor do relato, uma vez que, ao incitar a memória do outro, o entrevistado, o faz dentro de uma chave de memória comum, uma das condições de possibilidade da entrevista. Aquele que ouve, vê ou lê a entrevista, em nosso caso ouvimos a voz de Alice na entrevista ao MIS/SP, pelas características apontadas, se aproxima mais do entrevistado do que através de qualquer outra modalidade do espaço biográfico ${ }^{839}$. A

RICOEUR, op. cit., p. 111-144. RICOEUR, Paul. Sexto estudo. O si e a identidade narrativa. In: RICOEUR, op. cit., p. 145-181. Para uma leitura dessa obra, ver: GAGNEBIN, Jean Marie. Uma filosofia do cogito ferido: Paul Ricoeur. In: .. Lembrar esquecer escrever. $2^{a}$ edição. São Paulo: Editora 34, 2009 , p. 163-178.

${ }^{835}$ Cf. CANABRAVA, op. cit., 1981.

${ }^{836}$ ESB (46)1-12. Fundo Ernani da Silva Bruno. Arquivo IEB/USP.

${ }^{837}$ ARFUCH, Leonor. Devenires biográficos: la entrevista mediática. In: El espacio biográfico. Dilemas de la subjetividade contemporânea. Buenos Aires: Fondo de Cultura Económica, 2010, p. 147. ${ }^{838}$ Cf. RICOEUR, op. cit., 2014.

839 Arfuch, inspirando-se em Bahktin, Ricoeur, Derrida, De Man, Habermas e Arendt, apropria-se metaforicamente da noção de espaço biográfico forjada por Philippe Lejeune. Compreende o espaço biográfico, não como uma reunião de modalidades biográficas, mas vai além: “[...] la consideración de un 
entrevista também possui alguns marcos que balizam sua lógica narrativa, atingindo a condição de biografema ${ }^{840}$, como a infância, a vocação e o "ser comum".

Nessa entrevista não ouvimos a rememoração da infância. Tampouco em sua segunda entrevista concedida à Flávio Saes e publicada na revista Economia Aplicada em $1997^{841}$. Em relação à primeira, uma hipótese aventada para tal ausência pode ser encontrada no fato de que a mesma se insere em um projeto que se propõe a tomar o depoimento daqueles que mais contribuíram para a área de estudos brasileiros. Assim, Alice dificilmente poderia esboçar algo sobre sua vida privada, afinal, sua fala deveria demonstrar seu mérito em ser considerada, ao lado de Florestan Fernandes, Sérgio Buarque de Holanda, Gilberto Freyre etc, uma intelectual. Este lócus discursivo nos faz evocar Michel de Certeau, ao pensar o condicionamento do discurso às condições institucionais de onde o historiador o emite ${ }^{842}$. Já aí um desvio, uma diferença a inventariar, uma singularidade: Alice é a única mulher.

Michel de Certeau no texto de abertura de "História e Psicanálise" sugere a necessidade de historicizar a própria historiografia e o sujeito historiador. "Interrogar o sujeito do saber é, igualmente, ter de pensar o tempo, se é verdade que, por um lado, o sujeito organiza-se como uma estratificação de tempos heterogêneos e, por outro, seja mulher, negro ou basco, ele é estruturado por sua relação com o outro" ${ }^{\text {843 }}$. Daí decorre a importância de tomarmos Alice Canabrava em relação ao outro. No que diz respeito à entrevista publicada em 1997, desconhecemos as perguntas efetuadas por Flávio Saes. Quanto à ausência do recurso à infância, podemos apenas conjecturar. Uma hipótese a considerar é que a natureza da publicação, um periódico de economia vinculado à FEA/USP e o lugar da entrevista na mesma, ou seja, em seção sobre experiências de pesquisa, tenha obliterado, ou até mesmo não estimulado tal recurso ${ }^{844}$.

espacio biográfico, como horizonte de inteligibilidade y no como una mera sumatoria de géneros ya conformados en otro lugar". ARFUCH, op. cit., 2010, p. 18.

840 O biografema, formulação de Roland Barthes, pode ser compreendido como a menor unidade que possibilita o discurso biográfico. Cf. DOSSE, François. Os biografemas. In: _ . O desafio biográfico: escrever uma vida. São Paulo: EDUSP, 2009, p. 306-314.

${ }^{841}$ Cf. CANABRAVA, op. cit., 1997.

${ }^{842}$ Cf. CERTEAU, op. cit., 2011.

${ }^{843}$ CERTEAU, Michel. A história, ciência e ficção. In: CERTEAU, op. cit., 2012, p. 67.

${ }^{844}$ Sylvia Molloy em seu ensaio sobre a escrita autobiográfica na América hispânica dos séculos XIX e $\mathrm{XX}$, ao se debruçar sobre a presença da infância e das histórias de família nesses relatos, destaca que para o século XIX, apesar de o modelo autobiográfico mais referenciado ser as Confessions de Rousseau, os autobiógrafos não se detém na infância. Quando o fazem, é pontualmente, logo saltando para a vida adulta. A explicação de Molloy reside no fato de que estas autobiografias do século XIX apresentavam interesse público e não individual. Interesse público ligado às vidas de homens públicos no contexto de 
Em outro lugar de fala, em depoimento concedido em sessão especial organizada pelo Centro de Estudos Rurais e Urbanos da USP (CERU), sob os auspícios de Eva Alterman Blay e Alice Beatriz da Silva Gordo Lang, durante a reunião anual da Sociedade Brasileira para o Progresso da Ciência (SBPC) em julho de 1984, Alice tece um fio narrativo que se estende da infância até o derradeiro concurso de 1946 na FFCL/USP. Este projeto consistia em recolher o depoimento das primeiras mulheres que frequentaram a FFCL e que se tornaram professoras da USP. Entre as depoentes, além de Canabrava, estão: Gilda de Mello e Souza, Jandyra França Barzaghi, Olga Pantaleão, Maria Conceição Vicente de Carvalho e como contraponto: Veronica Rapp de Eston, da Faculdade de Medicina.

Jandyra França Barzaghi é da primeira turma do curso de Química da FFCL, chegou à posição de primeira assistente de cadeira, depois demitiu-se em 1951 para se dedicar à família; Olga Pantaleão ingressou na turma de 1936 do curso de Geografia e História da FFCL, chegou a reger a cadeira de História da Civilização Moderna e Contemporânea interinamente, mas quem assumiu como catedrático foi Eduardo D’Oliveira França; foi uma das fundadoras do curso de História da FFCL de Marília/SP juntamente com José Roberto do Amaral Lapa; Maria Conceição Vicente de Carvalho, autora da primeira tese de doutorado em Geografia no Brasil sob a orientação de Pierre Monbeig. Os depoimentos foram transcritos e entregues às autoras para aprovação. Estes depoimentos seriam publicados somente em 2004 no livro "Mulheres na USP" 845.

Alice agora está entre seus pares, entre mulheres, como ela, distinguidas enquanto pioneiras em um momento em que a inserção da mulher na cátedra era dificultada por uma cultura acadêmica misógina. Aqui, o recurso à infância explica o caminho até o concurso de 1946.

Havia crescido sem medo. Sentia-me forte, afeita à luta, e tinha a impressão de que, em toda a minha infância e juventude, havia-me preparado, psiquicamente, para o momento. Surpreendi-me, passada a tempestade, quando me vieram falar, com admiração, sobre o que chamavam "minha fibra". Nada mais estranho a mim do que o

independência e afirmação dos Estados Nacionais. No caso da condessa de Merlin, um exemplo também de "eu" exilado - passa seus doze primeiros anos de idade em Havana, entre os quais seus pais vão para a Espanha e depois ela mesma é levada até sua mãe na França - não apenas em relação ao passado, mas também geograficamente, pelo fato de ser mulher, pôde tratar de sua infância de forma nostálgica, uma vez que os autobiógrafos, por sua condição de autores, não podiam tratar da infância nesses termos, pois seus escritos seriam tratados como literatura e não como história. Cf. Cf. MOLLOY, Silvia. Vale o escrito - a escrita autobiográfica na América hispânica. Chapecó: Argos, 2003, p. 131-159.

${ }^{845}$ Cf. BLAY; LANG, op. cit., 2004. 
desempenho do papel de heroína. Avançava tranquila no exercício do que considerava um direito. Na infância havia sido uma criança destemida, travessa, transbordante de energia e saúde. Pouco afeita às bonecas, estas se circunscreveram à fase pré-escolar. Depois, as horas que não pertenciam ao grupo escolar e ao estudo, atenta e espontaneamente cumpridas, enchiam-se com as correrias pelas ruas ermas da minha cidade $[\ldots]^{846}$.

A explicação para o enfrentamento das condições adversas do concurso para a cadeira de História da Civilização Americana de 1946 se inicia pelo recurso à infância. A imagem descrita por Alice é de uma criança singular, até mesmo masculinizada, tática discursiva interessante quando se tem que concorrer com homens e provar ser tão competente quanto eles.

Outro biografema presente em entrevistas e também em depoimentos é a vocação ${ }^{847}$. Alice escreve seu depoimento enquanto mulher e acadêmica. Trata-se de uma das características apontadas por Popkin em relação as autobiografias escritas por historiadores: reflete uma experiência de grupo. No caso de Canabrava, também uma experiência de gênero, à medida que retrata os obstáculos enfrentados pelas mulheres no alvorecer da vida acadêmica no Brasil. Ademais, notamos a ancoragem social desta memória voluntária, uma vez que ela está entre as mulheres incluídas enquanto pioneiras da USP, ou seja, aquelas que, em um momento de pequena inserção da mulher na academia, conseguiram alcançar o topo da carreira acadêmica. Suas memórias estão ancoradas em espaços compartilhados por seus próximos, como as memórias que fluem dela para Maria Celestina Teixeira Mendes Torres em relação à FFCL/USP; as compartilhadas entre e com Antônio Emílio Muniz Barreto, Zélia M. Cardoso de Mello e Ronaldo Marcos dos Santos em relação à cadeira de História Econômica da FCEA/USP ou ainda as memórias compartilhadas a partir da pertença à comunidade de historiadores, com Iglésias.

\footnotetext{
${ }^{846}$ CANABRAVA, op. cit., 2004, p. 100.

${ }^{847}$ Uma das questões apontadas por Jeremy Popkin diz respeito ao fato de que ao historiar a própria vida, o historiador, por seu aparato crítico, expresso por um ofício particular, possui a habilidade de derivar de sua experiência, consequências e conexões que outros não estão habituados a empreender. Porém, para o autor, historiadores quando escrevem sobre si mesmos não estão praticando seu ofício, tampouco escrevendo um romance e propõe as seguintes questões para reflexão. "[...] why should anyone, other perhaps historians themselves, be interested in the autobiographies of members of that profession? Second, what special challenges does autobiographical writing pose for historians? Third, how widespread has autobiographical writing become among historians? A fourth question has to do with the motives and circumstances that make some historians more likely than others to publish personal stories". POPKIN, Jeremy. History, historians, and autobiography. Chicago: The University of Chicago Press, 2005, p. 57.
} 
No caso de Alice Canabrava não encontramos rememorações ao ambiente familiar que invocassem a presença de livros, o estímulo a viagens como atividade cultural e à uma vida cultural ${ }^{848}$. Ela rememora que, como Popkin aponta para várias mulheres que encontraram apoio familiar em um momento em que enfrentavam barreiras sociais à inserção educacional, seus pais sempre a estimularam ao trabalho e demarcaram a inexistência de diferenças entre homens e mulheres no que tange às aptidões intelectuais.

Desde menina, ouvira meu pai, homem culto, afirmar muitas vezes sobre a ausência de diferenças de inteligência entre o homem e a mulher que se reportassem ao sexo; tratava-se apenas de variações individuais. Não se requerendo o dispêndio de força física, as mulheres, se preparadas, podiam executar qualquer tarefa com eficiência, sem excluir as realizações intelectuais. Minha mãe, de nacionalidade austríaca, de grande vigor físico e invulgar iniciativa, tinha sempre uma palavra de exaltação ao valor do trabalho. Insistia que nós devíamos nos preparar para o desempenho de uma profissão, de modo a nos tornarmos independentes economicamente quando adultos. Desde cedo aprendi a tomar decisões, a assumir responsabilidades, a sair sozinha para as compras e visitas a amigas, a viajar também sozinha, a um tempo em que as pessoas do sexo feminino não saíam à rua desacompanhadas ${ }^{849}$.

Alice também demarca uma singularidade: saía e viajava sozinha em um período em que as mulheres não eram, como se diz, "bem-vistas" desacompanhadas por alguém do sexo masculino. No excerto acima, para além das características autobiográficas descritas por Canabrava, causa-nos mossa a referência a seu pai como homem culto. Sabemos, por meio do relato de Lúcia Carvalho, que a historiadora assim como Clementina Canabrava, sua irmã, eram filhas de um fazendeiro que não reconheceu a paternidade de ambas. Por que então adotar essa tática narrativa e autobiográfica? Não devemos nos esquecer que seu depoimento foi tomado ao lado de outras mulheres, todas provenientes da classe média paulista/paulistana, como Gilda de Mello e Souza e

\footnotetext{
${ }^{848}$ Para analisar uma variedade de memórias de historiadores e historiadoras - dos EUA, Reino Unido, Austrália, Nova Zelândia, França, Alemanha, Áustria - que empreenderam relatos autobiográficos, Popkin adota como parâmetro o caso de Friedrich Meinecke, em um empreendimento prosopográfico. A explicação da maioria desses historiadores e historiadoras para o desenvolvimento de sua vocação se liga à um ambiente familiar em que o estímulo à cultura e à leitura eram uma constante, até mesmo entre os mais pobres. Ademais, muitos remetem sua escolha à uma tradição intelectual familiar e ao estímulo a viagens, em um período em que os transportes de massa ainda não haviam se desenvolvido, ou seja, as viagens eram um investimento de grande monta. Poucos são provenientes de famílias ricas, sendo que no caso da maioria seus pais possuíam ocupações como advogados, engenheiros, homens de negócios com variados graus de sucesso, clérigos, professores, funcionários públicos, médicos e alguns professores universitários. Quando os recursos familiares eram insuficientes, contaram com subsídios públicos. Cf. POPKIN, Jeremy. Choosing history: the issue of vocation in historians' autobiographies. In: POPKIN, op. cit., 2005, p. 120131.

${ }^{849}$ CANABRAVA, op. cit., 2004, p. 100-101.
} 
capitalizadas social e culturalmente. Assim, publicamente, uma professora universitária e emérita, não poderia narrar a si mesma como filha bastarda ${ }^{850}$.

Sabemos que Alice veio à São Paulo com o fito de cursar estabelecimento de ensino frequentado pela classe média paulistana, Colégio Stafford, de tradição angloamericana e depois permaneceu para cursar a Escola Normal Caetano de Campos (19251930). Quanto à essa última lembra seu desempenho notável em Geografia e História, tendo recebido o prêmio Barão do Rio Branco para os alunos com as maiores notas nessas disciplinas. Porém, em relação ao conteúdo, qualifica seu ensino como "tradicional", em uma concepção de nomes, datas e locais, onde a Geografia consistia em "lista telefônica"851.

Como analisado por Popkin, Alice se enquadra entre aqueles historiadores em que a falta de condições materiais da família requeria subsídios governamentais para o ingresso na carreira. Assim, ela foi uma das muitas professoras primárias que ingressaram na FFCL/USP em 1935 por comissionamento. Canabrava rememora que, antes de ingressar no curso de Geografia e História, “[...] gostaria de seguir, talvez, seguiria a faculdade de direito" ${ }^{\$ 52}$. Porém, lembra que sua mãe dizia que morreria de fome. Talvez uma proteção em relação à filha, uma vez que, naquele momento, a carreira em direito era exercida majoritariamente por homens.

Ao analisar as autobiografias de mulheres judias, Popkin encontra similaridades entre essas e mulheres de outras etnias, demarcando as dificuldades de gênero enfrentadas entre 1945 e 1970. Dentre elas, menciona as trajetórias de Natalie Zemon Davies e da australiana Jill Ker Conway. A primeira rememora que até mesmo entre professoras encontrou a oposição entre ter filhos e seguir uma carreira profissional e que o estímulo à mesma se restringia à graduação. Conway lembra que para obter reconhecimento, o trabalho da mulher deveria apresentar um desafio teórico e ser uma pesquisa mais brilhante que a dos homens ${ }^{853}$. Quando comparamos esses relatos com a trajetória de

\footnotetext{
${ }^{850}$ Nas narrativas analisadas por Popkin, o ambiente familiar é rememorado como mais importante do que as experiências escolares primárias e secundárias. Poucos estabelecem relações entre a escolha de seu ofício e o conteúdo aprendido na escola. Nesse último aspecto, há relatos de que um primeiro encontro com a possibilidade de seguir uma carreira docente em história se apresenta através do professor da escola secundária, devido a seu carisma e não ao conteúdo da disciplina propriamente. Cf. POPKIN, op. cit., 2005, p. 133.

${ }^{851}$ Cf. CANABRAVA, op. cit., 2004.

852 CANABRAVA, op. cit., 1981.

${ }^{853}$ Cf. POPKIN, op. cit., 2005, p. 146-148.
} 
Alice Canabrava, temos algumas similaridades, como não ter se casado para se dedicar plenamente à carreira e sua escolha, quando na Faculdade de Economia da USP, pelos estudos em história quantitativa. Vemos nessa escolha, um método proveniente das "hard sciences", uma tática para atestar sua competência intelectual junto aos seus pares masculinos.

Em sua entrevista Alice rememora que 854

[...] tanto o professor Monbeig quanto o professor Braudel eram pessoas que conquistavam os estudantes, conquistavam intelectualmente. Quando acabei o curso não desejava outra coisa a não ser, ser... Não tinha bem ideia do que queria ser, se eu seria geógrafa ou seria historiadora. Na realidade eu tinha estudado muito mais geografia do que história ${ }^{855}$.

Se tivermos em conta que os cursos de Geografia e História eram oferecidos juntos na FFCL/USP, Alice também se deparou com a escolha entre carreiras. Sabemos que sua escolha se deu pela história, uma vez que, pouco capitalizada financeiramente, Canabrava, dentre os convites de Plínio Ayrosa, Pierre Monbeig e Paul Vanorden Shaw escolheu esse último pela bolsa oferecida ${ }^{856}$. Mas quanto à inspiração pelos estudos históricos, em suas entrevistas e no depoimento sempre se refere à Braudel.

Aulas maravilhosas de História, cheias de vida, ricas de substância, nenhuma palavra inútil. A exposição oral acompanhava o esquema que ia sendo apresentado no quadro-negro; os eventos e a interpretação, sempre que possível, associavam-se ao quadro geográfico, apresentado em rápido croqui; a bibliografia especializada completava a geral, dada no início do curso. [...] Acostumadas a conhecer as grandes figuras da História apenas pelos nomes, datas e alguns eventos, sobretudo guerras e batalhas, ficávamos fascinados com a nova perspectiva, a de conhecêlas e interpretá-las dentro de seu meio e de sua época e, sempre que possível, com o auxílio de textos da própria autoria, biografias ou estudos especializados. A leitura destes pelo Mestre constituía-se em inesquecível mostra de sua faceta de ator: a dicção perfeita, as variações da voz, a expressão da fisionomia ${ }^{857}$.

\footnotetext{
${ }^{854}$ Quanto ao momento da escolha da profissão, Popkin afirma que muitos historiadores atribuem a opção ao envolvimento com movimentos políticos. A maioria, porém, atribui essa preferência ao fato de que a história - considerando que no ambiente acadêmico tomado por Popkin, a escolha pela história se dava já na universidade e não após os estudos secundários como no caso brasileiro - lidaria com o "concreto" e não com abstrações teóricas. Outro aspecto presente nas autobiografias de historiadores e historiadoras que justificam sua opção pela história possui relação com professores que os entusiasmaram.

${ }^{855}$ CANABRAVA, op. cit., 1981.

${ }^{856} \mathrm{Cf}$. Idem.

${ }^{857}$ CANABRAVA, op. cit., 2004, p. 91-92.
} 
Um dos tópicos importantes para Popkin e que poucos historiadores abordaram em suas memórias trata-se de como se deu a escolha por um campo específico de trabalho. Esse não é o caso de Alice. Na entrevista de 1997 ela atribui seu interesse pela história econômica à Braudel. "Creio que o gosto que adquiri pela História Econômica possa ter sido influência de meus professores. Talvez seja por causa do Braudel que tinha um grande interesse por assuntos de economia" ${ }^{\circ 58}$.

Outro aspecto das autobiografias de historiadores diz respeito ao fato de que a maioria lembra ao menos um evento traumático durante seu treinamento como historiador, ao passo que poucos tratam do alto preço emocional que o doutoramento trouxe $\mathrm{e}^{859}$. Alice inventa para si uma imagem de mulher "trabalhadeira" e apenas nas cartas - que trataremos adiante - expressa a seus próximos seu cansaço mental proveniente do excesso de trabalho. "A pesquisa histórica, desde minha licenciatura, absorvia cotidianamente muitas das minhas horas; reservava as férias para o trabalho na Biblioteca Nacional, no Rio de Janeiro" ${ }^{\$ 60}$. Em trecho da entrevista à Flávio Saes, ao comentar sobre seus trabalhos, ela rememora os tempos em que trabalhava intensamente. "Naquela época eu era moça e trabalhava até altas horas da noite. Havia em mim muito entusiasmo e muita mocidade. Tinha forças para isso e boa saúde" ${ }^{861}$. Ao rememorar sua mudança de método, ao privilegiar a história quantitativa em seus estudos, Canabrava também recorre à imagem de mulher "trabalhadeira".

Posteriormente, meus trabalhos ingressaram na história quantitativa, especialmente aqueles sobre a estrutura da posse da terra e da riqueza em São Paulo. Então eu já estava na Faculdade de Economia. Esta mudança não me intimidou, pois sendo muito trabalhadeira aquela massa incrível de dados não me impressionava ${ }^{862}$.

Outro ponto do fio narrativo construído pela historiadora nas duas entrevistas e no depoimento é a descrição de uma mulher aguerrida, dedicada à pesquisa e que enfrenta as hostilidades de gênero. Na entrevista ao MIS/SP, Alice rememora as relações de sociabilidade até o concurso de 1946:

[...] a guerra até eu chegar à 46 foi uma guerra desenfreada e que lançaram dos argumentos e dos atos mesquinhos e que se eu acho que se não tivesse trabalhado intensamente, enormemente, se não tivesse

\footnotetext{
${ }^{858}$ CANABRAVA, op. cit., 1997, p. 157.

${ }^{859}$ POPKIN, op. cit., 2005, p. 139-140.

${ }^{860}$ CANABRAVA, op. cit., 2004, p. 99.

${ }^{861}$ CANABRAVA, op. cit., 1997, p. 159.

${ }^{862}$ Idem, p. 160.
} 
uma saúde magnífica, e não tivesse coragem e força, eu não teria afrontado, porque foi uma afronta de uma criatura contra a maioria, contra a maioria, que eram todos contrários a presença de uma mulher numa cátedra ${ }^{863}$.

Após sua ida à FCEA/USP, as barreiras que se punham eram de outra natureza e Canabrava mobiliza, novamente, o recurso à imagem da mulher aguerrida:

[...] quando eu cheguei a faculdade de economia em 46 e uma vez pedi se era possível, se havia verba para estar no Rio de Janeiro, ouvi do seu diretor que o importante era ter leite para as crianças e não pesquisa de história. Eu argui e tive sempre assim durante a gestão dele que eu era briguenta e que eu criava caso. Continuei lutando pela pesquisa lá dentro ${ }^{864}$.

Em seu depoimento, ao narrar as condições que a conduziram ao concurso de 1946, mais uma vez nos deparamos com a imagem da mulher "guerreira". "Sem dúvida, a resistência do meio que sentia crescer e o desafio à adversidade constituíram-se em estímulos para enfrentar a luta" ${ }^{\$ 65}$. Esse fato também é rememorado em sua entrevista à Flávio Saes em 1997:

Na Faculdade de Filosofia, o Prof. Dreyfus, que era o diretor, me estimulou a prestar o concurso para a Cadeira de História da Civilização Americana. Ele não queria abrir o concurso para apenas um candidato. Eu ainda não possuía uma tese. Naquela época, ninguém queria mulheres nas cátedras. As mulheres eram ótimos elementos para serem datilógrafas e secretárias. No entanto, não me deixei intimidar e disse: "Eu faço o concurso e vocês que me reprovem. Estamos entendidos". Eu tive a audácia de concorrer com o meu chefe [itálico no original] ${ }^{866}$.

Outro biografema identificado por Leonor Arfuch em entrevistas e depoimentos é o "ser comum", que apresenta um signo mitológico ligado à notoriedade: a dos começos difíceis, como quando Alice rememora sobre as hostilidades enfrentadas na FFCL/USP até o concurso de 1946; as dificuldades para obter financiamento para suas pesquisas quando de sua chegada à FCEA/USP e o período em que foi diretora da instituição (19541957).

Em duas ocasiões Canabrava estabeleceu um flerte com a escrita autobiográfica. A primeira na entrevista ao MIS/SP, quando afirma que pediram a ela para que escrevesse um livro de memórias.

\footnotetext{
${ }^{863}$ CANABRAVA, op. cit., 1981.

${ }^{864}$ CANABRAVA, op. cit., 1981.

${ }^{865}$ CANABRAVA, op. cit., 2004, p. 99.

${ }^{866}$ CANABRAVA, op. cit., 1997, p. 162.
} 
Disseram-me, pediram-me, até acharam que eu deveria escrever um livro de memórias. Eu disse não. Não merece tanto. [...] De modo que eu digo que... então me disseram que eu deveria escrever. Eu digo não, eu não tenho tempo, nem talvez gosto de escrever um livro sobre isto ${ }^{867}$.

Esta negação à escrita autobiográfica se converte em desejo apenas três anos depois, quando concede seu depoimento junto ao projeto das mulheres pioneiras da USP.

Sempre pensei na possibilidade de um relato sobre minha vivência como aluna e professora da Universidade de São Paulo, a ser preservado como testemunho, eventual subsídio para a história das mentalidades em nosso país. Entusiasmei-me logo pela ideia de publicá-lo, consciente, como historiadora, do papel que pode ter a contribuição memorialista na reconstituição do passado ${ }^{868}$.

E mais, em nota da revisão da transcrição do depoimento, dispõe-se até mesmo à uma autobiografia: "Deixei correr os dedos na máquina de escrever, ao leve toque das reminiscências, deixando desenrolar o fio narrativo. Não omiti alguns pormenores que me pareceram significativos para caracterizar o ambiente. Outros, também significativos, ficaram para um possível livro autobiográfico".

Além dos biografemas que estabelecem pontos de seu fio narrativo autobiográfico, quais outras características de sua personalidade e do exercício de seu ofício Alice quer nos transmitir através das duas entrevistas e do depoimento? Na entrevista ao MIS/SP ela se insinua como professora próxima dos alunos. Essa proximidade é atribuída às posturas de Fernand Braudel e de Pierre Monbeig, uma vez que ambos são rememorados como professores que se aproximavam dos alunos, que falavam com os alunos. "[...] eu acho que eu tive uma grande influência do professor... dos dois professores, do professor Monbeig e do professor Paul Fernand Braudel, no sentido de criar com os alunos não um distanciamento, houve sempre assim uma proximidade muito grande entre os alunos e o professor" ${ }^{\text {" }}$. Por suas viagens pelo Brasil, Canabrava se coloca como conhecedora das condições de ensino e pesquisa.

Eu tenho viajado intensamente pelo Brasil. Eu tenho vistoriado em faculdades, tenho andado em cartórios, tenho andado em arquivos, tenho andado em faculdades, dado cursos... E o que eu vejo é que ninguém tem apoio de pesquisa. Mas ninguém faz pesquisa, é uma minoria que faz pesquisa, nem sabe como faz, nem sabe como fazer,

\footnotetext{
${ }^{867}$ CANABRAVA, op. cit., 1981.

${ }^{868}$ CANABRAVA, op. cit., 2004, p. 85.

${ }^{869}$ CANABRAVA, op. cit., 1981.
} 
nunca viram um documento, porque o seu curso foi puramente oral, foi de notinha em cima do joelho ${ }^{870}$.

Ainda na seara do ensino e da pesquisa Alice é formadora de grupo de pesquisa em história econômica, único estabelecido em Faculdade de Economia que empreende pesquisas a partir de "fontes primárias". "Eu acho que eu vou pecar pela modéstia dizendo ao professor Oracy e aos presentes nesse depoimento, que a Faculdade de Economia tem o único grupo de historiadores da Economia [...] no Brasil" ${ }^{\prime 871}$. Ao rememorar sua trajetória na ANPUH a historiadora quer se identificar com uma ala da associação, como vimos no terceiro capítulo, que democratiza a mesma e faculta a participação de professores de todos os níveis na apresentação de trabalhos. "[...] um dos problemas que nós tínhamos nos simpósios era justamente da seleção dos trabalhos, porque nós sempre permitimos que todos falassem, que todos apresentassem as suas comunicações. E publicavam-se todas elas seja do nível que for" ${ }^{872}$. Professora próxima aos alunos; exímia pesquisadora; pioneira em história econômica; perfil democrático; mulher que vence hostilidades... Poderia ela ensaiar outra memória sobre si? Está com 69 anos e é consagrada professora catedrática com 30 anos de exercício junto à cadeira de História Econômica da atual Faculdade de Economia, Administração e Contabilidade (FEA). Alguns elementos dessa entrevista nos permitem aproximar essa narrativa autobiográfica de um ensaio de ego história, no sentido em que essa modalidade do espaço biográfico é desprovida de elementos da vida privada, tendendo à trajetória intelectual. Mas por outro lado, como analisamos, o fato de se tratar de uma entrevista em que o corpo se faz presente através da voz, há maior dificuldade em se manter fora da instância privada e os deslizes e lapsos podem ser frequentes ${ }^{873}$.

No depoimento ao projeto "mulheres na USP" reencontramos o esforço autobiográfico de Alice no sentido de se vincular aos "mestres" franceses no trato ameno com os alunos, no ensino de uma nova história, distante daquela dita "tradicional" e o estabelecimento do contraponto em relação à Afonso Taunay e Plínio Ayrosa.

\footnotetext{
${ }^{870}$ Idem.

${ }^{871}$ CANABRAVA, op. cit., 1981.

872 Idem.

873 “A preocupação com a exclusão da intimidade e da subjetivação surge como uma forma de intermediação, de autocensura daquele que escreve, sendo também um conjunto de rastros e pistas a partir de lapsos e deslizes (mais comuns em entrevistas e depoimentos, nos quais processos de remodelação discursiva são mais difíceis)". SILVA, Wilton Carlos Lima. Espelho de palavras: Escritas de si, autoetnografia e ego-história. In: AVELAR; BISSO, op. cit., 2012, p. 56.
} 
Toda essa metodologia para o ensino da História e da Geografia a que acabamos de nos referir, podem parecer hoje rotineiras; todavia, à época da fundação da Faculdade de Filosofia, representavam verdadeira revolução, quando o aprender, habitualmente, se resumia em repetir o professor com base em apontamentos de aula, o ensino, puramente verbal, sem qualquer outro recurso, o formalismo solene nas relações entre professor e aluno. Estes característicos, encontrávamos nas aulas dos professores Taunay e Ayrosa ${ }^{874}$.

Dentre outros aspectos que analisamos acima, Canabrava também se identifica como professora e pesquisadora pioneira na formação de grupo de pesquisa em história econômica.

O último momento público em que podemos ouvir Alice Canabrava é 1997, com 86 anos de idade. Não está entre professores do sexo masculino; não figura entre os intelectuais do projeto estudos brasileiros; não está entre seus pares femininos, as pioneiras... Está diante de seu mais dileto orientando, Flávio Saes que na entrevista de 1981 foi referido por ela como a maior esperança para a continuação da área de história econômica na FEA. Esta entrevista, assim como o depoimento, também sofreu sob o império da escrita, que exclui e marginaliza aquilo que não quer fazer ver e/ou ouvir ${ }^{875}$. Quem é Alice Canabrava avançada em anos? Como quer ser lembrada? Braudel e Monbeig são presenças. Ao primeiro ela atribui seu gosto pela história econômica e seus esquemas de aula em três tópicos, no máximo quatro; Taunay e Ayrosa voltam como professores antiquados; seu legado é relacionado ao grupo de pesquisa em história econômica da FEA e suas pesquisas em história quantitativa, pioneiras ${ }^{876}$. Nenhum dado sobre a vida privada, talvez também pelas perguntas formuladas por Flávio Saes, que desconhecemos.

É possível responder quem é Alice Canabrava a partir de cada uma destas falas e escritos? Há rachaduras em seu empenho memorialístico. Exatamente nisso reside a riqueza do sujeito inventado pelo historiador ${ }^{877}$. Destaco duas: uma diz respeito à um intento autobiográfico e memorialístico que é negado na primeira entrevista e afirmado, exaltado, no depoimento. A segunda em relação aos obstáculos de gênero na FEA: na

\footnotetext{
${ }^{874}$ CANABARAVA, op. cit., 2004, p. 95.

${ }^{875}$ Cf. CERTEAU, op. cit., 2011.

${ }^{876}$ Cf. CANABRAVA, op. cit., 1997.

877 “"...] a biografia só terá sentido para o historiador se inventariar as diferenças constituintes do próprio indivíduo biografado, se encontrar, naquele que se diz um, muitos outros, se empenhar-se em marcar os momentos de descontinuidade e inflexão na vida que é contada". ALBUQUERQUE JÚNIOR, op. cit., 2012, p. 31.
} 
primeira entrevista, a FEA é exaltada, mas também desvela todo problema que enfrentou quando foi diretora, o que a teria feito desistir de qualquer cargo administrativo posterior; no depoimento, a FEA é exaltada, assim como na segunda entrevista.

Da mesma forma que refletimos acerca das especificidades das narrativas autobiográficas buscando a marca do ofício de historiador, devemos proceder de modo semelhante quando tomamos o arquivo pessoal de Alice Canabrava como narrativa autobiográfica. $\mathrm{O}$ arquivo manipulado por um historiador também pode deixar marcas próprias do ofício.

\subsection{Alice através de seu arquivo}

Michel de Certeau concebe a história enquanto heterologia, ou seja, enquanto um discurso sobre o outro ${ }^{878}$. Nesse caso, para o historiador, o passado. Através dos restos, ou rastros, vestígios desse outro, o historiador procede através de seu texto ao encurtamento dessa alteridade, porém sem conseguir apagar suas marcas. Forja a presença de um ausente. Sendo a ausência condição de possibilidade do discurso histórico ${ }^{879}$.

\footnotetext{
878 Ver, principalmente: CERTEAU, Michel de. Heterologies: discourse on the other. Minneapolis: University of Minnesota Press, 2010. Trata-se de trabalhos dispersos de Certeau que foram traduzidos por Brian Massumi e revisados por Luce Giard sob a supervisão do jesuíta-historiador. A maioria dos textos presentes neste livro compõe a edição: CERTEAU, op. cit., 2012. O livro original data de 1986 e sua edição ampliada, de 2002. Conta com prefácio de Luce Giard intitulado "Um caminho não traçado".

${ }^{879}$ Em texto publicado em 1970, proveniente de conferência no Centre de intellectuels catholiques em 1969, intitulado "História e estrutura", Michel de Certeau utiliza-se da metáfora do morador de rua (clochard) para explicar práticas etnológicas e historiadoras a partir de sua experiência com a história religiosa do século XVI. Ao iniciar seus estudos sobre a Companhia do Santo Sacramento, Certeau confessa que sua prática estava impregnada por uma busca identitária: imaginava que encontraria razões para sua fé cristã nesse passado. Qual seu embasbacamento ao se deparar com a diferença. O morador de rua, para Certeau, assemelha-se ao etnólogo à medida em que ao exumar nas latas de lixo, restos de mantimentos ou roupas, sonha com a casa que nunca irá morar; com a refeição que nunca terá e com intimidades que nunca desfrutará. A partir dos restos catados, inventa mundos que nunca irá frequentar. Da mesma maneira procede o historiador quando frequenta arquivos e bibliotecas. Estes "restos" catados pelo historiador permitem somente que encontre esse outro em sua imaginação. Essa ausência é uma condição para o discurso histórico. Cf. CERTEAU, Michel de. História e estrutura. In: . História e psicanálise: entre ciência e ficção. $2^{\mathrm{a}}$ edição. Belo Horizonte: Autêntica, 2012, p. 163-178. Não por acaso, o capítulo seguinte do livro "História e psicanálise" intitula-se "O ausente da história" e foi publicado originalmente em 1973. Nesse texto, Certeau nos convida a pensar a história enquanto uma heterologia, ou seja, como um discurso sobre o outro. Esse outro pode ser tomado como tudo aquilo que instaura uma diferença: o europeu em relação ao novo mundo; o Outro, como Deus para o místico; a linguagem do possuído; a mulher para o homem etc.
} 
Muito afeito as metáforas ${ }^{880}$, Certeau evoca o personagem Robinson Crusoé, também título do romance de Daniel Defoe publicado em 1719, para refletir acerca dos procedimentos do historiador em relação aos vestígios do passado. Crusoé é o único sobrevivente de um naufrágio e está em uma ilha deserta. Organiza toda uma técnica para que possa sobreviver através da construção de uma cabana e coleta de alimentos. Porém, algo perturba sua economia. Crusoé delira em sonhos após ver pegadas na areia. Não estaria sozinho? Quem é este outro? Crusoé está em devaneios. Aqui, Certeau entrevê os lugares que no século XIX serão ocupados, respectivamente, pela ciência econômica e pela interpretação dos sonhos; pela racionalidade e pela ficção. O outro de Crusoé se desvela: é Sexta-feira, um nativo que irá escravizar. Ao contrário desse outro de Crusoé, o outro do historiador é ausência permanente; não chega, não volta. Deixa somente pegadas, vestígios... ${ }^{881}$

Entre agosto de 2015 e maio de 2016, ao adentrar, quase todos os dias, à sala número 2 do Arquivo/IEB, com umidade e temperaturas controladas, bastante fria, me sentia procedendo tal qual médico legista ao tomar um corpo e, a partir de evidências fisiológicas, tentar inferir uma causa mortis. Com luvas de látex, colocava os "restos mortais" na forma de "rastros mortais" de Alice Canabrava no carrinho do arquivo e rumava para a sala de trabalho à fim de exumá-los; no caso, descrevê-los.

Cartas recebidas de sua irmã, Clementina; cartas recebidas de sua mãe, Ottília; cartas recebidas de amigos e de colegas historiadores; cartas recebidas de seus orientandos. Cartões postais remetidos de diversas partes do mundo, por amigos, colegas e por sua irmã. Fotos quando professora em Araras/SP; fotos ainda moça em excursões com sua turma do curso de Geografia e História da FFCL/USP promovidas pelo geógrafo Pierre Monbeig, regente da cadeira de Geografia Física e Humana; fotos de formatura;

\footnotetext{
${ }^{880}$ As noções de estratégia e tática são provenientes de uma metáfora de guerra. Este par talvez seja o mais usado entre historiadores, antropólogos e cientistas políticos, conforme pudemos inferir das apresentações do Colóquio "Michel de Certeau em uso", organizado pelo coletivo Artes, Saberes e Antropologia (ASA) do departamento de Antropologia da FFLCH/USP entre 19 e 21 setembro de 2016. Cf. $\langle$ http://www.coletivoasa.dreamhosters.com/coloquio-michel-de-certeau-em-uso/>. Acessado em 18 de dez. 2016. Grosso modo, a estratégia vincula-se ao planejamento de longo prazo e relaciona-se ao poder dos fortes, enquanto a tática é forjada pelos mais fracos com o fito de subverter a estratégia dos dominantes e, por isso, vincula-se ao tempo curto, ao instante. A tensão imbricada na relação entre estratégia e tática, não se resolve dialeticamente, pois uma não existe sem a outra. Cf. CERTEAU, Michel de. Fazer com: usos e táticas. In: _. . A invenção do cotidiano: artes de fazer. 22a edição. Petrópolis: Vozes, 2014, p. 86-100. Esta edição é estabelecida e apresentada por Luce Giard. Na conferência de abertura desse Colóquio, Luce Giard atribui a inspiração da elaboração desse par nocional à leitura da obra de Marx pelo grupo de jesuítas da casa na qual Certeau morava e que foi participante.

${ }^{881}$ Cf. CERTEAU, Michel de. O ausente da história. In: CERTEAU, op. cit., 2012, p. 179-188.
} 
fotos em sua casa, em jantares com os assistentes de pesquisa e auxiliares de ensino da cadeira de História Econômica da FCEA/USP ${ }^{882}$; fotos com sua mãe, sua irmã e seu irmão por adoção. Canabrava nunca está sozinha, sempre em alteridade. É muitas: irmã, filha, professora, orientadora, colega, amiga, historiadora... Muitas são as pegadas. Muitas são as Alice.

Três questões despertaram nossa atenção no convívio com este outro ausente: por que o espólio foi doado ao IEB/USP? Por que uma parte foi doada em 2005 e a parte mais significativa dez anos depois, em 2015? O que aconteceu com o restante de seu espólio, uma vez que alguém que por toda vida nunca fez uso de computador, teria um volume de documentação muito maior do que a que compõe seu fundo? Teria Alice se desfeito de uma parte de seus papéis? Por fim, por que ela possuía cópias carbonadas de várias cartas remetidas, estaria "arquivando a própria vida"? 883

Em 24 de junho de 1975 Alice deixou carta à sua irmã Clementina (referida na mesma por "Tinin") para que, em caso de morte repentina, modificasse seu testamento. Um dos pontos a serem alterados dizia respeito à doação de seus livros. Estes deveriam ser vasculhados com o fito de averiguar se dentro de algum constariam papéis particulares; proceder à seleção dos mesmos e doá-los ao IEB/USP e não mais à

\footnotetext{
${ }^{882}$ Como na ocasião de sua aposentadoria, conforme relatado em carta à Francisco Iglésias em 17 de novembro de 1981: "Minha aposentadoria saiu afinal dia 21 de Outubro e desde então, só agora, nesta semana, tenho um pouco de folga. Andei muito ocupada. Resolvi reunir os colegas do IPE e da Faculdade, aqui em casa, para um almoço, um almocinho simples. Trinta pessoas. Devo muito aos meus amigos do IPE, quase todos meus ex-alunos". APC-CP-P1, 27-(2). Fundo Alice Piffer Canabrava. Arquivo IEB/USP. ${ }^{883}$ Não somos os primeiros a empreender essas reflexões. A partir de sua experiência de pesquisa em arquivos pessoais de várias instituições francesas, Rafael F. Benthien aponta algumas questões relevantes ao pesquisador que se envereda por este tipo de arquivo. Sua ida aos arquivos pessoais de Henri Hubert, Solomon Reinach e Joshep Déselette relaciona-se com sua pesquisa de doutoramento envolvendo o problema da institucionalização da sociologia na França ante o já consolidado campo de estudos clássicos, compreendido pelos helenistas e latinistas. Cf. BENTHIEN, Rafael Faraco. Interdisciplinaridades: latinistas, helenistas e sociólogos em revistas (França, 1898-1920). 367 f. Tese (Programa de Pós-graduação em História Social), FFLCH/USP, 2011. A partir de figuras-chave para a institucionalização da sociologia na França, como Durkheim e Marcel Mauss, Benthien se depara com toda uma rede de relações que envolvia o estudioso das religiões, o sociólogo durkheimiano Hubert, e os arqueólogos Reinach e Déselette, uns dos poucos que dialogavam com a sociologia e a antropologia. $\mathrm{O}$ "impessoal" dos arquivos pessoais diz respeito à importância de se ter em conta três procedimentos metodológicos: historicizar o arquivo, ou seja, a história de sua composição, como foi acumulado pelo indivíduo, porque foi doado à esta ou àquela instituição, desde quando está acessível ao pesquisador; conhecer as instituições e os sistemas aos quais estão vinculados; relacionar um arquivo pessoal à outros, uma vez que é muito difícil que se tenha a totalidade da correspondência ativa e passiva do titular do acervo ou fundo. Desta maneira, é possível vislumbrar as lacunas, silêncios etc. Cf. BENTHIEN, Rafael Faraco. O que há de impessoal em arquivos pessoais: considerações a partir de uma experiência de pesquisa na França. Vozes, Pretérito e Devir. Teresina, v. 3, p. 42-57, 2014.
} 
FEA/USP. Asseverando que a esta última nada deveria ser doado ${ }^{884}$. Na mesma carta, Alice Canabrava determina que todos os seus papéis "[...] escritos à mão e à máquina, (materiais de estudo, fichas de estudo, cópia de fontes etc) tudo deverá ser queimado". Apenas sua coleção de cartões de natal deverá ser guardada e, posteriormente, doada à Hebe Marsiglio Carvalho ${ }^{885}$. Essa carta revogava o testamento anterior de 10 de dezembro de 1973, que determinava que: “[...] no caso de sua irmã e única herdeira, Clementina Canabrava, falecer antes dela testadora, ou simultaneamente consigo, todos os bens serão assim distribuídos: -I-Os bens imóveis, os títulos de financiamento e os depósitos bancários caberão à FIPE [...]"886 . Neste caso especial, todos os seus bens seriam transferidos à FIPE/USP, onde deveriam ser utilizados para financiar pesquisas em nível de pós-graduação em história econômica do Brasil na forma de concessão de bolsas de estudos e auxílio para publicação, na condição de que fossem pesquisas originais e que se remontassem no mínimo 40 anos no tempo.

Como analisado no capítulo 1, as memórias de Alice em relação à FFCL/USP parecem se caracterizar por uma perenidade, no sentido de, após ter sido preterida em concurso para a cadeira de História da Civilização Americana em 1946, expressar os sentimentos mais negativos em relação a esse lugar social, seja na correspondência com seu próximo ("ninho de víboras") ${ }^{887}$, seja em entrevista ("intelectualóides extremamente preconceituosos para com a mulher" ${ }^{888}$. Em relação à FCEA/USP, suas memórias

\footnotetext{
${ }^{884}$ Cf. Processo 2003.1.59.31.0. Doação do acervo Alice Canabrava. IEB/USP.

${ }^{885} \mathrm{Ibidem}$. Esta determinação de Alice, para que tudo seja queimado, nos lembra do personagem Matthew Pearce do romance "Ever After" do escritor inglês Graham Swift - que compreende o homem como um animal narrativo em sua característica ontológica de viver entre o passado e o futuro - na assertiva: "Keep them, burn them - they are evidence of $m e$ ". Sue McKemmish se inspira nesse personagem para empreender reflexão acerca das motivações que nos impelem a arquivar a própria vida como testemunho e os mecanismos pelos quais uma prova de si se torna uma prova de nós. Ver: MCKEMMISH, Sue. Evidence of me. Archives and Manuscripts, n. 24, v. 1, 1996, p. 28-45. Disponível também em: <http://www.infotech.monash.edu.au/research/groups/rcrg/publications/recordscontinuum-smckp1.html >. Acessado em 18 de dez. 2016. A compreensão de McKemmish da expressão "provas de mim" é "[...] como sinônima de arquivo pessoal, no sentido mais amplo, reunindo todas as formas que as narrativas podem assumir". MCKEMMISH, Sue. Provas de mim... Novas considerações. In: TRAVANCAS, Isabel; ROUCHOU, Joëlle; HEYMANN, Luciana. Arquivos pessoais: reflexões multidisciplinares e experiências de pesquisa. Rio de Janeiro: FGV, 2013, p. 23. Este texto é fruto da apresentação de conferência em evento promovido pela Fundação Casa de Ruy Barbosa entre 23 e 25 de agosto de 2010 no Rio de Janeiro sobre arquivos pessoais. Nele, Sue McKemmish atualiza as reflexões empreendidas em 1996 sobre as provas de si e as provas de nós em um ambiente de crescente informatização e digitalização da vida. Nele também é apresentada uma contribuição original à teoria arquivística: o records continuum.

${ }^{886}$ Testamento de Dona Alice Piffer Canabrava em posse de Lúcia Carvalho, p. 2.

${ }^{887}$ Cf. Carta a Francisco Iglésias. São Paulo, 29 de abril de 1982. APC-Ca-P2, 11-(5). Fundo APC. Arquivo IEB/USP.

${ }^{888}$ CANABARAVA, op. cit., 1997.
} 
expressam sentimentos em trânsito e, por vezes, contraditórios, tanto em cartas, quando concorda com seu amigo Francisco Iglésias de que seu "único bilhete de loteria" foi ter ido para a FCEA/USP em $1946^{889}$, quanto em entrevistas ${ }^{890}$. Na entrevista ao MIS/SP em 1981, após ser questionada por Flávio Saes acerca das dificuldades enfrentadas pela mulher na universidade, afirma que nunca teve problemas na FCEA/USP pelo fato de ser mulher. Porém, afirma ter sofrido muito quando foi diretora da instituição entre 19541957, enfrentando oposição de um grupo de professores que não a queriam no cargo ${ }^{891}$. Já em entrevista à Flávio Saes, em 1997, afirma que é muita grata à Faculdade de Economia $^{892}$.

Além dos sentimentos conflitantes em relação à FCEA/USP, uma das hipóteses para que Alice tenha revogado o testamento de 1973 em favor do IEB/USP, diz respeito à sua relação de admiração e respeito por Sérgio Buarque de Holanda.

Quanto aos dois momentos da doação, um primeiro em 2005 e outro em 2015, podemos apenas conjecturar. Na primeira doação realizada por Hebe Marsiglio Carvalho, foram doados livros, fichas de estudo, anotações e quatro conjuntos de correspondências passivas: recebidas de Antônio Emílio Muniz Barreto (neste caso também há presença de cópias carbonadas de cartas remetidas), Francisco Iglésias (o mesmo do caso anterior), Fernand Braudel e Paullete Braudel. Sua sobrinha não queimou seus papéis, conforme determinava a carta de Canabrava mencionada acima. Teria Hebe M. Carvalho, doado somente a parte do espólio da historiadora que pôde examinar com cuidado, procedendo a uma seleção de arquivamento de sua tia? Fato é que o restante do espólio, selecionado ou não, somente foi doado após a morte de Hebe, por sua filha e sobrinha-neta de Alice Canabrava, Lúcia Marsiglio Carvalho.

O volume da documentação presente no Arquivo/IEB quando confrontado com o fato de que Alice Canabrava nunca fez uso de computador, conduz-nos a inferir que ela mesma procedesse à seleção de seus papéis, arquivando uns e dispensando outros, procedimento cotidiano da maioria das pessoas com seus papéis pessoais, seja recibos de

\footnotetext{
${ }^{889}$ Cf. São Paulo, 22 de outubro de 1972. FI-C-CP (100). Acervo FI. IMS/RJ.

${ }^{890}$ Cf. CANABRAVA, op. cit., 1981.

891 Ibidem.

${ }^{892}$ Cf. CANABRAVA, op. cit., 1997.
} 
contas pagas, cartas, material escolar de infância/adolescência, xerox etc ${ }^{893}$. Mas quando se trata de um historiador realizando esse procedimento, cabem algumas reflexões ${ }^{894}$.

No caso de Alice Canabrava a guarda de seus papéis parece estar ligada à uma gestão de sua correspondência vis a vis sua não-intencionalidade em que seus papéis fossem encaminhados à algum arquivo como explicitado em sua carta-testamento endereçada à sua irmã. Uma marca do arquivo privado de Georges Duby diz respeito ao fato de que somente sua correspondência profissional foi preservada, não havendo a presença de vestígios de suas relações pessoais e/ou familiares, marca de um historiador que, apesar de ter praticado história da vida privada, não expôs sua própria esfera privada, ao contrário, concebeu-a como refúgio ${ }^{895}$. Em contraste com o caso Duby, no Fundo Alice Piffer Canabrava temos a presença de correspondência endereçada à sua irmã e à sua mãe. Nesse sentido, o Fundo APC dá a entrever um sujeito muito além da profissão historiadora. Como afirmamos acima, Alice figura como historiadora, professora, irmã, amiga, colega, orientadora...

O fato de Alice ter determinado a destruição de seus papéis, pode denotar um outro sentido para seu autoarquivamento, para além de uma preocupação em forjar uma memória de si e sobre si para a posteridade. Por isso, faz-se mister que nos atentemos para o caráter social de seu arquivo ${ }^{896}$.

\footnotetext{
${ }^{893}$ As últimas reflexões de Philippe Artières sobre o procedimento de arquivar a própria vida nos inspiraram nessa reflexão. Ver: ARTIÈRES, Philippe. Arquivar-se: a propósito de certas práticas de autoarquivamento. In: TRAVANCAS; ROUCHOU; HEYMANN, op. cit., 2013, p. 45-54. O ato de arquivar-se é tomado como uma arte, onde não são os atos e acontecimentos da vida valorizados, mas sim o ato de arquivá-los.

${ }^{894}$ Felipe Brandi, ao tomar o arquivo pessoal do medievalista francês Georges Duby, enquanto fonte para sua tese de doutoramento acerca da prática historiográfica desse historiador, não deixa de refletir sobre esse arquivo enquanto objeto. Para tanto, ressalta a singularidade desse arquivo pessoal: é um arquivo pessoal de historiador. E aponta algumas questões para reflexão: "1) os arquivos de historiadores trazem o selo de atividade intelectual que se entregam, em contraste com o de especialistas de outras disciplinas? Ou, ainda: 2) por sua prática e seu longo contato com os arquivos, está o historiador mais aplicado na conservação de sua documentação privada?". BRANDI, Felipe. Arquivos privados e história dos historiadores: sobrevoo no acervo pessoal de Georges Duby. In: TRAVANCAS; ROUCHOU; HEYMANN, op. cit., 2013, p. 120. ${ }^{895}$ Idem, p. 101-130.

${ }^{896}$ Miguel Soares Palmeira empreende algumas reflexões sobre seu trabalho com os Finley Papers, arquivo pessoal do historiador estadunidense radicado em Cambridge, Moses I. Finley, a partir de um exercício de história intelectual que mobiliza essa documentação com o fito de perscrutar os textos publicados; o processo de consagração de um modelo de história antiga e a trajetória de Finley. Cf. PALMEIRA, Miguel Soares. Moses Finley e a "economia antiga": a produção social de uma inovação historiográfica. 2007. 214 f. Tese (Programa de Pós-Graduação em História Social), FFLCH/USP, 2007. Apesar de seu trabalho ser com o arquivo e não sobre o arquivo de Finley, um imperativo apontado pelo historiador diz respeito a se conhecer o arquivo com o qual se trabalha para não reproduzir o senso comum em relação à vida intelectual. Ademais, aponta para a necessidade de se tomar os arquivos pessoais em seu caráter social e extrair deles as devidas consequências, para além de um arquivamento da própria vida como forjamento de
} 
Alice não exerceu funções públicas; não escreveu em jornais; não se manifestou publicamente sobre questões nacionais. A noção clássica de intelectual não lhe cabe. Ela, para nós, é um dos primeiros frutos da profissionalização do ofício de historiador na Universidade. Canabrava é uma professora e pesquisadora strictu sensu. É uma acadêmica. Se posiciona politicamente apenas nas cartas aos seus amigos Francisco Iglésias e Antônio Emílio Muniz Barreto. Sua única aparição pública se dá nos anos 1980, quando é protagonista de uma reportagem em que é representada como "Professora do Delfim, do Pastore, do Viacava...", que ocupavam importantes postos na gestão da política econômica nacional. O caráter social de seu arquivo pessoal, portanto, se liga à estruturação de uma rede estritamente acadêmica de professores e pesquisadores de história, a APUH (depois de 1971, ANPUH), bem como ao IEB/USP e à FEA/USP. Seu arquivo permite vislumbrar os (des)caminhos pelos quais se estruturou a comunidade profissional de historiadores no Brasil ${ }^{897}$.

Do ponto de vista das práticas de arquivamento, no caso de Alice P. Canabrava, chama-nos a atenção o fato de que muitas das cartas remetidas possuem cópia em papel carbono. Qual a intenção de Alice ao adotar esse procedimento? A presença de cópias é mais intensa entre seus principais correspondentes: Francisco Iglésias, Maria Celestina Teixeira Mendes Torres, Antônio Emílio Muniz Barreto e Zélia Maria Cardoso de Mello. A primeira cópia de carta carbonada, constante na primeira doação, remetida por ela à Iglésias possui data inferida em 1981, (uma vez que a historiadora menciona que está aposentada, mas que continuará por mais um ano na FEA/USP para concluir sua pesquisa sobre escravidão financiada pela FINEP) e trata-se, na verdade, de um fragmento, pois se inicia na página três ${ }^{898}$. Podemos supor que as cópias das cartas remetidas à Iglésias a partir de 1981, sirvam para que Alice saiba a data da última carta escrita e também para

uma memória de si e sobre si. Cf. PALMEIRA, Miguel Soares. Arquivos pessoais e história da história: a propósito dos Finley Papers. In: TRAVANCAS; ROUCHOU; HEYMANN, op. cit., 2013, p. 80-99.

${ }^{897}$ Luciana Heymann analisa o caráter social do arquivo Darcy Ribeiro recebido pelo CPDOC/FGV a pedido da Fundação Darcy Ribeiro (Fundar). O arquivo pessoal de Darcy desvela seu papel de intelectual e de homem público. De "fazedor" como gostava de se referir à esta ação intelectual engajada, que se consubstanciou em participações nos dois governos de Leonel Brizola no RJ durante os anos 1980 e 1990 e também em suas funções de senador em Brasília. Sua atuação junto ao Serviço de Proteção ao Índio merece destaque, bem como a criação de instituições como o Museu Nacional do Îndio, a Universidade de Brasília e a Universidade Estadual do Norte Fluminense. Cf. HEYMANN, Luciana. Os fazimentos do arquivo Darcy Ribeiro: memória, acervo e legado. Estudos Históricos. Rio de Janeiro, n. 36, p. 43-58, 2005. Para uma abordagem etnográfico dos arquivos pessoais ver da mesma autora: HEYMANN, Luciana. Arquivos pessoais em perspectiva etnográfica. In: TRAVANCAS; ROUCHOU; HEYMANN, op. cit., 2013, p. 67-76.

${ }^{898}$ São Paulo, 1981. APC-CP-P1, 13(5). Fundo Alice Piffer Canabrava. Arquivo IEB/USP. 
cobrar a ausência do amigo, quando este demora a respondê-la. Os indícios indicam que ela desenvolveu um sistema de registro de correspondências em que anota a carta recebida e a resposta remetida. Deste sistema, deriva a necessidade de ter cópias das cartas remetidas.

Uma constante na correspondência com seus próximos é a cobrança em relação à ausência epistolar. Por exemplo, em cópia de carta carbonada com o logotipo da FEA/USP datada de 26 de setembro de 1983, Canabrava cobra notícias de Iglésias.

Cabe aqui o velho refrão: se Maomé não vai à montanha, a montanha vai à Maomé! Prometeu escrever-me, esvaiu-se o tempo, andei sondando a rua à espera do carteiro: nada. Tantos meses sem uma palavra sua, quando o longo silencio foi rompido por seu telefonema. E eu estava magoada, muito magoada. Pensei muitas vezes: será que meu amigo Iglésias - meu único amigo, nem sequer se interessa em saber o que me aconteceu? Será que nossa velha amizade se prende ao esquema convencional da carta que chega e resposta que vai? ${ }^{899}$.

Não é diferente em relação à sua amiga de graduação Maria Celestina Teixeira Mendes Torres. Em cópia carbonada de carta remetida em 26 de janeiro de 1986, Alice Canabrava queixa-se da ausência da amiga e a questiona sobre sua lide com a correspondência:

Há muito tempo não tenho cartas suas. Fico pensando porque não escreve. Seria que tem um registro de 'carta vem, resposta vai'? Se tem, não deveria ser assim. Escrever cartas é como conversar com amigas, à distância, um bate papo cordial, sempre bem-vindo, independentemente de ter sido provocado ou não $0^{900}$.

As cópias de cartas remetidas, além de ter a função de um sistema de registros das correspondências recebidas e de respostas enviadas, também funcionam para retomada de assuntos e para remissões. Em cópia de carta remetida a Antônio Emílio Muniz Barreto em 29 de dezembro de 1983, a historiadora dá notícias da equipe de história econômica da FEA/USP e remete Muniz Barreto à carta anterior:

O Nelson H. Nozoe passou brilhantemente no concurso de Doutorado: 10 com louvor, por unanimidade. Ele estava muito nervoso nos dias que antecederam à defesa, mas na hora, estava calmo, firme nas respostas. Eu fiquei muito contente. É mais um da equipe que avança na carreira.

Como lhe disse na carta anterior, Flávio se prepara para um ano em França, deverá partir em Fevereiro. Ibrahin está trabalhando com o Pastore, no Banco Central, em Brasília. Luna, na Secretaria da Fazenda, com o Sayad. Iraci, firme nas pesquisas. Tomás Aquino, pouco vejo.

\footnotetext{
${ }^{899}$ APC-Ca-P2, 13-(2). Fundo Alice Piffer Canabrava. Arquivo IEB/USP.
}

900 APC-TORR-006. Fundo Alice Piffer Canabrava. Arquivo IEB/USP. 
Zélia, trabalhando como sempre. E todos sempre sentindo falta de você [negrito nosso] ${ }^{901}$.

Por fim, o fato de parte da correspondência ativa de Alice Canabrava ter sido por ela copiada, facilita o trabalho do pesquisador, uma vez que, dentre seus principais correspondentes, somente parte do espólio de Francisco Iglésias se encontra em instituição de custódia, no caso, o Instituto Moreira Salles do Rio de Janeiro.

\subsection{Alice através do próximo}

Uma das constantes na troca epistolar entre Alice e Francisco Iglésias é a cobrança em relação à demora na resposta, afinal, uma das condições de possibilidade do diálogo epistolar, ou contrato epistolar, é a garantia da resposta e a regularidade da troca ${ }^{902}$.

Logo no início da relação epistolar Alice Canabrava não tergiversa e expõe seu desconforto em relação ao silêncio do novo missivista. "Meu pensamento nestes últimos tempos tem voado muitas vezes para Belo Horizonte e procurado devassar o grande silêncio que você fez, depois do seu cartão vindo de Congonhas do Campo" "903. A postura epistolar de Iglésias, decorridos mais de duas décadas de amizade, não é diferente diante do silêncio de Canabrava e de sua falta de resposta ao convite para publicar uma reunião de estudos na Coleção Estudos Brasileiros da editora Nova Fronteira, da qual Iglésias foi designado diretor: "V. não respondeu, eu fiquei no ar"904. Diante dessas demandas pela presença epistolar há escusas pela demora na escrita: "Desde que cheguei de SP que estou para escrever-lhe, mas fui adiando" 905 . E promessas de escrita: "Recebi suas cartas. Nos primeiros dias de março lhe escreverei longamente" 906.

\footnotetext{
${ }^{901}$ APC-Ca-P4, 15-(2). Fundo Alice Piffer Canabrava. Arquivo IEB/USP.

902 "Uma das qualidades fundamentais para que se estabeleça o comércio epistolar: a atenção e a capacidade de responder". HAROCHE-BOUZINAC, Geneviève. Escritas epistolares. São Paulo: EDUSP, 2016, p. 126-127. Angela de Castro Gomes define esse pacto epistolar através de uma relação de sociabilidade marcada pela intimidade. "A escrita epistolar é, portanto, uma prática eminentemente relacional e, no caso das cartas pessoais, um espaço de sociabilidade privilegiado para o estreitamento (ou o rompimento) de vínculos entre indivíduos e grupos. Isso ocorre em sentido duplo, tanto porque se confia ao "outro" uma série de informações e sentimentos íntimos, tanto porque cabe a quem lê, e não a quem escreve (o autor/editor), a decisão de preservar o registro. A ideia de pacto epistolar segue essa lógica, pois envolve receber, ler, responder e guardar cartas". GOMES, Angela de Castro. Escrita de si, escrita da história: a título de prólogo. In: ___ (org.). Escrita de si, escrita da história. Rio de Janeiro: FGV, 2004, p. 19.

${ }^{903}$ São Paulo, 14 de junho de 1954. FI-C-CP (062). Acervo Francisco Iglésias. IMS/RJ.

${ }^{904}$ Belo Horizonte, 31 de janeiro de 1978. APC-CP-P1, 12-(1). Fundo Alice Piffer Canabrava. Arquivo IEB/USP.

905 Belo Horizonte, 20 de junho de 1966. APC-CP-P1,2-(1). Fundo Alice Piffer Canabrava. Arquivo IEB/USP.

${ }^{906}$ São Paulo, 17 de fevereiro, 1956. FI-C-CP (063). Acervo Francisco Iglésias. IMS/RJ.
} 
Além da demanda em relação à regularidade da correspondência, que está implicada em um espaço-tempo particular da troca epistolar, ou seja, o remetente deve ter em perspectiva que escreve para o futuro, que seu destinatário receberá sua carta no futuro e este último deve ter consciência de que as notícias, afetos etc que recebe pertencem ao passado, há também a cobrança por visitas. Porém, apenas da parte de Alice. Dessa forma, busca romper com a condição de possibilidade da carta, qual seja, a ausência.

Veja como sou ingênua: fiquei pensando que, transitando por S. Paulo, a caminho de Marília, você não deixaria de vir dar uma prozinha comigo como prometera, num momento de distração em Franca. Soube que V. andou circulando por aqui, esteve na casa de Fulano e de Beltrano... Mas eu não estava na sua agenda. Havia guardado a cópia do artigo que me pediu para lhe entregar pessoalmente, mas sexta feira enviei-o pelo correio ${ }^{907}$.

O período em que encontramos esse tema nas cartas de Canabrava à Iglésias se estende de 1953, quando iniciam sua correspondência por carta, até 1982. Qual a razão para que ela necessite mais da presença de Iglésias para além daquela ilusão de presença forjada pela carta? A carta possui uma característica paradoxal: ao mesmo tempo em que quem escreve geralmente é porque está só, ela também mantém essa solidão ${ }^{908}$. Assim, pela anunciada timidez de Iglésias, esse evitaria contato tete-a-tete. Ou, simplesmente, como afirmado por Alice no excerto de carta acima, Iglésias tivesse outras sociabilidades a privilegiar naqueles momentos.

Essas cobranças e manifestações de afeto somente são possíveis em um contexto de trocas em que a amizade define a relação ${ }^{909}$. Em resposta da historiadora à carta de

\footnotetext{
${ }^{907}$ São Paulo, 01 de maio de 1966. FI-C-CP (088). Acervo Francisco Iglésias. IMS/RJ. Em diversas outras missivas Alice expressa o mesmo sentimento.

908 Giselle Martins Venâncio, a partir da correspondência trocada entre Machado de Assis e Oliveira Vianna, destaca um aspecto peculiar da sociabilidade de Vianna: alguém isolado, porém que recorria à correspondência para se inserir nas redes intelectuais de seu tempo. Exemplo dessa peculiaridade é o fato de que Lobato e ele nunca se conheceram pessoalmente. Cf. VENÂNCIO, Giselle Martins. Cartas de Lobato a Vianna: uma memória epistolar silenciada pela história. In: GOMES, Angela de Castro. Escrita de si, escrita da história. Rio de Janeiro: FGV, 2004, p. 111-137.

${ }^{909}$ A partir da tipologia construída por Michel Trebitsch podemos afirmar que o tipo de correspondência que define a relação entre Alice e Iglésias é a "amizade epistolar", uma vez que, além da troca de ideias e favores, há evocação intensa de sentimentos. Cf. TREBITSCH, Michel. Correspondances d'intelectuels: le cas de lettres d'Henri Lefebvre à Norbert Guterman (1935-1947). Les Cahiers de l'IHTP, n. 20, mars 1992. O primeiro tipo de correspondência sugerido pelo autor diz respeito à troca epistolar que permite traçar as redes de sociabilidade de um grupo. A própria amizade torna-se tópica da carta pelo fortalecimento da relação. "Quando uma amizade se fortalece com a regularidade da troca de cartas, torna-se ela própria um dos temas da correspondência. O ritmo desta, a importância que se lhe atribuirá, os assuntos que abordará são objeto de um pacto mais ou menos tácito". HAROCHE-BOUZINAC, op. cit., 2016, p. 125.
} 
Iglésias na qual esse último se mostra bastante sensível à crítica de seu trabalho pela amiga, essa agradece à confiança e afirma estar

[...] muitíssima comovida com sua carta que é, em essência, uma prova de quanto acredita em mim, do quanto confia em mim, do quanto mereço de você, e de quanto, todo este tesouro o levou a dizer-me espontaneamente o que sentia, sem reticências nem formalismos. Digolhe de novo: estou comovidíssima ${ }^{910}$.

Ainda na mesma carta, Alice pede para que o amigo sinta o "incidente" como elemento fortalecedor da amizade e que contribui para aumentar o mútuo conhecimento e ressalta uma importante característica definidora de sua concepção de amizade: a confiança.

O fato de que o tenha decepcionado, peço-lhe que o considere apenas episódico, sem significação maior para a estima que há tanto tempo nos une. Ela é feita de tantos elos comuns, de muito idealismo recíproco, de um grande lastro de confiança mutua. É tão difícil a gente poder sempre pensar em voz alta, com respeito a um amigo, como penso em você. Peço-lhe que considere o incidente apenas como uma experiência que nos levou a nos conhecermos melhor ${ }^{911}$.

Francisco Iglésias foi convidado para apresentar trabalho sobre a "Natureza e ideologia do colonialismo no século XIX" no IV Simpósio da APUH ocorrido em Porto Alegre/RS em 1967. Em carta de 25 de março de 1967, Iglésias relata à Canabrava uma série de preocupações em relação a seu texto, principalmente por conta da grande envergadura do tema e solicita a opinião da amiga. "Tinha intenção de ir na Semana Santa a São Paulo, depois não pude: se tivesse ido, levava o texto para V. ver, que ando um pouco angustiado com ele. Para que tenha uma ideia do que fiz, vou dar a síntese, com os subtítulos que apresenta"912. Após comentar que não respondeu sua carta de 11 de fevereiro pelo fato de que ficou sabendo pelo "Dr. Sérgio" que viria na Semana Santa, Alice Canabrava reforça o substrato de sua concepção de amizade.

Você me comove profundamente com a sua confiança, antecipando para mim o seu esquema e falando-me de suas atividades e de seus temores. Dói-me a sua angustia, tanto mais que eu a creio em grande parte infundada, resultante em grande parte de seu grande sentido de responsabilidade ${ }^{913}$.

\footnotetext{
${ }^{910}$ São Paulo, 17 de junho de 1967. FI-C-CP (078). Acervo Francisco Iglésias. IMS/RJ.

911 São Paulo, 17 de junho de 1967. FI-C-CP (078). Acervo Francisco Iglésias. IMS/RJ.

912 Belo Horizonte, 25 de março de 1967. APC-CP-P1,4-(1). Fundo Alice Piffer Canabrava. Arquivo IEB/USP.

${ }^{913}$ São Paulo, 02 de abril de 1967. FI-C-CP (076). Acervo Francisco Iglésias. IMS/RJ.
} 
Após receber e analisar o texto enviado por Iglésias, a historiadora estabelece outra qualidade para esse ethos da amizade: a sinceridade. "Pode ficar tranqüilo, não estou fazendo concessões em nome da nossa amizade, mas sendo sincera, que é a única atitude para com um amigo"914.

$\mathrm{Na}$ correspondência entre ambos, tornou-se prática o envio de textos de Iglésias para avaliação de Alice. Em 4 de março de 1982, afirmando tratar-se de "bilhete", Iglésias envia texto que irá apresentar no CNPq sobre a situação da história no Brasil. "Pediria a V. o favor de lê-lo, com as sugestões que tem a dar, para possível acréscimo, ou corte" ${ }^{915}$. Em pronta resposta, Canabrava afirma que

Li de um só folego o seu trabalho e gostei muito, e agradeço-lhe a confiança em tê-lo enviado a mim e pedir minha opinião. Apreciei enormemente o seu estilo limpo, fluente, agradável, a dizer coisas muito importantes de modo simples e claro. Achei excelente a síntese, que não é muito fácil ${ }^{916}$.

A historiadora novamente reitera a confiança como elemento básico da relação de amizade e destaca a síntese como qualidade na escrita do amigo. Por vezes, ela dá sua impressão sobre o trabalho de Iglésias mesmo sem sua solicitação, o que pode ser tomado como característica de uma amizade aprofundada e fundada em íntimos afetos. Alice Canabrava, ao ler o artigo de Iglésias "Nova versão da história do Brasil" publicado no suplemento literário de $O$ Estado de $S$. Paulo afirma que

Gosto sempre do que V. escreve, o estilo ameno, e a capacidade de captar o que de fato é essencial. Mas além disso, o que caracteriza sempre seus trabalhos e me parece extremamente enriquecedor é a larga perspectiva na qual coloca o assunto, o que só é possível a alguém que muito leu e muito assimilou. O artigo é um modelo no gênero ${ }^{917}$.

Mais uma vez destaca como característica da escrita de Iglésias e como sua maior qualidade a síntese. Este vai e vem de impressões e avaliações historiográficas permite que o próximo tenha um tipo de troca intelectual diferenciada das trocas públicas, em seminários e congressos, por exemplo, uma vez que, no caso de Alice, a sinceridade seria

\footnotetext{
${ }^{914}$ São Paulo, 17 de junho de 1967. FI-C-CP (078). Fundo Alice Piffer Canabrava. Arquivo IEB/USP.

915 Belo Horizonte, 4 de março de 1982. APC-CP-P2, 6-(1). Fundo Alice Piffer Canabrava. Arquivo IEB/USP.

${ }^{916}$ Cópia carbonada. São Paulo, 10 de março de 1982. APC-Ca-P2, 7-(3). Fundo Alice Piffer Canabrava. Arquivo IEB/USP.

917 Cópia. São Paulo, 21 de maio de 1985. APC-Ca-P2, 19-(3). Fundo Alice Piffer Canabrava. Arquivo IEB/USP.
} 
o crivo dessa troca. Assim, podemos perceber nessas trocas entre ambos uma relação de amizade que implica em um "método de trabalho historiográfico" 918.

Mesmo pautada na confiança e na sinceridade, as fissuras típicas a qualquer relação de amizade apresentam, nesse caso, um trânsito de afetos duplo. Alice se decepciona, uma vez que a expectativa que retroalimenta essa amizade, a confiança, é quebrada, no momento em que a notícia de que Iglésias não iria assumir a cadeira de História da Civilização Brasileira da FFCL/USP por conta da aposentadoria de Sérgio Buarque de Holanda, não provém do amigo.

Não me leve a mal falar-lhe com franqueza sobre o que me pareceu quebra sua em relação à amizade e admiração pessoal que tenho para com você. Minha sensibilidade e lealdade para com você me impelem a isso. Mas quero esclarecer bem: fiquei sentida por não ter comunicado a mim a sua decisão. $\mathrm{O}$ fato de ter mudado de ideia e as razões que o levaram a essa atitude são assunto seu. Não peço para me responder, mas espero o seu cartão de natal que me prometeu ${ }^{919}$.

Alice parece mais à vontade para expressar seus afetos por carta do que pessoalmente, o que nos coloca diante da seguinte questão: “[...] o que se diz numa correspondência e o que não se poderia dizer em outro lugar?" ${ }^{920}$. Nesse caso, a mágoa encontra lugar de expressão através da carta.

Que aconteceu? Não consegui entender a sua atitude na quarta feira, monossilábico ou calado, a olhar deliberadamente para frente ou para o lado, ao almoço, deixando-me sem resposta quando me dirigia a $\mathrm{V}$. Uma agressividade velada, ou pelo menos no limite dela, que me pareceu muito estranha. Fiquei desolada ${ }^{921}$.

A demonstração de amizade de Canabrava por Iglésias passava pela dedicatória de livros. Em carta de 16 de janeiro de 1984, Iglésias comenta que, ao chegar do Rio de Janeiro, se deparou com a missiva da amiga que o encheu de alegria. Ademais, afirma que ficou satisfeito em saber que ela prepara o prefácio de "Licenças para as Minas" e que dedicará o livro ao amigo. "Muito obrigado, Alice. Esta homenagem está entre as

\footnotetext{
${ }^{918}$ ALBUQUERQUE JÚNIOR, Durval Muniz de. Íntimas histórias: a amizade como método de trabalho historiográfico". In: _. História: a arte de inventar o passado. Ensaios de teoria da história. Bauru: Edusc, 2007, p. 211-217. Nesse texto em homenagem a seu orientador, Alcir Lenharo, Durval Muniz de Albuquerque Júnior define o amigo. "O amigo é aquele que faz o outro alçar voos para fora de si mesmo, aquele que faz o outro na busca de si encontrar o entre-si. O amigo marca, ocupa, é atuante. Ele forma e transforma no exercício da amizade".

${ }^{919}$ São Paulo, 11 de dezembro de 1966. FI-C-CP (075). Acervo Francisco Iglésias. IMS/RJ.

${ }^{920}$ HAROUCHE-BOUZINAC, op. cit., 2016, p. 13.

${ }^{921}$ Cópia. São Paulo 10 de fevereiro de 1985. APC-Ca-P2, 18-(1). Fundo Alice Piffer Canabrava. Arquivo IEB/USP.
} 
mais altas que já recebi; devo mesmo dizer que é a mais alta, pois nosso convívio não foi amplo. Em algumas conversas e muitas cartas estabelecemos amizade que está entre o que tenho de mais precioso"922. Outro selo de amizade pública, temos na orelha do livro "O Comércio português no Rio da Prata (1580-1640)"923 escrita por Iglésias. "E devo também lhe falar da orelha, que também é obra sua, tanto trabalho e generosidade para com esta sua amiga!"924.

O corpo se manifesta na correspondência entre os dois missivistas, principalmente em relação a notícias sobre saúde ${ }^{925}$. Em carta de 3 de fevereiro de 1979 Iglésias justifica sua ausência epistolar. "De fato, há muito estava para escrever-lhe. Se não o fiz nem mandei o cartão de Natal - recebi o seu - é que estive doente. Em novembro - dia 11 fui vítima de um problema coronário: nada mais nada menos que um enfarte do miocárdio"926. Na carta seguinte, após comentar que está em falta com Alice, passa em revista seu estado de saúde: "Devo dizer-lhe que estou em processo de restabelecimento. Segundo os médicos, vou bem. Não sinto nada que me perturbe, a não ser algumas eventuais crises de desânimo"927. Após o mencionado enfarte, referências à sua saúde se tornaram uma constante na troca epistolar, uma vez que o missivista vê a si mesmo como

\footnotetext{
${ }^{922}$ Belo Horizonte, 16 de janeiro de 1984. APC-CP-P2, 15-(2). Fundo Alice Piffer Canabrava. Arquivo IEB/USP.

${ }^{923}$ CANABRAVA, Alice Piffer. O comércio português no Rio da Prata (1580-1640). Belo Horizonte: Editora Itatiaia/São Paulo: EDUSP, 1984. O livro é dedicado à memória de sua mãe.

${ }^{224}$ Cópia. São Paulo, 01 de julho de 1984. APC-Ca-P2, 16-(2). Fundo Alice Piffer Canabrava. Arquivo IEB/USP. Através das cartas podemos acompanhar a longa história da publicação dessa tese em livro. Em um primeiro momento, o texto deveria sair pela editora Nova Fronteira sob o selo da Coleção Estudos Brasileiros, coordenada por Iglésias. Porém, diante da crise financeira enfrentada pela editora, os amigos mudaram a estratégia de publicação da obra e passaram a negociar junto à editora Itatiaia e à EDUSP. Alice e Iglésias conseguiram ver a edição publicada. Porém, não da maneira que os dois gostariam. A ideia original era que a edição fosse publicada com a resenha de autoria de Fernand Braudel publicada nos Annales em 1946, no lugar do prefácio escrito por Afonso Taunay quando da publicação da tese no "Boletim da Cadeira de História da Civilização Americana" em 1944. Ademais, deveria também figurar uma nota da autora quanto ao momento da publicação da tese. O que aconteceu foi que a publicação da tese em livro manteve o mesmo formato da publicação de 1944.

${ }^{925}$ Essa relação de amizade também comporta o efeito quase físico da presença e do cuidado de si. Maria Helena Werneck analisa os cuidados de si na correspondência entre Machado de Assis e Mário de Alencar. Ver: WERNECK, Maria Helena. "Veja como ando grego, meu amigo." Os cuidados de si na correspondência machadiana. In: GALVÃO, Walnice Nogueira; GOTLIB, Nádia Battella (orgas.). Prezado senhor, prezada senhora: estudos sobre cartas. São Paulo: Companhia das Letras, 2000, p. 137-145. Michel Foucault aproxima este vai e vem epistolar dos hypomnemata dos antigos na medida em que "[...] A carta enviada actua [sic], em virtude do próprio gesto da escrita, sobre aquele que a envia, assim como actua [sic], pela leitura e a releitura sobre aquele que a recebe". FOUCAULT, Michel. A escrita de si. In: O que é um autor? $2^{\mathrm{a}}$ edição. Lisboa: Veja/Passagens, 1992, p. 145.

${ }_{926}$ Belo Horizonte, 03 de fevereiro de 1979. APC-CP-P1,17-(1). Fundo Alice Piffer Canabrava. Arquivo IEB/USP.

${ }_{927}$ Belo Horizonte, 19 de abril de 1979. APC-CP-P1,18-(1). Fundo Alice Piffer Canabrava. Arquivo IEB/USP.
} 
hipocondríaco. "V. sabe que eu já era um pouco hipocondríaco, agora naturalmente sou bem mais" $" 928$.

A esfera corporal de Alice aparece com menos frequência nas trocas epistolares do que a de seus amigos - por vezes, ela também manifesta preocupação em relação à saúde de sua mãe ${ }^{929}$ e de seu irmão adotivo. Porém, não está ausente. Em carta com data estipulada em 26 de julho de 1981 em retorno da ANPUH ocorrida em João Pessoa/PB, afirma que quando aterrissou em São Paulo o frio era tão intenso que resultou em um resfriado. "Apanhei uma gripe que durou 15 dias, com ritmos alternados e melhora e recrudescência, até desaparecer de vez"930. Em outra, comenta largamente sobre seu estado de saúde a ponto de pedir perdão ao amigo por "falar" tanto sobre doença. Canabrava, após relembrar Iglésias de seu acidente que resultou em queda em asfalto molhado, comenta que o fato de ficar dois meses sem poder utilizar sua máquina de escrever deixou-a deprimida. "Sinto-me aliviada e não imagina a satisfação em ouvir de novo o tamborilar do teclado da máquina de escrever, de voltar de novo aos papéis. Durante estes dois meses de tratamento, vivia sempre muito deprimida [...]"931.

Além da Alice enquanto amiga forjada na relação com esse próximo, Iglésias constrói uma imagem de Alice historiadora. Essa imagem de si pelo próximo se constrói através da avaliação da produção historiográfica da amiga somada à um horizonte de expectativas de outra produção em espera. Em carta de 28 de junho de 1960, Francisco Iglésias, após comentar que está terminando a leitura do primeiro volume da "História Geral da Civilização Brasileira" e que a mesma estaria aquém da monumental edição francesa, afirma que espera que o segundo volume tenha mais qualidade. "Ele terá, estou certo, pois há, entre outras, colaboração sua (não há?)"932. Uma década depois, Iglésias

\footnotetext{
${ }^{928}$ Belo Horizonte, 03 de fevereiro de 1979. APC-CP-P1,17-(1). Fundo Alice Piffer Canabrava. Arquivo IEB/USP.

${ }^{929}$ Em carta à Francisco Iglésias, Alice descreve minuciosamente a condição de saúde de sua mãe e seus temores despertados por um horizonte de expectativa cujo limite é a morte. São Paulo, 17 de junho de 1967. FI-C-CP (078). Acervo Francisco Iglésias. IMS/RJ.

${ }_{930}$ APC-CP-P1,24-(6).

${ }^{931}$ Cópia. São Paulo, 21 de maio de 1985. APC-CA-P2, 19-(3), p. 2. Fundo Alice Piffer Canabrava. Arquivo IEB/USP.

932 Belo Horizonte, 28 de junho de 1960. APC-CP-P1, 1-(1). Fundo Alice Piffer Canabrava. Arquivo IEB/USP. Esta não é a única vez em que Francisco Iglésias comenta uma obra com Alice. Nessa troca epistolar encontramos toda uma biblioteca lida e comentada pelos missivistas. A partir da correspondência trocada entre Gilberto Freyre e Oliveira Lima, Angela de Castro Gomes traça uma rede de relações intelectuais e práticas de leitura que permitem vislumbrar uma biblioteca comum. Ver: GOMES, Angela de Castro. Em família: a correspondência entre Oliveira Lima e Gilberto Freyre. In: GOMES, op. cit., 2004, p. 51-75.
} 
comenta que irá ler o segundo texto da historiadora publicado na "História Geral da Civilização Brasileira" e, diante dos trabalhos anunciados por ela - seus trabalhos nos quais mobiliza o aparato metodológico da história quantitativa - sugere que a amiga publique estes estudos em livro.

Acho que V. devia reunir o que escreveu aí e mais os dois estudos a que fez referência - feitos para o IPE - e fazer um livro. Há muito não aparece nada de valor excepcional. O seu deve ser. Longe da historiografia rançosa e convencional, que cada dia se torna mais volumosa, e de certa sofisticação de cientista social que não conduz a grande coisa - a sofisticação pela sofisticação, o gosto do numero, de gráfico, de variáveis, de funções, que se esgotam em si mesmos, não são feitos para expressar uma realidade viva, mas para provar que o autor é moderno e cientista. Enfim, assunto de conversa, não de carta. Quero só dizer-lhe que urge a publicação de seu livro ${ }^{933}$.

No excerto acima, Iglésias erige a produção historiográfica de Alice Piffer Canabrava à um lugar de distinção: distante de uma produção vinculada às ciências sociais, em particular à economia e aos modelos econométricos de alta sofisticação e de uma historiografia tradicional. Se Canabrava, como vimos, expressava seus afetos em relação à espera de cartas de Iglésias, aqui temos o caso de uma espera intelectual. "Aguardo com ansiedade o seu livro: que será, como já disse, uma obra nova, revolucionária na historiografia brasileira: não o simples modismo, a adoção infantil de novas técnicas, mas sua absorção a serviço de um verdadeiro saber"934. Para Iglésias, Alice seria capaz de revolucionar a historiografia brasileira ao adotar a história quantitativa, não como "modismo", mas sim como técnica que permite esclarecer problema histórico.

Espero que V. tenha avançado no livro que promete, espero que o publique em 75. Sei que vai ser um marco na bibliografia, que é a primeira vez que alguém usa metodologia sofisticada com bom conhecimento de História e para esclarecer de fato problema de História. Não o deixe de lado Alice. Só V. pode dar esse passo na bibliografia nativa ${ }^{935}$.

\footnotetext{
${ }_{933}$ Belo Horizonte, 24 de março de 1972. APC-CP-P1, 7-(1). Fundo Alice Piffer Canabrava. Arquivo IEB/USP.

${ }^{934}$ Belo Horizonte, 18 de agosto de 1974. APC-CP-P1, 8-(2). Fundo Alice Piffer Canabrava. Arquivo IEB/USP. 
Após se queixar de que a amiga não tem escrito e que soube, através de José Francisco de Camargo ${ }^{936}$, que suas pesquisas vão a todo vapor com passagens pelo Rio de Janeiro e pela Bahia, afirma:

Fico feliz, pois vejo que seus planos de trabalho prosseguem em ritmo acelerado. Já estou vendo a próxima publicação do seu esperado livro. Torço para que tal aconteça, de modo a sacudir esse marasmo que é a chamada historiografia brasileira, que se compraz em fazer estudos sobre si mesma, em levantamentos de problemas, em questões de método, sem outras realizações. [...] Estou ansioso pelos seus escritos, Alice: enquanto os novos críticos, que se supõe descobridores do mundo, se consomem em pregações ou obras menores, V. no silêncio e sem anunciar que vai fundar a historiografia brasileira produz em nível em que eles não se colocarão jamais ${ }^{937}$.

A espera de Iglésias continuará, passando por 1978, 1980 e 1987, em uma história intelectual da espera ${ }^{938}$ marcada pela não realização de um projeto.

[...] Espero agora, para quando puder, o novo livro com a reunião de seus últimos estudos. Acho que fica bem, aí, o que já publicou na História, sob a direção de Sérgio Buarque de Holanda. Seus textos são sempre bons, o que apareceu aí é de magnífica qualidade. Quanto ao códice sobre as entradas nas Minas, a que V. se refere, fico entusiasmado com a matéria: umas duzentas páginas, V. diz, com introdução de sua autoria. Quem sabe pode publicar na "Revista do Arquivo Público Mineiro"? A Revista reapareceu, já publicou quatro números. Com esse material talvez se possa organizar um volume. Que tal lhe parece? Pense no assunto ${ }^{939}$.

Em carta de 25 de janeiro de 1980, o amigo apressa Alice. "Fale-me de V.. Em que pé está seu livro? Publique logo, será um marco na bibliografia"940. Sete anos depois

\footnotetext{
${ }^{936}$ As cartas trocadas entre os missivistas também permitiriam traçar uma rede de sociabilidades, uma vez que vários intelectuais são assunto de suas cartas entre eles Sérgio Buarque de Holanda e Barradas de Carvalho. Lúcia Maria Paschoal Guimarães e Valdei Lopes de Araújo analisaram as redes intelectuais formadas entre Jonh Casper Branner e intelectuais brasileiros. Ver: ARAÚJO, Valdei Lopes de; GUIMARÃES, Lúcia Maria Paschoal. O sistema intelectual brasileiro na correspondência passiva de Jonh Casper Branner. In: GOMES, op. cit., 2004, p. 93-109.

937 Belo Horizonte, 23 de março de 1975. APC-CP-P1, 10-(3). Fundo Alice Piffer Canabrava. Arquivo IEB/USP.

${ }^{938}$ Laurent Vidal reflete sobre as implicações temporais e espaciais do deslocamento de uma fortaleza militar, Mazagão, fundada por portugueses no século XVI no Marrocos. Em 1769 a cidade e seus 2 mil habitantes estão cercados por mais de 120 mil soldados mouros. Portugal desloca a cidade para Lisboa e, após seis meses, para Belém, na Amazônia. Foi necessário ainda uma longa espera para que Mazagão Novo fosse instalada. $\mathrm{O}$ autor formula a noção de uma história social da espera para refletir acerca dos significados dos movimentos, expectativas e esperas sobre determinada comunidade. Cf. VIDAL, Laurent. Mazagão, a cidade que atravessou o Atlântico: do Marrocos à Amazônia (1769-1783). São Paulo: Martins Fontes, 2008.

939 Belo Horizonte, 26 de abril de 1978. APC-CP-P1,16(2). Fundo Alice Piffer Canabrava. Arquivo IEB/USP.

940 Belo Horizonte, 25 de janeiro de 1980. APC-CP-P1,19-(1). Fundo Alice Piffer Canabrava. Arquivo IEB/USP.
} 
Iglésias ainda espera os estudos de Canabrava sobre a economia de São Paulo. "Como andam seus trabalhos? Em que pé está o livro sobre São Paulo do século XVII? Desconfio que pronto, esperando só um arranjo final. Por que ainda não o fez?"941.

A espera de Iglésias se torna publica na orelha do livro que resultou da publicação da tese de doutoramento da historiadora em livro. Após demarcar a qualidade de sua produção de estreia e posterior como sinal dos dotes de um "autêntico" historiador, Iglésias anuncia uma produção em espera. "Deve aparecer em breve um livro que aproveita amplas pesquisas, com esmerada técnica de elaboração. Será um dos títulos mais notáveis da historiografia econômica, que tem em Alice Canabrava um de seus maiores nomes" 942 .

Tanto o livro reunindo os dois textos publicados na "História Geral da Civilização Brasileira" e os estudos sobre as formas da riqueza em São Paulo com o apoio na história quantitativa quanto o códice acima referido nunca foram publicados. Se somarmos a esses, o livro "Licenças para as Minas" referido acima, são três projetos intelectuais em espera e não concluídos. Pensamos aqui em uma história intelectual da espera que inventariasse todo o vai e vem de elaboração de um texto até sua publicação ou malogro, considerando problemas metodológicos, de acesso a fontes, à editores etc.

Em nenhum momento a espera de Iglésias se transformou em outro sentimento e significado que não o da historiadora que poderia dar um salto qualitativo na historiografia brasileira. Alice se reconhecia nessa imagem forjada por Iglésias também de uma intérprete do Brasil ao lado de Sérgio Buarque de Holanda e Gilberto Freyre - no capítulo 1 expusemos como ela forja uma interpretação de Brasil a partir de São Paulo.

Agradeço-lhe também a ideia de escrever um artigo sobre meus trabalhos. Barradas de Carvalho falou-me mais de uma vez que tinha em mente escrever um ensaio sobre Gilberto Freyre, Sérgio Buarque e eu. Dizia-me que era questão de dispor de tempo, porque já tinha pensado o que iria escrever ${ }^{943}$.

As trocas epistolares entre Alice Canabrava e esse próximo, Francisco Iglésias, nos trazem uma construção de Alice como amiga em um ethos que privilegia a confiança

\footnotetext{
${ }^{941}$ Belo Horizonte, 21 de junho de 1987. APC-CP-P2, 26-(1). Fundo Alice Piffer Canabrava. Arquivo IEB/USP.

${ }^{942}$ Orelha de livro. In: CANABRAVA, Alice Piffer. O comércio português no Rio da Prata (1580-1640). Belo Horizonte: Editora Itatiaia/São Paulo: EDUSP, 1984.

${ }^{943}$ São Paulo, 31 de dezembro de 1981, p. 3. APC-CP-P1, 28-(4). Fundo Alice Piffer Canabrava. Arquivo IEB/USP.
} 
e a sinceridade na troca de afetos. Há também uma dimensão nas trocas intelectuais entre ambos que eleva Canabrava à um grau superior, tanto na avaliação dos textos do amigo, como na imagem da historiadora que revolucionaria a historiografia brasileira.

As cartas trocadas entre Alice P. Canabrava e Maria Celestina Teixeira Mendes Torres, sua colega de graduação, apontam para uma relação afetiva cujo foco é a amizade $^{944}$. Essa intimidade permite a cobrança em relação à ausência epistolar, uma constante em vários momentos dessa troca. Em carta de 3 de abril de 1985, Alice cobra a ausência da amiga e se questiona se estaria preparando seu enxoval ou o de sua irmã. "Que acontece que não me escreve mais? Fico pensando que anda muito ocupada com o enxoval de Marília, para as novas núpcias (ou já se realizaram?). Mas não descarto a hipótese de que esteja preparando o seu próprio, para suas segundas núpcias"945. Diante da ausência de resposta da amiga em relação à várias cartas, Maria Celestina também expressa seus sentimentos em relação à ausência epistolar de Canabrava. "Esta é a segunda ou terceira carta que lhe escrevo, sem resposta. Penso, às vezes, que V. não mora mais em S. Paulo. Mas não acredito que V. se mudasse sem ao menos um adeus!"946.

Outra quase presença na troca epistolar das amigas é o corpo na forma de notícias sobre saúde. Porém, somente provenientes de Maria Celestina.

Fiquei algum tempo sem poder escrever e só lia com muita dificuldade. A catarata do olho direito não me dava chance. Por causa dela, indo a Campinas visitar Tonzé, ia levando um tombo ao sair do ônibus. Se não fosse o motorista teria quebrado a cabeça no para-brisa. Mas ele me segurou com tanta força que quebrou meu braço! $!^{947}$.

A grande conversação ${ }^{948}$ entre as amigas se dá através de uma memória compartilhada em torno de seus tempos de graduação em Geografia e História na

\footnotetext{
${ }^{944}$ Assim como na relação com Francisco Iglésias, aqui encontramos uma biblioteca comum lida pelas amigas que se consubstancia na troca de livros. Ver: APC-TORR-001; APC-TORR-002. Fundo Alice Piffer Canabrava. Arquivo IEB/USP.

${ }^{945}$ São Paulo, 03 de abril de 1985. APC-TORR-018. Fundo Alice Piffer Canabrava. Arquivo IEB/USP.

${ }^{946}$ Piracicaba, 09 de dezembro de 1991. APC-TORR-016. Fundo Alice Piffer Canabrava. Arquivo IEB/USP. Há ainda três cartas nas quais encontramos o sentimento de ausência epistolar: São Paulo, 26 de janeiro de 1986. APC-TORR-006; Piracicaba, 04 de março de 1987. APC-TORR-007; Piracicaba, 02 de março de 1988. APC-TORR-011.

947 Piracicaba, 04 de março de 1987. APC-TORR-007. Fundo Alice Piffer Canabrava. Arquivo IEB/USP. Há outra carta na qual Maria Celestina trata da saúde de sua irmã: Piracicaba, 02 de março de 1988. APCTORR-011.

948 A carta enquanto conversação está presente em: DIAZ, Brigitte. Por uma breve história da carta. In: O gênero epistolar ou o pensamento nômade: formas e funções da correspondência em alguns percursos de escritores no século XIX. São Paulo: EDUSP, 2016, p. 11-70.
} 
FFCL/USP ${ }^{949}$. Em carta de 10 de novembro de 1987, Maria Celestina expressa sua saudade daquele tempo. "Tenho saudades daquele tempo, Alice. Com todas as horas tomadas pelos estudos, a gente era feliz!"950. Em resposta de carta da amiga na qual rememora os professores Monbeig, Braudel e Gagé $e^{951}$, Maria Celestina evoca o tema da saudade para expressar a relação com esse passado comum. "V. pode avaliar a onda de saudade que me atingiu. Bons tempos, dias felizes, cheios de sonho e de esperanças"952.

Para Maria Celestina, a carta não basta para imitar a presença da amiga. Após cobrar uma visita para lembrarem os tempos da FFCL/USP, rememora a impressão de Braudel sobre elas e o quanto os estudos privou-a do convívio com seu noivo. "Daquele tempo, só lamento não ter sabido "sugar" o Braudel e o Monbeig. Afinal, acho que eles nos consideravam boas alunas, embora o Braudel me achasse preguiçosa. Se ele soubesse que o grande sacrificado daquela época foi o Nelson...." ${ }^{953}$. Em carta de 09 de dezembro de 1991, Maria Celestina comenta que encontrou uma carta de Canabrava na qual comenta sobre Fernand Braudel e o quanto, mais uma vez, essa encheu-a de saudade.

Que saudade tive daquele tempo, Alice. Fomos felizes, estudando desesperadamente. Acho que V. era a mais estudiosa e, como dizia o Braudel, eu era a mais preguiçosa. Mas não era preguiça, Alice. Afinal eu tinha meus compromissos e Nelson foi o noivo mais abandonado e mais paciente do mundo. Acho que tudo isso era mesmo o grande amor que nos uniu ${ }^{954}$.

Guiados pela memória de Maria Celestina, Braudel, dentre as mulheres da turma de 1935, considerava nossa historiadora a mais estudiosa e sua amiga a mais "preguiçosa". Maria Celestina atribui seu não tão alto desempenho a seu noivado. Ela está entre aquelas primeiras mulheres da FFCL/USP que se viram divididas entre escolher a carreira acadêmica e a vida doméstica, uma vez que ambas se apresentavam naquele momento como irreconciliáveis. Alice, por seu turno, está entre aquelas que escolheram por uma dedicação plena e total à vida acadêmica, o que implicou a suspensão de alguns

\footnotetext{
949 Antonio Paulo Rezende, a partir do diário de Gilberto Freyre, analisa como este empreende uma conversação com suas memórias na invenção de um eu. Cf. REZENDE, Antonio Paulo. Freyre: as travessias de um diário e as expectativas da volta. In: GOMES, op. cit., 2004, p. 77-91.

950 Piracicaba, 10 de novembro de 1987. APC-TORR-010. Fundo Alice Piffer Canabrava. Arquivo IEB/USP.

${ }_{951}$ São Paulo, 21 de agosto de 1987. APC-TORR-008. Fundo Alice Piffer Canabrava. Arquivo IEB/USP.

952 Piracicaba, 25 de junho de 1988. APC-TORR-012. Fundo Alice Piffer Canabrava. Arquivo IEB/USP.

953 Piracicaba, 27 de agosto de 1988. APC-TORR-014, p. 4. Fundo Alice Piffer Canabrava. Arquivo IEB/USP.

${ }_{954}$ Piracicaba, 09 de dezembro de 1991. APC-TORR-016. Fundo Alice Piffer Canabrava. Arquivo IEB/USP.
} 
afetos, como o casamento e a maternidade, por exemplo. Não temos indício na correspondência de Canabrava, mesmo considerando as cartas trocadas entre ela e sua irmã Clementina, de que tenha estabelecido relação de namoro.

A imagem construída de Alice através das memórias desse próximo é de uma amiga cujo eu se prende à um lugar de memória específico: a FFCL/USP. Ademais, um sujeito extremamente dedicado aos estudos.

Se nas trocas epistolares entre Alice Canabrava e Francisco Iglésias os dois gozavam de semelhante hierarquia acadêmica, nas trocas entre a historiadora e seu segundo principal correspondente, seu ex-orientando, Antonio Emílio Muniz Barreto, a relação possui um certo grau de hierarquização, tendendo à uma relação discipular. Em carta de 27 de janeiro de 1972, Muniz Barreto agradece os anos que trabalhou junto com Alice e afirma que os mesmos foram importantes, não somente em sua formação profissional, mas também humana. “Os 5 anos que passei lecionando junto com a Sra foram anos que marcaram profundamente a minha formação. Não só no campo ou no plano dos estudos mas também toda uma série de coisas no exemplo pessoal e humano"955.

Em carta de 26 de dezembro de 1977, Muniz Barreto expressa seu sentimento de gratidão pela orientadora, uma vez que entende que sem sua influência não teria alcançado a livre-docência.

Faz dias que queria escrever pois este ano foi bastante complexo e marcante para mim, talvez um divisor de águas na minha vida, e disso mais uma vez eu tenho que agradecer à Sra. Eu não sei, mas embora aparentemente não tenha muita importância, mas a livre-docência é passo extremamente importante na vida universitária e intelectual pela segurança que dá. E certamente sem a influência da Sra não sei até que ponto eu teria condições de fazê-lo, portanto agora que posso pensar com calma no realizado é que quero lhe manifestar minha extrema gratidão, tanto pelo estímulo como pelo exemplo ${ }^{956}$.

A historiadora reforçava esse vínculo discipular, porém perpassando-o pelo crivo de um afeto quase materno. Em carta de 26 de outubro de 1983, ela relata a condição de cada membro da equipe de história da FEA/USP, se mostra sensibilizada com a situação de Ibrahin João Elias, uma vez que esse não teve seu contrato renovado, fruto, para ela,

\footnotetext{
955 Buenos Aires, 27 de janeiro de 1972. APC-CP-P4, 4-(4). Fundo Alice Piffer Canabrava. Arquivo IEB/USP.

${ }^{956}$ El Callejón, 26 de dezembro de 1977. APC-CP-P4, 6-(3). Fundo Alice Piffer Canabrava. Arquivo IEB/USP. A última carta escrita por Muniz Barreto antes desta foi em 10/08/73.
} 
do despontar de antigas "richas" e do fato de aquele não ter defendido nenhum título desde seu ingresso na equipe. Após afirmar que o mesmo aguarda convocação do ministro da Fazenda enquanto trabalha com Afonso Celso Pastore em seu escritório, revela que: "Tive a impressão de que mais um "filho" havia partido para mares estranhos"957.

O fato de Muniz Barreto ter que cuidar dos negócios da família em Buenos Aires o afastou da FEA/USP. Aliás, esse afastamento gerou a condição de possibilidade dessa troca epistolar ${ }^{958}$. Em carta de 10 de setembro de 1982, após afirmar que esse afastamento o causou intenso sofrimento, sente por não ter correspondido à mestra, à matriarca da equipe de história.

Professora Alice agradeci muito e fiquei emocionado com a sua carta. Pena que a minha passagem pela Faculdade não correspondeu às suas expectativas, nem às minhas, mas toda uma série de fatores alheios ao meu controle e nem sempre agradáveis foram os responsáveis de tudo isto $^{959}$.

Entretanto, em carta de $1^{\circ}$ de novembro de 1982, Alice afirma que há possibilidade para que Muniz Barreto retorne, uma vez que os concursos estão abertos. "Mas, segundo me parece, V. só deverá pensar no retorno quando tiver absoluta certeza de que será para dedicar-se à Faculdade, de corpo e alma, não mais para breves passagens, e, mesmo assim, o corpo aqui, a alma lá na Argentina"960. Aqui Canabrava lembra ao "discípulo" o ethos de todo seu trabalho intelectual, marca de seu ofício de historiadora: a dedicação total, o ofício como sacerdócio.

Essa relação discipular, quase maternal, passa também pelo cuidado de si. Em carta de 27 de agosto de 1970, Muniz Barreto comenta a preocupação da orientadora de que pudesse estar deprimido "Também vi, pela carta que a Sra está preocupada com eu estar deprimido. Na realidade não é depressão, mas sim preocupação pelos muitos problemas que estou tendo em Buenos Aires"961. Após tomar conhecimento das aflições que tem atingido Muniz Barreto, ela propõe: “A melhor terapia é sempre o trabalho, e, no

\footnotetext{
957 São Paulo, 26 de outubro de 1983. APC-CA-P4, 14-(6). Fundo Alice Piffer Canabrava. Arquivo IEB/USP.

${ }^{958}$ A noção de equívoco epistolar formulada por Vincent Kaufmann expressa bem esse duplo jogo: a carta, ao mesmo tempo em que simula a presença, possui enquanto condição de possibilidade a manutenção da distância. Cf. KAUFMANN, Vincent. L'équivoque epistolaire. Paris: Minuit, 1990.

959 El Callejón, 10 de setembro de 1982. APC-CP-P4, 12-(2). Fundo Alice Piffer Canabrava. Arquivo IEB/USP.

960 São Paulo, 01 de novembro de 1982. APC-CA-P4, 13-(4). Fundo Alice Piffer Canabrava. Arquivo IEB/USP.

${ }^{961}$ São Paulo, 27 de agosto de 1970. APC-CP-P4, 2-(4). Fundo Alice Piffer Canabrava. Arquivo IEB/USP.
} 
seu caso, o trabalho com o apoio dos seus amigos daqui, que estão sempre perto de V"962. Em carta de 16 de agosto de 1981, Alice tenta reanima-lo frente ao câncer de sua irmã.

Lamentamos muito a doença de sua irmã e a fase da medicina em que vivemos, ainda cheia de obscuridades com referência ao mal. Que sabemos nós de positivo sobre as origens, as vinculações? [...] Diante disso, o bom senso e a razão nos indicam o único caminho: prosseguir nossas atividades, fazer do trabalho do qual gostamos, um derivativo para a carga de angústia, trabalho, trabalho, nem que for para começar com pequenas doses diárias. Esta é a posição mais sadia, porque lágrimas e wisky deixam outras sequelas ${ }^{963}$.

A ação das cartas enviadas por Alice talvez tenha feito com que Muniz Barreto recobrasse a saúde mental. "Felizmente já consegui sair da depressão acarretada pelo falecimento do Emílio e estou lendo muita história, mas o problema de escrever e ficar lá; ainda o estou cogitando"964. Porém outro golpe debilitaria a saúde mental de Muniz Barreto: o câncer de sua irmã e o temor de que poderia ser genético. "Eu muito preocupado e às vezes penso que pode ser genético o problema, pois ninguém conhece bem o assunto" ${ }^{965}$. Diante desse quadro, Canabrava tenta, mais uma vez, reanima-lo, expressa sua admiração, eleva a relação ao status de amizade e recomenda, como terapêutica, o trabalho.

Você sabe o quanto o estimo, o quanto desejaria vê-lo ultrapassar o vale da depressão. Conte sempre com a minha amizade, a minha admiração pessoal e procure pensar que esse patrimônio não vai se perder com a minha aposentadoria. Escreva-me sempre. Serei mais pontual na minha correspondência. Veja se rabisca o artigo para o livro do Adroaldo, para alegria dele e minha ${ }^{966}$.

Essa amizade levou a historiadora até à Argentina. Em carta de 16 de agosto de 1981, ela rememora a estadia na fazenda de Muniz Barreto. "Mas, na natureza, há um esplendor - as azaléas, lindíssimas neste período do ano, que me reportam à sua ilha, às suas plantas dessa espécie de colorido único, e a todo aquele ambiente onde os dias foram tão amenos e inesquecíveis"967.

A relação discipular também passa pela apreciação intelectual da produção de Muniz Barreto e também encontramos o estímulo à escrita de um livro.

\footnotetext{
962 São Paulo, 16 de agosto de 1981. APC-CA-P4, 10-(4). Fundo Alice Piffer Canabrava. Arquivo IEB/USP. ${ }^{963}$ São Paulo, 16 de agosto de 1981. APC-CA-P4, 10-(4). Fundo Alice Piffer Canabrava. Arquivo IEB/USP. ${ }^{964}$ El Callejon, 18 de maio de 1981. APC-CP-P4, 8-(3). Fundo Alice Piffer Canabrava. Arquivo IEB/USP. 965 Buenos Aires, 20 de julho de 1981. APC-CP-P4, 9-(2). Fundo Alice Piffer Canabrava. Arquivo IEB/USP.

${ }^{966}$ São Paulo, 16 de agosto de 1981. APC-CA-P4, 10-(4). Fundo Alice Piffer Canabrava. Arquivo IEB/USP.

${ }^{967}$ São Paulo, 16 de agosto de 1981. APC-CA-P4, 10-(4). Fundo Alice Piffer Canabrava. Arquivo IEB/USP.
} 
Acabei de ler o artigo que escreveu para o livro do Prof. Adroaldo. Fiquei entusiasmada com o veio que descobriu e está desenvolvendo, tão importante e ainda completamente inexplorado. Tenho certeza de que o seu artigo chamará a atenção de muitos pesquisadores que compreendem o alcance da sua contribuição. Espero que, nos lazeres de fazendeiro, dedique o seu interesse no sentido de elaborar a pesquisa completa. Será um grande livro, consulta obrigatória, V. ficará famoso. $\mathrm{O}$ meu apelo: os dados estão na sua mão, elabore-os, escreva o trabalho ${ }^{968}$.

Esse estímulo à produção de seus discípulos e "fillhos" da equipe de história da FEA/USP também se dava em seu esforço de divulgação. Em carta de 15 de agosto de 1982, após afirmar que irá tirar xerox do artigo de Muniz Barreto publicado na "Revista de História"969 com o fito de entrega-lo a Borges de Macedo, um dos maiores historiadores portugueses vivos, segundo ela, ao lado de Vitorino Magalhães Godinho, afirma que se empenha "[...] para que conheça os trabalhos da equipe de História"970.

O corpo também está presente nessa troca epistolar através, novamente, da temática da saúde. Em carta de 10 de agosto de 1973, Muniz Barreto relata sua recuperação após cirurgia. "Eu felizmente estou bem melhor e partir de $2^{a}$ feira já vou poder sair da cama. Os resultados das análises deram já quase normal a bibirubina e isso significa melhoria total. Após 35 dias de cama não vejo o momento de voltar a fazer a minha vida normal [..."”971. Alice manifesta cansaço após organização da obra sobre história da FEA/USP e com a saúde de outro próximo, seu irmão por adoção. "Sinto-me muito cansada, pois tive muitas preocupações com o meu irmão de criação, o Guilherme" 972 .

Em carta de 26 de outubro de 1983, a historiadora, já aposentada da FEA/USP e dedicando-se à vida doméstica, se alegra com o recebimento da carta, expressa a saudade do amigo e "discípulo" e cobra sua presença, nem que seja através da voz.

Sei que tem estado em S. Paulo algumas vezes, procura sempre o Ibrahim, têm estado juntos, telefona para o Akio, para o Silbner, etc., etc. A mim nem te ligo. Possivelmente não tem tempo para dar uma palavrinha, pelo telefone com a velha professora... Nunca recebi o seu

\footnotetext{
${ }^{968}$ São Paulo, 15 de agosto de 1982. APC-CA-P4, 11-(2). Fundo Alice Piffer Canabrava. Arquivo IEB/USP. ${ }^{969}$ MUNIZ BARRETO, Antonio Emílio. O fluxo de moedas entre o rio da Prata e o Brasil (1800-1850). Revista de História. São Paulo, v. 51, n. 101, p. 207-227, 1975.

970 São Paulo, 15 de agosto de 1982. APC-CA-P4, 11-(2), p. 2. Fundo Alice Piffer Canabrava. Arquivo IEB/USP.

971 Buenos Aires, 10 de agosto de 1973. APC-CP-P4, 5-(2). Fundo Alice Piffer Canabrava. Arquivo IEB/USP.

${ }^{972}$ São Paulo, 01 de novembro de 1982. APC-CP-P4, 13-(4). Fundo Alice Piffer Canabrava. Arquivo IEB/USP.
} 
livro publicado, um resumo do comércio argentino-brasileiro, ao que sei, embora muitos o tenham recebido. Contudo, o seu telegrama pelo meu aniversário deu-me muita alegria, deu-me certo consolo de tanta omissão e sobretudo, trouxe-me a certeza de que não estou esquecida, que tantos anos de convívio não decorreram em vão, algo terá ficado em sua alma ${ }^{973}$.

Em carta de $1^{\circ}$ de julho de 1984 Canabrava lamenta com Francisco Iglésias a morte de seu ex-orientando e professor da FEA/USP, Antonio Emílio Muniz Barreto.

A morte do Prof. Muniz Barreto, em 17 de março último, me deixou prostrada. Havia deixado a Faculdade, exatamente há dois anos, quando pediu licença de dois anos para tratar dos interesses e lhe negaram. Sofreu muito com a resolução. [...] Morreu da ruptura de uma úlcera no estomago $0^{974}$.

Os dois últimos correspondentes mais frequentes de Canabrava também são exorientandos: Zélia Maria Cardoso de Mello ${ }^{975}$ e Ronaldo Marcos dos Santos ${ }^{976}$. A troca epistolar entre Alice Canabrava e Zélia se dá pelo fato de que esta última estava realizando estágio de pesquisa em Londres. Ao contrário da Alice amiga na relação com Iglésias, Maria Celestina e Muniz Barreto, aqui o eu de Alice se mantém no campo professoral e aproveita a estada da aluna em Londres para solicitar favores, como a compra de livros e outros objetos, por exemplo. Alguns deles, como perucas e louças, compreendemos que somente puderam ser solicitados pelo fato de ser uma relação entre pessoas do mesmo gênero.

Como já lhe falei anteriormente não tenho notícias da louça. Gostaria que a senhora me escrevesse sobre o que gostaria que eu comprasse, além do remédio e dos livros do Braudel. Confesso que vi muitas perucas mas a variação de preço é tão grande que não foi possível guardar. Vou tentar dar um intervalo de preços para a senhora, que então poderá me dizer quanto quer gastar nela ${ }^{977}$.

A condição de possibilidade para o estabelecimento de troca epistolar entre a historiadora e Ronaldo passa pela estadia desse em Paris, também para um estágio de pesquisa. À semelhança da relação com Zélia, Canabrava também aproveita a estada do

\footnotetext{
${ }^{973}$ São Paulo, 26 de outubro de 1983. APC-CA-P4, 14-(6). Fundo Alice Piffer Canabrava. Arquivo IEB/USP.

${ }^{974}$ Cópia carbonada. São Paulo, 01 de julho de 1984. APC-Ca-P2, 16-(2). Fundo Alice Piffer Canabrava. Arquivo IEB/USP.

${ }_{975}$ Constam 6 cartas recebidas por Alice no Arquivo IEB/USP. Fundo Alice Piffer Canabrava. Arquivo IEB/USP.

${ }^{976}$ Constam 5 cartas recebidas por Alice no Arquivo IEB/USP. Fundo Alice Piffer Canabrava. Arquivo IEB/USP.

${ }^{977}$ Londres, 27 de janeiro de 1982. APC-MELL-010. Fundo Alice Piffer Canabrava. Arquivo IEB/USP.
} 
ex-orientando em Paris para solicitar favores. Em carta de 25 de março de 1974, Ronaldo afirma que irá relatar os fatos dos dois últimos meses ${ }^{978}$, inclusive que se separou da mulher. "Fui novamente ao livreiro perguntar do Vilar e do Goubert. A resposta foi a de sempre: ainda não acharam mas continuam pesquisando. Fui a um outro livreiro e ele nem quis anotar meu nome porque disse que é mesmo muito dificil encontrar as duas obras" "979. Além da solicitação de livros, a orientadora aproveita a estadia do exorientando em Paris para estabelecer redes que propiciem a vinda de professores para proferir curso na FEA/USP.

Procurei imediatamente informações sobre Maurice Niveau e soube que atualmente ele é reitor da academia em Grenoble, cargo muito alto na carreira universitária e por isso mesmo as pessoas duvidam que ele tenha tempo de ir ao Brasil principalmente porque no mes de outubro ele deve estar aqui para o reinicio dos cursos de graduação. Antes de tentar qualquer pessoa da equipe do Labrousse, fui imediatamente procurar o professor Vilar que foi muito atencioso ${ }^{980}$.

Percebemos a solicitação de favores, como a obtenção de livros, mas também uma instância que não está presente na correspondência com Zélia: a intimidade. Ronaldo, mesmo como ex-orientando, sente-se seguro ao confidenciar um dado da vida privada.

Mesmo na condição de ex-orientando, Alice ainda dava sugestões de pesquisa e formação, afinal, Ronaldo era membro da equipe de história. "Segui também o seu conselho e estou assistindo o curso de Sociologia na École Pratique com Alain Tourraine, considerado por aqui como dos melhores sociólogos atuais" ${ }^{\text {"981 }}$. Ronaldo também fazia eco à militância de Canabrava pela projeção da equipe. "Fiquei muito alegre com a notícia da colaboração dos colegas no livro sobre História Econômica do Brasil e estou ansioso para ver a publicação. Sempre achei que teremos que nos projetar como equipe"982.

Em carta de 25 de março de 1974, Ronaldo relata as leituras que tem empreendido para sua tese e que que leu a tese sobre historiografia brasileira de Guy Martinière-Vialar “Contribution a l'etude de l'economie retrospective du Brésil - Essai d'historiographie” de

\footnotetext{
${ }^{978}$ A narração do cotidiano, além do corpo, faz parte de uma narração de si. Cf. KOHLRAUSCH, Regina. Apresentação - Literatura gênero epistolar: a carta na literatura, a literatura na carta, rede de sociabilidade, escrita de si... . Letrônica. Revista digital do programa de pós-graduação em letras da PUCRS. Porto Alegre, v. $8, \quad$ n. $1, \quad$ p. $148-155, \quad 2015 . \quad$ Disponível em: <http://revistaseletronicas.pucrs.br/ojs/index.php/letronica/article/view/21361/13422 >. Acessado em $22 \mathrm{de}$ abr. 2019.

979 Paris, 25 de março de 1974. APC-SANT-001. Fundo Alice Piffer Canabrava. Arquivo IEB/USP.

${ }^{980}$ Paris, 24 de janeiro de 1975. APC-SANT-003. Fundo Alice Piffer Canabrava. Arquivo IEB/USP.

${ }^{981}$ Paris, 25 de março de 1974. APC-SANT-001. Fundo Alice Piffer Canabrava. Arquivo IEB/USP.

982 Paris, 24 de janeiro de 1975. APC-SANT-003. Fundo Alice Piffer Canabrava. Arquivo IEB/USP.
} 
1973 e em 3 volumes. "Na introdução ele cita o nome da Senhora como uma das pessoas a quem enviou um questionário sobre a posição e dificuldades do historiador brasileiro" $" 983$.

\subsection{As representações de Alice}

Nesse item percorreremos as representações forjadas de Alice desde seu desaparecimento, a partir da sugestão de que "[...] convém então interrogar todos os traços de memória que fazem uso dessa figura, tanto no plano discursivo como no da imagem" 984 .

A publicação de "História econômica: estudos e pesquisas" em 2005, dois anos após a morte da historiadora, constrói uma determinada memória sobre a mesma. Organizado por seu ex-orientando e professor da FEA/USP, Flávio Saes, o livro conta com "introdução", "bibliografia de Alice Piffer Canabrava", com transcrição de depoimento concedido em 1984 na sessão especial organizada pelo CERU/USP na reunião anual da SBPC, "O caminho percorrido" e "textos de Alice Piffer Canabrava". Flávio divide a introdução em duas partes: uma trata da biografia intelectual e pessoal de Alice e a segunda de suas pesquisas. Para ele, a obra de Canabrava é reflexo de sua personalidade, em uma concepção biográfica em que a obra é explicada pela vida ${ }^{985}$.

O pioneirismo da obra de Alice P. Canabrava no campo da História Econômica é o reflexo de sua personalidade: incapaz de se acomodar a situações fáceis, jamais poupou esforços quando se tratava de alcançar objetivos determinados. Por isso, sua biografia pessoal mostra trajetória profissional que poucas mulheres, à sua época, puderam percorrer e sua obra apresenta caráter pioneiro diante da produção historiográfica coetânea ${ }^{986}$.

A não acomodação da historiadora, em seguida, é explicada através de uma breve síntese de sua trajetória contida no texto "O caminho percorrido" ${ }^{987}$. Flávio descreve seus primeiros estudos ainda em Araras/SP, a vinda para São Paulo para cursar a Escola Normal, o retorno à Araras para lecionar no ensino primário e o fator da não acomodação: seu retorno à São Paulo para cursar Geografia e História na recém-criada FFCL/USP. Nesse ambiente, afirma que Alice Canabrava se singularizava pela dedicação aos estudos

\footnotetext{
983 Paris, 25 de março de 1974. APC-SANT-001. Fundo Alice Piffer Canabrava. Arquivo IEB/USP.

${ }^{984}$ DOSSE, op. cit., 2009, p. 346.

${ }^{985}$ Cf. DOSSE, op. cit., 2009, p. 81.

${ }^{986}$ SAES, Flávio Azevedo Marques de. Introdução. In: CANABRAVA, op. cit., 2005, p. 8.

${ }^{987}$ CANABRAVA, Alice Piffer. O caminho percorrido. In: CANABRAVA, op. cit., 2005, p. 23-34.
} 
e se situava acima da média dos alunos, corroborada pelos prefácios e resenhas de suas teses feitas por seus "mestres". Ao término do curso ela ingressa no corpo docente da Faculdade e produz duas teses: a de doutoramento sobre o comércio português no Rio da Prata $^{988}$ e a de livre-docência sobre a indústria do açúcar no mar das Antilhas ${ }^{989}$.

Flávio Saes continua construindo a trajetória de sua orientadora, afirmando que, após uma breve passagem pelo Instituto de Administração da antiga FCEA/USP, tornase catedrática de História Econômica dessa Faculdade, com a tese sobre a produção do algodão em São Paulo ${ }^{990}$, silenciando acerca das circunstâncias que a conduziram a obtenção do título de livre-docente. Nessa Faculdade assumiu a condição de liderança na área, formando a tão referida "equipe de história". “[...] ela criou [...] uma "escola" de pesquisa em História Econômica que, consolidada pelos estudos que realizou tem amplitude crescente pela multiplicação de trabalhos de seus assistentes e orientandos"991.

A historiadora ainda é rememorada por Saes como aquela que dirigiu a instituição entre 1954 e 1957, aposentando-se em 1981 e recebendo o título de professora emérita em 1987. Flávio também lembra a atuação de Alice na criação da APUH, seus vários anos de secretariado, sua presidência e criação da "Revista Brasileira de História".

Ao analisar as três teses de Alice Canabrava, Flávio enxerga nelas uma unidade quanto à preocupação central. No caso de "O comércio português no Rio da Prata (15801640)", ao mostrar os caminhos que conduziram à penetração portuguesa no escoamento da prata de Potosí até Buenos Aires, a autora demonstraria os fundamentos para a independência da Argentina no século XIX ${ }^{992}$. Tratando de "A indústria do Açúcar nas ilhas inglesas e francesas do mar das Antilhas (1697-1735)", ao analisar as condições de produção do açúcar nessa região e compará-la com a brasileira, Canabrava teria demonstrado como os movimentos de independência ocorreram primeiro no Brasil do que naquela região, uma vez que os senhores de engenho das Antilhas eram absenteístas residentes na metrópole ${ }^{993}$. No que tange à "O desenvolvimento da cultura do algodão na Província de São Paulo (1861-1875)", mesmo não tratando diretamente do período colonial, Saes destaca que, reconhecendo o condicionamento da produção do algodão ao

\footnotetext{
988 CANABRAVA, op. cit., 1944.

989 CANABRAVA, op. cit., 1981a.

990 CANABRAVA, op. cit., 2011.

${ }^{991}$ SAES, op. cit., 2005, p. 10.

992 Cf. CANABRAVA, op. cit., 1944.

${ }^{993}$ Cf. CANABRAVA, op. cit., 1981 a.
} 
mercado externo, a historiadora demonstra que a posterior queda nas exportações, devido à concorrência externa, se deu pelas baixas condições técnicas dos produtores ${ }^{994}$. Dessa forma, aproxima a temática de fundo dessas três teses à produção de autores com as mesmas preocupações, como Roberto Simonsen e Caio Prado Júnior, demarcando que a singularidade da autora se encontra no método empregado e na mobilização de "fontes primárias".

Ao mencionar a resenha de Fernand Braudel de sua tese de doutoramento ${ }^{995}$, Flávio adota estratégia discursiva que a identifica à escola dos Annales. Para ele, trata-se de uma escola formada em oposição à "velha história positivista", que se caracterizaria por privilegiar uma história factual dos grandes homens agentes da história. Para Saes, os Annales, por seu turno, seria uma escola que privilegia o diálogo com as ciências sociais e que por isso, apresentaria métodos e objeto de estudo diferenciados. O objeto privilegiado não são os grandes homens, mas sim as massas anônimas e seus fatos, como os grandes movimentos populacionais, de mercadorias, da produção, dos preços etc. Outro elemento da "escola" destacado por Flávio diz respeito ao "enquadramento geográfico". Segundo ele, os problemas históricos deveriam ser tratados em sua relação com o meio ambiente ${ }^{996}$.

O leitor não terá dificuldade em identificar, na obra de Alice P. Canabrava, os princípios metodológicos da Escola dos Annales, esquematicamente traçados acima. Aí está o elemento que distingue a obra de Alice P. Canabrava dos demais trabalhos de História Econômica produzidos à época. Pode-se mesmo dizer que seus estudos tornam-se "modelos" para muitas teses de História Econômica elaboradas no âmbito da Universidade ${ }^{997}$.

Para Flávio, os mesmos princípios metodológicos e a preocupação com as mudanças da economia colonial estão presentes em sua produção posterior, principalmente na introdução ao livro de Antonil, "Cultura e Opulência do Brasil por suas drogas e minas"998 , e nos dois capítulos de "História Geral da Civilização Brasileira"

\footnotetext{
994 Cf. CANABRAVA, op. cit., 2011.

995 Cf. BRAUDEL, op. cit., 1948.

996 No capítulo 3 de minha dissertação tratei da apropriação da Geografia na produção de Alice. Ver: ERBERELI JÚNIOR, Otávio. Um conhecimento de formação: Alice Piffer Canabrava geógrafa. In: ERBERELI JÚNIOR, op. cit., 2014, p. 142-201.

997 SAES, op. cit., 2005, p. 14.

998 CANABRAVA, op. cit., 1967.
} 
de sua autoria: "A grande propriedade rural"999 e "A grande lavoura"1000, estes dois últimos presentes nesse livro sob a tipologia "história econômica do Brasil".

Outra vertente temática rememorada por Saes, diz respeito aos estudos de Alice sobre a história econômica de São Paulo. São os três textos que analisamos no último item do primeiro capítulo, que permitiram à historiadora demostrar que a capitania de São Paulo possuía canais internos de acumulação por meio da mobilização do aparato metodológico da história quantitativa: "Uma economia de decadência: níveis de riqueza na capitania de São Paulo, 1765-1767”1001, “A Repartição da Terra na Capitania de São Paulo, 1818"1002 e "Decadência e Riqueza"1003. Some-se a esses: "Esboço da história econômica de São Paulo" "1004, sendo que o primeiro consta da tipologia de Flávio em "História econômica de São Paulo".

Além da produção de Alice em história econômica, Flávio lista uma ampla gama de temas:

estudos bibliográficos (sobre bandeiras, história administrativa, história do Brasil); estudos sobre fontes primárias (sobre moeda e crédito em São Paulo no século XVI, escravismo); estudos historiográficos (sobre Varnhagen, Martius, Capistrano de Abreu); estudos metodológicos (sobre as relações entre história e economia, sobre a história quantitativa); estudos sobre a história administrativa do Brasil ${ }^{1005}$.

Uma mulher que não se acomoda diante das condições sociais pouco favoráveis de seu tempo; professora e pesquisadora pioneira em história econômica do Brasil e de São Paulo a partir de metodologia inovadora e da mobilização de "fontes primárias": essa é a Alice de Flávio Saes.

A Alice Canabrava construída por José Jobson de Andrade Arruda é bem diferente. Ou melhor, as Alices... O texto "Alice Canabrava: História e mito" figura na

\footnotetext{
${ }^{999}$ CANABRAVA, Alice Piffer. A grande propriedade rural. In: HOLANDA, op. cit., 1960, p. 192-217.

${ }^{1000}$ CANABRAVA, Alice Piffer. A grande lavoura. In: HOLANDA, Sérgio Buarque de. (dir.). História Geral da Civilização Brasileira. O Brasil monárquico. t. II, v. 4: declínio e queda do império. São Paulo: difusão europeia do livro, 1971, p. 85-137.

${ }^{1001}$ CANABRAVA, Alice Piffer. Uma Economia de Decadência: Os níveis de Riqueza na Capitania de São Paulo, 1765-1767. In:_— op. cit., 2005, p. 169-202. Publicado originalmente em: CANABRAVA, Alice Piffer. Uma Economia de Decadência: Os níveis de Riqueza na Capitania de São Paulo, 1765-1767. Revista Brasileira de Economia. Rio de Janeiro, v. 26, n. 4, p. 93-221, 1972a.

1002 CANABRAVA, Alice Piffer. A Repartição da Terra na Capitania de São Paulo, 1818. Estudos Econômicos. São Paulo, v. 2, n. 6, p. 77-129, 1972 b.

1003 CANABRAVA, Alice Piffer. Decadência e Riqueza. Revista de História. São Paulo, n. 100, p. 335366, 1974.

${ }^{1004}$ CANABRAVA, Alice Piffer. Esboço da História Econômica de São Paulo. In: BRUNO, Ernani Silva (org.). São Paulo: Terra e Povo. Porto Alegre: Editora Globo, 1967.

${ }^{1005}$ SAES, op. cit., 2005, p. 15-16.
} 
abertura da terceira edição da tese de cátedra de Alice defendia em 1951 na FCEA/USP: “O Desenvolvimento da cultura do algodão na Província de São Paulo (1861-1875)" publicada em 2011 por ocasião de uma dupla comemoração: se ela estivesse viva, completaria 100 anos de idade e a associação da qual foi uma de suas fundadoras, a APUH, atual ANPUH completava 50 anos. Quanto à escolha dessa tese de cátedra e não das outras, talvez se possa também justificar pelo fato de que expressa uma data redonda: a tese completava 60 anos ${ }^{1006}$.

Apesar dos vários itens nos quais o texto de Jobson está dividido, podemos pensálo em dois eixos principais: um que traz a biografia pessoal e intelectual de Canabrava e outro que discute sua obra. Quanto ao primeiro, Arruda analisa as condições em que se deram o concurso para a cadeira de História da Civilização Americana de 1946 do qual a historiadora foi preterida, mesmo obtendo as maiores notas ${ }^{1007}$. O autor enxerga nesse evento a invenção de Alice como "[...] ícone do movimento de afirmação feminina na academia, um exemplo candente da perfídia orquestrada pela corporação masculina em defesa de seu espaço acadêmico e, por conseguinte, de seus privilégios de gênero"1008 ${ }^{\text {. A }}$ operação intelectual e política de Jobson Arruda ao longo de todo restante do texto será uma tentativa de descontruir esse julgamento que o mesmo trata por mito. Para tanto, mobiliza os depoimentos de Olga Pantaleão, Maria Conceição Vicente de Carvalho e Gilda de Mello e Souza presentes no livro "Mulheres na USP: horizontes que se abrem" 1009 .

Olga afirma que o concurso de Alice foi o evento mais marcante da FFCL/USP no que tange à busca do elemento feminino pela cátedra. Maria Conceição trata da misoginia presente na cultura acadêmica. Porém, segundo Jobson, quando se trata de si mesma, relativiza. Ao comparar Gilda e Canabrava, Arruda afirma que ambas vieram do interior, respectivamente, de Araraquara/SP e Leme/SP. Gilda de uma família de fazendeiros abastados e Alice Canabrava da média burguesia interiorana, ambas provenientes de ambientes polidos e cultos. Gilda acentua que mesmo na FFCL/USP sentiu os mesmos preconceitos de que fora alvo em sua cidade natal, qualificando-os de

\footnotetext{
${ }^{1006}$ ARRUDA, José Jobson de Andrade. Alice Canabrava: história e mito. In: CANABRAVA, op. cit., 2011, p. 9-70.

${ }^{1007}$ Analisamos esse episódio em: ERBERELI JÚNIOR, op. cit., 2016.

1008 ARRUDA, José Jobson de Andrade. Alice Canabrava: história e mito. In: CANABRAVA, op. cit., 2011, p. 24.

${ }^{1009}$ BLAY; LANG, op. cit., 2004.
} 
geracionais e de gênero. Para o autor, “[...] se a conspiração antifeminina era geracional e grassava tradicionalmente em todos os setores, fica sem explicação a acolhida que Alice teve na Faculdade de Ciências Econômicas e Administrativas, tão logo se desligou da Faculdade de Filosofia" ${ }^{" 1010}$.

A partir da inserção de Canabrava no ambiente institucional da FCEA/FEA/USP, Jobson, através de entrevistas, que toma por "autoexplicativos", com ex-assistentes e exorientandos constrói duas imagens da historiadora. Uma primeira desenha um perfil de professora de difícil trato e que exigia demais de seus assistentes, caso rememorado por Mirian Moreira Leite, sua segunda assistente. Quando se casou com Dante Moreira Leite e não pôde mais dedicar-se integralmente à pesquisa como o requeria a catedrática, foi demitida. A mesma razão é rememorada por Fernando Novais e Fernando Henrique Cardoso. Ambos lembram o grau de exigência da professora quanto às funções de ensino e pesquisa e que, quando se casaram, não podendo mais dedicar-se como ela queria, foram substituídos. O quadro se altera quando da extinção do regime de cátedras e incorporação de professores via regime departamental. Flávio Saes rememora que não teve nenhum incidente de ordem pessoal ou profissional. Para ele, a historiadora compreendia a carreira universitária como um sacerdócio, que requeria dedicação integral, principalmente em relação à pesquisa.

[...] entre os colegas de área, havia alguns que, diante dos baixos salários dos auxiliares de ensino, mantinham outros empregos a fim de garantir sua sobrevivência. Nesses casos, a professora Alice exercia pressão para que abandonassem seus empregos fora da USP, ingressassem no RDIDP e se dedicassem à pesquisa ou então que se desligassem da área de História ${ }^{1011}$.

Para Nelson Nozoe a frequência e intensidade de trabalho exigidas pela professora objetivavam preservar a qualidade da área de História, o que não impedia, segundo Flávio, que ela estabelecesse relação de grande apreço e quase maternal com alguns, como Ronaldo Rocha Vecchia e Zélia Cardoso de Mello. O fato de Alice ter mais assistentes homens do que mulheres é visto por Jobson como conservadorismo. É com esse qualificativo que enquadra sua produção historiográfica.

\footnotetext{
${ }^{1010}$ ARRUDA, op. cit., p. 34. O autor se esquece de mencionar os tempos difíceis enfrentados por Alice quando foi diretora da instituição entre 1954 e 1957.

${ }^{1011}$ SAES, Flávio Azevedo Marques de. Entrevista concedida à José Jobson de Andrade Arruda em 17 de maio 2010.
} 
Se Flávio Saes no texto que expusemos acima tenta aproximá-la da "escola dos Annales", Arruda irá tentar afastá-la. Para ele, quando da chegada da "missão francesa" havia uma cultura historiográfica alicerçada nos estudos sobre bandeiras, principalmente a partir da produção de Afonso Taunay e Alfredo Ellis Júnior. A cadeira de História da Civilização Brasileira iria se modernizar somente com a chegada de Sérgio Buarque de Holanda, sendo que a renovação ficava por conta da cadeira de História Geral da Civilização, por onde passara Braudel. Taunay utilizava o texto de Langlois e Seignobos que traduzia os passos da escola metódica: "pesquisa documental, análise e síntese histórica, etapas estas plenamente realizadas nos três trabalhos acadêmicos de maior relevância realizados por Alice, suas teses de doutoramento, livre-docência e cátedra"1012. Afirma que a historiadora possuía grande apego a documentação o que se configura como sua maior qualidade, mas também seu maior defeito, recusando-se a grandes sínteses.

Se sua tese de doutoramento foi resenhada na revista dos Annales por Braudel, Jobson vê nisso uma tentativa de busca de poder historiográfico da escola, uma vez que trabalhos de menor monta também foram resenhados como o de J F. de Almeida Prado. Quanto à tese sobre o algodão, afirma que a autora adotou uma perspectiva de média duração, mas que se alicerçou em um problema do tempo presente, qual seja, a industrialização de São Paulo, fator que a aproximaria dos pressupostos da escola. Porém, quanto à Geografia, Canabrava não dispensaria o mesmo tratamento concebido pelos Annales. "A geografia surge aí mais como pano de fundo, conjunto de elementos a favorecer ou constranger as atividades econômicas, mas nunca como interação complexa homem/natureza. E se havia um tema que se prestava a esse tipo de abordagem, era a tese sobre o algodão"1013.

Jobson continua sua comparação da tese de Alice com o que denomina de pressupostos dos Annales. A mobilização de agregados quantitativos, conforme estabelecido por Ernest Labrousse, está ausente da tese. O encadeamento dos fatos de modo linear é outro problema apontado por Jobson Arruda, não havendo superposição de tempos. Ademais, Canabrava partiria de uma constatação - aumento da produção de algodão na província de São Paulo devido à interrupção de fornecimento no mercado mundial pelos EUA devido à Guerra de Secessão - e não de um problema. Para ele, os

1012 ARRUDA, op. cit., 2011, p. 46.

1013 Idem, p. 53. 
conceitos mobilizados pela autora também estariam vinculados à uma historiografia conservadora como a caracterização de uma economia brasileira dependente externamente expressa nos vários ciclos ${ }^{1014}$.

Outro problema que afastaria Alice Canabrava da escola dos Annales seria a própria concepção de sua tese em uma chave de causas e consequências, ou seja, a guerra de secessão é a causa do desenvolvimento da produção algodoeira em São Paulo e a incipiente industrialização é sua consequência.

Causas e consequências são expressões-chave da corrente historiográfica dita tradicional, combatida pelos adeptos da metodologia dos Annales mas entranhada no arcabouço mental e na prática concreta da história de extração positivista, que se buscava superar, e frequentam as páginas escritas por Alice ${ }^{1015}$.

Assim, para Jobson, a tese sobre o algodão seria uma tese "menor" quando comparada as duas primeiras e aos trabalhos posteriores da autora, principalmente os dos anos 1970 com mobilização do aparato da história quantitativa, os maços populacionais e a busca pela compreensão da estrutura da riqueza em São Paulo.

Antes de encerrar sua abertura, Arruda quer demarcar o que ele denomina de "perfil conservador da historiadora", expresso, segundo ele, na heroicização do fazendeiro Carlos Ilidro ${ }^{1016}$ e na apresentação que, ainda segundo ele, apesar de não estar assinada por Alice, seria de sua autoria, do número inaugural da "Revista de História da Economia Brasileira" de janeiro de 1953. A historiadora teria escolhido a foto de capa, de Roberto Simonsen, e no texto de abertura afirmaria que o periódico iria tratar do século XIX, uma vez que Simonsen estudou todo o período colonial expresso em "História Econômica do Brasil" "1017. Após encetar mais algumas críticas sobre a construção dos gráficos e sua análise, encerra com um exercício que busca comparar a tese com a produção posterior sobre o algodão com o fito de demonstrar que a mesma ainda merece ser lida.

Se a intenção do editor do livro era que Alice fosse homenageada, pois completaria 100 anos e a associação da qual foi uma de suas fundadoras, completaria 50 anos, o texto de abertura não logra tal objetivo. Parece ir em direção oposta.

\footnotetext{
${ }^{1014}$ Para nós, como demonstramos no último item do primeiro capítulo, o conceito que mais é mobilizado pela historiadora é o de "sentido da colonização" de Caio Prado Júnior.

${ }^{1015}$ ARRUDA, op. cit., 2011, p. 55.

1016 Idem, p. 57.

${ }^{1017}$ Idem, p. 61-62.
} 
A orelha do livro, escrita por Raquel Glezer, faz jus ao evento comemorativo. Glezer rememora a Alice Canabrava especializada em história econômica, fundadora da APUH, presidente da ANPUH e fundadora da $R B H$ em 1981. Ademais, rememora seu convívio com a historiadora. A primeira vez em que Glezer a viu foi em Franca/SP, por ocasião do III Simpósio da APUH em 1965. A segunda lembrança se dá pelo envolvimento firme de Canabrava na abertura da associação nos debates que tiveram lugar na Assembleia Geral de 1977 em Florianópolis, como tivemos a oportunidade de analisar no segundo capítulo dessa tese. Nesse mesmo ano, a morte de Eurípedes Simões de Paula desestabilizou a entidade e, após a publicação dos Anais em quatro volumes, ficou claro que aquela estrutura não poderia ser mantida. Por conta disso, Alice sugeriu a fundação de uma revista. Glezer rememora que teve a oportunidade de trabalhar como secretária da revista - as reuniões e todo trabalho ocorriam na casa da catedrática - e que nesse período aprendeu muito com ela, sempre disposta a transmitir "conhecimentos e experiências". "No quinquagésimo aniversário da Associação Nacional de História, a edição de uma das obras referenciais de Alice Canabrava fica como o melhor agradecimento dos historiadores por toda sua dedicação e atuação na entidade"1018 .

Por ocasião das comemorações dos 25 anos de existência da Associação Brasileira de Pesquisadores em História Econômica (ABPHE) em 2018, no ano de 2017 foi lançada uma alentada publicação em livro com artigos especializados em história econômica, balanços sobre a área no Brasil a partir das áreas temáticas do Congresso e "homenagem aos mestres". Dentre estes figuram os nomes de Alice Piffer Canabrava, Francisco Iglésias, Eulália Maria Lahmeyer Lobo, Tamás József Károly Szmrecsányi e Carlos Roberto Antunes dos Santos.

$\mathrm{Na}$ seção "história econômica em debate" figura texto de Maria Alice Rosa Ribeiro tratando das primeiras mulheres que se formaram na FFCL/USP e que produziram teses em história econômica. Rosa Ribeiro afirma que, diferentemente de artigo anterior no qual analisou a produção em história econômica de algumas mulheres tomadas enquanto pioneiras, dentre elas Alice Canabrava ${ }^{1019}$, seu foco nesse texto é, para além da contribuição historiográfica, analisar também as histórias de vida de: Alice Piffer

\footnotetext{
${ }^{1018}$ GLEZER, Raquel. Orelha. In: CANABRAVA, op. cit., 2011.

1019 RIBEIRO, Maria Alice Rosa. As primeiras pesquisadoras brasileiras em história econômica e a construção da disciplina no brasil. história econômica \& história de empresas. São Paulo. v. II, n. 2, 1999, p. 7-40.
} 
Canabrava, Olga Pantaleão, Mafalda Zemella, Myriam Ellis, Nícia Villela Luz, Emília Viotti da Costa, Maria Thereza Schorer Petrone e Suely Robles Reis de Queiroz. ${ }^{1020 .}$

Rosa Ribeiro traça a trajetória de Alice desde seu nascimento em Araras/SP em 1911 até o ingresso como auxiliar de ensino na cadeira de História da Civilização Americana da FFCL/USP em 1937. Detém-se na análise dos fatos que conduziram a historiadora a ser preterida no concurso da mesma cadeira em 1946 e avança até a obtenção da cátedra em 1951 na FCEA/USP. Nesse interim, sintetiza sua tese de doutoramento a partir do prefácio de Afonso Taunay e exalta as qualidades de sua tese de livre-docência. Rosa Ribeiro finaliza o item sobre Alice Canabrava afirmando que foi a primeira mulher a presidir a ANPUH e que foi também editora da $R B H$. A Alice construída por Rosa Ribeiro é de uma mulher que vence as hostilidades de gênero e se projeta enquanto pioneira na pesquisa em história econômica do Brasil ${ }^{1021}$.

O texto de Flávio em homenagem à sua orientadora, quando comparado ao anterior, de sua autoria, em termos de estrutura, apresenta uma novidade: inicia fornecendo as condições sociais de possibilidade para as escolhas realizadas por Alice nos anos 1930. Flávio se refere às mudanças pelas quais passavam a sociedade brasileira e em especial paulistana pós-1930, quais sejam: industrialização, urbanização, surgimento de uma classe média urbana e, principalmente, a reforma educacional de 1931. Até então, o sistema educacional brasileiro funcionava de forma dual, expressando também a conformação de classes no Brasil: uma educação popular, que consistia no ensino primário, em geral de quatro anos que facultava o ingresso nos cursos de formação profissional, como as escolas de comércio; e uma educação para as elites, as quais, após o curso primário, para atingir o ensino superior, tinham que passar pelo ensino secundário. Caso o indivíduo que já trabalhasse e fosse formado pelo ensino profissional quisesse ingressar no ensino superior, teria que reiniciar os estudos no secundário, oferecidos apenas, no Estado de São Paulo, na capital, em Ribeirão Preto e Campinas. Havia também a possibilidade de, após o ensino primário, cursar uma escola normal. A reforma de 1931, abriu a possibilidade de ingresso no ensino superior daqueles que tivessem passado por escola profissionalizante e por escola normal.

1020 Cf. RIBEIRO, Maria Alice Rosa. Lutas e conquistas das primeiras historiadoras em História Econômica, 1934-1972. In: SAES, Alexandre Macchione. RIBEIRO, Maria Alice Rosa. SAES, Flávio Azevedo Marques de (orgs.). Rumos da história econômica no Brasil: 25 anos da ABPHE. São Paulo: Alameda, 2017, p. 142.

${ }^{1021}$ Cf. RIBEIRO, op. cit., 2017, p. 152-157. 
Outro elemento fundamental foi a criação da FFCL/USP em 1934. Assim, Alice se beneficiou das mudanças sociais e educacionais dos anos 1930, uma vez que, após cursar a Escola Normal pôde ingressar na FFCL. Porém, como demarcado por Flávio, ela não se acomodou e, diante dessas condições, escolheu ingressar no curso de Geografia e História. Poderia ter permanecido em Araras/SP como professora primária, após sua passagem pelo Colégio Stafford e pela Escola Normal. Saes atribui esse não comodismo da historiadora ao ambiente familiar, onde seus pais teriam demarcado a não diferenciação entre homens e mulheres no que tange ao trabalho intelectual ${ }^{1022}$.

A partir desse ponto, o autor adota estrutura narrativa igual a do texto anterior: perpassa a trajetória de Canabrava e sua obra. Quanto à "nota biográfica" o excurso possui quase os mesmos elementos e fontes do texto anterior. Quanto às ultimas, Flávio acrescenta apenas que seu texto também se baseia nas conversas informais que teve com a autora. Quanto aos primeiros, Saes retrocede até Araras/SP, ao ambiente familiar da historiadora, perpassa sua formação no Colégio Stafford, na Escola Normal, seu retorno à Araras/SP e sua volta à São Paulo para cursar Geografia e História na FFCL/USP. Destaca seu contato com Braudel e Monbeig, o ingresso na cadeira de História da Civilização Americana, o sucesso de sua tese de doutoramento. As condições do concurso de 1946, silenciadas no texto anterior, são analisadas ${ }^{1023}$. Em seguida, Flávio inicia a narrativa da nova fase de Alice Canabrava na FCEA/USP, passando por sua estada no IA, a vitória na conquista da cátedra de História Econômica, sua diretoria junto à Faculdade, seus assistentes e orientandos. Destaca também sua importância na formação e vida da ANPUH, bem como a criação da $R B H$. Conclui essa primeira parte, afirmando que, se ela encontrou as condições de possibilidade para se projetar além do esperado para uma mulher nascida em uma pequena cidade na década de 1910, enfrentar a hostilidade masculina somente foi possível pela qualidade de sua obra.

No entanto, seu sucesso não pode ser explicado apenas em termos da tenacidade em enfrentar os obstáculos. Ele é fruto também de um dado objetivo, qual seja, a qualidade de seu trabalho de pesquisa que acabou por se impor diante da resistência oposta pelo elemento masculino ${ }^{1024}$.

1022 Cf. SAES, Flávio Azevedo Marques de. Alice Piffer Canabrava (1911-2003). In: SAES; RIBEIRO; SAES, op. cit., 2017, p. 237-239.

${ }^{1023}$ Flávio se vale das análises de: ARRUDA, op. cit., 2011 e ERBERELI JÚNIOR, op. cit., 2014.

${ }^{1024}$ SAES, op. cit., 2017, p. 249. 
Ao analisar a obra de Alice, Flávio procura inserir as três teses da historiadora em seu contexto de produção. Afirma que até 1930 a produção historiográfica brasileira era marcada pela concepção de história do IHGB e seus congêneres estaduais e compara as teses da historiadora às obras de Roberto Simonsen e Caio Prado Júnior. Uma primeira diferença inventariada por Saes, diz respeito à mobilização das "fontes primárias". Em seus estudos, de caráter monográfico, somente se sentiria segura alicerçada em "fontes primárias", sem grandes voos. As grandes interpretações são a marca da produção de Simonsen e Prado Júnior. No entanto, Flávio propõe uma unidade para as três teses e aproxima-as da preocupação intelectual de Simonsen e Prado Júnior, qual seja, o estatuto colonial da economia brasileira.

Para o autor, Alice Canabrava em sua tese de doutoramento, ao partir da fundação de Buenos Aires e analisar as condições de comércio de contrabando português no estuário do Prata, demonstraria que a dinâmica em torno do porto de Buenos Aires instituiria uma cidade de caráter mercantil, na qual estaria o gérmen da independência do século XIX. A tese de livre-docência, por sua vez, ao estabelecer as condições de produção do Açúcar nas Antilhas e compará-las com o Brasil, demonstraria porque os movimentos de independência começaram primeiro no Brasil quando comparado àquela região, uma vez que os produtores daquela região não se estabeleceram nela como senhores de engenho. Por fim, na tese sobre o algodão Alice demonstraria que, mesmo que a produção do algodão em São Paulo estivesse ligada às condições do mercado externo, seu declínio se deve também a outros fatores, de ordem técnica e de financiamento. Assim, para Flávio, as três teses, sem realizar grandes excursos, estão preocupadas com o estatuto colonial de cada região tratada. Ademais, a escolha do método, das fontes e do objeto, o autor identifica ao modus operandi dos Annales, através das resenhas de Braudel e Godinho das duas primeiras teses da historiadora.

Por fim, Saes cita os trabalhos de Alice em que a mesma se sentiu segura para alçar "grandes voos" interpretativos, porém sempre alicerçada em "fontes primárias": sua introdução ao livro de Antonil e os dois capítulos presentes na "História Geral da Civilização Brasileira". Cita também seus trabalhos de análise historiográfica e finaliza com o pioneirismo atribuído às suas análises quantitativas sobre a distribuição e estrutura da riqueza em São Paulo. 


\section{Considerações finais}

Na memória disciplinar, Alice Piffer Canabrava é rememorada por suas contribuições à história econômica. Especificamente à uma moderna história econômica, gestada no âmbito da universidade e informada pela teoria econômica e métodos quantitativos. Mas quando tomamos essa mulher como sujeito de uma empreitada como uma tese acadêmica - prefiro aqui o termo sujeito à objeto, uma vez que uma vida também atua sobre aquele que a escreve - constatamos que as contribuições de Alice para o ofício de historiador e para as instituições acadêmicas estão para além daquela área específica.

Como vimos, a atuação e engajamento de Canabrava passam por uma concepção de ciência econômica quando da reformulação do currículo do curso de Ciências Econômicas da FCEA durante o período em que foi diretora; a luta pela permanência da cadeira de História Econômica junto à essa faculdade, o que propiciou o fortalecimento da "equipe de história" com a produção de dissertações e teses orientadas privilegiando os métodos quantitativos e uma interpretação de Brasil à partir de São Paulo tributária da mobilização desses mesmos métodos.

Além de sua produção em história econômica e do cuidado na formação daqueles que iriam consolidar seu legado na FCEA após seu desaparecimento, Alice Canabrava esteve engajada na consolidação da APUH/ANPUH, não somente em termos institucionais, mas também batalhando para que essa comunidade de historiadores estivesse ligada à uma epistemologia histórica específica. A partir dessa concepção pudemos localizar em Alice uma identidade historiadora. Ao lado desse empreendimento, surge um "filho", a Revista Brasileira de História, importante canal de divulgação da produção historiográfica profissional.

Outra instituição na qual nossa historiadora esteve inserida é o IEB/USP que se tornaria referência mundial em estudos sobre Brasil, principalmente pela riqueza de seus acervos pessoais. A consolidação dessa instituição esteve ligada à sua atuação junto a seu conselho administrativo. Nesse lugar social ocorreu o EIEB. I SEB nos quais se discutiram as várias áreas integrantes do IEB naquele momento e outras que foram incorporadas ao evento. Destacamos o papel de Canabrava na elaboração do trabalhobase para as discussões da área de História e como a partir de seus debates estava em disputa uma concepção de história da historiografia. 
Uma trajetória intelectual também comporta uma vida. Assim, refletimos, a partir da relação de Alice com o outro e com o próximo, como a historiadora concebia a si mesma; que sujeito seu arquivo pessoal nos deixa ver e como seus colegas e amigos inventaram uma Alice para si. Ademais, nos preocupamos também com as manipulações da memória da historiadora após seu desaparecimento, qual Alice Piffer Canabrava cada uma delas quis forjar. Problema no qual essa tese também se insere.

Chama-nos atenção nesse momento para a continuidade das manipulações da memória da historiadora por um grupo particular de economistas vinculados ao Insper em São Paulo. No dia 15/08/2018 realizou-se nessa instituição um evento em homenagem à Alice Canabrava com as presenças de Antonio Delfim Netto, Samuel Pessôa e Francisco Vidal Luna. Deixando de lado várias imprecisões sobre a trajetória intelectual da historiadora e sua obra, destacamos as tentativas de vincular Alice à figura de Delfim Netto, principalmente em relação à sua suposta contribuição na tese do economista sobre o problema do café no Brasil ${ }^{1025}$.

Dias depois, em matéria veiculada no jornal Folha de S. Paulo, Marcos Lisboa, presidente do Insper, comenta sobre algumas mulheres que sofreram preconceitos no exercício de sua profissão, dentre elas Alice Canabrava. Destaca o episódio do concurso e também vincula a historiadora à Delfim Netto. "A magistral tese de doutorado de Delfim Netto deve muito a Canabrava"1026.

Aqui é necessário, como nos convoca Paul Ricoeur, fazer a justa memória. Não há nenhum indício de que Alice tenha colaborado com a tese de Delfim Netto, uma vez que o mesmo não foi seu assistente de pesquisa e/ou orientando. Essa operação de homens brancos privilegiados em tentar vincular Alice àquele que tem as mãos sujas de sangue, é mais um ato de violência simbólica semelhante àqueles que a historiadora sofreu durante sua vida e que Marcos Lisboa reproduz em seu artigo com o paradoxal título "preconceito".

Ao tratar de Alice Canabrava problematizamos os caminhos pelos quais a profissionalização do ofício de historiador no Brasil se inicia e se consolida, destacando também o que significa ser mulher nesse processo. Assim, inspirados nos procedimentos da história intelectual, da história da historiografia e da sociologia dos intelectuais,

${ }^{1025}$ Para assistir ao evento online, ver: <https://www.insper.edu.br/agenda-de-eventos/alice-canabravahomenagem-insper/>. Acessado em 05 de out. 2019.

${ }^{1026}$ LISBOA, Marcos. Preconceito. Folha de S. Paulo. 26/08/2018. A2, Opinião. 
esperamos ter contribuído para os estudos que nesse momento de nossa disciplina estão tomando as historiadoras como sujeito de reflexão. Mesmo sendo escassos - o nosso é a terceira tese que trata de historiadoras - esperamos também poder inspirar outros a trazer à lume os problemas do ofício quando exercido por mulheres.

Conviver com uma mulher como Alice Canabrava por tanto tempo também teve seus impactos sobre minha vida e meu ofício, principalmente no trato com sua correspondência privada, algo tão íntimo e marcado pelo corpo. A dedicação total ao ofício, a preocupação com a formação de seus alunos e orientandos trazem todo um ethos profissional que sem dúvida me serve de inspiração no exercício da profissão, bem como a postura ética ao manejar os mais diversos conflitos. De certa forma, historiar uma vida, também é historiar a si mesmo... 


\section{FONTES}

\section{Obras de autoria de Alice Piffer Canabrava}

\section{Livros, prefácios e capítulos de livro}

O Comércio Português no rio da Prata (1580-1640) (1942). São Paulo: Faculdade de Filosofia, Ciências e Letras. Boletim XXXV. História da Civilização Americana. N. 2, 1944.

O Açúcar nas Antilhas (1697-1755) (1946). $2^{\circ}$ edição. São Paulo: Instituto de Pesquisas Econômicas, 1981.

História. Obras Gerais. In: MORAES, Rubens Borba de; BERRIEN, Willian (dirs.). Manual Bibliográfico de Estudos Brasileiros. Rio de Janeiro: SOUZA, 1949, p. 379-386.

História. Período Colonial. In: MORAES, Rubens Borba de; BERRIEN, Willian (dirs.). Manual Bibliográfico de Estudos Brasileiros. Rio de Janeiro: SOUZA, 1949, p. 401-407.

Independência. Primeiro Reinado. Regência. In: MORAES, Rubens Borba de; BERRIEN, Willian (dirs.). Manual Bibliográfico de Estudos Brasileiros. Rio de Janeiro: SOUZA, 1949, p. 424-432.

Segundo Reinado. In: MORAES, Rubens Borba de; BERRIEN, Willian (dirs.). Manual Bibliográfico de Estudos Brasileiros. Rio de Janeiro: SOUZA, 1949, p. 440-446.

República. In: MORAES, Rubens Borba de; BERRIEN, Willian (dirs.). Manual Bibliográfico de Estudos Brasileiros. Rio de Janeiro: SOUZA, 1949, p. 458-491.

Prefácio. In: Bandeirantes no Paraguai. Século XVII. Documentos Inéditos. São Paulo: Divisão do Arquivo Histórico do Departamento de Cultura da Prefeitura do Município de São Paulo, 1949a, p. VIII-XVI.

O Desenvolvimento da Cultura do Algodão na Província de São Paulo (1861-1875) (1951). $3^{\circ}$ edição. São Paulo: EDUSP; ANPUH, 2011.

A Grande Propriedade Rural. In: HOLANDA, Sérgio Buarque de. (dir.). História Geral da Civilização Brasileira. Época Colonial: Administração, Economia, Sociedade. t. I, v. 2. São Paulo: Difusão européia do livro, 1960, p. 192-217.

João Antonio Andreoni e sua obra. In: ANTONIL, André João. Cultura e Opulência do Brasil por suas drogas e minas. São Paulo: Companhia Editora Nacional, 1967.

Esboço da História Econômica de São Paulo. In: BRUNO, Ernani Silva (org.). São Paulo: Terra e Povo. Porto Alegre: Editora Globo, 1967a, p. 19-46. 
A Grande Lavoura. In: HOLANDA, Sérgio Buarque de. (dir.). História Geral da Civilização Brasileira. O Brasil Monárquico: Declínio e Queda do Império. t. II, v. 4. São Paulo: Difusão européia do livro, 1971, p. 85-137.

Terras e Escravos. In: PELÁEZ, Carlos Manuel; BUESCU, Mircea (coords.). A Moderna História Econômica. Rio de Janeiro: APEC, 1976, p. 13-26.

Prefácio. In: SAES, Flávio Azevedo Marques de. As ferrovias de São Paulo, 1870-1940. São Paulo: HUCITEC, 1981, p. 7-11.

Apresentação. In: MELLO, Zélia Maria Cardoso. Metamorfoses da riqueza. São Paulo, 1845-1895. São Paulo: HUCITEC, 1985, p. 13-17.

As condições sociais, econômicas e políticas da fundação. In: CANABRAVA, Alice Piffer (org. coord.). História da Faculdade de Economia e Administração da Universidade de São Paulo, 1946-1981. V. 1: A Instituição. São Paulo: FEA/USP, 1984, p. 7-33.

História Econômica: estudos e pesquisas. São Paulo: Hucitec; Unesp; ABPHE, 2005.

\section{Artigos}

A Região de Piracicaba. Revista do Arquivo Municipal. São Paulo, vol. 45, p. 275-328, 1938.

Primeiras notas para um estudo acerca dos bairros no estado de São Paulo. Anais do IX Congresso Brasileiro de Geografia. Rio de Janeiro, vol. III, p. 650-652, 1944a.

Ensaio Bibliográfico sobre as Bandeiras. Boletim Bibliográfico. São Paulo, Biblioteca Municipal de São Paulo, vol. V, p. 7-20, 1944 b.

Ensaio Bibliográfico sobre as Bandeiras. Boletim Bibliográfico. São Paulo, Biblioteca Municipal de São Paulo, vol. VIII, p. 33-84, 1945.

O Direito de Cidadania dos Portugueses na América Espanhola. Sociologia, vol. VIII, n. 1, p. 1-23, 1946.

Tendência da bibliografia sobre a História Administrativa do Município. Revista de Administração. São Paulo, n. 1, p. 80-87, 1947.

As Fontes primárias para o estudo da Moeda e do Crédito em São Paulo no século XVI (1948). In: CANABRAVA, Alice Piffer. História Econômica: estudos e pesquisas. São Paulo: Hucitec; Unesp; ABPHE, 2005, p. 285-300.

A influência do Brasil na Técnica do Fabrico do Açúcar nas Antilhas Francesas e Inglesas no meado do século XVII. In: Anuário da Faculdade de Ciências Econômicas e Administrativas (1946-1947). São Paulo: USP; Faculdade de Ciências Econômicas e Administrativas, p. 63-76, 1948. 
A Evolução das posturas municipais de Sant'Ana de Parnaíba, 1829-1867. Revista de Administração. São Paulo, n. 9, p. 34-62, 1949.

A Administração Municipal de Sant'Ana de Parnaíba nos anos de 1829-1867. Revista de Administração. São Paulo: Instituto de Administração, ns. 11-12, p. 3-83, 1949b

Documentos sobre os índios do rio Juquiá. Revista do Museu Paulista. São Paulo, vol. III, p. 391-404, 1949c.

Um desembarque clandestino de escravos em Cananea, SP. Revista de História. São Paulo, n. 4, p. 559-562, 1950.

Os contratos de trabalho e os índios da Província de S. Paulo, 1853. Revista do Museu Paulista. São Paulo, vol. IV, p. 433-438, 1950a.

A força motriz: um problema da técnica da indústria do açúcar colonial (A solução antilhana e a brasileira). Anais do primeiro congresso de História da Bahia. Salvador: tipografia beneditina Ltda, v. IV, p. 337-350, 1950 b.

A lavoura canavieira nas Antilhas e no Brasil (primeira metade do século XVIII). Anais do primeiro congresso de História da Bahia. Salvador: tipografia beneditina Ltda, v. IV, p. 351-387, 1950b.

Um capítulo da História das técnicas no Brasil: o emprego do bagaço de cana como combustível dos engenhos (1949). Anais IV Congresso de História Nacional. Rio de Janeiro: Imprensa Nacional, v. 11, p. 459-471, 1950c.

As chácaras paulistanas. Anais da Associação dos Geógrafos Brasileiros, v. IV, t. 1, 1949-1950, São Paulo, p. 95-104, 1953.

Tema - III. O estudo da História da América e da História do Brasil no curso universitário: ensino tradicional e renovação. Anais do I Simpósio de Professores de História do Ensino Superior. Marília: FFCL, p. 119-139, 1962.

Manufaturas e indústrias no período de D. João VI no Brasil (1963). In: CANABRAVA, Alice Piffer. História Econômica: estudos e pesquisas. São Paulo: Hucitec; Unesp; ABPHE, 2005, p. 85-101.

Apontamentos sobre Varnhagen e Capistrano de Abreu. Revista de História. São Paulo, n. 88, p. 417-424, 1971.

CANABRAVA, Alice Piffer. Roteiro sucinto do desenvolvimento da historiografia brasileira. In: CANABRAVA, Alice Piffer; LUZ, Nícia Villela; MAURO, José Eduardo Marques. Introdução ao estudo da história do Brasil. São Paulo: IEB/USP, 1971a.

Roteiro sucinto do desenvolvimento da historiografia brasileira. In: CANABRAVA, Alice Piffer; HOLANDA, Sérgio Buarque de; LUZ, Nicia Vilela. Anais Encontro 
Internacional de Estudos Brasileiros. I Seminário de Estudos Brasileiros. São Paulo: Universidade de São Paulo/Instituto de Estudos Brasileiros, p. 4-9, 1972.

Uma Economia de Decadência: Os níveis de Riqueza na Capitania de São Paulo, 17651767. Revista Brasileira de Economia. Rio de Janeiro, v. 26, n. 4, p. 193-221, 1972a.

A Repartição da Terra na Capitania de São Paulo, 1818. Estudos Econômicos. São Paulo, v. 2 , n. 6 , p. $77-129,1972$ b.

Discurso da professora Alice Piffer Canabrava, $1^{\circ}$ secretária da ANPUH. Anais do VI Simpósio de Professores Universitários de História. Trabalho livre e trabalho escravo. São Paulo: FFLCH/USP, v. 1, 1973, p. 85-91.

Decadência e Riqueza. Revista de História. São Paulo, n. 100, p. 335-366, 1974.

Terras e escravos na Grande Lavoura paulista. Anais do VIII Simpósio dos Professores Universitários de História. A propriedade rural. São Paulo: FFLCH/USP, v. 1, p. 889898, 1976.

Nota explicativa. Anais do IX Simpósio dos Professores Universitários de História. O Homem e a técnica. São Paulo: FFLCH/USP, v. 1, p. 5-9, 1979.

O conceito de Indústria (primeira metade do século XIX). Anais do IX Simpósio dos Professores Universitários de História. O Homem e a técnica. São Paulo: FFLCH/USP, v. 2, p. 421-424, 1979.

Uma fazenda-modelo na Província de São Paulo (1863). Anais do IX Simpósio dos Professores Universitários de História. O Homem e a técnica. São Paulo: FFLCH/USP, v. 4, p. 1173-1213, 1979

Varnhagen, Martius e Capistrano de Abreu (1980). In: CANABRAVA, Alice Piffer. História Econômica: estudos e pesquisas. São Paulo: Hucitec; Unesp; ABPHE, 2005, p. 245-270.

A Associação dos Professores Universitários de História. Revista Brasileira de História. São Paulo, v. 1, n. 1, 1981 b.

História e Economia (1985). In: CANABRAVA, Alice Piffer. História Econômica: estudos e pesquisas. São Paulo: Hucitec; Unesp; ABPHE, 2005, p. 271-283.

\section{Depoimento e entrevistas}

Entrevista. Projeto Estudos Brasileiros. MIS/SP, 1981. 00035EBR00026AD (Estudos brasileiros rolo 116.27 A-0150).

Alice Piffer Canabrava: historiadora (1984). In: BLAY, Eva Alterman; LANG, Alice Beatriz da Silva Gordo (orgas.). Mulheres na USP: horizontes que se abrem. São Paulo: Associação Editorial Humanitas, 2004. 
Minhas Reminiscências. Economia aplicada, São Paulo, v. 1, n. 1, p. 157-163, 1997.

\section{Correspondência recebida}

CANABRAVA, Clementina. Carta a Alice Piffer Canabrava. São Paulo, 01 dez. 1977. Fundo Alice Piffer Canabrava. Arquivo IEB/USP. APC-CANA-003.

DANTAS, Hélio. Carta a Alice Piffer Canabrava. Natal, 08 abr. 1970. Fundo Alice Piffer Canabrava. Arquivo IEB/USP. APC-DANT-001.

GRAHAM, Richard. Carta a Alice Piffer Canabrava. Austin, 10 dez. 1970. Fundo Alice Piffer Canabrava. Arquivo IEB/USP. APC-GRAH-001.

IGLÉSIAS, Francisco. Carta a Alice Piffer Canabrava. Belo Horizonte, 28 jun. 1960. Fundo Alice Piffer Canabrava. Arquivo IEB/USP. APC-CP-P1, 1-(1).

Carta a Alice Piffer Canabrava. Belo Horizonte, 01 dez. 1965. Acervo Francisco Iglésias. IMS/RJ. FI-C-CA.

Carta a Alice Piffer Canabrava. Belo Horizonte, 20 jun. 1966. Fundo Alice Piffer Canabrava. Arquivo IEB/USP. APC-CP-P1,2-(1).

. Carta a Alice Piffer Canabrava. Belo Horizonte, 25 mar. 1967. Fundo Alice Piffer

Canabrava. Arquivo IEB/USP. APC-CP-P1,4-(1).

. Carta a Alice Piffer Canabrava. Belo Horizonte, 06 dez. 1971. Fundo Alice Piffer Canabrava. Arquivo IEB/USP. APC-CP-P1,5-(2).

. Carta a Alice Piffer Canabrava. Belo Horizonte, 24 mar. 1972. Fundo Alice Piffer Canabrava. Arquivo IEB/USP. APC-CP-P1, 7-(1).

. Carta a Alice Piffer Canabrava. Belo Horizonte, 18 ago. 1974. Fundo Alice Piffer Canabrava. Arquivo IEB/USP. APC-CP-P1, 8-(2).

. Carta a Alice Piffer Canabrava. Belo Horizonte, 23 mar. 1975. Fundo Alice Piffer Canabrava. Arquivo IEB/USP. APC-CP-P1, 10-(3).

. Carta a Alice Piffer Canabrava. Belo Horizonte, 31 jan. 1978. Fundo Alice Piffer Canabrava. Arquivo IEB/USP. APC-CP-P1, 12-(1).

Carta a Alice Piffer Canabrava. Belo Horizonte, 26 abr. 1978. Fundo Alice Piffer Canabrava. Arquivo IEB/USP. APC-CP-P1,16(2).

. Carta a Alice Piffer Canabrava. Belo Horizonte, 03 fev. 1979. Fundo Alice Piffer Canabrava. Arquivo IEB/USP. APC-CP-P1,17-(1).

Carta a Alice Piffer Canabrava. Belo Horizonte, abr. 1979. Fundo Alice Piffer Canabrava. Arquivo IEB/USP. APC-CP-P1,18-(1). 
. Carta a Alice Piffer Canabrava. Belo Horizonte, 25 jan. 1980. Fundo Alice Piffer Canabrava. Arquivo IEB/USP. APC-CP-P1,19-(1).

. Carta a Alice Piffer Canabrava. Belo Horizonte, 23 set. 1980. Fundo Alice Piffer Canabrava. Arquivo IEB/USP. APC-CP-P1,20-(1).

. Carta a Alice Piffer Canabrava. Belo Horizonte, 04 mar. 1982. Fundo Alice Piffer Canabrava. Arquivo IEB/USP. APC-CP-P2, 6-(1).

. Carta a Alice Piffer Canabrava. Belo Horizonte, 24 abr. 1982. Fundo Alice Piffer Canabrava. Arquivo IEB/USP. APC-CP-P2, 10-(2).

. Carta a Alice Piffer Canabrava. Belo Horizonte, 16 jan. 1984. Fundo Alice Piffer Canabrava. Arquivo IEB/USP. APC-CP-P2, 15-(2).

. Carta a Alice Piffer Canabrava. Belo Horizonte, 21 jun. 1987. Fundo Alice Piffer Canabrava. Arquivo IEB/USP. APC-CP-P2, 26-(1).

MATTOSO, Kátia. Carta a Alice Piffer Canabrava. Salvador, 30 set. 1974. Fundo Alice Piffer Canabrava. Arquivo IEB/USP. APC-MATT-002.

. Carta a Alice Piffer Canabrava. Salvador, 11 out. 1974. Fundo Alice Piffer Canabrava. Arquivo IEB/USP. APC-MATT-004.

Carta a Alice Piffer Canabrava. Salvador, 10 nov. 1974. Fundo Alice Piffer Canabrava. Arquivo IEB/USP. APC-MATT-005.

Carta a Alice Piffer Canabrava. Salvador, 13 nov. 1974. Fundo Alice Piffer Canabrava. Arquivo IEB/USP. APC-MATT-007.

MELLO, Zélia Maria Cardoso de. Carta a Alice Piffer Canabrava. Londres, 27 jan. 1982. Fundo Alice Piffer Canabrava. Arquivo IEB/USP. APC-MELL-010.

MONTEIRO, Norma de Góes. Carta a Alice Piffer Canabrava. Rio de Janeiro, 12 de mar. 1985. Fundo Alice Piffer Canabrava. Arquivo IEB/USP. APC-MONT-004.

. Carta a Alice Piffer Canabrava. Belo Horizonte, 24 de out. 1974. Fundo Alice Piffer Canabrava. Arquivo IEB/USP. APC-MONT-001.

MUNIZ BARRETO, Antonio Emilio. Carta a Alice Piffer Canabrava. Buenos Aires, 25 mai. 1970. Fundo Alice Piffer Canabrava. Arquivo IEB/USP. APC-CP-P4, 1-(2).

Carta a Alice Piffer Canabrava. Buenos Aires, 27 jan. 1972. Fundo Alice Piffer Canabrava. Arquivo IEB/USP. APC-CP-P4, 4-(4).

. Carta a Alice Piffer Canabrava. Buenos Aires, 10 ago. 1973. Fundo Alice Piffer Canabrava. Arquivo IEB/USP. APC-CP-P4, 5-(2). 
. Carta a Alice Piffer Canabrava. El Callejón, 26 dez. 1977. Fundo Alice Piffer Canabrava. Arquivo IEB/USP. APC-CP-P4, 6-(3).

. Carta a Alice Piffer Canabrava. El Callejon, 18 mai. 1981. Fundo Alice Piffer Canabrava. Arquivo IEB/USP. APC-CP-P4, 8-(3).

Carta a Alice Piffer Canabrava. Buenos Aires, 20 jul. 1981. Fundo Alice Piffer Canabrava. Arquivo IEB/USP. APC-CP-P4, 9-(2).

Carta a Alice Piffer Canabrava. El Callejón, 10 set. 1982. Fundo Alice Piffer Canabrava. Arquivo IEB/USP. APC-CP-P4, 12-(2).

PICCOLO, Helga Iracema Landgraf. Carta a Alice Piffer Canabrava, Porto Alegre, 18 mar. 1974. Fundo Alice Piffer Canabrava. Arquivo IEB/USP. APC-PICC-001.

. Carta a Alice Piffer Canabrava, Porto Alegre, 06 jan. 1975. Fundo Alice Piffer Canabrava. Arquivo IEB/USP. APC-PICC-002.

. Carta a Alice Piffer Canabrava, Porto Alegre, 24 ago. 1981. Fundo Alice Piffer Canabrava. Arquivo IEB/USP. APC-PICC-006.

RIBEIRO, Daniel Valle. Carta a Alice Piffer Canabrava. Belo Horizonte, 26 jun. 1973. Fundo Alice Piffer Canabrava. Arquivo IEB/USP. APC-RIBE-001.

SANTOS, Ronaldo Marcos dos. Carta a Alice Piffer Canabrava. Paris, 25 mar. 1974. Fundo Alice Piffer Canabrava. Arquivo IEB/USP. APC-SANT-001.

Carta a Alice Piffer Canabrava. Paris, 24 jan. 1975. Fundo Alice Piffer Canabrava. Arquivo IEB/USP. APC-SANT-003.

SCHELlENBERG, Hans Bruno. Carta a Alice Piffer Canabrava. Aachen, 14 jan. 1976. Fundo Alice Piffer Canabrava. Arquivo IEB/USP. APC-SCHE-002.

TAVARES, Luís Henrique Dias. Carta a Alice Piffer Canabrava. Salvador, 21 jun. 1974. Fundo Alice Piffer Canabrava. Arquivo IEB/USP. APC-TAVA-001.

TORRES, Maria Celestina Teixeira Mendes. Carta a Alice Piffer Canabrava. Piracicaba, 04 mar. 1987. Fundo Alice Piffer Canabrava. Arquivo IEB/USP. APC-TORR-007.

Carta a Alice Piffer Canabrava. Piracicaba, 10 nov. 1987. Fundo Alice Piffer Canabrava. Arquivo IEB/USP. APC-TORR-010.

. Carta a Alice Piffer Canabrava. Piracicaba, 02 mar. 1988. Fundo Alice Piffer Canabrava. Arquivo IEB/USP. APC-TORR-011.

Carta a Alice Piffer Canabrava. Piracicaba, 25 jun. 1988. Fundo Alice Piffer Canabrava. Arquivo IEB/USP. APC-TORR-012. 
. Carta a Alice Piffer Canabrava. Piracicaba, 27 ago. 1988. Fundo Alice Piffer Canabrava. Arquivo IEB/USP. APC-TORR-014.

. Carta a Alice Piffer Canabrava. Piracicaba, 09 dez. 1991. Fundo Alice Piffer Canabrava. Arquivo IEB/USP. APC-TORR-016.

\section{Correspondência enviada}

CANABRAVA, Alice Piffer. Carta a Aidyl Ferreira de Carvalho Preis. São Paulo, 06 abr. 1979. Fundo Alice Piffer Canabrava. Arquivo IEB/USP. APC-PREI-002.

. Carta a Aidyl Ferreira de Carvalho Preis. São Paulo, 09 abr. 1979. Fundo Alice Piffer Canabrava. Arquivo IEB/USP. APC-PREI-005.

. Carta a Aidyl Ferreira de Carvalho Preis. São Paulo, 21 mai. 1981. Fundo Alice Piffer Canabrava. Arquivo IEB/USP. APC-PREI-001.

. Carta a Cid José Teixeira Cavalcante. São Paulo, 16 abr. 1982. Fundo Alice Piffer Canabrava. Arquivo IEB/USP. APC-CAVA-001.

. Carta a Cid José Teixeira Cavalcante. São Paulo, 27 out. 1983. Fundo Alice Piffer Canabrava. Arquivo IEB/USP. APC-CAVA-002.

. Carta a Antonio Emilio Muniz Barreto. São Paulo, 27 ago. 1970. Fundo Alice Piffer Canabrava. Arquivo IEB/USP. APC-CP-P4, 2-(4).

. Carta a Antonio Emilio Muniz Barreto. São Paulo, 16 ago. 1981. Fundo Alice Piffer Canabrava. Arquivo IEB/USP. APC-CA-P4, 10-(4).

. Carta a Antonio Emilio Muniz Barreto. São Paulo, 15 ago. 1982. Fundo Alice Piffer Canabrava. Arquivo IEB/USP. APC-CA-P4, 11-(2).

. Carta a Antonio Emilio Muniz Barreto. São Paulo, 01 nov. 1982. Fundo Alice Piffer Canabrava. Arquivo IEB/USP. APC-CA-P4, 13-(4).

. Carta a Antonio Emilio Muniz Barreto. São Paulo, 26 out. 1983. Fundo Alice Piffer Canabrava. Arquivo IEB/USP. APC-CA-P4, 14-(6).

. Carta a Antonio Emilio Muniz Barreto. São Paulo, 29 dez. 1983. Fundo Alice Piffer Canabrava. Arquivo IEB/USP. APC-CA-P4, 15-(2).

. Carta a Antonio Emilio Muniz Barreto. São Paulo, 01 jul. 1984. Fundo Alice Piffer Canabrava. Arquivo IEB/USP. APC-Ca-P2, 16-(2).

. Carta a Helga Iracema Landgraf Piccolo. São Paulo, 19 ago. 1981. Fundo Alice Piffer Canabrava. Arquivo IEB/USP. APC-PICC-005. 
. Carta a Helga Iracema Landgraf Piccolo. São Paulo, 17 out. 1981. Fundo Alice Piffer Canabrava. Arquivo IEB/USP. APC-PICC-007.

. Carta a Akihiro Ikeda. São Paulo, 14 nov. 1982. Fundo Alice Piffer Canabrava. Arquivo IEB/USP. APC-IKED-001.

. Carta a Akihiro Ikeda. s/d. Fundo Alice Piffer Canabrava. Arquivo IEB/USP. APCIKED-002.

Carta a Antônio Carlos da Ressurreição Xavier. São Paulo, 20 ago. 1982. Fundo Alice Piffer Canabrava. Arquivo IEB/USP. APC-XAVI-001.

. Carta a Benedito Heloiz Nascimento. São Paulo, 12 nov. 1982. Fundo Alice Piffer Canabrava. Arquivo IEB/USP. APC-NASC-001.

. Carta a Benedito Heloiz Nascimento. São Paulo, 27 nov. 1982. Fundo Alice Piffer Canabrava. Arquivo IEB/USP. APC-NASC-002.

. Carta a Benedito Heloiz Nascimento. São Paulo, 08 abr. 1983. Fundo Alice Piffer Canabrava. Arquivo IEB/USP. APC-NASC-003.

. Carta a Carlos Viacava. São Paulo, 23 ago. 1982. Fundo Alice Piffer Canabrava. Arquivo IEB/USP. APC-VIAC-001.

. Carta a Célia Freire D’Aquino Fonseca. São Paulo, 22 de abr. 1981. Fundo Alice Piffer Canabrava. Arquivo IEB/USP. APC-FONS-001.

. Carta a Estella Ferraz Costa Negraes. São Paulo, 12 nov. 1982. Fundo Alice Piffer Canabrava. Arquivo IEB/USP. APC-NEGR-001.

. Carta a Francisco Iglésias. São Paulo, 14 jun. 1954. Acervo Francisco Iglésias. IMS/RJ. FI-C-CP (062).

. Carta a Francisco Iglésias. São Paulo, 17 fev. 1956. Acervo Francisco Iglésias.

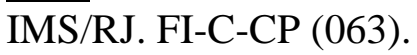

. Carta a Francisco Iglésias. São Paulo, 13 nov.1962. Acervo Francisco Iglésias. IMS/RJ. FI-C-CP (068).

Carta a Francisco Iglésias. São Paulo, 02 jan. 1963. Acervo Francisco Iglésias. IMS/RJ. FI-C-CP (070).

. Carta a Francisco Iglésias. São Paulo, 24 jun. 1963. Acervo Francisco Iglésias. IMS/RJ. FI-C-CP (071).

. Carta a Francisco Iglésias. São Paulo, 01 mai.1966. Acervo Francisco Iglésias. IMS/RJ. FI-C-CP (088). 
. Carta a Francisco Iglésias. São Paulo, 06 ago. 1966. Acervo Francisco Iglésias. IMS/RJ. FI-C-CP (072).

. Carta a Francisco Iglésias. São Paulo, 11 dez. 1966. Acervo Francisco Iglésias. IMS/RJ. FI-C-CP (075).

Carta a Francisco Iglésias. São Paulo, 02 abr. 1967. Acervo Francisco Iglésias. IMS/RJ. FI-C-CP (076).

. Carta a Francisco Iglésias. São Paulo, 17 jun. 1967. Acervo Francisco Iglésias. IMS/RJ. FI-C-CP (078).

. Carta a Francisco Iglésias. São Paulo, 31 mar. 1968. Acervo Francisco Iglésias. IMS/RJ. FI-C-CP (083).

. Carta a Francisco Iglésias. São Paulo, 21 jun. 1968. Acervo Francisco Iglésias. IMS/RJ. FI-C-CP (085).

Carta a Francisco Iglésias. São Paulo, 22 out. 1972. Acervo Francisco Iglésias. IMS/RJ. FI-C-CP (100).

. Carta a Francisco Iglésias. São Paulo, 03 ago. 1973. Acervo Francisco Iglésias. IMS/RJ. FI-C-CP (103).

. Carta a Francisco Iglésias. São Paulo, 18 ago. 1980. Acervo Francisco Iglésias. IMS/RJ. FI-C-CP (117).

. Carta a Francisco Iglésias. São Paulo, 21 set. 1980. Acervo Francisco Iglésias. IMS/RJ. FI-C-CP (119).

- Carta a Francisco Iglésias. São Paulo, 1981. Fundo Alice Piffer Canabrava. Arquivo IEB/USP. APC-CP-P1, 13(5).

. Carta a Francisco Iglésias. São Paulo, 03 jan. 1981. Acervo Francisco Iglésias. Arquivo IMS/RJ. FI-C-CP (123).

. Carta a Francisco Iglésias. São Paulo, 21 jan. 1981. Acervo Francisco Iglésias. IMS/RJ. FI-C-CP (124).

. Carta a Francisco Iglésias. São Paulo, 04 jun.1981. Acervo Francisco Iglésias. IMS/RJ. FI-C-CP (127).

Carta a Francisco Iglésias. São Paulo, 26 jul. 1981. Fundo Alice Piffer Canabrava. Arquivo IEB/USP. APC-CP-P1,24-(6).

Carta a Francisco Iglésias. São Paulo, 16 ago. 1981. Fundo Alice Piffer Canabrava. Arquivo IEB/USP. APC-CA-P4, 10-(4). 
. Carta a Francisco Iglésias. São Paulo, 17 nov. 1981. Fundo Alice Piffer Canabrava. Arquivo IEB/USP. APC-CP-P1, 27-(2).

. Carta a Francisco Iglésias. São Paulo, 31 dez. 1981. Fundo Alice Piffer Canabrava. Arquivo IEB/USP. APC-CP-P1, 28-(4).

Carta a Franciso Iglésias. São Paulo, 06 jan. 1982. Acervo Francisco Iglésias. IMS/RJ. FI-C-CP (132).

Carta a Francisco Iglésias. São Paulo, 10 mar. 1982. Fundo Alice Piffer Canabrava. Arquivo IEB/USP. APC-Ca-P2, 7-(3).

. Carta a Francisco Iglésias. São Paulo, 29 abr. 1982. Fundo Alice Piffer Canabrava. Arquivo IEB/USP. APC-Ca-P2, 11-(5).

. Carta a Francisco Iglésias. São Paulo, 07 mai. 1982. Acervo Francisco Iglésias. IMS/RJ. FI-C-CP (138).

. Carta a Francisco Iglésias. São Paulo, 01 nov. 1982. Fundo Alice Piffer Canabrava. Arquivo IEB/USP. APC-CA-P4, 13-(4).

. Carta a Francisco Iglésias. São Paulo, 26 set. 1983. Fundo Alice Piffer Canabrava. Arquivo IEB/USP. APC-CA,P2, 13-(2).

. Carta a Francisco Iglésias. São Paulo, 01 jul. 1984. Fundo Alice Piffer Canabrava. Arquivo IEB/USP.APC-Ca-P2, 16-(2).

Carta a Francisco Iglésias. São Paulo 10 fev. 1985. Fundo Alice Piffer Canabrava. Arquivo IEB/USP. APC-Ca-P2, 18-(1).

Carta a Francisco Iglésias. São Paulo, 21 mai. 1985. Fundo Alice Piffer Canabrava. Arquivo IEB/USP. APC-Ca-P2, 19-(3).

. Carta a Frederic Mauro. São Paulo, 6 jun. 1970. Fundo Alice Piffer Canabrava. Arquivo IEB/USP. APC-MAUR-001.

. Carta a George Jekabson. São Paulo, 08 set. 1982. Fundo Alice Piffer Canabrava. Arquivo IEB/USP. APC-JEKA-001.

Carta a George Jekabson. São Paulo, 16 nov. 1982. Fundo Alice Piffer Canabrava. Arquivo IEB/USP. APC-JEKA-002.

. Carta a Gil José Pace. São Paulo, s/d. Fundo Alice Piffer Canabrava. Arquivo IEB/USP. APC-PACE-001.

. Carta a Hans Bruno Schellenberg. São Paulo, 26 jan. 1986. Fundo Alice Piffer Canabrava. Arquivo IEB/USP. APC-SCHE-003. 
. Carta a José Albertino Rodrigues. São Paulo, 20 ago. 1982. Fundo Alice Piffer Canabrava. Arquivo IEB/USP. APC-RODR-001.

. Carta a Maria Celestina Teixeira Mendes Torres. São Paulo, 26 de set. 1983. Fundo Alice Piffer Canabrava. Arquivo IEB/USP. APC-TORR-002.

. Carta a Maria Celestina Teixeira Mendes Torres. São Paulo, 20 de jan. 1985. Fundo Alice Piffer Canabrava. Arquivo IEB/USP. APC-TORR-005.

Carta a Maria Celestina Teixeira Mendes Torres. São Paulo, 03 de abr. 1985. Fundo Alice Piffer Canabrava. Arquivo IEB/USP. APC-TORR-018.

. Carta a Maria Celestina Teixeira Mendes Torres. São Paulo, 26 de jan. 1986. Fundo Alice Piffer Canabrava. Arquivo IEB/USP. APC-TORR-006.

. Carta a Maria Celestina Teixeira Mendes Torres. São Paulo, 21 de ago. 1987. Fundo Alice Piffer Canabrava. Arquivo IEB/USP. APC-TORR-008.

. Carta a Norma de Góes Monteiro. São Paulo, 12 de nov. 1984. Fundo Alice Piffer Canabrava. Arquivo IEB/USP. APC-MONT-002.

. Carta a Norma de Góes Monteiro. São Paulo, 18 de abr. 1985. Fundo Alice Piffer Canabrava. Arquivo IEB/USP. APC-MONT-005.

Carta a Paulo Mendroni. São Paulo, 14 nov. 1982. Fundo Alice Piffer Canabrava. Arquivo IEB/USP. APC-MENDR-001.

Carta a Mirian Moreira Leite. São Paulo, 20 ago. 1982. Fundo Alice Piffer Canabrava. Arquivo IEB/USP. APC-LEIT-001.

Carta a Ruy Ribeiro de Moraes Leme. São Paulo, 08 set. 1982. Fundo Alice Piffer Canabrava. Arquivo IEB/USP. APC-LEME-001.

\section{Correspondência outros}

BRAUDEL, Fernand. Carta ao diretor da FFCL/USP. São Paulo, 16 out. 1937. Fundo Alice Piffer Canabrava. Arquivo IEB/USP. APC-CT-P3, 1(2).

\section{Bilhetes enviados}

CANABRAVA, Alice Piffer. Bilhete a Aidyl Ferreira de Carvalho Preis. São Paulo, 06 de abr. 1979. Fundo Alice Piffer Canabrava. Arquivo IEB/USP. APC-PREI-003.

\section{Anais APUH/ANPUH, Elenco e textos neles contidos ${ }^{1027}$}

\footnotetext{
${ }^{1027}$ Excluímos os textos produzidos como "exposições de simposistas", "respostas às exposições", "últimas intervenções" e "respostas finais", pois a listagem ficaria exaustiva. Eles podem ser encontrados facilmente em cada um dos "Anais".
} 
Anais do I Simpósio de professores de História do ensino superior (1961). Marília: Faculdade de Filosofia, Ciências e Letras, 1962.

Anais do II Simpósio dos Professores Universitários de História (1962). Curitiba: UPR, 1962a.

Anais do III Simpósio dos Professores Universitários de História (1965). São Paulo: FFCL/USP, 1966.

Anais do IV Simpósio Nacional dos Professores Universitários de História (1967). São Paulo: FFCL/USP, 1969.

Anais do V Simpósio Nacional dos Professores Universitários de História (1969). São Paulo: FFLCH/USP, 1971.

Anais do VI Simpósio Nacional dos Professores Universitários de História (1971). São Paulo: FFLCH/USP, 1973.

Anais do VII Simpósio Nacional dos Professores Universitários de História (1973). São Paulo: FFLCH/USP, 1974.

Anais do VIII Simpósio Nacional dos Professores Universitários de História (1975). São Paulo: FFLCH/USP, 1976.

Anais do IX Simpósio Nacional dos Professores Universitários de História (1977). São Paulo: FFLCH/USP, 1979.

Elenco do X Simpósio Nacional dos Professores Universitários de História (1979). São Paulo: ANPUH, 1979.

Elenco do XI Simpósio Nacional dos Professores Universitários de História (1981). São Paulo: ANPUH, 1981.

Elenco do XIII Simpósio Nacional dos Professores Universitários de História (1985). São Paulo: ANPUH, 1985.

BRESCIANI, Maria Stella. Escravos, libertos e imigrantes: estudo sobre a passagem do trabalho escravo para o livre em Campinas e Porto Feliz de 1870 a 1910. Anais do VII Simpósio Nacional dos Professores Universitários de História (1973). São Paulo: FFLCH/USP, 1974, p. 947-949.

CALMON, Pedro. História do Brasil, programa de cultura, consciência e patriotismo. In: Anais do I Simpósio de professores de História do ensino superior (1961). Marília: Faculdade de Filosofia, Ciências e Letras, 1962, p. 35-47.

CANABRAVA, Alice Piffer. Uma perspectiva da formação econômica do Brasil. Anais do VIII Simpósio Nacional dos Professores Universitários de História (1975). São Paulo: FFLCH/USP, 1976, p. 44-45. 
Nota explicativa. Anais do IX Simpósio Nacional dos Professores Universitários de História (1977). São Paulo: FFLCH/USP, 1979, p. 5-9.

CAVALCANTI, Zélia. MARSON, Izabel. MOURA, Sérgio Lobo de. Insurreições liberais: fenômeno urbano? Anais do VII Simpósio Nacional dos Professores Universitários de História (1973). São Paulo: FFLCH/USP, 1974, p. 333-343.

FRANÇA, Eduardo D'Oliveira. Resumo do relatório do prof. Eduardo D'Oliveira França. Anais do I Simpósio de professores de História do ensino superior. Marília: Faculdade de Filosofia, Ciências e Letras, 1962, p. 103-110.

IGLÉSIAS, Francisco. Artesanato, manufatura e indústria. Nota conceitual e tentativa de aplicação no Brasil. In: Anais do III Simpósio dos Professores Universitários de História (1965). São Paulo: FFCL/USP, 1966, p. 105-124.

LAGA, Carl. A especialização. As condições por ela pressupostas e as possibilidades inerentes ao curso de História do Brasil. Anais do I Simpósio de professores de História do ensino superior. Marília: Faculdade de Filosofia, Ciências e Letras, 1962, p. 189-205.

LINHARES, Maria Yedda Leite. O lugar das disciplinas pedagógicas no curso de História. Anais do I Simpósio de professores de História do ensino superior (1961). Marília: Faculdade de Filosofia, Ciências e Letras, 1962.

MARSON, Adalberto. Urbanização e relações cidade-campo na obra de Alberto Torres. Anais do VII Simpósio Nacional dos Professores Universitários de História (1973). São Paulo: FFLCH/USP, 1974, p. 791-803.

MOLLAT, Michel. Pour étude équilibrée d'histoire, recherche et enseignement. In: Anais do I Simpósio de professores de História do ensino superior (1961). Marília: Faculdade de Filosofia, Ciências e Letras, 1962, p. 49-61.

MOTTA, Carlos Guilherme. Mudanças sociais e estruturas mentais no Brasil (17891937). Anais do VII Simpósio Nacional dos Professores Universitários de História (1973). São Paulo: FFLCH/USP, 1974.

MUNIZ BARRETO, Antonio Emílio. A Primeira República. In: Anais do IX Simpósio Nacional dos Professores Universitários de História (1977). São Paulo: FFLCH/USP, 1979, p. 131-132.

PANTALEÃO, Olga. Reestruturação do currículo. Anais do I Simpósio de professores de História do ensino superior (1961). Marília: Faculdade de Filosofia, Ciências e Letras, 1962.

PAULA, Eurípedes Simões de. História Antiga e História Medieval: dois espíritos e duas especializações. Problemas que suscita a sua definição numa só cadeira. Anais do I Simpósio de professores de História do ensino superior. Marília: Faculdade de Filosofia, Ciências e Letras, 1962, p. 81-88. 
- As origens do latifúndio: da 'villa' romana aos engenhos e fazendas do Brasil Colonial. Anais do II Simpósio dos Professores Universitários de História (1962). Curitiba: UPR, 1962a, p. 85-101.

Discurso do Prof. Eurípedes Simões de Paula. Anais do IV Simpósio Nacional dos Professores Universitários de História (1967). São Paulo: FFCL/USP, 1969, p. 49-53.

PAULA, Maria Regina da Cunha Rodrigues Simões de. Relatório sobre o III Simpósio dos Professores Universitários de História. Anais do III Simpósio dos Professores Universitários de História (1965). São Paulo: FFCL/USP, 1966, p. 7-16.

. O IV Simpósio Nacional dos Professores Universitários de História. Anais do IV Simpósio Nacional dos Professores Universitários de História (1967). São Paulo: FFCL/USP, 1969, p. 7-20.

. O V Simpósio Nacional dos Professores Universitários de História. Anais do V Simpósio Nacional dos Professores Universitários de História (1969). São Paulo: FFLCH/USP, 1971, p. 7-23.

A Associação Nacional dos Professores Universitários de História e o VI Simpósio. Anais do VI Simpósio Nacional dos Professores Universitários de História (1971). São Paulo: FFLCH/USP, 1973, p. 7-25.

. Na plataforma nordestina o VIII Simpósio de História (Aracaju/75). Anais do VIII Simpósio Nacional dos Professores Universitários de História (1975). São Paulo: FFLCH/USP, 1976.

IX Simpósio de História. Mudanças Estruturais (Florianópolis, 1977). Anais do IX Simpósio Nacional dos Professores Universitários de História (1977). São Paulo: FFLCH/USP, 1979, p. 13-32.

Programa do IV Simpósio Nacional dos Professores Universitários de História. Anais do IV Simpósio Nacional dos Professores Universitários de História (1967). São Paulo: FFCL/USP, 1969, p. 29-34.

REIS, Arthur Cezar Ferreira. As regiões brasileiras: formação, peculiaridades e integração no nosso processo histórico. Anais do I Simpósio de professores de História do ensino superior (1961). Marília: Faculdade de Filosofia, Ciências e Letras, 1962, p. 63-75.

RIBEIRO, Emília Thereza Alves. Problemas jurídico-sociais do Estado muçulmano, para o cultivo do Iraq, nos primeiros séculos do Islã. Anais do II Simpósio dos Professores Universitários de História (1962). Curitiba: UPR, 1962a, p. 111-124.

SIQUEIRA, Sônia Maria. Artesanato e privilégios. Os artesãos no Santo Ofício no Brasil do século XVIII. Anais do III Simpósio dos Professores Universitários de História (1965). São Paulo: FFCL/USP, 1966, p. 503-522. 
VIANNA, Eremildo Luiz. Matérias complementares e auxiliares: o alargamento do horizonte no estudo da História. Anais do I Simpósio de professores de História do ensino superior. Marília: Faculdade de Filosofia, Ciências e Letras, 1962, p. 141-147.

WESTPHALEN, Cecília Maria. Discurso de instalação do II Simpósio. Anais do II Simpósio dos Professores Universitários de História (1962). Curitiba: UPR, 1962a.

A crise da civilização ocidental. In: Anais do VIII Simpósio Nacional dos Professores Universitários de História (1975). São Paulo: FFLCH/USP, 1976, p. 45-46.

\section{Anuários}

Anuário da Faculdade de Filosofia, Ciências e Letras, 1934-1935. FFCL, USP, São Paulo: Empreza Grafica da "Revista dos Tribunaes", 1937.

Anuário da FFCL.,1936. FFCL, USP, São Paulo: Empreza Grafica da "Revista dos Tribunaes", 1937.

Anuário da FFCL., 1937-1938. FFCL, USP, São Paulo: Empreza Grafica da "Revista dos Tribunaes", 1939.

Anuário da FFCL., 1939-1949. FFCL, USP, São Paulo: Seção Gráfica; Industria Gráfica José Magalhães Ltda., 1953, 2v.

Anuário da Faculdade de Ciências Econômicas e Administrativas, 1946-1947. São Paulo: USP; Faculdade de Ciências Econômicas e Administrativas, 1948.

Anuário da Faculdade de Ciências Econômicas e Administrativas, 1949-1950. São Paulo: USP; Faculdade de Ciências Econômicas e Administrativas, 1950.

Annuario estatístico do Brazil - Vol. 1 (1908/1912) editado pela Directoria Geral de Estatística do Ministério da Agricultura, Indústria e Commércio.

\section{Atas}

Atas. Congregação. São Paulo: FCEA/FEA, v. 1 (1946-1964). Arquivo da assessoria acadêmica da FEA/USP.

Atas do Conselho Universitário da Universitário da Universidade de São Paulo. Vol. 8 (1946-1947). Arquivo da Secretaria Geral. Reitoria da USP.

Atas do Conselho Universitário da Universidade de São Paulo. V. 17 (1954-1955). Arquivo da Secretaria Geral. Reitoria da USP.

Atas do Conselho Universitário da Universidade de São Paulo. V. 19 (1956-1957). Arquivo da Secretaria Geral. Reitoria da USP. 
Atas do Conselho Universitário da Universidade de São Paulo. V. 34 (1968). Arquivo da Secretaria Geral. Reitoria da USP.

Atas do Conselho de Administração do Instituto de Estudos Brasileiros da Universidade de São Paulo. Livro I (1964-1977). Arquivo IEB/USP. Fundo IEB.

Atas do Conselho de Administração do Instituto de Estudos Brasileiros da Universidade de São Paulo. Livro II (1977-1981). Arquivo IEB/USP. Fundo IEB.

Atas do Conselho Deliberativo do Instituto de Estudos Brasileiros da Universidade de São Paulo. Livro III (1981-1989). Arquivo IEB/USP. Fundo IEB.

Ata $128^{\mathrm{a}}$ reunião do Conselho Deliberativo do Instituto de Estudos Brasileiros da Universidade de São Paulo. In: Processo 2003.1.59.31.0.

\section{Depoimentos e entrevistas}

MELlO E SOUZA, Antonio Candido. Entrevista. In: FREITAS, Sonia Maria de. Reminiscências. São Paulo: Maltese, 1993, p. 35-57.

CARDOSO, Fernando Henrique. Entrevista. In: BASTOS, Elide Rugai; ABRUCIO, Fernando; LOUREIRO, Maria Rita; REGO, José Márcio. Conversas com sociólogos brasileiros. São Paulo: Ed. 34, 2006.

LOPES, Juarez Brandão. Entrevista. In: BASTOS, Elide Rugai; ABRUCIO, Fernando; LOUREIRO, Maria Rita; REGO, José Márcio. Conversas com sociólogos brasileiros. São Paulo: Ed. 34, 2006, p. 95-113.

MELlO E SOUZA, Gilda de. Gilda de Mello e Souza: Filósofa. In: BLAY, Eva Alterman; LANG, Alice Beatriz da Silva Gordo (orgas.). Mulheres na USP: horizontes que se abrem. São Paulo: Associação Editorial Humanitas, 2004, p. 61-75.

MOREIRA LEITE, Mírian. Entrevista. In: FREITAS, Sonia Maria de. Reminiscências. São Paulo: Maltese, 1993.

NOVAIS, Fernando. Entrevista. In: MORAES, José Geraldo Vinci de; REGO, José Márcio. Conversas com historiadores brasileiros. São Paulo: Ed. 34, 2002, p. 119-144.

PANTALEÃO, Olga. Olga Pantaleão. Historiadora. In: BLAY, Eva Alterman; LANG, Alice Beatriz da Silva Gordo (orgas.). Mulheres na USP: horizontes que se abrem. São Paulo: Humanitas, 2004, p. 107-115.

SAFFIOTI, Heleieth. Entrevista. In: TRINDADE, Hélgio. Ciências Sociais no Brasil: diálogos com mestres e discípulos. Brasília: Anpocs/Liber Livro Editora, 2012.

TAPAJÓS, Vicente. Entrevista. In: FERREIRA, Marieta de Moraes. A História como ofício: a constituição de um campo disciplinar. Rio de Janeiro: Editora FGV, 2013. 


\section{Jornais}

A Faculdade de Ciências Econômicas e Administrativas de São Paulo. Sindicato dos Economistas no Estado de São Paulo/ Sindicato dos Contabilistas de São Paulo, publicado na seção "Colaboração dos leitores". O Estado de S. Paulo. 14 fev. 1946.

Ao público e aos contabilistas e economistas do Estado de S. Paulo. A propósito da instalação da Faculdade de Ciências Econômicas e Administrativas na Universidade de São Paulo. O Estado de S. Paulo. 26 fev. 1946.

A nomeação de professores para a Faculdade de Ciências Econômicas. $O$ Estado de $S$. Paulo. 24 jul. 1946.

Conferências e Cursos. O Estado de S. Paulo. 16 abr. 1948.

Associação dos Geógrafos Brasileiros. O Estado de São Paulo, 09 dez. 1949.

Conferências e cursos. O Estado de S. Paulo. 01 jun. 1954.

O Conselho de presidentes da União Estadual de Estudantes declara greve geral. $O$ Estado de S. Paulo. 16 set. 1954.

A Faculdade de Ciências Econômicas e Administrativas. O Estado de S. Paulo. 05 nov. 1954.

Termina hoje a greve dos alunos de economia da USP. $O$ Estado de S. Paulo. 19 set. 1956.

Retornam as aulas os estudantes de Ciências Econômicas. $O$ Estado de S. Paulo. 20 set. 1956.

O reitor receberá sábado os grevistas. O Estado de S. Paulo. 21 set. 1956.

Caso velho que se renova. O Estado de S. Paulo. 23 set. 1956.

\section{Processos}

Processo 46.1.325.8.0 (Arquivo da Faculdade de Filosofia, Letras e Ciências Humanas (FFLCH) da USP: concurso para a cátedra de História da Civilização Americana, 1946).

Processo 46.1.126.8.7 (Arquivo da FFLCH da USP: inscrição no concurso para a cadeira de História da Civilização Americana, 1946).

Processo 51.1.12250.1.8 (Arquivo da Reitoria USP: concurso para a cadeira de História Econômica Geral da Faculdade de Ciências Econômicas e Administrativas, USP, 1951).

Processo 2003.1.59.31.0. Doação do acervo Alice Canabrava. IEB/USP. 


\section{Outras fontes}

ARRUDA, José Jobson de Andrade. DECCA, Edgard Salvadori de. SILVA, Marcos Antonio. Aos leitores. In: Noticiário. Revista Brasileira de História. São Paulo, v. 3, n. 6, 1983.

BRUNO, Ernani Silva. Projeto Estudos Brasileiros. Fundo Ernani da Silva Bruno. Arquivo IEB/USP. ESB (46) 1-12.

BRAUDEL, Fernand. Primeiras histórias. USP, 50 anos: Lembranças de um pioneiro francês. Isto É. São Paulo, n. 371, 01 fev. 1984.

BUESCU, Mircea; PELAÉZ, Carlos Manuel (coords.). Apresentação. A moderna história econômica. In: . (coords.). A moderna história econômica. Rio de Janeiro: APEC, 1976, p. 7-9.

Cadeira de História da Civilização Brasileira. In: Noticiário. Revista do Instituto de Estudos Brasileiros. São Paulo, n. 2, 1967, p. 189-193.

Cadeira de Línguas indígenas do Brasil. In: Notícias. Revista do Instituto de Estudos Brasileiros. São Paulo, n. 2, 1967, p. 195-198.

Cadeira de Literatura brasileira. In: Noticiário. Revista do Instituto de Estudos Brasileiros. São Paulo, n. 3, 1968, p. 193-198.

Caderno de matrícula e notas (1926-1930), n. 60. Arquivo Histórico Escola Normal Caetano de Campos (AHECC). Centro de Referência em Educação Mário Covas (CRE). Escola de Formação e Aperfeiçoamento dos Professores (EFAP). Secretária de Educação do Estado de São Paulo (SEE/SP).

Caderno de matrícula e notas (1926-1930), n. 61. AHECC. CRE Mário Covas. EFAP. SEE/SP.

CANABRAVA, Alice Piffer. Certidão de Nascimento. Fundo Alice Piffer Canabrava. Arquivo IEB/USP. APC-IC-001. GIN-001.

Boletim Escolar (1924). Fundo alice Piffer Canabrava. Arquivo IEB/USP. APC. Boletim Escolar (1925). Fundo Alice Piffer Canabrava. Arquivo IEB/USP. APCGIN-002.

. Curriculum Vitae. São Paulo, 22 de fevereiro de 1991.

Catálogo dos sócios fundadores. APUH. São Paulo: Secretaria geral, 1962. Arquivo da ANPUH. 
CASTELLO, José Aderaldo. Regulamento geral do Seminário de Estudos Brasileiros. In: Anais Encontro Internacional de Estudos Brasileiros. I Seminário de Estudos Brasileiros. v. I. São Paulo: Instituto de Estudos Brasileiros, 1972, p. 22-24.

Saudação do coordenador geral. In: Anais Encontro Internacional de Estudos Brasileiros. I Seminário de Estudos Brasileiros. v. I. São Paulo: Instituto de Estudos Brasileiros, 1972, p. 8.

Regulamento geral do Seminário de Estudos Brasileiros. In: Anais Encontro Internacional de Estudos Brasileiros. I Seminário de Estudos Brasileiros. v. I. São Paulo: Instituto de Estudos Brasileiros. v. I, 1972.

CASTRO, Jeanne Berrance de. Considerações a respeito da população preta escrava e livre num período de mudança: 1875-1930. In: Anais Encontro Internacional de Estudos Brasileiros. I Seminário de Estudos Brasileiros. v. II. São Paulo: Instituto de Estudos Brasileiros, 1972, p. 88-98.

PRIMEIRA CIRCULAR: IV SIMPÓSIO - PORTO ALEGRE - 1967. FI-C-CP (073). Acervo Francisco Iglésias. IMS/RJ.

COSTA, Emília Viotti da. Anotações à margem do relatório de história. In: Anais Encontro Internacional de Estudos Brasileiros. I Seminário de Estudos Brasileiros. v. II. São Paulo: Instituto de Estudos Brasileiros, 1972.

COSTA, Iraci Del Nero da. Vila Rica: Mortalidade e morbidade (1799-1801). In: BUESCU, Mircea; PELAÉZ, Carlos Manuel (coords.). Apresentação. A moderna história econômica. In: __ ( (coords.). A moderna história econômica. Rio de Janeiro: APEC, 1976, p. 115-127.

Curso integrado sobre o Recôncavo. In: Noticiário. Revista do Instituto de Estudos Brasileiros. São Paulo, n. 8, 1970, p. 159-160.

Vila Rica: população (1719-1826). São Paulo: IPE/USP, 1979.

Populações Mineiras: Sobre a estrutura populacional de alguns núcleos mineiros no alvorecer do século XIX. São Paulo: IPE/USP, 1981.

Estatutos da Sociedade de Estudos Históricos. In: Noticiário. Revista de História. São Paulo, n. 5, 1951, p. 228-229.

Estatutos da Associação dos Professores Universitários de História. In: Noticiário. Revista de História. São Paulo, n. 50, 1962, p. 568-572.

Faculdade de Filosofia, Letras e Ciências Humanas da Universidade de São Paulo. Relatório do departamento de História. 1970. In: Noticiário. Revista de História. São Paulo, n. 85, 1971.

FREITAS, Sônia Maria. Reminiscências. São Paulo: Maltese, 1993. 
KELLENBEZ, Hermann. Um mercador neerlandês em Lisboa tratando com o Brasil. In: Anais Encontro Internacional de Estudos Brasileiros. I Seminário de Estudos Brasileiros. v. II. São Paulo: Instituto de Estudos Brasileiros, 1972, p. 127-157.

GLEZER, Raquel. A fundação da Revista. In: Noticiário. Revista Brasileira de História. São Paulo, v. 1, n. 1, 1981.

Instituto de Estudos Brasileiros. Regulamento - Histórico - Organização. In: Noticiário. Revista do Instituto de Estudos Brasileiros. São Paulo, n. 1, 1966.

Legislação informatizada. Decreto-lei n. 1.190, de 04 de abril de 1939.

Legislação informatizada. Decreto-lei n. 9.092, de 26 de março de 1946.

Legislação informatizada. Lei n. 2.594, de 08 de setembro de 1955.

LUNA, Francisco Vidal. Minas Gerais: escravos e senhores - análise da estrutura populacional e econômica de alguns centros mineratórios (1718-1804). São Paulo: IPE/USP, 1981.

LUZ, Nícia Villela. Bibliografia. In: CANABRAVA, Alice Piffer; HOLANDA, Sérgio Buarque de; LUZ, Nicia Vilela. Anais Encontro Internacional de Estudos Brasileiros. I Seminário de Estudos Brasileiros. São Paulo: Universidade de São Paulo/Instituto de Estudos Brasileiros, 1971, p. 62-173.

MAURO, Frédéric. Remarques sur quelques sources françaises de l'histoire du Brésil. In: Anais Encontro Internacional de Estudos Brasileiros. I Seminário de Estudos Brasileiros. v. II. São Paulo: Instituto de Estudos Brasileiros, 1972, p. 101-112.

MAURO, José Eduardo Marques. A pesquisa histórica no Brasil. In: CANABRAVA, Alice Piffer; HOLANDA, Sérgio Buarque de; LUZ, Nicia Vilela. Anais Encontro Internacional de Estudos Brasileiros. I Seminário de Estudos Brasileiros. São Paulo: Universidade de São Paulo/Instituto de Estudos Brasileiros, 1971, p. 41-61.

MELlO, Zélia Maria Cardoso de. Metamorfoses da riqueza. São Paulo, 1845-1895. Contribuição ao estudo da passagem da economia mercantil-escravista à economia exportadora capitalista. São Paulo: Hucitec, 1985.

MONBEIG, Pierre. Orientação didática. In: Anuário da Faculdade de Filosofia, Ciências e Letras, 1934-1935, 1937.

MUNIZ BARRETO, Antonio Emilio. Evolução histórica do comércio argentinobrasileiro (1800-1930). 396 f/290 f. 1972. 2v. Programa de Pós-Graduação em Economia (IPE/USP), 1972.

O Comércio: Brasil-Argentina (1867-1930). In: BUESCU, Mircea; PELAÉZ, Carlos Manuel (coords.). A moderna história econômica. Rio de Janeiro: APEC, 1976, p. 49-58. 
MUNIZ BARRETO, Antônio Emílio et alli. História econômica: ensaios. São Paulo: IPE/USP, 1983.

NOZOE, Nelson Hideiki. São Paulo: economia cafeeira e urbanização. Estudo da estrutura tributária e das atividades econômicas na capital paulista (1889-1933). São Paulo: IPE/USP, 1984.

Organização e regulamentos gerais. In: Anais Encontro Internacional de Estudos Brasileiros. I Seminário de Estudos Brasileiros. v. I. São Paulo: Instituto de Estudos Brasileiros, 1972.

O Instituto de Estudos Brasileiros - 1979/81. Revista do Instituto de Estudos Brasileiros. São Paulo, n. 23, 1981, p. 148.

PELAEZ, Carlos Manuel. A note on the state and the future of research on Brazilian Economic History. In: Anais Encontro Internacional de Estudos Brasileiros. I Seminário de Estudos Brasileiros. v. II. São Paulo: Instituto de Estudos Brasileiros, 1972, p. 69-71.

PINHO, Diva Benevides. O departamento de Ciências Econômicas. In: CANABRAVA, Alice Piffer (orga.). História da Faculdade de Economia e Administração da Universidade de São Paulo, 1946/1981. Vol. 1. A instituição. São Paulo: FEA/Associação dos exalunos FEA, 1984.

. Reminiscências da faculdade da Maria Antonia. In: SANTOS, Maria Cecília Loschiavo dos (org.). Maria Antônia: uma rua na contramão. São Paulo: Nobel, 1988.

O tempo revisitado: releitura proustiana de 70 anos como estudante e docente da USP. São Paulo: FUNDACI, 2015.

Projeto da Comissão de Ensino da Faculdade, instituída em decorrência do decreto $\mathrm{n}$. 27.056 de 19/10/1956: para estudar e propor medidas relativas à reestruturação da mesma (1957). In: CANABRAVA, Alice Piffer (orga.). História da Faculdade de Economia e Administração da Universidade de São Paulo, 1946/1981. Vol. 1. A instituição. São Paulo: FEA/Associação dos ex-alunos FEA, 1984, p. 403-412.

"Relação de dissertações Economia FEA/USP". Disponível em: <http://www.fea.usp.br/media/fck/MestEcon.pdf> Acessado em 06 de dez. 2016.

"Relação de teses-Economia FEA/USP". Disponível em: <http://www.fea.usp.br/media/fck/DoutEcon.pdf >. Acessado em 17 de dez. 2016.

Relatório geral das atividades do Instituto de Estudos Brasileiros da Universidade de São Paulo em 1967. In: Noticiário. Revista do Instituto de Estudos Brasileiros. São Paulo, n. $5,1968$.

Relatório geral das atividades do Instituto de Estudos Brasileiros da Universidade de São Paulo em 1968. In: Noticiário. Revista do Instituto de Estudos Brasileiros. São Paulo, n. 6, 1969. 
Relatório geral das atividades do Instituto de Estudos Brasileiros da Universidade de São Paulo em 1969. In: Noticiário. Revista do Instituto de Estudos Brasileiros. São Paulo, n. 8, 1970.

Relatório geral das atividades do Instituto de Estudos Brasileiros da Universidade de São Paulo em 1970. In: Noticiário. Revista do Instituto de Estudos Brasileiros. São Paulo, n. $11,1972$.

Relatório de atividades do Instituto de Estudos Brasileiros da Universidade de São Paulo em 1971. Revista do Instituto de Estudos Brasileiros. São Paulo, n. 12, 1972a, p. 205209.

Relatório de atividades do Instituto de Estudos Brasileiros da Universidade de São Paulo em 1972. Revista do Instituto de Estudos Brasileiros. São Paulo, n. 14, 1973.

Relatório sucinto das atividades do Instituto de Estudos Brasileiros da Universidade de São Paulo em 1973. Revista do Instituto de Estudos Brasileiros. São Paulo, n. 15, 1974.

Relatório sucinto das atividades do Instituto de Estudos Brasileiros da Universidade de São Paulo em 1974. Revista do Instituto de Estudos Brasileiros. São Paulo, n. 17, 1975.

Relatório das atividades do Instituto de Estudos Brasileiros da Universidade de São Paulo em 1975. Revista do Instituto de Estudos Brasileiros. São Paulo, n. 18, 1976.

Relatório das atividades do Instituto de Estudos Brasileiros da Universidade de São Paulo em 1976. Revista do Instituto de Estudos Brasileiros. São Paulo, n. 19, 1977.

Relatório das atividades do Instituto de Estudos Brasileiros da Universidade de São Paulo em 1977. Revista do Instituto de Estudos Brasileiros. São Paulo, n. 21, 1979.

Relatório de atividades do Instituto de Estudos Brasileiros da Universidade de São Paulo em 1978. Revista do Instituto de Estudos Brasileiros. São Paulo, n. 21, 1979.

Regulamento geral do Encontro Internacional de Estudos Brasileiros. In Anais Encontro Internacional de Estudos Brasileiros. I Seminário de Estudos Brasileiros. v. I. São Paulo: Instituto de Estudos Brasileiros, 1972.

Regulamento interno. In: Anais Encontro Internacional de Estudos Brasileiros. I Seminário de Estudos Brasileiros. v. I. São Paulo: Instituto de Estudos Brasileiros, 1972, p. 25-26.

RIBEIRO, Maria da Conceição Martins. A problemática da arquivística nacional. In: Anais Encontro Internacional de Estudos Brasileiros. I Seminário de Estudos Brasileiros. v. II. São Paulo: Instituto de Estudos Brasileiros, 1972, p. 114-124.

SAES, Flávio Azevedo Marques de. Expansão e declínio das ferrovias paulistas: (18701940). In: BUESCU, Mircea; PELAÉZ, Carlos Manuel (coords.). A moderna história econômica. Rio de Janeiro: APEC, 1976, p. 77-85. 
As ferrovias de São Paulo, 1870-1940: expansão e declínio do transporte ferroviário em São Paulo. São Paulo: Hucitec, 1981.

. Alice Piffer Canabrava (1911-2003). In: SAES, Alexandre Macchione. RIBEIRO, Maria Alice Rosa. SAES, Flávio Azevedo Marques de (orgs.). Rumos da história econômica no Brasil: 25 anos da ABPHE. São Paulo: Alameda, 2017, p. 237-261.

SANTOS, Ronaldo Marcos dos. O término do escravismo na Província de São Paulo (1885-1889). 167f. Dissertação. Instituto de Pesquisas Econômicas/USP (Programa de Pós-graduação em Economia), 1972.

Resistência e superação do escravismo na Província de São Paulo (1885-1888). São Paulo: IPE/USP, 1980.

SCARANO, Júlia Maria Leonor. Comentários sobre imigrantes que demandaram uma zona cafeeira. In: Anais Encontro Internacional de Estudos Brasileiros. I Seminário de Estudos Brasileiros. v. II. São Paulo: Instituto de Estudos Brasileiros, 1972, p. 71-83.

SINGER, Paul. Nos arredores da Maria Antônia. In: SANTOS, Maria Cecília Loschiavo dos (org.). Maria Antônia: uma rua na contramão. São Paulo: Nobel, 1988.

TRIGO, Maria Helena Bueno. Espaços e tempos vividos: estudo sobre os códigos de sociabilidade e relações de gênero na Faculdade de Filosofia da USP (1934-1970). 250 f. 1997. Programa de Pós-Graduação em Sociologia (Tese), FFLCH/USP, 1997.

Relatório da direção da Faculdade de Filosofia, Ciências e Letras da Universidade de São Paulo, referente ao ano de 1937. In: Anuário da Faculdade de Filosofia, Ciências e Letras, 1937-1938, 1938, p. 151-154.

\section{BIBLIOGRAFIA}

ABRAHÃO, Maria Helena Menna Barreto; MOROSIN, Marília Costa. Pontifícia Universidade Católica do Rio Grande do Sul (PUC-RS): uma universidade inovadora no contexto da confessionalidade. In: MOROSINI, Marilia (orga.). A universidade no Brasil: concepções e modelos. Brasília: Instituto Nacional de Estudos e Pesquisas Educacionais Anísio Teixeira, 2006, p. 187-199.

ALBERTTI, Luiz Antonio. Apresentação da epistemologia de Paul Veyne: entre a história e a filosofia. 2007. 154 f. Dissertação (Programa de pós-graduação em história e sociedade) - FFCL/UNESP. Assis, 2007.

ALBUQUERQUE JÚNIOR, Durval Muniz de. História: a arte de inventar o passado. Ensaios de teoria da história. Bauru: Edusc, 2007.

Íntimas histórias: a amizade como método de trabalho historiográfico". In: ALBUQUERQUE JÚNIOR, Durval Muniz de. História: a arte de inventar o passado. Ensaios de teoria da história. Bauru: Edusc, 2007, p. 211-217. 
. A dimensão retórica da historiografia. In: LUCA, Tania Regina de; PINSKY, Carla Bassanezi (orgas.). O historiador e suas fontes. São Paulo: Contexto, 2009, p. 223-249.

. O significado das pequenas coisas. História, prosopografia e biografemas. In: AVELAR, Alexandre; BISSO, Benito Schmidt (orgs.). Grafia da vida: reflexões e experiências com a escrita biográfica. São Paulo: Letra e Voz, 2012, p. 16-38.

AB’SÁBER, Aziz Nacib. Pierre Monbeig: a herança intelectual de um geógrafo. Estudos Avançados. São Paulo, p. 221-232, 1994.

AMOROSO, Marta; IUMATTI, Paulo Teixeira. A construção de uma biblioteca na trajetória de Manuel Correia de Andrade. Revista do Instituto de Estudos Brasileiros. São Paulo, n. 60, p. 199-210, 2015.

ANHEZINI, Karina. Um metódico à brasileira: a história da historiografia de Afonso Taunay (1911-1939). São Paulo: UNESP, 2011.

ANTUNES, Charlles da França. A Associação dos Geógrafos Brasileiros (AGB) origens, ideias e transformações: notas de uma história. 2008. 311 f. Tese. (Programa de pós-graduação em Geografia) - IG/UFF, Niterói, 2008.

ARAÚJO, Tarcísio Patricio de; VIANNA, Salvador Teixeira Werneck; ACAMBIRA, Júnior (orgs.). 50 anos de Formação Econômica do Brasil: ensaios sobre a obra clássica de Celso Furtado. Rio de Janeiro: Ipea, 2009.

ARAÚJO, Valdei Lopes de; GUIMARÃES, Lúcia Maria Paschoal. O sistema intelectual brasileiro na correspondência passiva de Jonh Casper Branner. In: GOMES, Angela de Castro Gomes (org.). Escrita de si, escrita da História. $1^{\circ}$ edição. Rio de Janeiro: FGV, 2004, p. 93-109.

ARFUCH, Leonor. Devenires biográficos: la entrevista mediática. In: __ El espacio biográfico. Dilemas de la subjetividade contemporânea. Buenos Aires: Fondo de Cultura Económica, 2010.

ARRAIS, Cristiano. Arnold Toynbee (1889-1975). In: BENTIVOGLIO, Julio; LOPES, Marcos Antônio. A Constituição da História como Ciência. De Ranke a Braudel. Petrópolis: Vozes, 2013.

ARRUDA, José Jobson de Andrade. O Brasil no Comércio Colonial. São Paulo: Ática, 1994.

Alice Canabrava: História e Mito. In: CANABRAVA, Alice Piffer. $O$ Desenvolvimento da Cultura do Algodão na Província de São Paulo (1861-1875). $3^{\circ}$ edição. São Paulo: EDUSP/ANPUH, 2011, p. 9-70.

ARRUDA, Maria Arminda do Nascimento. A construção da sociologia acadêmica no Brasil: Florestan Fernandes e a Escola Paulista. Inter American Review of Bibliography. Washington, v. 44, n. 4, p. 607-636, 1994. 
ARTIÈRES, Philippe. Arquivar-se: a propósito de certas práticas de autoarquivamento. In: TRAVANCAS, Isabel; ROUCHOU, Joëlle; HEYMANN, Luciana. Arquivos pessoais: reflexões multidisciplinares e experiências de pesquisa. Rio de Janeiro: FGV, 2013, p. 45-54.

AYMARD, Maurice. Histoire et comparaison. In: ATSMA, Hartmut; BURGUIÈRE, Andre (dirs.). Marc Bloch aujourd'hui. Histoire comparée \& sciences sociales. Paris: L’École des Hautes Études em Sciences Sociales, 1990.

BARROS, José D'Assunção. Origens da história comparada. A experiência com o comparativismo histórico entre o século XVIII e a primeira metade do século XX. Anos 90. Porto Alegre, v. 14, n. 25, p. 141-173, 2007.

. História comparada - da contribuição de Marc Bloch à constituição de um moderno campo historiográfico. História Social. Campinas, n. 13, p. 7-21, 2007a.

BARROS, José D’Assunção. Arnold Toynbee e a história comparada das civilizações. Biblos. Rio Grande, n. 23, p. 219-229, 2009.

A história serial e história quantitativa no movimento dos Annales. História revista. Goiânia, v. 17, n. 1, p. 203-222, 2012.

BATISTA, Marta Rossetti (coorda.). $A B C$ do IEB: guia geral do acervo. São Paulo: EDUSP, 1997.

Sérgio Buarque de Holanda e o Instituto de Estudos Brasileiros. In: CALDEIRA, João Ricardo de Castro (org.). Perfis buarqueanos: ensaios sobre Sérgio Buarque de Holanda. São Paulo: Fundação Memorial da América Latina/IMESP, 2005, p. 49-55.

BEIGUELMAN, Paula. Formação política do Brasil: teoria e ação no pensamento abolicionista. v. 1. São Paulo: Livraria Pioneira Editora, 1967.

BELLOTTO, Heloísa Liberalli. Da administração à história: ciclo vital dos documentos e função arquivística. In: Arquivos permanentes: tratamento documental. $4^{\mathrm{a}}$ edição. Rio de Janeiro: FGV, 2007, p. 23-34.

. Arquivos pessoais como fonte de pesquisa. In: In: _. Arquivos permanentes: tratamento documental. $4^{\text {a }}$ edição. Rio de Janeiro: FGV, 2007, p. 263-270.

Identificação de fundos. In: In:__ _ Arquivos permanentes: tratamento documental. $4^{\text {a }}$ edição. Rio de Janeiro: FGV, 2007.

Sistemática do arranjo. In: Arquivos permanentes: tratamento documental. $4^{\mathrm{a}}$ edição. Rio de Janeiro: FGV, 2007.

O sentido da descrição documental. In: documental. $4^{\mathrm{a}}$ edição. Rio de Janeiro: FGV, 2007. Arquivos permanentes: tratamento 
O processo da descrição: a norma Isad $(\mathrm{G})$ e os instrumentos de pesquisa. In: . Arquivos permanentes: tratamento documental. $4^{\mathrm{a}}$ edição. Rio de Janeiro: FGV, 2007, p. 180-218.

BENTHIEN, Rafael Faraco. Interdisciplinaridades: latinistas, helenistas e sociólogos em revistas (França, 1898-1920). 367 f. Tese (Programa de Pós-graduação em História Social), FFLCH/USP, 2011.

O que há de impessoal em arquivos pessoais: considerações a partir de uma experiência de pesquisa na França. Vozes, Pretérito e Devir, v. 3, p. 42-57, 2014.

BENTIVOGLIO, Júlio. Revistas de história: objeto privilegiado para se estudar a história da historiografia? In: ARRAIS, Cristiano Alencar; BENTIVOGLIO, Júlio (orgs.). As revistas de história e as dinâmicas do campo historiográfico. Serra: Milfontes, 2017.

BESSA, Karla Adriana Martins. Três nomes, três caminhos: José Honório Rodrigues, Eurípedes Simões de Paula, Alice P. Canabrava e a historiografia brasileira no século XX. História \& Perspectivas. Uberlândia, n. 27/28, 2002/2003.

BITTENCOURT, Feijó. O COMÉRCIO BRASILEIRO NO RIO DA PRATA - 15801640) - por Alice P. Canabrava. Revista do Instituto Histórico e Geográfico Brasileiro. Rio de Janeiro, v. 186, 1945.

BLAY, Eva Alterman; LANG, Alice Beatriz da Silva Gordo. O cenário paulista. In: (orgas.). Mulheres na USP: horizontes que se abrem. São Paulo: Associação Editorial Humanitas, 2004.

. A Faculdade de Filosofia Ciências e Letras. In: (orgas.). Mulheres na USP: horizontes que se abrem. São Paulo: Associação Editorial Humanitas, 2004a.

BLOCH, Marc. Pour une histoire comparée des sociétés européenes. Revue de Synthèse Historique. Paris, n. XLVI, p. 15-50, 1928.

BLOCH, Marc. História e historiadores. Lisboa: Teorema, 1998, p. 119-150.

BORGES, Simone Aparecida. Os cursos de História da Universidade Católica de Goiás e da Universidade Federal de Goiás: um olhar histórico. 2006. 239 f. Dissertação (Programa de Pós-Graduação em Educação) - FE/UFG, Goiânia, 2006.

BOURDIEU, Pierre. A ilusão biográfica. In: AMADO, Janaína; FERREIRA, Marieta de Moraes (orgas.). Usos \& abusos da história oral. $8^{\mathrm{a}}$ edição. Rio de Janeiro: FGV, 2006, p. 183-191.

A ilusão biográfica. In: Razões práticas: sobre a teoria da ação. $11^{a}$ edição. Campinas: Papirus, 2011, p. 77-80.

BOURDIEU, Pierre; PASSERON, Jean-Claude. A Reprodução. Elementos para uma teoria do sistema de ensino. $6^{\text {a }}$ edição. Petrópolis: Vozes, 2013. 
BRANDI, Felipe. Arquivos privados e história dos historiadores: sobrevoo no acervo pessoal de Georges Duby. In: TRAVANCAS, Isabel; ROUCHOU, Joëlle; HEYMANN, Luciana. Arquivos pessoais: reflexões multidisciplinares e experiências de pesquisa. Rio de Janeiro: FGV, 2013, p. 101-130.

BRAUDEL, Fernand. Du potosi à Buenos Aires: Une route clandestine de l'argent. Fin du XVe, début du XVIIe siècle. Annales. Économie, Sociétés, Civilisations. Paris, n. 4, p. 546-550, 1948.

Georges Gurvitch ou la discontinuité du social. Annales: économies, sociétés, civilisations. Paris, ano 8, n. 3, p. 347-361, 1953.

BUENO, Newton Paulo. Possíveis contribuições da Nova Economia Institucional para à pesquisa em história econômica brasileira: uma releitura das três obras clássicas sobre o período colonial. Estudos Econômicos. São Paulo, v. 34, n. 4, p. 777-804, 2004.

CALDEIRA, João Ricardo de Castro. IEB: origem e significados. São Paulo: Oficina do livro Rubens Borba de Moraes, Imprensa oficial do Estado, 2002.

CALÓGERAS, João Pandiá. ["Necrológio de Capistrano de Abreu”]. Atas da 6a Sessão Ordinária, 13/09/1927. Revista do IHGB. Rio de Janeiro, t. 101, v. 155, 1927.

CAMARGO, Ana Maria de; GOULART, Silvana. Tempo e circunstância: a abordagem contextual dos arquivos pessoais. São Paulo: IFHC, 2007.

CAMPOS, Pedro Moacyr. Esboço da historiografia brasileira nos séculos XIX e XX. In: GLÉNISSON, Jean. Iniciação aos Estudos Históricos. $6^{\mathrm{a}}$ edição. Rio de Janeiro: Bertrand Brasil, 1991, p. 250-293.

CANDIDO, Antonio. O Significado de "Raízes do Brasil". In: HOLANDA, Sérgio Buarque de. Raízes do Brasil. 26a edição. Rio de Janeiro: José Olympio, 1995, p. 9-21.

CAPELATO, Maria Helena Rolim; FERLINI, Vera Lucia Amaral; GLEZER, Raquel. Escola uspiana de História. Estudos Avançados, São Paulo, v. 8, n. 22, p. 349-358, 1994.

CATANI, Afrânio Mendes; CATANI, Denise Bárbara; PEREIRA, Gilson. As apropriações da obra de Pierre Bourdieu no campo educacional brasileiro, através de periódicos da área. Revista Brasileira de Educação. São Paulo, n. 17, p. 63-154, 2001.

CARDOSO, Irene. A universidade da comunhão paulista. O projeto de criação da Universidade de São Paulo. São Paulo: Cortez, 1982.

. Para uma crítica do presente. São Paulo: USP, curso de pós-graduação em Sociologia/ Ed. 34, 2001.

CARVALHO, Fernando Cardim de. Keynes e o Brasil. Economia e Sociedade. Campinas, v. 7, n. especial, p. 569-574, 2008. 
CARVALHO, Maria Conceição Vicente de. Geógrafa. In: BLAY, Eva Alterman; LANG, Alice Beatriz da Silva Gordo (orgas.). Mulheres na USP: horizontes que se abrem. São Paulo: Associação Editorial Humanitas, 2004, p. 117-123.

CARVALHO, Rapahel Guilherme de. Sérgio Buarque de Holanda, do mesmo ao outro: escrita de si e memória (1969-1986). 2017. 328 f. Setor de Ciências Humanas - UFPR. Tese (Programa de Pós-Graduação em História). 2017.

CASSARES, Norma Cianflone. Como fazer conservação preventiva em arquivos $e$ bibliotecas. São Paulo: Arquivo do Estado/Imprensa Oficial, 2000.

CASTILHO, Myrian Lucia Ruiz. Memória e história da formação da Faculdade de Filosofia, Ciências e Letras de Marília (1956-1976). 2009. 252 f. Tese (Programa de PósGraduação em Educação) - FFC/UNESP, Marília, 2009.

CASTRO, Nivalde José de. As origens da Faculdade Nacional de Ciências Econômicas da Universidade do Brasil. In: __. O Economista: a história da profissão no Brasil. Rio de Janeiro: COFECON; CORECON-RJ; CORECON/SP, 2001, p. 47-67.

A regulamentação da profissão. In: O Economista: a história da profissão no Brasil. Rio de Janeiro: COFECON; CORECON-RJ; CORECON/SP, 2001, p. 13-45.

CHRISTINO, Beatriz Protti. A rede de Capistrano de Abreu (1853-1927): uma análise historiográfica do rã-txa hu-ni-ku- i em face da Sul-americanística dos anos 1890-1929. 2006. 242 f. Tese (Programa de Pós-Graduação em Semiótica e Linguística Geral) DL/FFLCH/USP, São Paulo, 2006.

CELESTE FILHO, Macioniro. A constituição da Universidade de São Paulo e a reforma universitária da década de 1960. São Paulo: EDUNESP, 2013.

CHARLE, Christophe. Les elites de la République (1880-1900). Paris: Fayard, 1987.

. Naissance des “intellectuels” (1880-1900). Paris: Les éditions de minuit, 1990.

. La République des universitaires (1870-1940). Paris: Éditions Du Seuil, 1994.

CERTEAU, Michel de. La prise de la parole et autres écrites politiques. Paris: Le Seuil, 1994. 2010.

. Heterologies: discourse on the other. Minneapolis: University of Minnesota Press,

. A operação historiográfica. In: . A Escrita da História. $3^{\circ}$ edição. Rio de Janeiro: Forense, 2011, p. 45-111.

. História e estrutura. In: . História e psicanálise: entre ciência e ficção. $2^{\mathrm{a}}$ edição. Belo Horizonte: Autêntica, 2012, p. 163-178. 
O ausente da história. In: . História e psicanálise: entre ciência e ficção. $2^{\mathrm{a}}$ edição. Belo Horizonte: Autêntica, 2012, p. 179-188.

CERTEAU, Michel. A história, ciência e ficção. In: História e psicanálise: entre ciência e ficção. $2^{\mathrm{a}}$ edição. Belo Horizonte: Autêntica, 2012.

CERTEAU, Michel de; JULIA, Dominique; REVEL, Jacques. A beleza do morto. In: CERTEAU, Michel de. A cultura no plural. $7^{a}$ edição. Campinas: Papirus, 2012.

CERTEAU, Michel de. Fazer com: usos e táticas. In: artes de fazer. $22^{\mathrm{a}}$ edição. Petrópolis: Vozes, 2014, p. 86-100. A invenção do cotidiano:

CONRAD, Robert. João Capistrano de Abreu, brazilian historian. Revista de hístoria de América, n. 59, p. 149-164, 1965.

CORREA, Mariza. As Reuniões Brasileiras de Antropologia - 50 anos. Campinas: Editora da Unicamp, 2003.

COSTA, Emília Viotti da. A dialética invertida: 1960-1990. In: e outros ensaios. São Paulo: Editora Unesp, 2014, p. 9-28.

. O historiador e a sociedade. In: . A dialética invertida e outros ensaios. São Paulo: Editora Unesp, 2014, p. 209-219.

CUNHA, Luiz Antônio. A Universidade crítica: o ensino superior na República Populista. Rio de Janeiro: Francisco Alves, 1983.

CUSTÓDIO, Vanderli. Fundamentos teórico-metodológicos do ensino e da pesquisa em Geografia: textos selecionados das primeiras publicações da Associação dos Geógrafos Brasileiros (AGB) - GEOGRAFIA (1935-1936) e BOLETIM DA AGB (1941-1944). São Paulo: AGB, 2012.

DAIX, Pierre. Braudel. Paris: Flammarion, 1995.

D’ALESSIO, Marcia Mansor. História vivida, história pensada. História da historiografia. Ouro Preto, n. 11, p. 300-304, 2013.

DELACROIX, Christian.; DOSSE, François.; GARCIA, Patrick. As correntes históricas na França: séculos XIX e XX. Rio de Janeiro: FGV, 2012.

DEFFONTAINES, Pierre. Regiões e paisagens do Estado de São Paulo. Primeiro esboço de divisão regional. Geografia. São Paulo, n. 2, p. 117-169, 1935.

DIAS, Maria Odila Leite da Silva. O fardo do homem branco: Robert Southey, historiador do Brasil. São Paulo: Nacional, 1974. 
DIAZ, Brigitte. Por uma breve história da carta. In:. O gênero epistolar ou o pensamento nômade: formas e funções da correspondência em alguns percursos de escritores no século XIX. São Paulo: EDUSP, p. 11-70.

DOSSE, François. Os biografemas. In: . O desafio biográfico: escrever uma vida. São Paulo: EDUSP, 2009, p. 306-314.

DUMOULIN, Olivier. Hoje: a encomenda e a expertise, em nome do interesse geral, em nome dos interesses particulares. In: ao tribunal. Belo Horizonte: Autêntica, 2017, p. 25-138.

ELIAS, Norbert. Introdução. Ensaio teórico sobre as relações estabelecidos-outsiders. In: ELIAS, Norbert; SCOTSON, John. Os estabelecidos e os outsiders: sociologia das relações de poder a partir de uma pequena comunidade. Rio de Janeiro: Zahar, 2000, p. $19-50$.

ERBERELI JÚNIOR, Otávio. Rigidez de preços e salários na teoria keynesiana. Iniciativa Econômica. Araraquara, ano 4, n. 4, p. 53-63, 2004.

Alice Piffer Canabrava e $O$ Desenvolvimento da Cultura do Algodão na Província de São Paulo (1861-1875). Revista de Teoria da História. Goiânia, ano 4, n. 8, p. 35-64, 2012.

Abordagem acerca do aporte listiano para a formação do pensamento de Raúl Prebisch. Revista de Economia Política e História Econômica. Maceió, ano 9, n. 31, p. 146-182, 2014.

A escrita da história entre dois mundos: uma análise da produção de Alice Piffer Canabrava (1935-1961). 2014. 243f. Dissertação (Mestrado em História) - Faculdade de Ciências e Letras, Universidade Estadual Paulista "Júlio de Mesquita Filho", Assis, 2014.

De preterida à preferida: considerações em torno da trajetória intelectual de Alice Piffer Canabrava (1935-1951). História da historiografia. Ouro Preto, n. 22, p. 97-115, 2016.

FALCON, Francisco José Calazans. O I Simpósio de Professores de História do Ensino Superior. Boletim de História. Centro de Estudos de História da Faculdade de Filosofia da Universidade do Brasil. Rio de Janeiro, n. 7, 1963.

. A identidade do historiador. Estudos Históricos. Rio de Janeiro, n. 17, 1996.

. Palestra do prof. Francisco Calazans Falcon. Revista Maracan. Rio de Janeiro, v. 1, n. 1, 1999.

Entrevista. In: GONÇALVES, Márcia de Almeida; GONTIJO, Rebeca. Sobre história, historiografia e historiadores: entrevista com Francisco José Calazans Falcon. História da historiografia. Ouro Preto, n. 7, p. 365-382, 2011. 
. A historiografia contemporânea e a identidade do historiador. In: _. Estudos de teoria da história e historiografia, volume I: teoria da história. São Paulo: Hucitec, 2011a, p. 58-82.

. Memória e História. A fundação da ANPUH. In: SIMPÓSIO NACIONAL DE HISTÓRIA - ANPUH, XXVI, 2011, São Paulo. Anais... São Paulo, 2011 b.

FALCON, Francisco José Calazans. Capistrano de Abreu e a historiografia cienticifista: entre o positivismo e o historicismo. In: NEVES, Lucia Maria Bastos Pereira das et all. (org.). Estudos de Historiografia Brasileira. Rio de Janeiro: Editora FGV, 2011c.

Francisco Falcon. In: FERREIRA, Marieta de Moraes. A história como ofício: a constituição de um campo disciplinar. Rio de Janeiro: FGV, 2013.

A historiografia brasileira contemporânea, 1958-1969. In: _. Estudos de teoria da história e historiografia, volume II: historiografia. São Paulo: Hucitec, 2015.

A cadeira de História moderna e contemporânea e o ensino e a pesquisa histórica da FNFi - UB. In: _. Estudos de teoria da história e historiografia, volume II: historiografia. São Paulo: Hucitec, 2015.

FÁVERO, Maria de Lourdes Albuquerque; LIMA, Helena Ibiapina. A Universidade Federal do Rio de Janeiro (UFRJ): origens, construção e desenvolvimento. In: MOROSINI, Marilia (orga.). A universidade no Brasil: concepções e modelos. Brasília: Instituto Nacional de Estudos e Pesquisas Educacionais Anísio Teixeira, 2006, p. 65-80.

FEBVRE, Lucien. Combates pela história. Lisboa: Editorial Presença, 1985.

FEBVRE, Lucien. Prefácio. In: - Combates pela história. Lisboa: Editorial Presença, 1985, p. 7-10.

FERREIRA, Marieta de Moraes. Diário pessoal, autobiografia e fontes orais: a trajetória de Pierre Deffontaines. In: INTERNATIONAL ORAL HISTORY CONFERENCE (10.: 1998: Rio de Janeiro, RJ). Oral history challenges for the 21 st century: proceedings [of the] X International Oral History Conference /Eds. Ilana Strozemberg .[et al]. Rio de Janeiro: CPDOC/FGV/Casa Oswaldo Cruz, v.1, p. 379-386, 1998.

. Um novo desenho: o curso de História, da FNFI à UFRJ. FERREIRA, Marieta de Moraes. A história como ofício: a constituição de um campo disciplinar. Rio de Janeiro: FGV, 2013.

A UDF e o primeiro curso universitário de História do Rio de Janeiro. In: FERREIRA, Marieta de Moraes. A história como ofício: a constituição de um campo disciplinar. Rio de Janeiro: FGV, 2013.

. O curso de História e Geografia da FNFi: um projeto de história nacional. In: FERREIRA, Marieta de Moraes. A história como ofício: a constituição de um campo disciplinar. Rio de Janeiro: FGV, 2013. 
FERREIRA, Oliveiros. Lourival Gomes Machado. Estudos Avançados. São Paulo, v. 8, n. 22, p. 279-284.

FISCHMANN, Alberto Américo; GUERREIRO, Reinaldo. As contribuições da FEA para o avanço da ciência e para a implementação de políticas públicas. In: GOLDEMBERG, José. USP 80 anos. São Paulo: EDUSP, 2015.

FOUCAULT, Michel. A escrita de si. In: _. O que é um autor? 2a edição. Lisboa: Veja/Passagens, 1992, p.

A ordem do discurso. 24a edição. São Paulo: Loyola, 2014.

FRAGOSO, João Luis Ribeiro; FLORENTINO, Manolo. $O$ arcaísmo como projeto: mercado atlântico, sociedade agrária e elite mercantil em uma economia colonial tardia: Rio de Janeiro, c.1790-c.1840. Rio de Janeiro: Record, 2001.

FRANCO, Maria Estela Dal Pai; MOROSINI, Marília Costa. Universidade Federal do Rio Grande do Sul (UFRGS): da universidade técnica à universidade inovadora. In:

MOROSINI, Marilia (orga.). A universidade no Brasil: concepções e modelos. Brasília: Instituto Nacional de Estudos e Pesquisas Educacionais Anísio Teixeira, 2006, p. 81-95.

FRANZINI, Fábio; GONTIJO, Rebeca. Memória e história da historiografia no Brasil: a invenção de uma moderna tradição, anos 1940-1960. In: SOIHET, Rachel et al (orgas.). Mitos, projetos e práticas políticas: memória e historiografia. Rio de Janeiro: Civilização Brasileira, 2009.

FRANZINI, Fábio. GONTIJO, Rebeca. Panorama da historiografia brasileira contemporânea (1930-1980). In: ABRÃO, Janete Silveira (orga.). Brasil: interpretações \& perspectivas. São Paulo: Marcial Pons/Universidade de Alcalá, 2016, p. 15-38.

FREYRE, Gilberto. O Nordeste e seus pontos de contacto com outras áreas americanas especializadas na producção do açúcar. In:_. O Mundo que o português criou. Aspectos das relações sociais e de cultura do Brasil com Portugal e as colônias portuguesas. Rio de Janeiro: José Olympio, 1940, p. 112-124.

FURTADO, André Carlos. Coleção História Geral da Civilização Brasileira (HGCB): organização interna, especialização acadêmica, disputas letradas e editoriais. In: . As edições do cânone. Da fase buarqueana na coleção História Geral da Civilização Brasileira (1960-1972). 2014. 248 f. Dissertação (Programa de Pós-Graduação em História) - IH/UFF, Niterói, 2014, p. 69-102.

As edições do cânone - Da fase buarqueana na coleção "História Geral da Civilização Brasileira" (1960-1972). Niterói: Eduff, 2016.

GAGNEBIN, Jeanne Marie. Os prelúdios de Paul Ricouer. In: escrever. $2^{a}$ edição. São Paulo: Editora 34, 2009, p. 179-192. Lembrar esquecer 
Uma filosofia do cogito ferido: Paul Ricoeur. In: . Lembrar esquecer escrever.

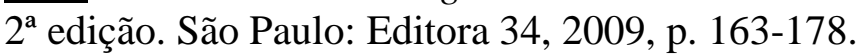

GAY, Peter. O coração desvelado: a experiência burguesa da rainha Vitória a Freud. São Paulo: Companhia das letras, 1999.

GLEZER, Raquel. Orelha. In: CANABRAVA, Alice Piffer. O Desenvolvimento da Cultura do Algodão na Província de São Paulo (1861-1875). $3^{\circ}$ edição. São Paulo: EDUSP/ANPUH.

. Do todo ao fragmento: um breve olhar sobre a pesquisa histórica no Brasil. In: BENTIVOGLIO, Júlio; NASCIMENTO, Bruno César (orgs.). Escrever história: historiadores e historiografia brasileira nos séculos XIX e XX. Serra: Milfontes, 2017, p. 123-136.

GLÉNISSON, Jean. Iniciação aos Estudos Históricos. $6^{\text {a }}$ edição. Rio de Janeiro: Bertrand Brasil, 1991.

GODINHO, Vitorino Magalhães. Industrie et commerce Antillais. Sur le sucre des Antilles. Annales. Économie, Sociétés, Civilisations. Paris, n. 4, 1948.

GOFFMAN, Erving. Manicômios, prisões e conventos. $7^{\mathrm{a}}$ edição. São Paulo: Perspectiva 2010 .

GOLOMBEK, Patrícia. Caetano de Campos: A escola que mudou o Brasil. São Paulo: EDUSP, 2016.

GOMES, Angela de Castro (coord.). Engenheiros e economistas: novas elites burocráticas. Rio de Janeiro: FGV, 1994.

. Escrita de si, escrita da História: a título de prólogo. In: GOMES, Angela de Castro Gomes (org.). Escrita de si, escrita da História. $1^{\circ}$ edição. Rio de Janeiro: FGV, 2004, p. 7-24.

Em família: a correspondência entre Oliveira Lima e Gilberto Freyre. In: GOMES, Angela de Castro Gomes (org.). Escrita de si, escrita da História. $1^{\circ}$ edição. Rio de Janeiro: FGV, 2004, p. 51-75.

GOMES. Angela Maria de Castro et ali. O Brasil Republicano: sociedade e política (1930-1964). In: FAUSTO, Boris (dir.). História Geral da Civilização Brasileira. T. 3, v. 10. $9^{a}$ edição. Rio de Janeiro: Bertrand Brasil, 2007.

GONÇALVES, Márcia de Almeida. Em terreno movediço. Biografia e história na obra de Octávio Tarquínio de Sousa. Rio de Janeiro: EDUERJ, 2009.

GONTIJO, Rebeca. A história da historiografia ano Brasil, 1940-1970: apontamentos sobre sua escrita. In: Anais do XXVI Simpósio Nacional de História. São Paulo: ANPUH, 2011, p. 1-11. 
GONTIJO, Rebeca; FRANZINI, Fábio. Panorama da historiografia brasileira contemporânea (1930-1980). In: ABRÃO, Janete Silveira (orga.). Brasil: interpretações \& perspectivas. São Paulo: Marcial Pons/Universidade de Alcalá, 2016, p. 15-38.

GONTIJO, Rebeca. Revisão e prospecção da historiografia no Brasil nos anos 1970. In: BENTIVOGLIO, Júlio; NASCIMENTO, Bruno César (orgs.). Escrever história: historiadores e historiografia brasileira nos séculos XIX e XX. Serra: Milfontes, 2017.

GUIMARÃES, Lúcia Maria Paschoal. Da Escola Palatina ao Silogeu: Instituto Histórico e Geográfico Brasileiro (1889-1938). Rio de Janeiro: Museu da República, 2007.

IV Congresso de História Nacional: tendências e perspectivas da história do Brasil colonial (Rio de Janeiro, 1949). Revista Brasileira de História. São Paulo, v. 24, n. 48, 2004.

Sobre a história da historiografia brasileira como campo de estudos e reflexões. In: NEVES, Lucia Maria Bastos Pereira das; GUIMARÃES, Lucia Maria Paschoal; GONÇALVES, Márcia de Almeida et alli (orgs.). Estudos de Historiografia Brasileira. Rio de Janeiro: Editora FGV, 2011, p. 19-35.

Produção e disseminação do saber histórico no oitocentos: a Revista do Instituto Histórico e Geográfico Brasileiro. In: ARRAIS, Cristiano Alencar; BENTIVOGLIO, Júlio (orgs.). As revistas de história e as dinâmicas do campo historiográfico. Serra: Milfontes, 2017, p. 31-53.

GUIMARÃES, Manoel Luiz Salgado. Nação e civilização nos trópicos: O Instituto Histórico e Geográfico Brasileiro e o projeto de uma História Nacional. Estudos Históricos. Rio de Janeiro, n. 1, p. 5-27, 1988.

Historiografia e cultura histórica: notas para um debate. Ágora. Santa Cruz do Sul, v. 11, n. 1, p. 31-47, 2005.

GURVITCH, Georges. Continuité et discontinuité em histoire et em sociologie. Annales: économies, sociétés, civilisations. Paris, ano 12, n.1, p. 73-84, 1957.

HANKE, Lewis. The portuguese in Spanish America, with special reference to the Villa Imperial de Potosí. Revista de Historia de América. Pan American Institute of Geography and History, n. 51, 1961.

HAROCHE-BOUZINAC, Geneviève. Escritas epistolares. São Paulo: EDUSP, 2016.

HEYMANN, Luciana. Os fazimentos do arquivo Darcy Ribeiro: memória, acervo e legado. Estudos Históricos. Rio de Janeiro, n. 36, p. 43-58, 2005.

Arquivos pessoais em perspectiva etnográfica. In: TRAVANCAS, Isabel; ROUCHOU, Joëlle; HEYMANN, Luciana. Arquivos pessoais: reflexões multidisciplinares e experiências de pesquisa. Rio de Janeiro: FGV, 2013, p. 67-76. 
HOBSBAWN, Eric; RANGER, Terence. A invenção das tradições. Rio de Janeiro: Paz e Terra, 1984.

HOLANDA, Sérgio Buarque de. A mineração: antecedentes luso-brasileiros \& metais e pedras preciosas. In:_(dir.). História Geral da Civilização Brasileira. A época colonial. t. I, v. 2: administração, economia, sociedade. São Paulo: difusão europeia do livro, 1960, p. 228-258.

. História Econômica. In: COSTA, Marcos (org.). Para uma nova História. São Paulo: Fundação Perseu Abramo, 2004.

O pensamento histórico nos últimos 50 anos. In: MONTEIRO, Pedro Meira; EUGÊNIO, João Kennedy (orgs.). Sérgio Buarque de Holanda: perspectivas. Campinas: Editora UniCamp; Rio de Janeiro: EdUERJ, 2008, p. 601-615.

Sobre o Colloquium. In: COSTA, Marcos (org.). Escritos coligidos, 1950-1979. São Paulo: Editora Fundação Perseu Abramo; Editora UNESP, 2011.

Portugueses na América. In: COSTA, Marcos (org.). Escritos coligidos, 19501979. São Paulo: Editora Fundação Perseu Abramo; Editora UNESP, 2011.

IEGELSKI, Francine. Astronomia das constelações humanas. Reflexões sobre Claude Lévi-Strauss e a história. São Paulo: Humanitas, 2016.

IGLÉSIAS, Francisco. Historiografia econômica brasileira. In: IGLÉSIAS, Francisco. Introdução à Historiografia Econômica. Belo Horizonte: Faculdade de Ciências Econômicas/UMG, 1959.

Comentário. In: CANABRAVA, Alice Piffer; HOLANDA, Sérgio Buarque de; LUZ, Nicia Vilela. Anais Encontro Internacional de Estudos Brasileiros. I Seminário de Estudos Brasileiros. São Paulo: Universidade de São Paulo/Instituto de Estudos Brasileiros, 1972.

A Historiografia da América Latina. Revista de Historia de América. Havana, n. 75/76, 1973.

A História no Brasil. In: FERRI, Mário Guimarães; MOTOYAMA, Shozo. História das Ciências no Brasil. São Paulo: EPU; Editora da Universidade de São Paulo, 1979.

A historiografia brasileira atual e a interdisciplinaridade. Revista Brasileira de História. São Paulo, v. 3, n. 5, p. 129-141, 1983.

Os historiadores do Brasil: capítulos de historiografia brasileira. Rio de Janeiro: Nova Fronteira; Belo Horizonte: UFMG, IPEA, 2000.

IUMATTI, Paulo Teixeira. Caio Prado Jr.: Uma trajetória intelectual. São Paulo: Brasiliense, 2007. 
- História, dialética e diálogo com as ciências: a gênese de Formação do Brasil contemporâneo, de Caio Prado Jr. (1933-1942). São Paulo: Intermeios/USP-Programa de Pós-Graduação em História Social, 2018.

IUMATTI, Paulo Teixeira; SEABRA, Manoel Fernandes; HEIDEMANN, Heinz-Dieter (orgs.). Caio Prado Jr. e a Associação dos Geógrafos Brasileiros. São Paulo: EDUSP/FAPESP, 2008.

KAUFMANN, Vincent. L'équivoque epistolaire. Paris: Minuit, 1990.

KOHLRAUSCH, Regina. Apresentação - Literatura gênero epistolar: a carta na literatura, a literatura na carta, rede de sociabilidade, escrita de si... . Letrônica. Revista digital do programa de pós-graduação em letras da PUCRS. Porto Alegre, v. 8, n. 1, p. 148-155, 2015.

LANNA, Ana Lúcia Duarte (orga.). Guia do IEB: o acervo do Instituto de Estudos Brasileiros. São Paulo: IEB, 2010.

LAPA, José Roberto do Amaral Lapa. História e Historiografia brasileira pós 64. Rio de Janeiro: Paz e Terra, 1985.

. A Bahia e a Carreira da Índia. São Paulo: HUCITEC, 2000.

LIBLIK, Carmen Silvia da Fonseca Kummer. Trajetória de Maria Yedda Linhares: notas sobre a construção de um devir. História da Historiografia. Ouro Preto, n. 22, 2016.

Uma história toda sua: trajetórias de historiadoras brasileiras (1934-1990). 2017. 343 f. Tese (Programa de Pós-Graduação em História) - SCH/UFPR, Curitiba, 2017.

LIMA, Luís Corrêa. Fernand Braudel e o Brasil: vivência e brasilianismo (1935-1945). São Paulo: Editora da Universidade de São Paulo, 2009.

LIMONGI, Fernando. Mentores e clientela da Universidade de São Paulo. In: MICELI, Sérgio (org.) História das Ciências Sociais no Brasil. São Paulo: Vértice; Editora Revista dos Tribunais: IDESP, 1989, v. 1, p. 157-187.

LOPEZ, André Porto Ancona. Como descrever documentos de arquivo: elaboração de instrumentos de pesquisa. São Paulo: Arquivo do Estado/Imprensa Oficial, 2002.

LORIGA, Sabina. A biografia como problema. In: REVEL, Jacques (org.). Jogos de escala: a experiência da microanálise. Rio de Janeiro: Editora FGV, 1998, p. 225-249.

O pequeno x: da biografia à história. Belo Horizonte: Autêntica, 2011.

LUCA, Tania Regina de. São Paulo no século XX: segunda metade. São Paulo: Imprensa Oficial/Poiesis, 2011. 
MACEDO, Roberto. Antonio Delfim Netto. Estudos Avançados. São Paulo, v. 15, n. 43, p. 375-388, 2001.

MACHADO, Daiane Vaiz. Institucionalização acadêmica da História: entre o autodidatismo e a profissionalização. História da historiografia. Ouro Preto, n. 12, p. 242-247, 2013.

. Por uma "ciência histórica": o percurso intelectual de Cecília Westphalen, 19501998. 2016. 338 f. Faculdade de Ciências e Letras de Assis - UNESP. Tese (Programa de Pós-Graduação em História e Sociedade). 2016.

Modo de ser historiadora: Cecília Westphalen no campo historiográfico brasileiro da segunda metade do século XX. História da historiografia. Ouro Preto, n. 22, p. 134151, 2016a.

MANCEBO, Deise. Universidade Estadual do Rio de Janeiro (UERJ): da gênese utilitária aos compromissos "pró-ciência". In: MOROSINI, Marilia (orga.). A universidade no Brasil: concepções e modelos. Brasília: Instituto Nacional de Estudos e Pesquisas Educacionais Anísio Teixeira, 2006, p. 245-253.

MARCOVITCH, Jacques. O Centro Acadêmico Visconde de Cairu (CAVC). In: CANABRAVA, Alice Piffer (org. coord.). História da Faculdade de Economia e Administração da Universidade de São Paulo, 1946-1981. v. 1: A Instituição. São Paulo: FEA/USP, 1984, p. 337-346.

MARROU, Henri-Irénée. L'histoire et les historiens. Second chronique de méthodologie historique. Revue historique. Paris, t. 217, f. 2, p. 270-289, 1957.

MARTINEZ, Paulo Henrique. Fernand Braudel e a primeira geração de historiadores universitários da USP (1935-1956): notas para estudo. Revista de História. São Paulo, v. 146, p. 11-27, 2002.

. Admirável mundo novo (1934-1935). In: A dinâmica de um pensamento crítico: Caio Prado Jr (1928-1935). São Paulo: EDUSP, 2008, p. 163-218.

MASSI, Fernanda. Franceses e norte-americanos nas ciências sociais brasileiras (19301960). In: MICELI, Sérgio (org.) História das Ciências Sociais no Brasil. São Paulo: Vértice; Editora Revista dos Tribunais: IDESP, 1989.

. Estrangeiros no Brasil: a missão francesa na Universidade de São Paulo. 1991. 283 f. Dissertação (Programa de Pós-Graduação em Antropologia Social) - IFCH, UNICAMP, Campinas, 1991.

MATOS, Odilon Nogueira de. Sociedade de Estudos Históricos. In: Noticiário. Revista de História. São Paulo, n. 6, 1951, p. 467-468.

MCKEMMISH, Sue. Evidence of me. Archives and Manuscripts, n. 24, v. 1, 1996, p. 28 45 . 
. Provas de mim... Novas considerações. In: TRAVANCAS, Isabel; ROUCHOU, Joëlle; HEYMANN, Luciana. Arquivos pessoais: reflexões multidisciplinares e experiências de pesquisa. Rio de Janeiro: FGV, 2013, p. 17-43.

MELLO, Ricardo Marques de. Tendências historiográficas na Revista Brasileira de História, 1981-2000. 125 f. Tese (Doutorado em História) - Universidade de Brasília, Brasília, 2012.

. Tendências historiográficas na Revista Brasileira de História: 1981-2000. Curitiba: Editora Prismas, 2016.

MELLO, Zélia Maria Cardoso de; NOZOE, Nelson Hideiki; SAES, Flávio Azevedo Marques de. Três Pesquisas Pioneiras em História Econômica (as teses universitárias de Alice Piffer Canabrava). Estudos Econômicos. São Paulo. v. 15, n. especial, 1985.

MESGRAVIS, Laima. O curso de pós-graduação do departamento de História da Faculdade de Filosofia, Letras e Ciências Humanas da Universidade de São Paulo. Revista Brasileira de História. São Paulo, n. 5, v. 3, 1983.

MESQUITA, Daniel. Descobrimentos de Capistrano: a História do Brasil "a grandes traços e largas malhas". Rio de Janeiro: Apicuri/Ed. PUC-Rio, 2010.

MICHELOTTO, Regina Maria. Universidade Federal do Paraná (UFPR): uma universidade para a classe média. In: MOROSINI, Marilia (orga.). A universidade no Brasil: concepções e modelos. Brasília: Instituto Nacional de Estudos e Pesquisas Educacionais Anísio Teixeira, 2006, p. 53-63.

MIRRA, Elisabeth Conceta. O Prof. Dr. Eurípedes Simões de Paula, o Centro de Apoio à Pesquisa em História - CAPH e a Memória da FFCL-FFLCH/USP: trajetória e possibilidades. Revista de História. São Paulo, n. 160, p. 51-69, 2009.

MOLLOY, Silvia. Vale o escrito - a escrita autobiográfica na América hispânica. Chapecó: Argos, 2003.

MONARCHA, Carlos. Escola Normal da Praça: O Lado Noturno das Luzes. Campinas: EdUnicamp, 1999.

MORAZÉ, Charles. Lucien Febvre et l'histoire vivante. Revue historique. Paris, t. 217, f. 1, p. 1-19, 1957.

MORSE, Richard. Entrevista. In: BOMENY, Helena Maria Bousquet. Uma entrevista com Richard Morse. Estudos históricos. Rio de Janeiro, v. 2, n. 3, p. 77-93, 1989.

MOREIRA LEITE, Mirian Lifchitz. O terceiro andar da Escola da Praça. In: REIS, Maria Candida Delgado (orga.). Caetano de Campos: fragmentos da história da instrução pública no Estado de São Paulo. São Paulo: Associação dos ex-alunos do Instituto de Educação Caetano de Campos, p. 105-114. 
MOROSINI, Marilia (orga.). A universidade no Brasil: concepções e modelos. Brasília: Instituto Nacional de Estudos e Pesquisas Educacionais Anísio Teixeira, 2006.

MOTTA, Rodrigo Patto Sá. As universidades e o regime militar: cultura política brasileira e modernização autoritária. Rio de Janeiro: Zahar, 2014.

MUNIZ BARRETO, Antonio Emílio. O fluxo de moedas entre o rio da Prata e o Brasil (1800-1850). Revista de História. São Paulo, v. 51, n. 101, p. 207-227, 1975.

NAGLE, Jorge. Ensino primário. In:___ Educação e Sociedade na Primeira República. $3^{\mathrm{a}}$ edição. São Paulo: EDUSP, 2009, p. 226-239.

NALLI, Marcos. Ricoeur leitor de Husserl. Trans/Form/Ação. São Paulo, n. 29, v. 2, p. 155-180, 2006.

NASCIMENTO, Bruno César. Para além do texto: os periódicos de história como elemento de definição do campo. O caso da Revista de História da USP (1950-2016). 2016. 347 f. Dissertação (Programa de pós-graduação em História Social das Relações Políticas ) - CCHN/UFES, Vitória, 2016.

. Um novo projeto para a História no Brasil. Eurípedes Simões de Paula e a Revista de História da USP. In: BENTIVOGLIO, Júlio; NASCIMENTO, Bruno César (orgs.). Escrever história: historiadores e historiografia brasileira nos séculos XIX e XX. Serra: Milfontes, 2017, p. 227-250.

A Revista de História da Universidade de São Paulo em perspectiva. In: ARRAIS, Cristiano Alencar; BENTIVOGLIO, Júlio (orgs.). As revistas de história e as dinâmicas do campo historiográfico. Serra: Milfontes, 2017, p. 81-104.

NICODEMO, Thiago Lima. Urdidura do vivido: Visão do Paraíso e a obra de Sérgio Buarque de Holanda nos anos 1950. São Paulo: EDUSP, 2008.

NICODEMO, Thiago Lima; PEREIRA, Mateus Henrique de Faria; CRISTOVÃO DOS SANTOS, Pedro Afonso. Teoria, historiografia e ensino nas páginas da Revista de História da USP (1950-1960). In: ARRAIS, Cristiano Alencar; BENTIVOGLIO, Júlio (orgs.). As revistas de história e as dinâmicas do campo historiográfico. Serra: Milfontes, 2017, p. 105-130.

NOGUERÓL, Luiz Paulo Ferreira. Histórias econômicas de economistas - Cliometria e Nova Economia Institucional. Locus: revista de história. Juiz de Fora, v. 14, n. 1, p. 91$112,2008$.

NOGUEIRA, Oracy. O Instituto de Administração - IA ( $1^{\text {a }}$ Fase). In: CANABRAVA, Alice Piffer (org. coord.). História da Faculdade de Economia e Administração da Universidade de São Paulo, 1946-1981. v. 1: A Instituição. São Paulo: FEA/USP, 1984.

NOVICK, Peter. That noble dream. The "objectivity question" and the American Historical Profession. New York: Cambridge University Press, 1988. 
OFFENSTADT, Nicolas. Colloques. In: DELACROIX, Christian; DOSSE, François; GARCIA, Patrick; OFFENSTADT, Nicolas (Orgs.). Historiographies: concepts et débats I. Paris: Gallimard (Folio histoire), 2010.

OLIVEIRA, Josiane Roza de. Um historiador em formação: os primeiros anos da vida intelectual de Capistrano de Abreu (1875-1882). 2011. 309 f. Tese (Pós-Graduação em História das Ciências e Saúde Pública) - Casa de Oswaldo Cruz, Fundação Oswaldo Cruz, Rio de Janeiro, 2011.

OLIVEIRA, Maria da Glória de. Escrever vidas, narrar a história: a biografia como problema historiográfico no Brasil oitocentista. Rio de Janeiro: Editora FGV, 2012.

. Crítica, método e escrita da história em João Capistrano de Abreu. Rio de Janeiro: Editora FGV, 2013.

. Quem tem medo da ilusão biográfica? Indivíduo, tempo e histórias de vida. Topói. Rio de Janeiro, v. 18, n. 35, p. 429-446, 2017.

PALMEIRA, Miguel Soares. Moses Finley e a "economia antiga": a produção social de uma inovação historiográfica. 2007. 214 f. Tese (Programa de Pós-Graduação em História Social), FFLCH/USP, 2007.

. Arquivos pessoais e história da história: a propósito dos Finley Papers. In: TRAVANCAS, Isabel; ROUCHOU, Joëlle; HEYMANN, Luciana. Arquivos pessoais: reflexões multidisciplinares e experiências de pesquisa. Rio de Janeiro: FGV, 2013, p. 80-99.

PAULA, Maria de Fátima. USP e UFRJ: a influência das concepções alemã e francesa em suas fundações. Tempo Social. São Paulo, v. 14, n. 2, p. 147-161, 2002.

A formação universitária no Brasil: concepções e influências. Avaliação. Campinas/Sorocaba, v. 14, n. 1, p. 71-84, 2009.

PAULA, Eurípedes Simões de. Desdobramento do curso de Geografia e História na Faculdade de Filosofia, Ciências e Letras da Universidade de São Paulo. In: Noticiário. Revista de História. São Paulo, n. 25, 1955, p. 285-286.

I Simpósio de Professores de História do Ensino Superior. In: Noticiário. Revista de História. São Paulo, n. 46, 1961.

PAULA, Maria Regina da Cunha Rodrigues Simões de. Teses defendidas no departamento de História da Universidade de São Paulo (1939-1974). In: Notícia informativa. Revista de História. São Paulo, n. 100, p. 821-856, 1974.

PAULA, João Antonio de. Francisco Iglésias, um historiador para o nosso tempo. In: SAES, Alexandre Macchione. RIBEIRO, Maria Alice Rosa. SAES, Flávio Azevedo Marques de (orgs.). Rumos da história econômica no Brasil: 25 anos da ABPHE. São Paulo: Alameda, 2017, p. 263-284. 
PAULA, Maria Regina Simões de; MELLO E SOUZA, Antonio Candido de. In Memoriam de Eurípedes Simões de Paula. São Paulo: Gráfica FFLCH/USP, 1983.

PEIXOTO, Fernanda. Lévi-Strauss no Brasil: a formação do etnólogo. Mana. Rio de Janeiro, v. 4, n. 1, p. 79-107, 1998. 2000 .

Diálogos brasileiros: uma análise da obra de Roger Bastide. São Paulo: EDUSP,

PERPÉTUO, César Haueisen Zimerer. Historiografia americana em revista: a American Historical Review (1895 a 1915). 100 f. 2017. Dissertação (Programa de Pós-Graduação em História), CCHN/UFES, Vitória, 2017.

PETITJEAN, Patrick. As missões universitárias francesas na criação da Universidade de São Paulo (1934-1940). In: HAMBURGER, Amélia Império et alli. (orgs.). A ciência nas relações Brasil-França (1850-1950). São Paulo: Edusp/FAPESP, 1996, p. 259-330.

PIERUCCI, Antônio Flávio de Oliveira et ali. O Brasil Republicano: economia e cultura (1930-1964). In: FAUSTO, Boris (dir.). História Geral da Civilização Brasileira. T. 3, v. 11. $9^{\text {a }}$ edição. Rio de Janeiro: Bertrand Brasil, 2007.

PINHO, Diva Benevides. Outros departamentos. In: CANABRAVA, Alice Piffer (org. coord.). História da Faculdade de Economia e Administração da Universidade de São Paulo, 1946-1981. v. 1: A Instituição. São Paulo: FEA/USP, 1984, p. 79-84.

Economia Política e a história das doutrinas econômicas. Economia Aplicada, São Paulo, 1994.

A FEA-USP no tempo: contribuição à memória de seus 60 anos. São Paulo: FEA/USP, 2006.

POLLAK, Michel. Memória e identidade social. Estudos Históricos. Rio de Janeiro, v. 5, n. 10, p. 200-212, 1992.

PONTES, Heloisa. Destinos mistos: os críticos do Grupo Clima em São Paulo (1940-68). São Paulo: Companhia das Letras, 1998. 2006.

A paixão pelas formas. Gilda de Mello e Souza. Novos Estudos, São Paulo, n. 74,

POPKIN, Jeremy. History, historians, and autobiography. Chicago: The University of Chicago Press, 2005.

Choosing history: the issue of vocation in historians' autobiographies. In: . History, historians, and autobiography. Chicago: The University of Chicago Press, 2005, p. 120-150. 
PORTO, Ana Luiz Araújo. O curso de História na Universidade Federal de Alagoas: dos primórdios à sua consolidação (1952-1979). Crítica histórica. Maceió, n. 1, p. 72-84, 2010.

PRADO JÚNIOR, Caio. Formação do Brasil Contemporâneo: colônia. $1^{\text {a }}$ edição. 1942. $11^{\mathrm{a}}$ reimpressão. $23^{\mathrm{a}}$ edição. São Paulo: Brasiliense, 2008.

. Grande Lavoura. In: _. Formação do Brasil Contemporâneo: colônia. $1^{a}$ edição. 1942. 11 a reimpressão. 23 a edição. São Paulo: Brasiliense, 2008, p. 128-154.

QUEIRÓZ, Maria Isaura Pereira de. Roger Bastide, professor da Universidade de São Paulo. Estudos Avançados. São Paulo, v. 8, n. 22, p. 215-220, 1994.

REIS, João José; SOUZA, Evergton Sales. Katia Mytilineou de Queirós Mattoso. AfroÁsia. Salvador, n. 48, p. 363-381, 2013.

REIS, Maria Candida Delgado. Masculino/feminino: fragmentos de uma construção assimétrica. In: ___ (orga.). Caetano de Campos: fragmentos da história da instrução pública no Estado de São Paulo. São Paulo: Associação dos ex-alunos do Instituto de Educação Caetano de Campos, p. 93-104.

REZENDE, Antonio Paulo. Freyre: as travessias de um diário e as expectativas da volta. In: GOMES, Angela de Castro. Escrita de si, escrita da história. Rio de Janeiro: FGV, 2004, p. 77-91.

RIBEIRO, Maria Alice Rosa. As primeiras pesquisadoras brasileiras em história econômica e a construção da disciplina no Brasil. história econômica \& história de empresas. São Paulo. v. II, n. 2, 1999.

. Lutas e conquistas das primeiras historiadoras em História Econômica, 1934-1972. In: SAES, Alexandre Macchione. RIBEIRO, Maria Alice Rosa. SAES, Flávio Azevedo Marques de (orgs.). Rumos da história econômica no Brasil: 25 anos da ABPHE. São Paulo: Alameda, 2017.

Notas sobre os sócios-honorários da Associação Brasileira de Pesquisadores em História Econômica - ABPHE. In: SAES, Alexandre Macchione. RIBEIRO, Maria Alice Rosa. SAES, Flávio Azevedo Marques de (orgs.). Rumos da história econômica no Brasil: 25 anos da ABPHE. São Paulo: Alameda, 2017, p. 331-333.

RICOUER, Paul. Da memória e da reminiscência. In: RICOEUR, Paul. A memória, a história, o esquecimento. Campinas: Editora da Unicamp, 2007, p. 23-142.

O testemunho. In: RICOEUR, Paul. A memória, a história, o esquecimento. Campinas: Editora da Unicamp, 2007, p. 170-175.

. O si mesmo como outro. São Paulo: Editora WMF Martins Fontes, 2014. 
p. XI-XLII.

. Prefácio. In: _. O si-mesmo como outro. São Paulo: WMF Martins Fontes, 2014,

. Quinto estudo. Identidade pessoal e identidade narrativa. In:

O si-mesmo

como outro. São Paulo: WMF Martins Fontes, 2014, 111-144.

Sexto estudo. O si e a identidade narrativa. In: . O si-mesmo como outro. São Paulo: WMF Martins Fontes, 2014, p. 145-181.

RINGER, Fritz K. Fields of knowledge: French academic culture in comparative perspective, 1890-1920. Cambridge: Cambridge University Press, 1992.

. O declínio dos mandarins alemães: a comunidade acadêmica alemã, 1890-1933. Tradução de Dinah de Abreu Azevedo. São Paulo: EDUSP, 2000.

A metodologia de Max Weber: unificação das ciências culturais e sociais. São Paulo: EDUSP, 2004.

RODRIGUES, José Honório. Teoria da História do Brasil. Introdução metodológica. $3^{\circ}$ edição. São Paulo: Companhia Editora Nacional, 1969.

RODRIGUES, Lidiane Soares. Florestan Fernandes: Interlúdio. São Paulo: Hucitec, 2010.

Os catedráticos da USP e o governo Jânio Quadros. Revista Pensata. São Paulo, v. 2, n. 1, p. 90-107, 2012.

Armadilha à francesa: homens sem profissão. História da Historiografia. Ouro Preto, n. 11, 2013.

RODRIGUES, Mara Cristina de Matos. O papel da universidade no "campo da história": o curso de Geografia e História da UPA/URGS na década de 1940. MÉTIS: história \& cultura. Caxias do Sul, v. 2, n. 2, p. 75-102, 2002.

. A formação superior em História na UPA/URGS/UFRGS de 1943-1971. História da historiografia. Ouro Preto, n. 11, p. 122-139, 2013.

RODRIGUES, Maria Regina da Cunha. Atividades da Sociedade de Estudos Históricos em 1961. In: Noticiário. Revista de História. São Paulo, n. 49, 1962.

ROIZ, Diogo da Silva. Entre a graduação e a cátedra: a movimentação dos alunos do curso de Geografia e História na Faculdade de Filosofia, Ciências e Letras da Universidade de São Paulo. In: ___ . Os caminhos (da escrita) da História e os descaminhos de seu ensino: a institucionalização do ensino universitário de História na Faculdade de Filosofia, Ciências e Letras da Universidade de São Paulo (1934-1968). $1^{\text {o }}$ edição. Curitiba: Editora Appris, 2012, p. 188-216. 
ROIZ, Diogo da Silva; SANTOS, Jonas Rafael dos. As transferências culturais na historiografia brasileira: leituras e apropriações do movimento dos Annales no Brasil. $1^{\circ}$ edição. Jundiaí: Paco Editorial, 2012.

ROIZ, Diogo da Silva. A dialética entre o "intelectual-letrado" e o "letradointelectual": projetos, tensões e debates na escrita da História de Alfredo Ellis Jr. e Sérgio Buarque de Holanda (1929-1959). 2013. 383 f. Tese (Programa de Pós-Graduação em História) - FCHS, UFPR, Curitiba, 2013.

ROIZ, Diogo da Silva; SANTOS, Jonas Rafael dos. Um intelectual e seu tempo: o caso Eurípides Simões de Paula (1910-1977). In: , Os caminhos (da escrita) da História e os descaminhos de seu ensino: a institucionalização do ensino universitário de História na Faculdade de Filosofia, Ciências e Letras da Universidade de São Paulo (1934-1968). $1^{\text {o }}$ edição. Curitiba: Editora Appris, 2012, p. 151-165.

ROSA, Waldeir Moreno. A práxis de Antônio Delfim Netto no reordenamento políticoeconômico da ditadura bonapartista: ideólogo orgânico da autocracia burguesa. $182 \mathrm{f}$. 2015. Dissertação (Programa de Pós-Graduação em História) - FCS/PUC-SP, São Paulo, 2015.

SAES, Flávio Azevedo Marques de. Introdução. In: CANABRAVA, Alice Piffer. História Econômica: estudos e pesquisas. São Paulo: Hucitec/Unesp/ABPHE, 2005.

O estado de São Paulo no século XX: café, indústria e finanças na dinâmica da economia paulista. In: ODALIA, Nilo; CALDEIRA, João Ricardo de Castro. (orgs.). História do Estado de São Paulo: a formação da unidade paulista. São Paulo: EDUNESP/Imprensa Oficial/Arquivo Público do Estado, 2010, v. 2, p. 13-40.

SALGUEIRO, Heliana Angotti (org.). Pierre Monbeig e a geografia humana brasileira: a dinâmica da transformação. Bauru: Edusc, 2006.

SANTOS, Alessandra Soares. A Universidade, A História e O Historiador: o itinerário intelectual de Francisco Iglésias. 2013. 345 f. Tese (Programa de Pós-Graduação em História) - Faculdade de Filosofia e Ciências Humanas/UFMG. Belo Horizonte, 2013.

SANTOS, Geminiano Wagner dos. A invenção da historiografia brasileira profissional, acadêmica: geografia e memória disciplinar, disputas político-institucionais e debates epistemológicos acerca do saber histórico no Brasil (1980-2012). 435 f. Tese (Doutorado em História) - Universidade Federal de Pernambuco, 2018.

SCHMIDT, Benito Bisso. Escrever biografias no Brasil hoje: entre inovações e modelos tradicionais. In: DUTRA, Eliana de Freitas (orga.). O Brasil em dois tempos: história, pensamento social e tempo presente. Belo Horizonte: Autêntica, 2013, p. 205-217.

SEGENREICH, Stela Cecília. Pontifícia Universidade Católica do Rio de Janeiro (PUCRJ): pioneirismo e mudança. In: MOROSINI, Marilia (orga.). A universidade no Brasil: concepções e modelos. Brasília: Instituto Nacional de Estudos e Pesquisas Educacionais Anísio Teixeira, 2006, p. 173-186. 
SILVA, Dimitri Pinheiro da. Da política à ciência política, da ciência política à política: a trajetória acadêmica de Paula Beiguelman (1949-1969). 120 f. 2008. FFLCH/USP (dissertação), Programa de Pós-Graduação em Sociologia, 2008.

. Jogo de damas: trajetórias de mulheres nas ciências sociais paulistas (1934-1969). Cadernos Pagu. Campinas, n. 46, 2016.

SILVA, Paulo Thiago Santos Gonçalves da. A Associação Nacional dos Professores Universitários de História: espaço de identificação profissional e legitimação do saber histórico (1961-1977). 334f. 2014. Tese (Programa de Pós-graduação em História) UnB. Brasília, IFCH, 2014.

SILVA, Taíse Tatiana Quadros da. A erudição ilustrada de Francisco Adolfo de Varnhagen (1816-77) e a passagem da historiografia das belas letras à historiografia nacional: breve análise histórica. In: GUIMARÃES, Manoel Luiz Salgado (org.). Estudos sobre a escrita da história. Rio de Janeiro: 7 Letras, 2006, p. 114-138.

SILVA, Wilton Carlos Lima. Espelho de palavras: Escritas de si, autoetnografia e egohistória. In: AVELAR, Alexandre; BISSO, Benito Schmidt (orgs.). Grafia da vida: reflexões e experiências com a escrita biográfica. São Paulo: Letra e Voz.

SIMIAND, François. Método histórico e ciência social. Bauru: EDUSC, 2003.

SMITH, Bonnie. Gênero e História: homens, mulheres e a prática histórica. Bauru/SP: EDUSC, 2003.

Mulheres profissionais: um terceiro sexo? In: Gênero e História: homens, mulheres e a prática histórica. Bauru/SP: EDUSC, 2003, p. 387-441.

SIRINELLI, Jean-François. Le hasard ou la nécessité? Une histoire em chantier: 1' histoire de intellectuals. Vingtième Siècle, revue d'histoire. N. 9, janvier-mars, 1986, p. 97-108.

. Khâgneux et normaliens des anées vingt. Histoire politique d'une génération d'intellectuels (1919-1945). Paris: Fayard, 1988.

. Os intelectuais. In: RÉMOND, René (org.). Por uma história política. $2^{\mathrm{a}}$ edição. Rio de Janeiro: FGV, 2003, p. 231-269.

. Entrevista. Revista Brasileira de História. São Paulo, n. 65, p. 407-412, 2013.

SKIDELSKY, Robert. John Maynard Keynes 1883-1946: Economist, Philosopher, Statesman. London: Penguin books, 2005.

SKIDMORE, Thomas. Governo Transitório (1954-1956). In: Brasil: de Getúlio Vargas a Castelo Branco, 1930-1964. $7^{a}$ edição. Rio de Janeiro: Paz e Terra, 1982, p. 181202. 
SOUSA, Ricardo Alexandre Santos de. Capistrano de Abreu: História Pátria, Cientificismo e Cultura - A construção da História e do Historiador. 2012. 309 f. Tese (Programa de Pós-Graduação em História das Ciências e da Saúde) - Casa de Oswaldo Cruz, FioCruz, Rio de Janeiro, 2012.

SZMRECSÁNYI, Tamás. Sobre a formação da Formação Econômica do Brasil de C. Furtado. Estudos Avançados. São Paulo, v. 3, n. 37, p. 207-214, 1999.

THEODORO, Janice. Eurípedes Simões de Paula (1910-1977). Revista de História. São Paulo, n. 160, p. 17-50, 2009.

TREBITSCH, Michel. Correspondances d'intelectuels: le cas de lettres d'Henri Lefebvre à Norbert Guterman (1935-1947). Les Cahiers de l'IHTP, n. 20, mars 1992.

VASCONCELLOS, Eliane. Intimidade das confidências. TERESA. Revista de Literatura Brasileira. São Paulo, n. 8/9, p. 372-389, 2008.

VENÂNCIO, Giselle Martins. Cartas de Lobato a Vianna: uma memória epistolar silenciada pela história. In: GOMES, Angela de Castro. Escrita de si, escrita da história. Rio de Janeiro: FGV, 2004, p. 111-137.

VENÂNCIO, Giselle Martins; FURTADO, André Carlos. Brasiliana \& História Geral da Civilização Brasileira: escrita da história, disputas editoriais e processos de especialização acadêmica (1956-1972). Tempo \& Argumento. Florianópolis, v. 5, n. 9, p. $5-23,2013$.

VENÂNCIO, Giselle Martins. Oliveira Vianna entre o espelho e a máscara. Belo Horizonte: Autêntica, 2015.

VEYNE, Paul. O inventário das diferenças. História e sociologia. São Paulo: Brasiliense, 1983.

VIDAL, Laurent. Mazagão, a cidade que atravessou o Atlântico: do Marrocos à Amazônia (1769-1783). São Paulo: Martins Fontes, 2008.

VITTE, Antonio Carlos. Breves considerações sobre o papel de Pierre Monbeig na formação do pensamento geomorfológico uspiano. Revista de Climatologia e Estudos da Paisagem. Rio Claro, v. 4, p. 50-69, 2009.

VOIGT, André Fabiano. Um debate sobre a descontinuidade temporal: Fernand Braudel, Gaston Bachelard, Gaston Roupnel e Georges Gurvitch. História da historiografia. Ouro Preto, n. 13, p. 188-203, 2013.

WEGNER, Robert. A conquista do oeste: a fronteira na obra de Sérgio Buarque de Holanda. Belo Horizonte: Editora UFMG, 2000.

WERNECK, Maria Helena. "Veja como ando grego, meu amigo." Os cuidados de si na correspondência machadiana. In: GALVÃO, Walnice Nogueira; GOTLIB, Nádia Battella 
(orgas.). Prezado senhor, prezada senhora: estudos sobre cartas. São Paulo: Companhia das Letras, 2000, p. 137-145.

WITTER, José Sebastião. Uma universidade autônoma. In: USP 50 anos: registros de um debate. $2^{\text {a }}$ edição. São Paulo: EDUSP, p. 53-99.

ZOREK, Bruno de Macedo. Concepções de sujeito e objeto do conhecimento na obra de Caio Prado JR. 2007. 136 f. Dissertação (Programa de Pós-Graduação em História) IFCH/UFRGS, 2007. 


\section{Apêndice biográfico ${ }^{1028}$}

Alfredo Ellis Júnior: bacharel em Ciências Jurídicas e Sociais; Prof. Interino da cadeira de História da Civilização Brasileira de 20/7/38 a 11/4/39; Prof. Catedrático da mesma cadeira.

Afonso Taunay: nascido em Desterro (capital da então Província de Santa Catarina), em 11 de julho de 1876. Concluiu os estudos humanísticos em 1894 e formou-se em engenheiro civil na Escola Politécnica do Rio de Janeiro em 1900. Nomeado preparador na Escola Politécnica de São Paulo em 1899, passou a professor substituto em 1904 e a professor catedrático de física experimental em 1910; sendo nomeado em 1917 diretor do Museu Paulista. É membro da Academia Brasileira, da Academia Paulista de Letras, dos Institutos Históricos Brasileiros, de São Paulo, Bahia, Ceará, Santa Catarina, Paraná, Espírito Santo, Sergipe, Pará, Rio Grande do Sul, Minas Gerais, Paraíba, Rio Grande do Norte, dos Institutos Arqueológicos de Pernambuco e Alagoas. Sua extensa lista de obras foi dividida em: "ficção"; "História do Brasil"; "De Brasiliae Rebus Pluribus"; "História de São Paulo"; "Biografia"; "História da cidade de São Paulo"; "História da Literatura e da Arte no Brasil"; "Linguística"; "Assuntos científicos"; "Traduções" e "Reedições comentadas".

Claude Lévi-Strauss: nasceu em Bruxelas na Bélgica em 1908. Cursou Filosofia (1928), Direito (1929) e diplomou-se em Estudos Superiores de Filosofia (1930). Obteve a agregação em Filosofia em 1931. Responsável por uma missão científica do governo francês no Brasil e regente da cadeira de Sociologia II da FFCL/USP.

Charles Morazé: licenciado em Letras e "agrégé" em História, assumiu a regência da cadeira de Política em 10 de agosto de 1948.

Diva Benevides Pinho: frequentou o curso clássico no Colégio Estadual de São João da Boa Vista/SP. Ingressou no curso de Ciências Sociais da FFCL/USP em 1945, época em que esta faculdade ocupava o terceiro andar da Escola Normal da Praça da República. Logo após a conclusão do curso tornou-se assistente de Paul Hugon na cadeira de

\footnotetext{
${ }^{1028}$ A maioria dos dados são extraídos dos vários volumes de Anuário da Faculdade de Filosofia, Ciências e Letras e de CANABRAVA, Alice Piffer (org. coord.). História da Faculdade de Economia e Administração da Universidade de São Paulo, 1946-1981. V. 2: Personália. São Paulo: FEA/USP, 1984a,
} 
Economia Política e História das Doutrinas Econômicas e ao mesmo tempo bacharelouse em Direto pela Faculdade de Direito da USP em $1954^{1029}$.

Dorival Teixeira Vieira: cursou Ciências Sociais e Políticas na FFCL/USP onde também obteve o doutoramento e livre-docência. Seus principais trabalhos são: "Evolução do Sistema monetário brasileiro"; "A obra econômica de Amaro Cavalcante"; O problema monetário brasileiro"; "Monopólio bilateral e seus principais problemas teóricos"; "A futura política econômica e financeira do Brasil" e "Informação de preços para administradores de empresas".

Eduardo D’Oliveira França: foi assistente de Émile Léonard na cadeira de História da Civilização Moderna e Contemporânea e defendeu seu doutoramento em 1942 sob a orientação de Eurípedes Simões de Paula. Em 1951 tornou-se catedrático, substituindo Émile Léonard ${ }^{1030}$.

Émile Coornaert: vindo da França, permaneceu em São Paulo apenas em 1934, indo no ano seguinte para o Rio de Janeiro, e, depois, retorna a França. Quando chegou ao Brasil, já tinha uma experiência com o ensino universitário na França. Provavelmente, sua contribuição não tenha sido tão marcante na História, como Pierre Deffontaines foi para a Geografia nessa instituição. E isso, porque Emile Coornaert, ainda que lembrado como pioneiro, não era referido como um inaugurador dos 'estudos históricos nacionais' em bases institucionais 'novas' na década de 1930, pelos ex-alunos e professores, que o conheceram no período. A lembrança de ex-alunos e professores, que tiveram aula com ele, relatavam apenas a renovação nos procedimentos metodológicos e nos temas e assuntos debatidos na disciplina ${ }^{1031}$.

Émile Léonard: doutor em Letras pela Escola de Chârtes da Sorbonne e professor contratado da cadeira de História da Civilização Moderna e Contemporânea de 12 de maio de 1948 até 1950. No Brasil, dedicou-se ao estudo do protestantismo brasileiro.

\footnotetext{
${ }^{1029}$ PINHO, Diva Benevides. O tempo revisitado: releitura proustiana de 70 anos como estudante e docente da USP. São Paulo: FUNDACI, 2015. A partir da inspiração em "Em busca do tempo perdido" de Marcel Proust, Diva Benevides Pinho perpassa sua trajetória intelectual. A narrativa não segue uma ordem cronológica. Aliás, sua única "ordem” é a da rememoração, ou seja, desordenada e fragmentada. ${ }^{1030}$ Cf. ROIZ, op. cit., 2012, p. 164-183.

${ }^{1031}$ Cf. ROIZ, Diogo da Silva; SANTOS, Jonas Rafael dos. As transferências culturais na historiografia brasileira: leituras e apropriações do movimento dos Annales no Brasil. $1^{\circ}$ edição. Jundiaí: Paco Editorial, 2012, p. 53.
} 
Ernani da Silva Bruno: formado em Direito, jornalista e historiador autodidata, com vasta produção sobre São Paulo, onde foi diretor do Museu da Casa Brasileira e diretor do MIS/SP. Seu acervo constitui fundo no arquivo do IEB/USP.

Eurípedes Simões de Paula: licenciado em Geografia e História; Doutor em Ciências; Bacharel em Ciências Jurídicas e Sociais - Prof. contratado da cadeira de História da Civilização Antiga e Medieval de 19/4/39 a 14/8/46; Prof. catedrático da mesma cadeira desde 15/8/46. Eurípedes substituiu Jean Gagé na regência da cadeira ${ }^{1032}$.

Eremildo Luiz Vianna: nasceu no Rio de Janeiro. Concluiu seus estudos no Colégio Pedro II, onde recebeu o título de bacharel em Ciências e Letras em 1932. Em 1933 entrou para a Faculdade de Direito do Rio de Janeiro e, em 1935, para o curso de História da UDF. Formou-se em Direito, mas não concluiu o curso de História; deixou a UDF em 1937, pois desde o ano anterior já dava aulas no Colégio Pedro II. Ingressou na FNFi em 1939 como assistente de História da Antiguidade e da Idade Média, e a partir de 1944 assumiu a cadeira interinamente. Prestou concurso em 1946 e pôde assumir a cátedra em caráter efetivo $^{1033}$.

Florestan Fernandes: iniciou sua carreira como assistente de Fernando de Azevedo na cadeira de Sociologia II em $1945^{1034}$.

Frédéric Mauro: foi orientando de Fernand Braudel em sua tese de doutoramento intitulada "Brasil e o Atlântico no século XVII (1510-1670), uma história econômica", defendida, com distinção, em 1957, tornando-se catedrático de História Moderna da Faculdade de Letras e Ciências Humanas da Universidade de Toulouse. Em 1949, esteve no Brasil com o fito de lecionar na FFCL/USP e coletar material para sua tese. Em 1962, deixou a cátedra de História Moderna daquela universidade e fundou um centro de pesquisas e uma cadeira de História Econômica Moderna e Contemporânea e mais uma vez atuou como professor convidado na FFCL. Uma de suas maiores realizações foi a direção, junto ao CNRS, do Instituto de Altos Estudos da América Latina (IHEAL - sigla em francês), grupo conhecido por Centro de Investigação e Documentação sobre América

\footnotetext{
1032 Ver: ROIZ, Diogo da Silva e SANTOS, Jonas Rafael dos. Um intelectual e seu tempo: o caso Eurípides Simões de Paula (1910-1977). In: _, op. cit., 2012, p. 151-165. THEODORO, Janice. Eurípedes Simões de Paula (1910-1977). Revista de História. São Paulo, n. 160, p. 17-50, 2009.

${ }^{1033}$ Cf. FERREIRA, op. cit., 2013, p. 136.

${ }^{1034}$ Sobre a sociologia de Florestan, ver: ARRUDA, Maria Arminda do Nascimento. A construção da sociologia acadêmica no Brasil: Florestan Fernandes e a Escola Paulista. Inter American Review of Bibliography. Washington, v. 44, n. 4, p. 607-636, 1994. Para uma análise detalhada da trajetória intelectual do autor, ver: RODRIGUES, Lidiane Soares. Florestan Fernandes: Interlúdio. São Paulo: Hucitec, 2010.
} 
Latina (CREDAL), tendo realizado três grandes colóquios internacionais, um deles sobre "História Quantitativa do Brasil, 1800-1930"1035.

Heraldo Barbuy: obteve o doutoramento na FCEA/USP (1961), livre-docência (1965) e cátedra por concurso (1968), aposentando-se em 1977. Seus principais trabalhos são: “As origens da crise contemporânea"; "O problema do ser"; "O pavlovismo como teoria da vida"; "Sociologia e sociografia"; "Marxismo e religião" e "Preâmbulo sobre a técnica". Jayme Coelho: é sabido que se formou em Direito na França e que foi professor do Colégio Pedro II e em 1936 ingressou na Cadeira de História da Antiguidade da UDF. Em entrevista concedida por Vicente Costa Santos Tapajós - que ingressou no curso de História da UDF em 1935, e foi ex-aluno de Jayme Coelho - a Marieta de Moraes Ferreira, em 1994, afirmou que o historiador da Antiguidade era discípulo de Capistrano de Abreu: "Discípulo de Capistrano de Abreu, possuía um extraordinário conhecimento do assunto e, embora não fosse um didata, falava sem parar na classe e na cantina, onde íamos encontrá-lo para aprender mais. Ele nos recebia em casa também e nos emprestava livros. Já formado, levou-me para dar aula no Instituto de Educação, e eu o substitui na cátedra, participando de concursos de provas e títulos, defesas de teses etc. Preguiçoso, não escrevia muito, mas como lia! Morreu, praticamente, nos meus braços" ${ }^{1036}$.

Jean Gagé: aluno, na "Ecole Normale Supérieure" e na "Sorbonne", de J. Carcopino (história romana), e, no "Collège de France", de R. Cagnat (epigrafia latína). Membro da “Ecole française de Rome” (palais Fernese), sob a direção de Emile Mâle, de 1925 a 1928. Encarregado de missões arqueológicas na Algéria em 1926 (escavações no Belezma) e em 1928 (escavações em Bône-Hippone). Viagens de estudos na Itália e na Grécia. Professor do "Lycée Kléber" de Strasburgo, em 1928-1929. "Chargé de cours" de História romana (em suplência de A. Piganiol) na Faculdade de Letras da Universidade de Strasburgo de 1929 a 1924. "Maître de conférences" de História romana na mesma Faculdade, desde 1934. [...] Membro do juri do exame vestibular da "École Normale Supérieure" de Sèvres, em 1937. Redator da “Année Epigraphique”, em colaboração com M. A. Merlin, desde 1937.

\footnotetext{
${ }^{1035}$ Cf. BRODER, Albert. La trayectoria de Frédéric Mauro. história econômica \& história de empresas. São Paulo, v. 5, n. 1, p. 165-169, 2002.

${ }^{1036}$ Cf. TAPAJÓS, Vicente. Entrevista. In: FERREIRA, Marieta de Moraes. A História como ofício: a constituição de um campo disciplinar. Rio de Janeiro: Editora FGV, 2013, p. 163-164.
} 
João Dias da Silveira: em 1939 foi contratado como professor da cadeira de Geografia do Brasil. O contrato de Dias da Silveira foi renovado até 1949 quando, aberto concurso para provimento efetivo da cadeira, foi o mesmo professor nomeado para reger o ensino interinamente (posteriormente, tendo realizado concurso de títulos e provas, tornou-se professor catedrático). É autor da primeira tese de Geomorfologia escrita no Brasil e defendida em 1947 sob o título de "Estudo geomorfológico dos contrafortes ocidentais da Serra da Mantiqueira" sob a orientação de Pierre Monbeig ${ }^{1037}$.

José Ignácio Benevides de Rezende: bacharel em Ciências Jurídicas e Sociais pela FD/USP. Iniciou sua carreira na FCEA como catedrático de Ciência das Finanças (1946) e aposentou-se como catedrático de Sociologia Geral e Aplicada (1966). Seus principais trabalhos são: "Da influência máxima do comércio nas relações internacionais"; "O novo tribunal de reclamações"; "Matéria processual na constituição" e "Relações internacionais da moeda. Estudo objetivo da conferência monetária de Bretton Woods". José Ribeiro de Araújo Filho: ingressou no curso de Geografia e História da antiga FFCL/USP, atual FFLCH/USP, em 1939, ocasião na qual foi examinado por Alice Canabrava em sua admissão e foi seu aluno na cadeira de Paul Vanorden Shaw, catedrático de História da Civilização Americana. No Anuário da Faculdade de Filosofia, Ciências e Letras, 1939-1949, volume I, Araújo Filho figura na seção “Assistentes” do “Corpo Docente", enquanto primeiro assistente da cadeira de Geografia do Brasil.

José Roberto do Amaral Lapa: graduou-se em Geografia e História pela Faculdade de Filosofia de Campinas (1952) e bacharelou-se em Ciências Jurídicas e Sociais pela mesma Universidade (1959). Realizou doutoramento sob a orientação de Sérgio Buarque de Holanda (1966). Iniciou sua carreira docente no curso de História da FFCL de Marília/SP. Transferiu-se para a UniCamp nos anos 1970, onde dedicou-se à história da cidade. Dentre sua produção também se destaca suas análises em historiografia brasileira. Seu acervo pessoal se encontra sob a custódia do Centro de Memória da UniCamp (CMU), do qual é fundador ${ }^{1038}$.

\footnotetext{
1037 Cf. VITTE, Antonio Carlos. Breves considerações sobre o papel de Pierre Monbeig na formação do pensamento geomorfológico uspiano. Revista de Climatologia e Estudos da Paisagem. Rio Claro, v. 4, p. $50-69,2009$.

${ }^{1038}$ Ver: RIBEIRO, Maria Alice Rosa. José Roberto do Amaral Lapa (1929-2000). História econômica \& história de empresas. São Paulo, v. 3, n. 1, p. 160-163, 2000.
} 
Leslie Stevens: estudou matemática e física nas Universidade de Reading e Cambridge (1928-1932). Foi catedrático de Estatística Matemática e Estatística Demográfica na FCEA/USP entre 1948 e 1958, quando faleceu.

Lenita Côrrea Camargo: Realizou o ensino secundário na Escola Normal do Liceu Nacional Rio Branco e graduou-se em Ciências Sociais pela FFCL/USP. Realizou doutoramento na antiga FCEA/USP, com a tese "O Cooperativismo e a formação de preços" (1958). Foi a segunda mulher da história da atual FEA/USP a atingir a cátedra por concurso (1963).

Licurgo do Amaral Campos: auxiliar de ensino da cadeira V (contabilidade geral e contabilidade pública) do departamento de Organização e Contabilidade.

Lourival Gomes Machado: autor da primeira tese de doutoramento da FFCL/USP na área de Ciências Sociais. Intitulada "Alguns aspectos atuais do problema do método, objeto e divisões da ciência política", foi defendida em 1942 e obteve distinção da banca examinadora composta por: "Radcliffe-Brown (um dos fundadores da antropologia social inglesa e que se encontrava como professor da ELSP/SP), Fernando de Azevedo, Roger Bastide, João Cruz Costa e Paul Arbousse-Bastide, seu orientador”1039.

Luiz de Freitas Bueno: realizou doutorado na ELSP/SP (1948), obteve a livre-docência na Faculdade de Economia da Universidade do Rio Grande do Sul, sob o título de "Base de análise estatística de procura de mercado" (1957) e tornou-se catedrático por concurso na FCEA/USP (1959). Ocupou cargos públicos no DEE e Conselho Federal de Educação. Maria José Villaça: realizou o ensino secundário no Instituto de Educação Caetano de Campos e graduou-se em Ciências Sociais pela FFCL/USP (1946). Obteve o doutoramento na antiga FCEA/USP, com a tese "A força de trabalho no Brasil" (1961). Obteve a livre-docência com a tese "Liquidez, moeda e crédito" (1966).

Oracy Nogueira: foi figura atuante na institucionalização das ciências sociais no Brasil, professor da Escola Livre de Sociologia e Política de São Paulo (ELSP/SP), onde realizou sua graduação (1942) e mestrado (1945). Iniciou sua carreira no antigo Instituto de Administração da antiga FCEA em 1952; foi instrutor da cadeira XI de sociologia geral e aplicada até 1969; realizou concurso para professor adjunto em 1978 e em 1981 figurava como professor titular da disciplina "sociologia aplicada à economia".

${ }^{1039}$ Cf. PONTES, Heloisa. Destinos mistos: os críticos do Grupo Clima em São Paulo (1940-68). São Paulo: Companhia das Letras, 1998, p. 23. 
Paula Beiguelman: licenciou-se em Ciências Sociais no ano de 1945, quando foi trabalhar no Departamento de Serviço Público (DSP), transferindo-se pouco tempo depois para o Departamento Estadual de Estatística (DEE), onde atuou até tornar-se auxiliar de ensino na cadeira de Política em $1949^{1040}$.

Pierre Deffontaines: nasceu em 1894 em Limoges na França. Em 1916 licenciou-se em Direito em Poitiers, obtendo também doutoramento em Direito civil pela mesma universidade em 1918. Em 1919 obtém licenciatura em História e Geografia pela Sorbonne e em 1920 o diploma de estudos superiores em Geografia pela mesma instituição. Também foi responsável por várias missões geográficas, como no Saara e na Europa central, com destaque para a antiga Tchecoslováquia. De suas principais publicações destacamos: "Geografia Humana da França”, publicado no segundo volume da "História da nação francesa" de Gabriel Hanotaux e em colaboração com o geógrafo Jean Brunhes; reeditou a obra de Jean Brunhes intitulada "Geografia Humana" em 3 volumes; e vários artigos sobre o Brasil, em especial: DEFFONTAINES, Pierre. Regiões e paisagens do Estado de São Paulo. Primeiro esboço de divisão regional. Geografia. São Paulo, n. 2, p. 117-169, 1935.

Pierre Monbeig: foi aluno de História Econômica de Henri Hauser na Universidade de Paris, bem como aluno de Geografia de Demangeon e De Martonne na mesma universidade. Licenciado em Letras em 1927. Em 1928 obtém o certificado de Geografia geral. Destaque é dado para suas colaborações nos Annales de Géographie, periódico fundado em 1891 por Paul Vidal de La Blache, marco da fundação da moderna Geografia na França.

Paul Vanorden Shaw: nascido a 11 de julho de 1898, em São Paulo, fez seus estudos secundários no Ginásio de Lavras/MG, no Wellsbore, High School, Pennsylvania, Estados Unidos. Nesse país, continuou os estudos superiores no College of Wooster (Ohio) onde, em 1919, obteve o grau de Bacharel em Artes. Depois de uma estada de dois anos na América do Sul, voltou a Nova York, e na Universidade de Columbia obteve o grau de Mestre em Artes (1926), e, em 1930, o de Doutor em Filosofia. Em sua produção devemos destacar seus estudos acerca de José Bonifácio e sua vasta publicação de artigos sobre a América Latina em jornais como o "New York Times" e o "Washington Post".

\footnotetext{
${ }^{1040} \mathrm{Cf}$. SILVA, Dimitri Pinheiro da. Da política à ciência política, da ciência política à política: a trajetória acadêmica de Paula Beiguelman (1949-1969). 2008. 120 f. FFLCH/USP (dissertação), Programa de PósGraduação em Sociologia, 2008.
} 
Plinio Ayrosa: nascido em São Paulo, capital, aos 13 de março de 1895. Bacharel em letras pelo antigo Ginásio Ciências e Letras e graduado em Engenharia pela Escola Politécnica do Rio de Janeiro. Obteve o primeiro prêmio de literatura, instituído pelo Jornal do Brasil em 1917 e direito ao prêmio de viagem à Europa para aperfeiçoamento de estudos. Encarregado de um curso de Tupi no Centro do Professorado Paulista. Secretário Geral do Instituto Histórico e Geográfico de São Paulo e membro dos Institutos Históricos do Rio Grande do Norte, Bahia e Santa Catarina.

Roger Bastide: Após o retorno de Lévi-Strauss para a França em 1938, Roger Bastide assumiu as funções da cadeira de Sociologia I, permanecendo no Brasil até 1984. Nasceu em Nimes em 1898, onde cursou o liceu (1908-1915). Em 1919, após servir na guerra, na cidade de Strasburgo se prepara para o concurso da Escola Normal Superior, ocasião na qual conheceu Paul-Arbousse Bastide. Em 1920 obteve o diploma de estudos superiores em Filosofia pela Universidade de Bordeaux. Obteve sua agregação em 1924, quando parte para Cahors. Permanece em Valence de 1928 a 1937, onde exerceu atividades políticas e literárias ligadas ao Partido Socialista Francês ${ }^{1041}$.

Theotônio Monteiro de Barros Filho: Cursou Ciências Jurídicas e Sociais (1923) na FD/USP, onde obteve a livre-docência e a cátedra.

1041 Cf. PEIXOTO, Fernanda. Diálogos brasileiros: uma análise da obra de Roger Bastide. São Paulo: EDUSP, 2000, p. 22. 


\section{Apêndice 2: Trajetória de uma pesquisa}

O Instituto de Estudos Brasileiros (IEB) da USP foi concebido por Sérgio Buarque de Holanda quando tornou-se catedrático de História da Civilização Brasileira em 1958 na FFCL/USP, substituindo Alfredo Ellis Jr. No desempenho de suas funções, Sérgio Buarque constatou que suas atividades não permitiam o aprofundamento necessário da pesquisa sobre a civilização brasileira, uma vez que a cadeira preconizava o ensino, inclusive os assistentes de pesquisa possuíam este como principal encargo. Ademais, em sua concepção, a disciplina histórica não poderia tratar sozinha de área tão ampla como a civilização brasileira, fazendo-se necessária a colaboração com outras disciplinas. Assim, entre 1958 e 1962, Sérgio Buarque amadureceu a ideia e neste último ano propôs a criação de um Instituto onde as várias cadeiras da USP que tomavam enquanto objeto assuntos relacionados à civilização brasileira estariam representadas em uma concepção de pesquisa multidisciplinar. Assim, com o apoio da reitoria, o IEB iniciou suas atividades um ano depois, em 1963 com a aquisição da brasiliana de Yan de Almeida Prado.

Dentre as várias cadeiras da USP que se dedicavam ao ensino e à pesquisa em temas brasileiros e que formaram o IEB, com seus respectivos catedráticos, temos: Sérgio Buarque de Holanda; Aroldo de Azevedo, cadeira de Geografia do Brasil da FFCL; Mário Pereira de Souza Lima, Literatura Brasileira da FFCL; Egon Schaden, catedrático de Antropologia e Etnografia do Brasil, também da FFCL; Dirceu Lino de Mattos, da cadeira de Geografia Econômica geral e do Brasil da FCEA; Antonio Delfim Neto, de Economia brasileira da FCEA e Eduardo A. Kneese de Mello, da cadeira de História da Arquitetura no Brasil, da FAU. Em 1963, Alice Canabrava possuía mais de dez anos como catedrática da FCEA em História Econômica geral e do Brasil e também compôs o primeiro Conselho de Administração do Instituto empossado em 10 de outubro de 1962.

Este Conselho, em reunião de quatro de novembro de 1966, recomendou a compra do acervo de Mário de Andrade, constituído por biblioteca, arquivo e fichários, desenhos, gravuras, imagens, ex-votos, quadros e esculturas. Em 1968 a FFCL doou ao IEB a biblioteca Alberto Lamego e em 1969 foi autorizada a compra da biblioteca Jorge Tibiriçá, composta por livros e documentos concernentes à Guerra do Paraguai ${ }^{1042}$.

${ }^{1042}$ Cf. CALDEIRA, João Ricardo de Castro. IEB: origem e significados. São Paulo: Oficina do livro Rubens Borba de Moraes, Imprensa oficial do Estado, 2002. Ver também: BATISTA, Marta Rossetti. Sérgio Buarque de Holanda e o Instituto de Estudos Brasileiros. In: CALDEIRA, João Ricardo de Castro 
Assim, ao longo dos anos, o Instituto foi formando seu rico arquivo, biblioteca e coleção de artes visuais, adquirindo ou recebendo por doação, importantes coleções como as de Yan de Almeida Prado (adquirido pela USP em 1962), Anita Malfatti (1989), Graciliano Ramos (1980 e 1994), João Guimarães Rosa (1973), Fernando de Azevedo (1970), Pierre Monbeig (1990), Antônio de Alcântara Machado (1977/1986/1988), Guilherme de Almeida (1992), Caio Prado Júnior (2001), Ernani da Silva Bruno (1988/1990), Camargo Guarnieri (2000) etc ${ }^{1043}$. Podemos notar que seu arquivo, biblioteca e coleção de artes visuais, receberam ao longo de décadas, coleções pessoais de intelectuais acadêmicos e não-acadêmicos, músicos, literatos, artistas etc. Assim, o arquivo/IEB especializou-se em acervos pessoais, tornando-se uma verdadeira brasiliana, composta por documentos de diversos tipos: fotos, correspondências, manuscritos, recortes de jornal, partituras etc ${ }^{1044}$.

A coleção Alice Piffer Canabrava, composta por biblioteca e acervo documental, chegou ao Instituto, como vimos, em 2005. Sua biblioteca não foi integralmente incorporada ao IEB/USP, uma vez que, conforme comissão de técnicos do Instituto em

(org.). Perfis buarqueanos: ensaios sobre Sérgio Buarque de Holanda. São Paulo: Fundação Memorial da América Latina/IMESP, 2005, p. 49-55.

1043 Até 1996 o IEB, considerando seu arquivo, biblioteca e coleção de artes visuais, possuía 27 acervos, perfazendo, respectivamente, 250 mil documentos, 110 mil volumes e 2.200 obras de arte. Cf. BATISTA, Marta Rossetti (coorda.). ABC do IEB: guia geral do acervo. São Paulo: EDUSP, 1997. Em 2009 o IEB já contava com 91 fundos e coleções. Quantitativamente trata-se de 450 mil documentos no arquivo, 180 mil livros na biblioteca e 8 mil objetos na coleção de artes visuais. Cf. LANNA, Ana Lúcia Duarte (orga.). Guia do IEB: o acervo do Instituto de Estudos Brasileiros. São Paulo: IEB, 2010. As novas aquisições, legados e doações podem ser consultados no guia online do Instituto em: 〈www.ieb.usp.br/guia-ieb $\rangle$. Acessado em 03 de nov. 2016.

${ }^{1044} \mathrm{O}$ Arquivo/IEB é um arquivo permanente especializado em acervos pessoais. A partir da teoria das três idades documentais, a arquivística classifica os arquivos em: correntes, intermediários e permanentes. Os arquivos correntes abrigam os documentos durante seu uso funcional, administrativo, jurídico para os quais foram criados. Seu tempo de uso é geralmente de um ano, podendo o órgão gerador possuir um arquivo central onde podem permanecer por cinco a dez anos, sem que se configure uma nova idade. Os arquivos intermediários abrigam os documentos de segunda idade, ou seja, aqueles que já perderam as funções para as quais foram criados, por um prazo de cerca de 20 anos. Findo esse prazo, aplica-se aos documentos a tabela de temporalidade, concebida, idealmente, por funcionário que conhece profundamente o expediente da administração ao qual essa documentação está ligada, um arquivista e um historiador. Juntos, e sob critérios acordados em comum, definem quais documentos serão descartados e quais possuem valor permanente, transformando-se em documentos históricos. Finalmente, os arquivos permanentes abrigam essa documentação de valor histórico. Cf. BELLOTTO, Heloísa Liberalli. Da administração à história: ciclo vital dos documentos e função arquivística. In: . Arquivos permanentes: tratamento documental. $4^{\mathrm{a}}$ edição. Rio de Janeiro: FGV, 2007, p. 23-34. Os arquivos pessoais não possuem três idades como os arquivos públicos, mas sim duas: a primeira idade diz respeito ao uso funcional dos documentos pelo próprio titular em suas atividades de trabalho e existência civil. Na segunda idade, que corresponde à fase da preservação, sua existência está ligada à pesquisa efetuada por terceiros. Cf. BELLOTTO, Heloísa Liberalli. Arquivos pessoais como fonte de pesquisa. In: BELLOTTO, op. cit., 2007, p. 263-270. 
visita ao acervo, juntamente com Iraci Del Nero da Costa - indicado por Alice - 1/3 do acervo estava comprometido por cupins ${ }^{1045}$.

A "Coleção Alice Piffer Canabrava"1046 contava com aproximadamente 2 mil volumes não processados em sua biblioteca (livros, separatas, teses e revistas) e 316 documentos processados, compostos por variados tipos documentais como programas de cursos, comunicados, recibos, resumos de eventos, artigos de periódicos e, principalmente, anotações e correspondências ${ }^{1047}$. Com a incorporação do restante do espólio de Alice ${ }^{1048}$ - que na verdade possui maior acervo documental que o primeiro a Coleção passou à constituir um Fundo ${ }^{1049}$, com, atualmente, 804 itens documentais descritos ${ }^{1050}$.

Após a chegada da documentação ao Arquivo (processo de recolhimento), procedeu-se à operações de conservação do material, como passagem de escova adequada (limpeza mecânica) e desmetalização, ou seja, remoção de grampos e clipes de metal que, com o tempo, enferrujam e agridem o papel. Para sua estabilização, cada documento foi acondicionado em papel neutro e guardado em caixa polionda lavável, que protege contra água, e disposta em prateleira basculante na sala de fundos do Arquivo/IEB, onde a umidade e temperatura são controladas (fatores ambientais) ${ }^{1051}$.

${ }^{1045}$ Cf. Ata $128^{\text {a }}$ reunião do Conselho Deliberativo do Instituto de Estudos Brasileiros da Universidade de São Paulo. In: Processo 2003.1.59.31.0.

${ }^{1046}$ Compreende-se por coleção "[...] conjuntos de documentos de vários tipos e origens reunidos por uma pessoa ou instituição, em geral relacionados a um assunto ou a uma personalidade”. Cf. LANNA, op. cit., 2010, p. 57.

${ }^{1047}$ Cf. Alice Piffer Canabrava. In: LANNA, op. cit., 2010, p. 73. Estas informações também estão disponíveis no guia online: <www.ieb.usp.br/guia-ieb/detalhe/91>. Acessado em 03 de nov. 2016.

${ }^{1048}$ Este espólio também era integrado por 126 títulos de livros que foram transferidos para a biblioteca do IEB/USP.

1049 "Por fundo, compreende-se um conjunto de documentos de caráter pessoal, científico, artístico, profissional ou técnico produzidos e/ou reunidos em decorrência das atividades de seu titular". Cf. LANNA, op. cit., 2010, p. 57.

${ }^{1050}$ Heloísa L. Bellotto, uma das maiores estudiosas de arquivística do país e que trabalhou como pesquisadora do IEB, fornece-nos uma ampla definição de fundo e uma advertência: "Admite-se como fundo o conjunto de documentos produzidos e/ou acumulados por determinada entidade pública ou privada, pessoa ou família, no exercício de suas funções e atividades, guardando entre si relações orgânicas, e que são preservados como prova ou testemunho legal e/ou cultural, não devendo ser mesclados a documentos de outro conjunto, gerado por outra instituição, mesmo que este, por quaisquer razões, lhe seja afim". BELLOTTO, Heloísa Liberalli. Identificação de fundos. In: BELLOTTO, op. cit., 2007, p. 128. O princípio da proveniência é a base da teoria dos fundos, uma vez que estes devem ser organizados de acordo com a origem do documento e seu órgão produtor.

${ }^{1051}$ Procedimentos básicos de conservação podem ser encontrados em: CASSARES, Norma Cianflone. Como fazer conservação preventiva em arquivos e bibliotecas. São Paulo: Arquivo do Estado/Imprensa Oficial, 2000. 
Após a estabilização da documentação, é necessário que se promova o arranjo do fundo. Diante da vasta gama de tipos documentais, desde fotos e cartões postais, passando por cadernos de receita culinária, boletins escolares, documentação de Guilherme Ahlberg, seu mordomo que adotou por irmão, documentação de sua irmã Clementina, até correspondências "profissionais" e "familiares", procedemos à elaboração do quadro de arranjo para a descrição documental do fundo Alice Piffer Canabrava na base de dados do Arquivo/IEB (Sistema de Gerenciamento de Acervos - SGA) ${ }^{1052}$. Esse quadro de arranjo foi concebido à partir da abordagem contextual da teoria arquivística, ou seja, cada grupo e subgrupo do quadro insere os tipos documentais em seus contextos de produção, onde nos perguntamos "como" e "quando" os mesmos foram produzidos (figura 1) ${ }^{1053}$ :

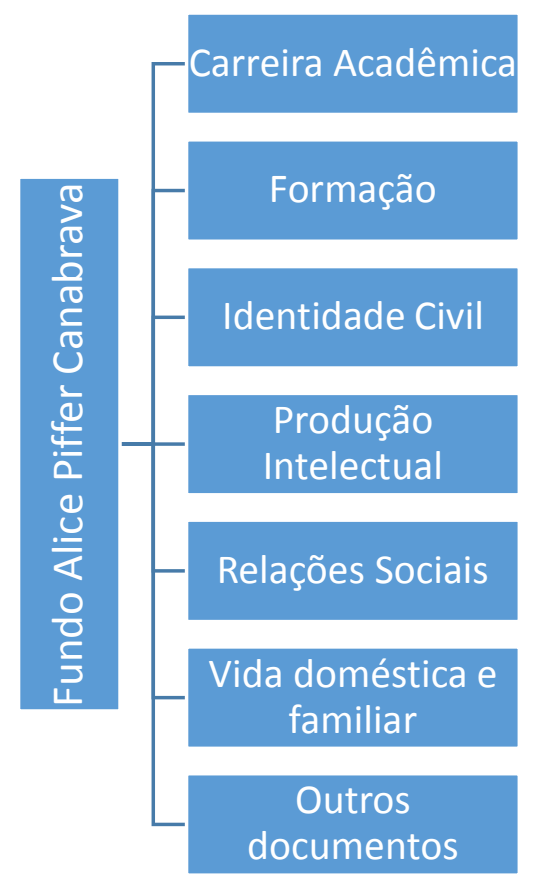

Em "Carreira acadêmica" se encontra documentação relacionada às atividades profissionais de Alice em várias instituições como a Associação de Geógrafos Brasileiros

\footnotetext{
${ }^{1052}$ A elaboração do quadro de arranjo é pautada no princípio da proveniência. Para a sistemática de elaboração do arranjo ver: BELLOTTO, Heloísa Liberalli. Sistemática do arranjo. In: BELLOTTO, op. cit., 2007, p. 135-145.

${ }^{1053}$ Cf. CAMARGO, Ana Maria de; GOULART, Silvana. Tempo e circunstância: a abordagem contextual dos arquivos pessoais. São Paulo: IFHC, 2007. O livro mostra a experiência das autoras na organização do arquivo pessoal de Fernando Henrique Cardoso, compreendendo arquivo e biblioteca.
} 
(1 item) e a Fundação Instituto de Pesquisas Econômicas (3). No grupo "Formação" está a documentação produzida pela vida escolar de Canabrava, como o subgrupo "Ginásio", onde estão seus boletins escolares do Colégio Stafford (2). Em seguida, no grupo "Identidade Civil" estão os documentos que fornecem a inserção da titular do fundo enquanto cidadã brasileira, como certidão de nascimento, cédula de identidade, passaportes etc (8). O grupo seguinte, agrupa os documentos produzidos pela historiadora na elaboração de suas obras, denominado "Produção Intelectual". Esse grupo está dividido em três subgrupos de acordo com o que conseguimos identificar como documento produzido em preparação para determinada obra, como o subgrupo "O Desenvolvimento da cultura do algodão na província de São Paulo (1861-1875)" (5), tese produzida pela titular do fundo para a obtenção da cátedra de História Econômica da FCEA/USP. Há ainda os subgrupos: "Estudos para a obra de Alice P. Canabrava" (45) que incluem diversas anotações de pesquisa e levantamentos bibliográficos e "O Comércio Português no Rio da Prata (1580-1640)" (1), que agrupa anotações para a elaboração de sua tese de doutoramento apresentada em 1942 na FFCL/USP.

No grupo "Relações sociais", encontra-se alocada documentação produzida por Alice em função do que François Sirinelli formulou como redes de sociabilidade ${ }^{1054}$. São correspondências geradas à partir de sua atuação como professora primária em Araras/SP e de sua carreira acadêmica, com outros acadêmicos do período, orientandos e amigos (582). Os mais frequentes correspondentes de Alice foram: Francisco Iglésias (63 itens), professor da antiga Faculdade de Ciências Econômicas da Universidade de Minas Gerais ${ }^{1055}$; Maria Celestina Teixeira Mendes Torres (18), sua colega de turma na graduação em Geografia e História na FFCL/USP em 1937 e sua primeira assistente de pesquisa na FCEA/USP; Antônio Emílio Muniz Barreto (16), seu orientando de

${ }^{1054}$ SIRINELLI, Jean-François. Os intelectuais. In: RÉMOND, René (org.). Por uma história política. $2^{\mathrm{a}}$ edição. Rio de Janeiro: FGV, 2003, p. 231-269.

1055 Para um estudo detalhado da trajetória desse historiador, ver: SANTOS, Alessandra Soares. A Universidade, A História e O Historiador: o itinerário intelectual de Francisco Iglésias. 2013. 345 f. Tese (Programa de Pós-Graduação em História) - Faculdade de Filosofia e Ciências Humanas/UFMG. Belo Horizonte, 2013. 
doutoramento $^{1056}$; Zélia Maria Cardoso de Mello (12), sua orientanda de doutoramento ${ }^{1057}$.

Em "Vida doméstica e familiar" alocamos a documentação produzida por suas relações familiares e também em relação à organização da vida cotidiana (129 itens). O subgrupo "Finanças" inclui documentação relacionada à vida financeira da titular, como recibos diversos, escrituras de imóveis, talões de cheques, cartões bancários etc (36). Outro subgrupo, "Guilherme Ahlberg" (51), inclui a documentação de Guilherme, mordomo das irmãs Alice e Clementina e que se tornou um irmão para ambas, como se referem à ele em várias cartas. Inclui receitas médicas, cédula de identidade, talões de cheque, cadernetas de poupança etc. Por fim, o agrupamento "Vida doméstica e familiar" ainda inclui o subgrupo "Saúde", onde constam receitas médicas e cartão de vacinação da titular. Por último, em “Outros documentos” estão tipos documentais variados, como aulas, cartas etc que ainda não foram por nós analisados ${ }^{1058}$.

Após a formulação do quadro de arranjo, passa-se ao processo de descrição documental, cujo objetivo é a elaboração de instrumentos de pesquisa. O trabalho de

1056 Muniz Barreto foi assistente de Alice durante o período 1967-1970 e também seu orientando de doutoramento. Em 23 de novembro de 1973, Muniz Barreto defendeu a tese "Evolução histórica do comércio argentino-brasileiro (1800-1930)" perante banca examinadora formada por: José Francisco de Camargo (FEA/USP), Heraldo Barbuy (FEA/USP), Eduardo D'Oliveira França (FFLCH/USP) e Myriam Ellis (FFLCH/USP), recebendo nota 9,0. Cf. Relação de tese-economia - doutorado. Cf. $\langle$ http://www.fea.usp.br/media/fck/DoutEcon.pdf $\rangle$. Acessado em 05 de nov. 2016.

1057 Outros correspondentes menos assíduos: Arquivo Público e Histórico do Município de Rio Claro/SP, Mbá de Ferrante, Adalberto Marson, Akihiro Ikeda, Alcides Serzedello, Aníbal Abadil-Aicardi, Antônio Atrazas, Antônio Carlos da Ressurreição Xavier, Beatriz Ricardina de Magalhães, Benedicto Heloiz Nascimento, Boris N. Komissarov, Branca Caldeira, Carlos Viacava, Célia Freire D’Aquino Fonseca, Célio da Cunha, Centro Acadêmico "Visconde de Cairu", Charles M. Hardin, Charles Boxer, Cid José Teixeira Cavalcante, Consuelo Meyer, Daniel Valle Ribeiro, Daphne Cesar, Eduardo Pereira de Carvalho, Estella Ferraz Costa Negraes, Eva Alterman Blay, Fernand Braudel, Fernando Manuel de Mendonça, Francisco de Assis Barbosa, Francisco Vidal Luna, Frederic Mauro, Edmundo de Macedo Soares e Silva, George Jekabson, Geraldo Cardoso, Gil José Pace, Hans Schellenberg, Harry Bernstein, Helga I. L. Piccolo, Hélio Dantas, Heloísa Liberalli Bellotto, Ibrahim João Elias, Joaryvar Macedo, Jornal da Roselância, José Aderaldo Castello, José Albertino Rosário Rodrigues, José Bonametti, José Brendan Macdonald, José Ênio Casalecchi, José Francisco de Camargo, José Gonçalves Salvador, José Luiz Pasin, José Ribeiro Júnior, José Roberto Barreto, José Roberto do Amaral Lapa, José Sebastião Witter, Kátia M. de Queirós Mattoso, Laura de J. Nunes, Lewis U. Hanke, Lúcia, professora do Grupo Escolar de Araras/SP, Manoel Salvador Ramos, Manuel Correia de Andrade, Maria Amélia Buarque de Holanda, Maria Luiza Alvarenga Freire Carette, Maria Yeda Leite Linhares, Mário Portugal Fernandes Pinheiro, Mário Wagner Vieira da Cunha, Mircea Buescu, Mirian L. Moreira Leite, Norma de Góes Monteiro, Oswaldo da Silveira Neves, Paulette Braudel, Paulo Mendroni, Pedro Calmon, Pedro Martinello, Peter Louis Eisenberg, Raquel Glezer, Richard Graham, Romulo Garcia de Andrade, Ronaldo Marcos dos Santos, Ruy Ribeiro de Moraes Leme, Sociedade Geográfica da URSS, Tamás Szmrecsanyi, Theo Santiago, Vilma dos Santos Cardoso Monteiro, Willian Alan Cole, Wilson Cano, Liceu de Humanidades de Campos e Museu da Imagem e do Som/SP.

${ }^{1058}$ Até o momento da organização e descrição do Fundo Alice Piffer Canabrava não tomamos as fotos e cartões postais. 
descrição realizado pelo arquivista deve identificar, condensar e apresentar todas as possibilidades de uso e aplicação da documentação descrita, com o fito de proporcionar um profícuo encontro entre o historiador e a documentação. Por isso, a intensa sinergia entre arquivística e história, uma vez que o arquivista deve estar ciente das práticas de pesquisa historiográfica para uma descrição que sirva ao historiador ${ }^{1059}$.

No caso do Arquivo/IEB, esta descrição é inserida em seu SGA, interligado ao catálogo eletrônico que dá acesso à uma busca integrada entre Arquivo, Biblioteca e Coleção de Artes Visuais. Um catálogo é elaborado no nível das séries que formam um fundo e sua base de descrição são as unidades documentais ${ }^{1060}$. No Arquivo/IEB adotase um nível de descrição por unidade documental.

A interface inicial do SGA, após a inserção de login e senha, é apresentada abaixo (imagem 1):

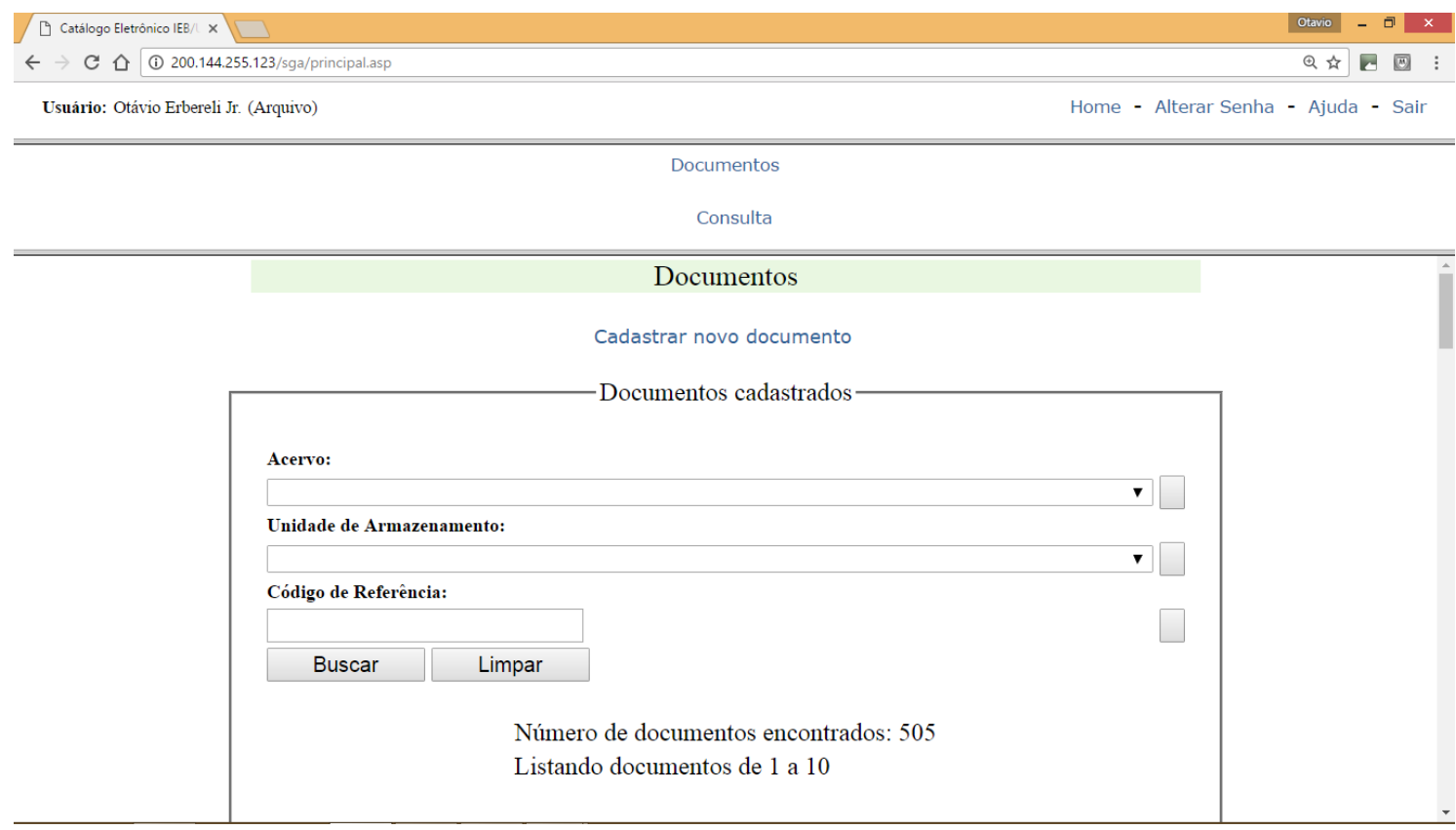

${ }^{1059}$ Cf. BELLOTTO, Heloísa Liberalli. O sentido da descrição documental. In: BELLOTTO, op. cit., 2007, p. 173-178.

${ }^{1060}$ Cf. LOPEZ, André Porto Ancona. Como descrever documentos de arquivo: elaboração de instrumentos de pesquisa. São Paulo: Arquivo do Estado/Imprensa Oficial, 2002. Há ainda outros instrumentos de pesquisa como o guia, primeiro instrumento de um arquivo, o inventário e o índice. O guia possui como base de descrição conjuntos documentais amplos e deve fornecer uma radiografia geral do arquivo, como suas origens, seus fundos e coleções, endereço, formas de contato, formas de consulta e requisitos para tanto. Na sequência de descrição hierárquica, temos o inventário, que deve fornecer uma descrição dos fundos do arquivo ou suas coleções. Há também os índices, que procuram decompor os documentos em descritores que podem ser temáticos, cronológicos, geográficos, onomásticos etc. Faz-se mister a utilização de um vocabulário controlado em sua elaboração. O mais comum é que o índice seja adotado dentro de outros instrumentos de pesquisa. 
Como podemos notar, o gerenciador dispõe das opções "consulta", que conduzirá ao catálogo online, e "documentos". Ao escolher a opção "documentos” temos acesso à uma listagem dos documentos cadastrados, em um total de 505 - à época da elaboração desse apêndice. Em nosso caso, temos acesso somente aos documentos do fundo Alice Piffer Canabrava.

Ao clicar em "cadastrar novo documento", somos remetidos ao formulário de descrição da unidade documental, conforme ilustração abaixo (imagem 2) ${ }^{1061}$ :

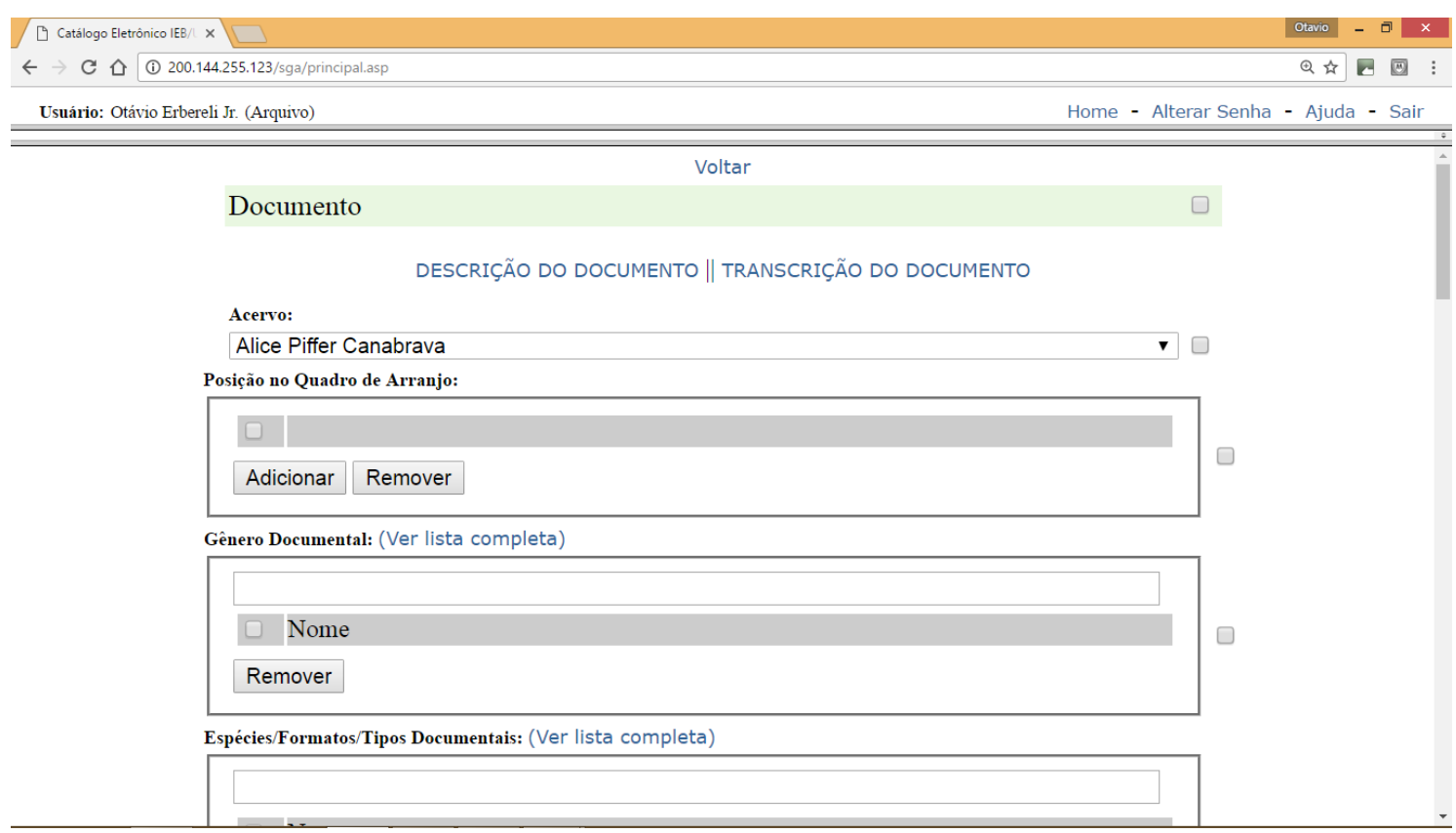

1061 A política de descrição do Arquivo/IEB foi inspirada pela norma Isad (G). O Conselho Internacional de Arquivos tenta, desde 1988, instituir uma norma internacional para a descrição de arquivos que deu origem à “General International Standard Arquival Description”, a Isad (G). Seu marco teórico é a relação hierárquica, agora denominada de estrutura multinível. Trata-se da descrição em níveis, do geral para o particular, respeitando os princípios de proveniência e organicidade. As descrições devem conter: uma "área de identificação" (nome e nível da unidade que está sendo descrita; duas datas de produção ou dataslimite, segundo o caso; sua dimensão e sua codificação, quando houver); "área de contexto de produção" (nome da entidade/pessoa física, história administrativa/biografia. História custodial (ou arquivística) e origem do recolhimento/aquisição); "área de conteúdo e estrutura" (os assuntos tratados e as espécies documentais componentes, de modo a demonstrar as potencialidades de pesquisa; o arranjo interno e informações sobre alterações na dimensão do conjunto); "área de acesso e uso" (condições legais, estado físico do suporte, idiomas, outras descrições já publicadas); "área de fontes relacionadas" (documentos de interesse relacionados aos descritos); "área de notas" (outras informações importantes). Cf. BELLOTTO, Heloísa Liberalli. O processo da descrição: a norma Isad $(\mathrm{G})$ e os instrumentos de pesquisa. In: BELLOTTO, op. cit., 2007, p. 180-218. 
Com o fito de exemplificarmos nosso trabalho de descrição, demonstraremos o processo de descrição do documento reproduzido abaixo (com a autorização do uso da imagem por Lúcia Carvalho) (imagem 3):

ffas, o seu discurso, que, achel mujto bonito. Realmente the emocionou. Ja lhe disse, e repito, só sinto näo ter estado al por ocasião destes eventos. Como a senhora sabe, sua influencia na minha vida, na mínha trajetoria é fundamental e gostaria de estar af para homenageá-la. Mas, por outro lado, a sua aposentadoria ñäo, significa a sua ausência, feiizmente, e neste sentido, a data não é fundamental.

Como já the escrevi, comecel finalmente a aproveitar Londres. Passel $\sigma$ Natal aqui com meu irmäo, que veio dos Estados Unidos. Depois fomos a França. Mas eu náo fiquel em paris. Fyi com uma amiga francesa me impressionou fol a capacidade de adaptaço do ser humano. Viver naquele frio, sempre com as ruas e casas cobertas de neve.., . É preciso uma roupa especial, alimentaçäo especial, enfim, uma série de providências para garantir a vida. Ficamos na casa de uns primos desta pinha if Alnda que por poucos dias pude perceber seus habitọs, suas preocupa çoes, experimentar a comida tipica da regia (que e otima) o ouvir frances o tempo todo. Eles so falavam em frances e fol diffclla a comunicação, mas deu "para quebrar o galho". Depois voltei a paris no fill de semana. Realmente eu ądoro paris. Não me refiro necessariamente aos franceses, mas a cidade e muito vibrante, alegre, tem vida. As pessoas seem as ruas, e animado. Londręs e muito diferentę: não se vê gente na rua, estao todos em casa, e muito discreta, sobria, protestante. Meu Irmäo, que velo de N. ork, me perguntava a todo momoneđo, rax "onde estão as pessoas, onde estão os ingleses?". paris é mais latina, maís parecida com são paulo. è como eu imagino que seja a Itália, a Espanha, glegria, vibraçāo, vida social intensa. Em Londres a vfoda cultural e intensa, náo se podę comparar com o Brasil, mas is to e "dentro", a senhora entende?, e fechado. Mas de tydo is to que estou vendo tenho tirado liçoës e ensinamenntos. Como ja Ihe falel tem sido una boa experiencia. Devo lhe confessar contudos, que não tenho sido muito disciplinada em minhas pesquisas. por muitos motivos. Em primeiro lugar, o tempo, necessar1o para me adaptar e poder "circular", me 1mpediu de realizá-las. Depols, quando ja estava instalada a ansia de conhecer tudo que a cldade podé oferecer, conheter os lugares, os museug, as gglerias, as lojas, enfim, tudo me desviava da pesquisa. Acho que tambęm Influiu meu cansaç, depols da tese, pois como a senhora sabe 1a_o wltimo ano fo1 exaystivo. Cheguel a trabalhah 18, 19 hors por d1a. Nâo me arrependo, fo1 ot1mo, mas acho que atuda estou na fase de tomar folego para começar de novo. Vamos ver agora, se neste tempo que me resta aqui aprovel to alguma colsa neste campo. O problema a que - tempo corre e as vezes a gente näo consegue controlar.

$$
\text { Vue fraud abraro e muitas saudades }
$$

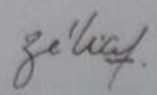


O primeiro item a ser preenchido trata-se de "posição no quadro de arranjo". Nele, inserimos o documento de acordo com seu contexto de produção. Neste caso, uma carta remetida por Zélia Maria Cardoso de Mello, iremos inseri-la no agrupamento "relações sociais" de nosso quadro de arranjo, no subgrupo correspondente à remetente. No item seguinte, gênero documental, trata-se de identificar o gênero do documento, ou seja, se textual, iconográfico, audiovisual etc. Neste caso, trata-se do gênero textual. No campo seguinte, trata-se de identificar o tipo documental. O documento reproduzido acima é uma carta. Até agora, nossa descrição está assim (imagem 4):

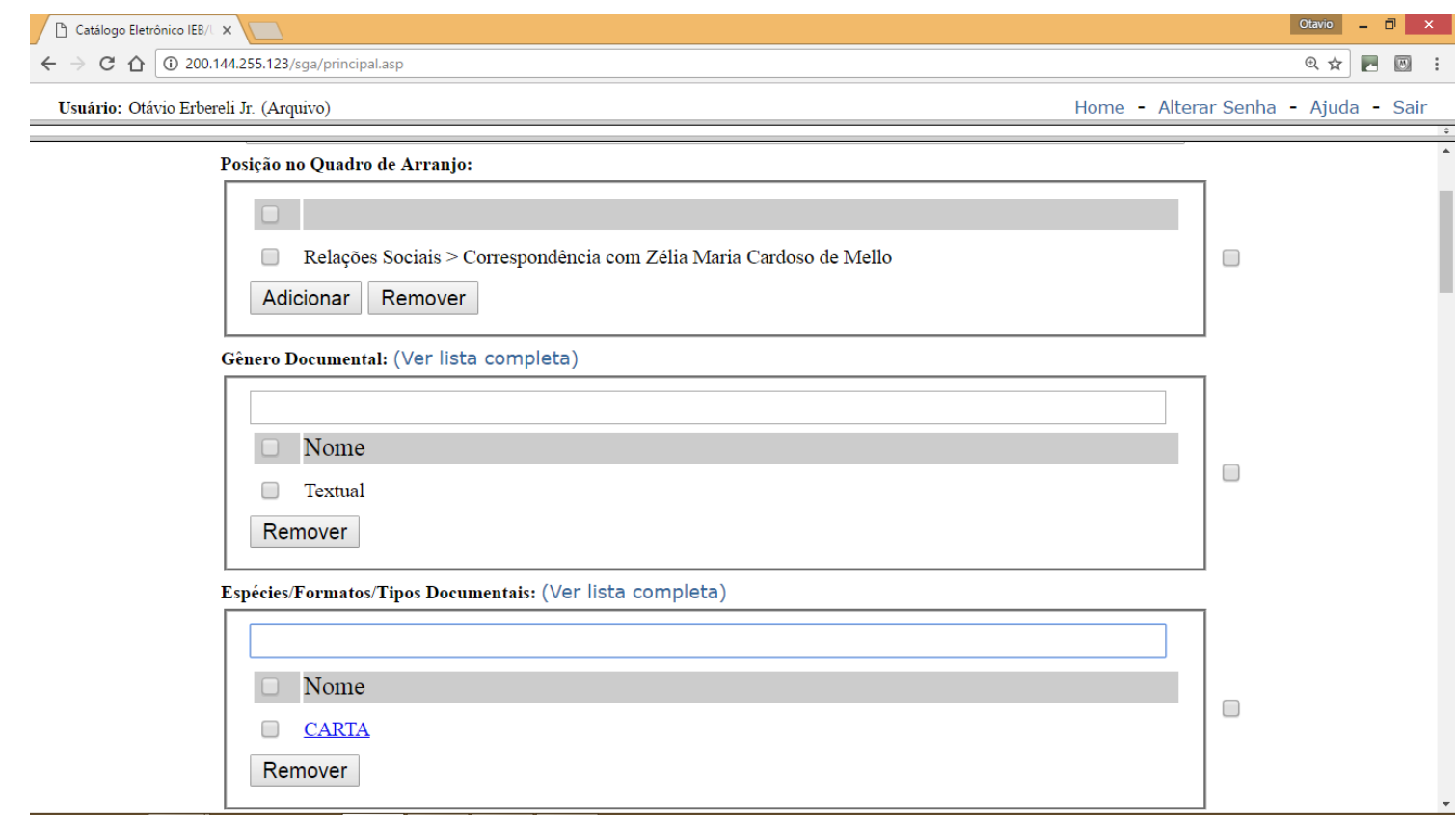

Na sequência, temos os campos: "suporte", "código de referência", "título ou legenda" e "descrição". Em "suporte" trata-se de identificar exatamente a interface do documento, neste caso, trata-se de papel de seda. No que tange ao "código de referência" convencionamos o seguinte sistema para a localização exata do documento em sua unidade de armazenamento, ou seja, a caixa no qual será depositado: APC-quatro últimas letras do sobrenome do remetente-número do item documental. APC refere-se à abreviação do nome da titular do fundo; neste caso o sobrenome da remetente é Mello e sua sigla será MELL, seguida do número do item. Neste caso a identificação do documento seria: APC-MELL-001. Como não há título ou legenda deixamos esse campo em branco. 
Em seguida, o campo mais importante: “descrição”. É nele que fornecemos as informações quanto ao conteúdo do documento, tendo sempre em perspectiva as necessidades de pesquisa do consulente. É fundamental que o arquivista conheça a trajetória da titular do fundo para que possa inserir a descrição documental no momento corresponde da respectiva trajetória. Saber que Alice Canabrava se aposentou da FEA/USP em 1981 e que Zélia Maria Cardoso de Mello foi sua orientanda de doutoramento e que, naquele momento, já havia defendido tese é imprescindível para a boa descrição deste documento. Assim fica nosso formulário com todas as últimas inserções (imagem 5):

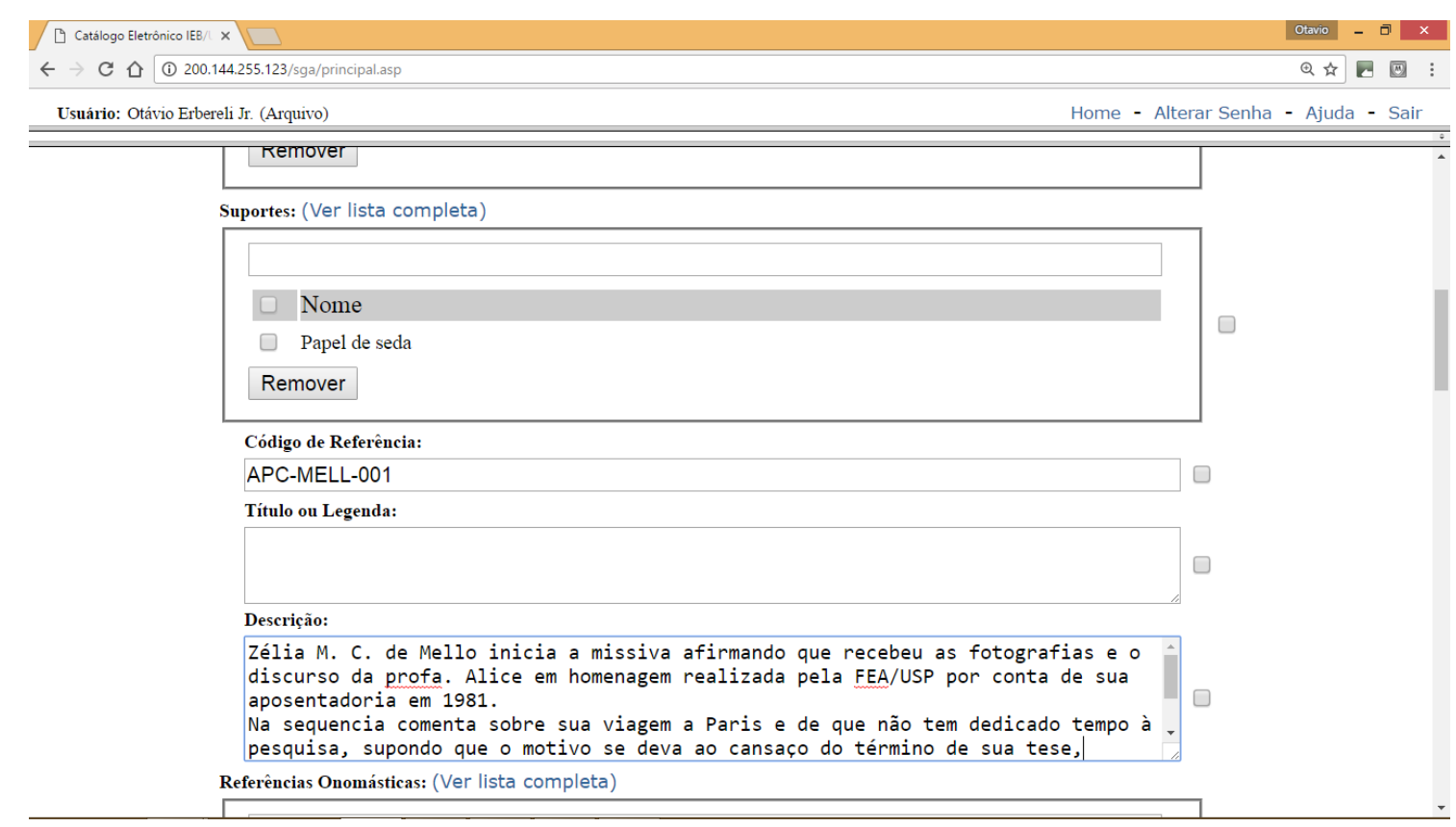

A descrição completa seria a seguinte: "Zélia M. C. de Mello inicia a missiva afirmando que recebeu as fotografias e o discurso da profa. Alice em homenagem realizada pela FEA/USP por conta de sua aposentadoria em 1981. Na sequência comenta sobre sua viagem a Paris e que não tem dedicado tempo à pesquisa, supondo que o motivo se deva ao cansaço do término de sua tese, orientada pela profa. Alice. Mas ainda espera que consiga dedicar-se à pesquisa no pouco tempo que lhe resta em Londres. Ao final, despede-se com "um grande abraço e muitas saudades"'. A descrição insere a carta no momento da trajetória da titular do fundo e fornece informações sobre por que e como foi 
produzida, ou seja, insere-a em seu contexto de produção: a relação da profa. Alice com sua orientanda Zélia.

Em seguida, temos que preencher o campo "localidade", ou seja, onde o documento foi produzido, juntamente com sua "data inicial" e "data final", "idioma" do documento e se trata-se de original ou cópia. Sabemos que a carta foi escrita por Zélia em Londres na data de 07 de janeiro de 1982 em língua portuguesa. Assim nosso formulário fica preenchido (imagem 6):

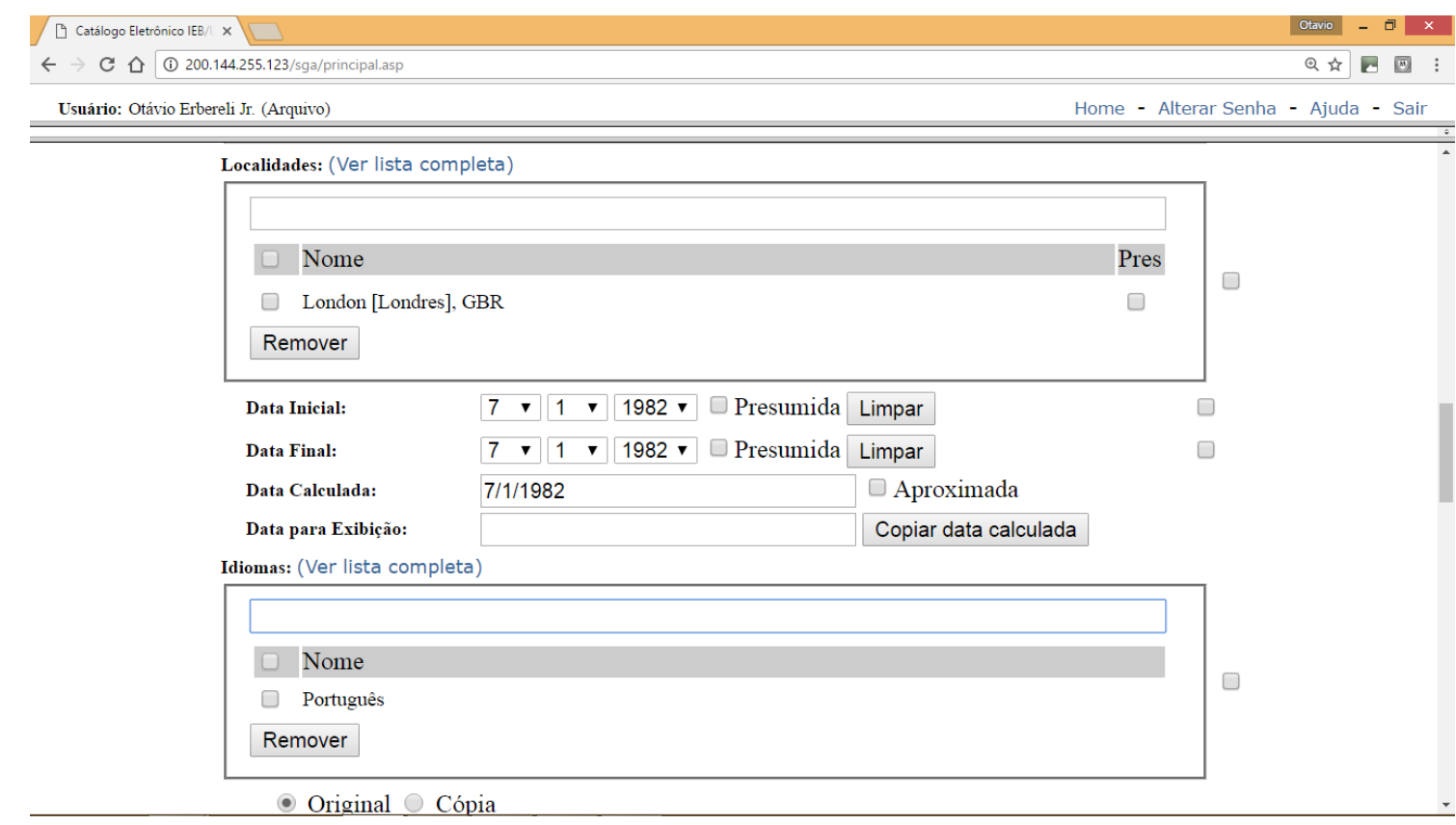

Agora devemos descrever o documento quanto à "técnica de registro empregada", que neste caso, é datiloscrito, ou seja, o documento foi datilografado, mas também possui marcas manuscritas. Deve-se informar o número de folhas e de páginas e também o remetente (imagem 7): 


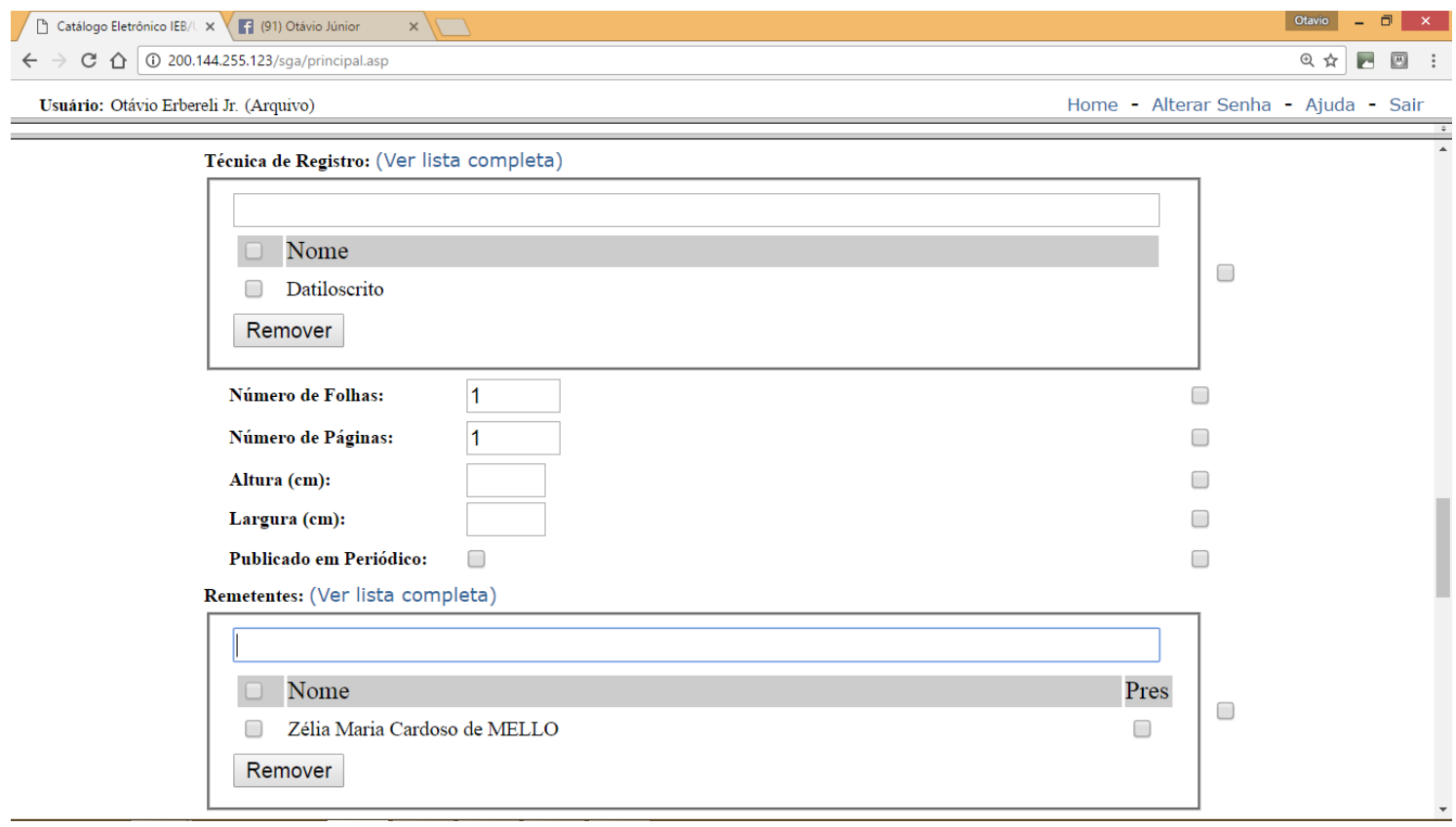

O formulário ainda apresenta os campos “destinatário", "número de exemplares", "estado de conservação", "observações" e "notas de pesquisa". Sabemos que a carta é endereçada à titular do fundo, sendo único exemplar. O campo "estado de conservação" não é preenchido. Quanto à “observações”, utilizamos para expor algum detalhe relevante do documento para o pesquisador, como, em alguns casos, tratar-se de cópia carbonada produzida e arquivada pela própria titular. No campo "notas de pesquisa" pode-se inserir alguma referência bibliográfica ou informação de pesquisa adicional, como o título da tese produzida por Zélia M. C. de Mello, por exemplo (imagem 8). 


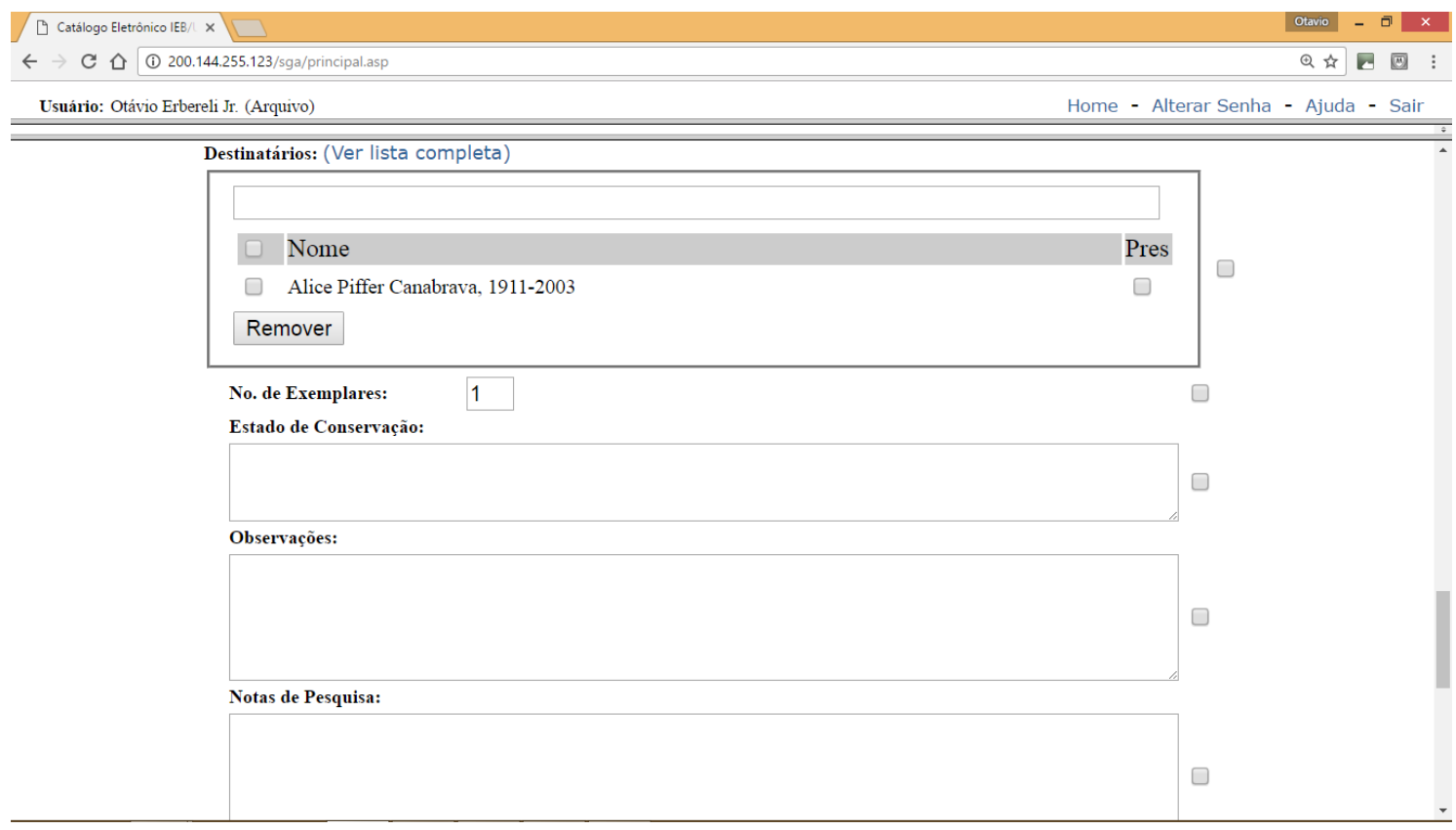

Por fim, os campos "unidades de armazenamento", ou seja, onde o documento será acondicionado (aqui suponhamos hipoteticamente a caixa de número 05) e "relacionamentos com outros documentos". Este último campo é utilizado quando, por exemplo, descrevemos o envelope no qual a carta estava contida e preenchemos o campo com seu código de localização (imagem 9).

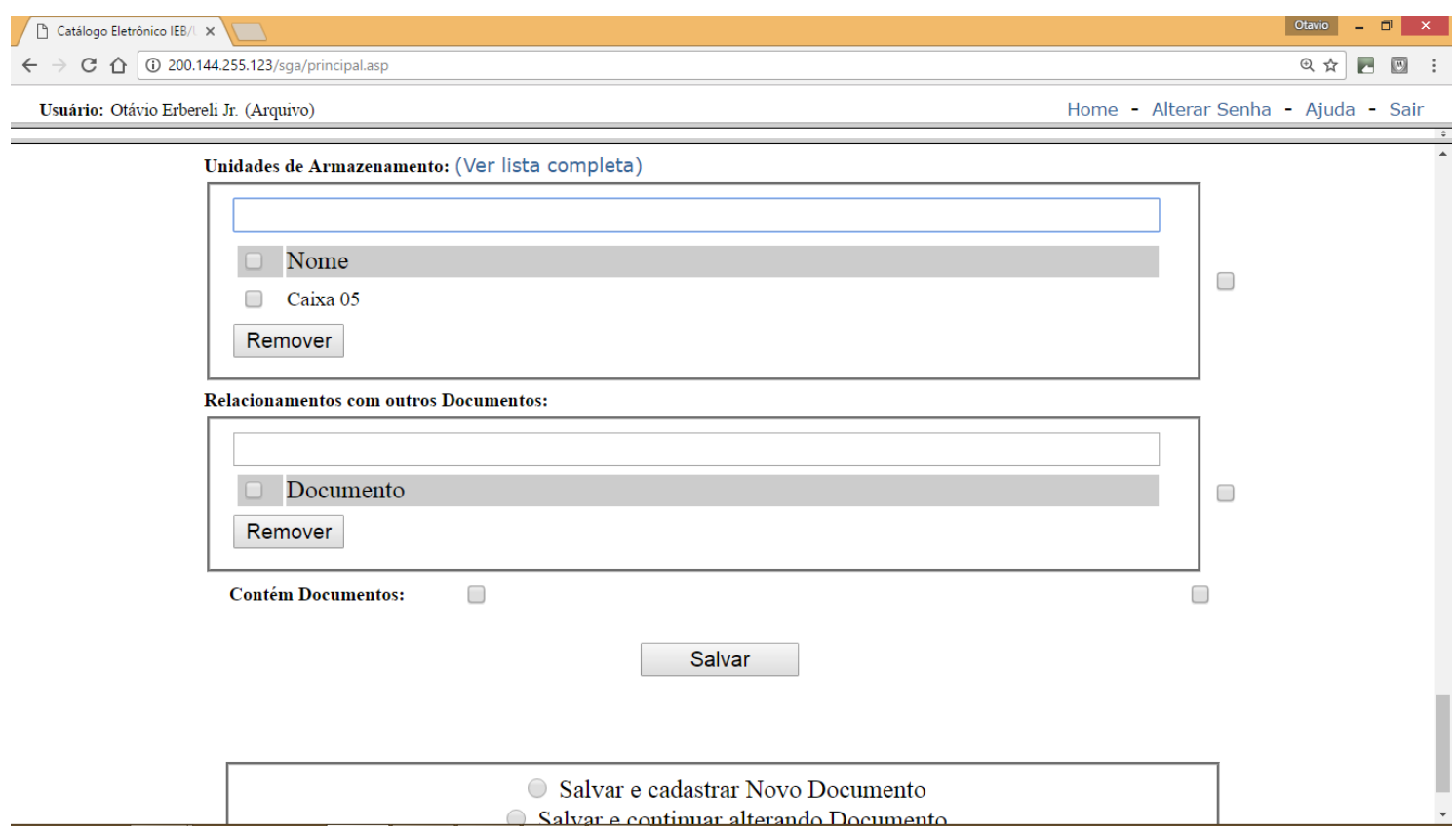


Pronto. Basta agora clicar no botão salvar e a descrição da unidade documental será inserida no banco de dados e disponibilizada automaticamente no catálogo online do site do Arquivo/IEB. 